Renata Borges La Guardia

\title{
O CONTROLE DOS PREÇOS DE TRANSFERÊNCIA. APLICAÇÃO EM OPERAÇÕES FINANCEIRAS E DERIVATIVOS.
}

Tese de doutorado.

Orientação: Prof. Heleno Taveira Tôrres.

Faculdade de Direito da Universidade de São Paulo

São Paulo

2010. 
Banca Examinadora: 
Para minha mãe,

que mesmo após tanto tempo continua sendo a fonte de inspiração para todos os meus passos. 


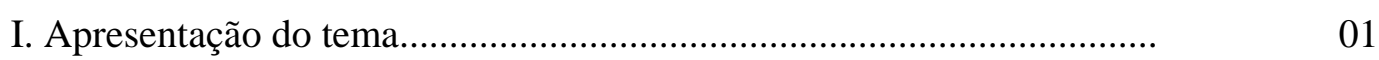

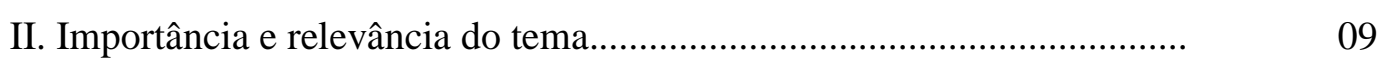

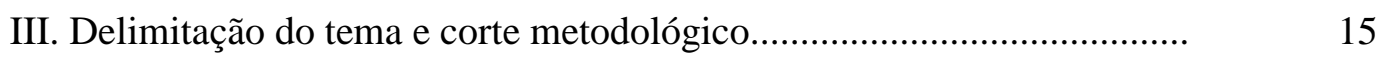

Capítulo 1. Conteúdo, origem e alcance das regras para o controle dos preços de transferência.

1.1. Definição e função dos preços de transferência...

1.2. Origem histórica das regras de preços de transferência e do princípio da plena concorrência. Exame do conteúdo do Relatório CARROLL...................

1.3. Evolução das regras para o controle dos preços de transferência no âmbito da Organização para a Cooperação e Desenvolvimento Econômico (“OCDE").

1.3.1. Transfer Pricing and Multinational Enterprises (1979).

1.3.2. Transfer Pricing and Multinational Enterprises, Three Taxation Issues (1984).

1.3.3. Reports of the Tax Force of the OECD Committee on Fiscal Affairs on US Transfer Pricing Regulations (1993)....

1.3.4. Transfer Pricing Guidelines for Multinational Enterprises and Tax Administrations (1995)

1.3.5. The Taxation of Global Trading of Financial Instruments (1998)...

1.3.6. Report on Attribution of Profits to Permanent Establishments (2008)

1.4. Evolução da legislação norte-americana para o controle dos preços de transferência e edição da Seção 482 do IRC

1.5. Origem e evolução da regulamentação sobre os preços de transferência da Organização das Nações Unidas ("ONU”)

1.6. Princípios constitucionais que amparam a realização de ajustes advindos das normas para o controle dos preços de transferência.

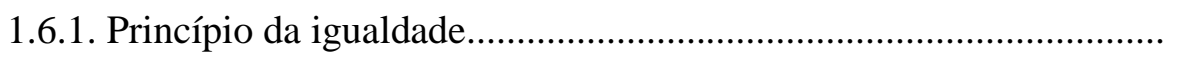


1.6.3. Princípios da generalidade, universalidade e noção de 'renda tributável' adotada pelo legislador brasileiro

1.6.4. Princípio da legalidade.

1.6.5. Princípio da praticabilidade.

1.6.6. Princípio da livre concorrência.

1.7. Constitucionalidade das regras para o controle de preços de transferência e precedentes no direito brasileiro.

1.8. A questão do ônus da prova.

1.9. Noções de ficção e presunção. As provas admitidas para contraditar as presunções contidas na Lei . $^{\circ}$ 9.430/96.

1.9.1. Provas previstas no artigo 21 da Lei n. ${ }^{\circ} 9.430 / 96$.

1.10. Contabilidade segregada, ficção de independência e princípio da plena concorrência.

Capítulo 2. Princípio da plena concorrência

2.1. Abrangência e conteúdo do princípio da plena concorrência.

2.1.1 Noções gerais

2.1.2 Ressalva brasileira ao Artigo $9^{\circ}$, parágrafo 2, da ConvençãoModelo.

2.2. Função essencial da "análise de comparabilidade" na aplicação do princípio da plena concorrência.

2.2.1. Fatores determinantes da comparabilidade.

(I.) Características dos bens, serviços ou direitos objeto da transação.

Bens idênticos e similares

(II.) Análise funcional.

(III.) Análise contratual.

(IV.) Circunstâncias econômicas

(V.) Estratégias empresariais

2.2.2. O "processo típico".

(I.) Comparabilidade dos dados transação-a-transação ou por cestas de transações conjugadas ou semelhantes 
(II.) Reconhecimento das transações vis-à-vis rearranjos contratuais.

(III.) Prejuízos e compensações privadas.

(IV.) Transações independentes comparáveis.

(V.) Utilização de comparáveis secretos.

(VI.) Noção de intervalo de plena concorrência.

(VII.) Possibilidade de utilização de dados de períodos fiscais anteriores ou posteriores para a obtenção das transações independentes comparáveis.

2.2.3. Custos administrativos envolvidos na aplicação do princípio da plena concorrência.

2.3. Discussão sobre a adoção do princípio da plena concorrência e sua integração ao ordenamento pátrio.

2.4. Ausência de obrigatoriedade de observância das orientações fornecidas pela OCDE frente ao ordenamento tributário brasileiro.

2.5. Compatibilidade da lei brasileira para o controle dos preços de transferência com os acordos para evitar a bitributação da renda celebrados pelo país.

2.6. Concretização do princípio da plena concorrência mediante a utilização de métodos. Consistência na aplicação dos métodos.

2.7. A "regra do melhor método" e a seleção do método mais apropriado no direito brasileiro.

2.8. Tratamento tributário nas hipóteses de impossibilidade de aplicação de um dos métodos prescritos na Lei n. ${ }^{\circ}$ 9.430/96.

2.9.1. Compatibilidade da sistemática dos safe harbours com o princípio da plena concorrência.

2.9.2. Safe harbours admitidos pela legislação brasileira.

(I.) Exportações por preço médio superior a $90 \%$ do preço médio praticado no mercado interno.

(II.) Margens predeterminadas de lucro.

(III.) Registro da taxa de juros a receber ou a pagar perante o Banco Central do Brasil. 
(IV.) Lucratividade mínima de 5\% nas operações de exportação ou receitas de exportação máximas de $5 \%$...

(V.) Margem de divergência de 5\%

(VI.) Conquista de novos mercados

Capítulo 3. Negociação global de instrumentos financeiros.

3.1. Conceito de negociação global de instrumentos financeiros.

3.2. Fatores que afetam a condução e estruturação de transações envolvendo a negociação global de instrumentos financeiros.

3.2.2. Estruturas principais de atuação das instituições financeiras e organização das atividades de trading.

3.2.3. Tipos de produtos oferecidos a clientes

3.2.4. Estratégias empresariais

3.3. Análise de comparabilidade

3.4. Análise funcional de operações de negociação global de instrumentos financeiros

3.4.1. Principais funções desempenhadas na negociação global de instrumentos financeiros.

(I.) Vendas e marketing.

(II.) Trading e administração de riscos.

(III.) Outras funções.

3.4.2. Ativos empregados nas transações de negociação global de instrumentos financeiros.

(I.) Capital e funding.....

(II.) Outros ativos.

3.4.3. Riscos assumidos

3.5. Exame de outras operações financeiras que apresentam desafios às regras para o controle dos preços de transferência.

3.6. Distinções principais entre as transações envolvendo a negociação global de instrumentos financeiros implementadas intra-grupo e intra- 
companhia

4.1. Considerações preliminares

4.2. Método de comparação direta de preços.

4.2.1. Comparable Uncontrolled Price Method (“CUP”)

4.2.2. Método dos Preços Independentes Comparados ("PIC").

4.2.3. Método do Preço de Venda nas Exportações (PVEx").

\subsubsection{Comparable Uncontrolled Financial Transactions ("CUFT"),} proposto pelas autoridades norte-americanas para o controle das negociações globais

4.3. Métodos de comparação indireta baseados no preço de revenda deduzido de determinada margem bruta de revenda

4.3.3. Método do Preço de Venda por Atacado do País de Destino, diminuído do Lucro ("PVA")

4.3.4. Método do Preço de Venda a Varejo no País de Destino, diminuído do Lucro ("PVV")

4.3.5. Gross Margin Method, proposto pelas autoridades norteamericanas para o controle das negociações globais.

4.4. Métodos de comparação indireta baseados no custo de aquisição, acrescido de margem bruta calculada sobre este custo.

4.4.3. Método do Custo de Aquisição ou de Produção mais Tributos e Lucro ("CAP")

4.4.4. Gross markup method, proposto pela legislação norte-americana para o controle das negociações globais.

4.5. Análise funcional e aplicação dos métodos tradicionais às transações intra-conglomerados bancários envolvendo a negociação global de instrumentos financeiros. 
4.6. Margens preestabelecidas para aplicação dos métodos de comparação indireta no direito brasileiro

4.6.1. Possibilidade de alteração de margens pelo Ministro de Estado da Fazenda [cf. artigos 19-A e 20, da Lei n. ${ }^{\circ}$ 9.430/96]

4.6.2. Regras de alteração de margens previstas no artigo 21 , §2º da Lei n. ${ }^{\circ} 9.430 / 96$

4.7. Vedação de aplicação das regras de preços de transferência a royalties em operações de importação, conforme artigo $18, \S 9^{\circ}$, da Lei n. ${ }^{\circ} 9.430 / 96 \ldots .$.

4.8. Metodologia para o controle dos juros praticados intra-grupo, conforme previsto no artigo 22 da Lei n. ${ }^{\circ} 9.430 / 96$.

Capítulo 5. Métodos baseados na comparação de lucros.

5.1. Considerações preliminares.

5.2.1. Regras gerais para a aplicação do método.

5.2.2. Aplicação do PSM às transações envolvendo a negociação global de instrumentos financeiros

(I.) Regras gerais propostas pela OCDE

(II.) Método específico proposto pelas autoridades norte-americanas para o controle das negociações globais.

5.3. Transaction Net Margin Method ("TNMM")

5.4. Comparable Profits Method ("CPI”), aplicável no direito norteamericano,

5.4.1. Obtenção de comparáveis para a aplicação do CPI. A questão dos SIC codes.

Capítulo 6. Críticas ao princípio da plena concorrência e ponderações sobre alternativas de simplificação compatíveis com o ordenamento tributário brasileiro.

6.1. Considerações preliminares e exposição das principais críticas ao princípio da plena concorrência.

6.2. Alternativa ao princípio da plena concorrência: método da divisão do lucro global segundo fórmulas predeterminadas. 
global segundo fórmulas predeterminadas.

6.2.2. Críticas da OCDE ao método da divisão do lucro global segundo fórmulas predeterminadas

6.3. Os princípios constitucionais tributários e sua relação com os métodos tradicionais, os métodos amparados na divisão global de lucros e as propostas alternativas ao princípio da plena concorrência

Conclusão 


\title{
LISTA DE ABREVIATURAS
}

\author{
Advance Pricing Arrangements [acordo prévio de \\ preços]. \\ BACEN \\ Banco Central do Brasil \\ BALRM \\ Basic Arm's Length Return Method. \\ CAP \\ Método do Custo de Aquisição ou de Produção mais \\ Tributos e Lucro \\ CATM \\ Comparable Adjustable Transaction Method / \\ Método dos Comparáveis Inexatos \\ CFC \\ Controlled Foreign Company \\ CNAE \\ Cofins \\ Código Nacional de Atividade Econômica, elaborado \\ pela Secretaria da Receita Federal, com orientação \\ técnica do Instituto Brasileiro de Geografia e \\ Estatística ("IBGE”).
CSLL Contribuição Social Sobre o Lucro Líquido
CPI
CPL Custo de Produção mais Lucro
CPM
CTN
CUFT
Comparable Profit Method ou Comparable Profit
Interval Method [Método da comparação dos lucros do direito norte-americano].
Cost Plus Method [Método do custo mais lucro]
Código Tributário Nacional
Comparable Uncontrolled Financial Transaction
CUP
Comparable Uncontrolled Price Method [Método
dos preços independentes comparáveis]
CUT
Comparable Uncontrolled Transactions [Método das transações comparáveis, aplicável a intangíveis].
DDL
Distribuição disfarçada de lucros
DIPJ Declarações de Informações Econômico-Fiscais das Pessoas Jurídicas
Transfer Pricing Guidelines for Multinational
Enterprises and Tax Administrations [OCDE, 1995].
EBIT
Earnings Before Income and Tax [Lucro antes dos
juros e tributos sobre a renda]
GATT
General Agreement on Taxes and Tariffs [Acordo
Geral sobre Tarifas e Comércio].
ICMS
IE
Imposto sobre a Circulação de Mercadorias e
Serviços de Transporte Interestadual e Intermunicipal e de Comunicação
Imposto sobre Exportação
IPI Imposto sobre Produtos Industrializados
IRPJ
Imposto sobre a Renda da Pessoa Jurídica
IRC
Internal Revenue Code
IRS
Internal Revenue Service
Livro de Apuração do Lucro Real
Libor
London Interbank Offered Rate
MAP
Mutual Agreement Procedures \\ Contribuição para o Financiamento da Seguridade \\ Social \\ Diretiva \\ LALUR
}


Minuta-2009

MTM

MPF

$M \& A$

OCDE

OEEC

OMC

ONU

PE

PIC

PIS

PLI

PRL

PSM

PVA

PVEx

PVL

PVV

Relatório GT-1998

Relatório-1979

Relatório-2008

RIR-99

RPM

SAT

SELIC

SIC

SISCOMEX

TNMM
Proposed Revision of Chapters I-III of the Transfer

Pricing Guidelines [OCDE, set./09]

Matching Transaction Method [Método dos

comparáveis exatos]

Mandado de Procedimento Fiscal

Mergers and Acquisitions

Organização para a Cooperação e Desenvolvimento Econômico.

Organization for Economic European Co-operation [Organização para Cooperacao Econômica Européia Organização Mundial do Comércio].

Organização das Nações Unidas

Permanent Establishment [estabelecimento

permanente]

Preços Independentes Comparados.

Contribuição para o Programa de Integração Social Profit Level Indicator [indicador de nível de lucros] Método do Preço de Revenda mais Lucro

Profit Split Method [Método da divisão dos lucros] Método do Preço de Venda por Atacado no País de Destino, Diminuído do Lucro.

Método do Preço de Venda nas Exportações

Método do Preço de Venda mais Lucro

Método do Preço de Venda a Varejo no País de

Destino

The Taxation of Global Trading of Financial

Instruments [OCDE, 1998]

Transfer Pricing and Multinational Enterprises

[OCDE, 1979]

Report on the Attribution of Profits to Permanent

Establishments [OCDE, 2008]

Regulamento do Imposto sobre a Renda [Decreto n. ${ }^{\circ}$ 3.000, de 26 de março de 1999].

Resale Price Method [Método do preço de revenda]

Contribuição para o Seguro de Acidente do Trabalho

Sistema Especial de Liquidação e Custódia.

Standard Industrial Classification.

Sistema Integrado de Comércio Exterior

Transaction Net Margin Method [Método de comparação das margens líquidas]. 


\section{INTRODUÇÃO.}

\section{Apresentação do tema.}

Em 27 de dezembro de 1996, foi promulgada a Lei n. ${ }^{\circ}$ 9.430, a qual, no seu Capítulo I, Seção V, introduziu no ordenamento jurídico brasileiro a disciplina para o controle dos preços de transferência. Preços de transferência são, em apertadíssima síntese, aqueles preços praticados em operações de importação ou exportação em que a contraparte estrangeira é vinculada à parte brasileira; em suma, trata-se de transações envolvendo bens, serviços ou direitos, operadas entre empresas do mesmo grupo econômico. Não obstante a Lei n. ${ }^{\circ} 9.430$ ter sido promulgada em 1996, a matéria ainda não tem recebido no país, seja pelos contribuintes, seja pela administração tributária, a mesma atenção a ela dispensada no cenário internacional, especialmente por organismos como a Organização para a Cooperação e o Desenvolvimento Econômico (“OCDE”) e a Organização das Nações Unidas ("ONU”), as quais perceberam que a questão dos preços de transferência supera o interesse isolado das nações, estando inseridas num amplo contexto macroeconômico e político.

Para a edição de suas normas, o Brasil inspirou-se no princípio "arm's length" ou princípio da plena concorrência ${ }^{1}$, que representa o critério de avaliação dos preços praticados em operações vinculadas ${ }^{2}$ internacionalmente adotado. Este princípio consta do Artigo $9^{\circ}$ do Modelo de Convenção para Evitar a Bitributação da Renda e do Capital da OCDE (“Convenção-Modelo"), cujo teor foi adotado pelo Brasil em todos os seus acordos internacionais dessa natureza.

\footnotetext{
${ }^{1}$ Na tradução [não-oficial] do Capítulo I das Diretivas para o português [“Síntese: Princípios aplicáveis em matéria de preços de transferência destinados às empresas multinacionais"], a expressão "arm's length principle" foi traduzida para "princípio da plena concorrência", sendo que essa será a expressão utilizada no âmbito do presente estudo para significar esse importante princípio atinente ao controle dos preços de transferência. A mesma expressão consta da seguinte obra da OCDE: Modelo de Convenção Fiscal sobre o Rendimento e o Patrimônio. Cadernos de Ciência e Técnica Fiscal n. ${ }^{\circ}$ 172. Lisboa: Centro de Estudos Fiscais, 1995. Jurandi Borges PINHEIRO optou pela expressão "princípio dos preços sem interferência" (Direito Tributário e Globalização. Ensaio crítico sobre preços de transferência. Rio de Janeiro: Renovar, 2001, p. 54), a qual também entendemos adequada, mas, para manter o rigor terminológico, optamos pela adoção da expressão comumente utilizada em Portugal. Na Espanha, adotou-se, dentre outras, a tradução "principio da plena competencia", cujo significado, na língua portuguesa, é, exatamente, princípio da plena concorrência (cf., nesse sentido, CARRERO, José Manuel Calderón. Precios de Transferencia e Impuesto sobre Sociedades. Un análisis de la normativa española desde una perspectiva Internacional, Comunitaria y Constitucional. op. cit.).

${ }^{2}$ Os negócios intra-grupo submetidos à disciplina dos preços de transferência serão referidos neste estudo como "negócios controlados", "operações controladas", "operações vinculadas" ou outras denominações semelhantes.
} 
A OCDE preconiza ser o princípio da plena concorrência o único critério admitido para informar a edição de regras para o controle dos preços de transferência. Com o objetivo de padronizar as normas editadas pela comunidade internacional e, especialmente, por seus Estados-Membros, publicou o "Transfer Pricing Guidelines for Multinational Enterprises and Tax Administrations" (1995), doravante designado "Diretiva"3. Desde 1995, intensos estudos têm sido desenvolvidos pelo Comitê de Assuntos Fiscais para a atualização da Diretiva, sempre com o objetivo de adequá-la às práticas internacionais, sendo que, em 09 setembro de 2009, foi publicado, para consulta pública, o documento "Proposed Revision of Chapters I-III of the Transfer Pricing Guidelines. $9^{\text {th }}$ September 2009- $9^{\text {th }}$ January 2010"4 , que apresenta uma minuta de nova redação para os Capítulos 1 a 3 da Diretiva.

Para fins de implementação do princípio da plena concorrência, assume-se, basicamente, que os preços praticados nas operações entre partes associadas ["preços praticados"] devem ser comparados com os preços que seriam estabelecidos entre partes independentes, em condições comerciais e financeiras semelhantes ["preços parâmetro"]; se for constatada diferença entre os preços praticados e os preços parâmetro, os primeiros sujeitar-se-ão a ajustes que integrarão a base de cálculo do Imposto sobre a Renda das Pessoas Jurídicas (“IRPJ”) e da Contribuição Social sobre o Lucro Líquido (“CSLL”).

${ }^{3}$ Cf. OCDE. Transfer Pricing Guidelines for Multinational Enterprises and Tax Administrations. Paris: OCDE. 2001.

Saliente-se, por relevante, que o Capítulo 1 desta Diretiva foi traduzido, por membros de Portugal no Comitê de Assuntos Fiscais, para a língua portuguesa. Esta tradução [não-oficial], que possui a denominação "Síntese: Princípios aplicáveis em matéria de preços de transferência destinados às empresas multinacionais", pode ser obtida no sítio eletrônico www.oecd.org. Neste trabalho, a expressão inglesa "guidelines" foi traduzida para "princípios directivos". No Brasil, o adjetivo "diretivo" indica aquele que dirige, imprime direção ou orientação (cf. Dicionário Houaiss da Língua Portuguesa. Rio de Janeiro: Objetiva, 2009). O substantivo "diretiva", por seu turno, possui sentido muito próximo e representa (a.) uma diretriz, uma instrução ou conjunto de instruções para a execução de um plano, uma ação etc.; e (b.) uma norma de procedimento (cf. Dicionário Houaiss da Língua Portuguesa, op. cit.). Optamos, no presente estudo, pela utilização do substantivo Diretiva, objetivando-se a simplificação do texto.

Ainda a respeito, saliente-se que na Espanha, a mesma expressão foi traduzida para "Directrices" (cf., dentre outros, CARRERO, José Manuel Calderón. Precios de Transferencia e Impuesto sobre Sociedades. Un análisis de la normativa española desde una perspectiva Internacional, Comunitaria y Constitucional. Valencia: Tirant lo Blanch, Colección Financiero n.. ${ }^{\circ}$ 27, 2005), cuja versão para o português seria justamente, a palavra "diretriz", sinônimo de "diretiva" (cf. Dicionário Larrouse Ática Avançado EspanholPortuguês. São Paulo, Ática, 2004).

${ }^{4}$ Esta minuta para consulta pública será referida no presente estudo simplesmente como "Minuta-2009. Trata-se de trabalho que propõe alterações nos Capítulos 1 a 3 da Diretiva. Sempre que for feita uma citação proveniente de um destes três parágrafos, assim, será feita referência à Minuta-2009, para identificar mudanças de numeração e alterações relevantes por ela trazidas. O texto desta minuta está disponível em http://www.oecd.org/document/26/0,3343,en_2649_33753_43656346_1_1_1_1,00.html. 
A partir da adoção deste princípio, busca-se evitar a manipulação de preços em operações internacionais, com a conseqüente transferência dos lucros [ou parte deles] para países com tributação mais favorecida da renda. Assim sendo, a legislação para o controle dos preços de transferência impõe (i.) um "preço máximo" dedutível nas operações de importação, sendo este preço máximo aquele que teria sido pago em operações nãovinculadas idênticas ou similares; e (ii.) um "preço mínimo" [ou uma receita mínima a ser reconhecida no país] nas operações de exportação, sendo este preço mínimo equivalente àquele que partes independentes contratariam com terceiros, em condições idênticas ou similares. Toda a sistemática para a aplicação do princípio da plena concorrência envolve, assim, a confrontação dos "preços reais" com aqueles que foram, ou hipoteticamente teriam sido, praticados por partes independentes em condições semelhantes.

Esta "comparabilidade" intrínseca ao princípio da plena concorrência exige a obtenção de "dados comparáveis" para cada espécie de transação levada a efeito pelo contribuinte. Não há dúvidas de que estes dados estão disponíveis para o "teste" dos preços de grande parte dos bens e serviços transacionados internacionalmente, como, v.g., commodities $^{5}$, serviços de industrialização padronizados, empréstimos bancários de curto prazo, operações a termo de moedas como o dólar norte-americano etc.. Na hipótese de localização de operações comparáveis idênticas [qualidade dos produtos ou serviços, condições comerciais, financeiras etc.], os dados obtidos deverão ser comprovados via documentação idônea, apta a provar a identidade das operações e a regularidade dos preços praticados. É importante ponderar, a esse passo, que a obtenção de dados ou documentos pode ser complexa em inúmeras hipóteses, especialmente porque as companhias em geral não disponibilizam, a seus concorrentes, suas margens brutas, taxas de lucratividade ou práticas comerciais e financeiras, sob o fundamento de que se tratariam de "dados sigilosos" ou de "segredo do negócio".

\footnotetext{
5 O termo da língua inglesa "commodity" é utilizado nas transações comerciais de produtos de origem primária nas bolsas de mercadorias. São commodities os produtos de base em estado bruto (matérias-primas) ou com pequeno grau de industrialização, de qualidade quase uniforme, produzidos em grandes quantidades e por diferentes produtores. Estes produtos praticamente in natura, cultivados (soft commodity) ou de extração mineral (hard commodity), podem ser estocados por determinado período sem perda significativa de qualidade. São produtos de base são importantes na economia porque, embora sejam mercadorias primárias, possuem cotação e "negociabilidade" globais; portanto, as oscilações nas cotações destes produtos de base têm impacto significativo nos fluxos financeiros mundiais, podendo causar perdas tanto a agentes econômicos individuais como até mesmo a países. Diante da ausência de um termo ou expressão na língua portuguesa que traduza adequadamente o conteúdo do termo commodity, neste caso específico será feita referência ao termo na língua inglesa.
} 
Se inexistirem operações comparáveis idênticas, mas apenas similares, deverão ser efetivados ajustes nos dados obtidos, de modo a se expurgar dos preços parâmetro quaisquer distorções econômicas que as dessemelhanças verificadas possam ter gerado ${ }^{6}$. São necessários, evidentemente, documentos e provas para sustentar não apenas os preços parâmetro aferidos mas, também, os ajustes nestes preços. Quaisquer fatores que influenciarem na precificação da operação podem ser objeto de ajuste, incluindo-se a característica dos bens, direitos ou serviços, a extensão das funções desempenhadas pelo contribuinte, o exame dos ativos utilizados e dos riscos assumidos, as condições contratuais, as circunstâncias econômicas, a estratégia empresarial adotada etc.; quanto maior a quantidade de ajustes, contudo, menor a confiabilidade dos dados obtidos. Não há dúvidas que, quanto maiores e mais numerosos forem os ajustes, mais trabalhoso será, para o contribuinte, o cumprimento das regras para o controle dos preços de transferência, e mais complexa será, para a administração tributária, a fiscalização destes preços.

Por fim, se inexistirem operações que sejam razoavelmente comparáveis mesmo após a efetivação de diversos ajustes, ou se não for possível a implementação de ajustes razoavelmente confiáveis e acurados, a aplicação do princípio da plena concorrência será muitíssimo limitada.

Nesse cenário, por mais que o raciocínio envolvido na aplicação do princípio da plena concorrência seja simples, i.e., basta a equiparação de uma operação controlada a uma operação não-controlada, sua efetivação, sob os pontos de vista técnico-contábil, econômico e jurídico, pode envolver questões sofisticadas e complexas. Na prática, quanto mais simples e habitual for a transação [v.g., venda de tonelada de aço com determinadas características no mercado internacional], melhor será sua precificação a partir das técnicas proporcionadas pelo princípio da plena concorrência. No outro extremo, quanto mais

\footnotetext{
6 “1.15. (...) To be comparable means that none of the differences (if any) between the situations being compared could materially affect the condition being examined in the methodology (e.g. price or margin), or that reasonably accurate adjustments can be made to eliminate the effect of any such differences. In determining the decree of comparability, including what adjustments are necessary to establish it, an understanding of how unrelated companies evaluate potential transaction is required. (...)

1.17. As noted above, in making these comparisons, material differences between the compared transactions or enterprises should be taken into account. In order to establish the degree of actual comparability and then to make appropriate adjustments to establish arm's length conditions (or a range thereof), it is necessary to compare attributes of the transactions or enterprises that would affect conditions in arm's length dealings. Attributes that may be important include characteristics of the property or services transferred, the functions performed by the parties (taking into account assets used and risks assumed), the contractual terms, the economic circumstances of the parties, and the business strategies pursued by the parties" (OCDE. Transfer Pricing Guidelines for Multinational Enterprises and Tax Administrations. op. cit., p. I-7 e I-8). Convertidos nos parágrafos 1.33 e 1.36 da Minuta-2009.
} 
atípicas e excepcionais forem as transações [v.g., venda de marcas mundialmente conhecidas ou de intangíveis únicos e exclusivos], maiores as dificuldades de mensuração de seu preço a partir deste princípio. Num ponto intermediário, podem-se vislumbrar as operações razoavelmente exclusivas e sem comparáveis idênticos, os quais, após a realização de ajustes acurados e precisos, podem servir à aplicação do princípio da plena concorrência; obviamente, quanto maior a quantidade dos ajustes, pior a qualidade dos dados comparáveis e mais difícil a obtenção de um preço parâmetro justo e adequado.

Em suma, pode-se concluir que a efetivação deste princípio é extremamente dependente da obtenção de dados comparáveis ou de dados que, após determinados ajustes razoavelmente acurados e precisos, tornem-se comparáveis.

Por intermédio dos artigos 18 e 19 da lei, pretendeu-se introduzir, no ordenamento tributário brasileiro, métodos inspirados nas "metodologias tradicionais" sugeridas pela OCDE ["Traditional Transaction Methods"], as quais eram consideradas os mais importantes mecanismos para a concretização do princípio da plena concorrência. Trata-se de métodos baseados na comparação de preços, na comparação de margens brutas de venda e na comparação de margens brutas adicionadas ao custo de produção do bem, serviço ou direito transacionado. Para a comprovação dos preços nas operações de importação, o artigo 18 da Lei n. ${ }^{\circ}$ 9.430/96, com alterações introduzidas pela Medida Provisória n. ${ }^{\circ}$ 478, de 29 de dezembro de 2009, prevê os seguintes métodos: Método Preços Independentes Comparados ("PIC"), Método do Preço de Venda mais Lucro ["PVL", antigo Método do Preço de Revenda mais Lucro ("PRL")] e Método do Custo de Produção mais Lucro ("CPL”). Para o teste dos preços de transferência nas operações de exportação, o artigo 19 da Lei n. ${ }^{\circ}$ 9.430/96 trouxe as seguintes sistemáticas: Método do Preço de Venda nas Exportações ("PVEx”), Método do Preço de Venda por Atacado no País de Destino, Diminuído do Lucro ("PVA"), Método do Preço de Venda a Varejo no País de Destino, Diminuído do Lucro ("PVV") e Método do Custo de Aquisição ou de Produção mais Tributos e Lucro (“CAP”). Não existe, no direito brasileiro, a possibilidade de adoção de outros métodos além dos sete ora referidos [cf. seção 2.4 da tese].

O princípio da plena concorrência, na forma como preconizado pela OCDE em seus estudos, é bastante "aberto", devendo sua aplicação ser precedida do exame exaustivo de cada transação controlada. Não obstante isso, a legislação brasileira "objetivou-o". Assim, v.g., sustenta a OCDE que, para a aplicação dos métodos baseados na comparação 
de preços [PIC ou PVEx], os dados obtidos podem ser objeto de quaisquer tipos de ajustes até que se tornem razoavelmente comparáveis. No Brasil, a lista de ajustes foi limitada pela Instrução Normativa n. ${ }^{\circ}$ 243, de 11 de novembro de 2002; com isso, evidentemente, foram restringidas também as hipóteses em que podem ser obtidos dados adequadamente comparáveis. Os métodos amparados na comparação de margens brutas [PVL, PVA, PVV, CPL e CAP], de outro lado, foram simplificados a partir da utilização da técnica das presunções legais, a tal ponto que as próprias margens foram definidas em lei; retirou-se, portanto, o mais importante fator de comparação destes métodos ${ }^{7}$. Nesse cenário, a legislação brasileira, a despeito de ter se inspirado no princípio da plena concorrência, não recepcionou toda a gama de mecanismos por ele disponibilizada. Por conseguinte, não são raros os casos de contribuintes "sem método", i.e., de contribuintes que não conseguem aplicar nenhum dos métodos admitidos na Lei n. ${ }^{\circ}$ 9.430/96 para a comprovação dos seus preços de transferência.

Pondere-se, a esse passo, que os métodos tradicionais sugeridos na Diretiva, embora possibilitem o "teste" e a comprovação dos preços praticados na maioria das situações, possuem limitações. Por conta disso, a Diretiva previu métodos baseados na comparação de lucros [“Transaction Profit Methods"], os quais, inclusive, deixarão de ser meramente subsidiários após a consolidação das alterações constantes da Minuta-2009 no texto da Diretiva ${ }^{8}$. Além dos métodos tradicionais baseados na comparação de preços e margens brutas, portanto, sustenta a OCDE ser possível a aplicação dos métodos transacionais, amparados na comparação de lucros operacionais; estes últimos, em princípio, poderiam ser aplicáveis a uma quantidade maior de casos, porque os lucros operacionais auferidos por um determinado contribuinte em relação a um produto, serviço ou direito, são normalmente publicados e disponibilizados ao mercado, ao contrário das margens brutas. Deste modo, não sendo viável a comparação direta de preços, é possível a obtenção das margens de lucro operacionais auferidas por empresas que atuam no mesmo segmento, de forma assemelhada.

\footnotetext{
${ }^{7}$ As alternativas para a alteração das margens prefixadas em lei e sua efetividade serão discutidas no CAPÍTULO 4, infra.

${ }^{8}$ No convite que acompanha a consulta pública da Minuta-2009, afirma-se que:

"Transactional profit methods (the transactional net margin method and the profit split method) currently have a status of last resort methods, to be used only in the exceptional cases where there are no or insufficient data available to rely solely or at all on the traditional transactional methods. Based on the experience acquired in applying transactional profit methods since 1995, the OECD proposes removing exceptionality and replacing it with a standard whereby the selected transfer pricing method should be the most appropriate method to the circumstances of the case" (OCDE. Proposed Revision of Chapters I-III of the Transfer Pricing Guidelines. 9th September 2009- 9th January 2010, op. cit., p. 02).
} 
Não obstante todas as metodologias acima descritas, há, na doutrina especializada, uma forte corrente que critica sobremaneira a adoção do princípio da plena concorrência como o único princípio de direito tributário internacional adotado para o controle dos preços de transferência, seja pelas dificuldades e detalhismos a ele inerentes, seja porque ele não serve para o cálculo do preço parâmetro em diversas situações nas quais inexistem "dados comparáveis" disponíveis. Sustenta-se, outrossim, que a ficção de que a negociação dá-se entre duas pessoas jurídicas independentes, a despeito de associadas, é economicamente incorreta, porque, ao controlar os preços desta forma, ignoram-se os benefícios decorrentes da atuação integrada e a obtenção de sinergias em concentrações verticais e/ou horizontais de empresas ${ }^{9}$. Como alternativa ao princípio da plena concorrência, sugere-se a adoção do método da partilha fracionada, que será analisado no CAPÍTULO 6 da tese. Em suma, este método prevê que, ao invés de se comparar cada transação, buscando-se imaginar hipoteticamente como terceiros contratariam, deve-se verificar o lucro total obtido e reparti-lo segundo fórmula que sopese as funções desenvolvidas e ativos empregados por empresa. A OCDE rejeita completamente esta alternativa, embora alguns países sustentem que este tipo de sistemática poderia ser aplicada como "ultima ratio", nas hipóteses de absoluta e total inaplicabilidade do princípio da plena concorrência ${ }^{10}$.

Transmudando-se o raciocínio dos dois parágrafos anteriores para o contexto das normas brasileiras, não há dúvidas de que a situação é muito mais complicada. De fato,

\footnotetext{
9"The administration of transfer pricing rules under the arm's length principle has faced two basic difficulties. First, it entails a focus on specific transactions; and, second, it relies on finding comparable transactions between unrelated parties. Underlying these is the basic problem that arm's length's depends on treating related companies as if they were unrelated. The essential advantages of a corporate group are that fixed costs can be jointly shared, and that a successfully integrated firm generates synergy profits, or additional returns attributable to the organization as a whole rather than any particular unit. The arm's length approach based on transactional analysis entails attempting to dissect this unity" (PICCIOTTO, Sol. International Business Taxation. A Study in the Internationalization of Business Regulation. New York: Quorum Books, 1992, p. 193).

10 "The prevailing opinion seems to be that formulary apportionment lacks any underlying principle and leads to arbitrary results. Consequently, some authors and institutions, the OECD being the most prominent and influential one, totally reject the application of formulary apportionment, as a method for allocating profits. Others, nevertheless deem it useful for cases in which transfer pricing [arm's length] cannot be applied in a practicable way, as a second best solution for achieving rough justice in cases in which transfer pricing [arm's length] does not work satisfactorily.

In contrast, there are also some authors, mostly supporters of worldwide unitary taxation from the United States, who adamantly prefer unitary taxation over transfer pricing [arm's length]. These authors claim that formulary apportionment (in the variant of unitary combination) is supported by sound economic theory and is superior in taking into account the economic reality of integrated multinational enterprises, apart from being more administratively more convenient and being more stable against international tax avoidance" (MAYER, Stefan. Formulary Apportionment for the Internal Market. Doctoral Series no. 17, Academic Council. Amsterdã: IBFD Publications BV, 2009, p. 20).
} 
as previsões rígidas da legislação pátria dificultam sobremaneira a aplicação das regras para o controle dos preços de transferência, porque, a despeito de sua inspiração nos métodos tradicionais da OCDE, há inúmeras simplificações; os contribuintes brasileiros não dispõem, assim, de toda a gama de metodologias inerentes aos métodos tradicionais ${ }^{11}$. Adicionalmente, nossa lei não possibilita a aplicação dos métodos baseados na comparação de lucros, por vezes essenciais para a justificação de preços de transferência. Também não há outros métodos ou critérios alternativos. Neste contexto, se o princípio da plena concorrência possui limitações, mesmo quando disponíveis todas as suas metodologias, o que se pode dizer de sua aplicação limitada prevista pelo direito brasileiro? Sem dúvidas, as restrições são mais numerosas e relevantes.

Situações envolvendo, v.g., intangíveis exclusivos ou a negociação global de instrumentos financeiros por conglomerados bancários, apresentam enormes desafios para os aplicadores do princípio da plena concorrência no direito brasileiro. No âmbito desta tese, serão discutidas as questões concernentes a preços de transferência supra referidas, a partir do exame, dentre outras, das transações envolvendo a negociação global de instrumentos financeiros praticadas entre instituições de um mesmo grupo econômico ${ }^{12}$, porque elas impõem inúmeros desafios às normas tributárias tradicionais vigentes ${ }^{13}$. Esta constatação, aliada à existência de dois relatórios sobre o assunto elaborados pela $\mathrm{OCDE}^{14}$, os quais foram amplamente examinados e, em alguns casos, contestados pelas multinacionais do setor financeiro, representa um dos fatores que justificaram a escolha desta natureza específica de transação para subsidiar as discussões deste estudo.

\footnotetext{
${ }^{11}$ Uma outra limitação relevante que importa consignar a respeito da legislação brasileira é a ausência de uma melhor definição das regras aplicáveis aos serviços e direitos, sendo os métodos e sua regulamentação especialmente voltados para a comercialização de mercadorias. Esta circunstância poderá ser observada durante os próximos capítulos, sempre que for examinada a lei pátria.

12 O conceito de "negociação global de instrumentos financeiros" consta do CAPÍTULO 3 da tese.

13 "The process of global trading consists of a number of functions, which generally can be categorized into trading, sales and marketing, management and support functions. Any combination of those functions can occur at any of the locations in which global trading takes place. As a result, global trading presents a number of challenges to traditional tax principles. Those involve questions as basic as when the trading activities conducted in other countries, either directly or through affiliates acting as agents, constitute a permanent establishment, how to determine the income attributable to those permanent establishments, how to apply traditional transfer pricing methodologies to transactions between associated enterprises involved in an integrated business, and basic timing issues" (OCDE. OECD Documents. The Taxation of Global Trading of Financial Instruments. Paris: OCDE, 1998, p. 13).

14 Confiram-se os relatórios (i.) OECD Documents. The Taxation of Global Trading of Financial Instruments, referido como "Relatório GT-1998"; e (ii.) Report on the Attribution of Profits to Permanent Establishments. Paris: OCDE, Centre for Tax Policy and Administration, 17 jul. 2008, referido como "Relatório-2008".
} 
Nesse contexto é que, ao longo dos próximos capítulos, buscar-se-á ponderar, à luz dos parâmetros apontados pela experiência internacional mais recente, as dificuldades que podem ser enfrentadas para o controle dos preços de transferência em operações financeiras, em especial as operações de negociação global de instrumentos financeiros, sempre que estiverem disponíveis para a administração tributária e/ou para os contribuintes tão-somente os métodos tradicionais prescritos pela OCDE para o atendimento do princípio da plena concorrência. As limitações desses últimos serão examinadas principalmente vis-à-vis as aludidas espécies de operações, mas as mesmas conclusões extraídas de tal análise poderão ser estendidas para outros tipos de negócios complexos envolvendo, v.g., ativos intangíveis, patentes ou processos industriais especiais, serviços exclusivos etc.. Em alguns casos específicos, serão indicados exemplos extraídos da legislação, doutrina ou jurisprudência estrangeiras encerrando operações de natureza nãofinanceira, com o intuito de corroborar a tese de que os métodos tradicionais têm aplicação circunscrita e não atingem negócios únicos e exclusivos, i.e., sem parâmetros comparativos disponíveis no mercado.

As questões a serem enfrentadas cingem-se, nesse contexto, ao exame dos métodos hauridos do princípio da plena concorrência, i.e., métodos tradicionais [CAPÍTULO 4] e métodos baseados na comparação de lucros [CAPÍTULO 5]. Em seguida, serão ponderadas as críticas a tal princípio para, ao final, sopesar algumas alternativas para tornar a legislação brasileira, a um mesmo tempo, mais simples, eficiente e justa, de modo que seja possível concentrar esforços, tanto dos contribuintes quanto da administração tributária, nas transações mais complexas [CAPÍTULO 6]. Vale notar que o cerne deste estudo não será o exame das especificidades da Lei n. ${ }^{\circ}$ 9.430/96 ou outros dispositivos regulamentares brasileiros, mas sim a análise dos mecanismos para o controle dos preços de transferência mundialmente estudados. Assim como o direito estrangeiro, o direito brasileiro será subsídio para o estudo, e não o único objeto dele. Por conseguinte, não há um capítulo específico sobre direito o direito comparado; a legislação, a doutrina e a jurisprudência estrangeiras serão abordadas como referencial teórico ao longo de cada um dos capítulos da tese.

\section{Importância e relevância do tema.}

Importa ponderar, a este passo, que as práticas adotadas entre empresas vinculadas de diferentes jurisdições fiscais podem ter maior impacto tributário sobre as 
rendas geradas internacionalmente que qualquer outro aspecto do direito tributário internacional. Assim sendo, a problemática dos preços de transferência apresenta-se muitíssimo relevante e demanda excessiva atenção dos estudiosos e das administrações tributárias, em razão dos danosos efeitos econômicos globais que a prática de preços "anormais" entre empresas associadas pode gerar.

Com efeito, por decorrência dos fenômenos da globalização e da concentração econômica, a cada dia as transações entre empresas associadas tornam-se mais predominantes no cenário internacional. Estima-se que $70 \%$ dos negócios transnacionais envolvam empresas relacionadas ${ }^{15}$. Segundo o "World Investment Report" (2008) da “United Nations Conference on Trade and Development" (“UNCTAD”), v.g., durante 2007, as 790.000 subsidiárias estrangeiras das 79.000 maiores empresas transnacionais auferiram faturamento da ordem de US\$31,197trilhões e geraram [não computados os resultados das matrizes e/ou controladoras] aproximadamente $11 \%$ do produto bruto global. Esse faturamento elevou-se 20,7\% em relação a 2006 e multiplicou-se por mais de 11 vezes se comparado ao faturamento de subsidiárias estrangeiras de empresas multinacionais em 1992, que era estimado em US\$2,741bilhões (UNCTAD, World Investment Report, 2008, p. 4).

Adicionalmente, ressalte-se que esses valores tendem a elevar-se muitíssimo por conta do fenômeno de concentração empresarial. Apenas em 2007, os fluxos internacionais de recursos decorrentes de operações de fusões e aquisições internacionais foram da ordem de US\$1,637trilhões, o que representou um crescimento de $21 \%$ em relação a 2000 (UNCTAD, 2008, p. 3). A cada ano, multiplicam-se os valores envolvidos nas operações entre empresas associadas. Tanto não bastasse, atualmente, pode-se verificar, de forma empírica, um grande número de operações visando à concentração de instituições financeiras, em todo o mundo. Ainda não há dados estatísticos disponíveis a respeito, mas é patente que, nos últimos anos e especialmente em 2008 e 2009, por conta da recente crise dos créditos sub-prime, o número de operações de fusões e aquisições (M\&A), bem assim o valor e relevância econômica respectivos, cresceu vertiginosamente.

\footnotetext{
${ }^{15}$ RODRIGUES DO AMARAL acrescenta, ainda, que, segundo estimativas, cerca de um terço do comércio mundial e $80 \%$ (oitenta por cento) dos pagamentos relativos a operações com intangíveis correspondam a negociações intra-grupo, e que, portanto, sujeitam-se ao controle dos preços de transferência. [O preço da transferência (transfer pricing) no Mercosul - II Jornada Tributária do Mercosul. Cadernos de Direito Tributário e Finanças Públicas. São Paulo: Revista dos Tribunais, ano 6, n. 22, jan./mar. 1998, p. 210].
} 
Estas constatações de ordem econômica demonstram que os preços de transferência podem se tornar um mecanismo relevante para evitar a fuga de receitas tributáveis para países com baixa ou nenhuma tributação da renda. Por conta deste recente fenômeno, não há dúvidas de que as questões envolvendo os preços em operações de negociação global tendem a tornar-se mais complexas e relevantes. De fato, um elevado nível de concentração empresarial tem por fim, dentre outros, a eliminação e/ou racionalização de custos e obtenção de ganhos de escala na prestação de serviços financeiros. Mas o alcance destes objetivos depende, em certa medida, da centralização de alguns tipos de serviços numa determinada jurisdição, ou da integração de atividades entre controladoras e subsidiárias ao redor do mundo, o que, conseqüentemente, propicia o aumento e a diversificação das transações entre instituições que se dedicam à negociação global de instrumentos financeiros.

Além do elevado índice de concentração empresarial, os avanços tecnológicos, a revolução das comunicações e a desregulamentação e liberalização das atividades financeiras também impactaram a globalização dos mercados ${ }^{16}$ e, principalmente, a disseminação, entre as instituições, da atividade de estruturação de derivativos de balcão para o atendimento de demandas globais dos clientes ${ }^{17}$.

\footnotetext{
${ }^{16}$ No mesmo sentido, a OCDE conclui, no Relatório GT-1998, que:

"Technological advances allow managers, traders, marketers and operations personnel to track, price and measure risk resulting from thousands of trades occurring around the world on a 'real time' basis. Financial intermediaries have invested enormous resources in developing systems that allow them to correlate risks and develop hedging strategies so that they can manage the risk they take on from their customers without subjecting the firms to unacceptable absolute levels of exposure to market changes. (...) The use of derivative instruments, in particular, has expanded because such instruments allow the parties to a transaction to tailor their risk exposure. On the liability side, issuers may be able to lower the cost of funds by issuing debt into global capital markets in a different currency and entering into an appropriate derivative transaction with a financial institution to hedge the currency risk. (...) Finally, favourable regulatory developments have allowed the expansion of activities in major capital centres. Markets have also developed in other countries that have kept pace with deregulation. These changes have allowed more financial intermediaries in countries outside traditional financial centres to provide an increasing variety of products do an expanding customer base both in domestic and foreign markets" (OCDE. The Taxation of Global Trading of Financial Instruments. op. cit., p. 15-16).

17 "Developments in derivatives markets continued to reflect a number of ongoing trends. These trends, including rapid growth, the increasing dominance of the OTC segment compared with the exchange-traded segment, and the preponderance of "plain vanilla" derivatives, are clearly illustrated by the most recent Bank of International Settlements (BIS) triennial survey of foreign exchange and derivatives markets (...). The survey covers traditional foreign exchange derivatives (out-right forwards and swaps); more sophisticated foreign exchange derivatives (options, currency swaps and others); and interest rate products. It conveys a sense of market size as measured by notional amounts and gross market value of derivatives outstanding, and activity as measured by average daily turnover of notional amounts. Notional amounts outstanding in derivatives markets are related to market risk exposure. From the end of March 1995 to the end of June 1998, notional amounts outstanding in de OTC markets rose by 52 percent to $\$ 72$ trillion, compared with $\$ 13,2$ trillion outstanding in exchange-traded foreign exchange and interest rate derivatives (which grew by 34,2
} 
Os avanços tecnológicos permitem, atualmente, avaliar operações em qualquer país, em tempo real. De fato, muito foi investido em sistemas que permitem obter estratégias de hedge imediatas e em softwares de avaliação de riscos e de produtos, sendo estes últimos utilizados também pelos "consumidores finais", que perceberam que as perdas em operações financeiras geram riscos adicionais a suas operações, tendo o condão, inclusive, de inviabilizá-las.

O fator econômico mais importante para a globalização dos mercados financeiros foi, contudo, o crescimento do comércio internacional, que gera preocupações concernentes aos riscos de câmbio e é influenciado pela volatilidade dos mercados nacionais. A crescente demanda dos clientes propiciou o desenvolvimento de um mercado financeiro mais sofisticado, o que, por seu turno, vem alterando a própria natureza da atividade de intermediação financeira; as instituições vêm deixando de atuar apenas como simples intermediários dos negócios para deles constar como parte. Com estes avanços, passou a ser possível desenvolver instrumentos para interesses díspares. Pode a instituição, portanto, criar um negócio que atenda tão-somente a seu cliente; em seguida, elabora-se novo derivativo para adequar a primeira transação aos seus critérios e limites internos de disponibilidade de capital e de nível de risco.

Ainda neste campo de análise, é importante destacar que a formulação e negociação de derivativos por instituições que se dedicam a sua negociação global é sobremaneira importante para o desenvolvimento do próprio comércio internacional, porque permite a implementação de operações de balcão entre investidores e captadores de recursos financeiros, que nem sempre têm necessidades convergentes. Não se pode afirmar se esta tendência foi a causa ou o efeito da expansão do comércio internacional, mas certamente ambas têm uma relação intrínseca importante. Este tipo de instrumento financeiro customizado e não negociado em bolsas de valores ou de mercadorias é essencial, outrossim, para a criação de novos tipos de hedge, buscando-se atender aos grandes grupos multinacionais. De fato, este tipo de proteção, em especial face à variação da cotação de moedas estrangeiras ou do preço de commodities, é essencial para a redução dos riscos de qualquer negócio.

percent). To put this figure in perspective, in 1998, world GPD was $\$ 29,2$ trillion; in 1997 , stock market capitalization and securitized debt in the European Union, North America and Japan amounted about 46,6 trillion (GPD in these countries totaled \$21,4 trillion)" (extraído de ADAMS, Charles et. al.. International capital market-developments, prospects, and key policy issues. Washington: International Monetary Fund, 1999, p. 22). 
Seguindo-se este raciocínio, os derivativos transacionados em bases globais atendem tanto aos investidores, que podem aumentar a diversidade de suas carteiras e reduzir riscos, quanto aos emissores dos títulos, que têm capacidade de captar recursos em outros países, a custos economicamente mais vantajosos. Com efeito, o atual estágio de globalização dos mercados financeiros permite eficiência na alocação de capital: uma determinada companhia pode investir de forma diversificada, moldando seu portfólio conforme a relação risco-retorno pretendida, ou emitir títulos para distribuição em todo o mundo. Os derivativos permitem, ademais, modelar a exposição ao risco; é possível, v.g., emitir título no exterior e captar recursos a juros mais baixos; para a proteção da variação cambial da dívida, contrata-se um hedge [compra-se, por exemplo, um futuro de dólar, prefixando-se a taxa para quitação da dívida].

A relevância do estudo do controle dos preços de transferência em transações envolvendo a negociação global de instrumentos financeiros pelos conglomerados bancários, nesse sentido, resta comprovada, seja sob o ponto de vista econômico, porque as operações globais crescem de forma exponencial e envolvem um número cada vez maior de empresas que necessitam destes instrumentos para atuar na economia globalizada, seja sob o ângulo do direito tributário internacional, constantemente desafiado pelas situações inovadoras e complexas existentes neste terreno de negócios. Estas inovações trazem desafios tanto para as instituições financeiras quanto para as administrações tributárias. A estas últimas importa o fato de que, se os preços de transferência em geral são aptos a deslocar uma quantidade inimaginável de lucros tributáveis para países sem [ou com pouca] tributação da renda, os preços específicos em transações envolvendo a negociação global de instrumentos financeiros podem gerar distorções ainda mais gravosas. Sob a perspectiva das instituições financeiras, há elevado nível de insegurança jurídica, na medida em que as metodologias disponíveis para a comprovação dos seus preços de transferência normalmente não são adequadas a estas espécies de transações intra-grupo; teme-se, na prática, arbitramentos abusivos pelas autoridades, em virtude da impossibilidade de aplicação das regras vigentes.

Note-se, a este passo, que a maioria das empresas transnacionais consideram a questão dos preços de transferência como o tópico mais relevante no direito tributário internacional, como se depreende da pesquisa "2007-2008 Global Transfer Pricing Survey. Global Transfer Pricing Trends, Practices and Analysis”, elaborada pela Ernst \& Young 
International Ltd. em de dez./07. Quando se examina especificamente as respostas das empresas brasileiras, contudo, percebe-se que a importância da questão ainda não foi adequadamente compreendida pelas companhias nacionais que possuem controladas ou coligadas no exterior. Confira-se, abaixo, um resumo de suas respostas, extraído da p. 40 do mencionado estudo:

\begin{tabular}{|c|c|c|c|}
\hline \multirow[t]{2}{*}{ Questões propostas: } & \multicolumn{3}{|c|}{$\begin{array}{l}\text { Local onde está estabelecida a } \\
\text { controladora do grupo: }\end{array}$} \\
\hline & Brasil & América & Global \\
\hline $\begin{array}{l}\text { A questão dos preços de transferência é o } \\
\text { assunto tributário mais importante para a } \\
\text { empresa? }\end{array}$ & $4 \%$ & $31 \%$ & $39 \%$ \\
\hline $\begin{array}{l}\text { A questão dos preços de transferência se } \\
\text { tornará crítica ou muito importante nos } \\
\text { próximos dois anos? }\end{array}$ & $36 \%$ & $66 \%$ & $74 \%$ \\
\hline $\begin{array}{l}\text { A questão dos preços de transferência é mais } \\
\text { importante agora que há dois anos? }\end{array}$ & $44 \%$ & $59 \%$ & $65 \%$ \\
\hline $\begin{array}{l}\text { Os preços de transferência foram, a partir de } \\
2003 \text {, fiscalizados em algum país onde atua? }\end{array}$ & $12 \%$ & $57 \%$ & $52 \%$ \\
\hline A fiscalização resultou em ajustes? & $0 \%$ & $29 \%$ & $28 \%$ \\
\hline $\begin{array}{l}\text { O fisco efetuou uma análise adicional de } \\
\text { comparabilidade para buscar comparáveis } \\
\text { locais? }\end{array}$ & $0 \%$ & $28 \%$ & $26 \%$ \\
\hline $\begin{array}{l}\text { A estratégia de definição dos preços de } \\
\text { transferência é utilizada primordialmente para } \\
\text { reduzir riscos? }\end{array}$ & $44 \%$ & $40 \%$ & $50 \%$ \\
\hline $\begin{array}{l}\text { A estratégia de definição dos preços de } \\
\text { transferência é utilizada primordialmente para } \\
\text { planejamento tributário? }\end{array}$ & $32 \%$ & $29 \%$ & $22 \%$ \\
\hline
\end{tabular}

Fonte: Ernst \& Young International Ltd.. 2007-2008 Global Transfer Pricing Survey. Global Transfer Pricing Trends, Practices and Analysis. Dez./99, p. 40.

Na coluna "Global" foram incluídos os resultados aferidos a partir do exame das pesquisas de todos os países consultados.

Um debate mais profundo sobre o tema evitaria tanto a ausência de tributação, pelo fisco brasileiro, de renda auferida por entidade estabelecida no país, quanto a tributação excessiva de contribuintes que praticam atividades cuja adequação aos métodos tradicionais beira o impossível. A solução das controvérsias relacionadas ao controle dos preços de transferência na negociação global de instrumentos financeiros, nesse contexto, apresenta-se importante tanto para a administração tributária quanto para os contribuintes. Seu estudo, de outro lado, justifica-se também porque o direito brasileiro precisa apresentar soluções para as instituições financeiras estrangeiras que pretendam atuar no Brasil, por 
meio de subsidiária, controlada, coligada etc., ou mesmo via filial ou outro tipo de estabelecimento permanente.

\section{Corte metodológico e delimitação do tema.}

A propósito do uso abundante de material e referenciais teóricos estrangeiros na elaboração da tese [doutrina, legislação, jurisprudência administrativa e judicial etc.], é importante ponderar que não será elaborado um estudo de direito comparado propriamente dito, o qual envolve um exame global do sistema jurídico estrangeiro que seria comparado, incluindo-se as características regionais daquela jurisdição, sua evolução histórica e o exame dos principais princípios constitucionais sociais e econômicos. Mesmo diante das diversas limitações metodológicas envolvidas ${ }^{18}$, pretende-se efetuar um estudo de "direito estrangeiro", não de direito comparado. Não se intenta, portanto, comparar os sistemas jurídicos brasileiro e estrangeiro em sua totalidade [metodologia dinâmica], mas tãosomente captar práticas aceitas internacionalmente, a título de informação útil para o estudo geral das regras para o controle dos preços de transferência, desenvolvendo-se, ao final, teoria aplicável ao ordenamento brasileiro [metodologia estática].

Este exame da legislação e doutrina estrangeira permite estudar suas experiências e, ademais, captar as singularidades do direito brasileiro, de modo a criticá-las com fundamento em outras práticas internacionais. Saliente-se, a esse passo, que a flexibilidade com que a maioria dos países trata a questão do controle dos preços de transferência não pode ser refletida, diretamente e antes de profundos questionamentos,

\footnotetext{
18 A respeito da necessidade de aplicação do 'direito comparado' ao invés do mero recurso ao direito estrangeiro, confira-se ASCARELLI:

"Sono presso a poco quelle sempre ripetute e basterebbe ricordare a questo proposito il vechio libro dell'Amari: oggeto di studio deve essere il dirito comparato, e non già semplice legislazione comparata, a meno che non si vogliano arrischiare delle conclusione che, pel fatto di essere incomplete, potrebbero risulare errate. È innanzi tutto indispensabile il tener sempre presente l'unità del sistema giuridico nel suo complesso. La portata della soluzione del più modesto problema, può spesso non essere intesa, quando non si tenga presente l'unità del sistema e l'influenza dei suoi principí generale su ogni singola questione (...).

Non è difficile notare che spesso le abitudini peculiari di ciascun popolo, le diverse carattesistiche regionali, le diversità di sviluppo storico, di constituzione economica e sociale, influiscono sulla maniera di impostare $\mathrm{i}$ problemi giuridici, anche più che sulla soluzione pratica definitiva data a determinati conflitti di interesse. Lo studio del dirritto comparato deve, in sostanza, indagare l'effettiva soluzione giuridica prospettando tutti gli elementi che concorrono a determinarla.

Questo lavoro constituisce tuttavia appena un primo passo, poichè per intendere nel suo giusto valore la soluzione giuridica, occorre poi collocarla nel suo ambiente, metterla in relazione col suo svolgimento storico, con le caratteristiche del paese, con la constituzione economica di questo, e così via. Solo attraverso questo esame si può arrivare ad intendere la portata della soluzione e a comprenderne le ragione" (ASCARELLI, Tullio. Studi di Diritto Comparato e in Tema di Interpretazione. Milano: Dott. A. Giuffrè Editore, p. 6 e 9).
} 
para o sistema constitucional tributário brasileiro ${ }^{19}$, cujas regras estão abundantemente tratadas no texto constitucional, que prima pela legalidade, rigidez e segurança jurídica [sempre no viés de evitar abusos na instituição de tributos sem lei]. Algumas regras mais "fluidas" previstas em outros países, assim, precisam ser alvo de escrutínio antes de serem reproduzidas em nosso ordenamento. Não obstante isso, basear-nos-emos em estudos de direito estrangeiro, e não de direito comparado, sendo que, sempre que necessário, qualquer sugestão de transposição de regras do direito estrangeiro para o regime pátrio será ponderada vis-à-vis os princípios constitucionais tributários.

Para uma melhor delimitação do tema, cumpre salientar, desde logo, que o aspecto subjetivo de incidência das regras para o controle dos preços de transferência não será analisado nesta tese. Nesse cenário, não serão abordados: (i.) a noção de empresas associadas contida no artigo $9^{\circ}$, parágrafo 1 , da Convenção-Modelo; (ii.) o conceito e abrangência da expressão "pessoa vinculada", regulamentada pelo artigo 23 da Lei n. ${ }^{\circ}$ 9.430/96; (iii.) operações envolvendo pessoas físicas ${ }^{20}$; (iv.) a legitimidade da ampliação da hipótese material de aplicação das regras para o controle dos preços de transferência pela legislação brasileira e sua relação com os limites indicativos da OCDE; e (v.) a aplicação dos artigos 18 a 22 da Lei n. ${ }^{\circ}$ 9.430/96 a operações entre contribuintes brasileiros e pessoas estabelecidas em países com tributação favorecida ou entes com regime fiscal privilegiado,

19 "Então, o que se pretende estabelecer como premissa metodológica básica é a circunstância de que (i) no Brasil, contrariamente ao que ocorre em todos os outros países, a matéria tributária foi objeto de exaustiva disciplina constitucional, fazendo com que o estudo da ação de tributar seja necessariamente procedido a partir da Constituição; e (ii) a análise de quaisquer normas infra-constitucionais deve ser precedida da verificação de sua eventual adequação material e formal às disposições constitucionais que lhes devem servir - a estas normas infra-constitucionais - de fundamento de validade. Estas duas exigências metodológicas básicas decorrem da premissa incontestada de que o ordenamento jurídico é um conjunto de normas jurídicas organizado em sistema a partir do critério fundamental do escalonamento hierárquico, segundo o qual a norma é válida se encontrar fundamento em outra que lhe seja superior, devendo todas as normas do ordenamento jurídico brasileiro, para serem consideradas válidas, derivar da Constituição Federal, ser com ela compatíveis, material e formalmente" (LIMA GONÇALVES, José Artur. Certos Aspectos da Disciplina dos Preços de Transferência em face do Ordenamento Constitucional Brasileiro. In: Luís Eduardo Schoueri e Valdir de Oliveira Rocha, Tributos e preços de transferência. São Paulo: Dialética, 1999, v. 2, p. 219).

${ }^{20}$ No direito brasileiro, as regras para o controle dos preços de transferência aplicam-se também às pessoas físicas, conforme se depreende dos artigos 23, 24 e 24-A da Lei n. ${ }^{\circ}$ 9.430, de 27 de dezembro de 1996 e subseqüentes modificações. Adicionalmente, a Instrução Normativa n. ${ }^{\circ}$ 243, de 11 de novembro de 2002, disciplina essa questão, de forma a não deixar margens a dúvidas. Confira-se:

“Art. $1^{\circ}$ Para efeito da legislação do imposto de renda e da Contribuição Social sobre o Lucro Líquido (CSLL), a dedutibilidade de custos de bens, serviços e direitos importados e o reconhecimento de receitas e rendimentos derivados da exportação, em operações praticadas por pessoa física ou jurídica residente ou domiciliada no Brasil, com pessoa física ou jurídica residente ou domiciliada no exterior, consideradas vinculadas, será efetuada de conformidade com o disposto nesta Instrução Normativa. (...)

$\$ 2^{\circ}$ As disposições relativas ao tratamento tributário nas operações praticadas por pessoa jurídica domiciliada no Brasil, com pessoa física ou jurídica residente ou domiciliada no exterior, aplicam-se, no que couberem, às operações praticadas por pessoa física residente no Brasil com pessoa física ou jurídica residente ou domiciliada no exterior". 
nos termos dos artigos 24 e 24-A da Lei n. ${ }^{\circ}$ 9.430/96. Ainda no que respeita ao aspecto subjetivo, importa destacar que as expressões "pessoa vinculada", "parte vinculada", "pessoa relacionada" ou "parte relacionada" serão mencionadas indistintamente no texto para o fim de indicar os sujeitos alcançados pelas regras para o controle dos preços de transferência. Adicionalmente, as expressões “empresas multinacionais" ou "transnacionais", não obstante as dificuldades apontadas por Heleno Taveira TÔRRES ${ }^{21}$, também não serão tratadas de forma indistinta, como sinônimos.

Um outro corte metodológico e limitador da tese consiste na ausência de exame das discussões jurídicas envolvendo a tributação dos rendimentos de aplicações financeiras e/ou derivativos propriamente ditos. Não serão analisadas, assim, as regras aplicáveis aos rendimentos gerados por aqueles instrumentos aos seus titulares, mas tão-somente as normas que regulamentam o controle que deve necessariamente existir sobre os preços de transferência entre instituições financeiras que desenvolvem, estruturam e/ou revendemnos. Por outras palavras, não se busca examinar a tributação do investidor no mercado financeiro, mas sim das instituições financeiras que intermedeiam ou participam diretamente daqueles negócios. Por decorrência, o tema da retenção de imposto sobre a renda na fonte sobre os pagamentos de rendimentos decorrentes de produtos financeiros ou derivativos, que geralmente envolve a discussão da aplicabilidade do artigo 21 da Convenção-Modelo da $\mathrm{OCDE}^{22}$, também não será abordado.

\footnotetext{
${ }^{21}$ Heleno Taveira TÔRRES aponta dificuldades que circundam a expressão "empresas multinacionais" e da necessidade de que uma determinada empresa seja dotada de múltiplas residências para se enquadrar nessa noção (In: TÔRRES, Heleno Taveira. Pluritributação internacional sobre as rendas de empresas. $2^{\mathrm{a}}$ ed. rev., atual. e ampl. São Paulo: Revista dos Tribunais, 2001, p. 178-179).

22 "Artigo $21^{\circ}$ OUTROS RENDIMENTOS.

1. Os elementos do rendimento de um residente de um Estado contratante e donde quer que provenham não tratados nos Artigos anteriores desta Convenção só podem ser tributados nesse Estado.

2. O disposto no n. $^{\circ} 1$ não se aplica ao rendimento, que não seja rendimento de bens imobiliários como são definidos no n. ${ }^{\circ} 2$ do Artigo $6^{\circ}$, auferido por um residente de um Estado contratante que exerce actividade no outro Estado contratante por meio de um estabelecimento estável nele situado ou que exerce nesse outro Estado uma profissão independente através de uma instalação fixa nele situada, estando o direito ou a propriedade, em relação ao qual o rendimento é pago efectivamente ligado com esse estabelecimento estável ou instalação fixa. Neste caso, são aplicáveis as disposições do Artigo $7^{\circ}$ ou do Artigo $14^{\circ}$, consoante o caso". Tradução extraída da obra OCDE. Modelo de Convenção Fiscal sobre o Rendimento e o Patrimônio. op. cit., p. 39-40.

Veja-se que o Artigo $21^{\circ}$ da Convenção-Modelo prevê, como regra geral, a tributação no Estado de residência. O Brasil, contudo, prevê outra redação nos seus acordos, como se depreende do Artigo $21^{\circ}$ da Convenção entre o Governo da República Federativa do Brasil e o Governo da República do Chile Destinada a Evitar a Dupla Tributação e Prevenir a Evasão Fiscal em Relação ao Imposto sobre a Renda, de 03 de abril de 2001, promulgada pelo Decreto n. ${ }^{\circ} 4.852$, de 02 de outubro de 2003:

"ARTIGO 21. Outros Rendimentos
} 
Outro aspecto a ser ponderado é que esta tese não discutirá o tema do controle dos preços de transferência vis-à-vis as regras do direito aduaneiro, em especial os métodos para a definição do valor aduaneiro. Não há dúvidas de que ambos os assuntos têm estreita proximidade, em especial porque ambos representam normas tributárias antielusivas relacionadas a negócios internacionais. Não se pode negar, outrossim, ser desejável uma aproximação entre os métodos previstos nos artigos 18 e 19 da Lei n. ${ }^{\circ}$ 9.430/96, com os métodos previstos no Acordo sobre a implementação do artigo VII do Acordo Geral sobre Tarifas e Comércio ("GATT") de 1994, constante do Anexo 1A ao Acordo Constitutivo da Organização Mundial de Comércio, aprovado pelo Decreto Legislativo n. ${ }^{\circ}$ 30, de 15 de dezembro de 1994, e promulgado pelo Decreto n. ${ }^{\circ}$ 1.355, de 30 de dezembro de 1994, os

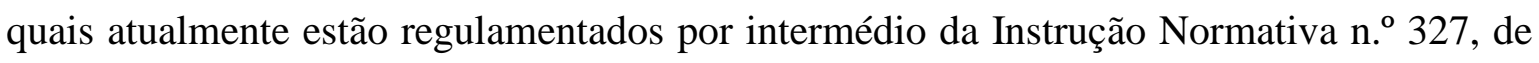
09 de maio de 2003. Com efeito, não seria lógico que um certo contribuinte estivesse sujeito a um procedimento de valoração aduaneira que considerasse seu preço de importação muito reduzido e, a um mesmo tempo, os custos daquela mesma importação fossem considerados indedutíveis na aferição do IRPJ e da CSLL por decorrência das regras de preço de transferência. Seria necessária, no mínimo, uma certa harmonia entre os dois regramentos. Independentemente disso, essa discussão não será alvo de análise detida no âmbito da tese, que concentrará esforços no exame dos desafios que alguns tipos de operações trazem aos métodos tradicionais e transacionais e, por vezes, ao próprio princípio da plena concorrência.

Não será objeto da tese, outrossim, a abrangência do conceito de estabelecimento permanente, definido no Artigo $5^{\circ}$ da Convenção-Modelo, nem especificamente a aferição do seu respectivo resultado tributável em cada nação contratante, nos termos do Artigo $7^{\circ}$; o foco da tese é o exame da partição de lucros entre pessoas jurídicas distintas, consideradas vinculadas, i.e., o estudo do conteúdo do Artigo $9^{\circ}$ da Convenção-Modelo e a elaboração de críticas construtivas à aplicação do princípio da plena concorrência no direito brasileiro. Não obstante isso, por vezes serão citados exemplos extraídos das normas de atribuição de lucros a estabelecimentos permanentes, dado que a estes casos também é aplicado o princípio da plena concorrência. Nesse cenário, os estudos e julgados envolvendo os lucros imputáveis a estabelecimentos

Os rendimentos de um residente de um Estado Contratante não mencionados nos Artigos anteriores da presente Convenção e provenientes do outro Estado Contratante podem ser tributados nesse outro Estado Contratante". 
permanentes podem, desde que ponderadas as diferenças entre os dois casos, ser aplicados à partição de lucros entre duas pessoas jurídicas.

A tese não abrangerá discussões sobre "Advance Pricing Arrangements" (“APA"), “Mutual Agreement Procedures" ("MAP”), ou outros procedimentos administrativos relacionados à implementação de regras para o controle dos preços de transferência. Em apertada síntese, os APA representam um procedimento que permite a determinação prévia, por um certo período, de critérios para aferição dos preços de transferência. Há APA unilaterais, firmados perante um uma única jurisdição e sem a intervenção das autoridades do outro país, onde se localiza a empresa vinculada contraparte daquelas mesmas operações; nestes casos, contudo, existe um elevado risco de redução indevida do lucro tributável no país não participante do APA. Existem, ademais, os APA multilaterais, firmados entre duas ou mais jurisdições, os quais são recomendados pela OCDE por permitirem, em grande medida, a eliminação de bitributação nas questões atinentes a preços de transferência ${ }^{23}$. Recomenda-se, outrossim, que os APA multilaterais sejam elaborados a partir do procedimento do MAP, previsto detalhadamente no Artigo $25^{\circ}$ da Convenção-Modelo. Considerando que o procedimento de "transação" entre a administração tributária e o contribuinte no Brasil ainda não está adequadamente regulamentado, havendo várias discussões sobre o assunto, a negociação de métodos e/ou critérios, consoante se sucede nos APA, não será abordada na tese.

\footnotetext{
23 "4.65. Between those countries that use APAs, greater uniformity in APA practices could be beneficial to both tax administrations and taxpayers. Accordingly, the tax administrations of such countries may wish to consider working agreements with the competent authorities for the undertaking of APAs. These agreements may set forth general guidelines and understandings for the reaching of mutual agreement in cases where a taxpayer has requested an APA involving transfer pricing issues" (OCDE. Transfer Pricing Guidelines for Multinational Enterprises and Tax Administrations. op. cit., p. IV-21).
} 


\section{CAPÍTULO 1. CONTEÚDO, ORIGEM E ALCANCE DAS REGRAS PARA O CONTROLE DOS PREÇOS DE TRANSFERÊNCIA.}

\subsection{Definição e função dos preços de transferência.}

Em sua Diretiva, a OCDE definiu os preços de transferência da seguinte forma: "transfer prices are the prices at which an enterprise transfer physical goods and intangible property or provides services to associated enterprises" (Paris: OCDE, 2001, p. P-3) ${ }^{24}$. Neste cenário, consideram-se preços de transferência aqueles definidos nos negócios jurídicos praticados entre empresas associadas, i.e., operações de venda e compra de bens corpóreos ou incorpóreos, de prestação de serviços, de cessão de direito de uso ou qualquer outra forma de transferência de intangíveis etc.. Note-se que, para a adequada compreensão da expressão "preços de transferência", não se deve recorrer à definição técnico-comercial de "preço" 25 , mas, pelo contrário, este termo deve ser apreendido de forma amplíssima, abrangendo todas as contraprestações pecuniárias envolvidas em operações que possam ser estabelecidas entre empresas vinculadas; o "preço" de uma determinada transação ou transferência representa, na prática, o valor de uma contraprestação contratual que seja apto a influir no rendimento tributável das partes que transacionam.

Para a caracterização dos preços de transferência "stricto sensu", nos moldes que se pretende discutir no presente estudo, é imprescindível que exista um negócio praticado entre duas empresas associadas [pertencentes a um mesmo grupo empresarial] estabelecidas em jurisdições distintas $^{26}$. O valor envolvido em operações realizadas no seio

\footnotetext{
${ }^{24}$ A expressão preços de transferência também é utilizada para designar o ramo de estudo do direito, economia e contabilidade que se dedica ao exame da precificação das operações entre partes relacionadas. Confira-se: "Transfer pricing is the area of tax law and economics that is concerned with ensuring that prices charged between associated enterprises for the transfer of goods, services and intangible property accord with the arm's length principle" (IBFD. International tax glossary, 5th ed. completely revised, Amsterdã: IBFD, 2005, p. 422).

25 "Mas o que se quer dizer, efetivamente, com o termo 'preços de transferência'? Aqui não se deve tomar a palavra 'preço' no seu sentido técnico, como 'valor a ser cobrado ou pago em uma operação mercantil de cunho lucrativo', de modo que 'preço' corresponderá sempre à noção de contraprestação pecuniária em face da venda de bens, prestação de serviços ou concessão de direitos, cuja efetivação permite às partes a concretização de transferências (físicas ou meramente escriturais), além do pagamento em si de lucros ou custos, elementos positivos ou negativos que possam influir no rendimento tributável das empresas conexas, em qualquer modo, num ou noutro país" (TÔRRES, Heleno Taveira. Direito tributário internacional: planejamento tributário e operações transnacionais. São Paulo: Revista dos Tribunais, 2001, p. 162-163).

${ }^{26}$ No direito brasileiro, não pairam dúvidas de que os preços de transferência são uma noção que envolve tão-somente transações internacionais, como se pode depreender dos subtítulos dos artigos 18 e 19 da Lei n. ${ }^{\circ}$ 9.430/96: "Bens, serviços e direitos adquiridos no Exterior" e "Receitas oriundas de exportação para o Exterior”. Esta noção de internacionalidade também está impregnada na Diretiva da OCDE. Confira-se:
} 
de um mesmo país não corresponde a um preço de transferência, porque se sujeita apenas a fórmulas de ajustes de resultados e correção de distorções no lucro contábil impostas pela legislação interna de cada nação. A problemática dos preços de transferência está, por conseguinte, diretamente vinculada ao direito tributário internacional.

Com efeito, a política de preços praticada em quaisquer negócios entre empresas vinculadas é objeto de amplos estudos, porque, como estão ausentes as forças de mercado no momento da negociação daqueles $\operatorname{preços}^{27}$, eles podem, eventualmente, ser fixados/impostos em desacordo com as práticas que seriam adotadas por empresas independentes, ou seja, podem ser definidos preços distintos dos que seriam "normais" ou “justos" para uma determinada transação ${ }^{28}$. Considerando que as partes que transacionam localizam-se em países distintos, a possível fixação/imposição de preços de transferência "artificiais" ou "manipulados" influi no resultado tributável alocado em cada jurisdição. O estudo das regras para o controle dos preços de transferência configura-se, assim, tanto uma importante problemática a ser discutida no seio dos países [que necessitam "proteger" seus resultados tributáveis], quanto um tópico que merece destaque no âmbito das organizações internacionais, porque a sobreposição de ajustes decorrentes da aplicação das leis internas acarreta efeitos maléficos como a bitributação econômica da renda; deve-se trabalhar, sempre, no sentido de obter um certo grau de uniformidade entre as leis internas.

\footnotetext{
"Transfer pricing issues originally arose in dealing between associated enterprises operating within the same tax jurisdiction. The domestic issues are not considered in this Report, which focuses on the international aspects of transfer pricing" (OCDE. Transfer Pricing Guidelines for Multinational Enterprises and Tax Administrations. op. cit., p. P-5).

27 " 1.2 . When independent enterprises deal with each other, the conditions of their commercial and financial relation (e.g. the price of goods transferred or services provided and the conditions of the transfer or provision) ordinarily are determined by market forces. When associated enterprises deal with each other, their commercial and financial relations may not be directly affected by external market forces at the same way, although associated enterprises often seek to replicate the dynamics of market forces in their dealings with each other (...)"(OCDE. Transfer Pricing Guidelines for Multinational Enterprises and Tax Administrations. op. cit., p. I-1). Texto não alterado pela Minuta-2009.

${ }^{28}$ Esta possibilidade de manipulação é tão ínsita à questão dos preços de transferência que consta da definição proposta por vários autores. Confiram-se, a título exemplificativo, as definições propostas por Luís Eduardo SCHOUERI e Alberto XAVIER:

"Por preço de transferência entende-se o valor cobrado por uma empresa na venda ou transferência de bens, serviços ou propriedade intangível a empresa a ela relacionada. Tratando-se de preços que não se negociaram em um mercado livre e aberto, podem eles se desviar daqueles que teriam sido acertados entre parceiros comerciais não relacionados, em transações comparáveis nas mesmas circunstâncias" (SCHOUERI, Luís Eduardo. Preços de Transferência no Direito Tributário Brasileiro. $2^{\mathrm{a}}$ ed. rev. e atual., São Paulo: Dialética, 2006, p. 10); e

"A prática denominada preços de transferência consiste na política de preços que vigora nas relações internas de empresas interdependentes e que, em virtude destas relações especiais, pode conduzir à fixação de preços artificiais, distintos dos preços de mercado" (XAVIER, Alberto. Direito Tributário Internacional do Brasil, $6^{\mathrm{a}}$ ed., ref. e atual. Rio de Janeiro: Forense, 2004, p. 362-363).
} 
Note-se, por relevante, que as empresas associadas "podem" eventualmente manipular seus preços de transferência, mas não necessariamente o fazem ${ }^{29}$. Na maioria dos grandes grupos multinacionais, v.g., não é viável que uma administração centralizada possa a monitorar e controlar todos os negócios de cada unidade que os compõem. Os negócios são, por conta disso, segregados em determinadas divisões, sendo cada uma delas dirigida por um diretor especializado e apto a apreender melhor e com mais detalhes os aspectos favoráveis e os obstáculos atinentes a cada divisão de negócios. Essa especialização permite um conhecimento aprofundado da divisão pelo respectivo diretor,além da tomada de decisões mais bem fundamentadas. No âmbito das empresas multinacionais, portanto, a freqüente segregação das atividades em divisões tem por fim (a.) permitir a cada divisão tomar suas próprias decisões, tal como a de fixar o preço de seus produtos finais; (b.) garantir a coordenação dos diversos segmentos da corporação; (c.) avaliar o desempenho de cada divisão de negócios e, por exemplo, avaliar necessidades de novos investimentos; e/ou (d.) calcular os bônus ou outras espécies de remuneração variável dos administradores de cada divisão ${ }^{30}$.

Em um banco comercial, por exemplo, é relevante, para fins gerenciais, a aferição do resultado proporcional que pode ser atribuído a cada agência e/ou área de negócio em relação ao lucro total da instituição. Nesse cenário, se uma certa agência capta maiores depósitos de seus correntistas, efetua mais empréstimos ou vende produtos como

29 "Tax administrations should not automatically assume that associated enterprises have sought to manipulate their profits";

"It should not be assumed that the conditions established in the commercial and financial relations between associated enterprises will invariably deviate from what the open market should demand. Associated enterprises in MNEs commonly have a considerable amount of autonomy and often bargain with each other as thought they were independent enterprises. Enterprises respond to economic situations arising from market conditions, in their relations with both third parties and independent enterprises" (OCDE. Transfer Pricing Guidelines for Multinational Enterprises and Tax Administrations. op. cit., p. I-1 e I-2). Textos não alterados pela Minuta-2009.

30 "No obstante, el control eficiente de las grandes empresas exige la autonomía de gestión de sus diferentes unidades organizativas y muchas de ellas optan por la gestión descentralizada creando centros de beneficios o de inversión, sobre todo en la cadena de producción. La configuración de los miembros vinculados como centro de beneficios o de inversión responde al objetivo de promover la propia maximización del beneficio contable de los mismos. Así, estos centros se caracterizan por la independencia operativa, por la libertad de acceso a las fuentes de aprovisionamiento y a los mercados y por la necesidad de establecer precios de transferencia neutrales con el propósito de conocer el valor de las transacciones internas. En consecuencia, las operaciones internas entre centros de beneficios pueden realizase en condiciones normales de mercado. Sus directores, motivados por la maximización de sus propios beneficios o incluso incentivados por una eventual remuneración extra establecida por la matriz, tenderán a actuar como empresas independientes en sus relaciones comerciales internas, negociando los precios de transferencia, es decir, reproduciendo el conflicto de intereses del esquema del mercado abierto. Así lo ha venido reconociendo la OCDE en sus Informes sucesivos" (GALVAÑ, Gemma Sala. Los Precios de Transferencia Internacionales. Su Tratamiento Tributario. Valencia: Tirant lo Blanch, 2003, p. 43). 
seguros e previdência privada em maior quantidade, essa segregação do lucro "por agência" permitirá que os diretores da instituição avaliem melhor seus investimentos naquela região geográfica e/ou na estrutura física daquela agência, além de facilitar o cálculo adequado dos bônus de seus funcionários. Esse exemplo é bastante simplista, mas permite inferir, v.g., que nunca o gerente de uma agência $X$ orientaria um de seus correntistas a adquirir seu fundo de previdência privada na agência $Y$, porque cada divisão/agência concentra esforços para angariar maiores resultados e, por conseguinte, melhor avaliação gerencial e bônus mais elevados.

Transmudando-se esse raciocínio para o caso de um banco de investimentos, pertencente a um conglomerado financeiro internacional, que presta serviços de estruturação de operações de fusões e aquisições ("merger and acquisitions" ou "M\&A"), poder-se-ia concluir que, também nesta hipótese, esta instituição buscará os maiores lucros (isolados) e uma melhor avaliação global. Assim, e.g., se a instituição for contratada, por terceiros não-vinculados, para estruturar uma operação avaliada em US\$500milhões, cobrará um percentual $\mathrm{X}$ a título de comissão para a condução do negócio; quando da realização de uma aquisição por conta de outra empresa de seu grupo econômico, em valor de patamar semelhante, aquela instituição também buscará remunerar-se pelo mesmo percentual $\mathrm{X}$, porque a concessão de quaisquer descontos ou abatimentos implicará na redução de sua lucratividade anual, além de impactar sua avaliação gerencial e os bônus dos seus administradores e funcionários.

Independentemente da constatação de que, em princípio, há uma busca de lucro por empresa ou por divisão do negócio, decorrente de fatores de ordem gerencial, não se pode negar que as transações entre partes relacionadas potencialmente podem ser utilizadas como eficiente mecanismo para a alocação dos lucros de um determinado grupo econômico em jurisdição com tributação reduzida e/ou mais favorecida ${ }^{31}$, mediante a fixação de preços artificiais. Por vezes, as empresas que compõem um determinado grupo econômico negociam seus preços de transferência mas, como decorrência "natural" de uma gestão administrativa mais eficiente, permitem o deslocamento de despesas dedutíveis para

\footnotetext{
31 “Os grupos multinacionais de sociedades possuem nos preços de transferência um considerável potencial de deslocamento dos lucros, em detrimento do Estado do destino ou da origem da mercadoria importada ou exportada" [ROTHMAN, Gerd W. Preços de transferência - Método do preço de revenda menos lucro: base CIF (+II) ou FOB. A margem de lucro (20\% ou 60\%) em processos de embalagem e beneficiamento. In: Revista Dialética de Direito Tributário. São Paulo: Dialética, v. 165, jun./09, p. 37].
} 
países com tributação mais elevada ${ }^{32}$; é importante ponderar que as empresas de um mesmo grupo não raciocinam tão "egoisticamente" quanto as empresas independentes. Ademais, à medida que ocorre uma centralização de poder no âmbito dos grupos multinacionais, reduz-se a influência das "forças de mercado" na precificação das operações. Nos casos em que, e.g., há um poder decisório único no âmbito de um grupo multinacional, que busca sempre o maior lucro e a menor carga tributária global possíveis, pode-se impor um regime de preços privilegiados ou anormais às empresas associadas, o qual passará a gerar importantes efeitos tributários [excesso de custos dedutíveis em operações de importação ou reduzido reconhecimento de receitas nas exportações, conforme o caso].

Os preços de transferência, neste cenário, podem servir para a prática de elusão fiscal internacional ${ }^{33}$, a qual deve ser fiscalizada [e eliminada] a partir de regras para o controle dos preços de transferência. Veja-se que, no exame da elusão fiscal, examina-se a realização de atos lícitos, praticados no âmbito da esfera de liberdade que o contribuinte possui para organizar mais racionalmente seus negócios diante de uma pluralidade de ordenamentos fiscais; a prática desses atos lícitos, todavia, tem por objetivo impedir a ocorrência da obrigação tributária em um país X [com legislação menos favorável], transferindo-a para Y [com tributação em nível inferior ao país X]; busca-se uma alteração nos elementos de conexão, com o objetivo de que a renda seja reconhecida por outra jurisdição, "escolhida" pelo grupo multinacional ${ }^{34}$. O país $Y$ não precisa ser

\footnotetext{
${ }^{32}$ Justamente por esta razão é que a prova de negociação, por si só, não é suficiente para o exame dos preços vinculados: sempre será preciso a aplicação dos métodos. Confira-se:

"Sometimes, it may occur that the relationship between associated enterprises may influence the outcome of the bargaining. Therefore, evidence of hard bargaining alone is not sufficient to establish that the dealings are at arm's length" (OCDE. Transfer Pricing Guidelines for Multinational Enterprises and Tax Administrations. op. cit., p. I-2). Texto não alterado pela Minuta-2009.

${ }^{33}$ A expressão "elusão fiscal" será utilizada nesta tese como sendo o fenômeno pelo qual o contribuinte, mediante a prática de atos lícitos, mas desprovidos de causa, tenta evitar o surgimento de uma obrigação tributária, consoante sentido a ela atribuído por Heleno Taveira TÔRRES, na obra Direito Tributário e Direito Privado, São Paulo: Revista dos Tribunais, 2003, p. 189.

Seguindo-se esta mesma linha de raciocínio, Alberto XAVIER qualifica a política de definição de preços de transferência como possível elisão fiscal internacional objetiva, i.e., como uma espécie de elisão fiscal que se concretiza a partir (a.) do impedimento da concretização da fonte de produção da renda ou (b.) da imputação, total ou parcial, daquela renda, a território sem tributação ou com regime mais favorável. Esse tipo de elisão foi qualificada como objetiva porque operam-se a partir da modificação de elementos de conexão objetivos, como, i.e., a fonte de produção da renda, visando impedir sua configuração jurídica. (XAVIER, Alberto. Direito Tributário Internacional do Brasil, $6^{a}$ ed., ref. e atual. Rio de Janeiro: Forense, 2004, p. 309 e 354).

${ }^{34}$ Alberto XAVIER sustenta que a figura da elisão fiscal "reside precisamente nesta faculdade de eleição da ordem tributária aplicável, (...) pela via indireta de localizar certo fato ou fatos num dado ordenamento ou território, exercendo uma influência voluntária no elemento de conexão da norma de conflitos, em termos tais que o fato jurídico em que este se traduz arraste a aplicação do ordenamento mais favorável" (XAVIER, Alberto. Direito Tributário Internacional do Brasil, op. cit., p. 310-311).
} 
necessariamente um país que não tribute aquela renda: basta que a tribute em condições mais favoráveis que aquelas impostas por X. Por “condições mais favoráveis” devem ser entendidos quaisquer benefícios econômico-financeiros ou tributários, de qualquer natureza, que o grupo obteve perante o país Y, como, e.g., o aproveitamento fiscal de prejuízos acumulados em Y, reduções na base de cálculo tributária como aproveitamento de depreciações aceleradas ou amortizações de qualquer tipo etc. ${ }^{35}$.

Veja-se que o controle dos preços de transferência e das condições dos negócios praticados entre partes vinculadas é relevantíssimo no atual estágio da globalização, porque sua prática pode consentir com uma transferência artificial de riqueza tributável, exercida ao sabor dos interesses estratégicos dos grupos multinacionais ${ }^{36}$. De outro lado, não se pode negar que as transações internacionais no interior de um mesmo grupo são quantitativamente mais relevantes que as transações independentes, haja vista a constante ampliação dos processos de expansão horizontal e vertical dos grupos transnacionais. Portanto, se, de um lado, os preços de transferência prestam-se à elusão internacional, de outro não há dúvidas acerca de sua relevância para a elevação da lucratividade total das empresas multinacionais e, por conseguinte, para o desenvolvimento global das nações.

Suponha-se, v.g., que as atividades do grupo multinacional W estejam repartidas entre as divisões $\mathrm{X}$ e $\mathrm{Y}$, sendo que cada divisão representa uma companhia

\footnotetext{
35 “Assim, as transações entre pessoas vinculadas ou submetidas a um único poder de decisão, envolvendo cessões de bens, financiamentos, utilização de bens imateriais ou prestações de serviços, passaram a ser praticadas com preços de transferência divergentes dos preços dos bens, taxas de juros, riscos de câmbio, royalties, recuperações de custos ou outros instrumentos, tal como praticado em regime de livreconcorrência. Por conseguinte, tais operações passaram a ter relevância fiscal porque muitas foram estrategicamente organizadas para, indiretamente: i) gerar transferências de bases de cálculo de países de maior tributação para outros de menor incidência; ii) compensar bases de cálculo negativas (perdas) com positivas; iii) reduzir a base de cálculo dos impostos indiretos; ou iv) diferir, espontaneamente, o pagamento dos tributos" (TÔRRES, Heleno Taveira. Direito tributário internacional: planejamento tributário e operações transnacionais. op. cit., p. 161-162).

No mesmo sentido, confira-se passagem de Gemma Sala GALVAÑ:

"Existen supuestos más complejos y SUS combinaciones son múltiples, como repartir los costes en los que incurre la matriz por actividades que sólo realiza en su calidad de socio entre sus filiales extranjeras haciéndolas pagar una contraprestación por esos servicios prestados, o establecer un centro de servicios centralizados en un Estado de baja tributación que presta servicios ya repetidos o sin conexión (o sólo en parte) con la actividad de las beneficiarias vinculadas ubicadas en países de alta tributación.

Otros supuestos de manipulación podrían darse entre Estados con tipos de gravamen más o menos parecidos. Así, la realización de ciertas operaciones trasladando todos los beneficios al Estado donde gozan de deducciones en la cuota, la enajenación por encima del valor de mercado de bienes amortizables a la empresa vinculada del Estado donde disfruten de libertad de amortización o la canalización los beneficios de las operaciones vinculadas a la entidad en situación prolongada de pérdidas. $\mathrm{O}$, simplemente, la preferencia por un contrato de compraventa que mueva a los beneficios a otros Estados sin estar sujetos a retención en el Estado de la fuente" (GALVAÑ, Gemma Sala. op. cit., p. 48-49).

36 A expressão 'transferência artificial de riqueza tributável' foi extraída de TÔRRES, Direito tributário internacional: planejamento tributário e operações transnacionais. op. cit., p. 168.
} 
autônoma e estabelecida em jurisdições distintas [países X e Y]. A Divisão X produz x, produto intermediário bastante raro que, quando processado pela Divisão Y, transforma-se no produto final $\mathrm{y} ; \mathrm{y}$ apenas pode ser produzido a partir da matéria-prima $\mathrm{X}$. A divisão $\mathrm{X}$ pode vender $\mathrm{x}$ tanto para a Divisão $\mathrm{Y}$ quanto para terceiros independentes, que são aptos a processar x mediante processo semelhante àquele adotado pela Divisão Y. O custo de produção de cada unidade de $\mathrm{x}$ é $\$ 5$, sendo que a Divisão $\mathrm{X}$ pode alienar x pelo preço unitário de $\$ 10$ a terceiros independentes, auferindo-se um lucro tributável de $\$ 5$ no país $X$ (Situação 1). Alternativamente, a Divisão X optou por vender sua produção para a Divisão Y por $\$ 5$, a qual processou $\mathrm{x}$ a um custo de $\$ 3$ por unidade e vendeu no mercado por $\$ 20$ (Situação 2). Nesta situação hipotética, se a Divisão $X$ tivesse vendido x para terceiros, $o$ lucro do grupo [por unidade] seria de $\$ 5$ e a Divisão Y não teria desenvolvido suas atividades industriais por ausência de matéria-prima. De outro lado, ao alienar $100 \%$ de sua produção para a Divisão $\mathrm{Y}$, o lucro tributável da Divisão $\mathrm{X}$ foi igual a zero, mas o lucro da Divisão Y [e do grupo, globalmente considerado] foi de \$12 [preço de venda de $\$ 20$ deduzido das despesas de $\$ 5$ e \$3], superior em $240 \%$ ao lucro que teria sido auferido isoladamente pela Divisão X. Neste exemplo está claro que a integração vertical do grupo W é desejável, porque possibilita uma elevação de seus lucros. Ao precificar suas operações na forma supra descrita, contudo, o grupo multinacional $\mathrm{W}$ reduziu indevidamente o lucro tributável no país $\mathrm{X}$ de $\$ 5$ para zero, transferindo-se todo o resultado tributável da operação para o país $\mathrm{Y}$, que possui alíquotas reduzidas do imposto sobre a renda. Confira-se, abaixo, organograma que melhor explica este exemplo: 


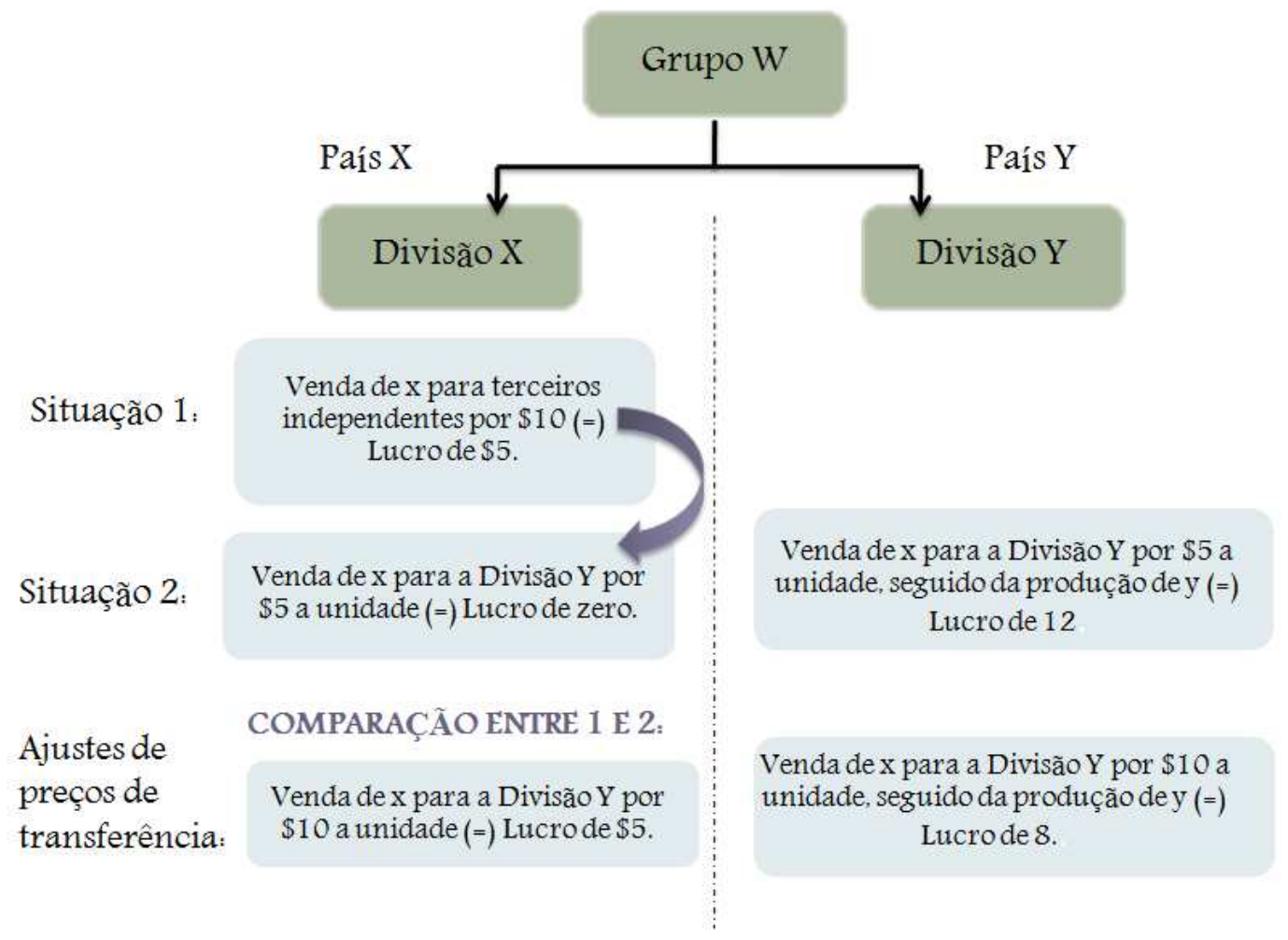

Note-se que, na situação 2, a redução do lucro tributável no País X foi indevida, porque não se pode coadunar com a prática da venda de bens para empresas vinculadas pelo "preço de custo", especialmente nas hipóteses em que há outras alternativas lucrativas disponíveis [como a alienação por \$10 para terceiros independentes]. Não é razoável a celebração de negócios em condições piores que aquelas que poderiam ser obtidas no livre mercado, especialmente quando se tem em vista que todo o lucro do grupo empresarial foi transferido para o País Y, que possui regime tributário mais benéfico se comparado àquele existente em X; trata-se, claramente, de hipótese de elusão fiscal. Nestes casos, há evidente afastamento da atuação das "forças de mercado", devendo a legislação para o controle dos preços de transferência garantir o ajuste nos preços praticados, adequando-os àqueles que seriam praticados entre empresas independentes em condições semelhantes. Como se demonstrará no CAPÍTULO 2, tem sido reconhecido, no direito tributário internacional, que a comparação dos preços praticados entre partes vinculadas com aqueles praticados [ou que teriam sido praticados] entre empresas independentes afigura-se como a forma mais justa e razoável para eliminar os efeitos da manipulação de preços. Por isso, na linha "Ajustes de Preços de Transferência" do esquema acima, foi reconhecido um lucro de \$5 no País X. 
Ainda no que concerne ao reduzido impacto das "forças de mercado" na definição dos preços de transferência, Luís Eduardo SCHOUERI consigna que "enquanto a moeda constante nas contas das empresas com transações controladas está expressa em unidades 'reais de grupo', empresas independentes têm seus resultados expressos em 'reais de mercado'. Nesta perspectiva, o papel da legislação de preços de transferência é apenas converter valores expressos em 'reais de grupo' para 'reais de mercado', possibilitando, daí, uma efetiva comparação entre contribuintes com igual capacidade econômica. Neste sentido, verifica-se que a legislação de preços de transferência não distorce resultados da empresa. Apenas 'converte' para uma mesma unidade de referência ('reais de mercado') a mesma realidade expressa noutra unidade",37. Na visão deste autor, a ausência de um efetivo mercado nas transações intra-grupo torna-as distintas das operações independentes, o que justifica [se necessário] o ajuste contábil nas operações, para fins da aferição da capacidade econômica tributável de cada contribuinte, nos termos do artigo $145, \S 1^{\circ}$, da Constituição Federal ${ }^{38}$.

${ }^{37}$ Cf. SCHOUERI, Luís Eduardo. Preços de Transferência no Direito Tributário Brasileiro. $2^{\mathrm{a}}$ ed. rev. e atual., São Paulo: Dialética, 2006, p. 15.

Seguindo-se esta mesma linha de raciocínio, Juan Ignacio Moreno FERNÁNDEZ, ao abordar a questão dos preços de transferência à luz da constituição espanhola, esclareceu que os possíveis ajustes são necessários por que o legislador constitucional busca a tributação igual de contribuintes com semelhantes capacidades econômicas "reais"; trata-se da tributação justa a partir da verdade material tributária. Veja-se:

"Un primer acercamiento a la cuestión que nos ocupa permite adelantar que el fundamento del ajuste valorativo en las operaciones vinculadas y, en su efecto, del trato desigual que les dispensa el ordenamiento tributario respecto de las operaciones efectuadas entre partes independientes, se encuentra, a nuestro juicio, en el intento del legislador de someter a tributación, no tanto la capacidad económica efectiva puesta de manifiesto por los sujetos pasivos en la operación de que se trate, sino la capacidad económica real que subyace a la citada operación.

Por este motivo, el aparente trato desigual que acoge el ordenamiento tributario para las partes vinculadas, implica justamente lo contrario: un intento de trato igual a todos los sujetos del Impuesto (salvo excepciones)" (La Tributación de las Operaciones Vinculadas. 2 ${ }^{\mathrm{a}}$ ed. Navarra: Thomson Aranzadi, Colección Monografías Aranzadi n. ${ }^{\circ}$ 128, 2003, p. 28).

38 “1.2.1.4. É sob esta perspectiva que se deve considerar a legislação sobre preços de transferência: será ela constitucional - porque compatível com o artigo 43 do Código Tributário Nacional - se os ajustes por ela impostos servirem para corrigir eventuais distorções do lucro contábil da pessoa jurídica, aproximando o resultado, destarte, da efetiva renda da empresa.

1.2.1.5. Neste sentido, cabe ponderar em que cenário se insere a legislação de preços de transferência. Trata ela de transações entre partes vinculadas. Estas transações diferenciam-se daquelas praticadas por partes independentes pela ausência do mercado como árbitro da distribuição de riquezas. (...)

1.2.1.9. Compreende-se, assim, por que razão o lucro contábil deixa de ser um parâmetro necessariamente confiável para a apuração da riqueza gerada pela pessoa jurídica: sendo ele o resultado aritmético das transações efetuadas, apenas servirá ele de medida da renda se os negócios se celebrarem entre partes independentes. Assim, á idéia de que o lucro contábil serviria para apurar a renda ganha uma condicionante: desde que o lucro reflita preços de mercado.

1.2.1.10. Que fazer quando as transações se efetuaram entre partes ligadas? Do mesmo modo, o lucro contábil servirá como medida da renda da pessoa jurídica se os preços ali computados foram os de mercado. Não o sendo, substituem-se os valores das transações concretas pelos preços de mercado, e chegar-se-á a um lucro, diverso do contábil, que melhor reflita a renda da pessoa jurídica. 
Pondere-se, a este passo, que o preço de transferência representa aquele preço praticado nas negociações intra-grupo, e não o preço anormal que favorece uma das empresas vinculadas e tem por efeito a transferência de resultados tributáveis de uma jurisdição para outra, com tributação mais favorável. Com efeito, em certa medida, as empresas associadas buscam reproduzir a dinâmica de negociação do mercado, não sendo possível assumir que a noção de preços de transferência, por si só, encerra qualquer conteúdo de licitude ou ilicitude ${ }^{39}$; como se demonstrou anteriormente, há inúmeros aspectos negociais que estimulam a reflexão das forças de mercado nas negociações intragrupo. Diante deste quadro, o preço de transferência, per se, pode ser compatível com os preços de mercado ou, eventualmente, incompatível, hipótese em que será alvo de ajustes. Justamente para aferir esta compatibilidade é que ele deve ser "posto à prova" ou "testado" pelas regras para o controle dos preços de transferência; se o preço de transferência for considerado idêntico ao [ou próximo do] preço de mercado, dispensam-se ajustes; se, por outro lado, ele for distante dos preços que seriam praticados no livre mercado por empresas independentes, efetuam-se ajustes para fins de adequação das bases de cálculo dos tributos sobre a renda. Note-se que a questão dos preços de transferência deve ser objetivamente ponderada, pouco importando se os atos intra-grupo praticados pelas partes são lícitos ou ilícitos: trata-se de uma análise objetiva da eventual redução tributária numa certa jurisdição ${ }^{40}$. Se houver divergências entre o preço estipulado e o preço de mercado em condições análogas, devem ser efetivados ajustes para "recompor" o lucro tributável de determinada jurisdição, independentemente da vontade manifestada pelas partes ${ }^{41}$.

1.2.1.11. Assim, entende-se que ao substituir os preços das transações entre partes ligadas pelos preços de mercado, a legislação sobre preços de transferência nada mais busca senão aferir com maior exatidão a riqueza gerada pela empresa" (SCHOUERI, Luís Eduardo. Preços de Transferência no Direito Tributário Brasileiro. op. cit., p. 11-12).

${ }^{39}$ A respeito, confira-se TÔRRES, Heleno Taveira. Direito tributário internacional: planejamento tributário e operações transnacionais. op. cit., p. 162-164.

40 "Não é este o momento para debater a questão da elisão e da evasão fiscal, mas apenas confirmar que, no caso, a licitude ou ilicitude dos atos e negócios jurídicos praticados não interfere com as incidências das normas sobre DDL e 'transfer pricing', pois elas se constituem, indubitavelmente, num conjunto normativo cujo objetivo precípuo é o de proteção da arrecadação tributária, anulando efeitos de atos ou negócios jurídicos que reduzem o lucro tributável pelo IRPJ, sem adentrar na licitude dos mesmos no terreno das relações jurídicas de direito privado" (MARIZ DE OLIVEIRA, Ricardo. Fundamentos do Imposto de Renda. São Paulo: Quartier Latin do Brasil, verão 2008, p. 805).

${ }^{41}$ Em sua Diretiva, a OCDE também se manifestou neste mesmo sentido. Veja-se parte do parágrafo 1.2: "Thus, a tax adjustment under the arm's length principle would not affect the underlying contractual obligations for non-tax purposes between the associated enterprises, and may be appropriate even where there is no intent to minimize or avoid tax. The consideration of transfer pricing should not be confused with the consideration of problems of tax fraud or tax avoidance, even though transfer pricing policies may be used for such purposes" (OCDE. Transfer Pricing Guidelines for Multinational Enterprises and Tax Administrations, op. cit., p. I-1). Texto não alterado pela Minuta-2009. 
Não é sempre, contudo, que a prática de preços anormais ou distantes dos parâmetros formados no mercado está relacionada à busca da redução da carga tributária numa determinada jurisdição. Por vezes, a política de alocação de preços está menos associada a uma economia fiscal e mais à equalização de dificuldades como pressões governamentais [alfândegas, departamentos de fixação de preços, de controles cambiais, regras anti-dumping etc.], conflitos com acionistas minoritários [pressão por lucro na holding em operações com o mesmo grupo, na hipótese de o resultado não ser consolidado], dificuldades financeiras ou distorções no fluxo de caixa dentre outras ${ }^{42}$.

Ademais, em muitos casos, as operações entre as empresas associadas são precificadas sem se amparar em um preço de mercado, simplesmente porque inexiste um “mercado", i.e., porque, via de regra, empresas independentes não estruturariam o negócio daquela maneira. Nestes negócios que inexistiriam caso as empresas não fossem

42 "1.4 Factors other than tax considerations may distort the conditions of commercial and financial relations established between associated enterprises. For example, such enterprises may be subject to conflicting governmental pressures (in the domestic as well in the foreign country) related to customs valuations, antidumping duties, and exchange or price controls. In addition, transfer price distortions may be caused by the cash flow requirements of enterprises within an MNE group. An MNE group that is publicly held may feel pressure from shareholders to show high profitability at the parent company level, particularly if shareholder reporting is not undertaken on a consolidated basis. All of these factors may affect transfer princes and the amount of profits accruing to associated enterprises within an MNE group" (OCDE. Transfer Pricing Guidelines for Multinational Enterprises and Tax Administrations, op. cit., p. I-2).

Ainda sobre os fatores que afetam a livre fixação dos preços de transferência entre sociedades de um mesmo grupo econômico, confira-se, por elucidativa, a seguinte listagem de Pablo Sergio VARELA, que os divide em fatores intrínsecos, extrínsecos e mistos:

"En primer lugar, notamos como factores intrínsecos:

1. asignación de mayores utilidades a determinada etapa de la producción de bienes o servicios;

2. aplicación de etapas de desarrollo en ciertos estados para luego ser aplicadas en otros;

3. complementación de etapas comerciales o industriales, conforme la especialización de mano de obra;

4. la política de distribución de dividendos conforme la intención de los accionistas;

5. la capacidad directiva de la conducción societaria en las distintas regiones.

Dentro de los factores extrínsecos hallamos:

1. la posibilidad de competencia con productos locales o también extranjeros en mercados proclives a la demanda del bien o servicio ofrecido;

2. penetración en el mercado;

3. $\quad$ el tipo de cambio y la política monetaria de los países;

4. el régimen político y la protección o discriminación de las inversiones extranjeras;

5. estabilidad económica;

6. acuerdos comerciales y de inversiones firmados con otras naciones;

7. cuestiones climáticas vinculadas con el bien o servicio a producir o prestar.

Son motivaciones de orden mixto aquellas por las cuales el peso del interés especial y propio de cada ente, conjuntamente con el ámbito legal y jurídico dado por un estado, conllevan a revisar:

1. la política de incentivos fiscales de normas de índole tributaria propiamente dichas y laborales;

2. la tributación de menor incidencia económica en el ente"

(VARELA, Pablo Sergio. Precios de transferencia. Una breve aproximación. Revista Tributária e de Finanças Públicas. São Paulo: Revista dos Tribunais, n. ${ }^{\circ} 36,2001$, p. 12). Outros fatores que influenciam a definição dos preços de transferência foram indicados por Carlos Herrero MALLOL em obra específica sobre o tema (Precios de Transferencia Internacionales. Estudio Tributario y Microeconómico. Espanha: Aranzadi Editorial, Colección Monografías Aranzadi n. ${ }^{\circ}$ 121, 1999, p. 32). 
relacionadas, bastante comuns em algumas formas de uso compartilhado de intangíveis, é complexa a definição do preço parâmetro a ser comparado com o preço praticado ${ }^{43}$; com efeito, pode existir uma legítima dificuldade em determinar de forma acurada um preço de mercado ante a ausência da tensão dialética própria das forças de mercado para pautar os negócios entre partes vinculadas.

A constatação de que há transações intra-grupo que não são habitualmente celebradas entre empresas não-associadas é relevante no âmbito do presente estudo, porque exemplifica uma hipótese em que inexistem parâmetros de comparação, imprescindíveis para a aplicação das regras para o controle dos preços de transferência fundadas no princípio da plena concorrência. Adicionalmente, cumpre destacar que as instituições financeiras e, especialmente, aquelas dedicadas à negociação global de derivativos, que serão objeto de análise mais detida no CAPÍTULO 3, infra, podem combinar suas atividades principais de tantas formas distintas que, por vezes, dependendo do grau de integração e/ou centralização de cada função desempenhada, é complexa a localização de concorrentes independentes que tenham se estruturado de maneira comparável. Em inúmeros casos envolvendo transações com instrumentos financeiros globais ou intangíveis, portanto, as empresas associadas podem praticar um preço impossível de ser "testado" pelas administrações tributárias mediante a aplicação do princípio da plena concorrência, simplesmente porque, diante da ausência de operações análogas, seria inviável a obtenção de um "preço de mercado" [ou outro dado comparável] que pudesse ser considerado o "normal" ou o "justo" para aquele determinado caso concreto.

No direito tributário internacional brasileiro, a introdução das normas para o controle dos preços de transferência deu-se com a promulgação da Lei n. ${ }^{\circ}$ 9.430/96, cuja edição era imperativa diante do estágio de integração dos mercados à época, assumindo o controle dos preços de transferência papel essencial na preservação da base tributária doméstica. A pretensão da administração tributária constou da exposição de motivos da Lei n. ${ }^{\circ}$ 9.430/96: impedir a perda de receita tributária, em decorrência de eventuais subfaturamentos ou superfaturamentos de preços em transações com empresas vinculadas no exterior; confirma-se, assim, a finalidade anti-elusiva nas normas brasileiras. $\mathrm{O}$ Ministério da Fazenda ponderou, ademais, que a introdução de normas para o controle dos

43 "There may be a genuine difficult in accurately determining a market price in the absence of market forces or when adopting a particular commercial strategy" (OCDE. Transfer Pricing Guidelines for Multinational Enterprises and Tax Administrations, op. cit., p. I-1). Texto não alterado pela Minuta-2009. 
preços de transferência "prestigiará as empresas mais competitivas em seus preços e será fator preponderante para o efetivo ingresso do país num sistema econômico globalizado". É mister se compreender, outrossim, que essa lei foi editada num contexto de internacionalização e modernização da legislação tributária brasileira, tendo sido editada apenas um ano após a adoção do princípio da universalidade da renda das pessoas jurídicas, instituído por intermédio da Lei n. ${ }^{\circ}$ 9.249, de 26 de dezembro de 1995.

Ao se admitir que as normas para o controle dos preços de transferência "prestigiarão as empresas mais competitivas", pode-se inferir que tais normas não são aptas a produzir reflexos apenas no âmbito da arrecadação tributária de cada nação: elas prestam-se também para o controle da livre concorrência, tendo em vista que as empresas multinacionais podem, a partir dos preços “artificiais" fixados em seus negócios intragrupo, distorcer a concorrência nos mercados local e/ou global ${ }^{44}$.

Seja como instrumento antielusivo, seja para fins de concretização do princípio da livre concorrência, é imprescindível a comprovação, caso a caso, de que os preços praticados nos negócios entre partes relacionadas foram realizados sob condições "normais", sem qualquer interferência endógena do seu grupo empresarial; por outras palavras, todos os preços de transferência, sem exceção, precisam ser "testados" pela legislação respectiva, de forma a avaliar possível manipulação artificial de preços.

Para que seja possível isolar o fenômeno da transferência indireta de lucros e conhecer suas fontes de manifestação, é imprescindível a identificação de seus pressupostos, tal como indicados por Heleno Taveira TÔRRES: (i.) pressupostos subjetivos: (i.1.) sujeitos da operação e estraneidade: a transação precisa ser pactuada entre duas sociedades, com personalidades distintas, residentes em países ou jurisdições nãocoincidentes; (i.2.) relação recíproca entre os sujeitos: relação de controle, dependência ou

\footnotetext{
${ }^{44}$ “Certamente que as transferências de preços não são praticadas apenas para reduzir a base de cálculo dos tributos que incidam sobre o lucro ou os ganhos de uma empresa. (...) Por isso mesmo, não é correto dizer que as normas tributárias que disciplinam o controle fiscal dos preços de transferência são normas de natureza simplesmente fiscal, regras antielusivas, portanto. São também normas de natureza extrafiscal, que operam o controle da livre concorrência no mercado, à medida que garantem um controle sobre o 'preço médio'. Como se pode dessumir, o processo de controle sobre os preços de transferência deve interessar, também, ao próprio grupo de empresas ou parte relacionadas, em face da redução das distorções nos regimes de concorrência nos mercados dos países responsáveis pelo controle" (TÔRRES, Direito tributário internacional: planejamento tributário e operações transnacionais. São Paulo: Revista dos Tribunais, 2001, p. 170).
} 
vínculo prevista em lei para a caracterização dos sujeitos como partes vinculadas ${ }^{45}$; (ii.) pressupostos objetivos: (ii.1.) a prática de preços de transferência e o tipo de operação; (ii.2.) a "artificialidade" dos preços (divergência entre o preço pactuado e o preço normal); e (ii.3.) a relevância fiscal respectiva: base de cálculo formada pelo rendimento que desponta da divergência apurada no ajuste; e (iii.) existência de nexo causal entre a vantagem anormal e a relação de reciprocidade ${ }^{46}$. A ordem lógica envolvida no processo de reconhecimento e mensuração de uma transferência indireta de lucros entre jurisdições seria a seguinte: (1.) "teste" dos preços de transferência; se for identificado um "preço normal", dispensam-se ajustes; se for identificado um "preço anormal", i.e., um preço não compatível com os preços de mercado, parte-se para o passo 2; (2.) exame da relevância fiscal das operações praticadas com os preços anormais; há relevância se for positiva a resposta à seguinte questão: o preço anormal influenciou o lucro tributável?; em seguida, uma vez detectada a relevância fiscal, procede-se ao (3.) cálculo do valor da "vantagem anormal", para que se possa proceder aos ajustes, aplicando-se um dos métodos disponíveis ${ }^{47}$.

Em adição aos pressupostos acima, Alberto XAVIER consigna que, sob a perspectiva objetiva, podem ser "testadas" operações ativas ou passivas ${ }^{48}$. Dentre as operações ativas estão a exportação de bens, a concessão de mútuos, a cessão do direito de uso de intangíveis, a prestação de serviços intra-grupo ou serviços vinculados à negociação global de derivativos etc.; na prática de "operações ativas", uma determinada empresa deve reconhecer resultados equivalentes àqueles que seriam obtidos por terceiros independentes; eventuais ajustes traduzem-se no cômputo de rendimentos não-registrados contabilmente. De outro lado, as operações passivas compreendem a importação de bens, a captação de mútuos ou empréstimos, a obtenção do direito de uso de intangíveis, a contratação de serviços intra-grupo ou serviços vinculados à negociação global de derivativos etc.; as

\footnotetext{
45 Como salientado na INTRODUÇÃO, no presente estudo não serão abordados os aspectos pessoais atinentes à aplicação das regras para o controle dos preços de transferência.

${ }^{46}$ Lista de pressupostos extraída da obra Direito tributário internacional: planejamento tributário e operações transnacionais. op. cit., p. 171.

47 "Atendendo aos pressupostos objetivos do transfer pricing, a disciplina do controle fiscal deve tomar em conta, nas operações responsáveis pela formação dos rendimentos, a 'divergência' entre o preço pactuado e o valor normal dos bens, serviços ou direitos, necessária para determinar a correspondente relevância fiscal, para ulterior incidência do imposto devido sobre a base formada pelo rendimento que despontar na divergência apresentada. Com isto, o Fisco encontrará a 'vantagem anormal' e, em função desta, promoverá a alteração dos preços e conseqüentes ajustes na base de cálculo dos tributos correspondentes” (TÔRRES, Heleno Taveira. Direito tributário internacional: planejamento tributário e operações transnacionais. op. cit., p. 182).

${ }^{48}$ Cf. XAVIER, Alberto. Direito Tributário Internacional do Brasil, op. cit., p. 375.
} 
“operações passivas" impõem limites à dedutibilidade dos dispêndios [custos ou despesas] da empresa "testada"49. Os ajustes dos preços de transferência podem, portanto, revestir-se da forma de arbitramento de receitas ou de indedutibilidade tributária de dispêndios, conforme se trate de operação ativa ou passiva, respectivamente.

Cumpre evidenciar, a este passo, que os ajustes dos preços de transferência no direito brasileiro servem, exclusivamente, para modificar a base de cálculo do Imposto sobre a Renda das Pessoas Jurídicas ("IRPJ") e da Contribuição Social sobre o Lucro Líquido (“CSLL”), conforme prescrito na Lei n. ${ }^{\circ} 9.430 / 96^{50}$, inexistindo previsão legal para alterações nas bases imponíveis de outros tributos como, v.g. os tributos aduaneiros. Nesse contexto, os ajustes de preços de transferência não impactam os tributos devidos na importação e na exportação de bens, as regras de controle cambial, a regulamentação antidumping, as administrações fiscais estaduais etc. ${ }^{51}$. A administração tributária não tem o direito de alterar o "valor" das transações, de modo que pudessem ser modificados o valor

\footnotetext{
${ }^{49}$ No âmbito da Lei n. ${ }^{\circ}$ 9.430/96, as operações ativas estão regulamentadas pelo artigo 19, ao passo que as operações passivas constam do artigo 18 . O pagamento/cobrança de juros tem previsão segregada, contida no artigo 22 da Lei n. ${ }^{\circ}$ 9.430/96.

${ }^{50}$ Esse limite de função dos ajustes de preços de transferência está expresso no texto legal, ao prever que os custos, despesas e encargos de bens importados somente serão "dedutíveis na determinação do lucro real" até o valor que não exceda o preço parâmetro, calculado a partir de um dos métodos legais (cf. artigo 18 da Lei n. ${ }^{\circ}$ 9.430/96). Da mesma forma, o artigo 19 da lei que regulamenta as regras para o controle dos preços de transferência prevê que as receitas auferidas nas exportações a empresas vinculadas serão arbitradas para fins de cômputo na "base de cálculo do imposto de renda". Essas regras são estendidas também à aferição da base de cálculo da CSLL em virtude do quanto previsto no artigo 28 da própria Lei n. ${ }^{\circ}$ 9.430/96. Confira-se:

"Art. 28. Aplicam-se à apuração da base de cálculo e ao pagamento da contribuição social sobre o lucro líquido as normas da legislação vigente e as correspondentes aos arts. $1^{\circ}$ a $3^{\circ}, 5^{\circ}$ a 14,17 a $24,26,55$ e 71 , desta Lei".

51 Discordamos, a esse respeito, da posição manifestada por RODRIGUES DO AMARAL em estudo publicado em 1997. Confira-se:

"Importante também salientar que, como as regras de preços de transferência afetam operações levadas a efeito internacionalmente, buscando alterar o preço originalmente praticado, no caso de superfaturamento, poderá haver reflexos de controle cambial (uma vez que houve remessa de divisas para o exterior, em desacordo com a legislação). Nesse caso, potencialmente, o Banco Central também poderá intervir na discussão, pela via de fraude cambial. Se houver a importação de produtos subfaturada, também poderá haver implicações na prática de dumping ou preço predatório (com o que o CADE e a Secretaria de Defesa Econômica também poderão intervir na discussão). (...) Como o preço praticado também é base de cálculo para o ICMS, os fiscos estaduais também poderão ter interesse nas discussões sobre os ajustes do preço de transferência" (RODRIGUES DO AMARAL, Antonio Carlos. O preço de transferência no Brasil e a experiência internacional. In: Valdir de Oliveira Rocha(coord.), Tributos e preços de transferência. São Paulo: Dialética, 1997, p. 16). De todo modo, entendemos que esse autor modificou seu entendimento em estudo posterior, ao afirmar que "um ajuste tributário sob o princípio do preço sem interferência [arm's length price] não deve afetar as subjacentes obrigações contratuais de propósitos não tributários entre as empresas relacionadas (...)" (RODRIGUES DO AMARAL, Antonio Carlos. O preço de transferência e critérios de comparabilidade. In: Luís Eduardo Schoueri e Valdir de Oliveira Rocha(coord.), Tributos e preços de transferência. São Paulo: Dialética, 1999, v. 2, p. 66).
} 
aduaneiro dos bens importados ${ }^{52}$ ou o preço efetivamente pago ao importador/exportador vinculado. As regras para o controle dos preços de transferência não se confundem, ademais, com a legislação anti-dumping, vinculada exclusivamente à valoração aduaneira. Impossível esperar-se, outrossim, quaisquer impactos no campo do Imposto sobre a Circulação de Mercadorias e Serviços de Transporte Interestadual e Intermunicipal e de Comunicação (“ICMS”) ou do Imposto sobre Produtos Industrializados (“IPI”): se houve importação superfaturada, os créditos de ICMS e IPI apropriados pelo importador serão elevados; quando da alienação desses bens no mercado interno, os débitos desses impostos serão registrados e, provavelmente, a diferença aferida entre débitos e créditos será reduzida comparativamente a uma "operação normal"; por serem o ICMS e o IPI tributos não-cumulativos, ao final, para um mesmo preço de venda no mercado interno, pouco importa o valor praticado nas operações de importação. O mesmo raciocínio pode ser aplicado à Contribuição para o Financiamento da Seguridade Social (“Cofins”) e à contribuição para o Programa de Integração Social ("PIS"), desde que aplicável a sistemática não-cumulativa.

Independentemente da existência de ajustes nos preços de transferência, os quais têm reflexos exclusivamente no cálculo dos tributos sobre a renda, é mister a conclusão de que, no direito brasileiro, o negócio praticado não sofre quaisquer alterações em seu preço e/ou condições, ante a clara a ausência de quaisquer outros reflexos quando da efetivação de ajustes com amparo nos artigos 18, 19 e 22 da Lei n. ${ }^{0}$ 9.430/96. A recomendação geral da OCDE também é no sentido de que "os ajustes tributários advindos da aplicação do princípio da plena concorrência não devem gerar reflexos não-tributários nas obrigações contratualmente assumidas entre as empresas independentes" "53. Não obstante isso, importa destacar que, em alguns países, dentre os quais os Estados Unidos da América, existem os "ajustamentos secundários", aptos a efetivamente modificar a substância do negócio implementado entre partes relacionadas ${ }^{54}$, atribuindo aos "novos

\footnotetext{
${ }^{52} \mathrm{O}$ procedimento de valoração aduaneira possui regras específicas e distintas daquelas concernentes aos preços de transferência, destacando-se o Acordo sobre a implementação do artigo VII do Acordo Geral sobre Tarifas e Comércio (“GATT") de 1994, constante do Anexo 1A ao Acordo Constitutivo da Organização Mundial de Comércio, aprovado pelo Decreto Legislativo n. ${ }^{\circ}$ 30, de 15 de dezembro de 1994, e promulgado pelo Decreto n. ${ }^{\circ} 1.355$, de 30 de dezembro de 1994.

${ }^{53}$ Cf. OCDE. Transfer Pricing Guidelines for Multinational Enterprises and Tax Administrations, op. cit., p. I.1, parágrafo 1.2. Texto não alterado pela Minuta-2009.

${ }^{54}$ Preliminarmente, importa ponderar que os ajustamentos secundários apenas são aplicados no âmbito da sistemática para evitar a bitributação econômica da renda delineada pelo Artigo $9^{\circ}$, parágrafo $2^{\circ}$, da Convenção-Modelo da OCDE, artigo esse que foi objeto de ressalva pelo Brasil e não consta do texto de nenhuma das convenções firmadas (cf. CAPÍTULO 2).
} 
negócios" construídos pelas autoridades tributárias os efeitos que lhe são típicos como, v.g., a necessidade de retenção de imposto sobre a renda na fonte. Mesmo nas hipóteses de ajustamentos secundários, há severas críticas à "construção" de operações secundárias que efetivamente alterem os comportamentos das partes, destacando-se as hipóteses de constituição de "ativos" ou "passivos", os quais geram questões a respeito do seu vencimento, modalidade de remessa [câmbio] dos recursos, necessidade de estabelecimento de juros, prazo de pagamento etc. ${ }^{55}$.

Diante da inexistência de previsão de aplicação dos ajustamentos secundários no direito tributário brasileiro, os ajustes decorrentes da aplicação das regras para o controle dos preços de transferência prestam-se, exclusivamente, para o

Independentemente disso, em breve síntese, pode-se afirmar que, se um país X efetiva um ajuste de preços de transferência em sociedade ali estabelecida, deve informar ao país da sociedade contraparte, o país $\mathrm{Y}$, a respeito de tal ajuste, de modo a se evitar a dupla tributação econômica de um mesmo rendimento. Esse representa o ajustamento primário. No país $\mathrm{Y}$, pode ser determinado um ajustamento correspondente, mediante a outorga dos créditos respectivos pelo país $\mathrm{Y}$ a seu contribuinte; em alguns casos, se prevê um ajustamento compensatório, lançado diretamente pelo contribuinte em seus livros e escrituração contábil. Uma terceira espécie de ajustamento seria o 'secundário', que poderia ser previsto pela legislação interna de Y a seus contribuintes, com o objetivo precípuo de evitar a evasão fiscal, mediante a requalificação jurídica dos valores advindos dos ajustes de preços de transferência. Confira-se a noção de 'ajustamento secundário constante da Diretiva da OCDE:

"4.74. (...) Primary transfer pricing adjustments and their corresponding adjustments change the allocation of taxable profits of an MNE group for tax purposes but they do not alter the fact that the excess profits represented by the adjustment are not consistent with the result that would have arisen if the controlled transactions had been undertaken on arm's length basis. To make the actual allocation of profits consistent with the primary transfer pricing adjustment, some countries having proposed a transfer pricing adjustment will assert under their domestic legislation a constructive transaction (a secondary transaction), whereby the excess profits resulting from a primary adjustment are treated as having been transferred in some other form and taxed accordingly. For example, a country making a primary adjustment to the income of a subsidiary of a foreign parent may treat the excess profits in the hands of the foreign parent having been transferred as a dividend, in which case withholding tax may apply. It may be that the subsidiary paid an excessive transfer price to the foreign parent as means of avoiding that withholding tax. Thus, secondary adjustments attempt to account for the differences between the redetermined taxable profits and the originally booked transactions. (...) secondary adjustments may serve to prevent tax avoidance (...)" (OCDE. Transfer Pricing Guidelines for Multinational Enterprises and Tax Administrations, op. cit., p. IV-22-23).

${ }^{55}$ A "construção" de mútuos é um das operações secundárias mais criticadas [e menos adotadas pelos países], por conta de suas inúmeras especificidades. Nesse sentido, veja-se orientação da OCDE:

"Another example of a tax administration seeking to assert a secondary transaction may be where the tax administration making a primary adjustment treats the excess profits as being a constructive loan from one associated enterprise to the other associated enterprise. In this case, an obligation to repay the loan would be deemed to arise. The tax administrations making the primary adjustment may then seek to apply the arm's length principle to this secondary transaction to impute an arm's length rate of interest. The interest rate to be applied, the timing to be attached to the making of interest payments, if any, and whether interest is to be capitalized would generally need to be addressed. The constructive loan approach may have an effect not only on the year to which a primary adjustment relates but to subsequent years (...). This might be avoided if the secondary transaction were a loan, but constructive loans are not used by most countries for this purpose and they carry on complications because of issues related to imputed interest" (OCDE. Transfer Pricing Guidelines for Multinational Enterprises and Tax Administrations, op. cit., p. IV-23).

As dificuldades práticas para a aplicação dos ajustamentos secundários e suas restrições diversas constam das p. IV-23 a IV-26 da Diretiva da OCDE. 
"redimensionamento" da base de cálculo do IRPJ e da CSLL. No caso dos contribuintes optantes pela sistemática do lucro real, reputam-se indedutíveis os ajustes em operações passivas e arbitram-se receitas correspondentes aos ajustes em operações ativas; em qualquer hipótese, os efeitos processam-se na definição da base de cálculo dos aludidos tributos, restando inalteradas as demais regras como o possível abatimento destas receitas com as perdas aferidas no ano-calendário, o aproveitamento dos prejuízos fiscais acumulados, a aplicação da alíquota e respectivo adicional etc..

Note-se que, enquanto os ajustes das operações passivas disciplinadas pelo artigo 18 da Lei n. ${ }^{\circ}$ 9.430/96 apenas afetam os contribuintes incluídos no regime do lucro real, as receitas não-contabilizadas decorrentes de ajustes em operações ativas também têm impactos nos regimes do lucro presumido e do lucro arbitrado, como se depreende do artigo $19, \S 7^{\circ}$, da aludida lei ${ }^{56}$. Especificamente no que concerne às operações financeiras de empréstimo remuneradas pelo pagamento de juros, abordadas pelo artigo 22 , tanto a receita "arbitrada" [operações ativas] quanto o pagamento "a maior" à empresa vinculada, que no regime do lucro real tem sua dedutibilidade glosada [operações passivas], devem ser incluídos no resultado tributável das empresas submetidas à sistemática do lucro presumido ou arbitrado ${ }^{57}$. Note-se que, a despeito de os custos e despesas em geral não impactarem o cálculo do IRPJ e da CSLL devidos nos regimes do lucro presumido e arbitrado, excepcionalmente, para fins da legislação de preços de transferência, determinase sua inclusão no lucro tributável, como se receita fosse. Entendemos que a inclusão desta "receita financeira", correspondente a uma "despesa não-admitida", apenas estaria autorizada caso se destinasse à eliminação de um lançamento contábil anterior e redutor da conta dos resultados financeiros tributáveis. Por outras palavras, se as despesas "inadmitidas" geraram a redução das receitas líquidas tributáveis, seria possível o seu ajuste; de outro lado, se as despesas financeiras próprias de determinada operação de renda fixa não impactaram a base de cálculo "original” do IRPJ e da CSLL, incabível o ajuste

56 “Art. 19. (...)

$\S 7^{\circ}$ A parcela das receitas, apurada segundo o disposto neste artigo, que exceder ao valor já apropriado na escrituração da empresa deverá ser adicionada ao lucro líquido, para determinação do lucro real, bem como ser computada na determinação do lucro presumido e do lucro arbitrado".

$\mathrm{O}$ artigo 18, que trata das operações passivas, alude tão-somente à indedutibilidade dos dispêndios quando do cálculo do "lucro real", denominação própria da sistemática do "lucro real" e inaplicável aos demais regimes.

${ }^{57}$ A respeito, veja-se o teor do $\$ 3^{\circ}$ do artigo 22 da Lei n. ${ }^{\circ} 9.430 / 96$ :

"Art. 22. (...)

$\S 3^{\circ} \mathrm{O}$ valor dos encargos que exceder o limite referido no caput e a diferença de receita apurada na forma do parágrafo anterior serão adicionados à base de cálculo do imposto de renda devido pela empresa no Brasil, inclusive ao lucro presumido ou arbitrado". 
nas operações financeiras passivas determinado pelo artigo 22 , $\S 3^{\circ}$, da Lei n. ${ }^{\circ}$ 9.430/96 ${ }^{58}$. Obviamente, não se pode converter uma dedução indevida, de relevância fiscal inútil nestes regimes, em "receita", sob pena de infração à noção de renda disciplinada no âmbito do artigo 43 do Código Tributário Nacional.

Seguindo-se o raciocínio exposto no parágrafo anterior, os contribuintes optantes pelo regime do lucro presumido estão sujeitos aos seguintes ajustes de preços de transferência: (i.) ajustes em operações ativas em geral, com fundamento no artigo 19 da Lei n. ${ }^{\circ}$ 9.430/96, devendo ser incluído na base tributável o resultado da multiplicação do percentual de presunção de lucros pelo valor do ajuste; (ii.) ajustes em operações financeiras ativas e passivas, com fundamento no artigo 22 [cf. artigo 36 da Instrução Normativa n. ${ }^{o}$ 93/97 $7^{59}$ ]. As mesmas regras aplicam-se ao regime do lucro arbitrado, que se

${ }^{58}$ A base de cálculo tributável no regime do lucro presumido está disciplinada no artigo 25 da Lei n. ${ }^{\circ}$ 9.430/96, que prevê o seguinte:

"Art. 25. O lucro presumido será o montante determinado pela soma das seguintes parcelas:

I - o valor resultante da aplicação dos percentuais de que trata o art. 15 da Lei n. ${ }^{\circ} 9.249$, de 26 de dezembro de 1995, sobre a receita bruta definida pelo art. 31 da Lei n. ${ }^{\circ}$ 8.981, de 20 de janeiro de 1995, auferida no período de apuração de que trata $o$ art. $1^{\circ}$ desta Lei;

II - os ganhos de capital, os rendimentos e ganhos líquidos auferidos em aplicações financeiras, as demais receitas e os resultados positivos decorrentes de receitas não abrangidas pelo inciso anterior e demais valores determinados nesta Lei, auferidos naquele mesmo período".

Note-se que a lei alude a "rendimentos e ganhos líquidos auferidos em aplicações financeiras". As autoridades administrativas interpretam esta expressão da seguinte forma: devem ser somados os rendimentos em operações de renda fixa e os ganhos líquidos em operações de renda variável [cf. artigo 37 da Instrução Normativa n. ${ }^{\circ}$ 93, de 24 de dezembro de 1997]. Portanto, as despesas em operações de renda fixa, como os empréstimos em geral, normalmente não são computados para fins tributários e, neste cenário, a aplicação do artigo $22, \S 3^{\circ}$, a operações passivas, seria inconstitucional, por tributar renda inexistente.

A base de cálculo no regime do lucro arbitrado encontra amparo no artigo 27 daquela mesma lei, possuindo tratamento praticamente idêntico no que concerne ao resultado financeiro. Veja-se:

"Art. 27. O lucro arbitrado será o montante determinado pela soma das seguintes parcelas:

I - o valor resultante da aplicação dos percentuais de que trata o art. 16 da Lei n. ${ }^{\circ} 9.249$, de 26 de dezembro de 1995, sobre a receita bruta definida pelo art. 31 da Lei n. ${ }^{\circ}$ 8.981, de 20 de janeiro de 1995, auferida no período de apuração de que trata o art. $1^{\circ}$ desta Lei;

II - os ganhos de capital, os rendimentos e ganhos líquidos auferidos em aplicações financeiras, as demais receitas e os resultados positivos decorrentes de receitas não abrangidas pelo inciso anterior e demais valores determinados nesta Lei, auferidos naquele mesmo período".

As mesmas considerações tecidas acima no que concerne à inconstitucionalidade de tal tributação podem ser transpostas para o regime do lucro arbitrado.

59 “Art. 36. O lucro presumido será o montante determinado pela soma das seguintes parcelas: (...)

VII - o valor resultante da aplicação dos percentuais de que tratam os $\S \S 1^{\circ} \mathrm{e} 2^{\circ}$ do art. $3^{\circ}$, sobre a parcela das receitas auferidas em cada atividade, no respectivo período de apuração, nas exportações às pessoas vinculadas ou aos países com tributação favorecida que exceder ao valor já apropriado na escrituração da empresa, na forma da Instrução Normativa SRF n. ${ }^{\circ}$ 38, de 1997;

VIII - o valor dos encargos suportados pela mutuária que exceder o limite calculado com base na taxa Libor, para depósitos em dólares dos Estados Unidos da América, pelo prazo de seis meses, acrescido de três por cento anuais a título de 'spread', proporcionalizados em função do período a que se referirem os juros, quando pagos ou creditados a pessoa vinculada no exterior e o contrato não for registrado no Banco Central do Brasil; 
sujeita a idêntica racionalidade e sistemática, alterando-se, tão-somente, os percentuais de presunção referidos em (i.).

Por fim, pondere-se que, no direito interno, as normas para o controle dos preços de transferência estão prescritas na Lei n. ${ }^{\circ}$ 9.430, de 27 de dezembro de 1996, alterada pela Lei n. ${ }^{\circ}$ 9.959, de 27 de janeiro de 2000, e, mais recentemente, pela Medida Provisória n. ${ }^{\circ} 478$, de 29 de dezembro de 2009, a qual modificou totalmente as disciplinas (i.) dos métodos aplicáveis nas operações de exportação, especialmente o método do preço de revenda menos lucro, que transformou-se no método do preço de venda menos lucro, com margem prefixada de 35\%; e (ii.) do momento da escolha dos métodos, a qual somente poderá ser efetuada até o início de um procedimento fiscalizatório. No plano das normas infra-legais, é aplicável a Instrução Normativa n. ${ }^{\circ} 243$, de 11 de novembro de 2002, alterada pelas Instruções Normativas n. ${ }^{\circ}$ s 321, de 14 de abril de 2003, e 382, de 30 de dezembro de 2003; até o presente momento, contudo, não foi editada nova regulamentação para disciplinar as importantes alterações introduzidas pela Medida Provisória n. ${ }^{\circ} 478 / 09$, de modo que estes normativos precisam ser aplicados com cautela, tendo em vista que inúmeros dispositivos foram tacitamente revogados após a edição da referida Medida. Há, outrossim, regras aplicáveis à determinação dos preços de transferência em um único ano-calendário, como, v.g., as Portarias do Ministério da Fazenda n. ${ }^{\circ}$ s 310, de 29.12.08; 329, de 26.12.07; 425, de 28.12.06; e 436, de 29.12.05, as quais introduziram fatores que devem ser multiplicados pelas receitas de exportação a serem "testadas", de forma a reduzir impactos relativos à apreciação da moeda nacional em relação a outras moedas.

\subsection{Origem histórica das regras de preços de transferência e do princípio da plena concorrência. Exame do conteúdo do Relatório CARROLL.}

As normas para o controle dos preços de transferência mais antigas de que se têm notícia surgiram em 1915, durante a I Guerra Mundial, na Inglaterra ${ }^{60}$, com o objetivo

IX - a diferença de receita correspondente ao valor calculado com base na taxa a que se refere o inciso anterior e o valor contratado, quando este for inferior, caso o contrato, não registrado no Banco Central do Brasil, seja realizado com mutuária definida como pessoa vinculada domiciliada no exterior".

Salientamos, uma vez mais, que entendemos inaplicável o inciso VIII caso a despesa anteriormente registrada não tenha impactado a aferição da base de cálculo "original", pré-ajustes.

60 As normas inglesas de 1915, consideradas o primeiro "marco" mundial na legislação de preços de transferência, eram aplicáveis apenas a empresas estabelecidas no interior do Reino Unido, cujo controle não fosse inglês ou de uma de suas colônias. Esta regra permitia a tributação do não-residente em razão de rendas 
precípuo de se evitar a fuga dos lucros tributáveis das empresas inglesas para paraísos fiscais ou, se fosse o caso, garantir a legítima tributação da renda auferida em território inglês ${ }^{61}$. Apenas dois anos mais tarde (1917), os Estados Unidos também editaram normas para proteção de seu lucro tributável durante a guerra, as quais determinavam que o Comissário Tributário tinha autorização para realocar receitas e despesas entre empresas afiliadas; inexistiam, contudo, regras específicas para se proceder a tal realocação ${ }^{62}$.

No que respeita especificamente ao princípio da plena concorrência, há pouca evidência sobre o momento de seu surgimento como princípio de direito tributário internacional. Sob a perspectiva do direito interno, os Estados Unidos da América e o Canadá foram as primeiras nações a editar, em 1924, normas amparadas no princípio da plena concorrência; seguidos pela Suíça (1928) e Itália $(1936)^{63}$. Sobre o seu aparecimento como critério para a avaliação dos preços de transferência em operações transnacionais, há apenas indícios de que a idéia de adoção deste princípio teria surgido durante estudos desenvolvidos pelas autoridades tributárias norte-americanas no início da década de $30^{64}$. Sua aceitação como uma espécie de dogma de direito internacional, contudo, apresenta relação intrínseca com a evolução dos modelos de convenções para evitar a bitributação da

supostamente não-tributadas, mediante a cobrança dos tributos respectivos diretamente do residente [cf. F(no. 2)A 1915, Sec. 31(3)]. Confira-se:

"These [1915 rules] aimed to prevent avoidance of high wartime taxes by foreign companies trading in UK through branches or subsidiaries. Hence, the 1915 Finance Act provided that a foreign non-resident person doing business through a local branch or agent could be taxed in its name; similarly, where the foreign nonresident was doing business with a UK resident and 'owing to the close connection and (...) to the substantial control exercised by the non-resident over the resident', business was carried on between the two in such a way as to produce to the resident person a profit lower than that which might be expected, the non-resident person should be should be chargeable to tax in the name of the resident person as agent" (PICCIOTTO, Sol. op. cit., p. 177-178).

Estas regras foram refletidas e atualizadas na General Rule 7, do Income Tax Act, 1918.

${ }^{61}$ Sol PICCIOTTO cita um caso [Gillette Safety Razor Co. v. Commrs. of Inland Revenue, 1920] que provavelmente contribuiu para a edição das normas de 1915 e 1918:

"These measures were undoubtedly taken in response to moves by foreign companies do minimize their exposure to UK tax. For example, the Gillette company of Boston set up a UK subsidiary in 1908, but then wound it up in 1912 and transferred its UK business to a separate subsidiary in Massachusetts, which as a non-resident of UK would have been taxable only in its UK business. In 1915 Gillette went further, ceased to trade directly in the UK, and instead licensed its UK business to a new company set up by its former UK manager director. Nevertheless, the Revenue tried to treat the new UK company as 'under the control' of Gillette in Boston, although their link was only contractual; but this was firmly rejected by the High Court as 'arbitrary taxation gone mad'" (PICCIOTTO, Sol., op. cit., p. 178). Após a publicação das normas de 1915 , este tipo de prática poderia ser fiscalizada [e tributada] pelo físco inglês.

621917 War Revenue Act, Regulation 41, Arts. 77-78.

${ }^{63}$ John F. AVERY JONES (et. al.). The Origins of Concepts and Expressions Used in the OECD Model and their Adoption by States. Bulletin for International Taxation. Amsterdã: IBFD, jun. 2006, p. 243.

${ }^{64}$ Nesse sentido, confira-se HAMAEKERS, Hubert. Arm's Length - How Long? International Transfer Pricing Journal. Amsterdã: IBFD, mar./abr. 2001, p. 32. 
renda publicados por comitês tributários de organizações internacionais. Por esse motivo é que apresentamos, nos parágrafos subseqüentes, algumas ponderações sobre o tema.

A partir de estudos encomendados, no início da década de 20, a acadêmicos e outros experts, em abril de 1927, o Comitê Econômico e Financeiro da Liga das Nações Unidas editou um relatório sobre providências que deveriam ser adotadas pelos seus membros para se evitar a bitributação da renda, o qual continha uma minuta de convençãomodelo como anexo. Nesta minuta previa-se que os lucros empresariais deveriam ser tributados nos países onde se localizassem os respectivos estabelecimentos permanentes, mas a terminologia era confusa e esta expressão abrangia tanto escritórios e filiais quanto sociedades subsidiárias, controladas e coligadas $^{65}$. A alocação de lucros deveria ser buscada, preliminarmente, na contabilidade do estabelecimento [na forma do método da contabilidade segregada]. Se esses registros inexistissem ou fossem inadequados, o lucro poderia ser alocado a partir de fórmulas predeterminadas baseadas no capital investido, nas receitas totais, na folha de salários, no turnover $^{66}$ etc. [método da partilha fracionada] ${ }^{67}$.

Em outubro de 1928, a Liga das Nações Unidas convocou uma Reunião Geral dos Experts dos Governos, com o objetivo de discutir aquele modelo, a qual resultou na aprovação dos três primeiros modelos de convenção, que se diferenciavam conforme o tipo de tributação sobre a renda adotado por cada um dos países contratantes [impostos pessoais

\footnotetext{
65 "The first League of Nations drafts of 1927 (...) considered subsidiaries to be permanent establishments of their parent company. In consequence, those drafts not need any provision along the lines of Art. 9 MC. It was not until the predecessor of present Art. 5 (7) excluded subsidiaries from the definition of a permanent establishment that it become necessary to lay down the arm's length principle in a separate rule for situations not covered by Art. 7" (VOGEL, Klaus. Klaus Vogel on Double Taxation Conventions. $3^{\mathrm{a}}$ ed. London: Kluwer Law International, 1997, p. 518).

${ }^{66}$ A expressão turnover pode ser traduzida por "rotatividade" e possui diversos significados. Na área de recursos humanos, v.g., o turnover representa a relação entre admissões e (a.) demissões ou (b.) a taxa de substituição de trabalhadores antigos por novos. A fórmula "clássica" para a sua aferição seria a seguinte: $\left[\mathrm{N} .^{\circ}\right.$ de demissões $(+) \mathrm{N} .^{\circ}$ de admissões] $(/) 2(/) \mathrm{N} .{ }^{\circ}$ de funcionários ativos no último dia do mês anterior. No âmbito financeiro, essa expressão indica o número de vezes que os valores e recursos de uma empresa [estoques, matérias-primas etc.] são substituídos num dado período. No âmbito do presente estudo, empregaremos o termo na língua inglesa.

67 "According to the explanation of the report [referência ao relatório da Liga das Nações de 1927], profit allocation should have primarily taken place on the basis of separate accounting, i.e. based on the accounts of the permanent establishment. If these were absent or inadequate, the tax authorities concerned should apportion the profit in some (unspecified) way. The applications referred, in this context, to applications which were based on formulas taking into account invested capital, payroll, turnover etc. (fractional apportionment, later called formulary apportionment)" (HAMAEKERS. Arm's Length - How Long? op. cit., p. 32).
} 
ou gerais versus impostos impessoais $]^{68}$. Esses primeiros modelos (1928) não enfrentaram diretamente a problemática dos preços de transferência, limitando-se a indicar, no que concerne à questão dos estabelecimentos permanentes, que as autoridades tributárias competentes deveriam acordar a respeito das regras de repartição de lucros, de forma que cada Estado tributasse a parcela de renda produzida no seu território. As referências ao critério da contabilidade segregada e à inclusão das sociedades controladas dentre as espécies de 'estabelecimento permanente', originalmente constantes da minuta de 1927, foram banidas nas três versões finais discutidas no âmbito da Reunião Geral dos Experts dos Governos ${ }^{69}$. Nesta reunião restou aprovada, outrossim, a recomendação acerca da continuidade dos estudos em certas matérias, incluindo-se "rules for the apportionment of the profits or capital of undertakings operating in several countries".

Em maio de 1930, com patrocínio da Fundação Rockefeller, o Comitê Fiscal da Liga das Nações indicou o advogado e consultor do Internal Revenue Service norteamericano [referido adiante sob a sigla "IRS"], Mitchell B. CARROLL, para estudar, mais aprofundadamente e cercando-se de elementos do direito comparado, a questão da alocação de lucros entre os países nas operações entre empresas associadas e, também, nas operações envolvendo estabelecimentos permanentes. Mitchell B. CARROLL conduziu seu estudo a partir da análise dos métodos utilizados por 27 países e três estados norteamericanos entre 1930 e 1933, quando apresentou seu relatório de 5 volumes e mais de

\footnotetext{
68 "Accordingly, in the resolutions, the Experts 'began by differentiating impots reels or scheduler taxes, on the one hand, and the personal or general tax, on the other, and intentionally making different suggestions in connection with each of these main categories. (...)

The General Meeting thought the Technical Experts' proposal was narrowly suited to the case of one contracting state imposing only personal taxes, and the other only impersonal taxes. It, therefore, issued two additional models, the second designed primarily for two states imposing only personal taxes and the third for situations other than those for which the first two were designed" (LANGBEIN, Stanley I. The Unitary Method and the Myth of Arm's Length. Tax Notes. fev. 1986, p. 630-631).

69 "In devising these original models, all of the various groups of Experts, and the General Meeting, consciously left open the method for allocating the business profits of an enterprise which had permanent establishments in both estates party to a convention. The drafts and models were not silent on the point, however. The original draft convention of expanded Technical Experts Committee provided that permanent establishments included 'the real centres of management, affiliated companies, branches, factories, agencies, warehouses, offices, depots', provided that if an undertaking had a permanent establishment in both states, each state would tax the 'portion of the income produced in its territory'; and provided that 'in the absence of accounts showing this income separately and in proper form, the competent administrations of the two Contracting States shall come to an arrangement as to the rules for apportionment'. The models finally approved by the General Meeting differed in two significant respects. First, they changed the list of operations constituting a permanent establishment, notably by omitting affiliated companies from the list. Second, they omitted any reference to the use of a taxpayer's separate accounts in allocating profits, saying, instead simply that the competent administrations should come to an arrangement as to the basis for apportionment" (LANGBEIN, Stanley I. The Unitary Method and the Myth of Arm's Length. op. cit., p. 631).
} 


\subsection{0 páginas $^{70}$. O denominado CARROLL Report [ou Relatório CARROLL, como será}

referido adiante] foi considerado um "giro copernicano" na evolução das regras internacionais para repartição de lucros entre os países, tendo sustentado fortemente (i.) o emprego da abordagem da contabilidade segregada por estabelecimento/empresa [referido constantemente na língua inglesa por "separate entity approach"] e (ii.) a ficção de empresas independentes (“independent enterprise approach") ${ }^{71}$.

Segundo consta do seu Relatório, o propósito de Mitchell B. CARROLL era formular um sistema de alocação ou repartição de renda das empresas que se apresentasse lógico e justo, passível de adequação a todos os tipos de contribuinte. Em sua análise comparada sobre a atribuição de lucros a estabelecimentos permanentes, CARROLL concluiu que existiam três gêneros de métodos principais adotados pelas leis e/ou autoridades tributárias dos países examinados: (a.) método da contabilidade segregada, segundo o qual o estabelecimento local estaria obrigado a manter contabilidade regular; (b.) métodos empíricos, que previam a estimativa da renda a partir da comparação com empresas similares ou levando-se em consideração ativos, taxa de retorno, dentre outros fatores; segundo relatado pelo autor, estes métodos eram freqüentemente empregados pelas administrações tributárias nas hipóteses em que os demonstrativos contábeis apresentados

${ }^{70}$ Mitchell B. CARROLL (ed.), Taxation of Foreign and National Enterprises. Geneva: League of Nations, 1932-1933. O principal volume da obra é o de n. ${ }^{\circ}$ IV, que se denomina "Methods of Allocating Taxable Income".

71 Alguns autores sustentam que Mitchell CARROLL distorceu o resultado de suas pesquisas, tendo modificado a tendência internacional de adoção do critério unitário, oposto à ficção das empresas independentes. Veja-se, neste sentido, Stanley I. LANGBEIN:

"The CARROLL report represents a turning point in the development of international allocation rules for the model conventions. As I have indicated, prior to the report, the community of experts designing the models appeared to be going in the direction of adopting some form of formula apportionment rules for allocating business profits. Thus, the reference to separate accounting in the original draft of the model was dropped in the final version. The pre-existing conventions, notably that among the Central European powers, included an allocation provision that called for formulary apportionment; that convention had been the principal source of precedent of the entire effort made during de 1920s. And the commentary to the 1928 models suggested formulary or empirical methods were to predominate in making allocations under the model provisions.

The CARROLL report and the ensuing work at the Fiscal Committee changed this direction. The CARROLL report advocated a separate accounting, independent enterprise approach, and that approach became the precursor of the contemporary model convention provisions" (The Unitary Method and the Myth of Arm's Length. op. cit., p. 631-632).

No mesmo sentido, Gemma Sala GALVAÑ também sustenta que, até a publicação do Relatório CARROLL, a tendência internacional era no sentido da adoção do critério unitário de repartição da renda. Confira-se:

"La recepción del principio de plena concurrencia supuso un giro copernicano en el curso de los acontecimientos internacionales, ya que, por un lado, los trabajos del Comité Ampliado de Expertos Técnicos sobre el Proyecto de Modelo original de Convenio sobre imposición directa de esta organización internacional, aunque sin método definido, parecían orientarse hacia métodos unitarios de prorrateo que tenían en cuenta, entre otros factores, la naturaleza del acuerdo o contrato entre las partes vinculadas, el capital implicado, el número de trabajadores de la empresa y los salarios abonados, y por otro lado, los convenios internacionales fiscales establecidos imponían sistemas de reparto proporcional de los beneficios de las empresas que operaban en varios Estados" (op. cit., p. 76-77). 
continham dados insuficientes ou falsos; e (c.) métodos de partilha fracionada ou métodos de divisão dos lucros por fórmulas predeterminadas (designados "fractional apportionment" ou "formulary apportionment systems") ${ }^{72}$. Esses últimos eram aferidos a partir da divisão do lucro líquido total entre os agentes envolvidos, proporcionalmente a certos fatores como, v.g., ativos, taxa de retorno, rotatividade de estoques, folha de salários ou percentuais previamente fixados, e eram os métodos preferíveis em nações como Suíça, Espanha e Áustria [legislação interna e na convenção entre Áustria, Hungria e Tchecoslováquia]; também eram aplicados como métodos secundários ou subsidiários em diversos outros países. Cada uma destas sistemáticas possuía vantagens e desvantagens e, como regra geral, eram empregadas de forma combinada pelas autoridades tributárias.

Ao final, Mitchell B. CARROLL concluiu ter uma predileção pelo método (a.), que seria o adotado pela grande maioria das 27 nações pesquisadas até aquele momento ${ }^{73}$.

\footnotetext{
72 A expressão "partição de lucros" será utilizada no texto com conteúdo muitíssimo genérico, no sentido de repartição ou divisão de lucros ou resultados, segundo quaisquer tipos de sistemas ou métodos. Já as expressões "partição de lucros por fórmulas predeterminadas" ou "partilha fracionada" serão utilizadas tãosomente para denotar o método a partir do qual se testa os preços de transferência mediante a aplicação de fórmulas predeterminadas envolvendo fatores como ativos empregados no negócio, folha de salários, número de empregados, turnover, despesas incorridas, dentre outros; trata-se, assim, de traduções das expressões inglesas "formulary apportionment systems", "formulary apportionment method" ou "fractional apportionment".

As expressões "partição de lucros por fórmulas predeterminadas" e "método unitário" [do inglês "unitary method", expressão bastante difundida nos Estados Unidos da América] serão utilizados como sinônimos.

${ }^{73}$ LANGBEIN. Stanley I. The Unitary Method and the Myth of Arm's Length. op. cit., p. 632.

Este autor sustenta, todavia, que a adoção das regras de contabilidade segregada não era tão difundida nas legislações dos países quanto preconizado por Mitchell B. CARROLL, mas, pelo contrário, raramente estas regras eram previstas formalmente. Em sua visão, a maioria dos países previa métodos de partilha fracionada ou não continham regras de alocação de lucros. Na prática, contudo, a contabilidade dos estabelecimentos permanentes servia como parâmetro para a alocação de lucros pelas administrações tributárias, o que, na visão desse autor, não poderia inspirar regras prescritas em convenções para evitar a bitributação.

Sol PICCIOTTO também sustenta que poucos sistemas tributários, à época, prescreviam critérios para a alocação de renda entre partes relacionadas; a contabilidade segregada era um critério utilizado pelas administrações tributárias para aferir o lucro de estabelecimentos permanentes (pela legislação interna) e normalmente era "testada" pelos métodos empíricos. Vejam-se as considerações desse autor sobre o relatório enviado a CARROLL pela Inglaterra, país que preconizava a contabilidade segregada, a despeito de reconhecer suas limitações como critério isolado:

"An important advocate of the separate accounting approach was the British Inland Revenue. Nevertheless, its report conceded difficulty in ascertaining separate UK profits, in particular for goods manufactured abroad and imported for sale by a related establishment. In such cases, and as a check in general, the validity of the accounts was tested by empirical methods. It emphasized the importance of having a clear picture of the course of the interlocking transactions, and attempting to establish by negotiation a reasonable basis, for example for the invoicing of goods. This might be by reference to the price of similar goods to an unrelated buyer; or if there were none or the goods were of a specialist kind, by taking the UK sale price and allowing a merchanting profit. The UK report estimated that some 55 per cent of total cases were settled on the basis of separate accounts, usually 'after negotiation. However, it emphasized that 'the fact that the revenue authorities have an alternative of basing profits on a percentage of turnover prevents the tax payer taking up an unreasonable attitude' (League of Nations, 1932, p. 191). In some 20 per cent of cases the proportion of turnover method would be resorted to, and in a further 25 per cent the proportion of another appropriate
} 
No âmbito do Relatório CARROLL, foram identificadas duas modalidades distintas de aplicação do critério da contabilidade segregada: (i.) a remuneração por serviços, segundo a qual seriam alocados à filial unicamente os lucros imputáveis aos serviços por ela performados; e (ii.) o critério da venda entre entes independentes, o qual previa que, nas operações entre matriz e filial, haveria a presunção de que existiria uma operação de venda e compra entre partes independentes, de forma que deveria ser alocado na filial, ficticiamente, também o custo do capital que seria necessário para que terceiros independentes desenvolvessem aquela atividade, com todos os riscos a ela inerentes. CARROLL manifestou predileção pela modalidade da remuneração por serviços, por conta de sua simplicidade, ignorando-se a questão dos intangíveis envolvidos nas atividades desempenhadas pelo estabelecimento permanente ${ }^{74}$. Confira-se: "if we recognize the fact that the real centre of management, especially if it is situated at the principal productive establishment, is the most vital part of the enterprise, the most practical approach to the problem is to give it the residuum of the profit after allocating to each outlying secondary establishment compensation for the services it has rendered to the enterprise, in accordance

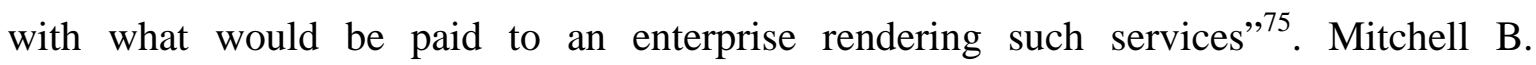
CARROLL não deixou de identificar, todavia, que: "in the alchemy of a successful business, the intangible, immeasurable element of brainwork is a very important factor, if not the most vital factor"76. Não obstante essa relevante ressalva, não analisou a circunstância de que a valoração dos intangíveis é complexa e poderia não estar refletida nos métodos envolvendo contabilidade segregada ali sugeridos.

factor, e.g., an assets basis for banks, premiums for insurance companies, freight for shipping and trainmileage for railways" (PICCIOTTO, Sol. op. cit., p. 29-30).

Este autor sustenta, outrossim, que Mitchell B. CARROLL conferiu ao princípio da plena concorrência maior importância do que ele realmente tinha à época, tendo deixado de indicar os bons resultados atingidos por países que optavam pelo método da partilha fracionada, especialmente a Espanha (op. cit., p. 33). Sustenta, ademais, que as autoridades tributárias buscavam mais uma justa alocação dos lucros do que sua comparação com operações praticadas por partes independentes, tendo sido esta visão distorcida por CARROLL quando do exame dos relatórios nacionais (op. cit., p. 184).

74 Décadas mais tarde, este entendimento foi refletido nos Comentários da OCDE ao Artigo $7^{\circ}$ da Convenção-Modelo, que recomendam a vedação do pagamento de royalties por estabelecimentos permanentes em geral, porque eles representam remuneração pelo uso de intangíveis, os quais pertencem à empresa em sua inteireza, e não à matriz. A OCDE recomenda, na maioria dos casos, a desconsideração de pagamentos "internos" ou intra-company a título de royalties ou direitos de uso de quaisquer intangíveis. Maiores considerações sobre o assunto, especificamente no que concerne às entidades que se dedicam à negociação global de instrumentos financeiros, constam do CAPÍTULO 3.

${ }^{75}$ Excerto do Relatório CARROLL extraído de LANGBEIN, Stanley I. The Unitary Method and the Myth of Arm's Length. op. cit., p. 633.

${ }^{76}$ Excerto do Relatório CARROLL extraído de LANGBEIN, Stanley I. The Unitary Method and the Myth of Arm's Length. op. cit., p. 633. 
Quanto às operações desenvolvidas no contexto das empresas associadas, Mitchell B. CARROLL manifestou sua preocupação com o fato de que uma subsidiária num determinado país poderia ter seus lucros desviados para sua controladora estabelecida num outro país, o que ocorreria sempre que os preços praticados não fossem estabelecidos em condições de plena concorrência. A jurisdição do país da subsidiária "prejudicada" poderia, nesta hipótese, atingir a controladora, para fins de promover uma adequada alocação de resultados ${ }^{77}$. CARROLL não relatou em suas conclusões os métodos preferíveis para a alocação de lucros em operações com empresas associadas; tão-somente manifestou sua opinião pessoal de que o método da contabilidade segregada seria preferível, em detrimento dos métodos de partilha fracionada, fundamentando-se nas fragilidades desses últimos ${ }^{78}$.

Em 1934, os Estados Unidos editaram regulamentação que prescreveu, pela primeira vez, a adoção do princípio da plena concorrência no direito tributário internacional estadunidense ${ }^{79}$. Não se sabe, ao certo, se o Relatório CARROLL influenciou estas alterações legislativas ou se, ao invés disso, os estudos norte-americanos que vinham sendo desenvolvidos desde o início da década [lembre-se que Mitchell B. CARROLL era o membro norte-americano do Comitê Fiscal da Liga das Nações] é que influenciaram as conclusões indicadas no Relatório CARROLL, especialmente no que concerne ao afastamento de critérios não-amparados no método da contabilidade segregada.

\footnotetext{
77 "He identified four ways the subsidiary's jurisdiction could reach the parent: by readjusting the price to an arm's length price, and taxing the subsidiary, citing the predecessor of section 482 in the United States as an example; by taxing the parent directly, for which express statutory provision was required; by making an assessment of the entire enterprise on the basis of economic unity; and by assessing on the basis of consolidated accounts. A United Kingdom statute represented the only instance in which the second method was used; the practices of the American states represented the primary instance of the fourth. CARROLL expressed no conclusion as to preferred methods for allocation in the associated enterprises context.

In his general discussion of a preferred allocation regime, Carroll expressed unqualified preference for separate accounting. His general justification had more to do with objections to a fractional apportionment than to commendations of a 'separate enterprise' standard" (LANGBEIN. Stanley I. The Unitary Method and the Myth of Arm's Length. op. cit., p. 633).

78 "Los motivos alegados para este cambio en el citado Informe Carroll constituyen objeciones a la implantación del sistema unitario en el ámbito internacional de los convenios de doble imposición. En primer lugar, la afirmación del principio de que la jurisdicción fiscal debe restringir su soberanía a las fuentes de renta que se hallan en su territorio. En segundo lugar, las diferencias existentes entre las normas tributarias e mercantiles de los Estados en cuanto a métodos, llevanza y conceptos de contabilidad y los problemas de evaluación e intercambio, que hacen inviable la instauración del principio unitario. En tercer lugar, las dificultades inherentes a la posibilidad de llegar a un acuerdo internacional sobre los ingresos netos totales del negocio unitario en las bases del reparto entre las jurisdicciones, junto con la reacción de los Estados en cuanto ven mermados sus beneficios imponibles (generados realmente en su territorio) en virtud de una formula preestablecida internacionalmente. Y, finalmente, la preferencia mostrada por la mayor parte de las jurisdicciones fiscales y por la Cámara Internacional de Comercio del principio de libre concurrencia" (GALVAÑ, Gemma Sala. op. cit., p. 77).

${ }^{79}$ A regulamentação de 1934 foi consolidada no Treas. Reg. 86, §45-1 (b) (1935).
} 
Em 1935, o Comitê Fiscal da Liga das Nações Unidas valeu-se das recomendações de Mitchell B. CARROLL para propor uma minuta de convenção multilateral para alocação de lucros das empresas [muitas vezes referida como "Convenção CARROLL", por ter sido inspirada no Relatório CARROLL]. Essa minuta nunca foi objeto de recomendação expressa pela Reunião Geral dos Experts dos Governos da Liga das Nações Unidas, ou por qualquer outro órgão composto por representantes dos governos dos Estados-Membros. A minuta de convenção para alocação de lucros das empresas de 1935, nesse contexto, não se tornou um "modelo de convenção" propriamente dito. Independentemente disso, no seu artigo III, que disciplinava a atribuição de lucros a estabelecimentos permanentes, constou, pela primeira vez, a recomendação de adoção do princípio da plena concorrência no direito tributário internacional convencional ${ }^{80}$; adicionalmente, o artigo VI da aludida minuta trouxe, com relação às empresas associadas, tratamento muito semelhante àquele atualmente explicitado no Artigo $9^{\circ}$ da ConvençãoModelo da OCDE, admitindo-se, contudo, a aplicação dos métodos empíricos e de partilha fracionada em determinadas circunstâncias ${ }^{81}$.

80 "Article 3. The fiscal authorities of the Contracting State shall when necessary, in executing the preceding paragraph, rectify the accounts produced, notably to correct errors or omissions or to re-establish prices or remunerations entered in the books at the value which would prevail between independent persons dealing at arm's length" (In: HAMAEKERS. Arm's Length- How Long? op. cit., p. 33).

Se não fosse possível a adoção do princípio da plena concorrência, os métodos empíricos e de partilha fracionada poderiam ser utilizados subsidiariamente, como constatado por Sol PICCIOTTO:

"If no accounts are produced, or if they cannot be rectified, or with the agreement of the taxpayer, the business income of the establishment might be determined by applying a percentage to the turnover comparable to that of enterprises in a similar line of business. If both of these methods failed, the income might be computed by applying to the total income of the enterprise, as a whole 'coefficients based on a comparison of gross receipts, assets, number of hours worked or other appropriate factors, provided such factors be so selected as to ensure results approaching as closely as possible to those which would be reflected by a separate accounting", (op. cit., p. 31-32).

81 "As related to enterprises, the CARROLL convention (1935) contained a provision which is the direct ancestor of Article 9 of the current OECD Model. Article 6 of the CARROLL convention provided that when an enterprise of one contracting state had a 'dominant position in the management or capital of an enterprise of another contracting state', or when the same interests had such a participation in both enterprises, and where, as a result, there existed 'conditions in their commercial or financial relations different from those which would have been made between independent parties', any item of profit or loss 'which normally have appeared in the accounts of one enterprise', but which were diverted to the other, would be restored to the accounts of the first enterprise.

This convention, however, and the point needs to be stressed, did not set its face wholly against methods of 'empirical assessment' or 'fractional apportionment'. As empirical methods, the conventions apparently permitted only a percentage of turnover method, which was allowed in four circumstances: if no accounts were produced; if the accounts failed to 'correspond to the normal usages in the trade in the country where the establishment is situated'; if rectifications could not be effected; or if the taxpayer 'agree(d)'. If these methods were found to be inapplicable, fractional apportionment was permitted. Fractional apportionment was to use 'coefficients' based on a comparison of gross receipts, assets, numbers of hours worked or other appropriate factors' so long as the factors 'ensure(d) results approaching as closely as possible to those which would be reflected by a separate accounting". (LANGBEIN, Stanley I. The Unitary Method and the Myth of Arm's Length. op. cit., p. 634). 
A minuta de convenção de 1935 representou o marco histórico da adoção daquele princípio como um padrão a ser adotado mundialmente ${ }^{82}$. Ademais, seu conteúdo foi acolhido pelos modelos de convenção editados por experts da Liga das Nações em 1943 e 1946, os quais foram elaborados em reuniões ocorridas no México e em Londres, respectivamente. Em ambos os modelos, as regras a respeito da alocação de lucros entre estabelecimentos permanentes e empresas relacionadas eram idênticas: primeiramente, deveria ser adotado (a.) o método da contabilidade segregada, sendo (b.) os métodos empíricos utilizados de forma secundária e (c.) os métodos de partilha fracionada de forma terciária. Esse último método poderia, eventualmente, ser aplicado em conexão com o método da contabilidade segregada, para, e.g., repartir de despesas entre filiais e, com isso, obter uma contabilidade "individual" mais adequada ${ }^{83}$.

A expressão "dealing at arm's length" constou expressamente do Artigo VI de ambos os Modelos, o qual tratava da repartição de lucros envolvendo estabelecimentos permanentes. Daí por diante, o princípio da plena concorrência assumiu a condição de dogma de direito tributário internacional, representando um consenso entre os membros da Liga das Nações Unidas e, posteriormente, entre os Estados-Membros da OCDE.

Os trabalhos do Comitê Fiscal da Liga das Nações foram prosseguidos tanto pela Organização das Nações Unidas (“ONU”) quanto pelo Comitê Fiscal da Organização para a Cooperação Econômica Européia (“OEEC") $)^{84}$, criado em 1956, o qual foi sucedido pelo Comitê de Assuntos Fiscais da OCDE.

\footnotetext{
82 "Thus was born the arm's length method as an international standard. Although it would still take some time to firmly implant the standard in international models, the language of the 1935 draft supplied the basis for the text later inserted into the general international models (LANGBEIN, Stanley I. The Unitary Method and the Myth of Arm's Length. op. cit., p. 632).

83 "Although the method of fractional apportionment is mentioned by the Model Convention only in the third place, after the methods of separate accounting and percentage of turnover, this does not mean that the partial use of fractional apportionment is excluded when as is generally desirable, branch establishments are taxed according to the method of separate accounting. There are, indeed, in most enterprises with two or more establishments, certain items of expenses that must necessarily be apportioned in order to achieve the object of separate accounting, which is to place branches of foreign enterprises on the same footing as domestic concerns" (LANGBEIN, Stanley I. The Unitary Method and the Myth of Arm's Length. op. cit., p. 633).

${ }^{84}$ A OEEC foi fundada em 16 de abril de 1948, por dezoito países. Essa organização pode ser considerada como "resultado" da implementação do Plano Marshall, iniciado a partir de discurso promovido por George C. Marshall, Secretário de Estado dos Estados Unidos da América, em 05 de junho de 1947. No âmbito desse discurso, Marshall esclareceu qual seria o plano de auxílio, a ser desenvolvido pelos Estados Unidos da América e pelo Canadá, aos países europeus desgastados pela II Guerra Mundial. A OCDE, por seu turno, surgiu a partir da aprovação de sua Convenção, em 14 de dezembro de 1960, tendo suas atividades sido iniciadas em set./61 (informações extraídas do endereço eletrônico www.oecd.org/pages/0,317,en_36734052_36761863_1_1_1_1_1,00.html, em 30.11.09).
} 
Durante os anos de 1958 a 1961, o Comitê Fiscal da OEEC publicou quatro estudos sob o título "A Eliminação da Dupla Tributação", os quais continham minuta de convenção para evitar a bitributação com $25 \operatorname{artigos}{ }^{85}$.

O texto sugerido para o Artigo XV, posteriormente reproduzido como o Artigo $7^{\circ}$ da Convenção-Modelo de 1963, determinava que, para a aferição dos lucros de estabelecimentos permanentes, deveria haver a presunção de "distinct and separate enterprise (...) dealing quite independently with the enterprise of which it is a permanent establishment". Note-se que o princípio da plena concorrência permaneceu aplicável, mas desapareceu do texto a expressão "dealing at arm's length", anteriormente constante dos Artigos VI dos Modelos de convenções do México e de Londres. Também foram abandonadas referências aos métodos empíricos, sendo que os métodos de partilha fracionada foram mantidos para aplicação secundária por estabelecimentos permanentes, nos termos do Artigo XV, parágrafo $4^{\circ}$, da minuta de convenção de 1960, e do Artigo $7^{\circ}$, parágrafo $4^{\circ}$, da Convenção-Modelo de 1963, que praticamente foi reproduzido no artigo $7^{\mathrm{o}}$, parágrafo $4^{\mathrm{o}}$, da atual Convenção-Modelo ${ }^{86}$.

Quanto ao Artigo $9^{\circ}$ da Convenção-Modelo ${ }^{87}$, seu conteúdo permaneceu praticamente inalterado nas minutas editadas pelo Comitê de Assuntos Fiscais da OCDE desde 1963, sendo que, na Convenção-Modelo de 1977, foi incluído o parágrafo 2, que trata dos ajustes para eliminação da dupla tributação que pode decorrer da aplicação do princípio da plena concorrência a partir da legislação interna em cada uma das nações contratantes.

\footnotetext{
${ }^{85}$ Cf. Introdução da Minuta de Convenção-Modelo de 1963.

${ }^{86}$ Ressalte-se que, mesmo diante da prevalência do princípio da plena concorrência, ainda é possível a adoção do método de partilha fracionada de lucros com relação aos estabelecimentos permanentes, conforme previsto no Artigo 7.4 da atual Convenção-Modelo, desde que (i.) tal regra esteja prescrita na legislação interna do Estado Contratante e (ii.) a partilha resulte em resultado compatível com o aludido princípio. Vejase o seu teor:

“Artigo 7. (...)“4. Se for usual num Estado contratante determinar os lucros imputáveis a um estabelecimento estável com base numa repartição dos lucros totais da empresa entre as suas diversas partes, a disposição do n. 2 não impedirá esse Estado Contratante de determinar os lucros tributáveis de acordo com a repartição usual; o método de repartição adotado deve, no entanto, conduzir a um resultado conforme os princípios enunciados neste Artigo" (tradução para a língua portuguesa extraída da obra OCDE, Modelo de Convenção Fiscal sobre o Rendimento e o Patrimônio. op. cit., p. 30).

$87 \mathrm{O}$ texto do Artigo $9^{\circ}$ da Convenção-Modelo será reproduzido no CAPÍTULO 2, quando do exame detalhado do princípio da plena concorrência.
} 


\subsection{Evolução das regras para o controle dos preços de transferência no âmbito da Organização para a Cooperação e Desenvolvimento Econômico (“'OCDE”).}

\subsubsection{Transfer Pricing and Multinational Enterprises (1979).}

A despeito de as regras para o controle dos preços de transferência terem constado, desde a década de 30, de praticamente todas as minutas de Convenção-Modelo da Liga das Nações e, posteriormente, da OCDE, apenas em 1979 foi publicado o primeiro Relatório sobre a interpretação e aplicação do princípio da plena concorrência, denominado “Transfer Pricing and Multinational Enterprises" ["Relatório-1979”], o qual possui forte influência das normas norte-americanas de $1968^{88}$. Este Relatório, que teve sua adoção recomendada aos países-membros pelo Comitê de Assuntos Fiscais e pelo Conselho de Ministros da OCDE, tinha por escopo apresentar uma espécie de guia com sugestões para a aplicação uniformizada do princípio da plena concorrência ${ }^{89}$. No âmbito deste Relatório, reconhece-se que regras mandatórias específicas e restritas são incompatíveis com a complexidade e diversidade dos negócios realizados entre partes vinculadas. Afirma-se, outrossim, que, se as administrações tributárias e os contribuintes não interpretarem o princípio da plena concorrência sob uma mesma ótica, o processo de estabelecimento dos preços parâmetro complicar-se-ia ainda mais ${ }^{90}$. Buscou-se, portanto, a elaboração de uma

${ }^{88} \mathrm{O}$ fisco norte-americano também foi o responsável, anos antes, por estimular o início dos estudos sobre o princípio da plena concorrência no âmbito do Comitê de Assuntos Fiscais da OCDE:

"Initially, the transfer pricing issue was not treated as a matter of great urgency, although it appears that the OECD Fiscal Committee, at the request of the US, set up a working group as early as 1965 to examine the problem" (PICCIOTTO, Sol. op. cit., p. 188).

${ }^{89}$ "De ahí a necesidad de armonizar el régimen tributario de las operaciones vinculadas en el ámbito internacional, no únicamente asentando el principio de plena competencia como criterio internacional a la hora de determinar la correcta distribución de los beneficios empresariales de las empresas y grupos multinacionales sino también instaurando unos métodos internacionales de aplicación de este principio para conseguir una homogeneidad en el tratamiento fiscal de esta clase de transacciones que neutralizara los efectos tributarios de los precios de transferencia.

Por otro lado, dada la indeterminación que en torno al principio de plena competencia había dejado el MCOCDE y sus Comentarios, se hacía necesaria una guía aprobada por la comunidad internacional sobre la forma de llevar a cabo el ajuste administrativo - tanto el MCOCDE como sus Comentarios guardaban silencio sobre los métodos de valoración de la base imponible de las transacciones vinculadas - y fijar, en consecuencia, los beneficios sobre los que tributaría cada parte de la operación vinculada internacional. Se imponía, por tanto, la adopción de unos métodos de determinación del valor normal de mercado con consenso internacional para aplicar eficazmente o principio arm's length a la hora de realizar el ajuste primario o inicial sobre la base imponible del contribuyente vinculado" (GALVAÑ, Gemma Sala. op. cit., p. 96-97).

90، 5 . The main objectives of the report are to set out as far as possible the considerations to be taken into account and to describe, where possible, generally agreed practices in determining transfer prices for tax purposes. It is hoped that, by doing so, the report will not only help tax officials to approach more effectively the problems presented to them by the transfer prices of multinational enterprises but also to help the 
diretriz internacional para a interpretação, na medida do possível internacionalmente padronizada, do conteúdo e abrangência do princípio. Até este momento, as nações [e, especialmente, a administração tributária e o Poder Judiciário de cada uma delas] interpretavam-no de formas distintas, dentre as quais a comparação de uma determinada transação com operações similares entre o contribuinte e terceiros independentes; a fixação de preços justos e razoáveis, independentemente da comparação com operações reais ou hipotéticas de terceiros etc..

Para o fim de concretização do aludido princípio, este Relatório abordou quatro espécies de negócios sujeitos à sistemática dos preços de transferência, i.e., bens em geral [Capítulo II], transferência de tecnologia e cessão de direitos envolvendo marcas [Capítulo III], serviços intra-grupo [Capítulo IV] e empréstimos [Capítulo V]. Não obstante as especificidades indicadas em cada um dos capítulos, o Relatório sugeriu, em todos os casos, a aplicação prioritária dos três métodos ditos tradicionais. Esses três métodos são os seguintes: (i.) Método dos Preços Independentes Comparados [“Comparable Uncontrolled Price Method" ou “CUP”]; (ii.) Método do Preço de Revenda [“Resale Price Method" ou “RPM”]; e (iii.) Método do Custo mais Lucro [“Cost Plus Method" ou "CPM”].

Por conta das cada vez mais complexas negociações no interior dos grupos multinacionais, reconheceu-se que poderia ser necessária a combinação dos métodos tradicionais ou a aplicação de outros métodos para a obtenção do preço da plena concorrência. Ao se discutir os métodos para a aferição do preço de referência em operações com bens corpóreos, v.g., afirma-se que poderia ser útil a comparação dos lucros [operacionais] de uma companhia com os auferidos por outra em situação idêntica ou similar; a comparação de margens líquidas de lucratividade, contudo, deveria ser utilizada apenas como um elemento adicional para a aplicação do princípio, nunca como o único método $^{91}$. A aplicação de métodos envolvendo fórmulas predeterminadas de partição de

enterprises themselves by indicating ways in which mutually satisfactory solutions may be found to those tax problems. The basic point of reference in all the various chapters of this report is the arm's length price (...) What is set out in the main body of the report must necessarily be regarded, however, as only a general guide setting out principles that may be relevant and appropriate to apply in most cases to the different circumstances arising. (...)

6. The process of establishing an arm's length price is often complex and difficult and the difficulties are likely to be greater for both taxpayers and tax authorities if there is a lack of a common approach to the matter" (OCDE. Report of the OECD Committee on Fiscal Affairs on Transfer Pricing and Multinational Enterprises. Paris: OCDE, 1979).

91 "71. Tax authorities may find some help in a comparison of an enterprise's overall performance with that of other similar enterprises in the same or similar circumstances. Levels of profit in as industry may for example conform to a pattern and an exception to the pattern might indicate that profits were being shifted by 
lucros ou comparações de índices de retorno sobre o capital investido, no entanto, foi totalmente desaconselhada, sob os fundamentos de que não eram diretamente vinculados às condições de mercado e às situações particulares dos contribuintes, por sua incompatibilidade com os Artigos $7^{\circ}$ e $9^{\circ}$ da Convenção-Modelo de 1963 e, ainda, por seu alegado caráter arbitrário ${ }^{92}$.

\subsubsection{Transfer Pricing and Multinational Enterprises, Three Taxation}

\section{Issues (1984).}

Os três estudos publicados sob o título supra foram os seguintes: (i.) "Transfer Pricing, Corresponding Adjustments and the Mutual Agreement Procedure"; (ii.) "The Taxation of Multinational Banking Enterprises" ["Relatório-1984/Bancos"]; e (iii.) "The Allocation of Central Management and Service Costs”. Os estudos (i.) e (iii.) não serão objeto de análise nesta tese, mas tão-somente o Relatório-1984/Bancos, o qual foi posteriormente atualizado pela Parte II do Relatório indicado em 1.3.6, infra.

Desde logo, importa esclarecer que este Relatório-1984/Bancos tinha por objetivo precípuo complementar o Relatório-1979, porquanto as regras expostas no Capítulo V [“Empréstimos”] deste último eram inaplicáveis a empréstimos bancários. Este

\footnotetext{
artificial transfer prices. But comparisons of this sort would need to be made with care. It does not necessarily follow that exceptional profits or losses are artificial. Moreover there are many ways of looking at the profit situation of an enterprise - analyzing for example what relation the profit bears to total receipts from sales, or to the operating expenses incurred, and a method which is appropriate for one company may not be appropriate for another. It may be helpful nevertheless to make comparisons of this sort in relation to the gross profits from sales of particular products or groups of products, but even so the results of the comparison could normally be regarded only as pointers to further investigations" (OCDE. Report of the OECD Committee on Fiscal Affairs on Transfer Pricing and Multinational Enterprises. op. cit.).

92 "14. Proposals for radical reformulations of the approach to intra-group transfer pricing which would move away from the arm's length approach towards so-called global or direct methods of profits allocation, or towards fixing transfer pricing by reference to predetermined formulae for allocating profits between affiliated are not endorsed in this report. The use of such alternatives to the arm's length principle in incompatible in fact with Articles 7 and 9 of the OECD Model Double Taxation Convention. Such methods would necessarily be arbitrary, tending to disregard market conditions as well as the particular circumstances of the individual enterprises and tending to ignore the management's own allocation of resources, thus producing an allocation of profits which may bear no sound relationship to the economic facts and inherently running the risk of allocating profits to an entity which is in truth making losses (or possibly the contrary)"; "73. By a somewhat similar process the reasonableness of transfer prices may perhaps be assessed by comparing the yield or return on the capital investment in the relevant associated enterprises with the yield or return on the capital invested in enterprises carrying on similar activities and requiring the same kind of capital investment. This too presents difficulties. One problem is that the financial structuring of the relevant entities would need to be essentially similar if this comparison was to be useful and if the structure was not essentially similar (because for example of the different impact of obligations to pay interest) then difficult adjustments would have to be made to the calculations in order to ensure comparability" (OCDE. Report of the OECD Committee on Fiscal Affairs on Transfer Pricing and Multinational Enterprises. op. cit.).
} 
Relatório reconheceu que a atuação multinacional das instituições financeiras, via subsidiárias ou filiais, seria cada vez mais ampla, porque era apta a gerar inúmeras eficiências, e, por conseguinte, as administrações tributárias e os contribuintes deveriam estar preparados para a aplicação do princípio da plena concorrência a estas operações. $\mathrm{O}$ Relatório-1984/Bancos pondera que o CUP poderia, na maioria dos casos, ser aplicável a operações entre empresas de um mesmo grupo financeiro; sua aplicação, todavia, requereria atenção, porque somente seriam comparáveis operações independentes com valor, prazo e moeda semelhantes, visto que estes fatores têm impactos relevantes na definição das taxas de juros aplicáveis. Com relação particularmente ao prazo, é importante levar em consideração que há mais dados comparáveis em operações de curto prazo do que em operações de longo prazo ${ }^{93}$.

Quanto às operações de empréstimos intra-empresa, o Relatório-1984/Bancos apresenta maiores preocupações, porque há discussões, no cenário internacional, sobre a necessidade de uma filial "remunerar" o capital mutuado por sua matriz; enquanto a maioria dos Estados-Membros da OCDE entende que devem ser pagos juros nos empréstimos entre matriz e filial, para o fim de se atingir o princípio da plena concorrência, Estados Unidos e Japão têm opinião distinta ${ }^{94}$. Este Relatório apresenta,

93 “36. The widespread existence of markets for the borrowing and lending Money in various forms, the fact that the banks frequently borrow and lend large sums to each other on inter-bank markets and the common phenomenon of recognized inter-banking lending rates indicates that it would normally be possible to derive arm's length interest rates for transactions between the various parts of a banking enterprise from the rates charged in comparable transactions between independent parties. Information about inter-bank deposit rates applied in the various market compartments is publicly available. For example, the London inter-bank offering rate (Libor) is quoted in the daily financial press. (It should be recognized, however, that the effective rate applied in any individual transaction may diverge somewhat from the rate quoted publicly: Euro-currency rates may vary sharply during a day, as money market rates may do generally in all countries). 37. There will often, therefore, be evidence for arm's length prices on the comparable uncontrolled price basis and the cost-plus or resale-minus basis will be much less importance in the context of bank interest than in other contexts. It has to be recognized, however, that usable evidence is likely to be more freely available for short-term borrowing than for longer-term borrowing (i.e. for up to five years). Normally the transactions to be used for comparison should be arm's length transactions between unrelated banks where the amount lend, the term of the loan, the currency involved and the other conditions are the same or similar to those in question" (OCDE. Report of the Committee on Fiscal Affairs on Transfer Pricing and MNEs. Three Taxation Issues. N. 2 The Taxation of Multinational Banking Enterprises. Paris: OCDE, 1984).

94 " 47 . It is, in the view of the majority of OECD Member Countries, necessary to take account of intra-bank payments of interest in ascertaining the arm's length profits of a branch of a bank, in order to ensure that the taxation of the operating profits of the foreign bank branch is consistent, in principle, with the Taxation of the profits of branches of other enterprises.

52. Japan and the United States are of the view that the conclusion reached by the majority of the OECD Members that intra-bank payments of interest are required to be taken into account go too far (...). In the view of Japan and the United States there is no basis for requiring that intra-bank interest should be taken into account. (...) It should be understood, however, that both Japan and the United States do provide for a deduction for interest paid when the profits of a branch of a foreign bank are being computed for tax purposes. It is on the question of what payments are to form the basis for calculating this deduction that they 
outrossim, três sistemáticas para se aferir a remuneração dos empréstimos intra-empresa verificados na ocasião: (i.) a análise transação-a-transação; (ii.) o denominado "tracing method", adotado por Japão e Estados Unidos, que buscava alcançar diretamente os empréstimos captados por terceiros e valer-se desta taxa para "testar" os valores contábeis lançados $^{95}$; e (iii.) o método da fungibilidade, que também ignorava as transações reais intra-empresa e admitia a dedutibilidade de uma taxa média apurada a partir dos juros pagos por toda a companhia; este método foi previsto na legislação norte-americana como uma alternativa à aplicação do "tracing method" e não existe mais em sua "forma pura"96.

differ from other OECD Member countries" (OCDE. Report of the Committee on Fiscal Affairs on Transfer Pricing and MNEs. Three Taxation Issues. op. cit.).

95 " 53 . Most OECD countries take the view that intra-bank payments of interest should be taken directly into account, that is to say by reference to the specific payments made between the relevant parts of the enterprise, possibly adjusted to arm's length amounts. In principle, this requires the identification of the source and amount of the particular funds loaned by the branch. It is recognized, however, by the countries which take this view [tracing method view] that because of the complex nature of a bank's transactions and the fact that the money, from whatever source it arises, may, to a certain extend (and possible even to a large extend), be interchangeable with money from other sources, this identification may often be difficult. (...) It will often be necessary in consequence to adopt some simplification approach to overcome this king of difficulty. Thus, it may be convenient to look at groups or categories of transaction rather than at each separate transaction individually, and to use rates of interest perhaps derived from averages of rates paid in a comparable market situation to unrelated parties (...).

54. While Japan and the United States do not feel that the Model Convention requires intra-bank payments to be included, nevertheless they allow for the use of a tracing approach that does take account of these payments. The tracing approach is a process of tracing back the loans made by a branch of the funds supplied by other parts of the enterprise to the original provision of funds by persons outside the enterprise.

55. In particular, the Japanese method provides for the deduction of the actual inter-branch or head office/branch interest in calculating the taxable profit of the Japanese branch. The interest cost is measured by the amount incurred to the third party provider of the funds only when the source of the funds can be traced and is demonstrable by documentation. Usually, however, such tracing of funds to specific sources is impossible and the interest cost reasonably estimated by the Japanese branch is acceptable as long as this estimated cost reflects the prevailing arm's length rate of interest" (OCDE. Report of the Committee on Fiscal Affairs on Transfer Pricing and MNEs. Three Taxation Issues. op. cit.).

Veja-se que, em certa medida, este método subsidiário proposto pelas autoridades japonesas aproxima-se daquele adotado pelos demais membros da OCDE para se atingir o princípio da plena concorrência.

96 "59. (...) The activity of the whole enterprise contributes so much, it is argued, to the profit or loss derived from each part of the enterprise that, though it may not be possible to quantify the contribution precisely, it must be acknowledged in the attribution of profit or loss to any particular permanent establishment of the enterprise. It would be going too far to do this by simply attributing to the permanent establishment a share of the total profit or loss of the whole enterprise, and in any case, if such an attempt were made, there would remain the question of what basis should be used for that attribution and all the other problems of the whole enterprise approach (Article 7, paragraph 4 of the OECD Model Convention). But it would be appropriate, it is argued, to regard the interest expenses of the whole enterprise as incurred for the common purposes of the enterprise and thus as properly attributable to each part on some average basis. Thus, on this basis the inflow to the point of access from sources outside the pool is registered as an appropriate starting point for calculating the profit arising at that point, and on this basis, the calculation of the tax liability in State A of a branch of a foreign bank would in essence take into account, first, the interest received by the branch from sources within State A and second, interest received from sources outside State A where loans were effective connected with that branch business. No account would be taken of any payments of interest by the branch to another part of the bank or vice versa. Nor, in general, would any deduction be allowed in computing the branch's profits for the actual interest paid by the branch. On the other hand, there would be set, against the branch's receipts for the third parties, a share of the average interest paid by the bank as a whole" (OCDE. Report of the Committee on Fiscal Affairs on Transfer Pricing and MNEs. Three Taxation Issues. op. cit.). 
Os métodos (ii.) e (iii.) não são reconhecidos pela maioria dos Estados-Membros da OCDE, porque ignoram as "transações reais" e, com isso, afastam-se, de certo modo, do princípio da plena concorrência.

\subsubsection{Reports of the Tax Force of the OECD Committee on Fiscal Affairs on US Transfer Pricing Regulations (1993).}

O IRS norte-americano vinha, desde o início da década de 80, desenvolvendo estudos mais aprofundados acerca dos métodos para a concretização do princípio da plena concorrência, resultando na publicação, em 21 de janeiro de 1993, do documento "The 1993 Temporary and Proposed Regulations" ["Regulamentação EUA-1993”] e, no ano seguinte, em 08 de julho de 1994, na publicação das "Final Regulations" ["Regulamentação Final EUA-1994"], que representou uma modificação "definitiva” da Seção 482 de seu “Internal Revenue Code" [doravante referido pela sigla "IRC”].

Logo após a publicação da Regulamentação EUA-1993, ainda naquele ano, o grupo especial dedicado à questão dos preços de transferência do Comitê de Assuntos Fiscais da OCDE reuniu-se para elaborar o documento "Tax Aspects of Transfer Pricing within Multinational Enterprises: The United States Proposed Regulations" ["Relatório1993"]. No Relatório-1979, a OCDE havia exposto suas preocupações concernentes à aplicação de métodos amparados na comparação de lucros [e não na comparação de transações, como o CUP, o RPM e o CPM]. Considerando que (a.) a Regulamentação EUA-1993 propunha tanto métodos baseados na divisão de lucros quanto métodos amparados na comparação dos lucros de determinada empresa com os lucros de terceiros que desenvolvessem atividades idênticas ou semelhantes, bem assim (b.) a necessidade de manutenção de uma espécie de "consenso internacional" quanto às metodologias para a efetivação do princípio da plena concorrência, a OCDE entendeu oportuna a elaboração do Relatório-1993, que tinha por escopo fornecer ao fisco norte-americano a posição dos demais Estados-Membros sobre a Regulamentação EUA-1993 ${ }^{97}$.

\footnotetext{
97 "1.3. The purpose of the present report, which has been prepared by a special Task Force established by the Committee on Fiscal Affairs of the OECD, is to provide the United States Administration with the collective views of the OECD Member countries on proposed Regulations" (OCDE. Reports of the Tax Force of the OECD Committee on Fiscal Affairs on US Transfer Pricing Regulations. Paris: OCDE, 1983, Parte I).
} 
A maior preocupação do grupo especial da OCDE era, justamente, a adoção, para operações com intangíveis, do método da comparação dos lucros da empresa "testada" com lucros de terceiros que se dedicassem a atividade idêntica ou semelhante ["Comparable Profit Interval Method", a seguir referido como "CPI"98]. Na visão majoritária dos Estados-Membros da OCDE, a existência de um "intervalo de lucros comparáveis" em cada atividade seria aplicada pelo fisco norte-americano preferencialmente aos métodos tradicionais de comparação de transações, tendo em vista a facilidade gerada por esta sistemática; o RPM e o CPM, nesse cenário, seriam suplantados pelo CPI. Tanto não bastasse, este último método produziria resultados "presumidos" e não compatíveis com o princípio da plena concorrência ${ }^{99}$, além de, na prática, ser complicada a definição do aludido "intervalo de lucros comparáveis", dado que as informações públicas disponíveis sobre a lucratividade operacional nos diversos ramos nem sempre seria adequada ou suficiente; somente estariam disponíveis informações sobre atividades em que a aplicação do CUP, RPM ou CPM também fosse viável; para os negócios raros e únicos, não seriam facilmente aplicáveis os métodos tradicionais e tampouco seriam obtidas informações para a aplicação do $\mathrm{CPI}^{100}$. Ao final, a OCDE propõe que o fisco norte-

98 "2.24. (iii.) In the absence of matching or comparable adjustable transactions, the proposed Regulation require that the arm's length consideration be determined by reference to the operating income earned by one of the parties (the tested party). This method $[C P I]$ refers to the various levels of operating income earned by unrelated parties performing functions and dealing with products similar to those of the tested party. Using a number of objective measures of profitability derived from these unrelated parties (referred to as 'profit level indicators'), an interval of comparable profits is determined. If the tested party's average 'reporting operating income' (generally the income of the tested party that was on the tax return) for the 3-year period, including the taxable year and the immediately preceding and following taxable years is within this interval, an adjustment is not made. If the reported operating income is outside of, but not far from the boundary of the interval, the size of the adjustment generally would be limited, based on the proximity of the reported operating income to the comparable profit interval" (OCDE. Reports of the Tax Force of the OECD Committee on Fiscal Affairs on US Transfer Pricing Regulations. Parte I).

99 "3.35. Of particular concern to the treaty partners of the United States is the fact that an adjustment made under the comparable profit method may leave the other party to the transaction with a reward for its contribution to the overall profit which is not an arm's length one. This is, of course, a fundamental problem with all transfer pricing adjustments and one that both tax administrations involved need to be as accommodating as possible within the arm's length standard if international double taxation is to be avoided. The comparable profit method, since it involves neither a comparable price nor acknowledgement of the contribution made by the other parties to the transaction, is more likely to produce a result that is not arm's length" (OCDE. Reports of the Tax Force of the OECD Committee on Fiscal Affairs on US Transfer Pricing Regulations. Parte I). Afirma-se, outrossim, que, se o intervalo de lucros comparáveis pudesse ser refutado pelos contribuintes, a partir da demonstração de dados [preço, rentabilidade etc.] obtidos em operações nãovinculadas da mesma natureza, o CPI tornar-se-ia mais "próximo" do princípio da plena concorrência.

100 "'3.37. Having examined the data available in Member Countries, the Task Force is of the opinion that there will be substantial problems in finding the relevant and reliable data necessary for the application of the comparable profit method, although it is acknowledged that it is not always easy to obtain reasonable data to implement other methods. The data available from public sources is usually inadequate. Not only it is frequently too general, it is often not "pure" enough in that is still includes many intra-group transactions. Moreover, there is the fundamental problem that it will be very difficult to find proper comparables for certain tested parties (...). 
americano, dada a complexidade de suas regras, edite safe harbours aplicáveis a pequenas e médias empresas (parágrafos 3.30 a 3.35 da Parte II deste Relatório-1993). Destaque-se, por fim, que os principais opositores a estas regras foram Alemanha e Suécia, que mantiveram reservas quanto a este tema mesmo após adoção de metodologia semelhante pela Diretiva da OCDE de 1995, a qual será discutida na próxima subseção. Na visão dos membros destes países do Comitê de Assuntos Fiscais, o CPI ou qualquer outro método que vise a comparação de lucros operacionais ao invés de transações não seriam compatíveis com o princípio da plena concorrência ${ }^{101}$.

\subsubsection{Transfer Pricing Guidelines for Multinational Enterprises and Tax}

\section{Administrations (1995).}

Desde 1986, os Estados Unidos da América vinham reformulando suas regras para o controle dos preços de transferência e instituindo normas mais severas e rígidas para coibir a prática de planejamentos tributários internacionais por empresas ali estabelecidas. Em 1994, como referido anteriormente, foi editada a Regulamentação Final EUA-1994, com substanciais alterações nos métodos aplicáveis para a concretização do princípio da plena concorrência. Não obstante as críticas teóricas elaboradas em desfavor destas regras, na prática, elas atraíram a preocupação de muitos países, que temiam que os grupos multinacionais concentrassem parcela relevante das rendas tributáveis de seus negócios no território norte-americano, com o objetivo de evitar as severas sanções que vinham sendo impostas pela administração tributária daquela nação ${ }^{102}$. Buscando superar as diferenças importantes que, nesse período, segregavam as regras norte-americanas de um lado e as

3.39. A number of the industry bodies as well as individual companies have stated that the data required to construct a CPI are just not available. Nevertheless it is undoubtedly true that business do undertake research into the commercial activities of their competitors. Where this is done, a company will often have a good idea of what terms are available to competitors, what its cost structure is and consequently what prices it can afford to charge and what profits it is making. However, this will be primarily in those industries where there is a measure of developed competition. The difficult cases are those involving the unique product or intangible where the data are always going to difficult to find" (OCDE. Reports of the Tax Force of the OECD Committee on Fiscal Affairs on US Transfer Pricing Regulations. Parte I).

${ }^{101}$ A Alemanha, especialmente, passou a prever em suas normas internas o TNMM, método inspirado no CPI norte-americano, a partir de 2003 [Sec. 90, Para. 3 of the General Tax Code (AO). Informação extraída de NIENTIMP, Axel; ROEDER, Achim. Global Trading. International Transfer Pricing Journal. Amsterdã: IBFD, nov./dez. 2005, p. 306.

${ }^{102}$ Prova disso é que, nos cinco anos que sucederam a reforma da Seção 482 do IRC, muitos países instituíram suas próprias regras de preços de transferência ou alteraram normativos anteriores, introduzindo requisitos documentais mais rigorosos e penalidades mais severas para a prática de preços anormais. Dentre os países que introduziram novos regramentos concernentes aos preços de transferência estão Austrália, Canadá, Chile, Coréia, Dinamarca, Espanha, França, Inglaterra, Japão, México, Nova Zelândia e Polônia. A publicação da Lei n. ${ }^{\circ}$ 9.430/96 no Brasil também se deu neste mesmo contexto. 
orientações da OCDE de outro, esta organização instituiu um grupo de trabalho para atualizar e consolidar estudos anteriores, até que, em 27 de junho de 1995, o "Transfer Pricing Guidelines for Multinational Enterprises and Tax Administrations” [Diretiva] foi aprovado pelo Comitê de Assuntos Fiscais daquela organização. A publicação destas novas regras foi aprovada pelo Conselho da OCDE em 13 de julho de 1995.

A Diretiva representa a compilação e revisão dos Relatórios referidos em 1.3.1 a 1.3.3 e do relatório denominado "Thin Capitalization", de $1987^{103}$.

Este trabalho tem sido objeto de constantes revisões. A versão original, de jul./95, continha apenas os cinco primeiros capítulos da versão atual da Diretiva [Capítulo I: "The Arm's length Principle"; Capítulo II: "Traditional Transaction Methods"; Capítulo III: "Other Methods", Capítulo IV: "Administrative Approach to Avoiding and Resolving Transfer Pricing Disputes"; e Capítulo V: "Documentation"]. Em mar./96 foram publicados os Capítulos VI e VII, denominados, respectivamente, "Special Considerations for Intangible Property" e "Special Considerations for Intragroup Services". Em ago./97 foi publicado o Capítulo VIII, a respeito dos acordos intra-grupo de repartição de despesas (“Cost Contribution Arrangements") e, em fev./98, o anexo com exemplos ilustrativos sobre a aplicação dos métodos recomendados no âmbito da Diretiva. Por fim, em out./99 foi publicado um novo anexo, com as recomendações principais para a condução de APA nos termos do MAP prescrito no Artigo 25 da Convenção-Modelo.

No âmbito da Diretiva, a OCDE reforça a posição já manifestada no Relatório1979 e reafirma a relevância do critério da contabilidade segregada, da ficção de empresas independentes e do princípio da plena concorrência no cenário internacional. Desaconselha-se totalmente a aplicação dos métodos de divisão de lucro segundo fórmulas predeterminadas, não amparados no princípio da plena concorrência ${ }^{104}$. Considerando que o escopo da Diretiva é, justamente, um maior detalhamento sobre a aplicação do princípio

\footnotetext{
103 (OCDE. Transfer Pricing Guidelines for Multinational Enterprises and Tax Administrations. op. cit., p. P4).

104 "3.74. For the foregoing reasons, OECD Member countries reiterate their support for the consensus on the use of the arm's length principle that has emerged over the years among Member and non-Member countries and agree that the theoretical alternative to the arm's length principle represented by global formulary apportionment should be rejected" (OCDE. Transfer Pricing Guidelines for Multinational Enterprises and Tax Administrations. op. cit., p. III-24). Convertido no parágrafo 1.32 da Minuta-2009.

Maiores ponderações sobre o princípio da plena concorrência versus a sistemática unitária serão tecidas no CAPÍTULO 6, onde o assunto será discutido com maior profundidade.
} 
da plena concorrência, ela também é aplicável à partição de lucros entre estabelecimentos permanentes, desde que ponderadas as devidas especificidades ${ }^{105}$.

Além dos métodos tradicionais discutidos no Relatório-1979, foram reconhecidos e examinados dois métodos baseados na comparação de lucros: (i.) o "Profit Split Method" ("método da divisão dos lucros" ou "PSM"), que compara a lucratividade das operações testadas com os lucros que seriam auferidos entre empresas independentes; e (ii.) o "Transaction Net Margin Method" ("método de comparação das margens líquidas" ou "TNMM"), inspirado no CPI um ano antes introduzido na legislação norte-americana. Como decorrência de sua contrariedade ao CPI, Alemanha e Suécia também atacaram a aplicação do TNMM e apresentaram oposição à sua inclusão na Diretiva. Na visão da OCDE, os métodos tradicionais [CUP, RPM e CPM] sempre seriam preferíveis porque (a.) permitiriam uma aplicação mais adequada do princípio da plena concorrência; e (b.) não existiria muita experiência na aplicação dos métodos de comparação dos lucros, o que dificultaria o exame [e a correção] de suas falhas e limitações. O PSM deveria ser aplicado subsidiariamente ou como complemento a um dos métodos tradicionais. Já ao TNMM foram impostas restrições ainda mais severas ${ }^{106}$, sendo que este método foi, à época, considerado o "quinto método" em ordem de preferência; ademais, sempre que possível, o TNMM deveria ser aplicado em conjunto com outro(s) método(s) e não isoladamente.

Com o objetivo de monitorar a implementação da Diretiva e angariar maiores informações sobre a aplicação do princípio da plena concorrência, em 2003, o Comitê de Assuntos Fiscais convidou as administrações tributárias, os contribuintes, associações de

\footnotetext{
${ }^{105}$ Cf. p. P-3 do Transfer Pricing Guidelines for Multinational Enterprises and Tax Administrations. op. cit.. 106 "3.52. In most countries the application of transaction profit methods has been limited to the profit split method, the use of which has not been frequent and has taken place largely in bilateral agreement procedures, situations where the risk of unrelieved double taxation is minimal. Very few countries have much experience in the application of the transactional net margin method and most consider it experimental and therefore prefer to use profit split method in cases of last resort.

3.53. As discussed in this Report, there are substantial concerns regarding the use of the transactional net margin method, in particular that it may be applied without adequately taking into account the relevant differences between the associated enterprises and the independent enterprises being compared. Many countries are concerned that safeguards established for the traditional transactional methods may be overlooked in applying the transactional net margin method. Thus, where differences in the characteristics of the enterprises being compared have a material effect on the net margins being used, it would not be appropriate to apply the transactional net margin method without making adjustments for such differences.

3.54. The recognition that the use of transactional profit methods may be necessary is not intended to suggest that independent enterprises would use this methods to set prices. Instead, traditional profit methods are being recognized as methods that assist in determining in cases of last resort whether transfer pricing complies with the arm's length principle" (OCDE. Transfer Pricing Guidelines for Multinational Enterprises and Tax Administrations. op. cit., p. III-18). Este entendimento foi modificado pela Minuta-2009, conforme será explicado no CAPÍTULO 5.
} 
classe etc. para responder a consulta pública sobre tópicos relacionados à comparabilidade. Valendo-se dos comentários recebidos, o Working Party no. 6 do Comitê de Assuntos Fiscais publicou, em 2006, o documento n. ${ }^{\circ}$ CTPA/CFA (2006)31, com doze tópicos sobre o assunto [doravante referido como "Minuta Comparabilidade-2006"] 107, o qual foi submetido a nova consulta pública. Adicionalmente, importa ponderar que, em janeiro de 2008, foi disponibilizada consulta pública acerca dos métodos baseados na comparação de lucros, sendo que os interessados poderiam manifestar-se sobre doze tópicos ali indicados [“Consulta Pública-2008”] ${ }^{108}$. Ambas as consultas públicas permaneceram abertas até nov./2008, quando foi realizada uma conferência de dois dias com especialistas no assunto, para discussão dos principais tópicos e comentários recebidos.

Com amparo em todas as discussões referidas no parágrafo anterior, a OCDE publicou em set./2009 uma minuta substitutiva dos Capítulos I a III da Diretiva ["Minuta2009”], aberta para consulta pública entre 09.09.09 e 09.01.10 ${ }^{109}$. Até o final da elaboração

${ }^{107}$ Foi apresentada uma minuta com discussões e conclusões preliminares envolvendo os seguintes itens: (1.) putting a comparability analysis and search for comparables into perspective; (2.) timing issues in comparability; (3.) internal comparables; (4.) determination of available sources of information and their reliability; (5.) uncontrolled transactions; (6.) examining the five comparability factors; (7.) selecting or rejecting third parties or third parties transactions: degree of objectivity of the list of external comparables; (8.) determination of making comparability adjustments where appropriate; (9.) multiple year data; (10.) aggregation of transactions; (11.) definition of the arm's length range, extreme results, methods to enhance reliability, loss-making comparables; (12.) documenting a search for comparables.

Este documento está disponível no seguinte endereço eletrônico: http://www.oecd.org/document/12/0,3343,en_2649_37989753_36651660_1_1_1_1,00.html.

${ }^{108}$ Os tópicos disponibilizados para consulta pública foram os seguintes:

(1.) status of transactional profit method as last resort methods; (2.) use of a transactional profit method either in conjunction with a traditional transaction method or as a sanity check to test the plausibility of the outcome of a traditional transaction method; (3.) application of transactional profit methods and intangibles; (4.) application of transactional profit methods and consideration of risks; (5.) the need for tax administrations to have access to all information needed to apply or review the application of a transactional profit method; (6.) application of a profit split method: determination of the profit to be split; (7.) application of a profit split method: reliability of a residual analysis and of a contribution analysis; (8.) application of a profit split method: how to split the profit; (9.) application of the transactional net margin method: standard of comparability; (10.) application of a the transactional net margin method: determination of the net margin; (11.) other methods; (12.) other issues.

A Consulta Pública-2008 está disponível no seguinte endereço eletrônico: http://www.oecd.org/document/53/0,3343,en_2649_37989753 39915061_1_1_1_1,00.html.

${ }_{109}$ As principais modificações introduzidas pela Minuta-2009, como relatado pela própria OCDE, são as seguintes:

"The main proposed changes are as follows:

- Hierarchy of transfer pricing methods: In the existing TPG [Diretiva], there are two categories of OECDrecognized transfer pricing methods: the traditional transaction methods (described at Chapter II of the TPG) and the transactional profit methods (described at Chapter III). Transactional profit methods (the transactional net margin method and the profit split method) currently have a status of last resort methods, to be used only in the exceptional cases where there are no or insufficient data available to rely solely or at all on the traditional transaction methods. Based on the experience acquired in applying transactional profit methods since 1995, the OECD proposes removing exceptionality and replacing it with a standard whereby the selected transfer pricing method should be the 'most appropriate method to the 
deste trabalho, ainda não haviam sido disponibilizados os comentários das autoridades tributárias e/ou contribuintes sobre a referida minuta; independentemente disso, pode-se desde logo concluir que os métodos baseados na comparação de lucros assumirão maior importância na próxima versão da Diretiva, tendo a OCDE reconhecido sua relevância diante da ausência de dados para a aplicação dos métodos tradicionais; esta decisão pode ter sido possivelmente influenciada pela legislação norte-americana, país onde o CPI assume papel cada dia mais importante. Saliente-se que, sempre que for relevante para o objeto da tese, serão indicadas ou explicadas, ao longo do texto, as alterações propostas no âmbito da Minuta-2009 para a Diretiva.

Por fim, esclareça-se que, em 07 de setembro de 2009, a OCDE publicou nova versão da Diretiva, com alterações no Capítulo IV ("Administrative Approach to Avoiding and Resolving Transfer Pricing Disputes"), as quais decorreram do desenvolvimento das regras internacionais relativas ao MAP e à utilização de arbitragem para solução de controvérsias na aplicação das convenções [cf. Artigo 25 da Convenção-Modelo] ${ }^{110}$. Como o Capítulo IV não é objeto da tese, esta nova versão não é relevante no presente caso.

\subsubsection{The Taxation of Global Trading of Financial Instruments (1998).}

A preocupação da OCDE com a disciplina da tributação da negociação global de instrumentos financeiros foi originalmente manifestada em 1997, ano em que foi

circumstances of the case'. In order to reflect this evolution, it is proposed to address all transfer pricing methods in a single chapter, Chapter II (Part II for traditional transaction methods, Part III for transactional profit methods).

- Comparability analysis: The general guidance on the comparability analysis that is currently found at Chapter I of the TPG was updated and completed with a new Chapter III containing detailed proposed guidance on comparability analyses.

- Guidance on the application of transactional profit methods: Proposed additional guidance on the application of transactional profit methods was developed and included in Chapter II, new Part III.

- Annexes: Three new Annexes were drafted, containing practical illustrations of issues in relation to the application of transactional profit methods and an example of a working capital adjustment to improve comparability"

(Informação extraída do endereço seguinte elênico: http://www.oecd.org/document/26/0,3343,en_2649 33753 43656346_1_1_1_1,00.html).

Sempre que houver alterações substanciais, o texto fará referência à Diretiva e ao tratamento conferido à matéria no âmbito da Minuta-2009.

110 Confiram-se explicações sobre a nova versão da Diretiva, constantes do endereço eletrônico http://www.oecd.org/document/10/0,3343,en_2649 $33753 \quad 43659338$ ___l_1_1,00.html:

"In this 2009 edition, amendments were made to Chapter IV, primarily to reflect the adoption, in the 2008 update of the Model Tax Convention, of a new paragraph 5 of Article 25 dealing with arbitration, and of changes to the Commentary on Article 25 on mutual agreement procedures to resolve cross-border tax disputes. References to good practices identified in the Manual for Effective Mutual Agreement Procedures were included and the Preface was updated to include a reference to the Report on the Attribution of Profits to Permanent Establishments adopted in July 2008". 
divulgado o estudo denominado "The Taxation of Global Trading of Financial Instruments: A Discussion Draft", elaborado pela Seção Especial sobre Inovações nas Transações Financeiras, grupo de estudos constituído, em 1994, pelo Comitê de Assuntos Fiscais daquela organização. Esse primeiro estudo foi aperfeiçoado a partir de contribuições das administrações tributárias dos Estados-Membros, das próprias instituições financeiras e de empresários, até que, em 1998, foi publicado o documento final, denominado "The Taxation of Global Trading of Financial Instruments" [doravante designado "Relatório GT-1998"]. Este Relatório reforça os preceitos indicados na Diretiva, especialmente o critério da contabilidade segregada, a ficção de independência e o princípio da plena concorrência; não obstante isso, pelas características intrínsecas e específicas das operações de negociação global de instrumentos financeiros, o PSM assume papel mais relevante que aquele a ele atribuído na Diretiva.

No âmbito deste Relatório GT-1998 foram abordados, em especial, os seguintes tópicos: (a.) definição da noção de negociação global de instrumentos financeiros; (b.) discussão das três estruturas básicas para a organização da atividade de negociação (“trading”); (c.) aplicação do princípio da plena concorrência; (d.) adoção do PSM e determinação do lucro a ser partilhado; e, ao final, (e.) aplicação dessas normas a operações conduzidas por estabelecimentos de uma única pessoa jurídica que se dedicam à negociação global de instrumentos derivativos. Em suma, este Relatório concluiu que, a despeito de os métodos tradicionais serem de aplicação complexa nestes casos, haja vista (i.) o alto grau de integração das atividades desempenhadas por cada uma das partes; e (ii.) a dificuldade de obtenção de dados comparáveis, na medida em que empresas independentes normalmente atuariam mediante a repartição de resultados, ainda assim deveriam ser adotados preferencialmente os métodos tradicionais, na linha do quanto recomendado pela Diretiva; subsidiariamente, deveria ser aplicado o PSM $^{111}$. Ao final,

\footnotetext{
111 "Global trading of financial products is an emerging phenomenon associated with the development of innovative financial instruments which presents new challenges to tax authorities. Because Articles 7 and 9 of the OECD Model Convention provide the governing principles, the traditional transactional methods of taxation or attribution of income principle should be the primary methods for analyzing global trading. However, experience shows that the activities of each location engaging in global trading are often so highly integrated, or conducted in so different manners from how the activities are conducted between independent parties, that traditional transactional methods may not fully be capable of reaching appropriate results. Indeed, independent parties in similar circumstances may well have agreed to 'set up a form of profit split'. The paper has attempted to put global trading issues in context, by means of a detailed analysis of its factual background. It has focused on the circumstances in which there are difficulties in applying traditional transactional methods so that, as a last resort, profit split methods may have to be applied" (OCDE. OECD Documents. The Taxation of Global Trading of Financial Instruments. op. cit., p. 65).
} 
reconheceu-se que, por vezes, nem mesmo o PSM poderia possibilitar a determinação do preço parâmetro; ainda assim, negou-se totalmente a vigência a qualquer método não amparado no princípio da plena concorrência. Maiores detalhes sobre cada um dos aspectos envolvidos neste Relatório GT-1998 constam dos CAPÍTULOS 3 a 5.

Este Relatório, a despeito de representar uma revisão e atualização do "The Taxation of Global Trading of Financial Instruments: A Discussion Draft" (1997), ainda não contém recomendações definitivas ou 'firmes', nem reflete uma conclusão das administrações tributárias dos Estados-Membros; sua finalidade primordial é o fomento de discussões com vistas à obtenção de um consenso multilateral entre os Estados ${ }^{112}$. Estes estudos permaneceram sendo desenvolvidos por um grupo de trabalho vinculado ao Working Party no. 6, o mesmo que estuda a questão dos preços de transferência e que, até 2008, trabalhou na elaboração do Relatório discutido na subseção subseqüente. A Minuta2009 também impacta o exame das operações desenvolvendo a negociação global de instrumentos financeiros, especificamente no que concerne às regras para a obtenção de dados comparáveis e à aplicação específica do método PSM.

\subsubsection{Report on Attribution of Profits to Permanent Establishments (2008).}

Em 17 de julho de 2008, foi publicado o "Report on the Attribution of Profits to Permanent Establishments" ["Relatório-2008”], aprovado poucos dias antes, em 24 de junho de 2008, pelo Comitê de Assuntos Fiscais da OCDE. Este "relatório final", cuja adoção é recomendada pelo Conselho da $\mathrm{OCDE}^{113}$, representa o resultado da consolidação

112 "This document is still however in the form of a discussion draft and so does not generally reach firm recommendations. This document is being released, since for public comment, since the Committee is very much aware of the need to have further input from business community on the options identified for governments to deal with the tax issues arising from global trading, in the light of the revisions made on the paper. (...) The Committee intends to use this document as the basis for its work on developing a multilateral consensus on how global trading activities should be taxed. (...) The views expressed in this document should not at this stage be taken as necessarily reflecting the final position of Member governments" (OCDE. OCDE Documents. The Taxation of Global Trading of Financial Instruments. op. cit., p. 3).

113 "Acknowledging the need to achieve consistency in the approaches of tax administrations, on the one hand, and of enterprises, on the other hand, in the determination of the profits attributable to permanent establishments:

I. RECOMENDS to the Governments of Member countries:

(i) that their tax administrations follow, when applying the provisions of their bilateral tax conventions that are drafted on the basis of Article 7 of the Model Tax Convention, the guidance in the 2008 Report to extend that its conclusions do no conflict with the 2008 Commentary on Article 7;

(ii.) that their tax administrations encourage taxpayers to follow the guidance in the 2008 Report when applying the provisions of bilateral conventions that are drafted on the basis of Article 7 of the Model Tax Convention and, to that end, that they give the Report publicity in their country and have it translated, where necessary, into their national language(s). 
de estudos anteriores e minutas de cada uma de suas Partes que vinham sendo publicadas desde 2001, bem assim dos respectivos comentários encaminhados à OCDE por administrações tributárias de diversas nações, empresas multinacionais, associações, auditorias especializadas etc.; mesmo se tratando de uma espécie de "relatório final", ainda suscita muitas discussões, especialmente entre instituições financeiras com atuação global. Este Relatório-2008 asseverou, como não poderia deixar de ser, que a determinação dos preços de operações intra-empresa deve obedecer ao princípio da plena concorrência ${ }^{114} \mathrm{e}$, como conseqüência disso, entendeu aplicável a operações desta natureza, por analogia e desde que ponderadas suas especificidades, a Diretiva referida em 1.3.4. Se a Diretiva for alterada no futuro pelo Comitê Fiscal da OCDE [o que ocorrerá nos próximos meses, após o término da consulta pública da Minuta-2009], a própria sistemática de imputação de resultados a estabelecimentos permanentes deverá ser modificada, devendo este Relatório2008 ser interpretado segundo o novo conteúdo da Diretiva, que estaria num "grau hierárquico superior" àquele ${ }^{115}$.

O Relatório-2008 espelhou-se nos princípios propagados pela Diretiva, mas também a complementou e atualizou, disciplinando, inclusive, o emprego do princípio da plena concorrência a operações intra-grupo [e não intra-companhia] envolvendo bancos, seguradoras, bem assim companhias dedicadas à negociação global de instrumentos financeiros. Independentemente da existência de regras específicas concernentes a operações intra-grupo no conteúdo do Relatório-2008, entendemos que, assim como a Diretiva aplica-se analogicamente na interpretação do Artigo $7^{\circ}$ da Convenção-Modelo, este Relatório-2008 apresenta grande utilidade no estudo dos preços de transferência [cf. Artigo $9^{\circ}$ ], desde que, claro, sejam ponderadas as particularidades que necessariamente

II. INVITES non-Member economies whose bilateral tax conventions contain provisions drafted on the basis of Article 7 of the model Tax Convention to take account of the terms of this Recommendations" (OCDE. Report on the Attribution of Profits to Permanent Establishments. op.. cit., p. 262).

${ }^{114}$ Note-se que a observância deste princípio está expressa no parágrafo 7.2 da Convenção-Modelo:

"2. Com a ressalva do disposto no n. ${ }^{\circ}$, quando uma empresa de um Estado contratante exercer a sua atividade no outro Estado contratante por meio de um estabelecimento estável aí situado, serão imputados, em cada Estado contratante, a esse estabelecimento estável os lucros que este obteria se fosse uma empresa distinta e separada que exercesse as mesmas actividades ou actividades similares, nas mesmas condições ou em condições similares, e tratasse com absoluta independência com a empresa de que é estabelecimento estável" (versão traduzida extraída de OCDE. Modelo de Convenção Fiscal sobre o Rendimento $e$ o Patrimônio. op. cit., p. 30).

115 "Finally, this Report has been based upon the principle of applying by analogy the guidance found in the Guidelines for purposes of determining the profits attributable to a PE. To the extend the Guidelines are modified in the future, this Report should be applied by taking into account the guidance in the Guidelines as so modified from time to time" (OCDE. Report on the Attribution of Profits to Permanent Establishments. op. cit., p. 8). 
diferem as operações intra-grupo das operações intra-companhia como, v.g., a remuneração pelo uso de intangíveis ou pelo suprimento de capital, que serão abordadas, oportuna e resumidamente, no CAPÍTULO 3.

Note-se, a este passo, que o Relatório-2008 é composto por quatro partes principais, dedicadas às considerações (i.) gerais [Parte I]; (ii.) concernentes a estabelecimentos permanentes de instituições bancárias [Parte II]; (iii.) aplicáveis a estabelecimentos permanentes de empresas que se dedicam à negociação global de instrumentos financeiros [Parte III]; e (iv.) próprias de estabelecimentos permanentes das empresas seguradoras [Parte IV]. No presente estudo, a Parte III assumirá especial relevância por sua maior proximidade com o tema a ser desenvolvido, mas também serão extraídas conclusões e exemplos das Partes I e $\mathrm{II}^{116}$. Especificamente no que concerne à Parte III, com o título "Special Considerations for Applying the Authorized OECD Approach to Permanent Establishments (PES) of Enterprises Carrying on Global Trading of Financial Instruments" ["Parte III do Relatório-2008”], importa salientar que ela representa uma atualização do Relatório GT-1998, como expressamente consignado em seu texto ${ }^{117}$. Os principais aprimoramentos foram: (1.) o aperfeiçoamento da noção de negociação global de instrumentos financeiros; (2.) o reforço da importância da análise funcional, em detrimento da definição de métodos e critérios a partir dos tipos de estrutura adotados; e (3.) o maior detalhamento da função risco de crédito [incluindo as estratégias de administração de riscos] e da mensuração dos ativos utilizados e riscos assumidos.

\subsection{Evolução da legislação norte-americana para o controle dos preços de transferência e edição da Seção 482 do IRC.}

Os Estados Unidos da América, que, ainda durante a I Guerra Mundial, editaram o 1917 War Revenue Act, Regulation 41, Arts. 77-78, provavelmente foi a primeira nação a preocupar-se mais densamente com a questão do controle dos preços de transferência. O tema foi objeto de intensos estudos pelo IRS até que, em 1934, foram publicadas as normas que consagraram o princípio da plena concorrência no direito norteamericano, com o objetivo de determinar se as transações vinculadas impactavam

\footnotetext{
116 Note-se, por oportuno, que a Parte II [considerações concernentes a estabelecimentos permanentes de instituições bancárias] representa uma atualização do "Relatório-1984/Bancos".

117 "Part III of the Report is therefore intended to update the issues and situations described in the Global Trading Report and to provide guidance on the application of both Article 7 and 9 to global trading" (OCDE. Report on the Attribution of Profits to Permanent Establishments. op. cit., p. 119).
} 
negativamente o valor da renda tributável que deveria ser reconhecido naquele país; estas regras, contudo, não prescreviam métodos suficientes para efetivar o princípio da plena concorrência, cuja aplicação deveria ser obrigatória naquele país ${ }^{118}$. Foi no final dos anos 60 e início da década de 70, coincidentemente o período em que o comércio internacional passou a se expandir em maior grau ${ }^{119}$, que o IRS iniciou um programa de auditoria dos preços de transferência praticados por contribuintes norte-americanos.

Em 1968 foi publicada a primeira grande reforma da Seção 482 do $\operatorname{IRC}^{120}$, a qual regulamentou as principais normas procedimentais para a aplicação do princípio da plena concorrência e previu os primeiros métodos para "testar" os preços de transferência e verificar sua adequação ao mencionado princípio; foram, neste momento, editados os métodos tradicionais, i.e., CUP, RPM e CPM. Estes três métodos eram aplicáveis a cinco categorias de negócios: (1.) transferência de propriedade tangível e (2.) intangível, (3.) empréstimos, (4.) prestação de serviços e (5.) leasing, arrendamentos e locações em geral $^{121}$. Pouco tempo mais tarde estes métodos obtiveram aceitação internacional, tendo sido, inclusive, adotados pela OCDE no Relatório-1979 [cf. subseção 1.3.1].

\footnotetext{
118، Comparando el Informe Carroll y el Congreso de la IFA de 1971 sobre distribución internacional de los beneficios empresariales de las transacciones vinculadas, se llega a la conclusión de que la situación normativa de los países no había experimentado variaciones considerables durante ese tiempo, esto es, eran escasos los Estados concienciados por el fenómeno del transfer pricing a nivel mundial. Aun las jurisdicciones fiscales que habían asumido el principio arm's length en su derecho interno, no prescribían métodos para hacerlo efectivo, con lo que la práctica administrativa y judicial concretaba el correcto precio de transferencia acudiendo a criterios muy diversos. Éste fue el caso de los Estados Unidos hasta 1968, momento en el que se aprobó una regulación de desarrollo de la Sección 482 en la que se imponían métodos de determinación del valor de mercado" (GALVAÑ, Gemma Sala. op. cit., p. 95-96).

119 "An international tax planning industry emerged to assist international business to maximize tax deferral, which led to the exploitation of the opportunities for tax avoidance and arbitrage. It was in this climate that there was a renewal of concern about possibilities for tax avoidance offered by transfer pricing manipulation. This was felt first and most strongly by the US, whose firms were the most active in expanding abroad" (PICCIOTTO, Sol. op. cit., p. 185).

${ }^{120}$ A Seção 482 ou $\$ 482$ representa um item do IRC norte-americano. Esta seção pertence ao Código n. ${ }^{\circ} 26$ da coleção de códigos norte-americana (Title 26: Internal Revenue Code), Subtítulo A (Income Taxes), Capítulo 1 (Normal Taxes and Surtaxes). Por esta razão é que sua referência legislativa será sempre a seguinte: 26 CFR Ch. 1 (4-1-09 Edition). Os dados entre parênteses refletem a edição consultada, em jan./10, no sítio eletrônico do U.S. Government Printing Office (www.gpo.gov).

${ }^{121}$ Desde esta época, o fisco norte-americano abandonou a idéia de que as normas para o controle dos preços de transferência deveriam ser gerais e abstratas para, ao contrário, especificar regras objetivas sobre o seu adequado atingimento. Confira-se, abaixo, um brevíssimo resumo da regulamentação de 1968, suficiente para demonstrar que as autoridades norte-americanas sempre tentaram, na medida do possível, objetivar a aplicação do princípio da plena concorrência [cujo conteúdo será melhor explorado no CAPÍTULO 2]:

"The regulations specify, for each category of transaction, that the primary test should be the Comparable Uncontrolled Price (CUP): the amount that was charged or would have been charged in independent transactions with or between unrelated parties dealing at arm's length. (...) Despite the emphasis on the primacy of the CUP, the regulations offered alternatives for each type of transaction. A 'safe harbour' was defined for three types of transaction, loans, services and leasing: as long as the supplier is not in the business of providing such services for unrelated parties, the arm's length price is specifically defined. For loans, the
} 
Durante a década de 80 a questão do controle dos preços de transferência tornou-se relevante, principalmente por decorrência da intensa atenção voltada para o exame dos sofisticados planejamentos tributários dos grupos multinacionais com sede nos Estados Unidos da América. Alguns casos importantes e com repercussão internacional foram julgados nesta década, destacando-se Eli Lilly \& Co. v. Commissioner, 84 TC 996 (1985) e G. D. Searle \& Co. v. Commissioner, ii TC 252 (1987). Nessa época, a legislação norte-americana permitia a subscrição de capital em subsidiárias e controladas estrangeiras mediante integralização da participação respectiva com intangíveis, sem a necessidade de reconhecimento de qualquer renda tributável no território norte-americano [\$351 do IRC vigente na ocasião]. Como resultado desse benefício legal, patentes caríssimas obtidas via estudos realizados inteiramente nos Estados Unidos da América eram gratuitamente transferidas para Costa Rica ou Porto Rico, onde a tributação da renda derivada da exploração desses ativos era reduzida. Foi necessária, neste cenário, a revisão da legislação concernente aos preços de transferência em operações com intangíveis, razão pela qual foram introduzidas alterações na Seção 482 do IRC por intermédio do Ato de Reforma Tributária de $1986^{122}$. A partir deste Ato passou a ser prescrito, para o exame do preço de transferência das operações envolvendo propriedade intangível, o critério da mensuração destes bens a partir da renda por eles gerada ["commensurate with income" ou método do rendimento standard $^{123}$ ]. Nesse mesmo contexto foi publicado, em 18 de outubro de 1988, o White Paper [Notice 88-123, 1988-2 C.B 458], documento que reformulou, mais uma vez, a aplicação dos preços de transferência a operações com intangíveis, tendo introduzido

safe harbour interest rate was originally 4-6 per cent; it was occasionally changed as rates rose, but this procedure was criticized as too slow US GAO 1981, p. 15) and eventually, in 1988, the safe harbour rate was defined in relation to Federal rates, which are specified monthly (US Treasury 1988, p. 74). For services and leasing, the safe harbour was defined on the basis of a cost formula; but the leasing safe harbour option was removed in 1988. In the case of intangibles (intellectual property and know-how), no specific alternative was provided for CUP, but the regulations listed a dozen factors that should be taken into account in fixing an arm's length pricing (ITR 1-482-2-d-2-iii). Finally, for pricing of tangibles (goods), the regulations provided a four-tier hierarchy of methods: first, CUP; then, Resale Price minus and appropriate profit mark-up; third, Cost of Production Plus an appropriate profit mark-up; and only where none of these methods can reasonably be applied may 'fourth methods' be used" (PICCIOTTO, Sol. op. cit., p. 187).

${ }^{122}$ Exatamente neste sentido, confira-se Stefan MAYER:

"Concerns about pharmaceutical business using transfer of valuable intangibles to shift profits outside the United States led to the adoption of an amendment do Sec. 482 do IRC, the 'commensurate with income' clause, in the Tax Reform Act of 1986. This 'super-royalty' clause allows retrospective adjustments of transfer prices in the case of transfer of intangibles" (MAYER, Stefan. op. cit., p. 11).

${ }^{123}$ Tradução extraída de XAVIER, Alberto. Direito Tributário Internacional do Brasil. op. cit., p. 365. 
um novo método específico para esta espécie de negócios, o método da taxa de retorno em plena concorrência ["Basic arm's length return method" ou "BALRM"] 124.

Ainda na década de 80, o Congresso norte-americano constatou que não bastava implementar alterações e atualizar as normas concernentes aos cálculos dos preços de transferência, mas era preciso que elas fossem efetivamente aplicadas pelos contribuintes; percebeu-se que, sem fiscalização efetiva, imposição de multas severas e obrigatoriedade de apresentação de formulários e documentos ao IRS, os contribuintes não se dedicariam à implementação de tarefa tão complexa. Consoante ponderado por Deloris R. WRIGHT, diante da ausência de penalidades ou autuações, os departamentos jurídicos das multinacionais não teriam sequer argumentos para questionar os critérios para fixação dos preços intra-grupo ${ }^{125}$. Também eram necessários mecanismos para que o IRS pudesse proceder à auditoria fiscal de forma adequada, evitando-se o cancelamento das multas pelo Poder Judiciário por "ausência de provas"126. Diante da necessidade de novas ferramentas e estratégias para a aplicação das regras para o controle dos preços de transferência, o

\footnotetext{
${ }^{124}$ Um resumo do White Paper consta da Introdução da Regulamentação Final EUA-1994. Veja-se:

“(...) The White Paper proposed two approaches for implementing the 'commensurate with income' standard with respect to transfers of intangible property. The first was based on either an 'exact comparable' method or an 'inexact comparable' method. The second was an income-based approach that also included two methods: the basic arm's length return method (the BALRM), and the BALRM with profit split. The BALRM generally assigned an average rate of return to the assets and functions devoted to the routine activities associated with the controlled transaction. When high profit intangibles are involved, any residual profit would be divided on the basis of the estimated relative values of the intangibles that each party contributed to the activity".

125 "Typically, companies did not take Section 482 into account unless they had experienced a competent transfer pricing audit. In the absence of a competent challenge to the company's transfer pricing system, there was no incentive to focus on complying with the Section 482 requirements. (...) In spite of the beliefs of the IRS regarding the way corporations work, it was ordinarily the case that transfer prices were established by operating personnel (and not by the tax department). Operating personnel set transfer prices to achieve operating goals that were usually designed to provide proper incentives to employees to maximize the profitability of the worldwide corporation. It should be obvious that in this context, if the tax department wanted to change transfer prices, they were required to justify the chance in policy and usually faced significant political battles to get the policy approved. Without a significant threat from a tax authority justifying changes to a long-held transfer pricing practice was virtually impossible" (WRIGHT, Deloris R. Report on the Application and Administration of Section 482: A Commentary. International Transfer Pricing Journal. Amsterdã: IBFD, set./out. 1999, p. 219).

${ }^{126}$ Essa questão da não-apresentação de documentos por ausência de lei que obrigue o contribuinte a apresentá-los pode ser depreendida a partir da seguinte explicação de Deloris R. WHIGHT:

"A common strategy for dealing with these audits emerged over time. This strategy has fed concerns of the IRS about compliance with Section 482. Specifically, the linchpin of this strategy involved providing very little, if any, relevant information to IRS international examiners during an audit. Information that was provided was given to the auditor very late in the audit. The strategy was very successful in preventing IRS auditors from effectively challenging the transfer pricing practices of the company. When very little information was provided very late in the audit, the IRS assessment was necessarily inadequately developed and almost always contained statements that were inaccurate. As a result, when the case went to appeals, the appeals office routinely either dropped the issue or settled for pennies on the dollar" (Report on the Application and Administration of Section 482: A Commentary. op. cit., p. 219).
} 
Congresso norte-americano solicitou ao IRS um estudo aprofundado sobre a quantidade de receitas "perdidas" por conta da manipulação dos preços. Como decorrência direta desta solicitação, foi elaborado o "Relatório sobre a Aplicação e a Administração da Seção 482", de 21 de abril de 1989. Algumas novas exigências procedimentais foram criadas, como, v.g., (i.) os documentos de controladas estrangeiras deveriam permanecer à disposição do IRS, na sede da controladora; (ii.) documentos não exibidos durante a auditoria do IRS não poderiam ser entregues para defesa em ações judiciais; (iii.) a ausência de preparação de documentação contemporânea para a comprovação dos preços de transferência sujeitaria o contribuinte a multa de $20 \%$ ou $40 \%$ etc..

Poucos anos mais tarde, em 30 de janeiro de 1992, foram introduzidas as "1992 Proposed Regulations” [57 FR 3571; “Regulamentação EUA-1992”], seguidas da Regulamentação EUA-1993 e da Regulamentação Final EUA-1994, que reformulou a Seção 482. A Regulamentação EUA-1992 propôs, como medida mais importante, a adoção de três novos métodos para a precificação de operações com intangíveis, sendo que o método dos comparáveis exatos ["Matching Transaction Method" ou "MTM"] e o método dos comparáveis inexatos ["Comparable Adjustable Transaction Method" ou "CATM"127] representavam variantes do CUP, ao passo que o CPI representava um método, aplicável tanto a intangíveis quanto a tangíveis, baseado na comparação de lucros. A Regulamentação EUA-1993 [58 FR 5263] introduziu regras sobre os acordos intra-grupo de repartição de despesas e sobre o método da divisão de lucros (PSM), propôs alterações em diversos outros tópicos da Seção 482 e, por fim, reforçou a aplicação dos três métodos supra referidos. O MTM e o CATM, contudo, foram reunidos num único método, o método das transações comparáveis ["Comparable Uncontrolled Transactions" ou "CUT"], que representa uma versão do CUP para os intangíveis. O CPI teve sua denominação alterada para método dos lucros comparáveis ["Comparable Profit Method" ou "CPM", sigla adotada na legislação norte-americana $]^{128}$. Para evitar confusão entre as siglas do

${ }^{127}$ Este método deveria ser sempre confirmado pelo CPI, tendo esta obrigação sido retirada com a edição da Regulamentação EUA-1993.

${ }_{128} \mathrm{Na}$ Introdução da Regulamentação Final EUA-1994 há um bom resumo deste princípio, na forma da Regulamentação EUA-1993:

"Section 1.482-T describes the CPM. The CPM may be applied to transfers of tangible and intangible property. In broad terms, the CPM is similar do the CPI set out in 1992 regulations. (...) Sec. 1.482-5T provides that CPM ordinarily is inappropriate if the tested party owns 'valuable non-routine intangible' property. This limitation was added to the other limitations generally applicable to all methods because CPM could be expected to understate the income attributable to such property due the difficulty in locating uncontrolled taxpayers that possess comparable intangible property. (...). Like the CPI under the 1992 regulations, a result will satisfy the arm's length standard under the CPM if it falls within a range of results, 
“Cost Plus Method" e do "Comparable Profit Method", no entanto, utilizaremos CPM para identificar o primeiro e referir-nos-emos ao segundo pela sigla CPI ou por seu nome, por extenso. A Regulamentação Final EUA-1994 trouxe modificações de forma e conteúdo, mas manteve as regras gerais constantes da versão publicada no ano anterior. O IRS dedica-se muito à questão dos preços de transferência e, por isso, ano a ano, são introduzidas pequenas modificações no conteúdo da Seção 482. A versão adotada na presente tese é aquela publicada sob o código 26 CFR Ch. 1 (4-1-09 Edition).

A legislação norte-americana para o controle dos preços de transferência sempre foi reconhecida por seu rigor e pela influência que mantém nas normas editadas por outras nações. Note-se, v.g., que a regulamentação de 1968 normalmente é apontada como o "estopim" para a elaboração do Relatório 1979, ao passo que as normas consolidadas na Diretiva de 1995 acompanham, em certa medida, a reformulação da Seção 482 do IRC, iniciada com a edição da Regulamentação EUA-1992. Ademais, alguns métodos e especificidades adotados por este país no que respeita às idéias de simplificação e à aferição dos preços de transferência em operações de negociação global de instrumentos financeiros interessam particularmente ao presente estudo. Nesse cenário, seja por sua relevância no contexto mundial, seja por sua intrínseca relação com a discussão que se pretende desenvolver, a legislação norte-americana, excepcionalmente, será objeto de alguns tópicos específicos nos capítulos subseqüentes. Não se pretende, frise-se, empreender um estudo voltado ao direito comparado, mas tão-somente indicar exemplos importantes que podem ser extraídos da legislação [ou implementação da legislação] daquele país e, na medida do possível, ponderar a constitucionalidade de sua adoção pelo direito tributário internacional brasileiro. Também serão efetuadas referências esparsas à legislação de outras nações, mas essas não serão objeto de seções ou itens específicos.

\subsection{Origem e evolução da regulamentação sobre os preços de transferência da Organização das Nações Unidas (“ONU”).}

A politização do debate em torno da atuação das grandes multinacionais e os desafios que sua atuação vinha gerando para os governos nacionais ${ }^{129}$ levou a ONU,

based on a single profit level indicator derived from uncontrolled comparables. Profit level indicators include the rate of return on capital employed (i.e., rate of return on assets) and financial ratios such as operating profit to gross sales and gross profit to operating expenses (berry ratio)".

129 "However, by the 1970 s the power of 'the multinationals' was becoming a highly politicized issue. Of particular concern was the ability of TNCs to move both short-term liquid funds and longer-term investment 
sucessora da Liga das Nações, a criar um comitê, denominado Centro das Nações Unidas para estudo das Corporações Transnacionais, o qual, dentre suas atribuições originais, também deveria abordar a questão da manipulação de preços com objetivos tributários. $\mathrm{O}$ primeiro estudo, com o título "O Impacto das Corporações Multinacionais no Desenvolvimento e nas Relações Internacionais" (1974), foi bastante tímido sob a perspectiva tributária: negou todas as idéias vinculadas a fórmulas predeterminadas para a alocação de resultados tributáveis, sugerindo a aplicação do princípio da plena concorrência, mas não apresentou idéias sobre métodos destinados a sua implementação; pelo contrário, sugeriu que o Grupo de Experts em Tratados Tributários desenvolvesse melhor e urgentemente o assunto.

Este Grupo de Experts em Tratados Tributários discutiu melhor a questão e, em 1979, publicou o Manual para Negociação de Tratados Tributários Bilaterais entre Países Desenvolvidos e em Desenvolvimento (“Manual-1979”), com orientações procedimentais e materiais a respeito da efetivação do princípio da plena concorrência ${ }^{130}$. No ano

capital between countries and currencies, partly by the adjustment of paying terms between affiliates. In this period of transition from the fixed exchange rate system to floating rates, the TNCs' primary need was to minimize their exposure to currency fluctuations; and the devices they used, such as 'leads and lags' in intrafirm international payments, in turn contributed to currency instability. The issues merged into a generalized debate about the power of international capital vis-à-vis the State. Not only did a leading academic economist announce that 'the national state is just about through as an economic unit' (Kindleberger 1969, p. 207), the Governor of the Bank of England in a published speech referred to public concern about whether the power of multinational enterprises 'is such as to represent a significant reduction in the sovereignty of the host government' and discussed in detail their effects on national economic policymaking (Governor of the Bank of England, 1073)" (PICCIOTTO, Sol. op. cit., p. 188).

${ }^{130}$ A questão dos preços de transferência foi realmente discutida nos encontros subseqüentes deste Grupo, tendo sido introduzida nos seguintes documentos: (a.) Tax Treaties between developed and developing countries, $6^{\text {th }}$ Report, Dept. of Economic \& Social Affairs (1976); (b.) The Control of Transfer Pricing in Greece, Conference on Trade and Development (1978, August 31 ${ }^{\text {st }}$ ); (c.) Dominant Positions of Market Power of Transactional Corporations; Use of the Transfer Pricing Mechanism, Conference on Trade and Development (1978); (d.) Manual for the Negotiation of Bilateral Tax Treaties Between Developed and Developing Countries (New York: UN Publications, 1979, doc. ST/ESA/94).

Especificamente quanto ao Manual-1979, a doutrina qualifica-o como mais "ambicioso" que o Relatório1979 da OCDE, porque nele há indicações e exemplos concretos, também baseados na legislação norteamericana de 1968, de possíveis acordos e negociações entre os países, nos termos dos artigos das Convenções-Modelo que disciplinam o MAP. Confira-se:

"Al hilo de la quinta reunión del Grupo de Expertos sobre convenios fiscales entre Estados desarrollados e en desarrollo, se determinó la urgencia de realizar una guía sobre el reparto de ingresos y gastos de empresas multinacionales, reconociendo el problema común de los precios de transferencia internacionales. Se sugirió tomar como punto de partida la reglamentación americana de 1968 y su práctica administrativa, los congresos de la IFA de 1969 e 1971 sobre la materia y los trabajos contemporáneos del CAF de la OCDE. Así, esta guía se asentó, por un lado, en el estabelecimiento del principio arm's length como criterio por el que deben regirse las relaciones comerciales y financieras internacionales entre empresas vinculadas y en la habilitación de las Administraciones Tributarias para ajustar los beneficios imponibles del sujeto pasivo vinculado en los supuestos de violación de tal principio. Y, por otro lado, en la necesidad de consulta mutua de las autoridades fiscales implicadas en el tráfico internacional vinculado sobre la atribución de los ingresos y gastos derivados de las operaciones intramultinacionales y en la delegación (por parte del CDI aplicable) del desarrollo 
subseqüente, foi publicada a Convenção-Modelo da ONU, fundada na inexistência de reciprocidade dos fluxos financeiros internacionais entre as nações desenvolvidas e em desenvolvimento. Com efeito, os dois pilares básicos identificados pela ONU na Convenção-Modelo da OCDE de 1963 foram os seguintes: (a.) o princípio da residência era o principal elemento de conexão utilizado, com (b.) redução da base tributável no país da fonte de produção do rendimento. Enquanto estivessem sendo negociadas convenções entre nações de situação econômica similar, não haveria maiores problemas; a ConvençãoModelo de 1963, contudo, foi considerada imprestável para amparar a negociação de convenções entre países "desenvolvidos" e "em desenvolvimento", porque a anteposição do elemento de conexão residência favorecia muito os primeiros, impondo sacrifícios financeiros de elevado grau aos últimos. Diante da constatação de tal situação, a ONU constituiu o Grupo de Experts em Tratados Tributários, que atuou entre 1969 e 1980, publicando, em 1980, a Convenção-Modelo supra aludida. Especificamente no que concerne aos preços de transferência, sempre foi consenso no âmbito deste Grupo de Experts que deveria ser mantida, sem alterações, a sugestão do Artigo $9^{\circ}$ constante da Convenção-Modelo da OCDE de 1977; também foram mantidos os comentários da OCDE ao Artigo $9^{\circ}$ e, nos Comentários à minuta de Convenção-Modelo da ONU revisada em 1999, sugeriu-se a observância dos relatórios publicados pela OCDE, especialmente a Diretiva de 1995 e alterações subseqüentes ${ }^{131}$.

normativo bilateral del procedimiento amistoso a las autoridades competentes. En consecuencia, el Grupo de Expertos trató de dotar de contenido a esos acuerdos bilaterales a desarrollar por las autoridades fiscales partes del CDI a través del procedimiento amistoso (...). Así, se fue elaborando una lista no exhaustiva y no vinculante de posibles criterios de determinación del valor de mercado en operaciones vinculadas internacionales de préstamo, de transferencia de bienes materiales e inmateriales y de prestación de servicios, que quedó plasmada en el 'Manual de 1979' como 'Sugerencias para la asignación de ingresos y gastos correspondientes a pagos por bienes, tecnología y servicios en relación con las transacciones entre entidades vinculadas"” (GALVAÑ, Gemma Sala. op. cit., p. 99-100).

131 "El Grupo de Expertos tomó como principal texto de referencia el PMCOCDE (y después el MCOCDE de 1977), estableciendo proyectos alternativos a su articulado a la hora de construir un nuevo MC que sirviera a la negociación y conclusión de CDIs entre países desarrollados y en desarrollo. No obstante, desde el primer momento, se llegó al consenso de que el art. 9 (1) del MCOCDE no planteaba objeciones, por lo que podría mantenerse en el eventual MCONU sin transformación alguna. Por ello, tanto en el 'Manual para la negociación de convenios fiscales bilaterales entre países desarrollados y en desarrollo' de 1979 como en el 'libro amarillo' de 1980, se reprodujo literalmente no únicamente su articulado sino también sus comentarios, reservas y observaciones; recomendando, así, el texto del art. 9(1) del MCOCDE como disposición sobre imposición de empresas vinculadas en los CDIs celebrados de acuerdo con el MCONU y su interpretación de acuerdo con los Comentarios del MCOCDE. De esta forma, quedó establecido en el MCONU el principio arm's length como criterio habilitador del ajuste primario administrativo tendente a aumentar los beneficios imponibles obtenidos por el sujeto pasivo residente vinculado cuando sus precios de transferencia internacionales no reflejen las condiciones normales de mercado. Es más, el MCONU ha sido revisado en 1999. Y en los nuevos Comentarios generales al art. 9 del MCONU de 1999, se establece una remisión expresa a los Informes sobre precios de transferencia de la OCDE como principios a seguir por los Estados 
Em 1988, o Centro das Nações Unidas para estudo das Corporações Transnacionais publicou o estudo "Tributação International da Renda e Países em Desenvolvimento", o qual contém um capítulo específico sobre "Os Abusos nos Preços de Transferência e Países em Desenvolvimento".

Este texto examina a magnitude dos abusos decorrentes da manipulação dos preços de transferência ${ }^{132}$ e os mecanismos para lidar com tais abusos, os quais podem ser diretos, i.e., mediante a introdução de regras para o controle dos preços de transferência amparados no princípio da plena concorrência, ou indiretos, dentre os quais se destacam a partição dos lucros totais segundo fórmulas predeterminadas ${ }^{133}$, a fixação nocional [ou hipotética] dos preços de exportação ${ }^{134}$ e a criação de sistemas tributários uniformes no tocante ao imposto sobre a renda, eliminando-se diferenças que induzam a manipulação dos preços. Especificamente no que concerne à partição dos lucros totais segundo fórmulas predeterminadas, a ONU reconhece que este método pode produzir resultados conflitantes entre as nações onde estão estabelecidas as partes, mas sustenta que provavelmente ele seria apto a reduzir os abusos na manipulação dos preços; seria esta, inclusive, a razão que justificaria a forte oposição e hostilidade dos grupos multinacionais no tocante aos métodos formulares e unitários.

Contratantes en los supuestos de aplicación del principio arm's length establecido en el art. 9 MCONU" (GALVAÑ, Gemma Sala. op. cit., p. 88-89.

132 “(...) the evidence that does exist suggests that transfer pricing abuses constitute a major problem and result in significant economic damage in both developed and developing countries. First, because a substantial portion of the world trade is intrafirm, it is clear that transnational corporations have substantial opportunities to engage in transfer pricing abuses. (...) Data for individual developing countries emphasize the importance of intrafirm trade and the concomitant opportunity for transfer prices abuses. In Brazil intrafirm transactions accounted for 50 per cent of the import and 73 per cent of the exports of United Stated subsidiaries in 1972" (UNITED NATIONS. International Income Taxation and Developing Countries. New York: UN, 1988. Chapter VII: "Transfer Prices Abuses and Developing Countries". Parte B).

133 "The simplicity and certainty of the apportionment method have led to its fairly widespread acceptance and use. Most bilateral tax treaties, the 1977 OECD Model Convention and the United Nations Guidelines for International Cooperation against the Evasion and Avoidance of Taxes, include the apportionment method as an acceptable way to determine the profits attributable to permanent establishments. A number of tax administrations already use apportionment formulae as an alternative to check on the arm's length approach" (UNITED NATIONS. International Income Taxation and Developing Countries. op. cit., Chapter VII: "Transfer Prices Abuses and Developing Countries". Parte E.2).

134 "Another alternative to the arm's length approach is the use of posted or notional export prices for exports of primary commodities. With this alternative, the basis objective is to set the price as a fraction of the price of a downstream product for which an established market exists. Hence, posted or notional prices are similar to the apportionment method since they as used to attribute to the exporting country a predetermined portion of the total value of the finished goods of which the primary commodities are part. They are also similar to the resale price method of establishing an arm's length price since the value attributable to the exporting country is determined by reference to the price at which the primary commodity is resold alter some processing of the commodity has taken place" (UNITED NATIONS. International Income Taxation and Developing Countries. op. cit., Chapter VII: "Transfer Prices Abuses and Developing Countries". Parte E.2). 


\subsection{Princípios constitucionais que amparam a realização de ajustes advindos das normas para o controle dos preços de transferência.}

Não é viável estudar as normas para o controle dos preços de transferência sem um exame atento dos mais importantes princípios constitucionais tributários que com elas se inter-relacionam, porque estas normas, ao mesmo tempo em que concretizam determinados princípios, têm aplicação limitada por outros, os quais estão em constante interação com os primeiros. Essa é a razão pela qual, nesta seção 1.6., dedicar-nos-emos a uma breve reflexão a respeito dos princípios da igualdade, capacidade contributiva, universalidade e generalidade da tributação da renda, legalidade, praticabilidade e livre concorrência. Não se pretende, frise-se, discutir as teorias relativas ao reconhecimento dos princípios jurídicos, as propostas para distinção entre princípios e regras ou os estudos acerca do reconhecimento da eficácia de ambos. Muito ao contrário, busca-se analisar os valores e princípios constitucionais intrinsecamente relacionados com o assunto da tese sob uma perspectiva objetiva, com o escopo de angariar elementos para a discussão da efetividade das normas que atualmente amparam o controle dos preços de transferência no Brasil, vis-à-vis a efetividade de outras sistemáticas adotadas internacionalmente, de modo a aferir a constitucionalidade/admissibilidade da recepção dessas últimas [com as adaptações necessárias, claro] pelo ordenamento constitucional brasileiro.

Preliminarmente, pondere-se que, consoante sustentado por Ricardo Lobo TORRES, há importantes distinções entre os "Valores" e os "Princípios", destacando-se a extensão, a eficácia e a positivação de cada um deles. Em suma, enquanto os valores são idéias absolutamente abstratas, supra-constitucionais, insuscetíveis de tradução em linguagem constitucional e destituídos de eficácia jurídica direta, os princípios têm menor generalidade e abstração, são positivados e têm eficácia jurídica direta, podendo ser, inclusive, invocados pelo Poder Judiciário em suas decisões; os princípios são o primeiro estágio de "concretização" dos valores, ainda que não expressos na Constituição ${ }^{135}$, sendo que um único princípio pode concretizar um ou mais valores ${ }^{136}$.

\footnotetext{
${ }^{135}$ Cf. TORRES, Ricardo Lobo. Tratado de Direito Constitucional, Financeiro e Tributário. Rio de Janeiro: Renovar, 2005, v. II: Valores e Princípios Constitucionais Tributários, p. 193-195.

${ }^{136}$ Segundo a doutrina de Paulo de Barros CARVALHO, o termo princípio é utilizado tanto para designar o próprio valor adotado no sistema quanto "o limite objetivo estipulado em regra de forte hierarquia, tomado, porém, sem levar em conta a estrutura da norma”. O signo princípio designa, assim, tanto um valor quanto um princípio propriamente dito.
} 
Segundo classificação proposta por Ricardo Lobo TORRES, os princípios constitucionais que importam ao direito tributário podem ser classificados em (1.) princípios de legitimação; (2.) princípios estruturais; (3.) princípios fundamentais; e (4.) princípios vinculados a valores. A legitimação dos direitos humanos e fundamentais “implica a resposta à pergunta sobre o merecimento e a razão de ser dos direitos e dos princípios" ${ }^{\prime 137}$; busca-se, pela legitimação, uma razão fora do ordenamento ou direito a ser justificado, o qual não pode legitimar-se a si próprio. O processo de justificação do Estado é contínuo e historicista, havendo sempre novas legitimações, inerentes à reflexão sobre o Estado de Direito. Os princípios de legitimação mais importantes são os da ponderação [e proporcionalidade], razoabilidade ${ }^{138}$, igualdade, transparência e clareza; trata-se de princípios formais e vazios, que se irradiam pelos princípios fundamentais e pelos princípios vinculados a valores, buscando ali seu "conteúdo". Enquanto os princípios da ponderação e da razoabilidade apóiam-se nos princípios vinculados ao valor Justiça, a clareza une-se aos princípios vinculados à Segurança Jurídica e a transparência exerce papel legitimador dos princípios vinculados à Justiça e à Segurança Jurídica. A igualdade, por seu turno, representa tanto um valor quanto um princípio de legitimação que se agarra

"O deparar-se com valores leva o intérprete, necessariamente, a esse mundo de subjetividades, mesmo porque eles se entrelaçam formando redes cada vez mais complexas, que dificultam a percepção da hierarquia e tornam a análise uma função das ideologias dos sujeitos cognoscentes.

Quanto aos 'limites objetivos', nada disso entra em jogo, ficando muito mais simples a construção do sentido dos enunciados. E na aplicação prática do direito, esses limites saltam aos olhos, sendo de verificação pronta e imediata (...). Atente-se, porém, para o seguinte: os 'limites objetivos' são postos para atingir certas metas, certos fins. Estes, sim, assumem o porte de valores. Aqueles limites não são valores, se os considerarmos em si mesmos, mas volta-se para realizar valores, de forma indireta, mediata.

Agora, se na pragmática jurídica é fácil conceber e provar os limites objetivos, outro tanto não se dá com os valores. Experimentemos, por exemplo, lidar com o valor 'justiça', com 'segurança jurídica', com 'igualdade'. Não é preciso dizer mais” (CARVALHO, Paulo de Barros. Curso de Direito Tributário, $16^{\mathrm{a}}$ ed.. São Paulo: Saraiva, 2004, p. 144-146). Este autor denomina estes valores como "sobreprincípios", porque ocupam lugar preeminente em relação aos demais princípios.

${ }^{137}$ Cf. TORRES, Ricardo Lobo. Tratado de Direito Constitucional, Financeiro e Tributário. op. cit., p. 203.

${ }^{138}$ É importante ponderar, a este passo, que Eros Roberto GRAU nega que a proporcionalidade ou a razoabilidade sejam princípios: tratar-se-iam tão-somente de postulados normativos de interpretação/aplicação do direito (regras), aplicáveis no momento da produção da norma jurídica em cada caso concreto [mais especificamente durante a consideração dos fatos na aplicação da lei], e não durante os trabalhos de formulação das leis abstratas pelo Poder Legislativo. Confira-se:

"Proporcionalidade e razoabilidade são, destarte, postulados normativos da interpretação/aplicação do direito e não princípios. Deveriam prestar-se unicamente a informar a formulação da norma de decisão, no momento da aplicação do direito (...). Lembre-se que a norma jurídica é produzida para ser aplicada a um caso concreto. Essa aplicação se dá mediante a formulação de uma decisão judicial, uma sentença, que expressa uma norma de decisão. O que afirmo é o fato de ambas as pautas - a da proporcionalidade e a da razoabilidade - serem atuadas no momento da norma de decisão [= interpretação 'in concreto'], não naquele da produção [= interpretação in abstrato]" (GRAU, Eros Roberto. Ensaio e discurso sobre a Interpretação/Aplicação do Direito. $5^{\text {a }}$ ed. Malheiros: São Paulo, 2009, p. 192-193).

Não obstante estas ponderações, filiar-nos-emos, no presente estudo, à doutrina de Ricardo Lobo TORRES, assumindo que a razoabilidade e a proporcionalidade são princípios "vazios" aptos a legitimar todo o ordenamento jurídico tributário. 
a todos os outros valores, i.e., Liberdade, Justiça, Segurança Jurídica e Solidariedade, permeando todo o ordenamento. Os princípios estruturais, segundo a teoria de Ricardo Lobo TORRES, expressam as decisões essenciais configuradoras da Constituição, i.e., Estado Democrático de Direito, Federalismo, República e Separação de Poderes [cf. artigo $1^{\circ}$, caput, e artigo $2^{\circ}$ da Constituição Federal], ao passo que os princípios fundamentais são aqueles que constam dos incisos I a V do artigo $1^{\mathrm{o}}$ do Texto Constitucional ${ }^{139}$, deixando-se tocar simultaneamente por diversos valores como Liberdade, Justiça, Solidariedade etc..

Por fim, Ricardo Lobo TORRES versa sobre os princípios vinculados aos valores Liberdade $^{140}$, Justiça ${ }^{141}$, Segurança Jurídica ${ }^{142}$ e Solidariedade ${ }^{143}$. Os princípios vinculados aos valores, na concepção de Ricardo Lobo TORRES, concretizam um valor moral, por intermédio dos princípios formais da legitimação, i.e., ponderação, razoabilidade, igualdade e transparência. Na prática, contudo, é impossível desenvolver o raciocínio jurídico vinculando-se a um único valor. Assim, v.g., a capacidade contributiva, que busca concretizar primordialmente o valor Justiça, nunca atingiria esse ideal se outros valores como a Segurança Jurídica ou a Solidariedade não permeassem sua aplicação. Sabe-se que a Justiça "perfeita" é um ideal inalcançável; nesse sentido, a aferição da capacidade contributiva de cada contribuinte, segundo suas próprias especificidades, seria tão custosa e árdua que os ganhos com sua implementação provavelmente não seriam suficientes para cobrir aqueles custos. Para tornar esse princípio aplicável, portanto, é imprescindível seu inter-relacionamento com a legalidade, com a proteção da confiança do

\footnotetext{
139 “Art. 1 ${ }^{\text {o }}$ A República Federativa do Brasil, formada pela união indissolúvel dos Estados e Municípios e do Distrito Federal, constitui-se em Estado Democrático de Direito e tem como fundamentos:

I - a soberania;

II - a cidadania;

III - a dignidade da pessoa humana;

IV - os valores sociais do trabalho e da livre iniciativa;

V - o pluralismo político".

${ }^{140}$ Imunidades e proibições de desigualdade, cf. TORRES, Ricardo Lobo. Tratado de Direito Constitucional, Financeiro e Tributário. op. cit., p. 285.

${ }^{141}$ Capacidade contributiva, custo/benefício, distribuição de rendas, poluidor pagador, "non olet", equidade e princípio da plena concorrência, cf. TORRES, Ricardo Lobo. Tratado de Direito Constitucional, Financeiro e Tributário. op. cit., p. 287-397.

Entendemos, baseando-nos na doutrina de Heleno Taveira TÔRRES, que o princípio da plena concorrência não é vinculado diretamente ao valor Justiça, mas um princípio limite-objetivo, que representa um grau maior de concretização da capacidade contributiva; tratar-se-ia de um princípio destinado a concretizar um outro princípio. Este assunto será abordado com mais detalhes no CAPÍTULO 3, seção 3.3.

${ }^{142}$ Legalidade, tipicidade, irretroatividade, anualidade e anterioridade, proibição de analogia e proteção da confiança do contribuinte, cf. TORRES, Ricardo Lobo. Tratado de Direito Constitucional, Financeiro e Tributário. op. cit., p. 399 a 582.

${ }^{143}$ Capacidade contributiva solidária e solidariedade do grupo, cf. TORRES, Ricardo Lobo. Tratado de Direito Constitucional, Financeiro e Tributário. op. cit., p. 583 a 588.
} 
contribuinte etc.. Da mesma forma, no âmbito do Estado Democrático de Direito, de nada adianta a garantia de absoluta Segurança Jurídica se não se efetiva, por seu intermédio, também a Justiça Social. Neste cenário, por mais que os princípios vinculados a valores positivem um "valor principal”, sempre estão envolvidos, na sua aplicação, outros valores, que com aquele interagem de maneira dinâmica e constante; os valores realizam-se, nesse sentido, pelo entrelaçamento dos princípios. Ainda a respeito dos princípios vinculados a determinados valores, Paulo de Barros CARVALHO destaca que, assim como os valores propriamente ditos ou "sobreprincípios", eles também são caracterizados por maior generalidade e pela abstração, sendo impossível sua descrição por esquemas objetivos; por outras palavras, princípios como a capacidade contributiva não podem ser descritos por fórmulas objetivas, por serem elas incompatíveis com o "subjetivismo ínsito" a esta espécie de princípios $^{144}$.

\subsubsection{Princípio da igualdade.}

Segundo a doutrina de Ricardo Lobo TORRES, a igualdade apresenta uma configuração ímpar, por ser um valor e também um princípio de legitimação [formal] do ordenamento jurídico. Mas na visão deste autor, o valor Igualdade seria "vazio", o que o extrema de outros valores como Justiça, Segurança ou Liberdade, todos com "conteúdo semântico"; este valor, pelo contrário, seria meramente relacional, i.e., estabeleceria comparações que encontram seu conteúdo em outros valores. Assim, v.g., para a concretização do valor Justiça, todos os contribuintes que se encontrem em situação equivalente devem ser tratados igualmente; sem esse tratamento isonômico, inexiste justiça; o valor Igualdade seria relacional, mas imprescindível para a concretização dos demais. Esta condição não lhe retira, todavia, a natureza de valor, porque "a aceitação da igualdade como valor é essencial ao Estado Democrático de Direito, eis que, mesmo destituído de conteúdo prévio, imanta todos os outros valores. Com efeito, o valor formal

\footnotetext{
144 "Refutamos, igualmente, qualquer tentativa de aprisionar tais núcleos de significação, que chamamos de valores, por meio de esquemas objetivos, adredemente preparados. Peleja contra eles o subjetivismo ínsito ao domínio do axiológico, que não admite esquemas desta ordem. Tudo se dá, repetimos, pela combinação dos valores do sistema. Não é de estranhar-se, por conseguinte, que ninguém tenha inventado uma fórmula adequada para indicar a presença e orientar a aplicação de princípios como o da capacidade contributiva, o da proibição de confisco, o da estrita legalidade, o da anterioridade, o da igualdade tributária, para nos cingirmos tão-só a alguns exemplos" (CARVALHO, Paulo de Barros. O Princípio da Segurança Jurídica. Revista de Direito Tributário n. ${ }^{\circ}$ 61. São Paulo: Malheiros, jul./ set. 1992, p. 89).
} 
não deixa de ser valor, tendo em vista que procura sempre permear os valores que apresentam conteúdo possível"145.

Como princípio constitucional positivado, a igualdade aparece repetidas vezes

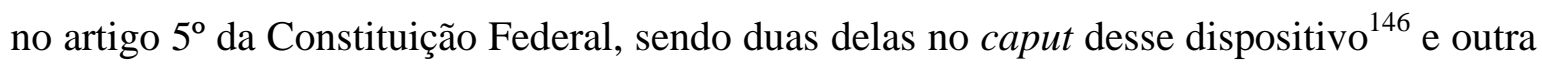
no inciso I. O artigo 150, II, também do texto constitucional, disciplina a igualdade no direito tributário ${ }^{147}$. Enquanto princípio constitucional, a igualdade reveste-se da característica de direito subjetivo, mas seu conteúdo é vazio, "competindo-lhe legitimar todos os outros princípios constitucionais, sejam os fundantes do ordenamento do Estado Democrático de Direito, sejam os estruturais, sejam os vinculados à justiça, à liberdade e à segurança jurídica"148. Cabe à igualdade, outrossim, efetivar os outros princípios de legitimação, com os quais mantém íntimo relacionamento ${ }^{149}$. Note-se, a esse passo, que o princípio da igualdade, ainda que "vazio" de conteúdo semântico, foi consagrado na Constituição Federal de 1988 tanto como uma "garantia formal", no sentido de que a lei aplica-se igualitariamente a todos, quanto uma "garantia material", segundo a qual todas as leis devem ter conteúdo isonômico; por outras palavras, a igualdade deve estar refletida tanto no conteúdo da norma quanto em sua aplicação ${ }^{150}$.

${ }^{145}$ Cf. TORRES, Ricardo Lobo. Tratado de Direito Constitucional, Financeiro e Tributário. op. cit., p. 143.

146 “Art. 5”. Todos são iguais perante a lei, sem distinção de qualquer natureza, garantindo-se aos brasileiros e aos estrangeiros residentes no País a inviolabilidade do direito à vida, à liberdade, à igualdade, à segurança e à propriedade".

147 “Art. 150. Sem prejuízo de outras garantias asseguradas ao contribuinte, é vedado à União, aos Estados, ao Distrito Federal e aos Municípios: (...)

II - instituir tratamento desigual entre contribuintes que se encontrem em situação equivalente, proibida qualquer distinção em razão de ocupação profissional ou função por eles exercida, independentemente da denominação jurídica dos rendimentos, títulos ou direitos".

${ }^{148}$ Cf. TORRES, Ricardo Lobo. Tratado de Direito Constitucional, Financeiro e Tributário. op. cit., p. 233.

${ }^{149}$ Cf. TORRES, Ricardo Lobo. A Legitimação da Capacidade Contributiva e dos Direitos Fundamentais do Contribuinte. in: Luís Eduardo Schoueri (coord.), Direto Tributário. Volume I. São Paulo: Quartier Latin do Brasil, Inverno 2003, p. 444-449. Especialmente a respeito do relacionamento intrínseco entre a igualdade e a razoabilidade, confira-se o seguinte trecho dessa obra:

"O grande problema da igualdade consiste em saber até que ponto a desigualdade que compõe a equação da igualdade é tolerável, ou, em outras palavras, quais as diferenças que importam em cada caso. Não há resposta certa e segura. O critério é formal e vai ser preenchido pelas valorações e pelos princípios constitucionais. Só a razoabilidade na escolha do legislador, que também tem função legitimadora, em equilíbrio com a própria igualdade, pode afastar a arbitrariedade em que radica a desigualdade" (p. 446).

${ }^{150}$ Sobre a obrigatoriedade de compreensão do princípio da igualdade prescrito no artigo $5^{\circ}$ da Constituição Federal de 1988 em termos formais e materiais, confira-se a seguinte citação de José Souto Maior BORGES, extraída de parecer inédito e citada por Eros Roberto GRAU:

"Estranha vocação constitucional, a da igualdade. Sobre ser uma norma definidora de um direito (norma que tem aplicabilidade imediata) e um princípio (mais eminente até que os outros princípios do art. $5^{\circ}$ ), é ela ainda um instrumento constitucional de preservação a si própria. É dizer: constitucionalmente a igualdade garante a igualdade material e a igualdade material garante a igualdade formal. Se todos são iguais na aplicação da lei, no sentido de que a lei indiscriminadamente a todos se aplica, mas o seu conteúdo não abriga a isonomia, há violação da igualdade material. Se reversamente lei isonômica a todos não se aplica, 
Pode-se concluir, a esse passo, com amparo na supra exposta doutrina de Ricardo Lobo TORRES, que o princípio da igualdade, per se, não serve para amparar a realização de ajustes advindos da aplicação da sistemática para o controle dos preços de transferência, porque não possui "conteúdo semântico". A igualdade seria, nesse contexto, o princípio legitimador do valor Justiça e do princípio da capacidade contributiva, esses sim "concretizados" via controle dos preços de transferência; com essa afirmação não se pretende, em nenhum momento, reduzir a importância do princípio da igualdade, mas tãosomente ponderar que sua efetividade prática na hipótese ora estudada depende de sua interação com o valor Justiça e o princípio da capacidade contributiva. Com efeito, consoante salientado por Luís Eduardo SCHOUERI, a realização dos ajustes nos preços de transferência encontra respaldo na "aplicação do princípio da igualdade em matéria tributária e de seu corolário, expresso na capacidade contributiva" ${ }^{" 151}$. No mesmo sentido, Misabel Abreu Machado DERZI asseverou que a capacidade contributiva "operacionaliza efetivamente o princípio da igualdade no Direito Tributário. Sem ele, não há como aplicar o mais importante e nuclear direito fundamental, ao Direito Tributário: a igualdade"152. Observe-se que, inclusive na Alemanha, onde o princípio da capacidade contributiva não está expresso no texto constitucional, mas é aplicado pela doutrina e pela jurisprudência da Corte Constitucional, sustenta-se que a obtenção de uma tributação material ou sistematicamente justa obtém-se a partir da aplicação da capacidade contributiva como parâmetro constitucional para a aplicação da igualdade ${ }^{153}$.

nem todos são iguais perante a lei: iguais serão apenas os beneficiários pela aplicação, ficando de fora da isonomia os que não o forem. Nessa hipótese, há violação da igualdade formal. (...) Torna-se manifesto por essa via que a $\mathrm{CF}$, no seu art. $5^{\circ}$, estrutura a isonomia de modo refinadamente complexo. Primeiro, como um direito à reta aplicação da lei (princípio formal). Segundo, como um princípio cujo conteúdo (não a mera forma de sua aplicação portanto) é inegavelmente amplo e até inexceptuável, pela vedação de distinções de qualquer natureza (princípio material e pessoal). Terceiro, porque ela regula também os meios assecuratórios desse direito (a lei e outros atos normativos, como as sentenças judiciais)" (extraído de GRAU, Eros Roberto. $O$ direito posto e o direito pressuposto. $7^{\mathrm{a}}$ ed. rev. e ampl. Malheiros: São Paulo, 2008, p. 166-167).

${ }^{151}$ Cf. SCHOUERI, Luís Eduardo. Preços de Transferência no Direito Tributário Brasileiro. op. cit., p. 12. Valendo-se da doutrina de Klaus TIPKE, este autor sustenta que a adequada aplicação do princípio da igualdade depende da adequada escolha dos critérios ou parâmetros para comparação; essa seria uma decisão valorativa, que deverá ser, a partir dali, consistentemente aplicada. "É, pois, sob pena de caracterizar o arbítrio, que o legislador se vê obrigado a eleger princípios e, uma vez escolhidos, aplicá-los consistentemente. Especificamente na matéria tributária, surge como primeiro parâmetro, escolhido pelo próprio constituinte, a capacidade contributiva. Nesse sentido, deve a tributação partir de uma comparação das capacidades econômicas dos potenciais contribuintes, exigindo-se tributo igual de contribuinte em equivalente situação" (Idem, p. 14).

${ }^{152}$ DERZI, Misabel Abreu Machado. In: BALEEIRO, Aliomar. Limitações Constitucionais ao Poder de Tributar. $7^{\mathrm{a}}$ ed. rev. e compl. à luz da Constituição de 1998 até a Emenda Constitucional n. ${ }^{\text { }}$ 10/1996 por Misabel Abreu Machado Derzi. Rio de Janeiro: Forense, 2001, p. 697.

153 "Na dogmática do princípio da capacidade contributiva desenvolvida por Klaus TIPKE, as concretizações do princípio da renda líquida objetiva e subjetiva criam diferenciações de um 'sistema interno', cujas 
Especificamente no campo do direito tributário, portanto, quando se aborda a necessidade de uma tributação paritária entre grupos multinacionais e empresas independentes ${ }^{154}$, a discussão cinge-se à busca de uma tributação justa e igual entre os contribuintes que manifestem semelhante capacidade econômica; esse "conteúdo axiológico" do princípio da igualdade, no campo do IRPJ, está refletido na capacidade contributiva [cf. artigo 145, $\S 1^{\circ}$, da Constituição Federal] e, ainda, na generalidade e na universalidade da tributação da renda [cf. artigo $153, \S 2^{\circ}$, I]. Por este motivo, todas as questões atinentes ao tratamento igualitário a que se propõem as regras para o controle dos preços de transferência serão abordadas nas subseções abaixo, conjuntamente com os ora mencionados princípios. Esta opção de sistematização possui, ademais, um segundo fundamento: na opinião de alguns autores, dentre os quais se destacam Heleno Taveira TÔRRES $^{155}$ e Ricardo MARIZ DE OLIVEIRA ${ }^{156}$, a igualdade e a isonomia prescritas no artigo 150, II, da Constituição Federal, representam tão-somente direitos subjetivos do

premissas surgem da valorização primária do princípio da igualdade. Correspondendo ao entendimento ultrapassado de que o princípio da igualdade seria apenas uma proibição do arbítrio, encontramos o princípio da capacidade contributiva como parâmetro constitucional para a igualdade tributária, principalmente na jurisprudência da corte constitucional federal, há tempo (apenas) como um mandamento da tributação materialmente, ou sistematicamente justa" (LEHNER, Moris. Consideração Econômica e Tributação conforme a Capacidade Contributiva. Sobre a Possibilidade de Interpretação Teleológica das Normas com Finalidades Arrecadatórias. Traduzido por Luís Eduardo Schoueri. In: Luís Eduardo Schoueri et. al. (coord.) Direito Tributário. Estudos em Homenagem a Brandão Machado. São Paulo: Dialética, 1998, p. 151).

${ }^{154}$ Cf. OCDE. Transfer Pricing Guidelines for Multinational Enterprises and Tax Administrations, op. cit., p. I-3, que alude a: "broad parity of tax treatment for MNEs and independent enterprises".

155 "Não há como pôr em dúvida que o princípio arm's length busca revelar uma desigualdade (verificada na divergência de preços) e, com base no parâmetro de preço normal (preço de livre concorrência), vir resgatado o regime de igualdade na fixação de preços (...). Em nenhum momento esse critério se presta ao tratamento isonômico do Fisco em relação ao contribuinte sujeito ao controle dos preços de transferência. É justamente o contrário! Deve o contribuinte alegar a igualdade (direito fundamental protetivo contra abusos do Fisco) justamente para se defender da imposição que eventualmente possa derivar da retificação de preços que emergiu com os procedimentos comparativos. (...)

Se o princípio arm's length serve a alguma forma de igualdade, será a que estabelece a 'generalidade' (art. $153, \S 2^{\circ}, \mathrm{I}, \mathrm{da} \mathrm{CF}$ ), segundo a qual todas as pessoas devem ser alcançadas pelo Imposto sobre a Renda, até o limite da respectiva capacidade contributiva, sem distinções ou privilégios. (...) E essa é uma outra situação jurídica, distinta da igualdade como reflexo do art. $5^{\circ}$, I, da CF. (...) Não perceber esta distinção e, por conseguinte, a que modelo de isonomia se presta o critério de controle sobre os preços de transferência at arm's length é um grave erro interpretativo com o qual não tergiversamos" (TÔRRES, Heleno Taveira. Direito tributário internacional: planejamento tributário e operações transnacionais. op. cit., p. 196).

156 “Também não é viável invocar a isonomia para justificar o tratamento que a lei dá aos preços de transferência, sob o pretexto de que o contribuinte, ao negociar com parte vinculada, deve receber o mesmo tratamento que recebem os demais contribuintes em seus negócios com partes não vinculadas.

Tal raciocínio é falso, por várias razões. A primeira delas é que a isonomia é uma garantia para o contribuinte contra o fisco, não podendo ser por este invocada a seu favor, contra o contribuinte (...). Portanto, o regime do lucro mínimo, a pretexto de instituir uma igualdade ideal dos negócios entre partes vinculadas com os negócios entre partes não vinculadas, não atende ao princípio da isonomia, com o qual, aliás, nada tem a ver" (MARIZ DE OLIVEIRA, Ricardo. Preços de Transferência, o Método do Custo mais Lucro, o Conceito de Custo. O Método do Custo mais Lucro e as Indústrias de Alta Tecnologia. Como conciliar Dispêndios Intensivos, em Pesquisa e Desenvolvimento, com esse Método. In: Luís Eduardo Schoueri e Valdir de Oliveira Rocha (coord.), Tributos e preços de transferência. São Paulo: Dialética, 1999, v. 2, p. 327). 
contribuinte e limitações constitucionais ao poder de tributar, não podendo ser invocadas pela administração tributária em seu favor; nesta perspectiva, o fisco não poderia recorrer ao princípio da igualdade como fundamento para efetivação de ajustes nos preços de transferência praticados ${ }^{157}$. Como o objetivo do presente estudo não é o exame aprofundado do princípio da igualdade, optamos por passar ao largo de tal discussão e abordar o necessário tratamento paritário exigido em qualquer discussão de natureza tributária nas subseções subseqüentes.

\subsubsection{Princípio da capacidade contributiva.}

Segundo relatado por Klaus VOGEL, historicamente, a capacidade contributiva desenvolveu-se no seio da "doutrina da justificação", à época do Iluminismo, quando os tributos representavam uma espécie de contrapartida pela proteção pessoal e patrimonial oferecida pelo Estado; logo, como os cidadãos de maior renda ou patrimônio tinham mais a proteger, deveriam pagar mais tributos ${ }^{158}$. Do ponto de vista teórico, coube a Adam Smith formular pela primeira vez o princípio, em março de 1779, nos seguintes termos: "os súditos de todos os Estados devem contribuir para a manutenção do Governo, tanto quanto possível, em proporção das respectivas capacidades, isto é, na proporção do crédito que respectivamente usufruem sob a proteção do Estado"159 . Ainda no século XVIII, em 1789, a capacidade contributiva foi incluída na Declaração de Direitos do Homem e do Cidadão da França, como se depreende de seu artigo 13: "Para a manutenção da força pública e para as despesas de administração, é indispensável uma contribuição comum que deve ser dividida entre os cidadãos de acordo com suas possibilidades" (tradução livre) ${ }^{160}$. Como

\footnotetext{
${ }^{157}$ Esta interpretação teria fundamento no texto do citado dispositivo constitucional, que veda “à União, aos Estados, ao Distrito Federal e aos Municípios (...) instituir tratamento desigual entre contribuintes que se encontrem em situação equivalente".

${ }^{158}$ Cf. VOGEL, Klaus. Tributação da renda mundial. Cadernos de Direito Tributário e Finanças Públicas. Traduzido por Luís Eduardo Schoueri. São Paulo: Revista dos Tribunais, n. ${ }^{\circ}$ 7, 1994, p. 133-134.

Fernando Aurélio ZILVETI, ao abordar a origem histórica da capacidade contributiva, esclarece que, com amparo em escritos de Erodoto, os historiadores apuraram que o conceito de justiça fiscal calcada nesse princípio remonta ao Egito Antigo [cf. Capacidade Contributiva e Mínimo Existencial. In: Luís Eduardo Schoueri et. al. (coord.) Direito Tributário. Estudos em Homenagem a Brandão Machado. São Paulo: Dialética, 1998, p. 39-40].

Carlos Palao TABOADA, por seu turno, rememora que, desde a Idade Média, São Tomás de Aquino sugeria a tributação "unicuique secundum suma facultatem y secundum aequalitatem proportionis" (El Principio de capacidad contributiva como criterio de justicia tributaria: aplicación a los impuestos directos e indirectos. In: Heleno Taveira Tôrres (coord.), Tratado de Direito Constitucional Tributário. Estudos em homenagem a Paulo de Barros Carvalho. São Paulo: Saraiva, 2005, p. 285).

${ }^{159}$ Citação extraída de TORRES, Ricardo Lobo. Tratado de Direito Constitucional, Financeiro e Tributário. op. cit., p. 288.

${ }^{160}$ Veja-se a versão original, extraída do sítio eletrônico do Ministério da Justiça francês:
} 
pondera Klaus VOGEL, no início do século XIX, o Estado passou a ser tido como um organismo dotado de superioridade em relação aos indivíduos isolados. Por conseguinte, os tributos deixaram de representar socialmente uma "contrapartida" para se tornarem um "sacrifício" em favor de um ente superior [o Estado], baseado na capacidade contributiva segundo alíquotas progressivas. A partir do século XX, o princípio da capacidade contributiva deixou de ser vislumbrado como consequiência da "doutrina de justificação" ou da "teoria do sacrifício"161. Desde então, passou a representar a concretização da tributação fundada na justiça social. Esse foi justamente o espírito da inclusão do princípio da capacidade contributiva no artigo 134 da Constituição de Weimar, de $1919^{162}$.

Atualmente, portanto, pode-se definir a capacidade contributiva como sendo o princípio fundamental para se alcançar uma tributação materialmente justa; na verdade, trata-se da "espinha dorsal" da Justiça Fiscal ${ }^{163}$. Seu conteúdo traduz-se na impossibilidade de cobrança de tributos sobre algo economicamente vazio; é essencial a averiguação de um fato econômico denso. Nesse sentido, o legislador deve captar um fato jurídico com conteúdo econômico para, dali, retirar uma parcela a título de contribuição para as despesas públicas. A busca deste substrato de riqueza passível de oneração é o propósito da capacidade contributiva, que deve orientar tanto a edição de leis pelo Poder Legislativo quanto sua regulamentação e aplicação pelo Poder Executivo.

A capacidade contributiva, como referido em 1.6.1, supra, é vinculada ao princípio de legitimação igualdade, de natureza relacional ${ }^{164}$. Assim sendo, por pretender

\footnotetext{
"Article 13. Pour l'entretien de la force publique, et pour les dépenses d'administration, une contribution commune est indispensable ; elle doit être également répartie entre les citoyens, en raison de leurs facultés".

161 “A frase do fundador da moderna teoria do Direito Administrativo, Otto Mayer, segundo a qual poderia o Estado 'sacrificar, em certa medida, as pessoas (...) para o futuro do grande povo da história que ele está destinado a formar' soa escandalosa e confusa a nossos ouvidos. Com isso retira-se a base conceitual, a partir da qual cresceu a teoria do sacrifício" (VOGEL, Klaus. Tributação da renda mundial. op. cit., p. 135).

${ }^{162}$ VOGEL também reproduz, em sua obra, teor do artigo 134 da Constituição de Weimar. Confira-se:

“Todos os cidadãos, sem distinções, contribuirão, em proporção a seus meios, para com todos os encargos públicos, nos termos da lei” (VOGEL, Klaus. Tributação da renda mundial. op. cit., p. 134).

${ }^{163}$ Segundo Ricardo Lobo TORRES, a idéia de Justiça Fiscal compreende a justiça tributária, i.e., “o processo sobre o justo na cobrança dos impostos, taxas, contribuições e empréstimos compulsórios", e a justiça financeira propriamente dita, a qual discute as transferências intergovernamentais e as subvenções econômicas e sociais (cf. TORRES, Ricardo Lobo. Tratado de Direito Constitucional, Financeiro e Tributário. op. cit., p. 122-123).

No presente estudo, as expressões justiça tributária e justiça fiscal serão tratadas como sinônimas, denotando a justiça que deve necessariamente estar atrelada ao processo de cobrança de tributos.

${ }^{164}$ Ricardo MARIZ DE OLIVEIRA sustenta que a isonomia representa um princípio de caráter amplo [cf. artigo $5^{\circ}$ da Constituição Federal], mas que se manifesta, no direito tributário, como verdadeira limitação constitucional ao poder de tributar. Por representar uma limitação, esse princípio é aplicado em momento lógico posterior à capacidade contributiva, com o objetivo de possibilitar a adequada concretização desse
} 
concretizar [primordialmente] o valor Justiça, a capacidade contributiva é aferível a partir da comparação entre contribuintes. Deve-se buscar a imposição de tributação igual a contribuintes que manifestem capacidade econômica semelhante. A capacidade contributiva é o mais importante "critério de comparação" admitido pela Constituição Federal para graduar distinções de regimes e tratamentos entre contribuintes, quando estes se encontrem em condições análogas. Com efeito, é preciso compreender as diferenças reais entre diversas situações jurídicas, obtendo-se categorias distintas, de modo a implementar a eqüidade, sem que isso represente a instituição de discriminação arbitrária, hostil ou injusta contra determinadas categorias. Existe a obrigação de estrita vinculação com o princípio de legitimação igualdade mas, também, da desigualdade, considerando que os desiguais devem ser tratados desigualmente. Deve, sempre, existir um critério lógicoracional, vinculado à razoabilidade, para justificar o discrímen e o conseqüente tratamento diferenciado dele decorrente.

Examinando-se a materialização da capacidade contributiva sob uma perspectiva "vertical", pode-se sustentar que ela representa o patamar a partir do qual a exigência tributária pode ocorrer e o limite após o qual a mesma exigência não pode ser efetivada, por inexistir dali por diante a capacidade de contribuir. $\mathrm{O}$ espaço de atuação (lógico) do princípio da capacidade contributiva, portanto, oscila entre dois limites inafastáveis no plano "vertical": (i.) o mínimo existencial ou os custos necessários à produção da renda e manutenção do patrimônio, esse último aplicável especialmente às pessoas jurídicas ${ }^{165}$; e (ii.) o não-confisco [cf. artigo 150, IV, da Constituição Federal];

último. Essa ordem lógica de aplicação dos referidos princípios pode ser aferida a partir do seguinte trecho de obra em que são discutidos o conteúdo e a aplicação de ambos os princípios:

"Importante não olvidar que a isonomia vem depois da capacidade contributiva, dependendo desta e se atrelando a esta, pois logicamente só se pode pensar em tratar desigualmente se houver a possibilidade de tributar, a qual supõe a capacidade para suportar o ônus econômico do tributo, além de que a igualdade de tratamento é aferida e mensurada em função de um fator econômico subjacente ao fato gerador de uma determinada obrigação tributária, e que se constitui exatamente na manifestação da capacidade de receber a carga econômica do respectivo tributo" [MARIZ DE OLIVEIRA, Ricardo. Breves Considerações sobre a Capacidade Contributiva e a Isonomia. In: Luís Eduardo Schoueri (coord.). Direto Tributário. Volume I. São Paulo: Quartier Latin do Brasil, Inverno 2003, p. 500-501].

${ }^{165}$ Mauro SILVA aponta uma tensão entre os princípios da justiça e da segurança jurídica na definição da abrangência e conteúdo do "mínimo existencial”. Em sua concepção, o mínimo existencial deve, sempre, alcançar sua máxima extensão, incluindo-se as despesas necessárias para uma existência física [alimentação, vestuário, habitação, despesas médicas etc.] e humana [instrução, educação, lazer etc.]; pode decorrência, conclui que "diante de tantas variáveis a serem consideradas na determinação do mínimo existencial e da ausência ou da impossibilidade de norma que o estabeleça, está configurado um cenário de tensão entre justiça fiscal e segurança jurídica" (SILVA, Mauro. Os limites para a capacidade contributiva - Mínimo Existencial e Confisco - como Elementos de Tensão entre Justiça Fiscal e Segurança Jurídica. In: Alcides Jorge Costa et. al.(coord.), Revista Direito Tributário Atual. n. ${ }^{\circ}$ 20. São Paulo: Dialética, 2006, p. 194). 
segundo o princípio-limite da vedação do confisco, a tributação pode gravar a riqueza de cada contribuinte, desde que não "absorva parte considerável do valor da propriedade, aniquilem a empresa ou impeça exercício de atividade lícita e moral"166. Há um liame tênue, ou uma "mera diferença de grau", entre um imposto constitucional e um gravame confiscatório $^{167}$, de modo que não é exeqüível a estipulação de critério matemático a partir do qual se configura o confisco; pelo contrário, o confisco é um conceito indeterminado e aberto, que deve ser verificado em cada caso concreto, a partir da aplicação princípio de legitimação razoabilidade, consoante decidido pelo Pleno do Supremo Tribunal Federal quando do julgamento de medidas liminares deferidas no âmbito da Ações Diretas de Inconstitucionalidade n. $^{\mathrm{o}} \mathrm{s}$ 1.075 MC/DF, julgada em 17.06.98 e 2.010 MC/DF, julgada em $30.09 .99^{168}$.

Em sentido diametralmente oposto, Fernando Aurélio ZILVETI propõe a determinação de um mínimo existencial objetivo, como se depreende do fragmento abaixo:

"O que deve haver em qualquer hipótese é a reserva legal para determinar o que venha a ser o mínimo existencial (...). Através de quadros fornecidos por um censo demográfico e social, pode o legislador obter custos necessários para a sobrevivência de um cidadão e ou de sua família. Estes custos poderiam ser elencados como sendo aqueles de alimentação, vestuário, higiene, saúde, educação e lazer. No caso do Brasil, por exemplo, estes estudos básicos para a sobrevivência digna do cidadão deveriam, por força das diversidades econômicas e sociais, ser apurados regionalmente. Assim, ao final do levantamento realizado pela pesquisa, teríamos vários mínimos existenciais, para cada qual das regiões analisadas” (op. cit., p. 46).

${ }^{166}$ Cf. BALEEIRO, Aliomar. op. cit., p. 564.

167 "Vê-se, por conseqüência, que o que distingue o imposto constitucional de um gravame confiscatório, ofensivo ao art. 153, §22, da Constituição é mera diferença de grau. Daí a perplexidade do intérprete ou aplicador da lei fiscal, no determinar se a absorção da propriedade se faz com tal intensidade, que se possa concluir seguramente tratar-se de confisco, disfarçado sob a capa de impostos. Daí também, a impossibilidade de se oferecer uma diretriz objetiva e genérica, aplicável a todas as circunstâncias, competindo uma vez mais à casuística dos tribunais apartar o joio do trigo, com as filtragens que julgue adequadas em cada caso concreto" (DÓRIA, Antônio Roberto Sampaio. Direito Constitucional Tributário e 'Due Processo $f$ Law'. Ensaio sobre o Controle Judicial da Razoabilidade das Leis. $2^{\mathrm{a}}$ ed. rev. Rio de Janeiro: Forense, 1986, p. 195). No mesmo sentido, cf. TORRES, Ricardo Lobo. Tratado de Direito Constitucional, Financeiro e Tributário. op. cit., p. 304.

${ }^{168}$ Confiram-se, porque refletem exatamente a posição ora discutida, excertos das seguintes ementas:

"A identificação do efeito confiscatório deve ser feita em função da totalidade da carga tributária, mediante verificação da capacidade de que dispõe o contribuinte - considerado o montante de sua riqueza (renda e capital) - para suportar e sofrer a incidência de todos os tributos que ele deverá pagar, dentro de determinado período, à mesma pessoa política que os houver instituído (a União Federal, no caso), condicionando-se, ainda, a aferição do grau de insuportabilidade econômico-financeira, à observância, pelo legislador, de padrões de razoabilidade destinados a neutralizar excessos de ordem fiscal eventualmente praticados pelo Poder Público. Resulta configurado o caráter confiscatório de determinado tributo, sempre que o efeito cumulativo - resultante das múltiplas incidências tributárias estabelecidas pela mesma entidade estatal afetar, substancialmente, de maneira irrazoável, o patrimônio e/ou os rendimentos do contribuinte. O Poder Público, especialmente em sede de tributação (as contribuições de seguridade social revestem-se de caráter tributário), não pode agir imoderadamente, pois a atividade estatal acha-se essencialmente condicionada pelo princípio da razoabilidade" (ADIN n. ${ }^{\circ} 2.010 \mathrm{MC} / \mathrm{DF}$, Relator Ministro Celso de Mello); e

"A proibição constitucional do confisco em matéria tributária - ainda que se trate de multa fiscal resultante do inadimplemento, pelo contribuinte, de suas obrigações tributárias - nada mais representa senão a interdição, pela Carta Política, de qualquer pretensão governamental que possa conduzir, no campo da fiscalidade, à injusta apropriação estatal, no todo ou em parte, do patrimônio ou dos rendimentos dos contribuintes, comprometendo-lhes, pela insuportabilidade da carga tributária, o exercício do direito a uma existência digna, ou a prática de atividade profissional lícita ou, ainda, a regular satisfação de suas necessidades vitais 
No plano "horizontal", as limitações à capacidade contributiva decorrem da persecução de fins de interesse superior, como, v.g., a proteção de liberdade dos cultos religiosos, da liberdade política e partidária [evitando-se perseguições políticas de qualquer natureza], do estímulo às atividades de entidades sem fins lucrativos dedicados à educação e saúde, ou, ainda, da proibição contra discriminações arbitrárias e os privilégios odiosos. Isso significa que capacidades de contribuir idênticas podem gerar tributações distintas, em razão da aplicação de outros princípios ou valores constitucionais ${ }^{169}$. Observe-se que o caput do artigo $5^{\circ}$ da Constituição Federal determina ser inadmissível a discriminação "de qualquer natureza", salvo, claro, se o fator de discrímen constar de exceção trazida pelo próprio texto constitucional; quaisquer privilégios aplicados a contribuintes específicos que estejam num mesmo nível de capacidade econômica, portanto, precisam (i.) possuir fundamento em princípios e valores expressamente consignados na Constituição Federal; e (ii.) ser balizados pela razoabilidade, igualdade, ponderação, transparência e clareza. Neste plano, a capacidade contributiva estende-se até o limite da liberdade individual, medido a partir dos princípios de legitimação.

A representação gráfica abaixo demonstra que os valores Justiça e Liberdade se complementam e se equilibram. A capacidade contributiva "nada mais é que o espaço jurídico aberto pelos direitos fundamentais para a tributação, nomeadamente para a exercida sobre o direito de propriedade e o direito de livre exercício da profissão" ${ }^{\text {170 }}$. Os pontos de tensão, representados pela linha azul que circunda a capacidade contributiva, são

básicas. O Poder Público, especialmente em sede de tributação (mesmo tratando-se da definição do 'quantum' pertinente ao valor das multas fiscais), não pode agir imoderadamente, pois a atividade governamental acha-se essencialmente condicionada pelo princípio da razoabilidade que se qualifica como verdadeiro parâmetro de aferição da constitucionalidade material dos atos estatais" (ADIN n. ${ }^{\circ} 1.075$ MC/DF, Relator Ministro Celso de Mello).

${ }^{169}$ Cf. MOSCHETTI, Francesco. Orientaciones Generales de la Capacidad Contributiva. Traduzido por Juan Gorospe Oviedo. Revista de Derecho Financiero y de Hacienda Pública. Madrid: Editorial de Derecho Financiero, vol. LIII, n. 269, set/dez. 2003, p.513-561. Na visão desse autor, a avaliação da capacidade contributiva tributável deve perpassar pelos seguintes passos:

"tal criterio presupone, como condición necesaria y no suficiente, la capacidad económica del sujeto; la capacidad económica debe ser superior a un cierto mínimo y debe ser considerada idónea para concurrir a los gastos públicos en relación a la elección de valores enunciados en la Carta constitucional; igualdad de importes puede, por tanto, subsistir diversidad de la capacidades contributivas, em relación a la calificación constitucional de la capacidad económica” (op. cit., p. 536).

${ }^{170}$ Cf. TORRES, Ricardo Lobo. A Legitimação da Capacidade Contributiva e dos Direitos Fundamentais do Contribuinte. op. cit., p. 434. No mesmo sentido, esse autor assevera que:

"A capacidade contributiva, representada pelo lucro ou pelos frutos da propriedade ou do trabalho, surge, portanto, no espaço de justiça aberto pela autolimitação da liberdade, que, por seu turno, é emoldurado pela reserva de liberdade consubstanciada nas limitações constitucionais ao poder de tributar, que exoneram os direitos fundamentais do contribuinte. As limitações ao poder de tributar são pré- e supraconstitucionais e não resultam, como afirma o positivismo, da autolimitação do próprio Estado no ato de se constituir" (TORRES, Ricardo Lobo. Tratado de Direito Constitucional, Financeiro e Tributário. op. cit., p. 305). 
definidos pelos princípios da legitimidade [ponderação, razoabilidade, igualdade e transparência $]^{171}$. Já os limites, "horizontais" e "verticais", estão expressamente indicados em cada uma das faces da capacidade contributiva.

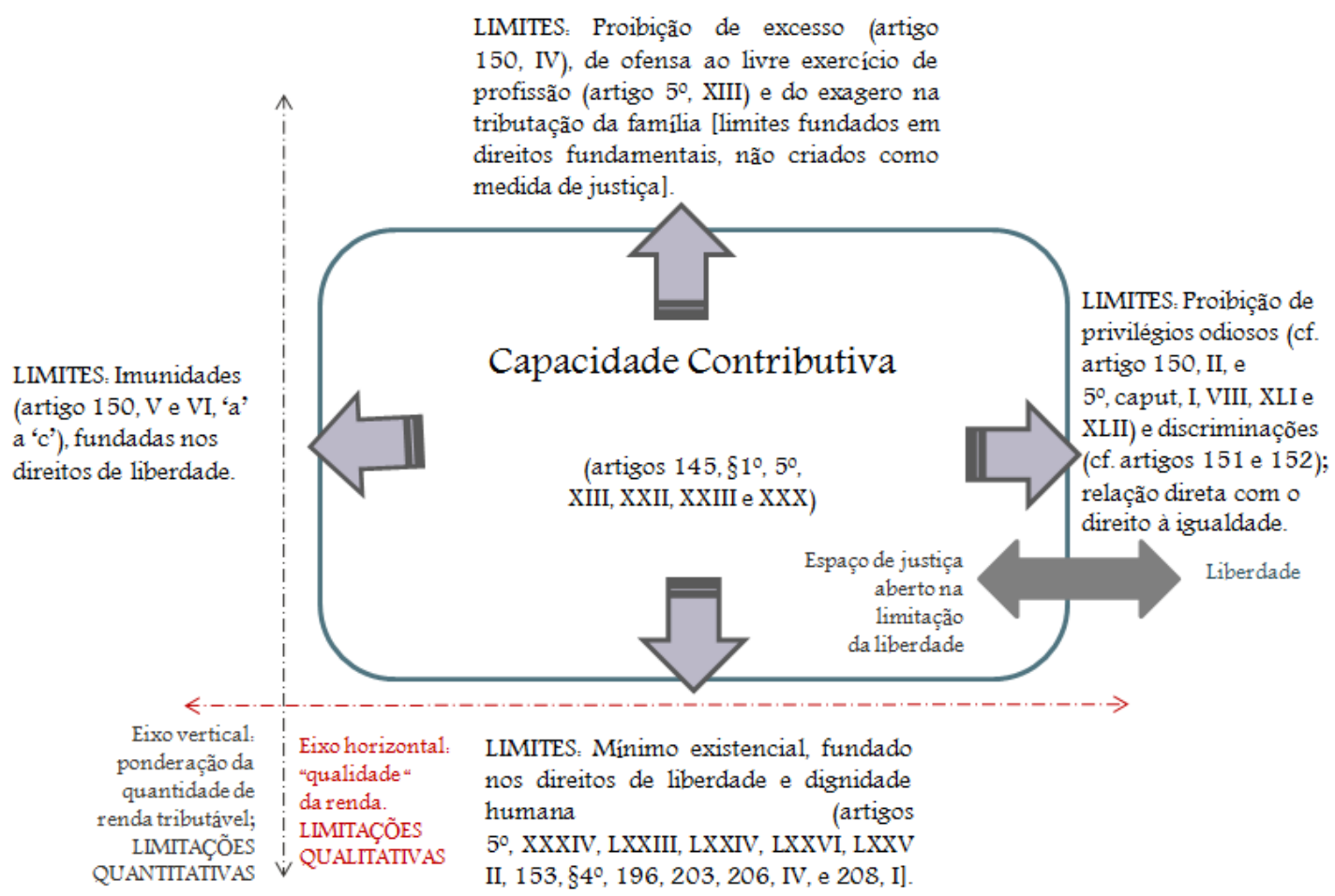

O princípio da capacidade contributiva encontra amparo no artigo $145, \S 1^{\circ}$, da Constituição Federal, o qual prescreve que "sempre que possível, os impostos terão caráter pessoal e serão graduados segundo a capacidade econômica do contribuinte ${ }^{172}$, facultado à administração tributária, especialmente para conferir efetividade a esses objetivos, identificar, respeitados os direitos individuais e nos termos da lei, o patrimônio, os rendimentos e as atividades econômicas do contribuinte". Conforme expressamente consignado em seu texto, o legislador, o aplicador e o intérprete da lei devem concretizar a capacidade contributiva "sempre que possível"; desta expressão pode-se depreender que, por vezes, será impossível a graduação segundo a capacidade econômica e, principalmente, segundo o critério da pessoalidade. É importante a adequada compreensão desta limitação fática inerente a estes dois critérios, reconhecida pelo próprio legislador constitucional.

${ }^{171}$ Inspirado em representação original de TORRES, Ricardo Lobo. Tratado de Direito Constitucional, Financeiro e Tributário. op. cit., p. 308.

172 Não serão objeto de estudo as correntes doutrinárias que igualam ou distinguem entre capacidade contributiva e capacidade econômica; ambas as expressões serão tratadas como sinônimos. 
Com efeito, a aferição da capacidade contributiva plena é utópica, pelas próprias dificuldades técnicas inerentes à sua obtenção ${ }^{173}$; também é irreal imaginar-se que serão aplicados iguais tributos a contribuintes com idênticas capacidades contributivas. Como bem salientado por Ricardo MARIZ DE OLIVEIRA a respeito desse último aspecto, "igualdade absoluta não existe no mundo fenomênico em que ocorre a tributação, onde mais provavelmente ocorram semelhanças de situação" ${ }^{174}$. Justamente por isso é que a isonomia, princípio de legitimação da capacidade contributiva estabelecido no artigo 150 , II, da Constituição Federal, alude à proibição de instituição de tratamento desigual [o tratamento tributário pode ser rigorosamente igual ou desigual] a contribuintes em situações equivalentes [os contribuintes nunca estão em posições exatamente iguais, mas é possível buscar-se situações equivalentes e dividi-las, na medida do possível, por categorias, para a aplicação de regras iguais].

Antônio Roberto Sampaio DÓRIA compreende o princípio da capacidade contributiva em dois níveis distintos: enquanto a capacidade contributiva objetiva consubstancia a exteriorização de riquezas capazes de suportar a incidência de um ônus fiscal, a capacidade contributiva subjetiva aparece em momento logicamente subseqüente, a fim de captar a proporção de renda tributável levando-se em conta fatores econômicos individuais [a "personalização" exigida no artigo 145, §1º da Constituição Federal, seria um dos elementos para o alcance dessa capacidade contributiva subjetiva] ${ }^{175}$. Esse autor apreende a complexidade do elemento subjetivo do princípio, por conta da necessária apreciação de múltiplos elementos aos quais se atribuem pesos e valores mutáveis em cada caso, concluindo que cabe ao Poder Judiciário averiguar se estão sendo gravadas riquezas objetivamente suscetíveis de apreciação; de outro lado, a graduação do imposto em cada

\footnotetext{
${ }^{173}$ Veja-se, exatamente nesse sentido, passagem da obra de Victor UCKMAR:

"Mas a fórmula da capacidade contributiva tem significado mais elevado e importante, na medida em que reafirma 'o princípio ou preceito da igualdade de posições dos cidadãos, diante do dever tributário de prover as necessidades da coletividade. (...) Ninguém se iluda quanto a ser possível obter igualdade, em sentido absoluto, nas cargas tributárias, e isto não só pela mensuração dos sacrifícios, mas pelas dificuldades técnicas de obter tal igualdade. É necessário contentar-se com uma igualdade relativa, de modo que os indivíduos que se encontram nas mesmas condições sejam submetidos a um mesmo tratamento fiscal, porque é utópico ter esperança em uma repartição absolutamente justa dos impostos entre indivíduos que não se encontram em idênticas situações" (UCKMAR, Victor, Princípios Comuns de Direito Constitucional Tributário. $2^{\mathrm{a}}$ ed. rev. e ampl. Tradução e Notas ao Direito Brasileiro por Marco Aurélio Greco. São Paulo: Malheiros, 1999, p. 84$85)$.

${ }^{174}$ Cf. MARIZ DE OLIVEIRA, Ricardo. Breves Considerações sobre a Capacidade Contributiva e a Isonomia. op. cit., p. 491. No mesmo sentido, veja-se TIPKE, Klaus. Princípio de Igualdade e Idéia de Sistema no Direito Tributário. In: Brandão MACHADO (coord.), Direito Tributário, Estudos em Homenagem ao Prof. Rui Barbosa Nogueira. São Paulo: Saraiva, 1984, p. 520.

${ }^{175}$ Cf. DÓRIA, Antônio Roberto Sampaio. op. cit., p. 181-182.
} 
caso concreto estaria no campo da discrição legislativa, puramente político, o qual deve "se conservar imune a qualquer contra-ordem judiciária"176.

Aliomar BALEEIRO, da mesma forma, sustenta haver duas capacidades contributivas. Sob o ponto de vista objetivo, a capacidade contributiva consistiria na aferição de uma base econômica [patrimônio ou renda] apta a suportar o tributo; seria a escolha, entre as situações de vida reveladoras de capacidade econômica, daquelas que seriam eleitas como hipóteses de incidência de tributos. A adaptação da base de cálculo a fatores subjetivos como idade, saúde, estado civil, encargos familiares etc. seria a implementação da capacidade contributiva subjetiva, vinculada à pessoalidade prevista no

176 "Se já é tarefa ingente e ingrata ao legislador a de graduar os níveis da tributação para cada caso, como admitir ainda a interferência do judiciário nessa matéria puramente discricionária, introduzindo-se novos critérios e valores em deliberação já de si tão complexa?

Destarte, o exame da constitucionalidade da ação legislativa em face da capacidade contributiva oscila entre a apuração da absoluta inexistência de capacidade contributiva e a de sua destruição, por exacerbado economicamente o imposto a graus ou alíquotas de incidência insuportáveis. No vasto campo balizado por essas raias, a discrição legislativa deve se conservar imune a qualquer contra-ordem judiciária" (DÓRIA, Antônio Roberto Sampaio. op. cit., p. 182-183).

Ressalte-se que a concepção da capacidade contributiva em suas formas objetiva ou subjetiva está diretamente relacionada à possibilidade de intervenção, pelo Poder Judiciário, para garantir a sua concretização. Os autores que compreendem este princípio de maneira exclusivamente subjetiva, não admitem seu exame pelo Poder Judiciário. Nesse sentido, Ricardo Lobo TORRES sustenta que "inexiste controle judicial da aplicação do princípio, dependente que é de apreciação política" (TORRES, Ricardo Lobo. A Legitimação da Capacidade Contributiva e dos Direitos Fundamentais do Contribuinte. op. cit., p. 446).

Já os autores que vislumbram sua face objetiva [ou ambas], concordam com este exame. Valendo-se da doutrina de Klaus TIPKE, que diferencia o princípio da tributação segundo a capacidade contributiva da consideração econômica, Moris LEHNER assevera o seguinte:

“(...) a consideração econômica 'permite abranger igualmente capacidades contributivas iguais e assim atende ao princípio da igualdade'. Este vínculo possibilita uma ponte entre o princípio da capacidade contributiva, o qual, enquanto mandamento de justiça, dirige-se em primeira linha ao legislador, e a consideração econômica, a qual, enquanto regra de interpretação, é concebida para aqueles que aplicam a lei. Fundamenta-se, outrossim, o vínculo, em que o princípio da capacidade contributiva, enquanto 'princípio fundamental da tributação justa', não deve ser observado apenas na edição de leis, mas também por ocasião de sua aplicação, o que traz a consequiência de que também a interpretação da lei é orientada, ou deve ser orientada, pelo telos deste princípio normativo diretivo" (LEHNER, Moris. op. cit., p. 144). Confira-se, ainda, a posição do próprio autor na p. 152.

Também Ricardo MARIZ DE OLIVEIRA é taxativo ao mencionar que os princípios, assim como a capacidade contributiva, "estão presentes tanto na fase pré-legislativa, quando da atividade legiferante, quanto o estão na fase pós-legislativa, quando da atividade de interpretação e aplicação da lei já existente" (MARIZ DE OLIVEIRA, Ricardo. Breves Considerações sobre a Capacidade Contributiva e a Isonomia. op. cit., p. 464). No mesmo sentido, confira-se, a respeito, Fernando Aurélio ZILVETI, op. cit., p. 39.

Concordamos com esta última corrente, porque entendemos que a capacidade contributiva representa princípio constitucional auto-aplicável, devendo ser observado não apenas pelo legislador, mas também pelo intérprete e aplicador da lei, incluindo-se o Poder Judiciário, que pode examinar se está presente, na hipótese definida pelo legislador, a capacidade de contribuir; o princípio da capacidade contributiva representa uma limitação constitucional ao poder de tributar e, por conseguinte, verdadeiro direito subjetivo dos contribuintes, que podem invocá-lo em sua defesa contra a inconstitucionalidade de leis ou contra atos arbitrários do Poder Executivo. O campo de liberdade legislativa, contudo, não deve ser atacado pelo Poder Judiciário, dado que o Poder Legislativo pode, dentro dos parâmetros e limites constitucionais, definir a melhor forma de captação da capacidade econômica dos contribuintes. O Poder Judiciário atua apenas como o "guardião dos parâmetros constitucionalmente exigidos". 
artigo 145, $\S 1^{0177}$. Misabel Abreu Machado DERZI, em notas à obra de Aliomar Baleeiro, complementa que a capacidade contributiva objetiva também pode ser denominada "absoluta", porque o texto constitucional já previu e regulamentou, amplamente, as circunstâncias que podem ser caracterizadas como reveladoras de capacidade contributiva objetiva $^{178}$. Caberia ao legislador infraconstitucional, nesse caso, fixar as principais normas para a cobrança do tributo, observando-se, porém, as limitações constitucionais ao poder de tributar [respeito à dignidade humana, igualdade, proibição de confisco etc.].

A discussão entre a capacidade contributiva objetiva e subjetiva assumiu relevância, sob uma outra perspectiva, também na Itália, onde o artigo 53 do texto constitucional prevê a capacidade contributiva como uma espécie de critério para a "repartição solidária" dos dispêndios de interesse comum, i.e., determina que todos os contribuintes são chamados a concorrer com os gastos públicos, na razão de sua capacidade contributiva. Parte da doutrina apega-se com tamanha força ao aspecto personalíssimo e "solidário" desse princípio que sustenta seu verdadeiro "abandono" ao se deparar com a declaração de legitimidade, pelo Poder Judiciário, de leis que, quando da imposição de tributos, aplicam critérios objetivos reveladores de riqueza. Nesse sentido, Francesco MOSCHETTI sustenta que "não concorre para os gastos públicos o 'homem médio', mas cada contribuinte, de acordo com todas as suas características específicas"179; as leis com "critérios objetivos" e que não buscassem a "máxima personalização dos tributos" deveriam, assim, ser declaradas inconstitucionais. A outra parte da doutrina critica esta defesa "ingênua" de uma capacidade contributiva absolutamente perfeita e

\footnotetext{
${ }^{177}$ BALEEIRO, Aliomar. op. cit., p. 748-749.

${ }^{178}$ Essa autora entende que, a despeito da competência residual da União Federal prevista no artigo 154 da Constituição Federal, prevalece a denominação capacidade contributiva objetivo-absoluta.

${ }^{179}$ Cf. MOSCHETTI, Francesco. op. cit., p. 551.
}

Ainda a respeito, cf. COCIANI, Simona Francesco. Attualitá o declinio del principio della capacità contributiva. Revista di Diritto Tributario. Milano: Dott. A. Giuffrè Editore, vol. XIV, jul/ago. 2004, p. 823906. Confira-se, abaixo, posição da autora a respeito da atual "discricionariedade" com que, atualmente, seria aplicado o princípio da capacidade contributiva na Itália:

"Anche nella giurisprudenza constituzionale più recente, poi, l'attitudinie alla contribuizione no risulta solo limitata alla mera rilevanza patrimoniale del fatto-pressuposto (cd. limite assoluto), bensì é riferita ad una più ampia (e generica) rilevanza economica, pure espressa attraverso la possibilità di operare economicamente sul mercato e quindi - come sembra - a prescindire dalla scambialità sul mercato dell'indice di riparto prescelto (cd. limite relativo). Deve pertanto ammettersi che ormai il cd. 'diritto vivente' - letitimando nuovi tributi giustificati anche attraverso il richiamo all'interesse fiscale - ha dunque sancito che la capacità contributiva può essere ravvisata in qualsiasi indice rivelatore di ricchezza, costruito secondo valutazione riservati alla discrezionalità del legislatore con il solo limite dell'arbitrarietà e dell'irragionevolezza e - per questa via - sembra dunque haver aperto la strada a quelle impostazioni che riconoscono la possibilità di interpretare il principio suddetto anche com riferimento all'elemento oggettivo, a cui fa da contraltare un indebolimento del collegamento soggettivo alla forza economica expressa dall contribuente" (COCIANI, Simona Francesco. op. cit., p. 942-843). 
individualizada ${ }^{180}$; a capacidade contributiva, aplicada racional e objetivamente, permaneceria sendo, na Itália, uma proteção dos contribuintes contra abusos por parte do Poder Legislativo e do Poder Executivo.

O debate supra, que sopesa a personalização versus a objetivação das normas tributárias, é importante no direito brasileiro, especificamente no que toca à aplicação da capacidade contributiva às regras para o controle dos preços de transferência. Não há dúvidas de que o Poder Legislativo deve esforçar-se para instituir impostos pessoais. O apego exacerbado a esta personalização, contudo, torna impraticável a cobrança dos tributos: além de muito dispendiosa, tanto para o contribuinte quanto para a administração tributária, a exigência de aplicação personalíssima da lei abre um enorme campo para a atuação discricionária do Poder Executivo [porque, obviamente, não constarão do texto legal as minúcias exclusivas de cada contribuinte]; foram estes os fatores que levaram o legislador constitucional a prever a cobrança pessoal dos impostos "sempre que possível". As leis tributárias não podem ser exageradamente subjetivas nem objetivas: deve-se buscar um equilíbrio apto a materializar tanto a Justiça quanto a Segurança Jurídica.

Consoante salientado na seção preliminar desta seção 1.6, a capacidade contributiva, que busca concretizar o valor Justiça, precisa manter-se num constante e dinâmico "jogo de ponderação" com o valor Segurança Jurídica; de fato, não é viável concretizar o princípio da capacidade contributiva sem a Segurança, mas o apego exacerbado a essa última, sem considerações sobre a isonomia e os direitos fundamentais, pode ferir valores como a Justiça, a Liberdade e a Solidariedade. Quando da concretização deste princípio, assim, deve-se buscar um equilíbrio dinâmico entre os valores Justiça e Segurança Jurídica, porque de nada vale um ordenamento jurídico justo e totalmente inseguro, dado que ele se torna ineficiente em decorrência da fluidez e subjetividade das normas que ali se formariam. De outro lado, um ambiente seguro e eficaz, mas totalmente

\footnotetext{
${ }^{180}$ Confira-se, nesse sentido, Gaspare FALSITTA, que critica diretamente a posição de Simona COCIANI, em texto publicado conjuntamente com o dessa autora:

"La capacità contributiva non versa in fase di estinzione. Non sta lottando con la morte e quindi non versa in fase di Todeskampf o di agonia (che lessicalmente vuol dire 'lotta per non morire'). Ha vissuto, in specie negli ultimi anni, una esistenza tribolata, ma è tuttora vegeta. (...) E i chierici del diritto tributario, a nostro sommesso avviso, fanne male a plaudire ai 'cedimenti', ai tentennamenti, alle elusività, di cui è costellata la giurisprudenza della Consulta in tema di capacità contributiva e a prestare il contributo della loro dottrina e el loro ingegno per indebolire l'usbergo dell'art. 53. Fanno male preché fabbricano un cavallo di Troia di cui è ignoto il beneficiario" (FALSITTA, Gaspare. Il doppio concetto di capacità contributiva. Anexo ao texto de COCIANI, Simona Francesco. op. cit., p. 906).

${ }^{181}$ Expressão extraída de TORRES, Ricardo Lobo. Tratado de Direito Constitucional, Financeiro e Tributário. op. cit., p. 415.
} 
injusto, também não se adequaria ao Estado Social de Direito constitucionalmente garantido. Qualquer radicalização põe fim à adequada funcionalidade do ordenamento. $\mathrm{O}$ princípio da capacidade contributiva precisa coexistir harmoniosamente com outros princípios e valores, inclusive a Segurança Jurídica e a previsibilidade de aplicação das normas jurídicas tributárias ${ }^{182}$. Em virtude disso, a capacidade contributiva, vinculada mais fortemente ao valor Justiça, também deve se prestar ao objetivo de garantir um nível adequado de Segurança Jurídica, garantindo-se uma "previsibilidade forte" quanto ao conteúdo e à aplicação das leis ${ }^{183}$.

A transposição da polêmica supra para o campo dos preços de transferência é, justamente, o objeto desta tese. Com efeito, não há dúvidas de que a capacidade contributiva é o princípio mais diretamente relacionado com a instituição das regras para o controle daqueles preços ${ }^{184}$. As metodologias para a aplicação do princípio e conseqüente aferição de métodos, todavia, podem ser mais ou menos subjetivas. No extremo da subjetividade, encontra-se o princípio da plena concorrência, tal como preconizado pela

182 Cf. TORRES, Ricardo Lobo. O Princípio Arm's Length, os Preços de Transferência e a Teoria da Interpretação do Direito Tributário. Revista Dialética de Direito Tributário. São Paulo: Dialética, v. 48, set./99, p. 131.

183 "Seguindo essa linha de raciocínio, no âmbito da dinâmica de criação de tributos, o reconhecimento do princípio da capacidade contributiva oferta aos contribuintes uma previsibilidade forte sobre a seleção dos fatos passíveis de serem alcançados por normas gerais e abstratas constitutivas de obrigações tributárias, na medida em que tal seleção, efetivada pelo legislador, somente poderá recair sobre fatos que tenham alguma relevância econômica, o suficiente para demonstrar capacidade de suportar o encargo da prestação tributo" (TÔRRES, Heleno Taveira. Segurança Jurídica em matéria tributária. In: MARTINS, Ives Gandra da Silva (coord.). Limitações ao Poder Impositivo e Segurança Jurídica. São Paulo: Centro de Extensão Universitária, 2005, p. 164).

${ }^{184} \mathrm{Na}$ visão de Luís Eduardo SCHOUERI, anteriormente referida, “o papel da legislação de preços de transferência é apenas 'converter' valores expressos em reais de grupo para 'reais de mercado', possibilitando, daí, a efetiva comparação entre contribuintes com a mesma capacidade econômica” (Preços de Transferência no Direito Tributário Brasileiro. op. cit., p. 12).

Heleno Taveira TÔRRES, ao comentar a relação das regras para o controle dos preços de transferência e os princípios constitucionais brasileiros, vincula o atendimento daquelas, de forma direta, à observância do princípio da capacidade contributiva. Confira-se:

"Em termos tributários, o atendimento ao princípio arm's length pela determinação do preço de referência, a partir da aplicação dos métodos de ajuste, serve para resgatar a efetiva capacidade contributiva do contribuinte, omitida pela manipulação de preços, mediante subfaturamentos ou superfaturamentos. (...) $\mathrm{O}$ que os métodos de comparação devem respeitar, portanto, é o princípio da capacidade contributiva, que corresponderão em maior ou menor medida ao critério arm's length na proporção do quanto o seu resultado reflita o preço efetivo de mercado (preço de livre concorrência). Se há um princípio para ser respeitado pela legislação e pelos aplicadores do direito, este é o da capacidade contributiva. Este sim, um verdadeiro princípio. Do contrário, a disciplina do transfer price serviria como um mecanismo de tributação por meio de ficções e presunções, o que colidiria frontalmente com o regime constitucional brasileiro" (Direito tributário internacional: planejamento tributário e operações transnacionais. op. cit., p. 198).

Ricardo Lobo TORRES manifestou-se no mesmo sentido:

“Os princípios jurídicos se vinculam a valores. O arm's length está intimamente ligado à justiça e à capacidade contributiva, eis que tem por objetivo garantir a transferência de bens e serviços pelo preço justo, normal ou de concorrência" (TORRES, Ricardo Lobo. O Princípio Arm's Length, os Preços de Transferência e a Teoria da Interpretação do Direito Tributário. op. cit., p. 126). 
OCDE em sua Diretiva. Como se demonstrará no CAPÍTULO 2, ele exige um exame particular das condições comerciais e financeiras de cada transação praticada pelo ente "testado", sendo os custos inerentes a sua aplicação [tanto para o contribuinte quanto para as administrações tributárias] a crítica mais ferrenha em desfavor da plena concorrência. $\mathrm{Na}$ extremidade oposta está o sistema unitário ou da partição fracionada do lucro, discutido no CAPÍTULO 6, o qual apura o preço parâmetro a partir de uma fórmula prefixada e objetiva. Pouca discussão existe no direito brasileiro sobre um possível meio-termo, i.e., sobre a investigação de um equilíbrio entre estes dois extremos que garanta a aplicação efetiva e segura da capacidade contributiva. Neste contexto, o que esta tese busca defender é justamente que, sob a perspectiva do direito tributário brasileiro, uma sistemática intermediária e equilibrada seria viável e satisfatoriamente praticável.

\subsubsection{Princípios da generalidade, universalidade e noção de 'renda tributável' adotada pelo legislador brasileiro.}

Ainda que o artigo $153, \S 2^{\circ}$, I, explicite que o imposto sobre a renda "será informado pelos critérios da generalidade, da universalidade e da progressividade ${ }^{185}$, na forma da lei”, não há dúvidas de que a generalidade e a universalidade são legítimos princípios jurídicos, porque atendem a todos os requisitos de abstração próprios desses últimos e são vinculados a valores específicos. Eles prestam-se à concretização do valor Justiça Fiscal, podendo, segundo a doutrina de Ricardo Lobo TORRES, serem considerados "subprincípios" vinculados à capacidade contributiva. Ambos os princípios têm forte vínculo com o princípio de legitimação igualdade, destinando-se, precipuamente, a vedar qualquer forma de discriminação odiosa.

Por generalidade deve-se entender o princípio que prescreve a incidência do imposto sobre todos aqueles, residentes no país, que sejam detentores de capacidade contributiva, independentemente de condições especiais de domicílio, sexo, nacionalidade, ou qualquer outra que não estiver fundada (a.) na manifestação de efetiva capacidade

\footnotetext{
${ }^{185}$ O princípio da progressividade não será objeto de estudo específico por não manter relação com a edição e/ou aplicação das normas para o controle dos preços de transferência.
} 
econômica; ou (b.) em outro fator de discrime previsto constitucionalmente e amparado em princípios de legitimação, em especial a razoabilidade ${ }^{186}$.

A universalidade deve ser compreendida como a incidência do imposto de renda sobre a totalidade dos rendimentos dos contribuintes, sem exceções não amparadas em previsões constitucionais mais valiosas como, v.g., a imunidade do patrimônio, renda e serviços relacionados com as finalidades essenciais de entidades sindicais e instituições de educação sem finalidade lucrativa [cf. artigo 150, VI, 'c', c.c. $\S 4^{\circ}$, da Constituição Federal]. A universalidade contribui para que aumentos patrimoniais semelhantes sejam tratados igualmente pela legislação tributária, evitando-se a instituição de privilégios nãorazoáveis sobre determinados tipos de rendimentos ${ }^{187}$. Como medida de reforço ao princípio da universalidade, o artigo $43, \S 1^{\circ}$, do Código Tributário Nacional, é expresso no sentido de que "a incidência do imposto independe da denominação da receita ou do rendimento, da localização, condição jurídica ou nacionalidade da fonte, da origem e da forma de percepção".

Advirta-se, a este passo, que é a partir da aplicação do princípio da universalidade que se torna viável a adoção da pessoalidade prescrita no artigo $145, \S 1^{\circ}$, da Constituição Federal; segundo consignado por Ricardo MARIZ DE OLIVEIRA, “todos os direitos e obrigações que compõem a universalidade patrimonial, e todos os fatores que acrescem ou diminuem esse patrimônio, somente se ligam entre si pela pessoa do seu titular, que é o único elo entre todos esses elementos" ${ }^{\prime 188}$. Nesse sentido, para se observar o critério pessoal na graduação do imposto sobre a renda segundo a capacidade econômica do contribuinte, é mister a consideração da universalidade [dos elementos positivos e negativos] do patrimônio pessoal, sem exclusão de quaisquer rendimentos.

\footnotetext{
${ }^{186}$ No Brasil, v.g., é proibida a tributação distinta de homens e mulheres, porque isso implicaria em ofensa direta aos artigos $5^{\circ}$, I, e $153, \S 2^{\circ}$, I, da Constituição Federal. De outro lado, pode-se discriminar a tributação imposta a contribuintes estabelecidos em diferentes regiões do país, desde que o discrime tenha por escopo a promoção do equilíbrio sócio-econômico entre elas [cf. artigo 151, I, da Constituição Federal].

187 Não será objeto de estudo, por não estar diretamente atrelado ao objeto da tese, o princípio da universalidade vis-à-vis a territorialidade na tributação da renda auferida no exterior por contribuintes residentes no país. A sistemática das normas para o controle dos preços de transferência cuida da renda auferida por residentes no país, renda essa que pode ser "transferida" irregularmente para sociedade do mesmo grupo econômico estabelecida no exterior; o cerne da discussão, assim sendo, cinge-se à tributação justa dos rendimentos auferidos por residentes a partir de atividades desenvolvidas no país.

${ }^{188}$ Cf. MARIZ DE OLIVEIRA, Ricardo. Breves Considerações sobre a Capacidade Contributiva e a Isonomia. op. cit., p. 473.
} 
Como não poderia deixar de ser, as normas para o controle dos preços de transferência prestam-se para a concretização dos dois princípios supra referidos, porque almejam a cobrança do imposto sobre renda não evidente ou manifesta na contabilidade. Essa renda "inevidente" também deve ser tributável, seja porque se deve perquirir, sempre, uma tributação mais justa, seja porque a Constituição Federal preceitua uma incidência geral e universal do imposto, sem a exclusão de qualquer rendimento ou provento. Aquelas normas prestam-se, ademais, para corrigir distorções e garantir a tributação da renda efetiva $^{189}$; a noção de renda tributável, neste cenário, também apresenta relação direta com as normas para o controle dos preços de transferência.

O artigo 153, III, da Constituição Federal, atribui competência à União Federal para a tributação da "renda", a qual foi definida pelos artigos 43 e 44 do Código Tributário Nacional. Não será objeto do presente estudo o importante exame das teorias econômicas e jurídicas sobre a noção de renda ${ }^{190}$; pelo contrário, limitar-nos-emos a ponderar que, no direito brasileiro, a "renda tributável" compreende o produto do capital, do trabalho, ou de ambos, ou outros acréscimos patrimoniais, desde que o contribuinte tenha adquirido a respectiva disponibilidade econômica ou jurídica [cf. artigo 43, caput e incisos I e II, do Código Tributário Nacional ${ }^{191}$ ]. O acréscimo patrimonial é o pressuposto legal para a realização do fato gerador tributário do imposto sobre a renda ${ }^{192}$. Tal acréscimo, por seu turno, deve ser verificado entre dois períodos distintos, mediante o confronto dos patrimônios em cada data; se o patrimônio aumentar de um período para outro, haverá

189 "É sob esta perspectiva que se deve considerar a legislação sobre preços de transferência: será ela constitucional - porque compatível com o conceito de renda, hoje positivado pelo artigo 43 do Código Tributário Nacional - se os ajustes por ela impostos servirem para corrigir eventuais distorções do lucro contábil da pessoa jurídica, aproximando o resultado, destarte, da efetiva renda da empresa" (Preços de Transferência no Direito Tributário Brasileiro. op. cit., p. 11).

${ }^{190}$ Para um estudo aprofundado dessas teorias econômicas e jurídicas, confira-se HOLMES, Kevin. The concept of income. A multi-disciplinary analysis. Doctoral Series no. 1, Academic Council. Amsterdã: IBFD Publications BV, 2001.

191 "Art. 43. O imposto, de competência da União, sobre a renda e proventos de qualquer natureza tem como fato gerador a aquisição da disponibilidade econômica ou jurídica:

I - de renda, assim entendido o produto do capital, do trabalho ou da combinação de ambos;

II - de proventos de qualquer natureza, assim entendidos os acréscimos patrimoniais não compreendidos no inciso anterior".

${ }^{192}$ Concordamos com a posição de Gilberto de ULHÔA CANTO, no sentido de que os dois incisos do artigo 43 do Código Tributário Nacional exigem, necessariamente, a verificação de um efetivo acréscimo patrimonial. Confira-se, nesse sentido, a seguinte passagem de obra deste autor:

"O requisito do acréscimo patrimonial aplica-se tanto ao caso do inciso I como ao do inciso II. Muito embora a ele o inciso I não aluda, a presença da palavra 'produto', que nele figura, é bastante para deixar clara a idéia de incremento" (ULHÔA CANTO, Gilberto de. A Aquisição e Disponibilidade e o Acréscimo Patrimonial no Imposto sobre a Renda. In: Ives Gandra da Silva Martins (coord.), Estudos sobre o Imposto de Renda (em memória de Henry Tilbery). São Paulo: Resenha Tributária Ltda., jul. 2004, p. 36). 
acréscimo tributável. Assumindo-se que o patrimônio é um "universitas juris", composto por direitos e obrigações dinâmicos e constantemente mutáveis, somente é viável a implementação do princípio da universalidade, supra referido, em conjunto com a periodicização do imposto de renda ${ }^{193}$; devem ser tributados os acréscimos patrimoniais a cada período predeterminado de tempo, sob pena de impossibilidade de aplicação do próprio princípio da tributação universal da renda. Esse período, para fim de cálculo dos impostos patrimoniais ou sobre a renda, tem sido mundialmente definido como 12 (doze) meses, admitindo-se, em alguns países, uma sobreposição do "ano econômico" sobre o ano-calendário para, v.g., determinados tipos de atividades especiais ou sazonais. No Brasil, esse período coincide com o ano-calendário ${ }^{194}$.

No que concerne à noção de disponibilidade econômica ou jurídica da renda, constante do caput do artigo 43 do Código Tributário Nacional, é importante delimitar que, enquanto a disponibilidade econômica representa a percepção efetiva de moeda ou de bens suscetíveis de avaliação monetária [existe a faculdade de pronta utilização dessa renda], a disponibilidade jurídica implementa-se a partir do momento em que nasce o direito de receber a renda; essa última é adquirida desde o aperfeiçoamento das obrigações contratuais das quais decorrem os rendimentos, como a entrega dos bens alienados ou a prestação do serviço ajustado. Segundo a doutrina de José Luiz BULHÕES PEDREIRA, a obtenção da disponibilidade jurídica da renda não representa a aquisição do poder para o seu emprego imediato, limitando-se à configuração de uma faculdade de obtê-la ${ }^{195}$.

\footnotetext{
193 “A propósito, note-se que o princípio da universalidade, estando expresso na Constituição, induz necessariamente a uma conseqüência que está implícita nele, que é a periodicização da incidência do imposto, pois não se pode conceber uma apuração universal do aumento patrimonial não referida a um determinado período de tempo (...)" (MARIZ DE OLIVEIRA, Ricardo. Breves Considerações sobre a Capacidade Contributiva e a Isonomia. op. cit., p. 475).

194 Segundo Misabel de Abreu Machado DERZI, o artigo 165, §5º, da Constituição Federal, consagra a obrigatoriedade da periodicização anual, a universalidade e o ciclo orçamentário anual. Com a estipulação constitucional do período de um ano, evita-se a instituição de prazos menores que poderiam comprometer a captação da capacidade contributiva, especialmente no caso dos tributos sobre a renda (In: BALEEIRO, Aliomar. op. cit., p. 66 e 166-169).

${ }^{195}$ Especificamente no que se refere às pessoas jurídicas, esse autor sustenta que:

"No caso de pessoa jurídica, que é organização estabelecida e participa permanentemente dos mercados, a caracterização da disponibilidade virtual não requer necessariamente ato da fonte pagadora, mas pode basearse na experiência da pessoa jurídica ao exercer a atividade que constitui seu objeto. Se a pessoa jurídica exerce função empresarial (venda de bens ou serviços no mercado) e a experiência dos seus negócios mostra que em regra as mercadorias remetidas aos compradores chegam ao destino e o preço de compra é pago contra a entrega da mercadoria, é razoável que se considere o preço virtualmente recebido quando a mercadoria é expedida, em execução do contrato de compra e venda" (BULHÕES PEDREIRA, José Luiz. Imposto de renda. Rio de Janeiro: Justec, 1979, v. 1, p. 200).
} 
Importa salientar, a esse passo, que o artigo 44 do Código Tributário Nacional determina ser a base de cálculo do imposto sobre a renda "o montante, real, arbitrado ou presumido, da renda ou dos proventos tributáveis". Portanto, o legislador ordinário pode optar pela tributação com amparo na contabilidade comercial ajustada ou, ainda, pela presunção ou arbitramento da renda ${ }^{196}$; trata-se de decisão discricionária do legislador ordinário, que possui alguma liberdade, num espaço aberto pelos demais princípios e valores constitucionais aplicáveis e pela própria noção de renda.

Sob a perspectiva das normas para o controle dos preços de transferência, optou o Poder Legislativo por, sempre, aferir os preços parâmetro a partir da contabilidade do contribuinte. Mesmo no caso de contribuintes optantes pelo regime do lucro presumido, e.g., os preços de transferência são aferidos a partir dos métodos disciplinados pela Lei n. ${ }^{\circ}$ 9.430/96, sendo que eventuais ajustes contábeis são somados à base presumida [cf. artigo $19, \S 7^{\circ}$, da aludida lei]. Essa foi a opção [discricionária] do legislador ordinário. Inexiste, contudo, vedação para que ele opte por critérios presumidos também para a determinação dos preços parâmetro, como já o faz para a definição do lucro operacional tributável.

A utilização da técnica das presunções não é vedada, desde que o contribuinte possua o direito de fazer contraprova [cf. seção 1.9, infra]. Nesse sentido, o exame contábil e a apresentação de documentação [própria e/ou de terceiros] para a comprovação de um dos métodos previstos na Lei n. ${ }^{\circ}$ 9.430/96 não é o único gênero de normas admitido: um segundo gênero, amparado em presunções, como medida de praticabilidade, também pode ser adequado. Voltaremos a esta discussão no CAPÍTULO 6, quando da ponderação dos prós e contras envolvidos nas sistemáticas vinculadas ao princípio da plena concorrência e ao método da partilha fracionada. Desde logo, ponderamos que nenhuma das duas sistemáticas, de forma pura, presta-se para atingir a tributação da renda de forma justa e, a um mesmo tempo, segura; entretanto, uma abordagem intermediária, a partir da ponderação de elementos dos dois gêneros de normas e, sempre, garantindo-se o direito à contraprova das presunções, pode se apresentar como mais adequada.

\footnotetext{
${ }^{196}$ É importante distinguir o lucro arbitrado, que representa uma das bases de cálculo do imposto de renda facultadas ao legislador ordinário pelo legislador complementar, com o arbitramento cabível no momento do lançamento tributário, disciplinado no artigo 148 do Código Tributário Nacional e discutido em 1.9, infra.
} 


\subsubsection{Princípio da legalidade.}

O princípio da legalidade é um dos pilares do nosso ordenamento jurídico, razão pela qual encontra previsão nos artigos $5^{\circ}$, II, e 37, da Constituição Federal, além de possuir disciplina específica, no âmbito do direito tributário, no artigo 150, I ${ }^{197}$. Este princípio objetiva materializar principalmente o valor Segurança Jurídica ${ }^{198}$, o qual visa conferir previsibilidade forte na regular positivação do direito. Este valor somente pode ser atendido se houver (a.) certeza na determinação do conteúdo jurídico aplicável; e (b.) garantia de manutenção da igualdade de tratamento por parte das autoridades competentes nos respectivos atos de aplicação do direito. A Segurança, nesse sentido, resulta da aplicação dos princípios legitimadores da certeza e da igualdade. Mas a Segurança Jurídica em matéria tributária não se resume à legalidade ou à isonomia: a Constituição Federal exige o envolvimento dos institutos e princípios do Estado Democrático de Direito na sua concretização, de modo que o tributo intervenha nas ordens social e econômica ${ }^{199}$.

Pode-se detectar, atualmente, duas correntes distintas para explicar o conteúdo e o alcance do princípio da legalidade em matéria tributária, sendo que uma delas, que possui amparo na doutrina de Alberto XAVIER, Sacha Calmon Navarro COÊLHO e Misabel Abreu Machado DERZI, sustenta a existência de um princípio da "estrita legalidade tributária" ou tipicidade em sentido impróprio; de outro lado, Ricardo Lobo TORRES, José Casalta NABAIS e Marco Aurélio GRECO, dentre outros, entendem ser a legalidade tributária um princípio um pouco mais aberto e fluido, ou tipicidade em sentido próprio.

\footnotetext{
197 “Art. 150. Sem prejuízo de outras garantias asseguradas ao contribuinte, é vedado à União, aos Estados, ao Distrito Federal e aos Municípios:

I - exigir ou aumentar tributo sem lei que o estabeleça”.

${ }^{198}$ Cf. TORRES, Ricardo Lobo. Tratado de Direito Constitucional, Financeiro e Tributário. op. cit., p. 308.

199 "Funda-se, assim, a partir de questões típicas de direito constitucional, uma proposta construtivista da idéia de segurança jurídica em matéria tributária, com objetivos de aprimorar o conhecimento necessário sobre a organização e o funcionamento do sistema tributário de um Estado Democrático e Social de Direito, consciente das vinculações com a ação do Estado nas ordens econômica e social, com finalidade ordenadora ou promocional, segundo criterioso planejamento público. Desse modo, a análise do conceito de segurança jurídica em matéria tributária vai muito além de uma simples alegação dos princípios da legalidade ou de isonomia, segundo as preferências individuais por maior certeza ou justiça projetadas pelo sistema, ou de mero respeito à sua hierarquia normativa. $\mathrm{Na}$ atualidade, deve-se buscar tanto mais a afirmação dos limites do papel do tributo como instrumento de intervenção do Estado nas ordens social ou econômica (a.), no respeito aos valores próprios do direito privado, que concentram em si os magnos preceitos das relações entre partícipes da sociedade civil (b.), nas medidas de simplificação e de solução célere de controvérsias (c.), nos tratamentos dos regimes especiais segundo as diversas situações dos sujeitos (d.) e na promoção do desenvolvimento nacional (e.)" (TÔRRES, Heleno Taveira. Segurança Jurídica em matéria tributária. op. cit., p. 159-160).
} 
Antes de esclarecer especificamente cada uma dessas correntes, importa determinar, com maior precisão terminológica, a utilização dos termos "conceito" e "tipo", sendo que para isso valer-nos-emos, especialmente, da doutrina de Misabel Abreu Machado DERZI. Segundo esta autora, tipo e conceito estão em tensão permanente no direito tributário, assim como também estão os valores jurídicos básicos que cada um deles busca atingir. De um lado, o tipo em sentido próprio [conceito aberto ou indeterminado] serve para se alcançar a Justiça, possibilitando uma estrutura flexível e gradual, aberta às mutações sociais. $\mathrm{O}$ conceito ${ }^{200}$, de outro lado, caracteriza-se por denotar o objeto a partir de notas rígidas e fixas, determinantes de uma forma de pensar seccionadora da realidade; não por outro motivo, o "conceito fechado" serve ao valor Segurança Jurídica ${ }^{201}$. Nesse sentido, a tensão entre as noções de conceito e tipo presta-se para refletir a tensão e interação dinâmica entre os valores Justiça e Segurança Jurídica no ordenamento, tema essencial nesta tese e que também foi abordado em 1.6.2, supra.

Para os defensores do princípio da estrita legalidade tributária ou da tipicidade tributária em sentido impróprio, "são prevalecentes os princípios da segurança, certeza e previsibilidade no Direito Tributário, assim como no Direito Penal" ${ }^{202}$. Por decorrência, devem ser evitados conceitos fluidos, indeterminados ou abertos nas leis tributárias, porque “o que prevalece no direito tributário não é a tipologia, mas a classificação; não é o tipo, mas o conceito" ${ }^{203}$. Alberto XAVIER reafirma esta aplicação do princípio da legalidade

\footnotetext{
${ }^{200}$ Também designado conceito fechado, conceito determinado ou tipo em sentido impróprio.

201 “O princípio da especificação conceitual - que costuma ser denominado, impropriamente, de tipologia ou tipicidade - diz respeito ao princípio da legalidade, materialmente considerado, como conteúdo mínimo imposto ao legislador, matéria indelegável. (...)

De um lado, encontramos o tipo como ordem rica de notas referenciais ao objeto, porém, renunciáveis, que se articulam em uma estrutura aberta à realidade, flexível, gradual, cujo sentido decorre dessa totalidade. Nele, os objetos não se subsumem, mas se ordenam, segundo método comparativo que gradua as formas mistas ou transitivas. De outro lado, observamos os conceitos fechados, que se caracterizam por denotar o objeto através de notas irrenunciáveis, fixas e rígidas, determinantes de uma forma de pensar seccionadora da realidade, para a qual é básica a relação de exclusão ou ... ou. Por meio dessa relação, calcada na regra da identidade, empreendem-se classificações com separação rigorosa entre as espécies.

O tipo propriamente dito, por suas características, serve mais de perto a princípios jurídicos como o da igualdade-justiça individual, o da funcionalidade e permeabilidade às mutações sociais. Em compensação, com o seu uso, enfraquece-se a segurança jurídica, a certeza, a legalidade como fonte exclusiva de criação jurídica e a uniformidade. O conceito determinado e fechado (tipo fechado no sentido impróprio), ao contrário, significa um reforço à segurança jurídica, à primazia da lei, à uniformidade no tratamento dos casos isolados, em prejuízo da funcionalidade e adaptação da estrutura normativa às mutações socioeconômicas" (DERZI, Misabel Abreu Machado. A Desconsideração dos Atos e Negócios Jurídicos Dissimulatórios, segundo a Lei Complementar n. ${ }^{\circ}$ 104, de 10 de janeiro de 2001. O Planejamento Tributário e a Lei Complementar n. ${ }^{\circ}$ 104. São Paulo: Dialética, 2001, p. 222-224).

${ }^{202}$ Cf. DERZI, Misabel Abreu Machado. A Desconsideração dos Atos e Negócios Jurídicos Dissimulatórios, segundo a Lei Complementar n. ${ }^{\circ}$ 104, de 10 de janeiro de 2001, op. cit., p. 224.

${ }^{203}$ Cf. DERZI, Misabel Abreu Machado. In: BALEEIRO, Aliomar. op. cit., p. 138.
} 
em sua máxima amplitude, sustentando a "reserva absoluta da lei" e a "tipicidade fechada" [em sentido impróprio, cf. doutrina de Misabel Abreu Machado DERZI]; mas não se trata da prevalência de uma de uma lei meramente formal; pelo contrário, esse autor salienta a necessidade de uma lei qualificada, porque o princípio da legalidade cerrada "exige que os elementos integrantes do tipo [em sentido impróprio] sejam de tal modo precisos e determinados na sua formulação legal que o órgão de aplicação do direito não possa introduzir critérios subjetivos na sua aplicação concreta" ${ }^{204}$. Na visão dos defensores da "estrita legalidade tributária", as fórmulas para a quantificação dos tributos devem ser rígidas e previstas integralmente no texto legal.

Sacha Calmon Navarro COÊLHO confirma essa tese, asseverando expressamente que o ordenamento tributário brasileiro privilegia tanto a legalidade formal quanto a legalidade material. Esse autor defende, inclusive, que "a tipicidade tributária ${ }^{205}$ é cerrada para evitar que o administrador ou o juiz, mais aquele do que este, interfiram na sua modelação, pela via interpretativa ou integrativa"206. Em estudo sobre o valor Segurança Jurídica, Heleno Taveira TÔRRES ratifica a existência de uma legalidade material ou substantiva, mas num sentido mais amplo e que não se confunde com o mero conteúdo típico [em sentido impróprio] da lei: essa legalidade condiciona o campo de atuação material do intérprete, como medida assecuratória de valores e princípios constitucionais como a Justiça, a Segurança, a Liberdade Individual, a dignidade humana,

\footnotetext{
${ }^{204}$ Cf. XAVIER, Alberto. Tipicidade da Tributação, Simulação e Norma Antielisiva. São Paulo: Dialética, 2001 , p. 19.

205 Esse autor vale-se da expressão "tipicidade tributária" em sentido impróprio, aproximando-a da "legalidade material" sustentada por Alberto XAVIER.

206 "Por primeiro, é preciso dizer que enquanto a legalidade formal diz respeito ao veículo (lei), a tipicidade [legalidade material] entronca com o conteúdo da lei (norma). O princípio da tipicidade é tema normativo, pois diz respeito ao conteúdo da lei. (...) Exigências ligadas aos princípios éticos da certeza e segurança do Direito, como vimos de ver, passaram a requerer que o fato gerador e o dever tributário passassem a ser rigorosamente previstos e descritos pelo legislador, daí a necessidade de tipificar a relação jurídico-tributária. (...) Conceituar até a exaustão, tipificar tudo o que diz respeito às matérias acima [transcrição do artigo 97 do Código Tributário Nacional] exalta o princípio da tipicidade. Equipole ao seguinte: se a lei for omissa, ou obscura, ou antiética em quaisquer desses pontos, descabe ao administrador (que aplica a lei de ofício) e ao juiz (que aplica a lei contenciosamente) integrarem a lei, suprindo a lacuna por analogia. É dizer, em Direito Tributário a tipicidade é cerrada oferecendo resistência ao princípio de que o juiz não se furta a dizer o direito ao argumento de obscuridade na lei ou dificuldades na sua intelecção. Na área tributária o juiz deve sentenciar, é certo, mas para decretar a inaplicabilidade da lei por insuficiência normativa somente suprível através de ato formal e materialmente legislativo" (COÊLHO, Sacha Calmon Navarro. Manual de Direito Tributário. $2^{\mathrm{a}}$ ed. Rio de Janeiro: Forense, 2001, p. 98-100).
} 
os direitos individuais etc.. Cabe ao Poder Executivo identificar o fato jurídico tributável, respeitados os direitos individuais constitucionalmente garantidos e nos termos da lei ${ }^{207}$.

Contrariamente à corrente supra exposta, há autores que compreendem a legalidade tributária num sentido mais frouxo ou fluido, a partir do modo de pensar tipificante, i.e., permeado por tipos, que são mais flexíveis e adaptados à realidade atual, comparativamente aos conceitos fechados. O principal expositor desta tese no direito brasileiro é Ricardo Lobo TORRES. Com efeito, enquanto os defensores da "legalidade cerrada" afeiçoam-se fortemente aos princípios da segurança, certeza e previsibilidade, aqueles que sustentam a tipicidade em sentido próprio vêem na Justiça Social um dos sustentáculos mais importantes do ordenamento tributário; esses últimos não afastam a importância da Segurança Jurídica, mas criticam o apego exacerbado a este valor em detrimento da Justiça; um valor não pode afastar o outro: ambos devem conviver e se interrelacionarem. Ricardo Lobo TORRES pondera que o Brasil isolou-se das discussões tributárias sobre a elisão fiscal internacional e, por isso, desenvolveu-se aqui um apego exacerbado à legalidade absoluta e à tipicidade fechada ${ }^{208}$. Este mesmo autor sustenta ser

\footnotetext{
207 "Estes são valores que acompanham a legalidade formal desde a formação do Estado Liberal - igualdade e certeza, como meios de justiça e segurança. E da legalidade num sentido formal passa-se à legalidade material, pois a legalidade substantiva condiciona o poder, põe-no dentro de limites, circunscrevendo seu campo de ação material, quando a uma dada matéria, como meio de assegurar valores constitucionais específicos. Essa é uma forma de garantia fundamental, pois quanto mais estiver disciplinado o exercício de poder, menor o espaço para o arbítrio (princípio da interdição da arbitrariedade), ao reduzir o campo de indeterminação dos conceitos (lex certa, stricta e completa), institutos e formas do direito. (...) a verdade material deverá respeitar os direitos individuais e efetivar-se nos termos da lei. Ora, respeitar direitos fundamentais é respeitar as garantias constitucionais de legalidade e igualdade, dentre outras; é assegurar certeza e segurança jurídica à organização dos atos e negócios praticados no exercício da autonomia privada. E tudo segundo um devido procedimento (ou processo) legal, pois a legalidade, em matéria tributária, não pode encontrar exceção - decorrência do princípio do consentimento legislativo que o primado republicano impõe. É a lei o limite positivo de atribuição dos campos de ação das competências administrativas; e, ao mesmo tempo, limite negativo para o agir de qualquer autoridade pública, no cumprimento de suas funções" (TÔRRES, Heleno Taveira. Segurança Jurídica em matéria tributária. op. cit., p. 163 e 165-166).

208 “(...) torna-se necessário que se anotem algumas dificuldades para o exame do tema dos princípios jurídicos. Seja o primeiro o isolamento da reflexão jurídica brasileira nas últimas décadas. A ideologia nacional desenvolvimentista e a política de fechamento do País à importação de mercadorias e de idéias tiveram sensível influência na construção do tema dos princípios jurídicos, que se fez de forma autárquica. Passaram a prevalecer princípios tupiniquins, como o da legalidade absoluta, tipicidade fechada, proibição de analogia, ao mesmo tempo em que se ausentavam, inclusive do texto constitucional, os princípios vinculados à justiça fiscal, principalmente o da capacidade contributiva. Só agora, com a globalização, é que se procura acertar o passo com a doutrina estrangeira, o que se faz sentir com maior intensidade no campo do direito internacional tributário" (TORRES, Ricardo Lobo. O Princípio Arm's Length, os Preços de Transferência e a Teoria da Interpretação do Direito Tributário. op. cit., p. 128).
} 
"ingênuo" acreditar que o direito tributário possa ser formado por conceitos fechados, principalmente porque os conceitos determinados são muito raros no direito ${ }^{209}$.

José Casalta NABAIS também considera que a reserva material integral da lei formal [ou tipicidade em sentido impróprio] não pode ser compreendida em termos absolutos, devendo ser temperada ou moderada, como vem se sucedendo em outros ramos do direito. Consoante sustentado por esse autor, há direitos, garantias e liberdades fundamentais que vêm sendo dispensados da reserva legal, a qual, "em termos materiais ou substanciais, não anda longe da que tradicionalmente tem sido reclamada e consagrada para os elementos essenciais dos impostos" ${ }^{, 210}$. Nesta linha de raciocínio, o direito tributário não estaria sujeito a nenhuma "reserva legal" distinta daquela aplicável aos demais direitos e garantias fundamentais dos cidadãos. Obviamente, a concessão de algum grau de moderação não implica, de forma alguma, um afastamento do princípio da legalidade: a lei deve disciplinar a estrutura para cobrança de um tributo até que reste um nível admissível de liberdade para o Poder Executivo, inclusive para garantir a operacionalidade do sistema; um certo afrouxamento das exigências formais, todavia, pode ser compensado com maiores exigências materiais, ampliando-se o atendimento da Justiça tributária $^{211}$. Entendemos que essa discussão assemelha-se, de certa forma, àquela que vem

209 "Supera-se também a crença algum tanto ingênua na possibilidade de permanente fechamento dos conceitos tributários, como se nesse ramo do direito houvesse a perfeita adequação entre pensamento e linguagem e se tornasse viável a plenitude semântica dos conceitos. O direito tributário, como os outros ramos do direito, opera também por conceitos indeterminados, que deverão ser preenchidos pela interpretação complementar da Administração, pela contra-analogia nos casos de abuso de direito e pela argumentação jurídica democraticamente desenvolvida.

O problema dos conceitos indeterminados está no cerne da metodologia jurídica. A sua maior ou menor abertura depende da própria natureza e estrutura do tributo que a aplica. Os impostos antigos, apoiados nas categorias do direito privado, como os impostos imobiliários, oferecem conceitos relativamente fechados, pois incidem sobre os direitos da liberdade (propriedade privada). Os impostos mais modernos, construídos no laboratório tributário e distanciados de categorias do Código Civil, como o imposto de renda e o imposto de circulação de mercadorias e serviços, por exemplo, exibem amplas zonas de penumbra em seus conceitos cardeais. Até hoje não se conhece em toda a sua extensão a virtualidade do conceito de lucro ou de acréscimo de patrimônio no imposto de renda" (TORRES, Ricardo Lobo. Legalidade Tributária e Riscos Sociais. Revista Dialética de Direito Tributário. São Paulo: Dialética, v. 59, ago. 2000, p. 95-96).

${ }^{210}$ Cf. NABAIS, José Casalta. Contratos Fiscais. Coimbra: Coimbra Editora, 1994, p. 248.

211 "Mas, por outro lado, a reserva de lei fiscal como reserva material integral de lei formal que é - o que impõe uma tipicidade fechada ou taxativa - exclui que a lei deixe à Administração qualquer margem de livre decisão, traduza-se esta na utilização pela lei de cláusulas gerais ou de conceitos indeterminados ou na concessão de faculdades discricionárias. Todavia, esta afirmação, freqüentemente repetida pelos autores, não pode hoje ser entendida em termos absolutos, devendo antes ser temperada ou moderada. (...) É que, em diversos sectores da reserva de lei formal (máxime, da reserva parlamentar), ente os quais sobressai naturalmente o relativo aos 'direitos, liberdades e garantias' fundamentais, é actualmente dispensada uma reserva de lei que, em termos materiais ou substanciais, não anda longe da que tradicionalmente tem sido reclamada e consagrada para os elementos essenciais dos impostos. (...) permite-se um certo afrouxamento das exigências formais (reserva de lei), compensando-o com maiores exigências materiais (proporcionalidade e imparcialidade), o que vai de encontro ao moderno entendimento do Estado de direito como um Estado de 
se sucedendo no âmbito da capacidade contributiva: alguns autores sustentam a necessidade de uma capacidade contributiva personalíssima, a qual exige uma certa moderação na legalidade tributária absoluta em matéria tributária; de outro lado, parte da doutrina, que apregoa a possibilidade de alguma objetivação da capacidade contributiva, pode apegar-se a tal legalidade e, ainda, aos conceitos determinados e fechados, em detrimento dos tipos. Novamente, a discussão remonta à tensão e interação dinâmica entre os valores Justiça e Segurança Jurídica.

Não subsistem dúvidas no sentido de que a lei tributária, ato formal emanado do Poder Legislativo, deve regular, no mínimo, os aspectos enumerados no artigo 97 do Código Tributário Nacional, i.e., definição do fato gerador, do respectivo sujeito passivo, da base de cálculo e da alíquota ${ }^{212}$. Na visão de Ricardo Lobo TORRES, esse artigo prevê o princípio da determinação ${ }^{213}$, corolário da legalidade, o qual "postula que todos os elementos do fato gerador abstrato sejam indicados com clareza na lei formal" ${ }^{\text {214 }}$. Ocorre

direito material, que constantemente apela para a afirmação de princípios materiais. Pois bem. Não vemos obstáculos a que essas idéias valham em princípio também relativamente à reserva fiscal: na verdade, as diferenças entre esta e outras reservas materiais de lei formal estão longe de ter o peso e relevo que a concepção tradicional do princípio da legalidade fiscal, excessivamente formalista e tributária do positivismo, nos sugere. (...)

Finalmente, as exigências de operacionalidade e flexibilidade do sistema fiscal e dos impostos singularmente considerados, agora definitivamente erigido(s) em instrumento de política econômica e social do Estado, reclamam, por inelutáveis imperativos de ordem prática - pela própria 'natureza das coisas' - um certo afrouxamento da densidade normativa, imposto pelo (entendimento tradicional do) princípio da reserva material de lei formal relativamente aos elementos essenciais dos impostos e a conseqüente admissibilidade de atribuição legal à Administração de uma certa margem de livre decisão adequada à aplicação flexível das leis fiscais, ou seja de uma liberdade de decisão consentânea com o cabal desempenho da função administrativa neste domínio do direito fiscal socialmente conformador" (NABAIS, José Casalta. op. cit., p. 248-251).

212 “Art. 97. Somente a lei pode estabelecer:

I - a instituição de tributos, ou a sua extinção;

II - a majoração de tributos, ou sua redução, ressalvado o disposto nos artigos 21, 26, 39, 57 e 65;

III - a definição do fato gerador da obrigação tributária principal, ressalvado o disposto no inciso I do $\S 3^{\circ}$ do artigo 52, e do seu sujeito passivo;

IV - a fixação de alíquota do tributo e da sua base de cálculo, ressalvado o disposto nos artigos 21, 26, 39, 57 e 65;

V - a cominação de penalidades para as ações ou omissões contrárias a seus dispositivos, ou para outras infrações nela definidas;

VI - as hipóteses de exclusão, suspensão e extinção de créditos tributários, ou de dispensa ou redução de penalidades".

${ }_{213}$ Misabel Abreu Machado DERZI denomina-o "princípio da especificação conceitual" (In: A Desconsideração dos Atos e Negócios Jurídicos Dissimulatórios, segundo a Lei Complementar n. ${ }^{\circ}$ 104, de 10 de janeiro de 2001, op. cit., p. 222).

${ }^{214}$ Cf. TORRES, Ricardo Lobo. Tratado de Direito Constitucional, Financeiro e Tributário. op. cit., p. 481. Ainda a respeito, confira-se a seguinte passagem dessa mesma obra:

"Segundo o princípio da determinação, os conceitos jurídicos devem, sempre que possível, ser determinados, trazendo toda a conformação do fato gerador, desde a definição do seu aspecto material até a fixação da base de cálculo e da alíquota. Há várias técnicas para que se obtenha a plena determinação dos conceitos, como sejam as enumerações taxativas e os fatos geradores suplementares, hipóteses nas quais a participação do 
que, como são raros os conceitos determinados fechados no direito [e a noção de "renda" definitivamente não é um deles], esse artigo não explicitaria, por impossibilidade técnica, uma "reserva absoluta da lei”. Sempre haveria um nível [limitado] de liberdade/discricionariedade para a atuação do Poder Executivo. Como sustentado por Alejandro C. ALTAMIRANO, a legalidade e a discricionariedade vivem em constante interação e equilíbrio. Uma não se contrapõe necessariamente à outra: apenas se repelem quando a discricionariedade converte-se em arbitrariedade; neste caso, o contribuinte pode questionar a atuação da administração perante o Poder Judiciário ${ }^{215}$. Eros Roberto GRAU, por seu turno, sustenta que os conceitos indeterminados não criam um espaço para a atuação discricionária, vinculada a um juízo de conveniência e oportunidade; a aplicação destes conceitos seria uma tarefa de interpretação da lei, passível de uma única conclusão justa em cada caso concreto [assim, v.g., existiria uma única solução possível para a determinação do conceito de "preço de plena concorrência"]. A razão prática da diferenciação entre interpretação da lei e atuação discricionária [em sentido estrito] estaria na circunstância de que a primeira pode ser apreciada pelo Poder Judiciário, ao passo que a segunda não ${ }^{216}$. Independentemente da denominação que se adote, não há dúvidas de que,

intérprete se retrai. Sucede que os conceitos indeterminados são inevitáveis no direito tributário (...), de modo que o princípio da determinação não leva à impossibilidade de adoção dos conceitos indeterminados" (op. cit., p. 485).

215 "En el cumplimiento de sus funciones la administración ejerce sus potestades discrecionales para allanar su camino tendiente a la recaudación. Por su parte, el contribuyente honesto lucha contra los abusos del poder discrecional para que este no derive en una mayor carga tributaria que la ley no autoriza, es decir, el operador jurídico debe preservar que la discrecionalidad administrativa no se transforme en arbitrariedad. Si el ejercicio de las facultades discrecionales de la administración se desenvuelve dentro de los confines de la legalidad, sin que el ejercicio de esa potestad afecte a algún elemento esencial de hecho imponible, no podrá el contribuyente esgrimir ningún agravio atendible. Lo contrario, es decir, que tales facultades discrecionales se utilicen para extender la configuración de la regla matriz de incidencia a niveles que la ley no autoriza, tal circunstancia resultara impugnable" (ALTAMIRANO, Alejandro C. Legalidad y Discrecionalidad. In: Heleno Taveira Tôrres (coord.), Tratado de Direito Constitucional Tributário. Estudos em homenagem a Paulo de Barros Carvalho. São Paulo: Saraiva, 2005, p. 150-151).

Na visão de Alejandro ALTAMIRANO, a discricionariedade não representa a liberdade plena de atuação Poder Executivo, mas um grau mínimo de "liberdade", essencial para a solução de casos concretos e presente em todos os ramos do direito. Cabe à lei disciplinar as relações jurídicas com o menor grau de imprecisões possível, para reduzir essa discricionariedade a níveis razoáveis (op. cit., p. 161 e 164).

${ }^{216}$ Eros Roberto GRAU sustenta que os conceitos indeterminados ou "noções" são idéias temporais e históricas, passíveis de interpretação; sua aplicação permitiria uma única solução justa. Esse processo de interpretação seria distinto da discricionariedade, cujo exercício permite uma pluralidade de soluções justas, fundadas em critérios econômicos, de oportunidade etc.. A discricionariedade, nesse contexto, não manteria relação com a legalidade, ao contrário do quanto sustentando por Alessandro ALTAMIRANO. Confira-se suas conclusões, fundadas em Eduardo García de ENTERRÍA:

"Os conceitos indeterminados - que compreendem conceitos de experiência ou de valor - não conduzem a uma situação de indeterminação na sua aplicação. A aplicação deles, segundo García de Enterría, só permite uma 'unidade de solução' em cada caso (1983/434). Assim, quando se fala em boa-fé, v.g., o conceito se dá ou não se dá. Em outros termos, em presença de um caso determinado há ou não há boa-fé; tertium non datur. Em razão disso, a aplicação dos conceitos determinados só permite uma única solução justa. Contrariamente, o exercício da potestade discricionária permite uma pluralidade de soluções justas ou, em 
no campo dos conceitos indeterminados ou tipos, há algum espaço de liberdade para atuação do Poder Executivo, sujeito a controle pelo Poder Judiciário; não se trata, contudo, de liberdade plena, mas de atuação condicionada ao alcance dos critérios consubstanciados na lei e dos valores e princípios constitucionais aplicáveis.

Victor UCKMAR divide as normas que podem ser editadas pelo Poder Executivo em dois tipos: (i.) leis em sentido formal, desde que autorizadas pela Constituição; ou (ii.) leis em sentido material ou regulamentos, as quais deveriam, em princípio, conter disposições meramente executivas. Em todos os países, contudo, os regulamentos vêm "substancializando-se", o que tem sido considerado legítimo ${ }^{217}$. Entendemos que a possibilidade de edição, pelo Poder Executivo, de regulamentos com alguma "substância", não representa, necessariamente, espécie de delegação de competência, vedada pela estrutura descritiva do Sistema Tributário Nacional e consignada no artigo $7^{\circ}$ do Código Tributário Nacional ${ }^{218}$; ao contrário, os regulamentos necessitam de

outros termos, a opção entre alternativas que são igualmente justas desde a perspectiva do direito (1983/434). A discricionariedade é essencialmente uma liberdade de eleição entre alternativas igualmente justas ou entre indiferentes jurídicos - porque a decisão se fundamenta em critérios extra-jurídicos (de oportunidade, econômicos etc.), não incluídos na lei e remetidos ao juízo subjetivo da Administração - ao passo que a aplicação de conceitos indeterminados é um caso de aplicação da lei.

A consequiência mais relevante que se extrai dessa distinção respeita precisamente ao papel a ser desempenhado pelo Poder Judiciário diante de ambas as hipóteses. Se não lhe cabe, por um lado, a apreciação da decisão discricionária, por outro lhe cumpre, inquestionavelmente, manifestar-se sobre a aplicação, pela Administração, dos conceitos indeterminados.

A distinção entre as duas técnicas - da discricionariedade e dos conceitos indeterminados - permite-nos, assim, a depuração, no campo da primeira delas, de uma série de expressões (da Administração) que notoriamente, em termos de fidelidade aos valores do chamado Estado de Direito, nele não poderiam caber, ainda que lá se as tivesse como incluídas. Daí por que García de Enterría (1983/435) - referindo que conceitos como urgência, ordem pública, justo preço, calamidade pública, medidas adequadas ou proporcionais, inclusive necessidade pública, utilidade pública e até interesse público, não permitem, em sua aplicação, uma pluralidade de soluções justas, mas apenas uma solução em cada caso - anota a virtual conversão, para a doutrina germânica, da generalidade das potestades discricionárias em regradas, posto que, explícita ou implicitamente, todas as potestades discricionárias se outorgam para alcançar um interesse público, conceito indeterminado cuja aplicação só permitiria, em cada caso concreto, uma solução justa" (GRAU, Eros Roberto. O direito posto e o direito pressuposto. op. cit., p. 203-204).

217 "Pode-se dizer que, atualmente, em todos os Estados, o Executivo expede regulamentos em matéria tributária; tal atividade é considerada constitucionalmente legítima pela maioria, desde que sejam observadas as seguintes regras:

a) A criação dos impostos, com a individualização dos sujeitos, do objeto e dos critérios de determinação do seu quantum, compete exclusivamente ao Poder Legislativo (...)

b) A segunda regra, no que concerne à 'legalidade', é que o Poder Executivo não pode arrecadar qualquer imposto que não tenha sido criado por lei. (...)

Por fim, o Poder Judiciário pode negar aplicação aos regulamentos que estejam em contraste com normas primárias: em última análise, este, regra geral, é o único controle de natureza jurídica exercido sobre a atividade legislativa material do Executivo" (UCKMAR, Victor. op. cit., p. 45).

${ }^{218}$ Cf. TORRES, Ricardo Lobo. Tratado de Direito Constitucional, Financeiro e Tributário. op. cit., p. 424. $\mathrm{O}$ teor literal do artigo $7^{\circ}$ do Código Tributário Nacional, fundamento de tal conclusão, possui o seguinte teor: 
um certo "conteúdo material", aferido nos estritos termos da lei ${ }^{219}$, para propiciar a execução das leis tributárias e viabilizar a própria atuação da administração pública, com vistas à Segurança Jurídica e à praticabilidade [este princípio será examinado na subseção 1.6.5, infra]. Não por outra razão, a elaboração dos regulamentos encontra previsão expressa nos artigos 84, IV, e 87, II, da Constituição Federal.

Este tipo de discussão concernente à delegação de competência tributária não é recente no direito brasileiro, podendo ser localizados importantes precedentes do Supremo Tribunal Federal, que examinam os "limites" de atuação do Poder Executivo em alguns casos concretos. Um primeiro exemplo seria a discussão da constitucionalidade da edição do Decreto-Lei n. ${ }^{\circ}$ 1.724, de 07.12.79, que autorizou o Ministro de Estado da Fazenda a aumentar, reduzir ou extinguir os estímulos fiscais previstos no Decreto-Lei n. ${ }^{\circ} 491$, de 05.03.69 [crédito-prêmio de IPI]. Como decorrência daquele Decreto-Lei, foi editada a Portaria n. ${ }^{\circ}$ 970, de 07.12.79, que suspendeu o benefício entre jan./80 e abr./81. Neste caso específico, foi declarada inconstitucional, por maioria de votos, a expressão "ou extinguir" constante do artigo $1^{\circ}$ do Decreto-Lei n. 1.724 , de 07.12.79, porque "trata-se de matéria versada em lei, o crédito-prêmio está versado num Decreto-Lei, num ato normativo primário, por isso o Presidente da República, no exercício da atividade legislativa, não

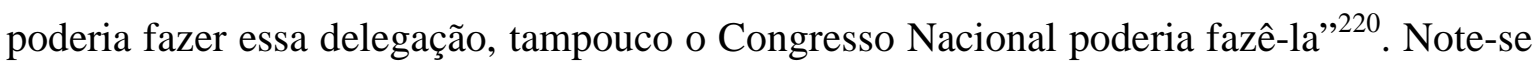
que, neste caso, houve uma efetiva delegação de competência legislativa ao Ministro da Fazenda, a qual foi declarada inconstitucional por violação ao princípio da legalidade tributária. Outro exemplo consta do Recurso Extraordinário n. ${ }^{\circ}$ 269.675-7, que analisou a situação jurídica do salário-educação após a publicação da Constituição Federal de 1988. O Ministro Marco Aurélio registrou em seu voto que os "elementos essenciais" do fato

\footnotetext{
“Art. $7^{\circ}$ A competência tributária é indelegável, salvo atribuição das funções de arrecadar ou fiscalizar tributos, ou de executar leis, serviços, atos ou decisões administrativas em matéria tributária, conferida por uma pessoa jurídica de direito público a outra, nos termos do $\S 3^{\circ}$ do artigo 18 da Constituição".

219 "Destarte, a natureza de ato vinculado, inerente ao ato administrativo de lançamento, requer, no processo de criação da norma individual e concreta, pela autoridade administrativa competente, prevalência do conteúdo semântico do texto interpretado (lei) numa relação de classe (conotação) e elemento (denotação) o ato administrativo. A aplicação do direito exige plena consonância com o que na lei vigora, sem o que o intérprete possa interferir na significação, impondo seus desejos, a título de 'fazer justiça' ou superar o 'formalismo' que o positivismo estipule. E assim, em vista da tipicidade, a ação do aplicador do direito encontra claros limites na lei, tanto de ordem formal (i.) sobre os procedimentos que deve adotar, quanto de ordem material (ii.), sobre o conteúdo que deve incluir nas normas que venha a produzir" [TÔRRES, Heleno Taveira. Garantias constitucionais aplicadas ao controle sobre preços de transferência (legalidade e uso de presunções no arbitramento da base de cálculo dos tributos, a partir do controle de preços de transferência. $\mathrm{O}$ direito ao emprego do melhor método. Um caso: limites ao uso do PRL-60 na importação). In: Octavio Campos Fischer (coord.), Tributos e direitos fundamentais. São Paulo: Dialética, 2004, p. 110-111].

${ }^{220}$ Excerto do voto do Ministro Carlos Velloso, no Recurso Extraordinário n. ${ }^{\circ}$ 186.359-5/RS, j. em 14.03.02.
} 
gerador tributário vinculam-se ao princípio da legalidade estrita, de modo que as alíquotas desta contribuição, pós 1988, deveriam ser fixadas por lei, sendo impossível sua edição pelo Poder Executivo ${ }^{221}$. De fato, não há dúvidas de que "a fixação da alíquota do tributo e da sua base de cálculo" [cf. artigo 97, IV, do Código Tributário Nacional] competem ao Poder Legislativo, subsistindo ao Poder Executivo tão-somente a tarefa de regulamentação.

Um último exemplo, diretamente relacionado às ponderações tecidas no âmbito desta seção, pode ser extraído do Recurso Extraordinário n. ${ }^{\circ} 343.446-2 / S C$, de 20.03.03, no qual se discutiu a constitucionalidade da cobrança do Seguro de Acidente do Trabalho (“SAT"). Parte da discussão relaciona-se ao seguinte argumento: as Leis n. ${ }^{\circ}$ s 7.789, de 30.06.89 e 8.212, de 24.06.91, disciplinaram a cobrança do SAT, mas deixaram para o regulamento a ser elaborado pelo Poder Executivo a definição das expressões "atividade preponderante" e "grau de risco leve, médio ou grave", o que supostamente representaria violação ao princípio da legalidade tributária, porque essas definições influenciariam diretamente na definição das alíquotas do SAT aplicáveis em cada caso concreto. Em votação unânime, os Ministros decidiram que a lei haveria disciplinado "satisfatoriamente todos os elementos capazes de fazer nascer uma obrigação tributária válida”. Remanesceu ao regulamento tão-somente executá-la e aplicá-la, porque nesta hipótese seria exigida "a aferição de dados e elementos. Nesses casos, a lei, fixando parâmetros e padrões, comete ao regulamento essa aferição. Não há que se falar, em casos assim, em delegação pura, que é ofensiva ao princípio da legalidade genérica $\left(\mathrm{CF}\right.$, art. $5^{\circ}$, II) e da legalidade tributária $\left(\mathrm{CF}\right.$, art. 150, I), ${ }^{, 222}$.

\footnotetext{
221 "Se de um lado, abstraída a remissão à lei contida no artigo 178 da Emenda Constitucional n. ${ }^{\circ}$ 1/69, verdadeira Constituição, seria dado dizer da adequação de ato do Poder Executivo na fixação da alíquota da contribuição especial, desprovida de natureza tributária, o novo texto constitucional, ao enquadrá-la como tributo, submeteu a fixação dos elementos essenciais - e a alíquota o é - ao princípio da legalidade estrita, que mediante o $\S 5^{\circ}$ do artigo 212 - "na forma da lei" -, que ante a regra linear do inciso I do artigo 150 , ao revelar ser defeso exigir ou aumentar tributo sem lei que o estabeleça. Ao fim, hão de estar em normas legais de diploma legal e material todos os elementos indispensáveis à exigibilidade do tributo, despontando com real importância o necessário a quantificar a obrigação, ou seja, a percentagem ou alíquota" (excerto do voto do Ministro Relator Marco Aurélio, p. 09 do acórdão).

${ }^{222}$ Excertos do voto do Ministro Relator Carlos Velloso. Por elucidativa, confira-se outra passagem:

"Em trabalho de doutrina que escrevi (...) registrei que, sob o pálio da Constituição americana de 1787, a velha Constituição da Filadélfia, que não admite a delegação, a Suprema Corte norte-americana tem admitido a legislação pelo Executivo, em termos de regulamentação, como técnica de administração, desde que observados os seguintes critérios: a) a delegação pode ser retirada daquele que a recebeu, a qualquer momento, por decisão do Congresso; b) o Congresso fixa standards e padrões que limitam a ação do delegado; c) razoabilidade da delegação. No controle de constitucionalidade da norma regulamentar, a Suprema Corte verifica a observância dos padrões mencionados.
} 
O precedente referido no parágrafo anterior indica que o fato de a administração tributária possuir alguma liberdade/discricionariedade para a edição de regulamentos não representa, per se, violação à legalidade tributária; pelo contrário, essa providência pode ser por vezes exigida para o adequado atendimento da pessoalidade prevista no artigo 145 , $\S 1^{\circ}$, da Constituição Federal. Note que "renda" é claramente um conceito aberto e indeterminado ${ }^{223}$. Provavelmente por decorrência disso, a concretização de tal pessoalidade no âmbito deste imposto por intermédio de leis [emanadas pelo Poder Legislativo] vem apresentando desafios muitas vezes insuperáveis. Pode ser constatado, e.g., que, desde a instituição do imposto de renda no direito brasileiro, convive-se com regulamentos e atos administrativos de conteúdo material para discipliná-lo. Exemplos de atos administrativos com "conteúdo material" são a Portaria do Ministério da Fazenda n. 436, de 30.12.58, e subseqüentes alterações, que estabelecem os percentuais máximos para a dedutibilidade de royalties pagos a não-residentes; a Instrução Normativa n. ${ }^{\circ}$ 162, de 31.12.98, que atualmente lista as quotas de depreciação mensais máximas admitidas para bens do 'Ativo Imobilizado', a Instrução Normativa n. ${ }^{\circ}$ 11, de 21.02.96, que lista os bens “intrinsecamente relacionados com a produção ou comercialização dos bens e serviços", cujas quotas de depreciação são consideradas dedutíveis, dentre inúmeras outras. Com efeito, a própria Lei n..$^{\circ}$ 9.430/97, no seu artigo 20 vale-se desse artifício, mediante a previsão de que o Ministro da Fazenda poderá alterar margens de lucro setoriais ou isoladas ${ }^{224}$. Todos estes exemplos demonstram que, em determinados casos, envolvendo dados técnicos ou constantemente atualizáveis, o regulamento pode apresentar-se mais eficaz que o texto legal.

Por conta desse e de outros fatores, a atuação da administração tributária na definição de normas "materiais" tem sido difundida, com o objetivo, inclusive, de garantir maior efetividade e eficácia aos valores e princípios constitucionais. Como sustentado por Dalmo de Abreu DALLARI, esse fenômeno tem generalizado-se, porque permite a elaboração de normas tecnicamente mais adequadas em prazo reduzido, especialmente se comparado aos prazos que os congressos e parlamentos demandam para a edição de leis.

Deixar por conta do Executivo estabelecer normas, em termos de regulamento, regulamento que não pode ir além da norma regulamentada, é medida que se adota tendo-se em linha de conta as necessidades da administração pública na realização do interesse coletivo, do interesse público.

Aqui, a lei, conforme vimos, fixou os padrões, condicionando e limitando o Executivo no estabelecimento da alíquota do salário-educação, impondo-se, no caso, a atividade regulamentar, tendo em vista a impossibilidade de a lei fixá-la, adequadamente".

${ }^{223}$ A noção de renda ainda é objeto de incessantes estudos no âmbito do direito internacional. A respeito, cf. HOLMES, Kevin. The concept of income. A multi-disciplinary analysis. op. cit..

${ }^{224}$ A questão específica das alterações de margens de lucros será abordada no CAPÍTULO 4. 
Contribuem para esta demora a lentidão do funcionamento dos congressos e parlamentos, o excesso de correntes políticas e ideológicas ali presentes, a postergação de apreciação de assuntos para obrigar o Poder Executivo a transacionar com os parlamentares, a quantidade de emendas não-técnicas [muitas delas impertinentes] introduzidas no texto original etc. ${ }^{225}$. Estas mesmas críticas de Dalmo de Abreu DALLARI, tecidas a partir do exame mais específico da realidade brasileira, são comungadas por Victor UCKMAR, que estudou a questão a partir da experiência italiana e de outros países europeus. Na visão desse autor, "a experiência mostra que os Parlamentos não têm a possibilidade - seja pela quantidade de trabalho que devem realizar, seja pelo insuficiente conhecimento dos problemas práticos e dos pormenores - de exercer por inteiro a função legislativa que, portanto, vai sendo confiada, sempre com maior freqüência e amplitude, ao Executivo"226.

Não se pode, diante das discussões sobre a legalidade e abrangência dos regulamentos "materiais", olvidar que, preferivelmente, a maior quantidade de elementos possível deve constar do texto legal. Quanto maior a circunscrição do campo de atuação material do Poder Executivo, mais disciplinado o exercício de sua "liberdade" e menor o espaço para o arbítrio. Sempre haverá, contudo, algum espaço de liberdade vinculada a padrões estabelecidos em lei, o qual deverá ser preenchido mediante a elaboração de regulamento amparado nos princípios e valores constitucionais aplicáveis ao caso concreto; estes últimos são a "baliza" e o limite da discricionariedade/liberdade do Poder Executivo.

\footnotetext{
225 "Há uma opinião generalizada no sentido de se reconhecer que os Parlamentos, por uma série de razões, são os órgãos do Estado que se mostram mais desaparelhados para cumprimento das novas tarefas. Entre as causas desse desajuste têm-se evidenciado, sobretudo, a lentidão de seu funcionamento, a imperfeição das leis elaboradas com a participação e interferência de pessoas despreparadas para esse trabalho e o caráter conservador dos Parlamentos, que resulta da participação, neles, de muitas correntes políticas de tendências contraditórias, que reciprocamente se neutralizam e se anulam quanto às iniciativas mais arrojadas e de alcance mais profundo. A lentidão do funcionamento é difícil de ser superada, por vários motivos. Em primeiro lugar, por se tratar de uma reunião de não-especialistas, torna-se imprescindível ouvir a opinião das chamadas 'comissões técnicas', que agrupam os membros mais ou menos conhecedores dos aspectos particulares de cada problema. Além disso, os Parlamentos perderiam sua razão de ser caso não lhes fosse concedida a possibilidade de emendar projetos, pois o mero pronunciamento a favor ou contra uma iniciativa legal, em seu todo, poderia ser feito diretamente ao povo, pois seria relativamente simples e colheria opinião direta dos interessados. Por outro lado, todavia, esse poder de emenda tem sido altamente prejudicial, pois, ou por desconhecimento dos assuntos ou por razões demagógicas, é comum que os parlamentares introduzam modificações que anulam a eficácia de medidas previstas no projeto de lei, ou que, mais grave talvez do que isso, desvirtuam suas finalidades.

(...) Acrescente-se a isso tudo o tempo que se gasta com os debates, bem ou mal-intencionados, levianos ou verdadeiramente esclarecedores. Muitas vezes se tem visto mesmo o prolongamento dos debates como simples artifício político, para obrigar o Executivo a transacionar com parlamentares. A essa lentidão, fácil de ser aquilatada pelos percalços aqui referidos, acrescenta-se a interferência de parlamentares despreparados, intelectual ou moralmente, para a importância tarefa de legislar" (DALLARI, Dalmo de Abreu. O renascer do Direito. São Paulo: José Bushatsky Editor, 1976, p. 160-162).

${ }^{226}$ Cf. UCKMAR, Victor. op. cit., p. 39.
} 
Obviamente, por se tratar de aplicação da lei, e não de decisão amparada em critérios de conveniência e política, o Poder Judiciário poderá ser chamado para examinar a legalidade/constitucionalidade dos regulamentos. Situação semelhante pode ser detectada também quando da aplicação das leis: como a definição da base de cálculo do imposto de renda envolve o exame de muitos conceitos abertos ou tipos, sua concretização fornece algum grau de liberdade para o Poder Executivo quando de sua aplicação. Novamente, são os valores e princípios constitucionais que limitam e balizam sua atuação.

Esta temática é relevante na questão dos preços de transferência, matéria extremamente técnica e que, para ser aplicada de forma justa, pode exigir constantes modificações de critérios ou a adoção de medidas rápidas, para a adequação da lei a circunstâncias econômicas específicas. Não por outra razão, a Lei n. ${ }^{\circ}$ 9.430/96 garantiu a modificação das margens brutas de lucro por ato do Ministro de Estado da Fazenda [cf. artigo 20]. Em outras oportunidades, para garantir que os métodos e safe harbours fossem aplicados de forma mais justa aos exportadores, que tiveram seus preços em $\mathrm{R} \$$ [reais] depreciados em função da valorização de nossa moeda em relação às demais, o próprio Ministro de Estado da Fazenda interveio, instituindo fatores que deveriam ser multiplicados pela quantidade de receitas em $\mathrm{R} \$$ e, com isso, garantir que a aplicação dos métodos com amparo na média ponderada de todo o ano-calendário não prejudicasse $\mathrm{o}$ contribuinte [cf., em relação ao ano 2008, v.g., a Instrução Normativa n. ${ }^{\circ}$ 898, de 29.12.08, que ajustou as receitas para fins de enquadramento nos safe harbours, e a Portaria do Ministério da Fazenda n. ${ }^{\circ}$ 310, também de 29.12.08, que adequou a base de receitas que seria submetida a "teste" pelos métodos]. Estes exemplos não conduzem, todavia, à conclusão de que a legalidade pode ser "afastada" na questão dos preços de transferência: os critérios devem estar indicados em lei, sendo que quaisquer exceções somente são admitidas se representarem medida de justiça; mesmo nesta hipótese, a legalidade/constitucionalidade dos regulamentos sempre poderá ser questionada perante o Poder Judiciário, que aferirá se o Poder Executivo atuou conforme os princípios e valores constitucionais que justificam sua "liberdade condicionada".

\subsubsection{Princípio da praticabilidade.}

Consoante doutrina de Misabel Abreu Machado DERZI, a praticabilidade é um princípio jurídico que não se encontra positivado expressamente na Constituição Federal, 
mas que, não obstante, acha-se impregnado em todo o ordenamento, como um "imperativo constitucional implícito", tendo como propósito garantir o cumprimento e a execução das leis, da forma mais simples possível. No âmbito da praticabilidade estão "todos os meios e técnicas utilizáveis com o objetivo de tornar mais simples e viável a execução das leis". Essas técnicas visam "evitar a investigação exaustiva do caso isolado, com o que se reduzem os custos de aplicação da lei; dispensar a colheita de provas difíceis ou mesmo impossíveis em cada caso concreto ou aquelas que representam ingerência indevida na esfera privada do cidadão e, com isso, assegurar a satisfação do mandamento normativo" 227 . Dada a abundância de especificidades e peculiaridades que envolvem as normas para o controle dos preços de transferência, a adequada compreensão e aplicação de tal praticabilidade parece-nos extremamente proveitosa.

A praticabilidade é um princípio vinculado à exeqüibilidade das leis e à economicidade que devem ser observadas pela administração pública ${ }^{228}$. São irrefutáveis os seus benefícios. Em primeiro lugar, a praticabilidade afeta o Poder Legislativo, que precisa se valer de abstrações e generalizações para viabilizar a execução das leis e de seus comandos. "As presunções, ficções legais e quantificações estabelecidas em lei, através de tetos e somatórios numericamente definidos, a tributação na fonte, a eleição de responsáveis e substitutos tributários, são meios a que recorre o legislador, com vistas à praticabilidade" 229 . Note-se que as presunções estão sempre desafiando o valor Justiça; por este motivo é que quaisquer presunções legais devem ser relativas e precisam, necessariamente, ser acompanhadas da garantia de que o contribuinte pode afastá-las mediante a produção de quaisquer provas admitidas em direito [cf. seção 1.9, infra]. Com efeito, a praticabilidade não pode servir como fundamento para a edição de legislação que contenha presunções absolutas ou limites à produção de provas. Não obstante, não entendemos que essa obrigatoriedade de se garantir o contraditório e a ampla defesa atenua o importante papel que as presunções desempenham na redução de complexidade das normas tributárias, no combate à evasão e na melhoria dos sistemas de arrecadação.

A praticabilidade afeta, outrossim, o Poder Executivo, responsável pela aplicação da lei a milhões de casos concretos. Os Decretos e outros atos por ele expedidos

\footnotetext{
${ }^{227}$ In: Direito Tributário, Direito Penal e Tipo. São Paulo: Revista dos Tribunais, 1988, p. 105.

${ }^{228}$ Especificamente na esfera do Poder Executivo, a praticabilidade está parcialmente positivada no caput do artigo 37 da Constituição Federal, que determina a eficiência na prática de quaisquer atos públicos por parte da administração direta e indireta.

${ }^{229}$ Extraído de DERZI, Misabel Abreu Machado. In: BALEEIRO, Aliomar. op. cit., p. 554.
} 
devem, nesse contexto, destinar-se à busca de soluções mais simples, exeqüíveis e econômicas para a aplicação das leis ${ }^{230}$. Nas hipóteses em que não se evita a investigação exaustiva de cada caso isolado a partir da invenção de técnicas simplificadoras, os custos administrativos de arrecadação podem ser elevados a ponto de a própria arrecadação tornar-se inviável ou antieconômica. Mas a busca desenfreada de tal economicidade pelo Poder Executivo não pode, jamais, sobrepor-se ao adequado cumprimento das leis [valor Segurança Jurídica] ou impossibilitar ao contribuinte a produção de provas para o afastamento de presunções legalmente estabelecidas [valor Justiça]. Como explicado por Heleno Taveira TORRES, a praticabilidade não pode ser confundida com uma busca desenfreada do aumento de arrecadação ${ }^{231}$. No campo específico das regras para o controle dos preços de transferência, a praticabilidade é um princípio relevantíssimo. Isso porque o princípio da plena concorrência possui conteúdo bastante fluido, com elevado grau de subjetivismo; o desafio, portanto, está na edição de regras facilmente exeqüíveis, mas sem prejuízo aos valores Segurança Jurídica e Justiça, cuja inter-relação permeia, em todos os casos, a sistemática para o controle dos preços de transferência.

\subsubsection{Princípio da livre concorrência.}

As regras para o controle dos preços de transferência também objetivam atender a uma finalidade extrafiscal, i.e., promover a lealdade da concorrência, nos termos do artigo $173, \S^{\circ}$, da Constituição Federal ${ }^{232}$. Na prática, busca-se a introdução de uma maior

230 “As normas que ensejam execução em massa pelo Poder Executivo elevam a seu ponto máximo as
necessidades de simplificação e praticabilidade. No direito tributário, continuamente, o lançamento para
cobrança de tributos representa a aplicação da norma legal a milhares de casos. Os regulamentos e demais
atos da Administração, baixados com vistas a possibilitar a execução das leis, guiam-se pelo princípio da
praticabilidade e devem buscar as soluções mais simples, cômodas e econômicas” (DERZI, Misabel Abreu
Machado. Direito Tributário, Direito Penal e Tipo. op. cit., p. 141).
231 "Que não se confunda, erroneamente, praticabilidade e eficiência da Administração Tributária com
qualquer espécie de busca desenfreada por aumento na arrecadação, que poderá ser alcançada como
decorrência, mas não propriamente como um fim em si mesmo. A economia dos procedimentos, a justa
identificação da capacidade contributiva, por meios práticos, e a celeridade para viabilizar a atuação
tributária, observados os direitos individuais e nos termos da legalidade, estes sim, devem ser os instrumentos
para promover o princípio da eficiência na Administração tributária. Eficiência esta que se há de refletir na
resolução de conflitos nesse domínio, cuja lentidão e excesso de procedimentos causam perdas inequívoca à
Administração e aos contribuintes” [TÔRRES, Heleno Taveira. Garantias constitucionais aplicadas ao
controle sobre preços de transferência (legalidade e uso de presunções no arbitramento da base de cálculo dos
tributos, a partir do controle de preços de transferência. O direito ao emprego do melhor método. Um caso:
limites ao uso do PRL-60 na importação). op. cit., p. 115].
232 “Ora, um preceito jurídico que toma como premissa basilar da sua compreensão, como descreve a OCDE,
o fato de que, enquanto uma empresa em relação a outras empresas independentes, nos atos de celebração
dos seus negócios, mantêm (em regra) condições mercantis e financeiras determinadas pelas forças do
mercado; mas quando em relação com partes relacionadas em qualquer modo, celebra os mesmos negócios
em condições comerciais e financeiras mais favoráveis e proveitosas, o controle sobre tais situações 
"paridade tributária", removendo-se, na medida do possível, vantagens geradas pelas regras para o controle dos preços de transferência da tomada de decisões empresariais ${ }^{233}$. Para este fim, torna-se necessária a redução das disparidades de tratamento tanto (a.) entre os contribuintes residentes num mesmo país [empresas vinculadas vis-à-vis empresas nãovinculadas]; quanto (b.) entre os residentes em países distintos. Especificamente nesta última hipótese, pondere-se que o fato de o direito tributário internacional permitir a fuga de lucros tributáveis para localidades com tributação favorecida gera redução tributária e, conseqüentemente, redução do preço do produto de um determinado fornecedor, de modo que a economia tributária, per se, passa a representar um outro fator que estimula a concorrência abusiva. Nesse sentido, além do aumento arbitrário da lucratividade gerado pela redução dos tributos globalmente devidos por um grupo em detrimento de outros, as distorções nas regras de concorrência possibilitam, ademais, o abuso de poder econômico mediante a prática de preços reduzidos por artifícios abusivos e ilegítimos.

\subsection{Constitucionalidade das regras para o controle de preços de transferência e precedentes no direito brasileiro.}

Há doutrinadores que sustentam a inconstitucionalidade das regras para o controle dos preços de transferência, sob o argumento de que a instituição de normas anti-

distorcivas das regras de mercado não serve a outra coisa, precipuamente, senão à realização de princípios da ordem econômica, como é o caso da livre concorrência (art. 173, IV, da nossa Constituição Federal), liberdade de iniciativa e, ainda, no caso brasileiro, à concretização do $\S 4^{\circ}$, do art. 173 , da Constituição Federal, segundo o qual: 'A lei reprimirá o abuso do poder econômico que vise à dominação dos mercados, à eliminação da concorrência e ao aumento arbitrário dos lucros"” [TÔRRES, Heleno Taveira. Garantias constitucionais aplicadas ao controle sobre preços de transferência (legalidade e uso de presunções no arbitramento da base de cálculo dos tributos, a partir do controle de preços de transferência. $\mathrm{O}$ direito ao emprego do melhor método. Um caso: limites ao uso do PRL-60 na importação). op. cit., p. 97].

233 "1.7. There are several reasons why OECD Member countries and other countries have adopted the arm's length principle. A major reason is that the arm's length provides broad parity treatment for MNEs and independent enterprises. Because the arm's length principle puts associated and independent enterprises on a more equal footing for tax purposes, it avoids the creation of tax advantages or disadvantages that would otherwise distort the relative competitive positions of either type of entity. In so removing these tax considerations from economic decisions, the arm's length principle promotes the growth of international trade and investment" (OCDE. Transfer Pricing Guidelines for Multinational Enterprises and Tax Administrations. op. cit., p. I-3). Convertido no parágrafo 1.8 da Minuta-2009.

Especificamente no que diz respeito à previsão acima, Juan Ignacio Moreno FERNÁNDEZ conclui que:

"En este sentido, en informe de La OCDE (...) justifica la necesidad de adoptar el precio de libre concurrencia (arm's length principle), en los supuestos de operaciones entre empresas asociadas, en el intento de otorgar una mayor paridad en el trato fiscal que los ordenamientos dispensen a las empresas multinacionales en relación con las empresas independientes, en orden a evitar la creación de ventajas o desventajas fiscales que, de otra forma, podrían distorsionar la competencia efectiva en el mercado (...). Es decir, se pretende evitar la competencia desleal (la quiebra del principio de libre competencia) en que incurren las empresas asociadas al intervenir en el mercado, ya que aun siendo jurídicamente independientes, la dependencia económica o la integración en una unidad económica, las sustrae a las reglas del mercado, neutralizando una competitividad que, en otro caso, sería determinante de los precios operantes y del gravamen del resultado" (op. cit., p. 30-31). 
elusivas baseadas em "presunções e ficções" não poderia se sobrepor a outros princípios constitucionais, mais relevantes ao interesse público e consagrados após conquistas seculares dos povos civilizados. O interesse de coibir a elusão ou a fraude até seria legítimo, mas se tornaria inconstitucional se dos mecanismos para tal coibição brotassem lucros tributáveis inexistentes ${ }^{234}$. Importante diferençar, entretanto, que estes autores não discutem precisamente a possibilidade de criação de instrumentos para fiscalizar os preços de transferência, ou mesmo a implementação de ajustes, se for o caso; objetam-se, isso sim, as normas específicas da legislação brasileira, em especial as margens fixas de lucro previstas nos artigos 18 e 19 da Lei n. ${ }^{\circ}$ 9.430/96, a impossibilidade de discussão da taxa de juros indicada no artigo 22 e a limitação dos elementos de prova que, além da própria contabilidade, podem ser apresentados pelos contribuintes para a comprovação do seu preço parâmetro [cf. artigo 21]. Cada um destes questionamentos será discutido oportunamente nos capítulos subseqüentes deste estudo.

Por ora, frise-se que, em teoria, as regras para o controle dos preços de transferência não apenas são legítimas como efetivam os princípios e valores constitucionais discutidos na seção anterior. De fato, o "teste" dos preços em operações praticadas entre empresas vinculadas, para fins de definição da base de cálculo dos tributos, não é uma questão recente no direito brasileiro; sempre se permitiu algum tipo de intervenção nos valores reais das transações, seja para fins de simplificação, seja na tentativa de implementação do valor Justiça. Há normas, nos mais variados tributos, que determinam a fixação da base de cálculo em operações vinculadas com amparo em preços que teriam sido praticados com terceiros independentes, as quais demonstram que, de certo

${ }^{234}$ A este respeito confira-se, a título exemplificativo, a seguinte passagem de José Artur LIMA GONÇALVES:

"A questão que deve ser colocada - e adequadamente respondida - é: há fundamento, no sistema constitucional brasileiro, para a criação válida de ficções (e presunções absolutas) em matéria tributária - no que diga respeito à constatação de ocorrência do fato imponível e quantificação do tributo devido, como pretendem estas normas veiculadas pela Lei n. ${ }^{\circ}$ 9.430/96 sobre 'preços de transferência'? (...)

Do ponto de vista jurídico, as lições da doutrina nacional e estrangeira, sobre os institutos da ficção e da presunção, não servem de fundamento de validade para a recepção, pelo sistema constitucional brasileiro, de norma jurídica que veicule ficção ou presunção para fins de criação ou quantificação de tributo. (...) A ficção e a presunção, no sistema constitucional brasileiro e respectivo sub-sistema tributário, servirão, única e exclusivamente, como instrumento ensejador do início do processo administrativo tendente à apuração de eventual ocorrência de fato imponível e imputação dos respectivos efeitos. (...)

De todo o exposto, conclui-se que as disposições normativas veiculadas pela Lei n. ${ }^{\circ}$ 9.430/96, naquilo em que pretendem imputar automaticamente aos particulares o reconhecimento da ocorrência de um lucro tributável, com o nascimento de obrigação tributária, são inválidas perante o sistema constitucional brasileiro, por vício de inconstitucionalidade, que deverá ser reconhecido pelo Poder Judiciário, quando chamado a pronunciar-se sobre a questão" [Certos Aspectos da Disciplina dos Preços de Transferência em face do Ordenamento Constitucional Brasileiro. In: Luís Eduardo Schoueri e Valdir de Oliveira Rocha (coord.), Tributos e preços de transferência. São Paulo: Dialética, 1999, v. 2, p. 239-242]. 
modo, sempre se reconheceu que as operações vinculadas poderiam, potencialmente, servir para a manipulação de preços. Como destacado por Heleno Taveira TÔRRES, "podemos afirmar, com tranqüilidade, que o princípio arm's length sempre esteve inserido no ordenamento jurídico brasileiro" ${ }^{235}$; a Lei n. ${ }^{\circ}$ 9.430/96, nesse contexto, não trouxe nenhuma novidade ao tentar pôr à prova os preços em operações vinculadas, mediante a comparação com preços ou transações não-vinculadas cujos dados estejam disponíveis. A inovação está na criação deste tipo de regras no campo do direito tributário internacional.

No âmbito do direito interno, pode-se admitir que as normas atinentes à distribuição disfarçada de lucros ("DDL"), disciplinadas pelo artigo 60 do Decreto-Lei n. ${ }^{\circ}$ 1.598, de 26 de dezembro de 1977, e pelos artigos 464 a 469 do Decreto n. ${ }^{\circ} 3.000$, de 17 de junho de 1999 ["Regulamento do Imposto sobre a Renda" ou "RIR-99"], seriam uma espécie de "ensaio" brasileiro para a posterior introdução das normas para o controle dos preços de transferência ${ }^{236}$. De fato, há muita proximidade entre a "essência", a função e o conteúdo destes dois tipos de regras.

Assim como se dá com relação aos preços de transferência, ocorrida uma das hipóteses de DDL, são aplicáveis as conseqüências definidas por lei, ainda que não tenha havido "intenção" de distribuição indireta de lucros ou de favorecimento nos negócios entre partes ligadas; as circunstâncias tipificadoras de sua ocorrência são, portanto, objetivas. Raciocínio idêntico pode ser conduzido a partir da leitura dos artigos 18 a 22 da Lei n. ${ }^{\circ}$ 9.430/96, como explicado em 1.1., supra. Mas há diferenças importantes entre estas duas espécies de regras, a saber: (i.) o campo de abrangência das normas de DDL é muito mais restrito, porque se limita aos incisos I a VI do artigo 464 do RIR-99 237 ; já as normas

\footnotetext{
${ }^{235}$ In: Direito tributário internacional: planejamento tributário e operações transnacionais. op. cit., p. 166.

${ }^{236}$ In: MARIZ DE OLIVEIRA, Ricardo. Fundamentos do Imposto de Renda. op. cit., p. 774.

${ }^{237}$ Mesmo diante do inciso VI do artigo 464 do RIR-99, segundo o qual se considera hipótese de DDL "qualquer negócio em condição de favorecimento", MARIZ DE OLIVEIRA sustenta que as hipóteses de ocorrência de distribuição disfarçada de lucros são aferidas objetivamente:

"Realmente, mesmo após 1977, a relação de hipóteses de DDL continua a ser taxativa e não comporta extensão por analogia. Assim, mesmo que ocorra uma situação em que haja passagem disfarçada de lucros a sócios ou acionistas da pessoa jurídica, se não estiver arrolada expressamente como hipótese de DDL, não pode incorrer nos lançamentos a esse título. Nestes casos, conforme as circunstâncias de cada um, pode haver glosa de despesa ou outro lançamento que caiba, mas não exigência tributária a título de DDL.

A taxatividade e objetividade das hipóteses de DDL não ficam comprometidas pela existência de uma hipótese mais genérica, consistente em qualquer negócio da pessoa jurídica em condições de favorecimento de pessoa ligada, comparativamente com as condições que prevaleceriam se o negócio fosse com pessoa não ligada, porque mesmo esta hipótese mais abrangente tem os seus próprios limites de definição e aplicação, assim como as suas próprias condições de exclusão, a começar de que ela se refere às situações em que a pessoa jurídica tenha custo ou despesa decorrente desse negócio" (Fundamentos do Imposto de Renda. op. cit., p. 780).
} 
para o controle dos preços de transferência aplicam-se a quaisquer transações internacionais entre partes vinculadas envolvendo "bens, serviços ou direitos"; (ii.) a noção de pessoa ligada é muito menos ampla que a de parte vinculada, estabelecida pelo artigo 23 da Lei n. 9.430/96; (iii.) no DDL o "valor de mercado" é um conceito subjetivo, devendo os negócios serem praticados em valores "notoriamente superiores ou inferiores ao valor de mercado" ${ }^{238}$. Não basta ser um pouco dissonante: deve-se aplicar a noção de "notoriamente", segundo a qual a diferença deve ser quantitativamente significativa e relevante; (iv.) as regras de DDL, a despeito de objetivamente aplicáveis, são afastadas se houver prova de que o negócio foi realizado no interesse da pessoa jurídica e em condições comutativas ou condições iguais àquelas em que a pessoa jurídica contrataria com terceiros [cf. artigo 464, §3을 do RIR-99]; inexiste previsão neste sentido nas normas para o controle dos preços de transferência; e (v.) no DDL há liberdade de contraprova de que o negócio ocorreu em condições estritamente comutativas: pode alegar compensação, ganho em um produto para venda em outro etc.; no âmbito da Lei n. ${ }^{\circ}$ 9.430/96 e de sua regulamentação, a análise deverá ser sempre transação-a-transação.

Não obstante as distinções indicadas no parágrafo anterior, o fato é que tanto as normas de DDL quanto as regras para o controle dos preços de transferência apregoam a aproximação dos preços praticados entre partes vinculadas aos preços de mercado, buscando tributar com maior exatidão a renda "real" dos contribuintes. Considerando que as normas de DDL já foram objeto de discussão no âmbito do Supremo Tribunal Federal e do Superior Tribunal de Justiça, nunca tendo sido alegada a sua inconstitucionalidade ${ }^{239}$, pode-se sustentar que o "teste" dos preços entre partes vinculadas é pacificamente admitido pelo direito brasileiro; as críticas, no caso da Lei n. ${ }^{\circ}$ 9.430/96, cingem-se a tópicos específicos e imaleáveis ali contidos. Nem se argumente que a legislação de DDL seria constitucional apenas por conta do artigo $464, \S 3^{\circ}$, do RIR-99 ${ }^{240}$, porque também há exemplos, no direito pátrio, de normas que limitam a dedutibilidade de despesas com amparo em critérios desvinculados do mercado, mas que, ainda assim, sempre foram admitidas, seja pela doutrina, seja pelos tribunais pátrios. Este é exatamente o caso dos

\footnotetext{
${ }^{238}$ Cf. artigo 464, incisos I, II e V, do RIR-99.

239 Apenas foram discutidos os limites e hipóteses de aplicação das normas de distribuição disfarçada de lucros, sendo que, nestes casos, a constitucionalidade das regras não foi examinada. Esse tipo de discussão pode ser apreendido a partir do exame dos seguintes acórdãos: (a.) Recurso Extraordinário n. ${ }^{\circ}$ 75.150, p. em 20.03.73; e (b.) Recursos Especiais n. ${ }^{\circ}$ 908.104, de 20.09.07; e n. ${ }^{\circ}$ 928.829, de 26.08.08.

240 " $\$ 3^{\circ}$ A prova de que o negócio foi realizado no interesse da pessoa jurídica e em condições estritamente comutativas, ou em que a pessoa jurídica contrataria com terceiros, exclui a presunção de distribuição disfarçada de lucros".
} 
pagamentos a título de royalties e assistência técnica, cuja dedutibilidade, nos pagamentos ao exterior, é limitada ao máximo de $5 \%$ sobre a receita líquida por eles gerada ${ }^{241}$.

Partindo-se para a comprovação de que o preço das transações controladas também é investigado quando da aferição da base de cálculo de outros tributos, veja-se que, no âmbito do "General Agreement on Taxes and Tariffs" ("GATT"), os métodos de valoração aduaneira, atualmente disciplinados no Decreto n. ${ }^{\circ} 2.498$, de 13 de fevereiro de 1998, determinam a tributação dos produtos importados segundo o seu "preço real" [preço de mercadorias iguais ou similares vendidas ou oferecidas à venda em condições de plena concorrência], aferido em épocas e locais determinados pela legislação do país importador.

Da mesma forma, a legislação do IPI prevê algumas hipóteses de "valor tributável mínimo", dentre as quais se enquadram as operações com empresas que mantenham "relação de interdependência"; detectada esta relação, o preço mínimo tributável para fins de IPI será o preço corrente no mercado atacadista da praça do remetente [cf. artigo 15 da Lei n. ${ }^{\circ} 4.502$, de 30.11.64, e alterações subseqüentes] ${ }^{242}$. Nas

${ }^{241}$ A limitação da dedutibilidade de despesas de royalties e assistência técnica, científica, administrativa e semelhante, existe, desde a introdução, no ordenamento, do artigo 74 da Lei n. ${ }^{\circ}$ 3.470, de 28.11.58. Veja-se:

"Art. 74. Para os fins da determinação do lucro real das pessoas jurídicas como o define a legislação do imposto de renda, somente poderão ser deduzidas do lucro bruto a soma das quantias devidas a título de royalties pela exploração de marcas de indústria e de comércio e patentes de invenção, por assistência técnica, científica, administrativa ou semelhantes até o limite máximo de 5\% (cinco por cento) da receita bruta do produto fabricado ou vendido [a expressão 'receita bruta' foi alterada para 'receita líquida' em regulamentação posterior].

$\S 1^{\circ}$ Serão estabelecidos e revistos periòdicamente mediante ato do Ministro da Fazenda, os coeficientes percentuais admitidos para as deduções de que trata este artigo, considerados os tipos de produção ou atividades, reunidos em grupos, segundo o grau de essencialidade".

O Supremo Tribunal Federal teve a oportunidade de examinar a discussão sobre a eventual revogação desse dispositivo pelo artigo 71 da Lei . $^{\circ}$ 4.506, de 30.12.64, mas nunca questionou a constitucionalidade de tal limitação à dedutibilidade de despesas, que tem sido unanimemente admitida. A respeito, confiram-se os seguintes acórdãos: (a.) Recurso Extraordinário n. ${ }^{\circ}$ 104.368-7/SP, de 23.03.92, e (b.) Recursos Especiais n. ${ }^{\circ}$ 204.696, de 19.05.05; n. 260.513 , de 06.10.05; e n. ${ }^{\circ} 378.575$, de 29.03.06.

${ }^{242}$ A matéria está assim regulamentada no artigo 136 do Decreto n. ${ }^{\circ} 4.544$, de 26.12.02 [doravante designado "Regulamento do IPI"]:

“Art. 136. O valor tributável não poderá ser inferior:

I - ao preço corrente no mercado atacadista da praça do remetente quando o produto for destinado a outro estabelecimento do próprio remetente ou a estabelecimento de firma com a qual mantenha relação de interdependência;

II - a noventa por cento do preço de venda aos consumidores, não inferior ao previsto no inciso I, quando o produto for remetido a outro estabelecimento da mesma empresa, desde que o destinatário opere exclusivamente na venda a varejo;

III - ao custo de fabricação do produto, acrescido dos custos financeiros e dos de venda, administração e publicidade, bem assim do seu lucro normal e das demais parcelas que devam ser adicionadas ao preço da operação, no caso de produtos saídos do estabelecimento industrial, ou equiparado a industrial, com destino a comerciante autônomo, ambulante ou não, para venda direta a consumidor;

$\mathrm{V}$ - a setenta por cento do preço da venda a consumidor no estabelecimento moageiro, nas remessas de café torrado a comerciante varejista que possua atividade acessória de moagem". 
normas gerais para a cobrança do Imposto sobre a Circulação de Mercadorias e Serviços de Transporte Interestadual e Intermunicipal e de Comunicação ("ICMS"), pode-se vislumbrar a aplicação do princípio da plena concorrência nos artigos 15 a 17 da Lei Complementar n. ${ }^{\circ}$ 87, de 13.09.96. Enquanto os artigos 15 e 16 prevêem que, na falta de "preço determinado", considerar-se-á que a transação deu-se pelo "preço corrente" da mercadoria ou do serviço no local da operação, o artigo 17 dispõe que, se o valor do frete cobrado por estabelecimento da mesma empresa ou outra com a qual mantenha relação de interdependência exceder os "preços praticados no mercado local", o excedente será havido como parte do preço da mercadoria; essa norma busca limitar o valor máximo cobrado a título de frete entre partes interdependentes, evitando-se que o preço do frete seja "manipulado", de modo a reduzir o valor tributável imputado à mercadoria.

Saliente-se, por fim, que o $\$ 3^{\circ}$ do artigo $2^{\circ}$ do Decreto-Lei n..$^{\circ} 1.578$, de 11 de outubro de 1977, determina que a base de cálculo do Imposto sobre Exportação ("IE”) não poderá ser inferior ao custo de aquisição ou produção do bem exportado, acrescido dos tributos e de margem de lucro de $15 \%$ sobre a soma dos custos e dos impostos e contribuições incidentes [cf. redação determinada pela Lei n. ${ }^{\circ}$ 9.716, de 26 de novembro de 1998]. Note-se que o "preço mínimo" supra apontado aproxima-se muito do critério para a determinação do preço parâmetro nos termos do método CAP, disciplinado pelo artigo 19, IV, da Lei n. 9.430/96, e abordado no CAPÍTULO 4, infra. A diferença é que, na regulamentação desta última lei, o preço pode, v.g., ser comprovado pelo PVEx, não sendo necessária uma lucratividade mínima de 15\%; no campo do IE, contudo, esse nível mínimo de lucro é obrigatório e, ademais, a regra aplica-se a todos os contribuintes, em quaisquer espécies de exportações, não se limitando a operações vinculadas.

\subsection{A questão do ônus da prova.}

Provar é fornecer elementos de convicção que permitam estabelecer parâmetros seguros para a formação de um juízo de valor e de justiça na aplicação da lei. Na visão de Pontes de MIRANDA, "ônus da prova é o ônus que tem alguém de dar a prova de algum enunciado de fato. Não se pode pensar em dever de provar, porque não existe tal dever, quer perante a outra pessoa, quer perante o juiz; o que incumbe ao que tem o ônus da prova há de exercer-se no seu próprio interesse (...) O que tem o ônus da prova pode dar prova,

Já a noção de "empresas interdependentes" consta do artigo 520 do Regulamento do IPI, abrangendo hipóteses como participação acionária superior a $15 \%$, exclusividade comercial etc.. 
ou não; dá-la como melhor a poderia dar, ou deixar de dá-la como poderia; não tem dever, nem há, de outro lado, direito de outrem à prova (...). O ônus da prova estabelece-se contra alguém que, se não der a prova, se terá como improvado o enunciado de fato"243.

No direito brasileiro, consoante prescrito no artigo 142 do Código Tributário Nacional, o lançamento é ato privativo da administração tributária, a quem são transferidos todos os ônus de comprovar: (a.) quando, como e onde ocorreu o fato gerador da obrigação tributária; (b.) qual a sua base de cálculo e alíquota; (c.) qual o montante do tributo devido; e (d.) quem são o sujeito passivo e os eventuais co-responsáveis ${ }^{244}$. No que concerne ao imposto sobre a renda, especificamente, a escrituração mantida com observância das disposições legais faz prova a favor do contribuinte, com relação aos fatos nela registrados e comprovados por documentos hábeis [cf. artigo $9^{\circ}$ do Decreto-Lei n. ${ }^{\circ} 1.598 / 77^{245}$ ]. A regra geral sobre a "prova" no campo do imposto sobre a renda, assim, é a de que os livros contábeis e fiscais são aptos a demonstrar a renda tributável do contribuinte. Para o arbitramento de uma outra renda, precisa ser comprovada a inveracidade/inutilidade dos elementos ali lançados. Mas as normas para o controle dos preços de transferência, tal como introduzidas no direito brasileiro, escapam a esta regra geral. Com efeito, o Poder Legislativo apegou-se ao artigo $9^{\circ}, 3^{\circ}$, do Decreto-Lei n. ${ }^{\circ} 1.598 / 77$, para inverter o ônus da prova e transferir aos contribuintes a obrigação de demonstrar que os seus registros contábeis passam no "teste" dos preços de transferência; desse modo, deve o contribuinte, com amparo na documentação comercial e fiscal das suas operações, bem assim em relatórios, pesquisas etc., justificar os preços praticados, a partir de um dos métodos disciplinados nos artigos 18 e 19 da Lei n. ${ }^{\circ}$ 9.430/96.

243 MIRANDA, Pontes de. Tratado de Direito Privado, Parte Geral. Tomo III: Negócios Jurídicos, Representação, Conteúdo, Forma, Prova. $3^{\mathrm{a}}$ ed. Rio de Janeiro: Editor Borsoi, 1970, p. 411.

244 “Art. 142. Compete privativamente à autoridade administrativa constituir o crédito tributário pelo lançamento, assim entendido o procedimento administrativo tendente a verificar a ocorrência do fato gerador da obrigação correspondente, determinar a matéria tributável, calcular o montante do tributo devido, identificar o sujeito passivo e, sendo o caso, propor a aplicação da penalidade cabível".

245 “Art. $9^{\circ}$ A determinação do lucro real pelo contribuinte está sujeita a verificação pela autoridade tributária, com base no exame de livros e documentos da sua escrituração, na escrituração de outros contribuintes, em informação ou esclarecimentos do contribuinte ou de terceiros, ou em qualquer outro elemento de prova.

$\S 1^{\circ}$ A escrituração mantida com observância das disposições legais faz prova a favor do contribuinte dos fatos nela registrados e comprovados por documentos hábeis, segundo sua natureza, ou assim definidos em preceitos legais.

$\S 2^{\circ}$ Cabe à autoridade administrativa a prova da inveracidade dos fatos registrados com observância do disposto no $\S 1^{\circ}$.

$\S 3^{\circ} \mathrm{O}$ disposto no $\S 2^{\circ}$ não se aplica aos casos em que a lei, por disposição especial, atribua ao contribuinte o ônus da prova de fatos registrados na sua escrituração". 
Este tipo de inversão do ônus da prova não é exclusivo da legislação brasileira mas, pelo contrário, tem sido muitíssimo difundido internacionalmente. Note-se, v.g., que a legislação argentina prevê, no artigo 15 da Lei n. ${ }^{\circ}$ 20.268/74, atualizada pela Lei n. ${ }^{\circ}$ 25.784/03, a obrigatoriedade de apresentação semestral de declarações especiais com informações detalhadas sobre todos os dados que permitiram o teste dos preços de transferência praticados ${ }^{246}$. De fato, são tantos os países que procederam a esta inversão do ônus da prova e instituíram deveres instrumentais específicos sobre o assunto que a questão foi analisada no âmbito da OCDE, inclusive sob a perspectiva do princípio da nãodiscriminação, tendo essas exigências sido admitidas pela maioria dos EstadosMembros $^{247}$. Mesmo diante da inexistência de um consenso na doutrina brasileira ${ }^{248}$,

246 “Art. 15. (...) La ADMINISTRACION FEDERAL DE INGRESOS PUBLICOS, entidad autárquica en el ámbito del MINISTERIO DE ECONOMIA Y OBRAS Y SERVICIOS PUBLICOS con el objeto de realizar un control periódico de las transacciones entre sociedades locales, fideicomisos o establecimientos estables ubicados en el país vinculados con personas físicas, jurídicas o cualquier otro tipo de entidad domiciliada, constituida o ubicada en el exterior, deberá requerir la presentación de declaraciones juradas semestrales especiales que contengan los datos que considere necesarios para analizar, seleccionar y proceder a la verificación de los precios convenidos, sin perjuicio de la realización, en su caso, de inspecciones simultáneas con las autoridades tributarias designadas por los estados con los que se haya suscrito un acuerdo bilateral que prevea el intercambio de información entre fiscos".

Há, todavia, críticas severas a esta regra argentina, porque este tipo de obrigação acessória gera a produção de informações custosas e por vezes inúteis, como se depreende da seguinte passagem:

"Surge a las claras, el exceso de tareas administrativas que se agrega a los contribuyentes, debiendo especificar vía declaración jurada especial, la modalidad de determinación de los precios de transferencia utilizados. Disentimos sustancialmente de la obligatoriedad de respaldar tales mecanismos en forme general, debiéndose reservar tal facultad exclusivamente en los casos de procedimientos individuales de fiscalización, sin ser su aplicación generalizada en absoluto conveniente.

Nuestra intransable postura radica no solo el mayor costo privado que tal conducta generara sino también en el exceso, muchas veces sin sentido alguno de acumulación de documentación por parte del Fisco, deviniendo inútil y hasta contra natura un excedente de información por utilizar.

En segundo término, entiendo que la documentación probatoria solo debería operar en aquellos casos en los cuales el Fisco probara la falta de aplicación de los precios de transferencia conforme el principio del arm's length. En efecto, deberá ser el Fisco quien determine la improcedencia del ajuste y no debe quedar en manos del contribuyente da carga probatoria de la exactitud del mecanismo utilizado" (VARELA, Pablo Sergio. op. cit., p. 29).

247 " 4 . The question arises as to whether special procedural rules which some countries have adopted for dealing with transactions between related parties are consistent with the Convention. For instance, it may be asked whether the reversal of the burden of proof or presumptions of any kind which are sometimes found in domestic laws are consistent with the arm's length principle. A number of countries interpret the Article in such a way that it by no means bars the adjustment of profits under national law under conditions that differ from those of the Article and that it has the function of raising the arm's length principle at treaty level. Also, almost all Member countries consider that additional information requirements which would be more stringent than the normal requirements, or even a reversal of the burden of proof, would not constitute discrimination within the meaning of Article 24" (OECD. Model Tax Convention on Income and Capital. Condensed version. Paris: OECD, 2008, p. 147).

248 "Tenho para mim que sempre que o preço real não corresponder a um dos critérios expostos nos artigos 18 e 19, há de prevalecer o preço real e não os critérios dos artigos 18 e 19, devendo a prova negativa ao preço real demonstrado ser feita pelo fisco, não à luz dos critérios pré-estabelecidos, mas de critérios reais.

Entender de outra forma, é admitir que a lei ordinária tenha mudado princípios tradicionais do direito pátrio em matéria fiscal (...).

Tenho sérias dúvidas de que o preço de transferência para o mercado 'oficial' e não 'real', fere, para efeitos de lançamento, o disposto no art. 142 do CTN, a hierarquia das leis e os princípios de tipicidade fechada, 
entendemos que a inversão do ônus da prova é admissível e não viola princípios ou valores constitucionais. Com efeito, ao transferir este ônus aos contribuintes e exigir a indicação dos métodos escolhidos e dos ajustes totais nas Declarações de Informações EconômicoFiscais das Pessoas Jurídicas ("DIPJ”) respectivas, garante-se maior efetividade da norma e seleciona-se melhor os contribuintes que devem ser investigados via procedimentos específicos $^{249}$, tudo isso sem prejuízos à Justiça, à Segurança e ao contraditório.

Reconhecer a possibilidade de inversão do ônus da prova não significa, contudo, concordar com as limitações trazidas pelo artigo 21 da Lei n. ${ }^{\circ}$ 9.430/96, as quais serão examinadas em 1.9, infra. Pelo contrário, sustentamos que o contribuinte deve apurar os respectivos preços parâmetro a partir dos métodos indicados na lei e proceder a ajustes no seu lucro tributável, se for o caso. A adequação do preço praticado ao preço parâmetro pode ser comprovada a partir de quaisquer meios admitidos em direito, consoante garantido no artigo $5^{\circ}, \mathrm{LV}$, da Constituição Federal; cessa, após estes passos, o ônus do contribuinte. Para alegar que os cálculos perpetrados pelo contribuinte são inexatos ou que a documentação foi objeto de fraude, v.g., incumbe à administração tributária trazer novos elementos ao processo. Portanto, o contribuinte elabora sua prova diante do ônus trazido por lei, mas, para desqualificá-la ou alegar fraude ${ }^{250}$, deve o fisco, com amparo nas regras estatuídas pelo artigo 148 do Código Tributário Nacional, apresentar sua "contraprova". Seguindo-se este raciocínio, qualquer lei que procede à inversão do ônus da prova pode gerar uma constante inversão de tal ônus durante o processo, porque, a cada prova, poderá a parte contrária proceder a sua contraprova; trata-se do "shifting burden" referido pela OCDE em sua Diretiva ${ }^{251}$.

estrita legalidade, reserva absoluta da lei formal, sobre criar fatos geradores mais fictícios do que presumidos e mais fantasiosos do que reais" (MARTINS, Ives Gandra da Silva. Preços de Transferência. In: Valdir de Oliveira Rocha (coord.), Tributos e preços de transferência. São Paulo: Dialética, 1997, p. 36-37).

249 "Para a produção do fato das provas no direito tributário, apresenta-se sobremodo importante o adequado cumprimento das obrigações acessórias e deveres instrumentais, cuja finalidade primordial é servir de base para as investigações probatórias da fiscalização na constituição dos fatos jurídico-tributários que contemplam" (TÔRRES, Heleno Taveira; UTUMI, e Ana Claudia Akie. O Controle Fiscal dos Preços de Transferência e os Meios de Prova Admitidos para a Definição de Preços e Custos Médios. In: Tributos e preços de transferência. São Paulo: Dialética, 1999, v. 2, p. 175).

${ }^{250}$ Especificamente no que concerne à prova da fraude, importa ponderar que este ônus sempre pertence à administração tributária, que deve efetivar o lançamento a partir de elementos indiscutíveis e inquestionáveis, e não em meras presunções.

251 "In the context of litigation in countries where the burden of proof is on the taxpayer, the burden of proof is often seen as a shifting burden. Where the taxpayer presents to a court a reasonable argument and evidence to suggest that its transfer pricing was arm's length, the burden of proof may legally or de facto shift to the tax administration to counter the taxpayer's position and to present argument and evidence as to why the taxpayer transfer pricing was not arm's length and why the assessment is correct. On the other hand, where a 


\subsection{Noções de ficção e presunção. As provas admitidas para contraditar as presunções contidas na Lei n. ${ }^{\circ}$ 9.430/96.}

Segundo lição de Pontes de MIRANDA, pode-se distinguir entre as presunções do homem e as presunções de direito. As força probatória das presunções facti ou hominis “assenta em convicções (e normas) oriundas da experiência. A lei só se interessa por elas para as arrolar como meio de prova, ou para alusões à experiência do juiz. Daí não fixar ou inverter o ônus da prova, a despeito delas" ${ }^{252}$. Essas presunções do homem distinguem-se das presunções de direito, as quais representam "o conteúdo de regras jurídicas que estabelecem a existência de fato, fato jurídico ou efeito de fato jurídico (e.g., direito), sem que se possa provar o contrário (praesumptiones iuris et de iure, presunções legais absolutas), ou enquanto não se prova o contrário (presunções legais relativas)". Na visão de Pontes de MIRANDA, portanto, enquanto as presunções legais relativas tem o condão de inverter o ônus da prova, as presunções hominis representam normas emanadas da verossimilhança entre duas situações e decorrem do raciocínio lógico do aplicador da $1 \mathrm{ii}^{253}$.

As presunções partem de um fato jurídico de existência certa para interferirem num fato de existência provável. Por outras palavras, a partir de um fato conhecido e demonstrado, conclui-se pela existência de outro fato desconhecido, mas que se quer provar, e cuja existência seja possível ou provável face àquele outro. São três as espécies de presunção: (i.) presunções absolutas ou iuris et iure, que não admitem prova em sentido contrário; (ii.) presunções relativas ou iuris tantum, que as admitem, e (iii.) presunções mistas, que podem ser contraditadas tão-somente por determinados meios de prova, prefixados na lei que as estabelece. As presunções atuam como meio de prova, porque a

taxpayer makes little effort to show its transfer pricing was arm's length, the burden imposed to the taxpayer would not be satisfied where a tax administration raised as assessment which was soundly based in law" (OCDE. Transfer Pricing Guidelines for Multinational Enterprises and Tax Administrations. op. cit., p. IV1).

${ }^{252}$ MIRANDA, Pontes de. op. cit., p. 411. Ricardo MARIZ DE OLIVEIRA descreve a funcionalidade das presunções hominis nos seguintes termos:

"Nas presunções, a partir de um fato conhecido e efetivamente ocorrido, deduz-se uma conclusão lógica sobre outro fato, este até então desconhecido ou controvertido. (...) Nesse sentido, o homem presume a verdade em todo e qualquer raciocínio que desenvolva, com mais ou com menos certeza. A presunção de fato ou presunção do homem ( 'presumptio hominis') é, portanto, a consequiência ou entendimento que o próprio homem tira dos fatos conhecidos” (MARIZ DE OLIVEIRA, Ricardo. Presunções no Direito Tributário. In: Ives Gandra da Silva Martins (coord.). Presunções no Direito Tributário. São Paulo: Resenha Tributária Ltda., 1984, p. 277-278).

${ }^{253}$ MIRANDA, Pontes de. op. cit., p. 411. No mesmo sentido, confira-se SOUSA, Rubens Gomes de. Um caso de ficção legal no direito tributário: a pauta de valores como base de cálculo do ICM. Revista de Direito Público. São Paulo: Revista dos Tribunais, v. 11, jan.-mar. 1970, p. 23. 
dispensam a respeito do que se presume, e servem à simplificação da aplicação do direito; demonstradas as premissas prescritas no texto legal, devem as presunções ser aplicadas ${ }^{254}$.

Quando conceitua a ficção, de outro lado, Pontes de MIRANDA sustenta que ela "enche de artificial o suporte fáctico; a presunção legal apenas tem como acontecido, ou não acontecido, o que talvez não aconteceu, ou aconteceu. A ficção tem no suporte fático elemento de que não se poderia induzir a situação que ela prevê. Daí, nada se pode presumir, quando se elabora a ficção. Se A, então B; e não se A, então AA" ${ }^{, 255}$. Pontes de MIRANDA diferencia a ficção das presunções de direito da seguinte forma: "na ficção, tem-se A, que não é, como se fosse. Na presunção legal absoluta, tem-se A, que não pode ser, como se fosse, ou A, que pode ser, como se não fosse. Na presunção legal relativa, tem-se A, que pode não ser, como se fosse, ou A, que pode ser, como se não fosse, admitindo-se prova em contrário. A presunção legal mista é a presunção legal relativa, se contra ela só se admite a prova contrária $a$, ou $a$ ou $b^{, 256}$. Na opinião do aludido autor, assim, as ficções tornam verdadeiros fatos que certamente não ocorreram na realidade, sendo esse o cerne de sua distinção com as presunções. Este raciocínio é partilhado por Rubens Gomes de SOUZA, que sustentou que "a diferença entre a presunção e a ficção é que a presunção confere certeza jurídica a algo que é provável, ou, pelo menos, não contrário à ordem natural das coisas. Em resumo, tira do possível uma ilação para o certo. Já a ficção dá como certo para (todos ou alguns) efeitos jurídicos, ao que se sabe não ser certo, ou que é contrário à natureza das coisas. Em resumo, cria uma 'verdade jurídica' existente apenas 'ex vi legis' mas diferente da verdade natural" 257.

Esta concepção da ficção como "preenchimento do suporte fático das normas com conteúdo não-verdadeiro", todavia, não é aceita pelos juristas que defendem a total abstração do sistema jurídico. Brandão MACHADO, e.g., sustenta ser a ficção legal uma

\footnotetext{
${ }^{254}$ Em texto no qual discute as pautas fiscais instituídas pela legislação do antigo ICM, Rubens Gomes de SOUZA sustenta que as presunções absolutas não são meios de prova, mas a substituem:

“(...) essa regra da pauta fiscal tem o caráter dispositivo a que se fez referência quando se disse que desta natureza são as ficções legais e suas co-irmãs, as presunções absolutas, no sentido de que nem uma nem outra é meio de prova. Tanto a ficção quanto a presunção absoluta são disposições legais determinando que, para tais fins, tal coisa tem tal natureza ou produz tal efeito. A pauta fiscal não faz prova do valor da mercadoria (...). Ao invés disso, a pauta fiscal substitui-se à prova, e dá como provado o que se trataria de provar" (SOUSA, Rubens Gomes de. op. cit., p. 25). Nosso entendimento, contudo, é idêntico ao de Luís Eduardo SCHOUERI, que sustenta que as presunções absolutas também representam normas relativas à teoria das provas, mais especificamente ao ônus da prova (SCHOUERI, Luís Eduardo. Distribuição Disfarçada de Lucros. São Paulo: Dialética, 1996, p. 116-117).

${ }^{255}$ MIRANDA, Pontes de. op. cit., p. 447.

${ }^{256}$ MIRANDA, Pontes de. op. cit., p. 446.

${ }^{257}$ In: SOUSA, Rubens Gomes de. op. cit., p. 24.
} 
espécie de técnica legislativa de que o legislador se vale para fazer uma remissão, ao invés de utilizar uma linguagem direta ${ }^{258}$. Nesse mesmo sentido, Yonne Dolácio de OLIVEIRA, valendo-se das idéias de Josef ESSER e Karl LARENZ, recusa qualquer conteúdo cognoscitivo às ficções, as quais, em sua opinião, representariam hipóteses especiais de remissão legal. Tratar-se-ia tão-somente da aplicação da regra dada para uma hipótese de fato (H1) a outra hipótese de fato (H2), como se depreende da explicação da autora: “em lugar de ordenar - as conseqüências jurídicas de $\mathrm{H} 1$ regem também para $\mathrm{H} 2$ - a lei 'finge' que H2 é um caso de H1. Como a lei não faz declarações mas dá ordens de validade, vemos que a ficção legal não afirma que na realidade H2 é igual a H1 ou a um caso de H1; ela encerra a remissão de que no caso $\mathrm{H} 2$ se produzem as mesmas conseqüências jurídicas do caso H1. Por outras palavras, o aplicador da lei deve considerar H2 'como se fosse' H1"259. Luís Eduardo SCHOUERI também discute o tema, afirmando, a partir das concepções de Franz BERNHÖFT, que as ficções como forma especial de remissão servem para a simplificação e comodidade do legislador ${ }^{260}$.

A utilização da presunção relativa de direito como medida de praticabilidade $\mathrm{e}$ de simplificação da aplicação das normas é geralmente aceita no direito tributário. Ricardo MARIZ DE OLIVEIRA, v.g., sustenta que as presunções relativas existentes na legislação do ICMS, do IPI ou do imposto sobre a renda são admitidas porque (i.) a efetiva ocorrência do fato gerador é constatada; (ii.) há correlação lógica entre o fato conhecido e o fato presumido; (iii.) o método de interpretação vale-se de presunção admitida em lei; (iv.) a

\footnotetext{
${ }^{258}$ Veja-se a esclarecedora exposição desse autor:

“(...) pode o legislador, dentro de certos limites, prescrever que a ocorrência de determinados fatos produzirá a obrigação tributária, ainda que eles não se subsumam no pressuposto. É que o legislador equipara um fato a outro, de maneira que a ocorrência do fato equiparado produza a mesma conseqüência de direito produzida pelo outro. No caso do imposto de renda, a ocorrência do fato equiparado fará nascer a obrigação tributária de pagá-lo, ainda que ele não revele a aquisição da disponibilidade da renda. Dá-se o nome de ficção legal a essa equiparação, que é expediente da técnica legislativa, de que se serve o legislador para fazer uma remissão, em vez de utilizar uma linguagem direta. As ficções, que tanto podem equiparar fatos como limitar as suas conseqüências jurídicas, nada mais são do que uma forma especial de remissão. Em lugar de prescrever que a norma $\mathrm{x}$, aplicável ao fato a, deve aplicar-se também ao fato $\mathrm{b}$, pode o legislador apenas equiparar o fato $\mathrm{b}$ ao fato $\mathrm{a}$, de modo que, equiparados, ambos sejam regidos pela mesma norma" [MACHADO, Brandão. Distribuição Disfarçada de Lucros no Direito Comparado. In: Ruy Barbosa Nogueira (coord.), Estudos Tributários em Homenagem à Memória de Rubens Gomes de Souza. São Paulo: Resenha Tributária, 1974, p. 180-181].

${ }^{259}$ In: OLIVEIRA, Yonne Dolácio de. Presunções no Direito Tributário. In: Ives Gandra da Silva Martins (coord.). Presunções no Direito Tributário. São Paulo: Resenha Tributária Ltda., 1984, p. 357-412.

260 "Bernhöft sugere, com razão, que a ficção serve para simplificação e comodidade do legislador, já que o legislador atingiria iguais resultados se, em vez de empregar a ficção, tivesse repetido, para a hipótese ficta, todas as sanções antes definidas para a base da ficção ou se, simplesmente, tivesse feito uma remissão aos dispositivos legais desejados" (SCHOUERI, Luís Eduardo. Distribuição Disfarçada de Lucros. op. cit., p. 102 e ss.).
} 
presunção admite prova em contrário; e (v.) representa tão-somente meio de prova, com inversão do ônus da prova ${ }^{261}$. A título exemplificativo, representa presunção relativa [legítima] de omissão de receitas no âmbito da legislação do imposto sobre a renda a constatação da existência de (a.) saldo credor de caixa; (b.) falta de escrituração de pagamentos ou manutenção de obrigações não comprovadas (passivo fictício); (c.) diferenças de estoque não justificadas; (d.) depósitos bancários creditados em contacorrente sem amparo em documentação hábil e idônea; (e.) suprimentos de caixa; (f.) ausência de emissão da respectiva nota fiscal, bem como de sua emissão em valor inferior à operação, dentre outras [cf. artigos 40 a 42 da Lei n. ${ }^{\circ}$ 9.430/96, artigo 12, $\S \S 2^{\circ}$ e $3^{\circ}$, do Decreto-Lei n. ${ }^{\circ}$ 1.598/77, e artigo $2^{\circ}$ da Lei n. ${ }^{\circ}$ 8.846, de 21.01.94]. É mister salientar que, em todas estas hipóteses, existe a possibilidade de afastamento da regra presuntiva, mediante a apresentação de contraprova pelo contribuinte.

Misabel Abreu Machado DERZI sustenta que as presunções são normas generalizantes que decorrem do princípio da praticabilidade; isso não lhes autoriza, contudo, sacrificar a adequada graduação da capacidade econômica dos contribuintes por motivos de simplificação. Com efeito, não há dúvidas de que, com a criação de presunções, sacrifica-se parcela da pessoalidade e da graduação dos tributos segundo a capacidade econômica de cada contribuinte, a fim de tornar menos complexa a aplicação do direito ${ }^{262}$.

261 "Em todos os casos de presunções legais relativas encontramos elementos que a própria doutrina acolhe para admiti-las como juridicamente válidas:

- a ocorrência do fato gerador é constatada a partir de fatos conhecidos e comprovadamente existentes;

- há correlação lógica entre o fato conhecido (índices de produção, consumo de materiais, sinais exteriores de riqueza, acréscimos patrimoniais, saldo credor de caixa, passivo fictício, suprimentos de caixa) e o fato desconhecido cuja existência se quer provar (fato gerador);

- o método de interpretação e aplicação da lei a partir da presunção é previsto e autorizado em lei, e não decorre apenas da suposição do agente lançador;

- a presunção não é absoluta, admitindo prova em contrário pelo contribuinte, característica implícita em todas as citadas hipóteses legais, quando não expressa;

- trata-se de mero meio de prova, com inversão do ônus da prova da inocorrência do fato gerador, pela comprovação de outros fatos, também desconhecidos mas hábeis a excluir a incidência tributária" (MARIZ DE OLIVEIRA, Ricardo. Presunções no Direito Tributário. op. cit., p. 299-300).

262 "Interessa-nos considerar as presunções que são padrões e esquemas generalizantes, contidas na lei e que se destinam a facilitar a execução de norma geral superior. Na medida em que a norma inferior é, ao mesmo tempo, criação e execução de norma superior, a lei que a veicula liga-se ao princípio da praticabilidade, tendendo:

- a facilitar a execução daquela hierarquicamente superior; e

- simplificar, por antecipação, a aplicação dos próprios preceitos que edita.

Como regra geral, a doutrina e a jurisprudência tendem a reconhecer a constitucionalidade das presunções, ficções ou somatórios que sejam definidos na lei. Entretanto, a norma inferior legal não pode ofender norma constitucional superior. (...)

A praticabilidade, como um princípio importante e difuso no ordenamento, autoriza a criação de presunções, tetos e somatórios em lei, desde que, com isso, não fiquem anulados princípios constitucionais, como aquele 
Logo, a presunção simplifica a prova, porque a dispensa a respeito do que se presume. No entanto, se as presunções forem utilizadas pela legislação como elemento de prova da ocorrência do fato gerador ou de algum(ns) de seus elementos, essa simplificação não pode ser tanta a ponto de a incidência tributária perder seu vínculo com o critério da capacidade econômica. Por conseguinte, a presunção relativa enquanto instrumento técnico para a simplificação das regras jurídicas não afasta, para o legislador, a necessidade de observância dos direitos fundamentais ou das limitações constitucionais ao poder de tributar. Como identificado por Yonne Dolácio de OLIVEIRA, a lei não pode reconhecer caprichos do legislador, o qual não é livre para formar seus conceitos; pelo contrário, este último não pode contradizer ou afastar-se muito dos elementos dados pelas leis e fatos naturais, devendo, ainda, restringir sua utilização às hipóteses em que houver probabilidade muito alta de que o fato presumido [por lei] corresponda ao fato real ${ }^{263}$. Luís Eduardo SCHOUERI, na mesma linha sustentada por esta autora, também ponderou que "a presunção legal [relativa], para ser aceita, deve ter um elevado grau de probabilidade"264. Desde que sopesados os limites ora tratados, assim, pode-se afirmar que a utilização da presunção relativa como técnica de simplificação e praticabilidade tem sido admitida no direito tributário brasileiro.

Consoante sustentado por Ricardo MARIZ DE OLIVEIRA, a estrutura básica para o surgimento da obrigação de pagamento do imposto sobre a renda está prevista no artigo 153, III, da Constituição Federal, c.c. artigos 43, 44, 113, §1º 114, 116 e 142 do Código Tributário Nacional. O imposto torna-se devido a partir do momento em que se

que veda utilizar tributos com efeito de confisco ou aquele que determina a graduação dos impostos de acordo com a capacidade econômica do contribuinte.

Sustentando que a capacidade contributiva consiste em algo concreto e não fictício, autores apontam a inconstitucionalidade das presunções fiscais absolutas (iure et iure) e a ilegitimidade daquelas que não sejam razoáveis e logicamente justificáveis, ou que não consintam, de modo amplo, na demonstração da prova contrária" (DERZI, Misabel Abreu Machado. In: BALEEIRO, Aliomar. op. cit., p. 581).

263 "Entendemos que o fato de ser a presunção um instrumento técnico para a elaboração de regras jurídicas não afasta, para o legislador, todos os limites que lhe são impostos na criação de leis instituidoras dos tributos. (...) Tomando exemplos acima citados de GENY, ESSER e LARENZ, podemos assinalar: $\underline{a}$ - se a presunção encobre princípio útil ou justo, este deve ser enucleado com clareza para delimitar sua extensão; a acrescentamos, também para confronto com princípios inarredáveis do direito tributário; $\underline{b}$ - se a presunção encobre uma solução empírica determinada, decretada arbitrariamente pelo legislador (aqui no sentido de cortar a dúvida e colocar o provável como certo), deve-se restringi-la ao caso específico; $\underline{c}$ - o emprego da presunção não deve configurar abuso, que se torna patente, quando as vantagens da simplificação matemática são pagas com o prejuízo da fidelidade para uma regulamentação justa; $\underline{\mathrm{d}}$ - a presunção não deve ser usada de modo a ensejar a ruptura de princípios que, no direito tributário, para a espécie, não comportam limitação; e - a lei que acolhe a presunção não deve, por capricho, contradizer o que vem previamente dado, nas leis e fatos naturais e, ainda, o conteúdo essencial ou núcleo de sentido das instituições reconhecidas” (OLIVEIRA, Yonne Dolácio de. Presunções no Direito Tributário. op. cit., p. 376-377).

${ }^{264}$ In: SCHOUERI, Luís Eduardo. Preços de Transferência no Direito Tributário Brasileiro. op. cit., p. 73. 
verifiquem as circunstâncias materiais e/ou jurídicas necessárias à ocorrência do fato gerador, i.e., deve efetivar e realmente ocorrer o evento disciplinado em lei, apto a se subsumir na norma tributária. Conseqüentemente, "face à sistemática do direito tributário, as presunções são aceitas como meios de prova [de ocorrência do evento tributável], desde que admitam prova em contrário. Já as ficções e presunções absolutas de existência ou de ocorrência do fato gerador contrariam toda a estrutura do direito tributário, tal como concebem a Constituição Federal e sua lei complementar, o CTN"265.

No que concerne ao emprego da técnica da presunção absoluta, observe-se que Yonne Dolácio de OLIVEIRA argumenta ser ela "incompatível para criar ou aumentar tributos"266. Luís Eduardo SCHOUERI corrobora esse entendimento, mas sob outro fundamento: este autor sustenta existir um confronto direto entre o emprego da presunção absoluta e o princípio da ampla defesa, insculpido no artigo $5^{\circ}, \mathrm{LV}$, da Constituição Federal, concluindo que "o princípio da ampla defesa, hoje estendido a todos os litigantes em processo administrativo ou judicial, exige que se questione a aplicação das presunções absolutas, quando um litigante ficar impedido de comprovar, em juízo, a ocorrência ou não de fato que seja relevante para que se dê, ou não, a subsunção"267.

Note-se, a esse passo, que as presunções são vedadas nas hipóteses em que um contribuinte fica absolutamente proibido de demonstrar, em juízo, a inocorrência da hipótese de incidência da norma tributária [v.g., presume-se que todos os contribuintes têm renda anual tributável de "X", sem possibilidade de contraprova]. Se, todavia, a parte possui a faculdade da prova, mas não se vale dela no momento apropriado, não há que se

\footnotetext{
${ }^{265}$ In: MARIZ DE OLIVEIRA, Ricardo. Presunções no Direito Tributário. op. cit., p. 288.

266 “(...) consideramos que a presunção legal absoluta é incompatível para criar ou aumentar tributos. Embora atendido o requisito formal, a existência de lei escrita emanada do Poder Legislativo, tal presunção estaria em total conflito com nosso princípio da tipicidade [em sentido impróprio]. (...)

O objeto constitucional busca, através de uma tipificação que define totalmente os elementos da hipótese de incidência, o máximo de certeza em relação ao fato que, realizado, ensejará o nascimento da obrigação tributária. Este princípio, como estruturado no nosso ordenamento, choca-se com o conceito de presunção absoluta. Este, ainda que fundado no raciocínio lógico e baseado na experiência, para extrair consequiências de um fato conhecido para outro desconhecido, representa uma decisão do legislador que corta a dúvida declarando como certo o que é apenas provável. (...) Estas características dessa presunção, de não ser prova da existência do fato gerador e da correspondente capacidade contributiva efetiva, proibindo a prova em contrário, levariam à total incerteza, colidindo com a 'ratio' do princípio da tipicidade" (OLIVEIRA, Yonne Dolácio de. Presunções no Direito Tributário. op. cit., p. 388-389).

Luís Eduardo SCHOUERI também considera as presunções absolutas inconstitucionais sob a perspectiva da repartição constitucional de competências tributárias (Distribuição Disfarçada de Lucros. op. cit., p. 128).

${ }^{267}$ In: SCHOUERI, Luís Eduardo. Distribuição Disfarçada de Lucros. op. cit., p. 126. Na p. 129 da mesma obra, Luís Eduardo SCHOUERI conclui que "não se admite, em nosso ordenamento, o emprego da presunção absoluta em matéria tributária, quando dele decorrer a exigência de tributo sem a ocorrência do gato gerador".
} 
falar em violação ao artigo $5^{\circ}, \mathrm{LV}$, sendo a presunção absoluta perfeitamente admitida. Nesse sentido, são constitucionais, porque amparam outros valores muito relevantes no ordenamento jurídico, (a.) a presunção de veracidade dos fatos alegados e não contestados por réu revel; e (b.) a presunção absoluta que cerca a coisa julgada. Nestes dois exemplos, não há restrição ao princípio constitucional da ampla defesa, mas tão-somente a garantia do valor Segurança Jurídica, que impede o abuso do emprego desse princípio ${ }^{268}$. Da mesma forma, é legítima a presunção absoluta constante do artigo 185 do Código Tributário, porque não mantém relação direta com a definição do fato gerador tributário ${ }^{269}$.

Diante destas ponderações, pode-se afirmar ser praticamente pacificada, no direito tributário brasileiro, a impossibilidade do emprego da presunção absoluta no campo da definição do fato gerador do tributo; a presunção é válida, desde que admita ampla contraprova, fundamentada no artigo $5^{\circ}$, inciso LV, da Constituição Federal. Saliente-se, a este passo, que tal vedação tem relação direta com o sistema tributário brasileiro, sendo a presunção absoluta admitida em outras nações como, v.g., a Argentina ${ }^{270}$.

Superada a questão das presunções de direito, importa abordar a possibilidade de emprego da técnica da ficção. Na prática, os autores que compreendem-na como o "preenchimento do suporte fático das normas com conteúdo não-verdadeiro", dentre os quais Rubens Gomes de SOUZA ${ }^{271}$, Ricardo MARIZ DE OLIVEIRA ${ }^{272}$ e José Artur LIMA GONÇALVES ${ }^{273}$, repugnam sua aplicação no ramo do direito tributário, por ser

\footnotetext{
${ }^{268}$ In: SCHOUERI, Luís Eduardo. Distribuição Disfarçada de Lucros. op. cit., p. 126.

269 “Art. 185. Presume-se fraudulenta a alienação ou oneração de bens ou rendas, ou seu começo, por sujeito passivo em débito para com a Fazenda Pública por crédito tributário regularmente inscrito como dívida ativa em fase de execução.

Parágrafo único. O disposto neste artigo não se aplica na hipótese de terem sido reservados pelo devedor bens ou rendas suficientes ao total pagamento da dívida em fase de execução".

${ }^{270} \mathrm{Na}$ Argentina, há presunções absolutas de renda mínima em operações de importação e exportação, as quais são consideradas compatíveis com as leis daquele país. A título exemplificativo, veja-se o artigo $9^{\circ}$ da Lei n. ${ }^{\circ} 20.628 / 97$ :

“ARTICULO $9^{\circ}$. Se presume, sin admitir prueba en contrario, que las compañías no constituidas en el país que se ocupan en el negocio de transporte entre la República y países extranjeros, obtienen por esa actividad ganancias netas de fuente argentina, iguales al DIEZ POR CIENTO (10\%) del importe bruto de los fletes por pasajes y cargas correspondientes a esos transportes".

Há também margens mínimas de lucratividade para operações envolvendo armadores, locação de containeres, empresas seguradoras e resseguradoras, agências de notícias internacionais, dentre outras.

${ }^{271}$ In: SOUSA, Rubens Gomes de. op. cit., p. 24.

${ }^{272}$ In: Presunções no Direito Tributário. op. cit., p. 288.

273 “Todas - e não menos que todas - as normas jurídicas que pretendam, por meio de ficção, imputar os efeitos de tal fato imponível a evento fenomênico que não se caracterize como tal, ou manipular o conteúdo patrimonial de obrigação tributária, ou alcançar particular não incluído na categoria de contribuinte (entendido este como o destinatário constitucional da carga tributária), deverão, simplesmente ser descritas
} 
inviável a sua cobrança sobre algo que não está [de fato] realmente abrangido pela hipótese de incidência tributária, mas que a lei trata como se estivesse. Valores como Justiça, Segurança Jurídica e Liberdade não se harmonizam com um raciocínio desse tipo ${ }^{274}$. Repare-se, a este passo, que, não obstante sua total e completa discordância em relação à utilização desta técnica legislativa, Ricardo MARIZ DE OLIVEIRA reconhece que, na legislação ordinária que disciplina o imposto sobre a renda, há exemplos concretos de tributação de renda efetivamente inexistente por ficção, criados artificialmente por leis ordinárias $^{275}$. Na visão desse autor, contudo, "a declaração de invalidade constitucional dessa legislação ordinária é um imperativo em guarda das supremas normas do Estado de Direito, sob pena de desmoronar todo o respectivo sistema" ${ }^{276}$. Segundo sua perspectiva, é mister a absoluta impossibilidade de introdução de normas tributárias baseadas em ficções, porque esta prática pode levar a uma ampliação desarrazoada da base de cálculo do imposto sobre a renda. Concordamos com esta percepção, especialmente a palavra "renda" consta expressamente do artigo 153, III, da Constituição, sendo impossível à lei ordinária fazer incidir este imposto sobre algo que não se adéqüe ao conceito de renda haurido do direito privado, sob pena de ofensa ao artigo 110, do Código Tributário Nacional. Este é, assim, um limite à instituição de ficções com conteúdo fático "não-verdadeiro" no direito tributário, e, porque não, também à instituição das presunções relativas em geral.

De outro lado, para os autores que sustentam serem as ficções meras remissões, como Luís Eduardo SCHOUERI, “o exame da constitucionalidade da ficção em matéria tributária não deve partir da ficção, em si, que, como ficou exaustivamente exposto, é mera técnica legislativa, mas da própria hipótese ficta"277. Na visão deste autor, se a hipótese ficta conformar-se com o campo de competência instituído pela Constituição Federal e

como normas inválidas, alheias ao sistema constitucional brasileiros, incompatíveis com o seu sub-sistema constitucional tributário” (LIMA GONÇALVES, José Artur. op. cit., p. 239-240).

${ }^{274}$ Ademais, a palavra "renda" consta do artigo 153, III, da Constituição, sendo impossível à lei, ordinária ou complementar, fazer incidir este imposto sobre algo que não se adéqüe ao conceito de renda haurido do direito privado, sob pena de ofensa ao artigo 110, do Código Tributário Nacional. Este é, assim, um limite à instituição de ficções "não-verdadeiras" no direito tributário, o qual também deve balizar a instituição das presunções em geral.

275 "Na legislação ordinária do imposto de renda nós temos exemplos concretos de rendas efetivamente inexistentes, mas criadas artificialmente por leis ordinárias, a saber, entre outros: (...)

- cessões gratuitas do uso de imóveis, que são consideradas como locação pelos valores locativos (DecretoLei n. ${ }^{\circ}$ 5.844/43, art. $7^{\circ}$, parágrafo único, e Lei n. ${ }^{\circ}$ 4.506, art. 23, VI), igualmente renda ficta, realmente inocorrente e, pois, impossível de gerar efeitos tributários" (MARIZ DE OLIVEIRA, Ricardo. Presunções no Direito Tributário. op. cit., p. 289-290). O autor ofereceu dois outros exemplos de tributação com amparo em ficção jurídica em seu estudo, os quais não foram reproduzidos na presente nota porque foram revogados posteriormente à elaboração de seu trabalho.

${ }^{276}$ In: MARIZ DE OLIVEIRA, Ricardo. Presunções no Direito Tributário. op. cit., p. 291.

277 In: SCHOUERI, Luís Eduardo. Distribuição Disfarçada de Lucros. op. cit., p. 130-131. 
regulamentado por lei complementar, nos termos do artigo 146, III, 'a', da Constituição Federal, sua instituição será constitucional. Mas as ficções, assim como quaisquer remissões, não podem ser utilizadas sem discernimento ou reserva; de fato, seu manejo pelo intérprete do direito deve ser pautado pela observância prudente dos princípios constitucionais. Consoante esclarecido por Brandão MACHADO, "o legislador não tem a liberdade de modificar, através de ficções, conceitos já definidos em leis de hierarquia superior, ou de equiparar conceitos contraditórios ou absurdos, como, no exemplo de Larenz, quando assimilasse a alimentos todas as plantas, inclusive as que fossem inteiramente inadequadas para a alimentação" 278 .

Transmudando-se as discussões supra para a sistemática dos preços de transferência e, especificamente, para aquela prescrita pela Lei n. ${ }^{\circ}$ 9.430/96, importa ponderar que todo o raciocínio envolvido em sua aplicação está amparado numa ficção: a ficção de independência, por intermédio da qual se assume, ficticiamente, que as partes vinculadas agem como se fossem independentes; na verdade, o que esta ficção acarreta é a aplicação, às partes vinculadas, das mesmas bases tributáveis que teriam sido estabelecidas por partes independentes, em condições comerciais e financeiras similares, i.e., aplicam-se às primeiras o conseqüiente das normas infligidas às últimas ${ }^{279}$. Sabe-se que as partes são dependentes, mas há remissão legal que determina a aplicação, a elas, das normas típicas das partes independentes, que negociam seus preços a partir das "forças do mercado". Ainda que o suporte fático da norma possua conteúdo "não-verdadeiro", entendemos tratar-se de ficção perfeitamente legítima, porque não gera a tributação de um conteúdo que escape à noção de renda, mas, pelo contrário, revela uma renda não contabilizada e assegura o cumprimento dos princípios da capacidade contributiva e da universalidade da tributação da renda, além dos demais indicados na seção 1.6, supra.

Note-se que toda a sistemática das normas brasileiras para o controle dos preços de transferência está pautada na ficção de independência, mas não se pode negar que a

\footnotetext{
${ }^{278}$ In: MACHADO, Brandão. op. cit., p. 181.

279 "Consignado que a ficção jurídica é uma figura que atribui a certo antecedente o conseqüente de norma diversa, parece correto afirmar que a legislação de preços de transferência apenas 'empresta' às transações entre partes ligadas o conseqüente jurídico das transações entre partes independentes.

Por meio da legislação dos preços de transferência, as transações entre partes vinculadas serão, para efeitos tributários, valoradas como se de transações entre partes independentes se tratasse, adotando-se os preços das últimas para efeito de apuração do imposto a pagar.

Há, pois, verdadeira ficção jurídica, no sentido acima exposto, já que se empresta, à transação entre partes relacionadas, o conseqüente jurídico daquelas similares, praticadas entre partes independentes" (SCHOUERI, Luís Eduardo. Preços de Transferência no Direito Tributário Brasileiro. op. cit., p. 73).
} 
legislação também esteja repleta de presunções, como, v.g., as margens fixas, a presunção da adoção das taxas SELIC ou Libor nas hipóteses de não-comprovação da prática consistente de uma determinada taxa de juros pelo contribuinte em suas operações comerciais etc. ${ }^{280}$. A principal discussão concernente às presunções trazidas pela Lei n. ${ }^{\circ}$ 9.430/96 é a seguinte: trata-se de presunções relativas, mistas ou absolutas?

Na concepção de Ricardo MARIZ DE OLIVEIRA, a Lei n. ${ }^{\circ}$ 9.430/96 não contém presunções relativas, mas absolutas, seja porque não consta expressamente do texto legal a possibilidade de produção de prova em contrário, seja porque, em muitos casos, tal prova seria inviável/impossível $^{281}$. Esse autor sustenta que a lei apregoa a tributação de um

\footnotetext{
${ }^{280}$ Para Luís Eduardo SCHOUERI, a presunção de que terceiros independentes formariam seus preços segundo determinados critérios é que daria origem aos métodos. Logo, os métodos legais seriam presunções e, como decorrência disso, suportariam prova em contrário; a respeito, examinem-se as seguintes passagens extraídas de sua obra:

"Com efeito, foi de presunção relativa que se valeu o legislador para sustentar que terceiros independentes utilizam-se dos métodos previstos legalmente para compor o seu próprio preço, por razões estabelecidas pelo próprio mercado.
}

A presunção legal, para ser aceita, deve ter um elevado grau de probabilidade. Vale, aqui, o raciocínio: como um terceiro independente costuma fixar seus preços? É razoável admitir que ele parta da prática do mercado, ou seja, que ao fixar seus preços, ele investigue preços de seus concorrentes. Do mesmo modo, é razoável admitir que ele busque fixar seus preços partindo de seus custos e a eles adicionando certa remuneração ou ao contrário, tendo um preço de venda fixado pelo mercado, recuse-se a adquirir produtos para revenda que não lhe assegurem margem de lucro adequada".

Desse modo, existe "a possibilidade de o contribuinte, afastando a presunção, trazer evidências de que, em determinado caso, terceiros independentes valer-se-iam de outros critérios, que não os adredemente fixados pelo legislador, para a determinação dos seus preços. Nesse caso, o argumento do contribuinte não poderá ser deixado de lado, sob pena de deixar-se buscar preços praticados por terceiros independentes" (SCHOUERI, Luís Eduardo. Preços de Transferência no Direito Tributário Brasileiro. op. cit., p. 73-75).

Segundo Alberto XAVIER, contudo, os métodos representariam um arbitramento legal ou uma ficção, i.e., gerariam "a substituição da prova, por força da própria lei, mediante a adoção de bases de cálculo substitutivas que, por normas dispositivas de direito material - por ficção legal - colocam as novas bases de cálculo (os 'preços parâmetro'), no lugar e nas vezes das reais e efetivas (os 'preços efetivos')" (XAVIER, Alberto. Direito Tributário Internacional do Brasil, op. cit., p. 388).

Como decorrência da técnica da ficção, os métodos legais não podem ser substituídos por outros, a despeito de todos os seus elementos conformadores poderem ser objeto de prova.

Por fim, saliente-se que, na visão desse autor, esse arbitramento legal representaria a criação de uma renda tributável substitutiva da original, na forma do artigo 44 do Código Tributário Nacional; o artigo 148 do Código Tributário Nacional não seria aplicável porque ali estaria previsto o arbitramento administrativo, i.e., o arbitramento como prova subsidiária às declarações dos contribuintes e de natureza exclusivamente instrutória; esse "arbitramento", como se demonstrou, aplica-se sempre que o fisco pretender contraditar as provas apresentadas pelos contribuintes para ilidir as presunções.

281 "Contudo, nos arts. 18 a 24 não existe o estabelecimento de uma presunção relativa, por duas razões. A primeira razão é que quando a lei cria uma presunção relativa, ela o diz expressamente e determina que o fato presumido seja verdade até prova em contrário. Ora, no caso da Lei n. ${ }^{\circ} 9.430$, isto não ocorre, mesmo porque o ônus da prova do extravasamento dos limites por ela impostos é do fisco, já que qualquer glosa de custo ou despesa, ou qualquer lançamento de receita a ser adicionada ao lucro tributável, deverá ser acompanhada dos elementos de comprovação adotados pelo agente fiscal (...).

A segunda razão pela qual não se trata de presunção relativa está em que, a despeito de caber ao fisco o ônus da prova do que alegar, ao contribuinte, como um qualquer processo, também será possível fazer contraprova. Todavia, tal contraprova sempre terá alcance limitado até determinado ponto, pois desse ponto em diante os parâmetros legais atuam como presunções absolutas, para não dizer ficções legais. (...) Pode-se 
"lucro mínimo", regra que pode se converter na tributação de uma "renda inexistente". Neste contexto, ao invés de corroborar a concretização da noção constitucional de renda, a Lei n. ${ }^{\circ}$ 9.430/96 violá-la-ia. Concordamos que a lei contém algumas impropriedades em seu texto, as quais poderiam ter sido melhor examinadas [e redigidas] pelo Poder Legislativo; de fato, a avaliação contraditória não está plenamente assegurada pelos artigos 18 a 22 da Lei n. ${ }^{\circ}$ 9.430/96, vez que ela impõe limites além dos quais não prevê provas aptas a contrariar o montante dos lucros que ela apura segundo os seus critérios.

O artigo 22, v.g., prevê a cobrança de juros mínimos de Libor para depósitos de dólares norte-americanos por 6 meses, deixando de indicar a possibilidade de contraprova; parece, pois, tratar-se de hipótese de presunção absoluta. No caso específico das margens fixas, há previsão de alterações nos artigos 20, pelo Ministro de Estado da Fazenda, e 21, $\S 2^{\circ}$, por solicitação do contribuinte, mas desde que se comprove outras margens com amparo nas publicações, relatórios oficiais ou pesquisas indicados no caput desse dispositivo legal. Sob o ponto de vista estritamente jurídico, esta técnica legislativa seria a da presunção mista; mas, na prática, dada a dificuldade de obtenção destes documentos na grande maioria das situações vivenciadas pelos contribuintes, poderia transmudar-se na técnica da presunção absoluta. Em nossa opinião, se o aplicador da lei entender que a presunção contida no artigo 22 e que a lista de documentos referida no caput do artigo 21 são absolutas, não podendo ser contraditadas, então não temos dúvida de que se trata de dispositivos inconstitucionais, porque incompatíveis com o artigo $5^{\circ}, \mathrm{LV}$, da Constituição Federal, e com o artigo 148 do Código Tributário Nacional. De outro lado, se a norma for compreendida sistematicamente no âmbito do sistema tributário, ponderando-se o conjunto de seus valores e princípios, poderá alcançar conclusão diversa. Segundo Ricardo Lobo TORRES, "se, portanto, se substituir a interpretação literal da norma pela ponderação dos princípios que a informam, a antinomia se torna aparente e será contornada" ${ }^{282}$. Nesse

dizer que a lei quer, nos atos sujeitos aos arts. 18 a 24, que o contribuinte tenha um lucro mínimo, razão pela qual, mesmo que não o tenha, a lei considerará que ele teve esse lucro por ela pretendido, e é este que tomará como base de cálculo dos tributos sobre a renda" [MARIZ DE OLIVEIRA, Ricardo. Tributos e preços de transferência. In: Valdir de Oliveira Rocha (coord.), Tributos e preços de transferência. São Paulo: Dialética, 1997, p. 83].

282 “As presunções se analisam à sombra de princípios jurídicos como os da legalidade, plena produção das provas, busca da verdade material, boa-fé etc., que não podem deixar de ser sopesados com o princípio da capacidade contributiva. Se, portanto, se substituir a interpretação literal da norma pela ponderação dos princípios que a informam, a antinomia se torna aparente e será contornada. A doutrina brasileira recente tem adotado este ponto de vista de que a Lei n. ${ }^{\circ}$ 9.430/96 criou presunções iuris tantum, que admitem prova em contrário. As margens de lucro, as pautas mínimas, as inversões do ônus da prova, tudo é objeto de ponderação e de equilíbrio entre princípios" (TORRES, Ricardo Lobo. O Princípio Arm's Length, os Preços de Transferência e a Teoria da Interpretação do Direito Tributário. op. cit., p. 132). 
caso, poder-se-á concluir que (i.) as partes envolvidas nos contratos de empréstimo poderão comprovar, por quaisquer provas admitidas em direito, que os juros praticados estão consonantes com os "juros de mercado"; e (ii.) a demonstração de margens distintas das presumidas não dependerá exclusivamente das publicações, pesquisas ou relatórios referidos no artigo 21 , I e II, da Lei n. ${ }^{\circ}$ 9.430/96.

Valendo-se deste último raciocínio, pode-se sustentar que as presunções consubstanciadas nos artigos 18 a 22 da Lei n. ${ }^{\circ}$ 9.430/96 são legítimas, desde que assegurados, na prática, para a efetivação da capacidade contributiva, a ampla defesa e todos os meios e recursos a ela inerentes. Com efeito, as presunções tributárias devem sempre ser compreendidas como medida de praticabilidade e de simplificação da prova, e não como "normas absolutas" de medição da base de cálculo do imposto. Claro que, idealmente, o texto legislativo deveria explicitar as garantias dos contribuintes; mas, independentemente disso, se (a.) forem assegurados o contraditório e a ampla defesa para o afastamento da presunção, e, uma vez apresentadas as provas, (b.) qualquer arbitramento posterior for acompanhado do procedimento do artigo 148 do Código Tributário Nacional, as presunções "tornam-se" relativas e, portanto, admitidas no direito tributário ${ }^{283}$. Nesta perspectiva, entendemos que são passíveis de contradição, por quaisquer meios de prova, as margens fixas, os juros, as médias ponderadas e seus efeitos ao longo do ano-calendário, o impacto da sazonalidade, as condições de mercado etc. ${ }^{284}$.

Para a comprovação da legitimidade e/ou veracidade dos preços parâmetro obtidos pelos contribuintes quando da aplicação de um dos métodos previstos nos artigos 18, 19 e 22 da Lei n. ${ }^{\circ}$ 9.430/96, portanto, devem ser admitidos todos e quaisquer meios de provas, sem restrições. Qualquer reserva ou condicionante transformará as presunções insertas na lei em mistas ou absolutas e, portanto, em presunções inconstitucionais.

\footnotetext{
283 "No caso de antecipação do método eleito pelo contribuinte, somente quando seus dados forem inconsistentes, inidôneos, e assim não mereçam fé, é que poderá ser aberto o procedimento de 'arbitramento' por novo método (...). Como se vê, nos termos do art. 148, do Código Tributário Nacional, o contribuinte pode dispor de todos os meios de prova admitidos; mas não poderia assim dispor quando se tratasse de controle de preços de transferência, segundo o art. 21 da Lei n. ${ }^{\circ}$ 9.430/96? Eis uma inconstitucionalidade, caso assim permanecesse tal limitação" (TÔRRES, Heleno Taveira. Garantias constitucionais aplicadas ao controle sobre preços de transferência (legalidade e uso de presunções no arbitramento da base de cálculo dos tributos, a partir do controle de preços de transferência. O direito ao emprego do melhor método. Um caso: limites ao uso do PRL-60 na importação). op. cit., p. 120).

284 "Não nos repugna, pois, que neste quadro sejam estabelecidos, por presunção, elementos de determinação dos preços paramétricos. Certo é, porém, que tais presunções só devem ser relativas, sem qualquer restrição à liberdade de o contribuinte provar a objetividade dos preços efetivamente praticados" (XAVIER, Alberto. Direito Tributário Internacional do Brasil, op. cit., p. 390).
} 
Partindo-se desta conclusão, serão examinadas sucintamente na subseção 1.9.1, infra, as provas descritas no artigo 21 da Lei n. ${ }^{\circ}$ 9.430/96. Não nos demoraremos na descrição e delimitação de cada uma delas porque, como se afirmou, sustentamos serem elas apenas exemplificativas, não aptas a impedir o oferecimento de outros tipos de prova.

Por fim, no que respeita ao procedimento de arbitramento previsto no artigo 148 do Código Tributário Nacional ${ }^{285}$, importa frisar que este dispositivo representa uma garantia dos cidadãos contra os excessos fiscais, estando estritamente vinculado ao atendimento da capacidade contributiva. Nas hipóteses de presunção legal, como aquelas prescritas no âmbito da Lei n. ${ }^{\circ}$ 9.430/96, este dispositivo aplica-se sempre que as provas que ilidirem a presunção forem refutadas pela administração fiscal, i.e., quando não merecerem fé as declarações e/ou esclarecimentos dos contribuintes que tentarem afastar a norma presuntiva num determinado caso concreto. Note-se que o termo "omisso" constante do artigo 148 deve ser interpretado segundo lógica distinta sempre que se tratar de norma que se vale da técnica da presunção relativa. A total omissão do contribuinte, em todas as fases do procedimento administrativo e/ou judicial, gerará a efetiva concretização da norma presuntiva, i.e., a base de cálculo definitiva passará a ser aquela descrita na norma. Se, contudo, forem apresentados documentos e/ou informações aptos a refutar essa presunção, então a autoridade administrativa deverá instaurar procedimento, na forma do artigo 148 do Código Tributário Nacional, para questionar os elementos de tal refutação. Especificamente no que toca à implementação do disposto no artigo 148, Aliomar BALEEIRO destacou que a autoridade "poderá arbitrar, isto é, estimar, calcular, buscar a verdade dentro ou fora da omissão, reticência, mentira. Poderá arbitrar, nesse sentido, mas não praticar o arbítrio puro e simples, indo até o absurdo ou às vizinhanças dele. $\mathrm{O}$ procedimento há de ser racional, lógico e motivado" 286 . Como não poderia deixar de ser, o processo de arbitramento deve respeitar todas as garantias e limites impostos aos processos administrativos em geral; na prática, quaisquer informações e/ou documentos apresentados pelos contribuintes ${ }^{287}$ somente poderão ser desprezados mediante processo regular e

\footnotetext{
285 “Art. 148. Quando o cálculo do tributo tenha por base, ou tome em consideração, o valor ou o preço de bens, direitos, serviços ou atos jurídicos, a autoridade lançadora, mediante processo regular, arbitrará aquele valor ou preço, sempre que sejam omissos ou não mereçam fé as declarações ou os esclarecimentos prestados, ou os documentos expedidos pelo sujeito passivo ou pelo terceiro legalmente obrigado, ressalvada, em caso de contestação, avaliação contraditória, administrativa ou judicial".

${ }^{286}$ BALEEIRO, Aliomar. Direito Tributário Brasileiro. $11^{\mathrm{a}}$ ed. at. por Misabel Abreu Machado Derzi. Rio de Janeiro: Forense, 2001, p. 818.

287 Não se trata, aqui, do questionamento fiscal a respeito dos dados informados nas DIPJ ou outras obrigações acessórias dos contribuintes, mas de quaisquer informações constantes de livros ou documentos
} 
motivado, sujeito ao mais amplo contraditório; no seu âmbito é possível, inclusive, avaliação administrativa ou judicial como contraprova.

\subsubsection{Provas previstas no artigo 21 da Lei $.^{\circ} 9.430 / 96$.}

O artigo 21 da Lei n. ${ }^{\circ}$ 9.430/96 determina que os custos e preços médios essenciais para a determinação dos preços parâmetro "deverão" ser apurados com amparo em publicações ou relatórios oficiais do governo do país onde estiver estabelecida a contraparte na transação "testada", ou em pesquisas ou publicações técnicas ${ }^{288}$. Dado que todos os métodos indicados nos artigos 18 e 19 da lei dependem da comprovação de "custos médios" ou "preços médios" de compra ou venda, poder-se-ia interpretar [literalmente] esse dispositivo legal do seguinte modo: as únicas provas admitidas no procedimento de aplicação das regras para o controle dos preços de transferência seriam aquelas indicadas nos incisos I e II do artigo 21. Não há dúvidas, porém, de que esta interpretação é ilógica e irrazoável, ainda mais diante do quanto disposto na subseção preliminar deste item 1.9. De fato, a demonstração dos dados exigidos nos artigos 18, 19 e 22 da Lei n. ${ }^{\circ}$ 9.430/96 pode dar-se a partir de quaisquer elementos de prova admitidos em direito, sob pena de inconstitucionalidade da norma. A administração tributária percebeu esta inexatidão do texto legal e, no artigo 29 da Instrução Normativa n. ${ }^{\circ}$ 243/02, tratou dessas publicações e relatórios como "elementos complementares de prova". Segundo este normativo, "além dos documentos emitidos normalmente pelas empresas, nas operações de compra ou venda, a comprovação dos preços" poderá ser efetuada, também, com base nos documentos indicados no artigo 21 da Lei n. ${ }^{\circ}$ 9.430/96.

fiscais, contratos, relatórios etc.; todos esses elementos podem ser provas para ilidir a presunção e, portanto, eventual processo subseqüente de arbitramento deverá contestar cada um deles.

288 “Art. 21. Os custos e preços médios a que se referem os arts. 18 e 19 deverão ser apurados com base em: I - publicações ou relatórios oficiais do governo do país do comprador ou vendedor ou declaração da autoridade fiscal desse mesmo país, quando com ele o Brasil mantiver acordo para evitar a bitributação ou para intercâmbio de informações;

II - pesquisas efetuadas por empresa ou instituição de notório conhecimento técnico ou publicações técnicas, em que se especifiquem o setor, o período, as empresas pesquisadas e a margem encontrada, bem como identifiquem, por empresa, os dados coletados e trabalhados.

$\S 1^{\circ}$ As publicações, as pesquisas e os relatórios oficiais a que se refere este artigo somente serão admitidos como prova se houverem sido realizados com observância de métodos de avaliação internacionalmente adotados e se referirem a período contemporâneo com o de apuração da base de cálculo do imposto de renda da empresa brasileira. (...)

$\S 3^{\circ}$ As publicações técnicas, as pesquisas e os relatórios a que se refere este artigo poderão ser desqualificados mediante ato do Secretário da Receita Federal, quando considerados inidôneos ou inconsistentes".

A discussão das provas necessárias à alteração das margens fixas, disciplinada pelo $\S 2^{\circ}$ deste artigo, será desenvolvida no CAPÍTULO 4, infra. 
Não poderia a autoridade administrativa proceder de modo distinto. Imagine-se, v.g., um contribuinte que pretende aplicar o CAP e que concorde com a margem de $15 \%$. Por que ele precisaria de relatórios ou publicações internacionais para a comprovação dos seus preços médios? De fato, sabe-se que a aferição do preço parâmetro a partir do CAP depende unicamente de dados internos do próprio contribuinte. A limitação aparentemente trazida pelo artigo 21 da Lei n. ${ }^{\circ} 9.430 / 96$, nesse contexto, ao invés de garantir elementos de contraprova para o contribuinte, traria vedações desnecessárias à aplicação dos métodos. Não por outra razão e com fundamento na interpretação sistemática do direito, que exige a constante ponderação de princípios e valores, sustenta-se que o contribuinte pode valer-se de quaisquer provas para a comprovação dos preços parâmetro, incluindo-se aquelas prescritas no artigo 21 da Lei n. ${ }^{\circ}$ 9.430/96 e regulamentadas pelo artigo 29 da Instrução

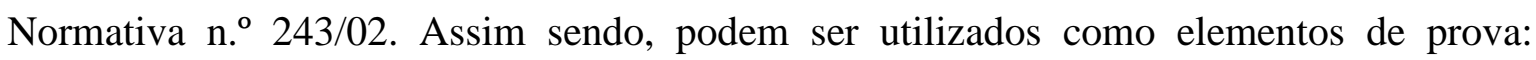
documentos elaborados por quaisquer contribuintes, listas de preços dos fabricantes, informações de clientes, relatórios gerenciais diversos, publicações em jornais e revistas especializadas etc.. Não há dúvidas de que a força probatória eleva-se se obtidos os documentos referidos no artigo 21, por suas próprias características intrínsecas, mas isso não significa que, na sua ausência, as autoridades administrativas e/ou judiciais não devam levar em consideração todos os elementos probatórios e indiciários trazidos aos autos pelo contribuinte, com o objetivo de se comprovar a regularidade dos preços por ele praticados.

Uma vez relatadas nossas ressalvas iniciais com relação a esse dispositivo legal, passamos, doravante, a descrever os "elementos complementares de prova" trazidos pelo artigo 21 da Lei n. 9.430/96, os quais podem ser empregados tanto pelos contribuintes, para a comprovação de seus "custos e preços médios", quanto pelas autoridades administrativas, para impugnar os elementos de prova apresentados pelos primeiros.

O inciso I do artigo 21 alude a "publicações ou relatórios oficiais do governo do país do comprador ou vendedor ou declaração da autoridade fiscal desse mesmo país, quando com ele o Brasil mantiver acordo para evitar a bitributação ou para intercâmbio de informações”. Entendemos que os documentos listados neste inciso I não precisam ser obtidos pelos processos descritos nas convenções para evitar a bitributação da renda ou nos acordos para intercâmbio de informações, porque "o texto da lei não exige que a informação se obtenha na forma do acordo. Apenas se exige que haja um acordo $(. . .)^{289, \text {, }}$

${ }^{289}$ In: SCHOUERI, Luís Eduardo. Preços de Transferência no Direito Tributário Brasileiro. op. cit., p. 59. 
Esta constatação é relevante porque a maioria dos acordos tão-somente prevê a possibilidade de troca de informações de um fisco com o outro, e não o fornecimento de dados a um contribuinte do outro Estado. Isso não significa, contudo, que os Estados responderão a solicitações particulares de contribuintes de um outro Estado: isso dependerá de sua legislação interna ${ }^{290}$; não há dúvidas, todavia, de que este elemento de prova servirá, na prática, mais ao fisco que aos contribuintes. É possível, ademais, que o importador ou exportador estrangeiro obtenha essas informações diretamente no seu país e remeta-as a sua contraparte no país. De fato, comprovada que a informação provém da autoridade fiscal da outra nação, mister seu reconhecimento pelo fisco brasileiro.

O inciso II, por seu turno, sustenta que representam elementos complementares de prova também as "pesquisas efetuadas por empresa ou instituição de notório conhecimento técnico ou publicações técnicas, em que se especifiquem o setor, o período, as empresas pesquisadas e a margem encontrada, bem como identifiquem, por empresa, os dados coletados e trabalhados". Não é preciso esforço para concluir que pesquisas deste tipo são raras: dificilmente as "empresas pesquisadas" autorizarão a publicação [ou a entrega ao físco] de seu nome e de todos os dados ali coletados; a maioria se recusará a participar de trabalhos deste tipo, alegando se tratar de hipótese de "sigilo comercial". Não por outro motivo, a Instrução Normativa n. ${ }^{\circ}$ 243/02, no seu artigo 29, §2 , ampliou a noção de "publicações técnicas", admitindo a comprovação dos preços a partir da cotação de bolsas de valores de âmbito nacional e de bolsas reconhecidas internacionalmente, além de pesquisas da OCDE ou da Organização Mundial do Comércio (“OMC”) ${ }^{291}$. Em nossa

\footnotetext{
${ }^{290}$ Sobre a abrangência das cláusulas de trocas de informações na Convenção-Modelo, bem assim sobre a possibilidade de obtenção de informações por particulares, confira-se Heleno Taveira TÔRRES:

"A cláusula de troca de informações, do Modelo da OCDE de acordo para evitar a bitributação em matéria de Imposto de Renda, adotada na maior parte dos acordos firmados pelo Brasil, dispõe que haverá troca de informações necessárias para aplicar as disposições do acordo e as disposições das leis internas concernentes aos impostos que seja objeto do acordo.

A disciplina legal dos preços de transferência é parte integrante da legislação do Imposto de Renda, mais especificamente do Imposto sobre a Renda das Pessoas Jurídicas (IRPJ). Desta forma, é perfeitamente possível a requisição de declaração ao país do comprador ou vendedor sobre os custos e preços médios dos produtos negociados em transações internacionais com pessoa vinculada.

Aos particulares, a possibilidade de requerer semelhante declaração somente será possível se a legislação do país do comprador ou vendedor permitir. Caso contrário, tal declaração, a princípio, não será fornecida pelas autoridades" (TÔRRES, Heleno Taveira. Direito tributário internacional: planejamento tributário e operações transnacionais. op. cit., p. 270).

291 “ $\$ 2^{\circ}$ Consideram-se adequadas a surtir efeito probatório as publicações de preços decorrentes:

I - de cotações de bolsas de valores de âmbito nacional;

II - de cotações de bolsas reconhecidas internacionalmente, a exemplo da de Londres, na Inglaterra, e da de Chicago, nos Estados Unidos da América;

III - pesquisas efetuadas sob a responsabilidade de organismos internacionais, a exemplo da Organização de Cooperação e Desenvolvimento Econômico (OCDE) e da Organização Mundial de Comércio (OMC)”.
} 
opinião, os preços e margens podem ser comprovados por quaisquer meios admitidos em direito e, por conta disso, obviamente as cotações de bolsas e pesquisas de organizações internacionalmente reconhecidas sempre devem ser consideradas como elemento "forte" de prova, no mesmo nível dos dados de governos ou instituições técnicas.

Não fossem suficientes tamanhas dificuldades, o $\S 1^{\circ}$ da lei traz mais outras duas, aplicáveis aos incisos I e II do caput: "as publicações, as pesquisas e os relatórios oficiais $^{292}$ a que se refere este artigo somente serão admitidos como prova se (a.) houverem sido realizados com observância de métodos de avaliação internacionalmente adotados e (b.) se referirem a período contemporâneo com o de apuração da base de cálculo do imposto de renda da empresa brasileira". A questão referida em (a.) parece-nos adequada, sob pena de ser extraída a "robustez" dessa prova ${ }^{293}$. Já o requisito indicado em (b.) praticamente elimina a possibilidade de obtenção de tais provas: é óbvio que esse tipo de pesquisa demanda meses e até anos, de modo que nunca estará disponível ao tempo da transação examinada, em "período contemporâneo" com o de apuração do IRPJ no país. Reconhecendo esta situação, no âmbito da Instrução Normativa n. ${ }^{\circ}$ 243/02, foi inserida regra no sentido de que pesquisas de períodos diferentes são admitidas, desde que ajustadas em função da taxa de câmbio $^{294}$. Este único ajuste, contudo, pode não ser suficiente, porque as condições de mercado [a oferta e a procura, as tecnologias utilizadas, a disponibilidade de matérias-primas etc.] variam constantemente. Imagine-se, v.g., que um preço de exportação seja "testado" por meio de relatórios ou pesquisas elaboradas a partir dos preços praticados durante a crise mundial de 2009: claramente este preço não pode ser comparado com aqueles de 2007 ou 2010, provavelmente mais elevados. Um mero ajuste

\footnotetext{
${ }^{292}$ Apenas as declarações das autoridades do país da contraparte não estão expressamente consignadas neste $\S 1^{\circ}$, o que pode permitir-nos concluir que tais declarações não se sujeitariam às duas exigências adicionais indicadas nesse parágrafo do artigo 21 da Lei n. ${ }^{\circ}$ 9.430/96.

293 Saliente-se, a este passo, que também se discute quais seriam os "métodos de avaliação internacionalmente aceitos": há ampla liberdade ou devem as instituições restringir-se aos métodos divulgados pelos organismos internacionais? Filiamo-nos ao entendimento de Heleno Taveira TÔRRES, que sustenta que:

"Cremos, nada obstante esse entendimento ser compartilhado por outros estudiosos [o entendimento da liberdade de escolha dos métodos] existirem princípios internacionais de avaliação, identificados por instituições internacionais - inclusive pela Organização Mundial do Comércio - cujas atividades consistem na busca de uma harmonização dos critérios e métodos de avaliação utilizados pelos vários países, como é o caso, no campo da contabilidade, por exemplo, da International Accounting Standards Committee (IASC)" (Direito tributário internacional: planejamento tributário e operações transnacionais. op. cit., p. 268).

294 “Art. 29. (...) $\$ 3^{\circ}$ No caso de pesquisa relativa a período diferente daquele a que se referir o preço praticado pela empresa, o valor determinado será ajustado em função de eventual variação na taxa de câmbio da moeda de referência, ocorrida entre os dois períodos".
} 
no câmbio, assim, pode não ser bastante para tornar o documento apto a comprovar a regularidade dos preços praticados pelos contribuintes.

Por fim, há enorme preocupação com relação ao disposto no $\S 3^{\circ}$ do artigo 21 da Lei n. ${ }^{\circ}$ 9.430/96, o qual prevê a desqualificação, pelo Secretário da Receita Federal do Brasil, de publicações técnicas, pesquisas e relatórios considerados "inidôneos ou inconsistentes". Não há dúvidas de que as noções de inidoneidade e inconsistência são muitíssimo amplas e subjetivas, "deixando uma margem de discricionariedade que pode ir da liberdade ao arbítrio, sem cerimônias" $" 295$. Por conta disso, este dispositivo legal deve ser invocado com especial atenção, devendo ser, sempre, elaborado relatório que explique claramente por que há inidoneidade na prova apresentada, ou que liste as inconsistências ali localizadas. De fato, o afastamento de quaisquer provas produzidas pelos contribuintes para rebater as presunções contidas na lei deve ser acompanhado de motivação razoável e objetiva, de modo a se atender o quanto disposto nos artigos 31 do Decreto n. ${ }^{\circ} 70.235$, de 06.03.72, e 50 da Lei n. $^{\circ} 9.784$, de 29.01.99. Na verdade, esta regra vale para quaisquer provas ou indícios apresentados pelo contribuinte em seu favor: sua desqualificação como elemento integrante do conjunto probatório do processo deve ser, sem exceção e de forma sensata, racional e objetiva, fundamentada e justificada.

\subsection{Contabilidade segregada, ficção de independência e princípio da plena concorrência.}

Preliminarmente, importa ponderar que o controle dos preços de transferência pode ser implantado a partir de dois tipos de sistemática: (i.) o critério do exame do lucro "unitário" do grupo empresarial ("critério unitário" ou "métodos de partilha fracionada"), o qual necessariamente é sucedido pela partição desse resultado entre os membros do grupo, segundo fórmula que avalia previamente o peso de cada fator econômico envolvido na operação examinada [materiais e insumos empregados, riscos assumidos, folha de salários, quantidade de funcionários, receita bruta, giro de estoque, custo de reposição de ativos industriais etc.]; o fundamento econômico principal do critério unitário é a constatação de que, no âmbito dos grupos multinacionais, todas as empresas contribuem para um lucro

295 In: TÔRRES, Heleno Taveira; e UTUMI, Ana Claudia Akie. O Controle Fiscal dos Preços de Transferência e os Meios de Prova Admitidos para a Definição de Preços e Custos Médios. op. cit., p. 179. 
global, superior à soma da lucratividade de todos os entes ${ }^{296}$; e (ii.) o critério da contabilidade segregada, segundo o qual o Estado de residência de cada ente grava-o segundo os resultados lançados em sua própria contabilidade ("critério da contabilidade segregada"). Este último critério examina os membros de um grupo multinacional sob a mesma perspectiva utilizada para examinar entidades separadas, ignorando a forma coordenada por eles utilizada para a consecução de um "negócio único", as sinergias, os lucros adicionais gerados por grupos verticalmente integrados etc.. A abordagem da contabilidade segregada é o primeiro elemento para a adoção do princípio da plena concorrência. Com efeito, o "critério da contabilidade segregada" origina o "critério da entidade segregada", o qual representa uma verdadeira ficção de independência ${ }^{297}$ : embora as partes pertençam ao mesmo grupo econômico, assume-se que se trata de empresas nãovinculadas, atuando em ambiente de livre mercado. Via remissão, as normas fiscais e contábeis aplicáveis a terceiros independentes tornam-se obrigatórias para entidades que atuam com sociedades consideradas vinculadas ${ }^{298}$.

Para a implementação do princípio da plena concorrência, portanto, (i.) as empresas vinculadas precisam possuir contabilidade própria e segregada [critério da

\footnotetext{
296 "La primera posibilidad consiste en considerar a la empresa o grupo multinacional como un negocio unitario - 'unitary business' - y gravarlo de acuerdo con sus beneficios conjuntos. Este gravamen unitario se basa, por un lado, en la teoría de que las actividades económicas llevadas a cabo por cada una de las entidades que conforman la empresa o grupo multinacional (situadas en diferentes Estados) contribuyen al beneficio global, y, por otro lado, en la realidad económica de los efectos sinérgicos que se producen en el seno de las empresas o grupo multinacionales: 'el conjunto supera la suma de sus partes'. De esta forma, los Estados asumirían el denominado principio unitario mediante el cual la empresa o grupo multinacional tributaria por la totalidad de los beneficios obtenidos por todas las entidades pertenecientes a la misma, si tener en cuenta para su cálculo los derivados de las operaciones vinculadas.

Pero a la hora de la distribución de los rendimientos conjuntos de la empresa o grupo entre las distintas jurisdicciones fiscales implicadas en el tráfico vinculado, se aplicaría el método del reparto proporcional (también denominado método indirecto) con arreglo a una fórmula, esto es, los beneficios globales del negocio unitario se prorratearían entre los Estados afectados por las relaciones comerciales y financieras de la empresa o grupo multinacional en función de las actividades económicas realizadas bajo su jurisdicción, bien en combinación de costes, activos, ventas y salarios, bien través de una formula a determinar a la luz de los hechos y circunstancias del caso concreto" (GALVAÑ, Gemma Sala. op. cit., p. 52-53).

${ }^{297} \mathrm{O}$ critério da entidade segregada e o princípio da plena concorrência podem ser considerados, ambos, ficções legais, como se pode depreender da seguinte assertiva de Juan Ignacio Moreno FERNÁNDEZ:

"Con carácter general, toda cesión de bienes y derechos se entiende retribuida, aunque pudiéndose probar la gratuidad de la misma, no naciendo, en consecuencia, ingreso computable alguno (o gasto deducible) a efectos del Impuesto sobre Sociedades. Sin embargo, em el caso de tratarse de operaciones entre sociedades que, según la normativa, se puedan considerar como vinculadas, aquella presunción - antes iuris tantum pasa a convertirse en una presunción 'iuris et iure', o más correctamente, en una ficción legal, por lo que la prueba de la gratuidad de la operación realizada carece de relevancia, dado que, en todo caso, debe computarse por su precio de mercado entre partes independientes" (op. cit., p. 29).

${ }^{298} \mathrm{Na}$ doutrina internacional, o critério unitário também é referido sob a designação "método indireto", ao passo que o critério da contabilidade segregada é conhecido como "método direto". No âmbito do presente estudo, todavia, evitaremos a utilização destas denominações, de modo a evitar confusões com os métodos tradicionais diretos (CUP) e indiretos (RPM e CPM) que serão examinados no CAPÍTULO 4.
} 
contabilidade segregada], devendo ser adotada, pela legislação interna (ii.) a ficção da independência das empresas, de modo que (iii.) os preços parâmetro sejam estabelecidos comparando-se os preços praticados com aqueles preços que foram [ou seriam, hipoteticamente] praticados com terceiros independentes ou por terceiros independentes. $\mathrm{O}$ critério da entidade segregada utiliza a metodologia da "comparação transação-atransação", podendo envolver a comparação de preços, de margens brutas, da lucratividade operacional ou, ainda, a comparação de critérios de repartição de lucros que seriam adotados por terceiros independentes. O critério unitário, de outro lado, não envolve comparação, mas sim a aplicação de fórmulas, cujos fatores e critérios para a respectiva ponderação foram predeterminados. Apenas se inserem, nas fórmulas, os dados das operações reais praticadas pelos contribuintes, obtendo-se o preço parâmetro sem a necessidade de aferição de informações relativas a terceiros independentes.

Em sua Diretiva, a OCDE assegura que o critério da contabilidade segregada é praticamente um "consenso internacional” e destaca sua relação intrínseca com o princípio da plena concorrência [a ser estudado no CAPÍTULO 2], sustentando que este último presta-se a garantir a adequada aplicação do primeiro ${ }^{299}$. A OCDE sustenta, ademais, ser este o único critério admitido, demonstrando repulsa ao método unitário ${ }^{300}$. De fato, tanto os Estados-Membros da OCDE quanto nações com regulamentação que divergem em alguns aspectos daquela recomendada na Diretiva como, v.g., os Estados Unidos da América, têm utilizado a contabilidade segregada como o "critério-base" para a definição

\footnotetext{
299 "In order to apply the separate entity approach to intra-group transactions, individual group members must be taxed on the basis that they act at arm's length in their dealings with each other. However, the relationship among members of an MNE group may permit the group members to establish especial conditions in their intra-group relations that differ from those that would have been established had the group members been acting as independent enterprises operating in the open markets. To ensure the correct application of the separate entity approach, OECD Member countries have adopted the arm's length principle, under which the effect of special conditions on the level of profits should be eliminated" (OCDE. Transfer Pricing Guidelines for Multinational Enterprises and Tax Administrations, op. cit., p. P-2).

300 "1.13. (...) the view of OECD Member countries continues to be that the arm's length principle should govern the evaluation of transfer pricing among associated enterprises. The arm's length principle is sound in theory since it provides the closest approximation of the working of the open market in cases where goods and services are transferred between associated enterprises. While it may not always be straightforward to apply in practice, it does generally produce appropriate levels of income between the members of MNE groups, acceptable to tax administrations. This reflects the economic realities of the controlled taxpayer's particular facts and circumstances and adopts as a benchmark the normal operation of the market.

1.14. A move away from the arm's length principle would abandon the sound theoretical basis described above and threaten the international consensus, thereby substantially increasing the risk of double taxation. (...) In sum, OECD Member countries continue to support strongly the arm's length principle. In fact, no legitimate or realistic alternative to the arm's length principle has emerged. The global formulary apportionment approach, sometimes mentioned as a possible alternative, would not be acceptable in theory, implementation or practice" (OCDE. Transfer Pricing Guidelines for Multinational Enterprises and Tax Administrations, op. cit., p. I-6). Convertidos nos parágrafos 1.14 e 1.15 da Minuta-2009.
} 
de suas normas para o controle dos preços de transferência. Isso não significa, contudo, que ele seja "unanimemente" aceito; pelo contrário, há, na doutrina internacional, inúmeras críticas à natureza fluida e de aplicação extremamente complexa do princípio da plena concorrência, o qual poderia, como medida de Segurança Jurídica, tornar-se mais objetivo. As principais objeções a esse princípio serão discutidas no CAPÍTULO 6. Por ora, importa apenas salientar que, em situações específicas e subsidiárias como, e.g., a repartição de despesas no contexto da prestação de serviços intra-grupo ou dos acordos para contribuição com os custos, nas quais o princípio da plena concorrência for totalmente inaplicável, a Diretiva admite a utilização de fórmulas predeterminadas. Não há dúvidas de que, como regra, permanece o critério da contabilidade segregada, mas as duas sistemáticas podem, em certa medida, ser combinadas ${ }^{301}$.

Saliente-se, ainda a respeito dos critérios discutidos neste subitem, que a legislação brasileira prevê a regra da contabilidade segregada e a ficção de independência também para sucursais, filiais ou agências de sociedades estrangeiras, como se depreende da leitura do artigo 70 do Decreto-Lei n. ${ }^{\circ}$ 2.627, de 26 de setembro de 1940, c.c. artigo 143, II, do RIR-99 902 , equiparando estes entes a pessoas jurídicas residentes no país para fins de apuração do IRPJ e da $\operatorname{CSLL}^{303}$. A legislação brasileira não apenas reconhece a individualidade e a personalidade jurídica destes entes para todos os fins de direito, como, também, obriga-os à publicação, no país, tanto do balanço e demonstrativos de resultados dos entes aqui estabelecidos quanto do balanço global da empresa. Como quaisquer pessoas jurídicas estabelecidas no país, as sucursais, filiais ou agências de sociedades estrangeiras são organizações econômicas "reveladoras de capacidade contributiva".

\footnotetext{
301 “(...) it is worth noting that the transfer pricing and formulary apportionment are not mutually exclusive approaches but actually constitutes the opposite ends of a whole range of allocation methods and instruments. In many instances, those two approaches are combined. Generally, the US Treasury and the OECD Committee have explicitly added profit-based methods to their respective transfer pricing standards. In the general context of income taxation, formulaic methods for deductions are also used sometimes, e.g., where expenditures have no specific location or where entities of several jurisdictions share credits. The OECD Guidelines recognize the need for apportioning deductions, e.g. in the context of Intragroup services or cost contributions agreements. Furthermore, tax administrations and taxpayers increasingly try to reach advance pricing agreements (APAs), using specific formulae to allocate income in cases that are too complex to solve on a transactional basis, such as global trading or the multinational Airbus consortium" (MAYER, Stefan. op. cit., p. 12-13).

302 "Art. 147. Consideram-se pessoas jurídicas, para fins do disposto no inciso I do artigo anterior: (...) II - as filiais, sucursais, agências ou representações no País, das pessoas jurídicas com sede no exterior”. ${ }^{303}$ Sob a perspectiva exclusiva da legislação interna, aplicam-se a elas as regras para o controle dos preços de transferência, como se fossem pessoas jurídicas estabelecidas no país, transacionando com sua "controladora" estrangeira [no caso, matriz].
} 
Especificamente neste ponto, a legislação interna brasileira está em linha com o prescrito no Artigo $7^{\circ}$ da Convenção-Modelo ${ }^{304}$.

O critério da contabilidade segregada também é aplicável a investimentos brasileiros no exterior, seja via filiais, sucursais ou agências, seja por intermédio de subsidiárias, coligadas ou controladas, como se depreende do artigo 16, I, da Lei n. ${ }^{\circ}$ 9.430/96 $6^{305}$. Esse dispositivo legal, juntamente com os artigos $1^{\circ}$ da Lei n..$^{\circ}$ 9.249, de 26.12.95; $1^{\circ}$ da Lei n..$^{\circ}$ 9.532, de 10.12.97; e 74 da Medida Provisória n. ${ }^{\circ}$ 2.158-35, de 24.08.01, dentre outros, cuidam da disciplina da tributação dos lucros indiretamente auferidos no exterior; são essas as denominadas "Controlled Foreign Company Rules" ou simplesmente "Regras CFC". Por seu intermédio, afere-se o resultado do "ente" estrangeiro e, na sequiência, transporta-se tal resultado para os livros da matriz, controladora ou coligada brasileira, como se ele tivesse sido distribuído, num regime de total "transparência". Com efeito, a Medida Provisória n. ${ }^{\circ}$ 2.158-35/01 prevê que os lucros auferidos por controladas ou coligadas no exterior são proporcionalmente reconhecidos e tributados pela controladora/coligada no Brasil em 31.12 de cada ano-calendário ${ }^{306}$. Alguns autores sustentam que as Regras CFC destinam-se a complementar as regras para o controle dos preços de transferência, as quais evitariam apenas algumas das modalidades de manipulação de lucros utilizadas ${ }^{307}$; por conta disso, seria recomendável a criação simultânea destes tipos de normas. Por vezes, contudo, estas Regras CFC sobrepõem-se às regras para o controle dos preços de transferência, como se passa a demonstrar.

304 “Artigo 7. Lucros das empresas. (...)

2. Com a ressalva do disposto no n. 3 , quando uma empresa de um Estado contratante exercer a sua atividade no outro Estado contratante por meio de um estabelecimento estável aí situado, serão imputados, em cada Estado contratante, a esse estabelecimento estável, os lucros que este obteria se fosse uma empresa distinta e separada que exercesse as mesmas actividades ou actividades similares, nas mesmas condições ou em condições similares, e tratasse com absoluta independência com a empresa de que é estabelecimento estável" (tradução para a língua portuguesa extraída da obra OCDE. Modelo de Convenção Fiscal sobre o Rendimento e o Patrimônio. op. cit., p. 30).

305 “Art. 16. Sem prejuízo do disposto nos arts. 25, 26 e 27 da Lei n. ${ }^{\circ}$ 9.249, de 26 de dezembro de 1995, os lucros auferidos por filiais, sucursais, controladas e coligadas, no exterior, serão:

I - considerados de forma individualizada, por filial, sucursal, controlada ou coligada".

306 “Art. 74. Para fim de determinação da base de cálculo do imposto de renda e da CSLL, nos termos do art. 25 da Lei n. ${ }^{\circ}$ 9.249, de 26 de dezembro de 1995, e do art. 21 desta Medida Provisória, os lucros auferidos por controlada ou coligada no exterior serão considerados disponibilizados para a controladora ou coligada no Brasil na data do balanço no qual tiverem sido apurados, na forma do regulamento".

307 "However, transfer pricing is not only quite burdensome, it also seems to yield less satisfactory results. (...) Moreover, transfer pricing only addresses certain kinds of profit manipulations so that it is has been supplemented in many countries by other anti-avoidance regimes such as CFC legislation or provisions on thin capitalization, again adding to complexity and compliance burdens" (MAYER, Stefan. op. cit., p. 17). 
Suponha-se que uma determinada companhia mantenha relações comerciais com sua subsidiária no exterior, operações essas que se sujeitaram a ajuste de preços de transferência de 100 [Preço praticado (200) (-) Preço de mercado (100) (=) Parcela indedutível do custo de importação (100)]. Este ajuste representou, na prática, a tributação no país de lucro que foi contabilizado pela subsidiária no exterior; houve uma "realocação" do lucro de 100 da subsidiária para a controladora. Quando da aplicação das Regras CFC, este mesmo lucro, contabilizado no exterior mas "realocado" para o país, será, novamente, lançado no LALUR da controladora brasileira, como se tivesse sido disponibilizado pela subsidiária, gerando-se uma bitributação econômica do rendimento [a controladora brasileira reconhece um lucro "extra" por conta das regras para o controle dos preços de transferência e um rendimento de participação societária no exterior, a um mesmo tempo]. Para melhor elucidação desta sobreposição de normas, confira-se o esquema abaixo:

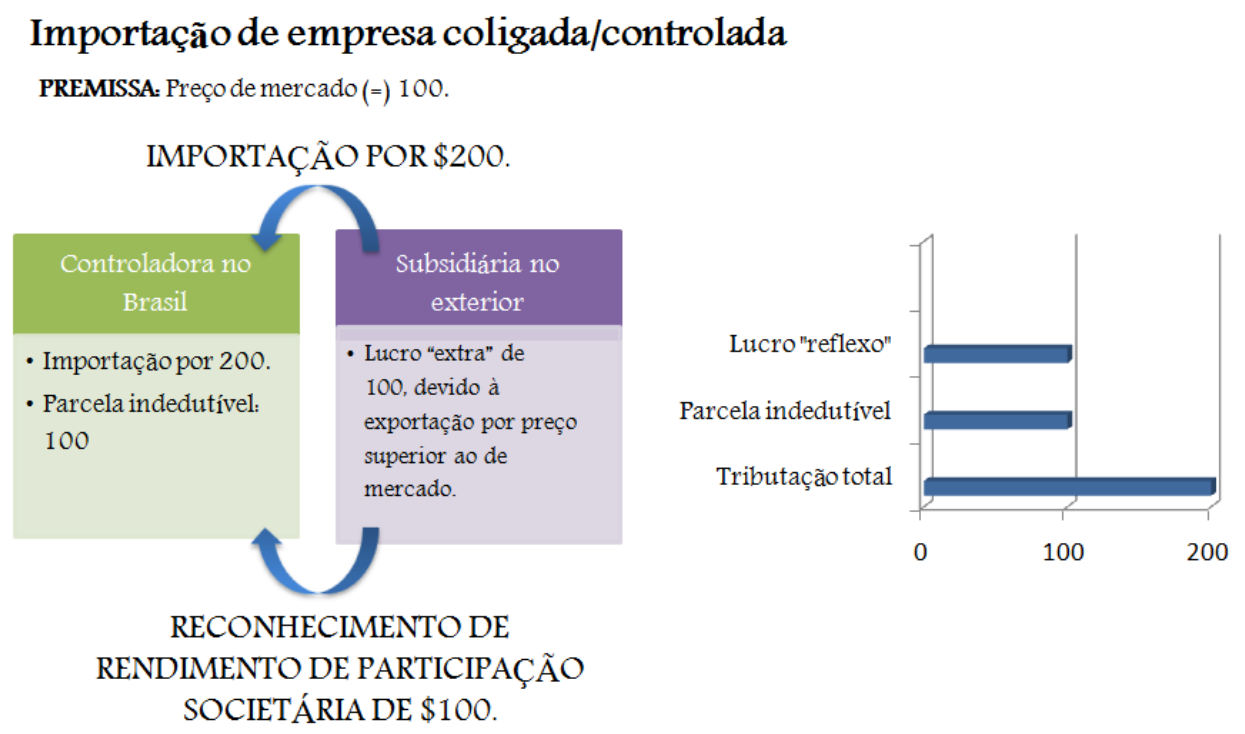

O exemplo supra envolve a importação, por uma controladora brasileira, de bens de sua subsidiária no exterior. Mas o mesmo raciocínio aplica-se a operações de exportação para subsidiárias no exterior, a preços inferiores àqueles que seriam praticados entre empresas independentes. Nesta hipótese, se, v.g., a controladora brasileira exportar para sua subsidiária um produto $X$, ao preço de $\$ 50$, sendo que o preço de mercado de $X$ seria de $\$ 100$, as autoridades brasileiras arbitrarão um lucro tributável adicional de \$50 no país, em virtude da aplicação do artigo 19 da Lei n. ${ }^{\circ}$ 9.430/96, e, quando o resultado da subsidiária no exterior for reconhecido no Brasil, em 31.12 daquele ano, estes mesmos $\$ 50$ serão tributados na esfera jurídica da controladora, pela segunda vez. 
Comprovada a possibilidade de sobreposição das Regras CFC e das normas para o controle dos preços de transferência, apta a gerar a "bitributação econômica" de um mesmo rendimento, importa salientar que tal bitributação [ajuste de preço de transferência (+) rendimento de participação societária] não é coerente nem compatível com os valores e princípios constitucionais que regem o ordenamento tributário brasileiro ${ }^{308}$; de fato, apenas existe autorização constitucional para a incidência do imposto sobre "uma renda"; o seu "segundo reconhecimento" no LALUR da controladora não representa uma nova "renda", mas tão-somente possibilita a incidência do imposto sobre algo já incluído em sua base imponível. Em virtude disso, a legislação brasileira deve prever norma específica para a “compatibilização" das duas sistemáticas.

Em princípio, parece ser possível tanto a previsão, nas Regras CFC, de exclusão do valor dos ajustes de preços de transferência do total do "lucro disponibilizado", quanto a determinação de não-aplicação dos ajustes de preços de transferência nas hipóteses em que o lucro "não-contabilizado" no país tenha sido reconhecido sob a rubrica "rendimentos de participações societárias". Importa reconhecer, a este passo, a posição de Luís Eduardo SCHOUERI, que sustenta a prevalência das regras para o controle dos preços de transferência e o afastamento do rendimento calculado nos termos das Regras CFC nas hipóteses em que se verificar a bitributação econômica dos rendimentos ${ }^{309}$. Realmente, parece-nos ser esta a alternativa mais adequada, porque é possível que os ajustes sejam

\footnotetext{
${ }^{308}$ Luís Eduardo SCHOUERI sustenta ser esta bitributação uma discriminação injustificada e odiosa, não compatível com os critérios que devem reger a aferição da capacidade econômica tributável. Veja-se:

"Ora, aplicando-se o exposto ao caso concreto, observa-se que eventual aplicação das regras CFC às situações já oneradas por incidência tributária anterior (com base na legislação de Preços de Transferência) implicaria discriminação das empresas brasileiras que mantêm controladas ou coligadas no exterior e importam produtos destas, em relação às empresas que apenas mantêm controladas ou coligadas.

De fato, ambos os grupos de empresas seriam obrigadas a tributar os lucros de suas controladas ou coligadas, em virtude da aplicação das regras CFCs; todavia, aquelas que também importam produtos de suas controladas ou coligadas teriam que tributar os lucros apurados nas importações com base nos ajustes de preços de transferência. Haveria, assim, a adoção de um discrime desarrazoado (sem qualquer fundamentação jurídica) para incidência por duas vezes de tributação, qual seja o mero fato de a empresa brasileira importar produtos de sua vinculada" [SCHOUERI, Luís Eduardo. Aplicação Concomitante da Legislação de Preços de Transferência e da Tributação do Lucro em Bases Mundiais. In: Heleno Taveira Tôrres (coord.), Direito Tributário Internacional Aplicado, Volume III. São Paulo: Quartier Latin, Primavera de 2005, p. 254].

309 "Ora, admitindo-se a conclusão de que tais lucros não teriam sido auferidos no exterior, e sim no País, parece correto afirmar que não haverá causa jurídica (i.e., fundamento jurídico) para a aplicação das regras CFC à situação sob análise.

De fato, consoante dispõe o parágrafo $2^{\circ}$ do artigo supramencionado, são computados na determinação do lucro real das pessoas jurídicas brasileiras 'os lucros, rendimentos e ganhos de capital auferidos no exterior' (g.n.). Tendo-se em vista as considerações supra apresentadas, parece que, sendo o lucro da operação sob análise auferido no Brasil, e tributado com base nas regras de preços de transferência, resta afastada a aplicabilidade das regras CFCs a tal operação" (SCHOUERI, Luís Eduardo. Aplicação Concomitante da Legislação de Preços de Transferência e da Tributação do Lucro em Bases Mundiais. op. cit., p. 246).
} 
superiores aos lucros que a controlada teria a distribuir para sua controladora; fosse adotada a hipótese inversa, não seria aferida a real capacidade econômica do contribuinte brasileiro. Imagine-se que todos os lucros de uma determinada operação foram concentrados na esfera jurídica de controlada no exterior, a qual incorreu em prejuízos por conta de outros negócios, praticados com terceiros; neste exemplo, somente a aplicação das regras dos preços de transferência seria apta para garantir a tributação no país do "lucro real" das operações. Também em situações envolvendo coligadas, parece-nos mais adequada esta alternativa: suponha-se que uma empresa brasileira pratique preços sempre $60 \%$ menores que os preços de mercado nas operações com coligada estrangeira, na qual detém participação de 30\%; o "prejuízo" da coligada brasileira seria, conforme definido pelas partes, compensado com benefícios futuros; nesta hipótese, como as Regras CFC abrangerão apenas $30 \%$ dos lucros da coligada, existe a possibilidade de seu valor ser inferior ao valor dos ajustes que seriam reconhecidos na aplicação das regras para o controle dos preços de transferência. 


\section{CAPÍTULO 2. PRINCÍPIO DA PLENA CONCORRÊNCIA.}

\subsection{Abrangência e conteúdo do princípio da plena concorrência.}

\subsubsection{Noções gerais.}

Considera-se respeitado o princípio da plena concorrência sempre que se estabelecerem, nos negócios jurídicos celebrados entre partes relacionadas, os preços e as condições comerciais e financeiras esperados em transações similares, realizadas sob as mesmas circunstâncias, entre partes independentes. A adoção do princípio da plena concorrência indica, portanto, a desejável aproximação dos preços praticados entre partes vinculadas com aqueles apurados segundo as forças de habitual atuação no mercado, sem interferência de elementos endógenos dos grupos econômicos; justamente por conta desta característica é que o preço parâmetro obtido a partir dos métodos amparados neste princípio é também denominado "preço de livre mercado". Este princípio consta expressamente do Artigo $9^{\circ}$ da atual Convenção-Modelo da $\operatorname{OCDE}^{310}$, cujo texto, inalterado desde a Convenção-Modelo de 1963, prevê o seguinte:

“Artigo 9. Empresas Associadas.

1. Quando:

a) Uma empresa de um Estado contratante participar, directa ou indirectamente, na direcção, no controle ou no capital de uma empresa do outro Estado contratante, ou

b) As mesmas pessoas participarem, directa ou indirectamente, na direcção, no controle ou no capital de uma empresa de um Estado contratante e de uma empresa do outro Estado contratante,

e em ambos os casos, as duas empresas, nas suas relações comerciais ou financeiras, estiverem ligadas por condições aceites ou impostas que defiram das que seriam estabelecidas entre empresas independentes, os lucros que, se não existissem essas condições, teriam sido obtidos por uma das empresas, mas não o foram por causa dessas condições, podem

\footnotetext{
${ }^{310}$ O princípio da plena concorrência também regula a definição dos preços praticados intra-empresa, razão pela qual também encontra amparo no Artigo 7, parágrafo 2, da Convenção-Modelo.
} 
ser incluídos nos lucros dessa empresa e, conseqüentemente, tributados" $" 311$.

Como se depreende do quanto disposto no Artigo 9, parágrafo 1, quando empresas associadas estabelecerem, em suas transações de qualquer natureza ${ }^{312}$, determinadas condições, negociadas livremente ou impostas por uma das partes ${ }^{313}$, que difiram daquelas que seriam estabelecidas entre empresas independentes, os lucros respectivos poderão ser ajustados, para fins tributários, de modo que reflitam estas últimas. Portanto, um "ajuste de preços de transferência" será adequado apenas se refletir a replicação das condições comerciais e financeiras que seriam observadas entre empresas independentes em operações idênticas e circunstâncias análogas. O conceito econômico primordial de que se vale o princípio da plena concorrência é o seguinte: terceiros independentes sempre buscam a maximização dos seus lucros ${ }^{314}$, examinando, a cada instante, todas as alternativas disponíveis no mercado ${ }^{315}$; nesse contexto, se uma empresa $\mathrm{X}$, fabricante de uma determinado produto semi-acabado que possui custo de $\$ 2$, puder

311 Tradução para a língua portuguesa extraída da obra OCDE. Modelo de Convenção Fiscal sobre o Rendimento e o Patrimônio. op. cit., p. 31.

312 "It is hardly possible to draw a line between commercial relations and financial relations. Those terms take account of different possibilities of exchanging goods, services etc. between associated enterprises. Financial relations are primarily relationships between associates and evolving from company law and extending to cover situations like payment or constructive dividends and concealed equity contributions. Commercial relations exist between enterprises if they deal with one another as participants in a competitive economy. The relations must be of a cross-frontier nature, so that relations between a domestic company or partnership in its shareholders or partners can, as a rule, not fall within the scope of the treaty provision" (VOGEL, Klaus. Klaus Vogel on Double Taxation Conventions. op. cit., p. 526).

313 "Conditions made are those that come into being as a result of either enterprise exercising its, or both of them there, owns free will. Such conditions also include mutual agreed practices. Imposed conditions are those which result from the influence which stems from company law and which is exercised by a person or persons participating in both enterprises, as envisaged in Art 9 (1)(b). In particular, conditions which are adopted following concern guidelines are included (VOGEL, Klaus. Klaus Vogel on Double Taxation Conventions. op. cit., p. 527).

314 "The main economic concept behind the arm's length principle is that all parties to a business transaction seek to maximize their profit. This is observable when the parties are not related, and so the idea has taken root that for tax purposes the same should apply when the parties are related. What this means in practice is that each party to an intra-group transaction is expected to make a profit (if not in the short term, then at least in the long run) from a transaction commensurate with the functions performed, risks assumed and assets utilized" (ADAMS, Chris; COOMBES, Richard. Global Transfer Pricing. Principles and Practice. Londres: Tottel Publishing, 2007, p. 3).

315 "1.15. (...) Independent enterprises, when evaluating the terms of a potential transaction, will compare the transaction to the other options realistically available to them, and they will only enter into the transaction if they see no alternative that is clearly more attractive. For example, one enterprise is unlikely to accept a price offered for its product by an independent enterprise if it knows that other potential customers are willing to pay more under similar conditions. This point is relevant to the question of comparability, since independent enterprises would generally take into account any economically relevant differences between the options realistic available to them (such as differences in the level of risk or other comparability factors discussed below) when evaluating these options" (OCDE. Transfer Pricing Guidelines for Multinational Enterprises and Tax Administrations. op. cit., p. I-7). Correspondente ao item 1.34 da Minuta-2009. 
processá-lo pelo custo adicional de $\$ 1$ e alienar toda a sua capacidade produtiva pelo preço unitário de \$10, obtendo-se um lucro de \$7 [10 (-)\$2 (-)\$1 (=)\$7], não aceitará uma oferta de $\$ 5$ proveniente de um determinado concorrente Z. Sob o ponto de empresarial “egoístico", será mais vantajoso a X o processamento do produto semi-acabado e a venda do produto final por $\$ 10$, ao invés da alienação do produto semi-acabado por 5 . A maisvalia gerada pelo processo industrial será internalizada por $X$, e não repassada a $Z$, a não ser que condições objetivas ou a possibilidade de lucratividade a longo prazo justifiquem esta decisão. Da mesma forma, qualquer empresa, atuando em condições de livre mercado, pesquisa fornecedores e avalia preços, condições de pagamento, qualidade, reputação do fornecedor etc..

Ressalve-se, contudo, que as empresas independentes comparam uma transação com outras realisticamente existentes no mercado, e não com operações que "em teoria" seriam possíveis; quaisquer operações que não estavam disponíveis às partes relacionadas [ou não eram perceptíveis] no momento da transação controlada, assim, devem ser prontamente descartadas, não servindo como dado comparável.

Saliente-se, a este passo, que tanto o Artigo 9 da Convenção-Modelo da ONU quanto o Artigo 9 da atual minuta de convenção dos Estados Unidos da América ["US Model Income Tax Convention"] têm conteúdo idêntico ao do dispositivo da OCDE supra transcrito. A legislação norte-americana contém, inclusive, referência expressa ao princípio da plena concorrência em sua legislação interna ${ }^{316}$. Especificamente no que concerne às convenções para evitar a bitributação da renda celebradas pelo Brasil, pondere-se que também elas têm o seu Artigo 9 com conteúdo idêntico ao da Convenção-Modelo da $\mathrm{OCDE}^{317}$. Dentre as alternativas disponíveis para o controle do nível de ingerência das demais empresas de um mesmo grupo econômico nos preços praticados por um certo agente, portanto, não há dúvidas de que a análise do atendimento, em cada caso concreto,

\footnotetext{
316 " \$1.482-1 (b) (1) In general. In determining the true taxable income of a controlled taxpayer, the standard to be applied in every case is that of a taxpayer dealing at arm's length with an uncontrolled taxpayer. A controlled transaction meets the arm's length if the results of the transaction are consistent with the results that would have been realized if uncontrolled taxpayers had engaged in the same transaction under the same circumstances (arm's length result). However, because identical transactions can rarely be located, whether a transaction produces an arm's length result generally will be determined by reference to the results of comparable transactions under comparable circumstances. See \$1.482-1 (d) (2) (Standard of Comparability). Evaluation of whether a controlled transaction produces an arm's length result is made pursuant to a method selected under the best method rule described in §1.482-1 (c)" [26 CFR Ch. I (4-1-09 Edition)].

${ }^{317}$ A única exceção a esta regra é a Convenção para Evitar a Dupla Tributação em Matéria de Impostos sobre Rendimentos, concluída entre a República do Brasil e o Japão, assinada em Tóquio em 24.01.67, portanto, antes do modelo de 1977, que contém regra semelhante no seu Artigo $7^{\circ}$.
} 
das regras que emanam do principio da plena concorrência, é a que tem tido maior aceitação em nível mundial nas últimas décadas. Esta circunstância pode ser claramente verificada, também, a partir do relato histórico tecido no CAPÍTULO 1. Nas orientações contidas em sua Diretiva, a OCDE sustenta, categoricamente, que o princípio da plena concorrência representa a norma internacionalmente acordada entre os países para a determinação dos preços de transferência, sendo, ademais, o único critério possível para os ajustes dos referidos $\operatorname{preços}^{318}$. Este princípio seria, por conseguinte, praticamente um "dogma" de direito tributário internacional, podendo ser citado como a "espinha dorsal" da problemática dos preços de transferência ${ }^{319}$.

Para a sua aplicação não é suficiente, todavia, a previsão do princípio da plena concorrência nas convenções bilaterais. Consoante salientado por Klaus VOGEL, as convenções não "criam” tributos, mas tão-somente restringem a aplicação da lei interna ${ }^{320}$; para que seja possível a realização de ajustes nos preços de transferência com amparo em tal princípio, portanto, é imprescindível sua reflexão no direito interno, que deverá estabelecer os métodos e parâmetros para a sua aplicação. Os acordos disciplinam as designadas "distributive rules" 321 ; se a competência para a tributação de um certo rendimento incumbe a uma determinada nação, a administração tributária dessa última deverá atuar segundo a sua legislação interna, e não exigir tributos [ou efetivar ajustes de preços de transferência] com fundamento em acordos ${ }^{322}$. A convenção destina-se tãosomente a proibir ajustes em desacordo com o princípio da plena concorrência, de modo a evitar a bitributação econômica da renda.

A importância da compreensão do conteúdo do princípio da plena concorrência advém da sua utilidade para a fiscalização, por parte das autoridades tributárias, do processo de formação dos preços praticados entre partes relacionadas, seguido da

\footnotetext{
${ }^{318}$ In: OCDE. Transfer Pricing Guidelines for Multinational Enterprises and Tax Administrations, op. cit., p. I-6, item 1.13 e 1.14. Entendimento constante dos itens 1.14 e 1.15 da Minuta-2009.

${ }^{319}$ Expressão utilizada por TORRES, Ricardo Lobo. O Princípio Arm's Length, os Preços de Transferência e a Teoria da Interpretação do Direito Tributário. op. cit., p. 122.

320 "When considering the treaty rules corresponding to Art. 9, it should again be noted that DTCs merely restrict, rather than generate, domestic law. The first conclusion to be drawn from this is that Art. 9 by itself cannot be an independent legal basis for upward income adjustments (...). The only legal basis for profit adjustments between associated enterprises are, therefore, the rules of domestic law. (...) The profits adjustments provisions make sense only if they are taken to have the same significance as DTC rules generally, viz. that they restrict domestic law" (VOGEL, Klaus. Klaus Vogel on Double Taxation Conventions. op. cit., p. 521-522).

${ }^{321}$ In: VOGEL, Klaus. Klaus Vogel on Double Taxation Conventions. op. cit., p. 518.

${ }^{322}$ A relação entre o princípio da plena concorrência prescrito no Artigo $9^{\circ}$ da Convenção-Modelo e a legislação interna brasileira será examinada nas subseções 2.3 a 2.5 , infra.
} 
comparação com os preços que se estabeleceriam no livre mercado para apurar, por conseguinte, se há desvio de resultados tributáveis para países com tributação mais favorecida da renda. O cerne da aplicação do princípio da plena concorrência está, assim, na comparação de operações. Considerando-se a experiência internacional acumulada nas últimas décadas, sabe-se que este princípio garante a efetividade no "teste" dos preços de transferência da grande maioria das situações. Sempre que inexistirem dados comparáveis, contudo, sua aplicação tornar-se-á mais complexa. Deste modo, a verificação dos preços de transferência em grupos que atuam de forma integrada para a consecução de produtos financeiros de negociação global ou para a produção de bens altamente especializados, que envolvem diretamente intangíveis únicos e exclusivos, v.g., apresenta um desafio às autoridades tributárias $^{323}$. Nestas hipóteses, praticamente inexistem dados sobre operações independentes; e, se não há informações sobre operações praticadas por terceiros, deve-se passar ao exame de como terceiros independentes hipoteticamente atuariam em condições e circunstâncias análogas. A partir desta sistemática, entende-se que a aplicação do princípio da plena concorrência é apta a produzir um nível de renda adequado para os grupos econômicos e aceitável para as administrações tributárias. O tema dos preços de transferência não é, obviamente, comparável a uma "ciência exata"; com fundamento neste argumento é que a OCDE sustenta que, sempre, haverá algum nível razoável e confiável de informações para o "teste" do preço praticado.

Mas, se a comparabilidade é a melhor qualidade do princípio da plena concorrência, sendo, inclusive, a principal justificativa para a sua adoção ${ }^{324}$, também é nela

323 "1.13. Both tax administrations and taxpayers often have difficulty in obtaining adequate information to
apply the arm's length principle. Because the arm's length principle usually requires taxpayers and tax
administrations to evaluate uncontrolled transactions and the business activities of independent enterprises,
and to compare these with the transactions and activities of associated enterprises, it can demand a substantial
amount of data. The information that is accessible may be incomplete and difficult to interpret; other
information, if it exists, may be difficult to obtain for reasons of its geographical location or that of the
parties from whom it may have to be acquired. In addition, it may not be possible to obtain information from
independent enterprises which could be relevant may simply not exist, or there may be no reasonable reliable
comparable independent enterprises, e.g., if that industry has reached a high level of vertical integration. It is
important not to lose sight of the objective to find a reasonable estimate of an arm's length outcome based on
reasonably reliable information. (...) It should also be recalled at this point that transfer pricing is not an
exact science but does require the exercise of judgment on the part of both the tax administration and
taxpayer" (OCDE. Proposed Revision of Chapters I-III of the Transfer Pricing Guidelines. $9^{\text {th }}$ September
2009- $9^{\text {th }}$ January 2010 . op. cit., p. 7$)$. Item alterado, correspondente a parte do item 1.12 da Diretiva.
324 " 1.7 . There are several reasons why OECD Member countries and other countries have adopted the arm's
length principle. A major reason is that arm's length principle provides broad parity of tax treatment for
members of MNE groups and independent enterprises. Because the arm's length principle put associated and
independent enterprises on a more equal footing for tax purposes, it avoids the creation of tax advantages or
disadvantages that would otherwise distort the relative competitive positions of either type of entity" (OCDE. 
que estão focadas as principais críticas a esta sistemática, sobressaindo-se (i.) a impossibilidade de ponderação dos ganhos de escala a partir desta técnica; (ii.) os elevados custos administrativos envolvidos, (iii.) a subjetividade e fluidez do princípio, que gera insegurança jurídica e espaço para o arbítrio etc. ${ }^{325}$. Não obstante todas essas críticas, os Estados-Membros da OCDE, na Minuta-2009, reiteraram que ainda existe um consenso no âmbito da organização a respeito da necessária aplicação do princípio da plena concorrência como o único norte para o controle dos preços de transferência ${ }^{326}$.

\subsubsection{Ressalva brasileira ao Artigo 9², parágrafo 2, da Convenção-}

\section{Modelo.}

O parágrafo 2 do Artigo $9^{\text {o327 }}$ foi introduzido na minuta de Convenção-Modelo da OCDE em 1977 e tem por escopo, primordialmente, evitar-se a bitributação econômica da renda ${ }^{328}$. Na verdade, o Artigo $9^{\circ}$ sequer constaria da Convenção-Modelo não fosse esse o seu fim. Diz-se "bitributação econômica", e não "jurídica”, porque uma mesma renda seria tributada por dois contribuintes distintos, a despeito de vinculados ${ }^{329}$. Com efeito, se a

Transfer Pricing Guidelines for Multinational Enterprises and Tax Administrations, op. cit., p. I-3). Convertido no item 1.8 da Minuta-2009.

${ }^{325}$ As críticas ao princípio da plena concorrência serão examinadas no CAPÍTULO 6.

326 “1.32. (...) OECD member countries reiterate their support for the consensus on the use of arm's length principle that has emerged over the years among member and non-member countries and agree that the theoretical alternative to the arm's length principle represented by global formulary apportionment should be rejected" (OCDE. Proposed Revision of Chapters I-III of the Transfer Pricing Guidelines. $9^{\text {th }}$ September 2009- $9^{\text {th }}$ January 2010. op. cit., p. 13). Item alterado, correspondente a parte do item 3.74 da Diretiva.

327 “Artigo $9^{\circ}$ (...)

2. Quando um Estado contratante incluir nos lucros de uma empresa deste Estado - e tributar nessa conformidade - os lucros pelos quais uma empresa do outro Estado contratante foi tributada neste outro Estado, e os lucros incluídos deste modo constituírem lucros que teriam sido obtidos pela empresa do primeiro Estado, s e as condições impostas entre as duas empresas tivessem sido as condições que teriam sido estabelecidas entre empresas independentes, o outro Estado procederá ao ajustamento adequado do montante do imposto cobrado sobre os lucros referidos.

$\mathrm{Na}$ determinação deste ajustamento, serão tomadas em consideração as outras disposições desta Convenção e as autoridades competentes dos Estados contratantes consultar-se-ão, se necessário" (tradução para a língua portuguesa extraída da obra OCDE. Modelo de Convenção Fiscal sobre o Rendimento e o Patrimônio. op. cit., p. 32).

328 "In essence, however, there is a close connection with the typical distributive rules inasmuch as Art. 9 concerns the question of whether an element of profits which has been (or possibly will be) subjected to tax in the foreign contracting State may nevertheless be attributed to, and taxed in the hands of, a domestic enterprise. Consequently, Art. 9 is designed to avoid economic double taxation" (VOGEL, Klaus. Klaus Vogel on Double Taxation Conventions. op. cit., p. 518).

${ }^{329}$ Segundo ponderado por Klaus VOGEL, a bitributação econômica teria o seguinte significado:

"In contrast, the term 'economic double taxation' is used to describe the situation that arises when the same economic transaction, item of income or capital is taxed in two or more States during the same period, but in the hands of different taxpayers (...). Further, economic double taxation can result from conflicting rules regarding the inclusion or deduction of positive and negative elements of income and capital as, for example, in cases of transfer pricing" 
nação $X$ procede a um ajuste de preços de transferência no valor de $\$ 10$ contra o contribuinte A1, essa mesma renda \$10 será "realocada" contábil e fiscalmente para a nação $\mathrm{X}$, a despeito de ter sido originalmente contabilizada [e tributada] na nação $\mathrm{Y}$, onde está estabelecido o contribuinte A2, vinculado a A1. Se as autoridades tributárias de X e Y não alcançarem um acordo a respeito do preço de plena concorrência aplicável, a operação resultará em bitributação econômica, i.e., na pretensão, por parte de dois países, sobre a mesma grandeza. Da leitura do parágrafo $2^{\circ}$ do Artigo $9^{\circ}$, portanto, pode-se concluir que o princípio da plena concorrência não tem apenas uma conotação positiva de garantir determinados ajustes por um Estado, mas também uma conotação negativa, no sentido de que o outro Estado precisa ajustar o lucro por ele tributável, de forma a não tributar duplamente o lucro alvo de ajuste ${ }^{330}$.

No Artigo 9, parágrafo 2, da Convenção-Modelo, estão previstos os critérios para a realização de ajustes por uma certa jurisdição, com o objetivo de se evitar a bitributação econômica daquela renda pelo outro país envolvido. Em suma, se o país X, com amparo no princípio da plena concorrência, efetua um "ajustamento primário" de preços de transferência na empresa $\mathrm{A} 1$, deve comunicar às autoridades tributárias do país Y, para que o lucro tributável de A2 seja reduzido naquele mesmo montante do ajustamento primário, mediante a realização de um "ajustamento correlativo"331. Em algumas jurisdições, admite-se que o próprio contribuinte A2 efetue este ajuste, mediante a indicação de um "lucro ajustado" em suas declarações do imposto sobre a renda; esse

\footnotetext{
A bitributação jurídica, por outro lado, poderia ser explicada a partir das seguintes ponderações:

"International juridical double taxation can be generally defined as the imposition of a comparable taxes in two (or more) States on the same taxpayer in respect of the same subject matter and for identical periods. Its harmful effects on the exchange of goods and services and movements of capital, technology and persons are so well known that it is scarcely necessary to stress the importance of removing the obstacles that double taxation presents to the development of economic relations between countries"

(VOGEL, Klaus. Klaus Vogel on Double Taxation Conventions. op. cit., p. 10 e 02).

${ }^{330}$ In: SCHOUERI, Luís Eduardo. Preços de transferência e acordos de bitributação. op. cit., p. 66. Ainda no que concerne ao afastamento da bitributação econômica como escopo do Artigo $9^{\circ}$, parágrafo $2^{\circ}$, da Convenção-Modelo, esse autor explica, nesse mesmo artigo, que:

"Diversamente do que acontece nos demais dispositivos dos acordos de bitributação, nota-se que, aqui, apenas a bitributação efetiva é evitada, não a virtual. Isso significa que o texto da convenção modelo exige que se comprove que o outro Estado efetivamente se valeu da prerrogativa que lhe confere o artigo $9^{\circ}$ e tributou o lucro que o contribuinte sob sua soberania não auferiu exclusivamente em razão do vínculo com outra empresa" (op. cit., p. 67).

${ }^{331}$ Existe, ademais, a possibilidade de realização de um "ajuste secundário".

O ajuste primário altera o lucro tributável, mas não o trânsito de recursos financeiros da operação. No ajuste secundário, de outro lado, os "novos" preços pós-ajustes devem ser refletidos nos caixas das empresas envolvidas, o que pode gerar nova tributação envolvendo, v.g., a retenção de imposto de renda na fonte sobre as remessas. Por sua complexidade, os ajustes secundários não são recomendados pela OCDE (OCDE. Transfer Pricing Guidelines for Multinational Enterprises and Tax Administrations, op. cit., parágrafos 4.67 a 4.77, p. IV-22 a IV-26).
} 
ajuste, realizado diretamente pelo contribuinte, é denominado "ajustamento compensatório".

A despeito de o parágrafo 2 do Artigo $9^{\circ}$ destinar-se justamente a evitar a bitributação econômica, i.e., servir para eliminar a dupla incidência no âmbito de uma "convenção para evitar a bitributação da renda", o Brasil reservou-se o direito de não incluir esse parágrafo 2 nas convenções que firmar a partir do texto da Convenção-Modelo. $\mathrm{Na}$ verdade, seja por conta de tal ressalva, seja porque sete das convenções brasileiras foram celebradas antes de 1977, não consta de nenhuma delas o parágrafo 2 do Artigo $9^{\circ}$ da Convenção-Modelo, de forma que o país não se considera obrigado a enviar comunicados relativos a ajustes primários ou a respeitar/negociar a implementação de ajustes correlativos $^{332}$. As regras brasileiras para o controle dos preços de transferência estão, assim, muito mais vinculadas ao combate à elusão e fraude fiscais do que propriamente à eliminação da dupla tributação econômica.

Ainda a respeito do parágrafo 2 do Artigo 9 da Convenção-Modelo, importa destacar que, no âmbito da II Jornada Tributária do Mercosul, realizada em out./97 em São Paulo, deliberou-se a respeito da Resolução n. ${ }^{\circ}$ 12, a qual sugeria o seguinte: "É imprescindível que as autoridades fazendárias dos Estados-membros do Mercosul atuem de forma consistente, a fim de minimizar as possibilidades do estabelecimento de um dispendioso contencioso entre as nações, derivado de interpretações divergentes sobre as regras do preço de transferência em cada uma das jurisdições consideradas, inclusive no que se refere à aplicação eficiente do denominado ajuste correlativo [corresponding ou appropriate adjustment], a fim de se evitar, na maior extensão possível, a dupla ou múltipla tributação de um mesmo rendimento"333. Não foi divulgado, todavia, nenhum progresso dos países do Mercosul a respeito desse assunto.

\footnotetext{
${ }^{332}$ Por decorrência disso, o tema dos ajustes primário, correlativo e compensatório não será objeto de exame detalhado nesta tese.

${ }^{333}$ As Resoluções sobre o tema "O preço de transferência (transfer pricing) no Mercosul" constam de RODRIGUES DO AMARAL, Antonio Carlos. O preço da transferência (transfer pricing) no Mercosul - II Jornada Tributária do Mercosul. Cadernos de Direito Tributário e Finanças Públicas. São Paulo: Revista dos Tribunais, ano 6, n. 22, jan./mar. 1998, p. 242-243.
} 


\subsection{Função essencial da "análise de comparabilidade" na aplicação do princípio da plena concorrência.}

O princípio da plena concorrência envolve a comparação dos preços e condições praticados em operações controladas com os preços e condições praticados [ou que seriam hipoteticamente praticados] em operações não-controladas que sejam idênticas ou muito semelhantes, i.e., com as denominadas "transações independentes comparáveis"334. A "essência" do princípio da plena concorrência está, assim, (i.) no exame detalhado das transações controladas [operações "testadas"]; (ii.) na procura de operações não-controladas que sejam suficientemente semelhantes [ou que se tornem suficientemente semelhantes após ajustes acurados e precisos] e que possam ser confrontadas com as transações controladas; e (iii.) na comparação das transações independentes comparáveis com as transações controladas, de modo a aferir a necessidade de reconhecimento de ajustes no cálculo do imposto sobre a renda. Note-se que, tão importante quanto a busca dos dados comparáveis, é o correto entendimento da transação efetivada pelo contribuinte ${ }^{335}$. O procedimento descrito nos passos (i.) a (iii.) é denominado "análise de comparabilidade". Essa análise encontra fundamento no Artigo 9, parágrafo 1 , da Convenção-Modelo ${ }^{336}$.

Saliente-se, a esse passo, que o princípio da plena concorrência assenta-se na comparação entre as transações praticadas entre partes vinculadas, de um lado, e entre partes independentes, de outro. Mas não são apenas as transações em si que são comparáveis: também as condições, i.e., as características economicamente relevantes em que se deram tais relações jurídicas, devem ser confrontadas para a aferição do grau de comparabilidade. Para que duas situações sejam comparáveis, não podem existir entre elas

${ }^{334}$ Expressão extraída de OCDE. Proposed Revision of Chapters I-III of the Transfer Pricing Guidelines. $9^{\text {th }}$ September 2009- $9^{\text {th }}$ January 2010. op. cit., p. 7, parágrafo 1.6.

335 "3.1. By definition, a comparison implies examining two terms: the controlled transaction under review and the uncontrolled transactions that are regarded as potentially comparable" (OCDE. Proposed Revision of Chapters I-III of the Transfer Pricing Guidelines. $9^{\text {th }}$ September 2009- $9^{\text {th }}$ January 2010. op. cit., p. 53). Item 3.1 novo, sem correspondente na Diretiva.

336 "1.7. (...) Paragraph 1 of Article 9 of the OECD Model Tax Convention is the foundation for comparability analysis because it produces the need for:

- A comparison between conditions (including prices, but not only prices) made or imposed between associated enterprises and those which would be made between independent enterprises, in order to determine whether a re-writing of the accounts of associated enterprises is authorized under Article 9 of the OECD Model Tax Convention (...);

- A determination on the profits which would have accrued at arm's length, in order to determine the quantum of any re-writing of accounts"

(OCDE. Proposed Revision of Chapters I-III of the Transfer Pricing Guidelines. $9^{\text {th }}$ September 2009- $9^{\text {th }}$ January 2010. op. cit., p. 8). Item novo, sem correspondente na Diretiva. 
diferenças materialmente relevantes aptas a alterar preços, margens brutas ou lucros. Se existirem estas diferenças, deve-se avaliar se é possível a implementação de ajustes razoavelmente precisos para se eliminar os respectivos efeitos materiais. Após os ajustes, contudo, não podem restar diferenças que afetem os preços, as margens brutas ou os lucros das operações. Nesse cenário, ser comparável significa: (a.) que as diferenças entre as situações não afetam materialmente as condições a serem examinadas; ou (b.) que ajustes razoavelmente precisos podem eliminar os efeitos de tais diferenças ${ }^{337}$. Se restarem, entre as operações, diferenças materialmente substanciais que não puderem ser alvo de ajustes, não é viável proceder-se à sua comparação, porque seu resultado não atenderá ao princípio da plena concorrência.

Os dados mais confiáveis em um determinado caso concreto são designados “comparáveis razoavelmente confiáveis" [ou "reasonably reliable comparables"] 338 .

Conforme exposto pela OCDE em sua Diretiva, há cinco fatores determinantes para a comparação de operações controladas e operações não-controladas, i.e., para a busca das transações independentes comparáveis. São eles: (I.) características dos bens, serviços e direitos objeto da transação; (II.) análise funcional; (III.) análise contratual; (IV.) circunstâncias econômicas; e (V.) estratégias empresariais [cf. subseção 2.2.1]. O exame de cada um destes fatores é que propiciará determinar se se trata de uma operação independente comparável ou se ela pode ser obtida a partir de ajustes razoavelmente precisos. Importa ponderar, a este passo, que a extensão dos efeitos de cada um deles para fins da "análise de comparabilidade" depende da natureza da operação e do método escolhido para concretização do princípio da plena concorrência ${ }^{339}$. Nesse sentido, pode-se

\footnotetext{
${ }^{337}$ In: OCDE. Transfer Pricing Guidelines for Multinational Enterprises and Tax Administrations. op. cit., p. I-7. Correspondente ao item 1.33 da Minuta-2009.

338 "3.2. As part of the process of selecting the most appropriate transfer pricing method (see paragraph 2.1) in applying it, the comparability analysis always aims at finding the most reliable comparables. This does not mean that there is a requirement for an exhaustive search for all possible sources of information and that searches for comparables data can be burdensome. (...) For this reason, the phrase 'reasonably reliable comparables' is used in this Guidelines to refer to the most reliable comparables in the circumstances of the case, keeping in mind the above limitations" (OCDE. Proposed Revision of Chapters I-III of the Transfer Pricing Guidelines. $9^{\text {th }}$ September 2009- $9^{\text {th }}$ January 2010. op. cit., p. 53). Item 3.2 novo, sem correspondente na Diretiva.

339 “1.38. (...) As part of a comparison exercise, the examination of the five comparability factors is by nature two-fold, i.e. it includes an examination of the factors affecting the taxpayer's controlled transactions and an examination of the factors affecting uncontrolled transactions. Both the nature of the nature of the controlled transaction and the transfer pricing method adopted (...) should be taken into account when evaluating the relative importance of any missing piece of information on possible comparables, which can vary on a caseby-case basis (...). Information on product characteristics might be more important if the method applied is a comparable uncontrolled price method than if it is a transactional net margin method" (OCDE. Proposed
} 
afirmar que a comparação das características e especificidades dos produtos é mais importante no CUP que nos métodos baseados em margens brutas; de fato, não há dúvidas de que estas últimas são menos impactadas, em relação aos preços, nas hipóteses em que há mínimas diferenças entre os dois tipos de produtos transacionados.

A análise de comparabilidade supra referida está vinculada a essa busca das transações independentes comparáveis, mas não se confunde com ela ${ }^{340}$, porque a primeira envolve todo um "processo de comparabilidade" que examina, também, outros aspectos como, v.g., o exame de compensações privadas, a eventual necessidade de segregação de várias transações constantes de um mesmo contrato antes de se iniciar a comparação etc. 341 . Para fins de sistematizar o exame de tal análise de comparabilidade, (a.) serão tratados na subseção 2.2.1, infra, os cinco fatores de comparabilidade imprescindíveis para a busca das transações independentes comparáveis, enquanto (b.) o processo de comparabilidade e demais aspectos importantes para a efetivação do princípio da plena concorrência serão discutidos em 2.2.2.

\subsubsection{Fatores determinantes da comparabilidade.}

Antes de abordar especificamente cada um dos cinco gêneros de fatores que devem ser sopesados durante o processo de busca das "transações independentes comparáveis", importa salientar que, nos artigos 18 a 22 da Lei n. ${ }^{\circ}$ 9.430/96, inexiste previsão expressa concernente aos fatores de comparabilidade que podem/devem ser aplicados no país, ou aos possíveis ajustes de dados, de modo a tornar comparáveis às operações "testadas" as operações independentes semelhantes, mas com distinções materialmente relevantes. Não obstante isso, consta da descrição dos métodos PIC, CPL, PVEx, PVA e PVV referência a "preços dos bens, serviços ou direitos, idênticos ou

Revision of Chapters I-III of the Transfer Pricing Guidelines. $9^{\text {th }}$ September 2009- $9^{\text {th }}$ January 2010. op. cit., p. 15). Item novo, sem correspondente na Diretiva.

340 "3.1. (...) The search for comparables are only part of the comparability analysis. It should be neither confused nor separated from the comparability analysis" (OCDE. Proposed Revision of Chapters I-III of the Transfer Pricing Guidelines. $9^{\text {th }}$ September 2009- $9^{\text {th }}$ January 2010. op. cit., p. 53). Item 3.1 novo, sem correspondente na Diretiva.

341 "3.1. (...) The search for information on potentially comparable uncontrolled transactions and the process of identifying comparables is dependent upon prior analysis of the taxpayer's controlled transaction and of the relevant comparability factors. A methodical, consistent approach should provide some continuity or linkage in the whole analytical process, thereby maintaining a constant relationship amongst the various steps: from the preliminary analysis of the conditions of the controlled transaction, to the selection of the transfer pricing method, though to the identification of potential comparables and ultimately a conclusion" (OCDE. Proposed Revision of Chapters I-III of the Transfer Pricing Guidelines. $9^{\text {th }}$ September 2009- $9^{\text {th }}$ January 2010. op. cit., p. 53). Item 3.1 novo, sem correspondente na Diretiva. 
similares"342. Em virtude dessa alusão à similaridade do objeto das transações, entendemos que podem ser efetivados ajustes relacionados a dessemelhanças encontradas nos bens, serviços ou direitos negociados [ajustes relacionados às características dos objetos das transações]. Considerando a ausência de limitações no âmbito da Lei n. ${ }^{\circ}$ 9.430/96, quaisquer ajustes relacionados às características do objeto da transação devem ser admitidos, não sendo possível a restrição de ajustamentos por intermédio de instruções normativas ou outras normas infralegais.

Note-se, a esse passo, que a legislação brasileira menciona "bens, serviços ou direitos, idênticos ou similares", e não a "transações idênticas ou similares". A interpretação literal e descuidada da lei permitiria concluir, pois, que somente as características do "objeto da transação" é que poderiam ser ajustadas, e não as suas condições comerciais e financeiras [quantidades, prazos de pagamento e entrega etc.]. Não pode ser este, todavia, o entendimento correto a ser conferido ao texto legal. Com efeito, uma operação de venda e compra de um determinado equipamento industrial, à vista, por $\$ 10$, não pode ser comparada com a aquisição daquele mesmo bem, por $\$ 10$, em 60 prestações. Obviamente o "preço" pago pelo primeiro adquirente é superior, por conta de suas condições financeiras menos favoráveis; seu preço de transferência não pode, então, ser confrontado com o preço praticado na operação à prazo. Supondo-se que (a.) a primeira operação seja vinculada e a segunda tenha sido praticada entre partes independentes; (b.) trate-se de operações de importação, sendo que os adquirentes brasileiros integrarão os equipamentos a seu 'Ativo Imobilizado'; e (c.) o equipamento industrial ora referido seja muitíssimo específico, sendo essas as duas únicas operações de importação desse tipo localizadas num determinado exercício, então (i.) se não forem admitidos ajustes, não será possível o "teste" dos preços de transferência na operação vinculada ${ }^{343}$; ou (ii.) se forem admitidos ajustes, poder-se-á calcular o valor presente da operação não-vinculada,

\footnotetext{
${ }^{342}$ Cf. artigo 18, I e II, e artigo 19, $\S 3^{\circ}$, I, II e III, da Lei n. ${ }^{\circ}$ 9.430/96, com redação dada pela Medida Provisória n. ${ }^{\circ}$ 478/09. A despeito de inexistir previsão semelhante para o PVL [antigo PRL] e o CAP, entendemos que, também nestes casos, devem ser admitidos dados relativos a bens, serviços ou direitos idênticos ou similares. Suponha-se, v.g., que um determinado contribuinte importe bens exclusivos e revenda-os exclusivamente para empresas vinculadas. Se não for viável a aplicação do PIC ou do CPL, a única metodologia possível para o cálculo do preço parâmetro seria a adoção do PVL, mediante a comparação com preços de venda praticados por terceiros independentes, envolvendo bens similares. Situação idêntica pode se dar com o CAP. Esta limitação legal, portanto, é totalmente desaconselhável, porque limita ainda mais as precárias metodologias disponíveis na legislação interna.

343 Assume-se não ser possível a aplicação do método PVL [antigo PRL] porque os equipamentos integrarão o 'Ativo Imobilizado', ou do CPL, na medida em que o fabricante estrangeiro não disponibilizaria sua planilha de custos para seus clientes. Restaria, nesta hipótese, unicamente o PIC.
} 
descontando-se o valor dos juros, e, a partir do resultado desse cálculo, aferir o preço parâmetro para "conferência" do preço praticado. Desse exemplo, pode-se deduzir que, ainda que duas operações estejam sujeitas a preços distintos, eventuais diferenças nas condições comerciais ou financeiras tornam-nas não-comparáveis. Ademais, se, nessas hipóteses, não forem admitidos ajustes para neutralizar tais diferenças, restringir-se-ão, em muitos casos, a localização de transações independentes comparáveis para fins de aferição dos preços parâmetro.

Entendemos, em virtude do quanto exposto, que a possibilidade de ajustes relativos às condições comerciais e financeiras das transações é imprescindível para a adequada funcionalidade da legislação: sem eles, restaria limitado o número de transações comparáveis, praticamente inviabilizando a aplicação dos métodos numa série de casos. Considerando, adicionalmente, a ausência de previsão ou vedação expressa de ajustes no texto da Lei n. ${ }^{\circ}$ 9.430/96, é mister concluir, com amparo no princípio da razoabilidade, que quaisquer distinções que afetem materialmente os preços, margens ou lucros de transações similares devem ser ajustadas, de modo a torná-las comparáveis às transações "testadas". Portanto, em nossa opinião, a Lei n. ${ }^{\circ}$ 9.430/96 admite a implementação de ajustes, incluindo-se, mas não se limitando a eles, aqueles referidos nos itens (I) a (V) desta subseção, e, como a lei não impõe restrições, não cabe aos normativos infralegais fazê-lo; estes últimos podem regulamentar as maneiras de se proceder aos ajustes, mas não vedálos ou limitá-los ${ }^{344}$.

Independentemente do posicionamento exposto no parágrafo anterior, os ajustes

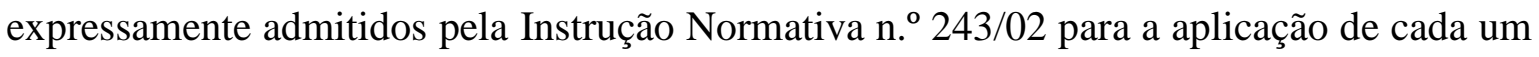
dos métodos, bem assim suas respectivas limitações, serão discutidos no CAPÍTULO 4.

\footnotetext{
${ }^{344}$ A respeito da necessidade de plena comparabilidade, ainda que não contemplada expressamente em lei ou normativos brasileiros, confiram-se as seguintes passagens de Luís Eduardo SCHOUERI:

“(...) Exige o princípio arm's length que o aplicador da lei indague, a todo tempo, qual teria sido o preço praticado entre partes independentes, em circunstâncias semelhantes, mesmo que para isso tenha de promover operação não expressamente prevista na regulamentação. Ora, tomando-se, por exemplo, uma venda de mercadorias em consignação, é claro que o chamado 'risco de estoque' ficará por conta do vendedor, que será obrigado a readquirir as mercadorias não vendidas. Neste sentido, uma análise funcional apontaria que aquele vendedor deveria ter uma margem de lucro suficiente para cobrir seu risco de estoque. Uma venda em consignação, portanto, jamais poderia ser comparada a uma venda pura e simples. Tal análise funcional não é expressamente contemplada pela regulamentação da Lei n. ${ }^{\circ}$ 9.430/96, mas, por concretizar o princípio arm's length, torna-se mandatória";

"A determinação taxativa de ajustes possíveis, tal como delineado na instrução normativa acima, não coaduna com o princípio norteador dos preços de transferência. Qualquer circunstância que possa influenciar o preço final da transação não só pode como deve ser levada em conta, sob pena de restar incompleta a determinação do preço para fins de comparação" (Preços de Transferência no Direito Tributário Brasileiro. op. cit., p. 42 e 120).
} 
Apenas a noção de identidade vis-à-vis similaridade, aplicável, em nossa opinião, a todos eles, será tratada em 2.2.1.(I), infra.

Convém destacar, por fim, que a legislação brasileira prevê a comparação de transações a partir de médias aritméticas ponderadas ${ }^{345}$ anuais, e não a partir do exame transação-a-transação propriamente dito. Nesse contexto, na forma do artigo $6^{\circ}$ da Instrução Normativa n. ${ }^{0}$ 243/02, são comparados os seguintes valores: (i.) preço médio ponderado anual dos bens, serviços ou direitos importados pelo contribuinte brasileiro; e (ii.) preço parâmetro, obtido a partir da média ponderada anual das transações vinculadas comparáveis ${ }^{346}$. Se a comparação das médias resultar em divergências, o preço parâmetro "médio" será comparado, agora sim, com os custos constantes dos documentos de aquisição e/ou importação de cada bem, serviço ou direito, para fim de determinação do exato ajuste em cada transação. Somente serão exigidos ajustes para as transações que divergirem do preço parâmetro em percentual superior a $5 \%{ }^{347}$. Entendemos ser razoável a sistemática adotada pela Instrução Normativa n. ${ }^{\circ}$ 243/02, porquanto a comparação da média dos preços praticados com a média consubstanciada no preço parâmetro pode, por exemplo, eliminar distorções decorrentes de sazonalidades e/ou de variações elevadas da cotação do dólar norte-americano durante o ano. Não se pode deixar de consignar, contudo, que, em algumas hipóteses envolvendo bens, serviços ou direitos negociados em reduzidíssima quantidade, a adoção do critério da média ponderada anual pode distorcer os preços, resultando-se em ajustes indevidos e injustos ${ }^{348}$; nesses casos, deve ser

345 A redação original dos artigos 18 e 19 da Lei n. ${ }^{\circ}$ 9.430/96 aludia a "médias aritméticas", noção alterada para "médias aritméticas ponderadas" pela Instrução Normativa n. "243/02. Diante das discussões que surgiram em virtude da "inovação" da legislação regulamentar, o texto legal foi alterado por intermédio da Medida Provisória n. ${ }^{\text {47 }}$ 48/09, que alçou ao patamar de lei a sistemática infralegal.

346 "Art. $6^{\circ}$ Para efeito de determinação do preço parâmetro com base nos métodos de que tratam os arts. $8^{\circ} \mathrm{e}$ 12, preliminarmente à comparação, os preços apurados serão multiplicados pelas quantidades relativas à respectiva operação e os resultados serão somados e divididos pela quantidade total, determinando-se, assim, o valor médio ponderado do preço a ser comparado com aquele registrado em custos, computado em conta de resultado, pela empresa.

Parágrafo único. Para efeito de comparação, o preço médio ponderado dos bens, serviços e direitos adquiridos pela empresa vinculada, domiciliada no Brasil, será apurado considerando-se as quantidades e valores correspondentes a todas as operações de compra praticadas durante o período de apuração sob exame".

Esta mesma disciplina aplica-se ao controle dos preços de transferência nas operações de exportação, como se depreende do disposto no artigo 16 do mesmo normativo:

“Art. 16. O preço médio praticado na exportação e o preço parâmetro serão obtidos pela multiplicação dos preços pelas quantidades relativas a cada operação e os resultados apurados serão somados e divididos pela quantidade total, determinando-se, assim, o preço médio ponderado".

${ }^{347}$ Cf. disciplina sobre a margem de divergência no artigo 38 da Instrução Normativa n. ${ }^{\circ}$ 243/02.

${ }^{348}$ Confira-se, nesse mesmo sentido, a posição de Luís Eduardo SCHOUERI sobre o assunto:

"Cabe ressaltar ser criticável a decisão do legislador brasileiro, ao exigir que se computem resultados de todo

o período-base. Melhor serviria ao princípio arm's length se fossem tomadas apenas as transações 
reconhecido, mesmo sem expressa previsão legal ou regulamentar, o direito de o contribuinte demonstrar os impactos da variação da moeda norte-americana entre a data da operação comparável e a data da operação praticada, ainda que ambas tenham ocorrido durante um mesmo exercício $^{349}$; de fato, não pode a autoridade administrativa

contemporâneas às examinadas, já que assim os possíveis reflexos da sazonalidade seriam percebidos. Ademais, o contribuinte fica à mercê de que sua negociação possa ser questionada em razão de variações de preços posteriores à própria transação. (...) Entretanto, dependendo do caso concreto, as alterações sazonais de preços de certos produtos têm obrigatoriamente de ser levadas em conta, sob pena de descumprimento do princípio arm's length. Esse é o caso de produtos que durante um ano tenham uma flutuação grande de preço, como é o caso das commodities. Um barril de petróleo,por exemplo, pode ter o seu preço alterado consideravelmente em um mesmo dia, sendo absolutamente injustificável tomar-se todas as operações de um ano em média aritmética" (Preços de Transferência no Direito Tributário Brasileiro. op. cit., p. 78-79).

${ }^{349}$ Cumpre notar, a esse passo, que a Instrução Normativa n. ${ }^{\circ}$ 243/02 prevê a possibilidade de ajustes em virtude de variações cambiais nos artigos 11 [PIC], 18 e 19 [métodos aplicáveis a operações de exportação]. O texto da norma não é suficientemente claro, mas de sua interpretação literal pode-se depreender que somente seriam admitidos ajustes por variações cambiais nas hipóteses em que forem utilizados dados de outros períodos [de apuração], i.e., de outros anos. Não existe previsão expressa de ajuste de variação cambial para a comparação de operações ocorridas no mesmo ano-calendário. Confiram-se, a respeito, os referidos artigos:

“Art. 11. Não sendo possível identificar operações de compra e venda no mesmo período a que se referirem os preços sob investigação, a comparação poderá ser feita com preços praticados em operações efetuadas em períodos anteriores ou posteriores, desde que ajustados por eventuais variações nas taxas de câmbio das moedas de referência, ocorridas entre a data de uma e de outra operação.

$\S 1^{\circ}$ Nos ajustes em virtude de variação cambial, os preços a serem utilizados como parâmetros para comparação, quando decorrentes de operações efetuadas em países cuja moeda não tenha cotação em moeda nacional, serão, inicialmente, convertidos em dólares americanos e, depois, para reais, tomando-se por base as respectivas taxas de câmbio praticadas na data de cada operação.

$\$ 2^{\circ} \mathrm{Na}$ hipótese desse artigo, serão consideradas, também, as variações acidentais de preços de commodities, quando comprovadas mediante apresentação de cotações de bolsa, de âmbito nacional ou internacional, verificadas durante o período";

“Art. 18. Não sendo possível identificar operações de venda no mesmo período a que se referirem os preços sob investigação, a comparação poderá ser feita com preços praticados em operações efetuadas em períodos anteriores ou posteriores, desde que ajustados por eventuais variações nas taxas de câmbio da moeda de referência, ocorridas entre a data de uma e de outra operação.

Parágrafo único. Na hipótese deste artigo, serão consideradas, também, as variações acidentais de preços de commodities, quando comprovadas mediante apresentação de cotações de bolsa, de âmbito nacional ou internacional, verificadas durante o período"; e

“Art. 19. Verificado que o preço de venda nas exportações é inferior ao limite de que trata o art. 14, com os ajustes referidos nos arts. 15 a 18, as receitas das vendas nas exportações serão determinadas tomando-se por base o valor apurado segundo um dos métodos de que trata os arts. 23 a 26.

$\$ 1^{\circ}$ Para efeito de aplicação dos métodos referidos neste artigo, as médias aritméticas ponderadas serão calculadas em relação ao período de apuração, exceto se a empresa estiver utilizando dados de outros períodos, caso em que as médias serão referidas ao respectivo período.

$\S 2^{\circ} \mathrm{Na}$ hipótese do $\S 1^{\circ}$, os preços apurados em moeda estrangeira serão ajustados em virtude de eventuais variações nas taxas de câmbio da moeda de referência, ocorridas entre as datas das operações".

Note-se que os artigos 11 e 18 aparentemente prevêem a possibilidade de ajustes por variação cambial apenas nas hipóteses em que não seja possível identificar "operações no mesmo período a que se referirem os preços sob investigação". Por "mesmo período" deve se compreender, a partir do exame sistemático de tal normativo, "mesmo período de apuração". Já o §2 do artigo 11 e o parágrafo único do artigo 18 mencionam os ajustes cambiais "na hipótese desse artigo", i.e., nos casos de dados comparáveis extraídos de outros anos. O texto do artigo 19 não é de fácil apreensão, mas, se for interpretado em conjunto com o artigo 18, leva-nos à mesma conclusão.

Entendemos serem estas limitações regulamentares ilegais nas hipóteses em que a variação cambial ocorrida num mesmo ano-calendário trouxer distorções relevantes entre o preço parâmetro e os preços praticados. Não 
simplesmente ignorar esse tipo de ajuste, facilmente aferível e que pode gerar o arbitramento de receitas ou a glosa de despesas de elevado valor em desfavor dos contribuintes.

\section{(I.) Características dos bens, serviços ou direitos objeto da transação.}

\section{Bens idênticos e similares.}

No processo de busca da transação independente comparável para o "teste" de determinados preços de transferência, parece-nos intuitivo que o primeiro exame a ser efetivado é, justamente, o das características específicas que afetam o valor dos bens, serviços ou direitos transacionados no livre mercado; isso porque o objeto da transação apresenta-se como seu primeiro elemento "individualizante". Como regra geral, as comparações entre bens corpóreos devem ser efetivadas a partir do exame das características materiais, da qualidade, da fiabilidade, do volume de oferta ${ }^{350}$ etc.. No que respeita aos bens incorpóreos, a comparabilidade demanda uma análise detida da forma/estrutura jurídica da operação, do tipo de ativo, da duração e grau de proteção do intangível e de outras vantagens que se espera obter com sua utilização ${ }^{351}$.

A relevância das características específicas do objeto das transações varia de acordo com o método a ser adotado para a concretização do princípio da plena concorrência. Com efeito, não há dúvidas de que as qualidades do objeto apresentam-se

se trata de ajuste "subjetivo" ou complicado, mas de dado de fácil cálculo e apreensão. Não se justifica, portanto, tal ilegalidade.

Entendemos, ademais, que devem ser admitidos ajustes também para os métodos PVL e CPL, a despeito de ausência de previsão regulamentar. Esse ajuste deve ser admitido tanto nas hipóteses de dados aferidos num mesmo ano-calendário quanto nos casos em que os únicos dados disponíveis para comparação referem-se a anos anteriores ou posteriores. Não obstante a limitação legal expressa trazida em relação ao PVL [cf. artigo

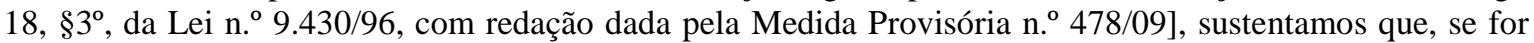
esse o único método aplicável e se inexistirem operações similares no mesmo ano da operação "testada", devem ser admitidos dados relativos a exercícios anteriores ou posteriores.

${ }^{350}$ Especificamente neste item (I.), examina-se tão-somente o volume de oferta vis-à-vis a demanda do bem no mercado. Os impactos das quantidades negociadas nos preços respeitam à análise das cláusulas contratuais, tratadas em (III.), infra.

${ }^{351}$ Veja-se, exemplificativamente, algumas características intrínsecas de bens e serviços que precisam ser alvo de comparação, na visão de Heleno Taveira TÔRRES:

"Desse modo, é preciso saber focalizar quais as características que são mais relevantes para os fins da comparação, variando pelo tipo de bem ou serviço. Para os bens materiais, as características físicas, a qualidade, a confiabilidade, o volume de venda, a disponibilidade sobre o mercado; para as prestações de serviços, ao invés, tais características correspondem à natureza e à objetiva extensão, a tipologia e relevância quantitativa; para a propriedade industrial, a tipologia jurídica da operação (venda ou licença) ao tipo do bem imaterial (brevê, know-how etc.), a duração e a intensidade da proteção jurídica, os benefícios atendidos pela utilização do bem imaterial" (Direito tributário internacional: planejamento tributário e operações transnacionais. op. cit., p. 185-186). 
mais importantes nos métodos de comparação direta de preços [CUP] e menos relevantes na mensuração de margens brutas [RPM e CPM] ou de lucros operacionais [PSM e TNMM], cujo resultado depende antes da complexidade do processo para sua produção/prestação/desenvolvimento e, em menor grau, do resultado final do bem, serviço ou direito propriamente dito; isso não significa que a adequada identificação do objeto da transação esteja dispensada nesta última hipótese, porque há uma relação intrínseca entre as características e funcionalidades do objeto e o respectivo processo destinado a sua obtenção $^{352}$.

Da legislação brasileira consta, exclusivamente no que concerne aos métodos PIC, CPL, PVEx, PVA e PVV ${ }^{353}$, a possibilidade de utilização de dados comparáveis de "bens, serviços ou direitos, idênticos ou similares", para a determinação do preço parâmetro. Se for adotada transação independente com objeto similar ao da transação "testada", devem ser efetivados ajustes, com o objetivo de se expurgar do primeiro todas as diferenças materialmente relevantes em relação ao segundo. $\mathrm{O}$ artigo 28 da Instrução Normativa n. ${ }^{\circ}$ 243/02 disciplinou tão-somente a noção de "bem similar" ${ }^{354}$, deixando de estabelecer os elementos caracterizadores dos serviços ou direitos similares; nestas últimas duas hipóteses, não há dúvidas de que cabem aos contribuintes indicar as razões da similitude [e também os ajustes necessários para a comparabilidade dos serviços ou direitos transacionados]. Pondere-se, a este passo, que o artigo 28 deixa transparecer a total despreocupação das autoridades brasileiras quanto à negociação de serviços e direitos em geral: todas as normas estão voltadas para o cálculo dos preços parâmetro em operações

\footnotetext{
352 "1.40. Depending on the transfer pricing method, this factor must be given more or less weight. Among the methods described at Chapter II of these Guidelines, the requirement for comparability of property or services is the strictest for the comparable uncontrolled price method. Under the comparable uncontrolled price method, any material difference in the characteristics of the property of services can have an effect on the price and would require an appropriate adjustment to be considered (...). Under the resale price method, some differences in the characteristics of the property or services are less likely to have a material effect on the gross profit margin or mark up on costs (...). Differences in the characteristics of property or services are also less sensitive in the case of the transaction profit methods than in the case of traditional transaction methods (...). This however does not mean that taxpayers can ignore the question of comparability in characteristics of property or services when applying these methods, because it may be that product differences entail or reflect different functions performed, assets used and/or risks assumed by the tested party" (OCDE. Proposed Revision of Chapters I-III of the Transfer Pricing Guidelines. $9^{\text {th }}$ September 2009$9^{\text {th }}$ January 2010. op. cit., p. 15-16). Item novo, sem correspondente na Diretiva.

${ }^{353}$ Cf. artigo 18 , I e II, e artigo 19, $^{\circ}$, I, II e III, da Lei n. ${ }^{\circ}$ 9.430/96, com redação dada pela Medida Provisória n. ${ }^{\circ}$ 478/09.

354 “Art. 28. Para efeito desta Instrução Normativa, dois ou mais bens, em condições de uso na finalidade a que se destinam, serão considerados similares quando, simultaneamente:

I - tiverem a mesma natureza e a mesma função;

II - puderem substituir-se mutuamente, na função a que se destinem;

III - tiverem especificações equivalentes".
} 
envolvendo bens tangíveis. Esta constatação pode ser comprovada, ademais, pela leitura dos artigos 10 [PIC] e 17 [métodos aplicáveis a operações de exportação], ambos da mencionada Instrução Normativa ${ }^{355}$, os quais, a despeito de se referirem a bens, serviços ou direitos, trazem ajustes claramente inspirados na comparação de bens, aludindo a "diferença física e de conteúdo" e "diferenças entre os modelos objeto da comparação".

No que toca aos "bens", importa ponderar que, nos termos do normativo antes referido, entende-se por bem similar aquele que (i.) possui a mesma natureza e função; (ii.) pode substituir o bem objeto da transação "testada" na função a que se destina; e (iii.) possui especificações equivalentes. A Minuta-2009 constatou que os países têm buscado uma similaridade de funções dos bens, e não das suas qualidades propriamente ditas ${ }^{356}$, característica que também pode ser percebida no normativo brasileiro. Entendemos, contudo, que a prática atualmente adotada pelas autoridades tributárias brasileiras quando do ajuste dos bens similares está equivocada, sendo totalmente incompatível com o que razoavelmente se depreenderia do texto legal.

De fato, tem-se entendido que os ajustes indicados nos artigos 10 e 17 da

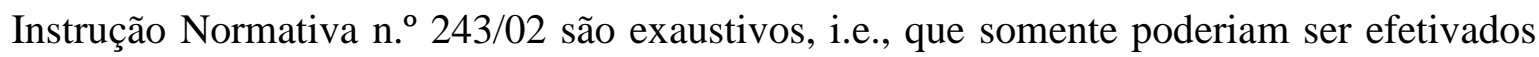
ajustes decorrentes de sua natureza física ou conteúdo. Diferenças relativas a marca, qualidade e reputação comercial do produto, confiança no fabricante etc. não têm sido objeto de ajuste ${ }^{357}$, causando distorções abusivas e absurdas.

\footnotetext{
${ }^{355}$ Considerando que os dois artigos têm conteúdo praticamente idêntico, confira-se o disposto no artigo 10 da Instrução Normativa n. ${ }^{\circ}$ 243/02:

“Art. 10. No caso de bens, serviços ou direitos similares, além dos ajustes previstos no art. $9^{\circ}$, os preços serão ajustados em função das diferenças de natureza física e de conteúdo, considerando, para tanto, os custos relativos à produção do bem, à execução do serviço ou à constituição do direito, exclusivamente nas partes que corresponderem às diferenças entre os modelos objeto da comparação".

356 "1.41. In practice, it is observed that comparability analysis often put more emphasis on functional similarities than on product similarities. It may be acceptable to broaden the scope of the comparability analysis to include transactions involving products that are different, but functionally similar. The acceptance of such an approach depends on the effects of the product differences on the reliability of the comparison and on whether or not more reliable data are available. Before broadening the search to very large categories (e.g. industry codes), thought should be given to what other types of products are likely to offer the closest comparables to the taxpayer's transaction" (OCDE. Proposed Revision of Chapters I-III of the Transfer Pricing Guidelines. $9^{\text {th }}$ September 2009- $9^{\text {th }}$ January 2010. op. cit., p. 16). Item novo, sem correspondente na Diretiva.

${ }^{357}$ Confiram-se, dentre outras, as seguintes decisões de primeira instância administrativa: (i.) acórdão n. ${ }^{\circ}$ 4.535, de 15.12.03, da $5^{\mathrm{a}}$ Turma da DRJ/SP-I; e (ii.) acórdão n. ${ }^{\circ} 2.510$, de 30.05.03, da $1^{\text {a }}$ Turma da DRJ/Porto Alegre.

Saliente-se, todavia, que não está claro, no texto dos artigos 10 e 17 da Instrução Normativa n. ${ }^{\circ}$ 243/02, se os ajustes ali descritos são exemplificativos ou exaustivos. As autoridades julgadoras poderiam, assim, ter adotado outro entendimento, com fundamento no mesmo normativo.
} 
Imagine-se, v.g., que a joalheria Tiffany produza um único relógio de ouro e diamantes, com design exclusivo, e remeta-o para sua subsidiária na cidade de São Paulo, por um preço de \$100.000; em seguida, a subsidiária de São Paulo reexporta o relógio para uma subsidiária européia da joalheria. Por se tratar de relógio exclusivo, inexistem produtos idênticos, mas apenas similares. Supondo-se que a controladora não forneça suas planilhas de custos, o preço de transferência praticado na operação de importação somente poderia ser "testado" a partir do PIC. Resolve, então, a administração tributária, comparar esse relógio com um outro, com a mesma quantidade de ouro e diamantes, mas de joalheria menos renomada, o qual foi importado pela empresa brasileira $X$ por $\$ 10.000$; em função disso, ajusta-se o preço de transferência da subsidiária Tiffany no país em $\$ 90.000$, impossibilitando-se a apropriação desse custo quando da exportação do bem. De fato, os dois relógios são semelhantes e possuem a mesma natureza, função e especificação. É notório, contudo, que seus preços nunca seriam idênticos, dada a reputação da joalheria Tiffany em todo o mundo. Não se admitir um ajuste relativo à marca nesse exemplo representaria, assim, não apenas um absurdo intuitivamente detectado, mas também uma medida inconstitucional, porque se tributaria um conteúdo não equivalente a "renda",358.

Diante das considerações supra e independentemente do quanto disposto nos artigos 10 e 17 da Instrução Normativa n. ${ }^{\circ}$ 243/02, os preços dos bens, serviços ou direitos similares devem ser objeto de todos os ajustes necessários para se eliminar as diferenças materialmente relevantes entre eles e os preços dos bens, serviços ou direitos "testados". De fato, não pode ser outro o entendimento a ser adotado na espécie, sob pena de se comparar bens que, a despeito de similares, contenham dessemelhanças aptas a impactar seus preços em elevado grau. O CAPÍTULO 4, no âmbito do qual serão discutidos os métodos admitidos pela Lei n. ${ }^{\circ}$ 9.430/96, será baseado nesta premissa e, para a adequada aplicação de cada uma das metodologias, será admitida a efetivação dos ajustes necessários

\footnotetext{
${ }^{358}$ Luís Eduardo SCHOUERI fornece-nos o seguinte exemplo sobre a necessidade de ajustes relativos à reputação comercial:

“A questão da qualidade e reputação comercial assume redobrada importância em setores nos quais a proteção da legislação de patentes não é suficiente, permitindo o surgimento de produtos de composição idêntica. Tal, por exemplo, o caso das auto-peças, em que se encontram produtos certificados pelas montadoras, com preços diferentes daqueles praticados por seus concorrentes, que não obtiveram o selo de aprovação dos fabricantes de veículos. Nos requisitos da permutabilidade e composição física, possivelmente se afirmaria tratar-se de produtos idênticos. A qualidade, tampouco, é, necessariamente, questão relevante, já que é possível que os produtos não certificados sejam de tão boa qualidade quanto seus concorrentes. Faltando, entretanto, o quesito da reputação comercial (que, no caso, surge a partir da certificação pelo fabricante), já não é possível falar-se em identidade ou semelhança" (Preços de Transferência no Direito Tributário Brasileiro. op. cit., p. 89).
} 
para tornar as operações independentes realmente comparáveis às operações praticadas pelas partes vinculadas.

\section{(II.) Análise funcional.}

A remuneração das empresas nos negócios em geral é, normalmente, mensurada a partir da função desempenhada, dos ativos utilizados e dos riscos assumidos por cada uma delas; a aferição destes três fatores representa o cerne da análise funcional ${ }^{359}$. Essa análise busca identificar e comparar a atividade exercida, sua relevância e as responsabilidades assumidas. Na prática, as principais "funções" precisam ser detectadas e ajustes razoavelmente precisos devem ser implementados sempre que houver diferenças materialmente relevantes que afetem a comparação; é necessário verificar a quantidade de funções e sua importância econômica, do ponto de vista de freqüência, natureza e valor. Devem ser observadas, v.g., as funções desempenhadas na produção, montagem, distribuição, pesquisa e desenvolvimento, marketing, transporte, financiamento, gerenciamento back office etc.) ${ }^{360}$. No "livre mercado", remunera-se cada uma das funções, de modo que este fator também deve ser comparado para fins de aferição do preço parâmetro. Com efeito, um revendedor com contrato de exclusividade numa determinada região do país, que se dedica a funções de propaganda e marketing para fortalecimento regional da marca do produto distribuído, não aceitará importar bens pelo mesmo preço pago por um revendedor de outra região, sem qualquer obrigação dessa espécie. Obviamente, o primeiro exigirá que o preço de importação dos produtos seja inferior, de modo que o lucro obtido quando de sua revenda seja suficiente não apenas para remunerar sua função de revenda mas, também, seus dispêndios relativos à estratégia de marketing regional implementada; para a comparação destas duas operações, assim, deve haver um

\footnotetext{
${ }^{359}$ A legislação norte-americana restringe análise funcional às funções desempenhadas e ativos envolvidos, tratando os riscos como um fator distinto. Confira-se:

"\$1.482-1 (d) (3) (i) Determining the decree of comparability between controlled and uncontrolled transactions requires a comparison of the functions performed, and associated resources employed, by the taxpayers in each transaction" [26 CFR Ch. I (4-1-09 Edition)].

360 Heleno Taveira TÔRRES oferece-nos os seguintes exemplos de atividades correspondentes a funções produtivas, de marketing e distributivas em geral:

"Funções produtivas - planejamento da produção, processo de produção, aquisição de matéria-prima, aprovação do fornecedor de matéria-prima, procedimento de controle de qualidade, execução do controle de qualidade, processo e desenvolvimento tecnológico.

Funções de marketing - planos estratégicos de marketing, publicidade, força de venda, autonomia das empresas específicas, previsões de venda, pessoa responsável pela venda, nova penetração comercial, formação.

Funções distributivas - estoque das mercadorias e distribuição, gestão das garantias etc." (Direito tributário internacional: planejamento tributário e operações transnacionais. op. cit., p. 186).
} 
ajuste, de modo a expurgar do preço da primeira operação, antes de proceder ao seu confronto com a segunda, o valor relativo ao exercício das funções de marketing.

Para delimitar e comparar as funções desempenhadas, é útil, outrossim, examinar os ativos utilizados para desenvolvê-las [tipo de ativo, características, valor dos intangíveis etc.] e as características desses ativos [idade, valor de mercado, localização, proteções relativas a patentes industriais ou processos produtivos etc. $]^{361}$.

No que concerne aos riscos assumidos, seu exame é essencial porque, entre partes independentes, um incremento de risco implica aumento da expectativa de retorno, ainda que nenhuma contingência materialize-se; isso precisa ser mensurado [e ajustado] nas comparações. Devem ser analisados os riscos de mercado, riscos de perda de ativos, de insucesso de pesquisas em desenvolvimento, riscos financeiros, de crédito etc. ${ }^{362}$. São as funções exercidas que determinam, de certa forma, a alocação de riscos ${ }^{363}$. Assim, v.g., se uma empresa independente responsável por projetos de pesquisa e desenvolvimento

\footnotetext{
${ }^{361}$ Confira-se, a respeito, o seguinte exemplo em que a utilização de intangíveis próprios altera a natureza das funções desempenhadas pelas partes:

"Example 3-11. MafCo is a manufacturing company located in Mafonia. DistCo, an unrelated distributor of optical products in Euronia, desires to have a line of optical lenses manufactured to its specifications and using its production technology. DistCo contracts with MafCo to produce an agreed volume of lenses that DistCo is obligated to purchase as long as the lenses meet the contractually agreed-upon specifications. Here, DistCo is the risk-taker, that uses its own valuable intangible property (design products and technology). The function of MafCo is that of a contract manufacturer, that makes its facilities available for use by other
} parties.

A significantly different analysis would result if the functions were reversed, as in Illustration 3-12.

Example 3-12. The situation is the same as in Illustration 3-11, except that DistCo owns no designs and production technology for optical lenses that it desires. Rather, MafCo owns those items.

Here, the functions of MafCo are far different from those in Illustration 3-11. MafCo is no longer a contract manufacturer. It is the owner of valuable intangible property that it produces. Here, DistCo assumes the role of a distributor. MafCo would receive a far different level of compensation than it would as a contract manufacturer in Illustration 3-11" (HAMMER, Richard M. et. al. International Transfer Pricing - OCDE Guidelines. United States: Thomson West, WGL Contents, 2005, item 3.03 [2]).

${ }^{362}$ A título exemplificativo, confiram-se os seguintes gêneros de riscos apontados pela legislação norteamericana:

"\$1.482-1 (d) (3) (iii) (A) Determining the decree of comparability between controlled and uncontrolled transactions requires a comparison of the significant risks that could affect the prices that would be charged or paid, or the profit that would be earned, in the two transactions. Relevant risks to consider include:

(1) Market risks, including fluctuation in cost, demand, pricing and inventory levels;

(2) Risks associated with the success or failure of research and development activities;

(3) Financial risks, including fluctuations in foreign currency rates of exchange and interest rates;

(4) Credit and collection risks;

(5) Product liability risks; and

(6) General business risks related to the ownership of property, plant and equipment" [26 CFR Ch. I (4-1-09 Edition)].

363“" 1.25 . The functions carried out (taking into account the assets used and the risks assumed) will determine in some extend the allocation of risks between the parties, and therefore the conditions of each party would expect in arm's length dealings" (OCDE. Transfer Pricing Guidelines for Multinational Enterprises and Tax Administrations. op. cit., p. I-11). Correspondente ao item 1.47 da Minuta-2009. 
(“P\&D”) assume os riscos do resultado/sucesso das pesquisas, é razoável que ela espere uma remuneração altíssima, porque se sabe que as atividades de $\mathrm{P} \& \mathrm{D}$, como regra geral, demandam elevados recursos para resultados de longo prazo e com sucesso financeiro indeterminado. Se, por outro lado, a empresa que se dedica a P\&D for ressarcida por todos os custos das pesquisas, ela, na prática, atua como mera prestadora de serviços e, portanto, sua remuneração deve ser muito inferior, porque praticamente não há riscos envolvidos. Seria perfeitamente factível, assim, que a primeira empresa recebesse $\mathrm{x} \%$ da receita líquida total das vendas dos produtos resultantes de suas pesquisas, ao passo que a segunda fosse remunerada tão-somente pelo somatório dos seus custos, acrescidos de uma pequena margem sobre estes custos. Esse exemplo demonstra a relevância da análise funcional dos riscos envolvidos na operação para a verificação de operações comparáveis. Também é importante assegurar se a alocação de riscos contratualmente delineada é consistente com a substância econômica da transação; a alocação precisa ser verdadeira e o comportamento das partes é o elemento determinante para este tipo de exame ${ }^{364}$.

\footnotetext{
${ }^{364} \mathrm{Na} \$ 1.482-1$, há diversos exemplos, elaborados pelo fisco norte-americano, envolvendo casos em que a repartição contratual de riscos deve ser admitida ou desconsiderada. Confira-se, abaixo, um exemplo no qual as previsões contratuais foram ignoradas, porque a prática adotada era distinta daquela negocial e inicialmente delineada:

"\$1.482-1 (d) (3) (iii) (C) Example 4. USSub is a wholly-owned US subsidiary of FP, a foreign manufacturer. USSub acts as a distributor of goods manufactured by FP. FP and USSub execute an agreement providing that FP will bear any ordinary product liability costs arising from defects in the goods manufactured by FP. In practice, however, when ordinary product liability claims are sustained against USSub and FP, USSub pays the resulting damages. Therefore, the district director disregards the contractual arrangement regarding product liability costs between FP and USSub, and treats the risk as having been assumed by USSub" [26 CFR Ch. I (4-1-09 Edition)].

No mesmo sentido, confiram-se os exemplos abaixo, que indicam possíveis formas de repartição de riscos e hipóteses em que as previsões contratuais merecem ser ignoradas:

"Example 3-18. DistCo is a distributor of optical products in Euronia that MafCo, its parent company MafCo, manufactures. The market for optical products in Euronia is extremely competitive, and MafCo's products are essentially unknown in this market, although they are well known in other parts of the world. In other to penetrate Euronian market and develop market share, it is determined that MafCo's optical products should be sold at significantly lower price than competing or substitute products.

This business strategy raises a threshold issue of which party bears the strategy's economic risk. In the context of Illustration 3-18, it is important to determine whether the manufacturer incurs the lower margins or a loss by charging a lower price to its distributor, or the distributor does this by its selling at a lower price than comparable products in incurring extraordinary marketing and promotion expenses. In the former situation, the economic risk is on the manufacturer; in the latter, the risk would be on the distributor, DistCo. To evaluate the assignment of risk between the parties, a tax administration may wish to examine the conduct of the parties to determine if it is consistent with the professed business strategy. Illustration 3-19 shows a possible scenario.

Example 3-19. The situation is the same as in the Illustration 3.18. The market development strategy is implemented by a provision in the distribution agreement between MafCo and DistCo that provides that DistCo will not be responsible for market development costs. Upon examination, the tax administration of Euronia determines that the strategy was implemented not in accord with the agreement (i.e. by DistCo incurring significant advertising and development costs). In this situation, the Euronian tax administration would appropriately treat DistCo, not MafCo, as the economic risk-taker, which would require a transfer
} 
Adicionalmente, é relevante avaliar que, em condições de plena concorrência, o risco geralmente está alocado naquele que pode "controlá-lo" melhor. Se uma empresa possui complexas estratégias de hedge, v.g., seria razoável que os riscos cambiais permanecessem ali alocados, porque o custo de administração do risco no âmbito daquela pessoa jurídica seria, comparativamente a sua contraparte, reduzido; de fato, esta seria a estratégia negocial adotada por terceiros independentes. No direito norte-americano, os riscos devem ser repartidos segundo a capacidade [financeira, gerencial, operacional etc.] que cada parte possui de assumi-los ${ }^{365}$. Nesse cenário, se, e.g., uma sociedade naquela nação criar um novo produto e for titular de todas as patentes e direitos de marca ou desenho industrial envolvidos, o risco [e o ganho] relativo ao "sucesso" do produto deve ser por ela assumido, não sendo possível transferi-lo [juntamente com a maior remuneração daí decorrente] a uma controlada estrangeira, constituída com capital reduzido para atuar como mera revendedora; o fisco norte-americano entende que a realocação de riscos, nesta hipótese, não seria admissível, diante da ausência de capacidade financeira da controlada para suportá-los. Na prática, há muita discussão em torno dessa proibição de livre alocação dos riscos naquele país. Independentemente disso, este raciocínio segundo o qual o risco deve ser assumido pela parte que desempenha a atividade apta a gerá-lo pode ser utilizado pelas autoridades tributárias para a pesquisa de possíveis desvios de comportamento entre partes relacionadas, principalmente porque terceiros independentes provavelmente negociariam segundo esta lógica, não assumindo riscos sobre os quais não possuem algum nível de controle ${ }^{366}$.

pricing adjustment. A related factor to consider is whether the nature of the relationship between the parties to the controlled transaction is consistent with the assignment of cost and risk inherent in the business strategy. For example, in arm's length dealings, a company acting solely as a sales agent with little or no responsibility for a long-term market development generally would not bear the costs of a market penetration strategy, as Illustration 3.19 indicates" (HAMMER, Richard M. et. al. International Transfer Pricing OCDE Guidelines. op. cit., item 3.03 [5] [a]).

${ }^{365}$ Os seguintes aspectos devem ser examinados para se aferir a "substância econômica" da transação: “\$1.482-1 (d) (3) (iii) (B) (1) Whether the pattern of the controlled taxpayer's conduct overtime is consistent with the purported allocation of risks between the controlled taxpayers; or where the pattern is changed, whether the relevant contractual arrangements have been modified accordingly;

(2) Whether a controlled taxpayer has the financial capacity to fund losses that might be expected to occur as the result of the assumption of a risk, or whether, at arm's length, another party to the controlled transaction would ultimately suffer the consequences of such losses;

(3) The extent to which each controlled taxpayer exercises managerial or operational control over the business activities that directly influence the amount of income or loss realized. In arm's length dealings, parties ordinarily bear a greater share of those risks over which they have relatively more control" [26 CFR Ch. I (4-1-09 Edition)].

366، 1.27. In arm's length dealings ii generally makes sense for parties to be allocated a greater share of those risks over which they have relatively more control. For example, suppose that Company A contracts to produce and ship goods to Company B, and the level of production and shipment of goods are to be at the 


\section{(III.) Análise contratual.}

Os contatos normalmente dispõem acerca do mecanismo de divisão, entre as partes, das responsabilidades, riscos e benefícios da transação; portanto, a análise contratual integra, em certa medida, a análise funcional. Nesse sentido, assim como as funções desempenhadas nas transações "testadas" devem ser confrontadas com as funções exercidas nas transações independentes comparáveis, o contrato que ampara as primeiras deve ser comparado com o contrato que ampara as últimas, de modo a se aferir a eventual existência de dessemelhanças [nas obrigações ou direitos] que afetem materialmente os preços das transações. As cláusulas contratuais com maior impacto nos preços referem-se a volumes $^{367}$, prazos de pagamento, garantias etc. ${ }^{368}$. Nas hipóteses em que não houver contrato escrito, as condições negociais podem ser deduzidas de trocas de correspondências, do comportamento das partes ou dos princípios econômicos que regem as relações entre partes independentes.

discretion of Company B. In such a case, Company A would be unlikely to agree to take on substantial inventory risk, since it exercises no control over the inventory level while Company B does. Of course, there are many risks such as general business cycle risks, over which typically neither party has significant control and which at arm's length could therefore be allocated to one or the other party of the transaction" (OCDE. Transfer Pricing Guidelines for Multinational Enterprises and Tax Administrations. op. cit., p. I-11). Correspondente ao item 1.49 da Minuta-2009.

${ }^{367}$ A respeito, veja-se o seguinte exemplo, haurido da legislação dos Estados Unidos da América:

“\$1.482-1 (d) (3) (ii) (C) Example 2. Reliability of adjustment for differences in volume. (i.) FS manufactures product XX and sells that product to its parent corporation, P. FS also sells product XX to uncontrolled taxpayers at a price of $\$ 100$ per unit. Except for the volume of each transaction, the sales to $P$ and to uncontrolled taxpayers take place under substantially the same economic conditions and contractual terms. In uncontrolled transactions, FS offers a $2 \%$ discount for quantities of 20 per order, and a $5 \%$ discount for quantities of 100 per order. If $\mathrm{P}$ purchases product XX in quantities of 60 per order, in the absence of other reliable information, it may reasonably be concluded that the arm's length price to $\mathrm{P}$ would be $\$ 100$, less a discount of $3,5 \%$.

(ii.) If $\mathrm{P}$ purchases product $\mathrm{XX}$ in quantities of 1,000 per order, a reliable estimate of the appropriate volume discount must be based on proper economic or statistical analysis, not necessarily a linear extrapolation from the $2 \%$ and 5\% catalog discounts applicable to sales of 20 and 100 units, respectively [26 CFR Ch. I (4-1-09 Edition)].

${ }^{368}$ Confiram-se exemplos de cláusulas contratuais cuja análise é recomendada pela legislação norteamericana durante a análise de comparabilidade:

"\$1.482-1 (d) (3) (ii) (A) Determining the decree of comparability between the controlled and uncontrolled transactions requires a comparison of a significant contractual terms that could affect the results of the two transactions. These terms includes:

(1) The form of consideration charged or paid;

(2) Sales or purchase volume;

(3) The scope and term of warranties provided;

(4) Rights to updates, revisions or modifications;

(5) The duration of relevant license, contract or other agreements and termination or renegotiation rights;

(6) Collateral transactions or ongoing business relationships between the buyer and the seller, including arrangements for the provision of ancillary or subsidiary services; and

(7) Extension of credit and payment terms" [26 CFR Ch. I (4-1-09 Edition)]. 
Nas operações não-vinculadas, as partes esforçam-se para cumprir os ditames do contrato, que apenas é alterado em hipóteses extremas de desequilíbrio contratual e desde que de comum acordo entre ambas as partes. Diferentemente, entre as partes vinculadas há uma certa tendência à alteração de condições negociais sempre que surge algum desequilíbrio, sendo que, em muitos casos, tais modificações sequer são refletidas em contrato escrito. Por isso é que, nesse último caso, recomenda-se averiguar se o comportamento real das partes demonstra a observância dos termos contratuais previamente firmados ou se indica que o contrato não passa de mera ficção, sendo os preços e condições das operações impostas por algum outro agente intra-grupo.

Por fim, saliente-se que a análise contratual tem escopo relativamente limitado, porque, se a parte "testada" não for parte também na transação independente comparável, será complexa a obtenção de cópia do contrato escrito para análise. Independentemente disso, o impacto da ausência deste elemento na análise de comparabilidade varia conforme o tipo de transação. Se se tratar de uma venda e compra à vista e sem exclusividade, v.g., a ausência do exame contratual tem menor relevância; de outro lado, a comparação de uma transação envolvendo cessão de marca ou outro direito de propriedade intelectual com outra similar resta bastante prejudicada sem o confronto dos direitos e obrigações contratualmente prescritos $^{369}$.

\section{(IV.) Circunstâncias econômicas.}

Também devem ser objeto de avaliação as circunstâncias econômicas verificadas no mercado onde se estabeleceram as operações "testadas" e no mercado das operações independentes a serem utilizadas como parâmetro, não podendo existir

\footnotetext{
${ }^{369}$ Esta preocupação relacionada à possível ausência dos contratos para fins de comparação de transações foi recentemente mencionada nos estudos da OCDE, tendo sido incluída tão-somente na Minuta-2009. Confirase, a respeito, o teor do item 1.53:

"1.53. In practice, information available on contractual terms of potentially comparable uncontrolled transactions can be limited, specially where a taxpayer is not a part on such uncontrolled transactions.

The importance of such missing information in establishing comparability depends upon the nature of the transaction that is being examined and the transfer pricing method, see paragraph 1.38. For instance, if the controlled transaction is a license agreement, for the exploitation of intellectual property rights and the transfer pricing method is the comparable uncontrolled price method, information on the key contractual terms of uncontrolled licenses, such as the license's duration, geographic area, exclusivity etc., can be assumed to be critical to assessing whether such uncontrolled licenses provide reasonably reliable comparables for the controlled transaction. Information on the third party contractual terms may be less critical if the controlled transaction is, for example, the provision of back-office accounting services and the comparison made is with the price of similar services offered by accounting firms" (OCDE. Proposed Revision of Chapters I-III of the Transfer Pricing Guidelines. $9^{\text {th }}$ September 2009- $9^{\text {th }}$ January 2010. op. cit., p. 18). Item novo, sem correspondente na Diretiva.
} 
diferenças materialmente relevantes entre os mercados dos negócios a serem cotejados. Com efeito, os preços e condições dos negócios podem variar em função de tais circunstâncias, não sendo aconselhável, v.g., a comparação de operações efetivadas num país com economia em plena expansão com outras que tenham incorrido em jurisdições que atravessam uma grave crise financeira; os preços de ambas podem ter sido afetados por fatores exógenos; também não podem ser comparados preços praticados num determinado mês de crise econômica com os preços pós-crise. Para se garantir um nível adequado de comparabilidade, é mister analisar o "mercado relevante" em que se efetivaram as operações, a partir de critérios de substitutibilidade, os quais devem envolver localização geográfica $^{370}$, dimensão do mercado, grau de concorrência e posição concorrencial relativa do ente usado como parâmetro, existência de substitutos, níveis de oferta e demanda, poder de compra dos consumidores, regulação e nível de ingerência do governo no mercado, custo de mão-de-obra e de capital $^{371}$, ciclo de vida do produto ${ }^{372}$ etc.. Após essa análise,

370 "1.56. The geographic market is another economic circumstance that can affect comparability. The identification of the relevant market is a factual question. For a number of industries, large regional markets encompassing more than on country may prove to be reasonably homogeneous, while for others, differences among domestic markets (or even within domestic markets) are very significant" (OCDE. Proposed Revision of Chapters I-III of the Transfer Pricing Guidelines. $9^{\text {th }}$ September 2009- $9^{\text {th }}$ January 2010. op. cit., p. 19). Item novo, sem correspondente na Diretiva. Ainda sobre o assunto, confira-se o quanto prescrito na legislação norte-americana, bem assim exemplo dali extraído:

“\$1.482-1 (d) (4) (ii) Different geographic markets. (A) Uncontrolled comparables ordinarily should be derived from the geographic market in which the controlled taxpayer operates, because there may be significant differences in economic conditions in different markets. If information from the same market is not available, an uncontrolled comparable derived from a different geographic market may be considered if adjustments are made to account for differences between the two markets. If information permitting adjustments for such differences is not available, then information derived from uncontrolled comparables in the most similar market for which reliable data is available may be used, but the extend of such differences may affect the reliability of the method for purposes of the best method rule. For this purpose, a geographic market is any geographic area in which the economic conditions for the relevant product or services are substantially the same, and may include multiple countries depending on the economic conditions.

(B) (...) Example. Manuco, a wholly-owned foreign subsidiary of P, a US corporation, manufactures products in country $\mathrm{Z}$ for sale to $\mathrm{P}$. No uncontrolled transactions are located that would provide a reliable measure of the arm's length result under the comparable uncontrolled price method. The district director consider applying the cost plus method or the comparable profits method. Information on uncontrolled taxpayers performing comparable functions under the same comparable circumstances in the same geographic area is not available. Therefore, adjusted data from uncontrolled manufacturers in other markets may be considered in order to apply the cost plus method. In this case, comparable uncontrolled manufacturers, as adjusted to account for differences between the United States and Country Z's geographic market, is used to test the arm's length price paid by P to Manuco" [26 CFR Ch. I (4-1-09 Edition)].

${ }^{371}$ Se uma transação independente comparável verifica-se num mercado geograficamente distinto daquele onde ocorre a transação "testada", podem ser necessários ajustes para eliminar as diferenças materialmente significativas nos custos que pudessem ser atribuídas à distinção dos mercados. Estes ajustes devem ser baseados nos efeitos que tais dessemelhanças teriam nos preços cobrados ou pagos nas transações "testadas", dada a posição competitiva relativa do vendedor e do comparador em cada mercado. Nesse contexto, o fato de os custos de operação numa determinada jurisdição $\mathrm{X}$ serem inferiores ao custos que seriam incorridos no país Y justificaria lucros maiores para o fabricante estabelecido em $\mathrm{X}$ tão-somente se tais diferenças de custos fossem capazes de elevar os lucros de fabricantes independentes atuando em regime de plena concorrência. Nesse sentido, veja-se o seguinte exemplo: 
deve-se ponderar o impacto das diferenças materialmente relevantes nos preços e/ou condições dos negócios cotejados e, na medida do possível, expurgá-los, para o fim de se garantir a comparabilidade das operações. Se os ajustes nos preços para a eliminação dos impactos das distintas circunstâncias econômicas não forem viáveis ou seu resultado não for confiável, as operações não poderão ser confrontadas, por inexistir um grau razoável de comparabilidade. Por fim, importa esclarecer que as circunstâncias econômicas a serem examinadas e comparadas são aquelas constatadas no momento em que a transação foi contratada, e não durante sua implementação/desenvolvimento, porque neste intervalo as circunstâncias podem ter se modificado, sem que as partes dispusessem de mecanismos para prever essas alterações.

\section{(V.) Estratégias empresariais.}

Consoante sustentado pela OCDE, o emprego do quinto fator de comparabilidade envolve o confronto entre as estratégias das empresas "testadas", de um lado, e as estratégias das empresas que praticaram as transações independentes, de outro. Na medida do possível, devem ser examinados a inovação, grau de diversificação, aversão ao risco, fatores políticos, legislação trabalhista etc.. É desejável, outrossim, a análise da estratégia de todo o grupo multinacional, para ponderar em que medida ela impacta a operação controlada fiscalizada.

As estratégias podem incluir, v.g., modalidades de penetração no mercado. Com efeito, a busca por novos mercados ou maior participação percentual pode acarretar redução de preços, de margens e de lucros, pois há custos mais elevados em esforços de marketing. Não é viável, nesse contexto, comparar transações "testadas" com operações

\footnotetext{
“\$1.482-1 (d) (4) (ii) (D) Example. Couture, a US apparel design corporation, contracts with Sewco, its wholly-owned Country Y subsidiary, to manufacture its clothes. Costs of operating in Country Y are significantly lower than the operating costs in the United States. Although clothes for the Couture label sells for a premium price, the actual production of the clothes does not require significant specialized knowledge that could not be acquired by actual or potential competitors to Sewco at reasonable cost. Thus, Sewco's functions could be performed by several actual or potential competitors to Sewco in geographic markets that are similar to Country Y. Thus, the fact that production is less costly in Country Y will not, in and of itself, justify additional profits derived from lower operating costs in Country Y inuring to Sewco, because the competitive positions of the other actual or potential producers in similar geographic markets capable of performing the same functions at the same low costs indicate that at arm's length such profits would not be retained by Sewco" [26 CFR Ch. I (4-1-09 Edition)].

372 "1.55. The existence of a cycle (economic, business, or product cycle) is one of the economic circumstances that may affect comparability" (OCDE. Proposed Revision of Chapters I-III of the Transfer Pricing Guidelines. $9^{\text {th }}$ September 2009- $9^{\text {th }}$ January 2010. op. cit., p. 19). Item novo, sem correspondente na Diretiva.
} 
independentes que se enquadrem nesta situação. Se, contudo, é o contribuinte que alega desenvolver esse tipo de estratégia, a administração pode enfrentar dificuldades em sua fiscalização; isso porque, se ela não apresentar sucesso futuro, porque o contribuinte não a adotou, poderá haver decadência do direito de reanalisar os primeiros anos do 'plano de penetração no mercado'. Justamente por esse motivo é que, normalmente, estes casos têm fiscalização mais severa. São muitos os fatores que devem ser considerados na busca de 'lucros futuros' às custas do presente; o principal deles é apreciar se a conduta do contribuinte é consistente com a estratégia de negócio apresentada. Além disso, é preciso analisar a "função" do contribuinte que suporta os custos efetivos de tal estratégia: na prática, um mero agente comercial sem exclusividade ou contrato de longo prazo não suportaria um "prejuízo inicial” decorrente da venda a preços reduzidos. Apenas se pode admitir este tipo de estratégia, assim, na esfera jurídica do contribuinte que irá, no futuro, ser beneficiado por ela; parceiros comerciais independentes jamais concordariam em incorrer em prejuízos para que sua contraparte experimentasse, sozinha, lucros futuros ${ }^{373}$. Ainda no que concerne a este tipo de estratégia de penetração ou de aumento da

373 "1.34. When evaluating a taxpayer's claim that it was following a business strategy that temporarily decreased profits in return for higher long-run profits, several factors should be considered. Tax administrations should examine the conduct of the parties to determine if it is consistent with the professed business strategy. For example, if a manufacturer charges its related distributor a below-market price as part of a market penetration strategy, the cost savings to the distributor may be reflected in the price charged to the distributor's customers or in greater market penetration expenses incurred by the distributor. A market penetrations strategy of a MNE group could be put in place by the manufacturer or by the distributor acting separately from the manufacturer (and the resulting cost born by either of them). Furthermore, usually intensive marketing and advertising efforts would often accompany a market penetration or market share expansion strategy" (OCDE. Transfer Pricing Guidelines for Multinational Enterprises and Tax Administrations, op. cit., p. I-14). Correspondente ao item 1.61 da Minuta-2009.

Veja-se, por exemplo, as exigências e ponderações do fisco norte-americano com respeito a estratégias para aumento de participação de um certo produto num determinado mercado:

"\$1.482-1 (d) (4) (i) Market share strategy. In certain circumstances, taxpayers may adopt strategies to enter new markets or to increase a product's share of an existing market (market share strategy). Such strategy would be reflected by temporarily increased market development expenses or resale prices that are temporarily lower than the prices charged for comparable products in the same market. Whether or not the strategy is reflected in the transfer price depends on which party to the controlled transaction bears the cost of pricing strategy. In any case, the effect of a market share strategy on a controlled transaction will be taken into account only if it can be shown that an uncontrolled taxpayer engaged in a comparable strategy under comparable circumstances for a comparable period of time, and the taxpayer provides documentation that substantiates the following:

(A) The costs incurred to implement the market share strategy are borne by the controlled taxpayer that would obtain the future profits that result from the strategy, and there is a reasonable likelihood that the strategy will result in future profits that reflect an appropriate return in relation to the costs incurred to implement it;

(B) The market share strategy is pursued only for a period of time that is reasonable, taking into consideration the industry and product in question; and

(C) The market share strategy, the related costs and expected returns, and any agreement between the controlled taxpayers to chare the related costs, were established before the strategy was implemented" [26 CFR Ch. I (4-1-09 Edition)]. 
participação de um certo produto no mercado, importa ponderar que a administração tributária brasileira admite este tipo de prática, desde que mediante a implementação de um "plano específico de exportação", de prazo não superior a um ano e previamente aprovado pela Receita Federal do Brasil. Esta regra, disciplinada no artigo 30 da Instrução

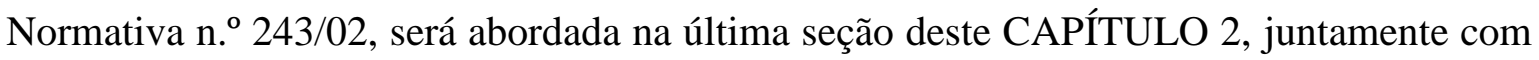
outras hipóteses de safe harbour no direito brasileiro.

\subsubsection{O "processo típico".}

Uma inovação trazida pela OCDE no âmbito da Minuta-2009, que contém propostas para alteração do teor da Diretiva, foi a sugestão de um passo a passo para a implementação do processo de comparabilidade, denominado "processo típico" [ou "typical process"] ${ }^{374}$, o qual representa uma espécie de guia para a aplicação do princípio da plena concorrência. Reconhece-se que o uso seqüencial do processo não garante necessariamente a obtenção de um resultado conforme o princípio da plena concorrência, ao mesmo tempo em que se admite que podem ser obtidos bons resultados sem a sua utilização. Independentemente dessas ponderações, a OCDE considera ser proveitosa sua observância durante qualquer procedimento de fiscalização, a partir do cumprimento de cada um dos seguintes passos:

374 Confira-se o texto integral com os dez pontos que devem ser perfilhados para o adequado desenvolvimento do processo de comparabilidade típico:

"3.5 (...) Step 1: Broad-based analysis of the taxpayer circumstances.

Step 2: Determination of years to be covered.

Step 3. Understanding the controlled transaction(s) under examination, based in particular on a functional analysis, in order to choose the tested party (where needed), the most appropriate transfer pricing method to the circumstances of the case, the financial indicator to be tested (in the case of transactional profit method), and to identify the significant comparability factors that should be taken into account.

Step 4. Review of existing internal comparables, if any.

Step 5. Determination of available sources of information on external comparables where such external comparables are needed and the sources' reliability.

Step 6. Selection of the most appropriate transfer pricing method and, depending on the method, definition of the relevant financial indicator (e.g., definition of the relevant net profit indicator in case of a transactional net margin method).

Step 7. Identification of potential comparables: defining the key characteristics to be met by any uncontrolled transaction in order to be regarded as potentially comparable, based on the relevant factors identified in step 3 and in accordance with the comparability factors (...).

Step 8. Determination of the making comparability adjustments where appropriate.

Step 9. Interpretation and use of data collected, determination of arm's length remuneration.

Step 10. Implementing support processes. Installing review process to ensure adjustment for material changes and documenting these processes" (OCDE. Proposed Revision of Chapters I-III of the Transfer Pricing Guidelines. $9^{\text {th }}$ September 2009- $9^{\text {th }}$ January 2010. op. cit., p. 54). Item novo, sem correspondente na Diretiva. 
asso 1: examinar as circunstâncias econômicas vigentes no mercado durante o período em que se deu a transação "testada" 375 .

- Passo 2: determinar o período a ser abrangido pela fiscalização.

- Passo 3: proceder à análise funcional da transação "testada", com o objetivo de se escolher (a.) o método mais adequado considerando-se as circunstâncias do caso; (b.) o indicador econômico a ser testado [na hipótese de aplicação do TNMM e do $\mathrm{CPI}$; e (c.) os fatores de comparabilidade que precisam ser considerados.

: Passo 4: revisar a existência de possíveis comparáveis internos ${ }^{376}$.

- Passo 5: determinar as fontes de informação disponíveis para a obtenção de comparáveis externos e sua fiabilidade.

: Passo 6: selecionar o método mais adequado e, se for o caso, o indicador econômico a ser testado;

- Passo 7: identificar as potenciais transações independentes comparáveis e definir as características e semelhanças que a tornaram um dado comparável, com apoio nos fatores identificados no Passo 3.

- Passo 8: determinar e implementar ajustes para expurgar as diferenças materialmente relevantes localizadas nas transações independentes comparáveis, se for o caso.

-1 Passo 9: interpretar os dados coletados e confrontá-los com as operações testadas, definindo-se qual seria a remuneração adequada a partir da aplicação do princípio da plena concorrência ao caso.

Passo 10: finalizar o processo, revisar ajustes necessários para eliminação de diferenças materialmente relevantes entre as transações confrontadas e documentar todo o procedimento.

Note-se que os passos supra não devem ser adotados linear e seqüencialmente $^{377}$. Se, v.g., no Passo 8, verificar-se que não são viáveis ajustes razoavelmente precisos para eliminação das diferenças entre as transações "testadas" e as

375 “3.7. The 'broad-based analysis' is an essential step in the comparability analysis. It can be defined as an analysis of the industry, competition, economic and regulatory factors and other elements that affect the taxpayer and its environment, but not yet within the context of looking at the specific transactions in question. This step helps understand the conditions in the taxpayer's controlled transaction as well as those in uncontrolled transactions to be compared, in particular the economic circumstances of the transaction" (OCDE. Proposed Revision of Chapters I-III of the Transfer Pricing Guidelines. $9^{\text {th }}$ September 2009- $9^{\text {th }}$ January 2010. op. cit., p. 55). Item novo, sem correspondente na Diretiva.

${ }^{376}$ A questão dos comparáveis internos e externos será abordada no item (IV) desta subseção.

377 Outros exemplos de inter-relacionamento entre os passos do "processo típico" constam do item 3.6 da Minuta-2009, o qual não possui correspondente na versão original da Diretiva. 
transações independentes, deve se retornar ao Passo 5, i.e., deve-se proceder a nova busca de comparáveis externos. O mesmo procedimento deve ser adotado se, no Passo 7 , perceber-se que o exame de um dos fatores de comparação praticamente inviabilizou a utilização daqueles dados comparáveis. Se, por outro lado, forem localizados comparáveis internos, pode-se, após o Passo 4, realizar diretamente as providências descritas no Passo 6, sem a necessidade de busca de comparáveis externos.

Examinados os passos recomendados pela OCDE para a condução do "processo típico" de fiscalização dos preços de transferência, passamos, nos itens abaixo, a expor alguns aspectos relevantes envolvidos em tal procedimento, os quais têm por fim, juntamente com os cinco fatores determinantes de comparabilidade, garantir a adequada aplicação do princípio da plena concorrência.

\section{(I.) Comparabilidade dos dados transação-a-transação ou por cestas de}

\section{transações conjugadas ou semelhantes.}

Em termos teóricos, o princípio da plena concorrência deve ser aplicado transação-a-transação, i.e., cada espécie de transação praticada pelo contribuinte deve ser "testada" mediante o seu confronto com transações independentes semelhantes, levadas a efeito pelo mesmo contribuinte ou por terceiros. Por vezes, no entanto, as operações são tão estreitamente ligadas que é impossível analisá-las isoladamente, como, e.g., (i.) nos contratos de fornecimento a longo prazo $^{378}$; (ii.) nos direitos de utilização de propriedade intangível $^{379}$; (iii.) na licença de uso de determinada tecnologia de produção, conjugada

378 "Como regra geral, o valor normal deveria ser examinado com referência a cada operação, seja essa uma
cessão de bens ou prestação de serviços (on a transaction-by-transaction basis). Todavia, em alguns casos, a
determinação dos preços de transferência pode ser efetuada só considerando uma série de operações idênticas
ou coligadas. Este é o caso, por exemplo, de contratos de fornecimento a longo prazo de matérias-primas ou
de serviços ou de direitos imateriais.
Trata-se de situações nas quais a determinação agrupada encontra fundamento na repetitividade de operações
idênticas executadas em um intervalo de tempo muito amplo; em outros casos, ao invés, a determinação do
transfer price motiva-se com a conexão entre duas operações ontologicamente diversas" (TÔRRES, Heleno
Taveira. Direito tributário internacional: planejamento tributário e operaçôes transnacionais. op. cit., p.
188 ).
379 "§1.482-1 (f) (2) (i) The combined effect of two or more separate transactions (whether before, during or
after the taxable year under review) may be considered, if such transactions, taken as a whole, are so
interrelated that consideration of multiple transactions is the most reliable means of determining the arm's
length consideration for the controlled transactions. Generally, transactions will be aggregated only when
they involve related products or services (...)
Example 2 . S1, S2 and S3 are Country Z subsidiaries of US manufacturer P. S! is the exclusive Country Z
distributor of computers manufactured by P. S2 provides marketing services in connection with sales of P
computers in Country Z, and in this regard uses significant marketing intangibles provided by P. S3 
com o fornecimento de insumo vital para a fabricação do produto final; (iv.) na prestação de serviços estritamente vinculada a um determinado bem tangível ou intangível; e (v.) na precificação de produtos muito vinculados, normalmente de uma mesma "linha de produtos", sempre que for impraticável precificar cada produto ou transação isoladamente ${ }^{380}$ etc.. Nestas hipóteses, recomenda-se o exame dos preços de transferência das operações de forma conjugada, excetuando-se a regra da análise transação-a-transação; esta seria a melhor alternativa para a obtenção de resultados compatíveis com o princípio da plena concorrência.

administers the warranty program with respect to $\mathrm{P}$ computers in Country $\mathrm{Z}$, including maintenance and repair services. In evaluating the arm's length character of the transfer price paid by $\mathrm{S} 1$ to $\mathrm{P}$, of the fees paid by $\mathrm{S} 2$ to $\mathrm{P}$ for the use of $\mathrm{P}$ marketing intangibles, and of the service fees earned byS2 and $\mathrm{S} 3$, it may be appropriate to consider the combined effects of these separate transactions because they are so interrelated that they are most reliably analyzed on an aggregate basis" [26 CFR Ch. I (4-1-09 Edition)].

${ }^{380} \mathrm{Na}$ legislação norte-americana existe a previsão de que as empresas com muitas linhas de produtos podem optar por ter seus preços de transferência testados "por linha”, e não na base transação-a-transação, como medida de simplificação e praticabilidade, mediante a utilização, inclusive, de técnicas estatísticas. Uma empresa de eletroeletrônicos, nesta perspectiva, deveria testar seus preços de transferência da linha de televisores, e não de cada tipo e variação de televisor. Veja-se:

"§1.482-1 (f) (2) (iv) Product lines and statistic techniques: The methods described in $\S \S 1.482-2$ through 1.482-6 are generally stated in terms of individual transactions. However, because a taxpayer may have controlled transactions involving many different products, or many separate transactions involving the same product, it may be impractical to analyze every individual transaction to determine it arm's length price. In such cases, it is permissible to evaluate the arm's length results by applying the appropriate method to the overall results from product lines or other groupings. In addition, the arm's length results of all related party transactions entered into by a controlled taxpayer may be evaluated by employing sampling and other valid statistical techniques" [26 CFR Ch. I (4-1-09 Edition)].

Ainda sobre o assunto, confira-se trecho da obra de Richard HAMMER:

"In actuality, taxpayers have controlled transactions involving the same or similar products, many different products, or many transactions involving different products lines. It would often be impractical to evaluate very single transaction of multinational companies. (...) In other words, the Guidelines initially provide that transfer pricing analyzes is to be undertaken on a transactional basis. This is done for convenience of presentation and analyses, rather than a prescription that every transaction of a multinational has to be evaluated. Obviously, this would be impossible as a practical matter. Accordingly, the Guidelines explicitly contemplate that related products or product lines will be evaluated on a combined basis when it is impractical to determine pricing on a more narrow basis. (...)

Any entity with many product lines, whether independent or part of an MNE, will always be exposed to numerous variations in pricing and volume at the product level. However, if adverse variances are matched by positive variances at product level, it may not be necessary to immediately negotiate prices with the suppliers, raise prices, or cease stocking the product that is underperforming against budget, particularly if the problem is considered short term. An illustration of a case where it would be appropriate to combine transactions for the purposes of applying the arm's length principle under the standards set out in the Guidelines is noted bellow:

Example: A MNE operates worldwide manufacturing and distributing computer components. It invests heavily in research and development. Manufacturing of the components takes place in country $\mathrm{X}$ where the MNE has its headquarters and incurs all relevant research and developing and marketing costs. The MNE manufactures and supplies thousands of individual components, some branded and partially branded, to its associated companies in countries $\mathrm{Y}$ and $\mathrm{Z}$, which distribute the components in those countries. The components themselves are spread over hundreds of product lines" (HAMMER, Richard M. et. al. International Transfer Pricing - OCDE Guidelines. op. cit., item 3.03 [7A]). 
Com efeito, não há dúvidas de que, em muitos casos, alguns produtos são comercializados com preços mais baixos para garantir competitividade, compensando-se essa perda com ganhos em outras operações. Isso porque aos contribuintes, envolvidos em transações vinculadas e/ou independentes, sempre importa a lucratividade global da companhia, e não o lucro de cada bem, serviço ou direito. Em virtude disso, muitas vezes estruturam negócios em que um determinado produto é vendido a preço reduzido, por vezes até abaixo do custo, para estimular a venda de outro mais lucrativo; estas duas operações de venda e compra, se examinadas isoladamente, não se adequariam ao princípio da plena concorrência; a estratégia "global”, todavia, seria compatível com o princípio. Um exemplo simples desse tipo de estratagema pode ser detectado em empresas que se dedicam à venda de sachês de café expresso; normalmente, esses contribuintes vendem, a preços reduzidos, também a máquina de café compatível com seus sachês, com o intuito de estimular a venda do seu café. Da mesma forma atuam as empresas que se dedicam à produção e venda de toners de impressora, que em sua maioria também vendem, a preços reduzidos, impressoras compatíveis exclusivamente com o seu produto. A única solução viável para o teste dos preços de transferência, nestes casos, estaria lastreada na análise combinada da operação total, e não nos efeitos unitários de cada uma delas ${ }^{381}$.

A lei brasileira, desde as alterações introduzidas pela Medida Provisória n. ${ }^{\circ}$ 478/09, prevê expressamente que os métodos admitidos para o controle dos preços de transferência devem ser aplicados, consistentemente, "por bem, serviço ou direito", proibindo, portanto, o exame conjunto de transações intrinsecamente relacionadas ou envolvendo uma mesma linha de produtos [cf. artigo 19-B, $§ 2^{\circ}$, da Lei n. ${ }^{\text {9 }} 9.430 / 96^{382}$ ].

\footnotetext{
${ }^{381}$ Nesse mesmo sentido, confira-se o seguinte trecho da Minuta-2009:

“3.10. Another example where a taxpayer's transactions may be combined is related to portfolio approaches. A portfolio approach is a business strategy consisting of a taxpayer's bundling certain transactions for the purpose of determining or testing transfer prices. For instance, some products may be marketed by a taxpayer with a low profit or even at a loss, because they create a demand for other products of the same taxpayer that are then sold with high profits (e.g. equipment and captive aftermarket consumables, such as vending coffee machines and coffee capsules, or printers and cartridges. Similar approaches can be observed in various industries" (OCDE. Proposed Revision of Chapters I-III of the Transfer Pricing Guidelines. 9th September 2009- 9th January 2010. op. cit., p. 55). Item novo, sem correspondente na Diretiva.

382 "Art. 19-B. (...)

$\S 2^{\circ}$ A utilização do método de cálculo do preço parâmetro deve ser consistente por bem, serviço ou direito, durante todo o ano-calendário, observado o disposto no caput deste artigo".

Até a publicação da Medida Provisória n. ${ }^{\circ}$ 478/09, esta previsão não constava do texto legal, mas tãosomente da Instrução Normativa n. ${ }^{\circ}$ 243/02, razão pela qual muitos autores julgavam-na ilegal. Se prevalecer a redação atual do artigo 19-B da Lei n. ${ }^{\circ}$ 9.430/96, essa previsão não poderá ser julgada ilegal, mas, em alguns casos concretos, inconstitucional, porque se sabe que, economicamente, transações muito relacionadas entre as mesmas partes geram impactos nos preços umas das outras, cedendo as partes em alguns casos, mas obtendo sua "contraprestação" adequada em um outro contrato.
} 
Entendemos não ser razoável esse tipo de vedação legal, porque o "cerne" do princípio da plena concorrência é, justamente, a comparação dos preços vinculados aos preços estabelecidos no livre mercado. Se, no mercado, há operações "mistas" e avaliadas conjuntamente, as quais conjugam, v.g., prestação de serviços e/ou fornecimento de mercadorias com cessão de intangíveis [marcas, patentes etc.], por que as partes vinculadas não podem também mensurar seus preços desta forma? A análise produto-a-produto pode, nesse cenário, gerar inconsistências graves, não compatíveis com os limites constitucionais a que a legislação para o controle dos preços de transferência deve se submeter. Em razão destas ponderações, entendemos que a interpretação mais adequada a ser conferida ao texto legal seria a seguinte: (a.) a regra geral aplicável é a do exame transação-a-transação; todavia, se não for viável/praticável a aplicação da lei segundo essa sistemática, ou se os resultados obtidos não forem adequados, (b.) o contribuinte poderá comprovar seus preços a partir de "cestas" de transações, desde que sejam explicados (1.) os critérios utilizados para a determinação das cestas e (2.) a fórmula de cálculo adotada para os preços de transferência. Se as autoridades administrativas discordarem da adoção de tais critérios, poderá o contribuinte demonstrar a adequação dos critérios adotados, com fundamento no artigo 148 do Código Tributário Nacional. Filiamo-nos, nesse sentido, à doutrina de Heleno Taveira TÔRRES ${ }^{383}$ e Luís Eduardo SCHOUERI ${ }^{384}$.

Se, de um lado, pode ser essencial congregar transações, de outro, alguns contratos "globais" podem exigir avaliações separadas. Assim, v.g., um acordo global que envolve concessão de patentes, processos técnicos, marcas, serviços técnicos e locação, pode ser melhor avaliado se for segregado em cinco operações distintas, sendo que cada uma delas seria comparada com um preço parâmetro específico. Normalmente, estes acordos não envolvem venda de produtos, embora uma venda possa ter serviços adicionais incluídos no seu preço. Logo, os acordos denominados "globais" envolvem tão-somente serviços e direitos, cujo exame e comparação é mais complexo. Depois de uma análise segregada de cada um de seus itens, o acordo deve ser avaliado globalmente, para se

\footnotetext{
383 "Mas esta [basket approach] não é a regra e sim a exceção, não sendo de todo adequado regular o todo pelo que ele tem de excepcional. Desse modo, caberá ao contribuinte demonstrar a inadequação de uma análise produto-a-produto, quanto ao controle das transações com as quais se encontra envolvido, com a solicitação de que se faça uma análise por 'cesta de produtos', tudo dentro do seu amplo direito de prova em contrário (art. 148 do CTN)" (TÔRRES, Direito tributário internacional: planejamento tributário e operações transnacionais. op. cit., p. 189).

${ }^{384}$ In: Preços de Transferência no Direito Tributário Brasileiro. op. cit., p. 80-84.
} 
examinar se o conjunto está conforme o princípio da plena concorrência ${ }^{385}$. Note-se que, em alguns casos, mesmo quando não se tratar de partes relacionadas, pode ser importante a segregação de um acordo global, quando, v.g., as espécies de receitas ali previstas sujeitarem-se a regras distintas de retenção de imposto sobre a renda na fonte, no âmbito de uma convenção bilateral; neste caso, será essencial distinguir o valor relativo a juros, royalties, lucro de empresas etc..

\section{(II.) Reconhecimento das transações vis-à-vis rearranjos contratuais.}

O controle do preço de transferência de uma transação vinculada deve basear-se na operação efetivamente ocorrida entre as partes e no modo como esta última foi originalmente estruturada. Não se pode ignorar as transações "reais", nem substituí-las, porque isto representaria uma espécie de arbitrariedade. Não obstante isso, em duas hipóteses a OCDE sustenta ser possível a não-adoção da estrutura implementada pelo contribuinte, admitindo sua requalificação; são elas: (i.) casos em que há discordância da forma da transação com sua substância econômica ${ }^{386}$; e (ii.) sempre que a transação vinculada for distinta daquela que teria sido adotada por partes independentes agindo de um modo comercialmente racional ${ }^{387}$. Nestes casos, explana a OCDE que o princípio da plena concorrência admitiria que a estrutura negocial fosse ajustada, de modo a refletir aquela que teria sido adotada por partes que se estivessem negociando em condições de plena concorrência. Não pretendemos aprofundar neste ponto específico porque, no Brasil,

\footnotetext{
${ }^{385}$ In: OCDE. Transfer Pricing Guidelines for Multinational Enterprises and Tax Administrations, op. cit., p. I-18, item 1.43. Correspondente ao item 3.11 da Minuta-2009.

${ }^{386}$ Confira-se, nesse mesmo sentido, a regra norte-americana de desconsideração, quando da concretização do princípio da plena concorrência, de transações sem propósito ou substância econômica:

“\$1.482-1T (f) (2) (ii) Allocation based on taxpayers actual transactions. The Commissioner will evaluate the results of a transaction as actually structured by the taxpayer unless its structure lacks economic substance. However, the Commissioner may consider the alternatives available to the taxpayer in determining whether the terms of the controlled transaction would be acceptable to an uncontrolled taxpayer faced with the same alternatives and operating under comparable circumstances. In such cases the Commissioner may adjust the consideration charged in the controlled transaction based on the cost or profit of an alternative as adjusted to account for material differences between the alternative and the controlled transaction as if the alternative has been adopted by the taxpayer" [26 CFR Ch. I (4-1-09 Edition)].

387 “1.37. (...) An example of this circumstance would be a sale under a long-term contract, for a lump sum payment, of unlimited entitlement to the intellectual property rights arising as a result of future research for the term of the contract (...). While in this case it may be proper to respect the transaction as a transfer of commercial property, it would nevertheless be appropriate for a tax administration to conform the terms of that transfer in their entirety (and not simply by reference to pricing) to those that might reasonably have been expected had the transfer of property been the subject of a transaction involving independent enterprises. Thus, in the case described above it might be appropriate for the tax administration, for example, to adjust conditions of the agreement in a commercially rational manner as a continuing research agreement" (OCDE. Transfer Pricing Guidelines for Multinational Enterprises and Tax Administrations, op. cit., p. I16). Correspondente ao item 1.64 da Minuta-2009.
} 
a desconsideração de operações para fins tributários envolve muitas discussões doutrinárias. Todavia, nos casos em que restar demonstrado dolo, fraude ou simulação, este tipo de estratagema pode ser adotado pelas autoridades fiscais brasileiras.

\section{(III.) Prejuízos e compensações privadas.}

Como regra geral, se uma determinada empresa, que atua preponderantemente em operações vinculadas, apresenta constantes prejuízos, ao passo que seu grupo empresarial divulga, com relação aos mesmos períodos, elevados lucros, pode-se afirmar que há sinais de não-adoção do princípio da plena concorrência para a fixação dos preços de transferência ${ }^{388}$. Claro que empresas independentes também podem apresentar prejuízos sucessivos, decorrentes, v.g., dos custos e despesas elevados no início de suas atividades, de condições econômicas desfavoráveis, do insucesso dos seus produtos etc.; elas, todavia, não suportam prejuízos ao longo de décadas; antes disso, cessam suas atividades. Em empresas vinculadas, o prejuízo pode ser suportado por período superior, desde que a operação resulte em lucro para o seu grupo econômico, globalmente considerado. Neste caso, é provável que a empresa associada não esteja sendo adequadamente remunerada pelo grupo; com efeito, uma empresa independente nunca aceitaria produzir apenas itens deficitários. Algumas estratégias empresariais por vezes justificam prejuízos como, v.g., a adoção de preços reduzidos para ingressar num determinado mercado ou para nele aumentar sua participação; de todo modo, estas estratégias apenas são adotadas por curtos períodos e a elas estão vinculadas expectativas de elevados lucros a médio prazo. Prejuízos

\footnotetext{
388 "The presence of losses, however, is especially difficult if the affiliate in question consistently realizes losses, while the MNE group as a whole is profitable. This problem is indicated by Illustration 3.26.

Example 3.26. DistCo is a distributor of optical products in Euronia that are manufactured by MafCo, its parent company, in Mafonia. During the years under examination by the tax administrations of Euronia, DistCo has operating losses every year. These losses aggregated \$1,000. During the same period, MafCo, the parent supplier of DistCo, was highly profitable in Dominia.

Here, the presence of losses in DistCo is likely to trigger special scrutiny in the transfer pricing area. Because an affiliate is generating losses but is doing business with profitable members of its MNE group, this will suggest to a tax administration that the transfer pricing structure should be examined. The loss enterprise might not be receiving adequate compensation from its MNE group in relation to the benefits derived from its activities. (...)

A somewhat different emphasis would apply where the MNE group as a whole experiences losses, as suggested by Illustration 3.27.

Example 3.27. The situation is the same as in Illustration 3.26, except that the MafCo MNE group experiences losses in every country and on a combined basis in the optical and camera business.

In this situation, the absence of arm's length transfer pricing policies, is less apparent than where there are profits outside the distributor's (DistCo) country of operation. The appropriate transfer pricing analysis for DistCo in Illustration 3.27 is whether independent enterprises performing the same economic functions as DistCo would have incurred losses for an extended period of time, applying the methods of the Guidelines" (HAMMER, Richard M. et. al. International Transfer Pricing - OCDE Guidelines. op. cit., item 3.03 [10]).
} 
recorrentes e por um longo período de tempo devem, portanto, ser investigados, porque representam potenciais hipóteses de manipulação dos preços de transferência. A lei brasileira não contém regras concernentes à fiscalização de empresas que incorrem em contínuos prejuízos.

A compensação privada intencional dá-se quando uma empresa fornece a outra do seu grupo uma prestação, cujo "preço" é pago com contraprestações distintas recebidas em troca; nesta hipótese, sustenta a OCDE ser possível alegar que os lucros e prejuízos auferidos nos diferentes negócios foram "compensados" pelas partes. Como, por vezes, em hipóteses nas quais é possível quantificar com precisão as diferentes contraprestações, empresas independentes também firmam acordos de compensação, sustenta-se que as compensações intencionais também são compatíveis com o princípio da plena concorrência $^{389}$. Nesse contexto, sempre que um determinado contribuinte sustentar a existência de compensações na definição dos seus preços de transferência, deverá (i.) demonstrar o preço parâmetro de cada prestação ou contraprestação, isoladamente, a partir dos métodos previstos em lei; e, em seguida, (ii.) somar os preços parâmetro das transações "compensadas", de modo a comprovar que as condições das transações globalmente consideradas atendem ao princípio da plena concorrência. Nem sempre as compensações intencionais são facilmente detectáveis, cabendo ao contribuinte fazer prova de sua ocorrência $^{390}$. Por fim, ponderamos que a lei brasileira não admite as compensações

389 "1.62. Recognition of intentional sett-offs does not change the fundamental requirement that for tax purposes the transfer price of controlled transactions must be consistent with the arm's length principle. It would be helpful for taxpayers to disclose the existence of sett-offs intentionally built into two or more transactions between associated enterprises and demonstrate (or acknowledge that they have relevant documentation and have undertaken sufficient analysis to be able to show) that, after taking account of setoffs, the conditions governing the transactions are consistent with the arm's length principle at the time of filling the tax return" (OCDE. Transfer Pricing Guidelines for Multinational Enterprises and Tax Administrations, op. cit., p. I-16). Correspondente ao item 3.15 da Minuta-2009.

390 "DomCo has developed valuable intangible property used in the manufacture of certain advanced optical devices. DomCo has licensed its wholly-owned subsidiary, MafCo, the right to use the technology in return for the provision of know-how by MafCo related to another manufacturing process. Both intangible property transfers have a zero royalty rate. DomCo and MafCo claims that the transactions result in no profit or loss to either party.

These arguments, which may at times be encountered between independent enterprises, should be assessed in accordance with the arm's length principle to quantify the value of the respective benefits claimed as settoffs. There could also be a question of nonresident withholding taxes in such a situation.

International set-offs may vary in size and complexity. These set-offs may range from a simple balance of two transactions (e.g., a favorable selling price for manufactured goods in return for a favourable purchase price for the raw material used in producing the goods) to an arrangement for a general settlement balancing all benefits accruing to both parties over a stipulated period. Independent enterprises would be very unlikely to enter into this type of arrangement unless the benefits could be accurately quantified and the contract created in advance. Otherwise, such enterprises normally prefer their receipts and disbursements to flow 
intencionais, na medida em que os preços de transferência e respectivos ajustes são aferidos "por bem, serviço ou direito" [cf. artigo 19-B, §2º da Lei n. ${ }^{\circ}$ 9.430/96]. Sustentase, contudo, que essas compensações devem ser permitidas, inclusive porque a própria base de cálculo do imposto sobre a renda é determinada a partir do somatório de transações superavitárias e deficitárias ${ }^{391}$.

\section{(IV.) Transações independentes comparáveis.}

As transações independentes comparáveis podem representar transações do próprio contribuinte "testado" com terceiros independentes ["comparação interna"] ou transações entre terceiros independentes [“comparação externa”] ${ }^{392}$.

A comparação interna é preferível em relação à externa, porque apresenta a vantagem de utilização tão-somente de dados do próprio contribuinte, elevando-se o grau de aproximação entre os negócios; as transações confrontadas, nessa hipótese, terão o mesmo custo e resultado operacional e serão impactados pelas mesmas condições estruturais [situação do parque industrial, composição de capital da empresa etc.] ${ }^{393}$;

independently of each other, taking any profit or loss resulting from normal trading" (HAMMER, Richard M. et. al. International Transfer Pricing - OCDE Guidelines. op. cit., item 3.03 [12] [a]).

${ }^{391}$ Ricardo MARIZ DE OLIVEIRA, que critica muitíssimo a forma adotada pela lei brasileira para "nacionalizar" o princípio da plena concorrência, argumenta que o não-reconhecimento de tais compensações representa mais um indício que o princípio foi erroneamente adotado:

"Numa legislação que procure efetivamente a inteireza do controle de preços de transferência, sob a inspiração do princípio 'arm's length', devem ser consideradas em conjunto as operações que sejam integrantes de uma negociação mais ampla, pois os seus efeitos podem ser compensados de maneira a se anularem total ou parcialmente, por exemplo, a prática de preços aumentados nas importações de certos produtos e diminuídos nas de outros, ou de preços diminuídos nas exportações de certos produtos e aumentados nas de outros, sendo todas essas operações realizadas entre as mesmas partes vinculadas e dentro de um mesmo período de apuração. Ou mesmo pode haver aumento de preços nas importações, contrabalançado pelo aumento de preços de exportações, ou diminuição de preços de exportações contrabalançados pela diminuição de preços de importações, sendo essas operações realizadas pelas mesmas pessoas e dentro de um mesmo período de tempo.

Nestes casos, apenas o resultado líquido desse conjunto de atos deveria ser levado em conta para se apurar uma eventual transferência de lucro, o que, entretanto, a lei brasileira não admite" (MARIZ DE OLIVEIRA, Ricardo. Fundamentos do Imposto de Renda. op. cit., p. 844-845).

${ }^{392}$ Klaus VOGEL assim explicita essa classificação:

"A so-called 'external' price comparison calls for reference to be made to prices which are capable of being ascertained via bourse quotations or transactions used in the industry or branch of activity concerned. Reference may additionally be made to tables of charges issued by trade associations are official agencies. By means of an 'internal' price comparison, the direct method reverts to a form of test where prices by one and the same enterprise are compared: those charged to an associated enterprise are compared with those charged to an unrelated party. Further, prices may be considered which a related person agreed with a third party. It may also be the prices agreed upon by a parent company or affiliated company with a third party" (Klaus Vogel on Double Taxation Conventions. op. cit., p. 530).

${ }^{393}$ In: ROTHMAN, Gerd W. Preços de transferência - Método do preço de revenda menos lucro: base CIF (+II) ou FOB. A margem de lucro (20\% ou $60 \%)$ em processos de embalagem e beneficiamento. op. cit., p. 38. 
ademais, as comparações de dados contábeis serão mais fidedignas, porque provavelmente foram utilizados, para o registro de ambas as transações, os mesmos critérios e práticas contábeis $^{394}$. Essa comparação integra o Passo 4 do "processo típico".

Se, todavia, não forem localizados comparáveis internos razoavelmente confiáveis, deverão ser buscados comparáveis externos, como se depreende do Passo 5 do “processo típico" supra descrito ${ }^{395}$, os quais poderão ser obtidos, segundo assinalado pela OCDE, em bancos de dados comerciais, em outros países ou a partir de informações internas obtidas pela administração tributária [cf. item (V.), abaixo]. Os bancos de dados comerciais têm se tornado uma fonte recorrente de dados comparáveis externos, a despeito das inúmeras críticas sobre a qualidade das informações ali constantes; de fato, esses dados não foram obtidos e categorizados para fins de aplicação das regras para o controle dos preços de transferência ${ }^{396}$. Existem, também, bancos de dados criados por empresas de consultoria, aos quais são dirigidas críticas ainda mais severas, porque, normalmente, têm informações mais limitadas. Quanto aos dados obtidos em transações estrangeiras, recomenda a OCDE seu exame caso-a-caso, ponderando-se os cinco fatores de

394 “3.27. (...) Internal comparables may have a more direct and closer relationship to the transaction under review than external ones. The financial analysis may be easier and more reliable as it will presumably rely on identical accounting standards and practices for the internal comparable and for the controlled transaction. In addition, access to information on internal comparables may be both more complete and less costly" (OCDE. Proposed Revision of Chapters I-III of the Transfer Pricing Guidelines. 9th September 2009- 9th January 2010. op. cit., p. 59). Item novo, sem correspondente na Diretiva.

395 Alberto XAVIER nega a possibilidade de utilização de comparáveis externos no direito brasileiro, como se depreende do seguinte fragmento de sua obra:

"Um ou outro método [PIC e PVEx] permitem ao Fisco considerar imediatamente como parâmetro relevante uma divergência externa entre o preço das operações praticadas entre duas pessoas vinculadas com o preço praticado em operações realizadas com outros importadores ou exportadores, com outras pessoas não vinculadas, seja no mercado brasileiro, seja no mercado internacional.

Ora, o art. $9^{\circ}$ não permite a realização de tais comparações externas, restringindo o seu âmbito de aplicação à hipótese de uma divergência interna entre preços praticados pelo mesmo importador ou exportador nas suas relações com pessoas vinculadas e nas suas relações com terceiros não vinculados" (Direito Tributário Internacional do Brasil, op. cit., p. 398).

396 "3.30. They can be a practical and sometimes cost-effective way of identifying external comparables. A number of limitations to commercial databases are frequently identified. Because these commercial databases rely on publicly available information, they are not available in all countries, since not all countries have the same amount of publicly available information about their companies. Moreover, where they are available, they do not include the same type of information for all the companies operating in a given country because disclosure and filling requirements may differ depending on the legal form of the company and on whether or not it is listed. Care must be exercised with respect to whether and how these databases are used, given that they are complied and presented for non-transfer pricing purposes. It is not always the case that commercial databases provide information that is detailed enough to support the chosen transfer pricing method. Not all databases include the same level of detail and can be used with similar assurance. Importantly, it is the experience in many countries that commercial databases are used to compare the results of companies rather the transactions because third party transactional information is rarely available" (OCDE. Proposed Revision of Chapters I-III of the Transfer Pricing Guidelines. 9th September 2009-9th January 2010. op. cit., p. 60). Item novo, sem correspondente na Diretiva. 
comparabilidade; se forem esses os únicos dados disponíveis, eles não devem ser simplesmente ignorados ${ }^{397}$.

\section{(V.) Utilização de comparáveis secretos.}

Entende-se por "comparável secreto" um determinado dado não-público e, portanto, não disponibilizado ao contribuinte "testado", obtido pelas autoridades tributárias via (a.) procedimentos de fiscalização; (b.) bancos de dados internos formados a partir de declarações ou quaisquer espécies de obrigações acessórias apresentadas pelos contribuintes; (c.) intimações a empresas com atividades semelhantes; ou (d.) por quaisquer outros meios de que se pode valer o fisco por decorrência de suas prerrogativas especiais. Geralmente, quando os comparáveis secretos são utilizados como preços parâmetro em procedimentos de fiscalização, não são fornecidos ao contribuinte "testado" os dados e critérios de cálculo envolvidos na sua determinação, mas, pelo contrário, comparam-se as operações "testadas" com parâmetros "secretos" e não-explicados. Não pode o contribuinte, nesse cenário, defender-se adequadamente, porque a ele não são oferecidos todos os "elementos de acusação"; resta prejudicado, portanto, o seu direito à ampla defesa. A utilização dos comparáveis secretos é totalmente desaconselhada pela OCDE, a não ser que os dados possam ser explicitados aos contribuintes ${ }^{398}$. Em alguns países como, v.g., os Estados Unidos da América ${ }^{399}$ e a Alemanha ${ }^{400}$, os “comparáveis

${ }^{397}$ In: OCDE. Proposed Revision of Chapters I-III of the Transfer Pricing Guidelines. 9th September 20099th January 2010. op. cit., p. 61, item 3.34. Item novo, sem correspondente na Diretiva.

398 "3.35. Tax administrators may have information available to them from examinations of other taxpayers or from other sources of information that may not be disclosed to the taxpayer. However, it would be unfair to apply a transfer pricing method on the basis of such data unless the tax administration was able, within the limits of its domestic confidentiality requirements, to disclosure such data to the taxpayer so that there would be an adequate opportunity for the taxpayer to defend its own position and to safeguard effective judicial control by the courts" (OCDE. Proposed Revision of Chapters I-III of the Transfer Pricing Guidelines. 9th September 2009- 9th January 2010. op. cit., p. 61). Item novo, sem correspondente na Diretiva.

399 "To start, it may be helpful to summarize the Unites States' position on secret comparables. Since 1994, when the US Internal Revenue Service (IRS) published revised transfer pricing regulations, the IRS has shifted its focus away from non-public sources of transactional information from companies in the same industry. The IRS prefers to evaluate a transfer pricing issue based on internal data of the tested party or through an analysis of publicly available data of companies that perform functions similar to the tested party. In addition, the US Justice Department has indicated to the IRS that it is unwilling to enforce a third-party summons for information related to examination of transfer pricing case, effectively annulling the use of secret comparables in court proceedings. In essence, given the shift in the IRS audit focus to publicly available data, and the fact that all third-party contacts must be disclosed, the use of secret comparables in the US has been virtually eliminated" (PRZYSUSKI, Martin. Secret Transfer Pricing Comparables Still Popular in Some Jurisdictions. BNAI Tax Planning International Transfer Pricing. Toronto: v. 06, jul. 2005, p. 07).

${ }^{400}$ Neste país, a utilização dos comparáveis secretos foi judicialmente proibida, inclusive, nas hipóteses em que os dados comparáveis eram disponibilizados pelo fisco ao Poder Judiciário, por violar o sigilo fiscal garantido aos contribuintes alemães: 
secretos" foram proibidos, ao passo que em outros, dentre os quais se destacam Austrália, Canadá, Japão e Índia ${ }^{401}$, eles ainda são utilizados recorrentemente pelas autoridades administrativas.

No Brasil, a revelação de "comparáveis secretos" pode, eventualmente, esbarrar no direito ao sigilo fiscal [cf. 198 do Código Tributário Nacional ${ }^{402}$ ]; por conta disso, entendemos que sua aplicação é total e completamente proibida sempre que os dados "secretos" não puderem ser adequadamente expostos e explicados ao contribuinte "acusado", sob pena de inconstitucionalidade do respectivo processo administrativo. Consoante frisado por Luís Eduardo SCHOUERI, “a comparação externa não permite que se usem dados secretos, que não estejam à disposição do contribuinte. Outro entendimento implicaria cerceamento da liberdade de o contribuinte incorrer, ou não, na tributação: qualquer importador ou exportador seria colocado diante de uma verdadeira 'roleta russa', sujeito a todo momento a vir a ser surpreendido por tributação com a qual não contava e da qual não sabia como escapar, ${ }^{403}$.

Estão relacionadas à questão dos "comparáveis secretos" as tentativas de aplicação dos métodos PIC e PVEx a partir de preços parâmetro constituídos por dados disponibilizados no Sistema Integrado de Comércio Exterior ("SISCOMEX”). Primeiramente, pondere-se que os dados insertos no SISCOMEX e programas a ele vinculados não são, atualmente, de domínio público; este motivo, per se, é suficiente para a sua caracterização como "comparável secreto" e, por conseguinte, para se deduzir que sua utilização violaria frontalmente o princípio da ampla defesa. Mas, mesmo que os dados de preços consignados no SISCOMEX fossem disponibilizados aos contribuintes, ainda assim entendemos que sua utilização apresenta dificuldades. De fato, os preços praticados são ali registrados por agrupamentos de produtos, ordenados por código da Nomenclatura Comum

\footnotetext{
"In Germany, the problem was very well defined and the legal situation was clarified by the Düsseldorf Regional Tax Court in its decision of 8 December 1998. The Court ruled that the disclosure of data relating to other taxpayers violated the rights of those taxpayers constituting a breach of tax secrecy, even if the information concerned was only given to the Court. In addition, the taxpayer concerned would put at a disadvantage if only the Court was allowed to see and take into account the information concerned. The use of information made anonymous by the tax administration would deprive the Court of the possibility to check whether the data was really comparable and complete" (IStR 1999, 311)" (HAMAEKERS. Arm's LengthHow Long? op. cit., p. 36).

Na esfera administrativa, contudo, as autoridades insistem ser possível a utilização desses comparáveis.

${ }^{401}$ In: PRZYSUSKI, Martin. op. cit. penúltima nota.

402 “Art. 198. Sem prejuízo do disposto na legislação criminal, é vedada a divulgação, por parte da Fazenda Pública ou de seus servidores, de informação obtida em razão do ofício sobre a situação econômica ou financeira do sujeito passivo ou de terceiros e sobre a natureza e o estado de seus negócios ou atividades”. ‘

${ }^{403}$ In: Preços de Transferência no Direito Tributário Brasileiro. op. cit., p. 123-124.
} 
do Mercosul ("NCM"), os quais, em muitos casos, congregam bens de diversas naturezas; não é possível, assim, certificar-se de que se trata de bens idênticos ou similares. Ademais, (i.) não constam do sistema as condições comerciais ou financeiras das transações ali refletidas, de modo que se revela impossível proceder-se a uma adequada análise de comparabilidade; (ii.) o SISCOMEX possui dados de operações vinculadas e nãovinculadas, indistintamente; (iii.) ali há informações não disponíveis no momento da transação "testada" e que, por conseguinte, não poderiam ter amparado a tomada de decisão do contribuinte etc. ${ }^{404}$. Por todas estas razões, se as autoridades tributárias utilizarem dados do SISCOMEX para a realização de ajustes em preços de transferência, poderão os contribuintes defender-se, com fundamento no princípio da ampla defesa e no artigo 148 do Código Tributário Nacional. Entendemos ser possível, contudo, a utilização dos dados por NCM do SISCOMEX como espécie de safe harbour, por intermédio da qual o fisco admitiria como adequados os preços parâmetro colhidos pelos contribuintes daquele sistema; esta seria uma medida de simplificação das regras para o controle dos preços de transferência no país. Não é sustentável, todavia, o inverso: sempre que o fisco valer-se de dados de tal sistema, terá o contribuinte o direito de efetivar sua contraprova, para demonstração das condições e circunstâncias específicas de suas transações "testadas".

\section{(VI.) Noção de intervalo de plena concorrência.}

Sustenta a OCDE que, por vezes, a aplicação de um determinado método não gera um único preço, margem ou lucro de referência, mas um intervalo, dentro do qual os valores têm fiabilidade mais ou menos equivalente. Há a obtenção de resultados distintos porque o emprego do princípio da plena concorrência possibilita tão-somente a aproximação das condições que seriam estabelecidas entre empresas independentes; ademais, mesmo em idênticas condições, empresas independentes não praticam exatamente o mesmo preço em todas as suas transações. Também é apta a produzir um intervalo a aplicação de dois métodos, complementarmente, na tentativa de se obter o mais adequado preço de plena concorrência. A aplicação de dois métodos também pode produzir dois intervalos, sendo que ambos serão válidos, e os dados sobrepostos

\footnotetext{
${ }^{404}$ In: SCHOUERI, Luís Eduardo. Preços de Transferência no Direito Tributário Brasileiro. op. cit., p. 124.
} 
determinarão com maior exatidão o preço de livre mercado ${ }^{405}$. Desvios significativos dos pontos do intervalo [segundo um ou mais métodos] podem indicar que os dados não são confiáveis e que são necessários ajustes ${ }^{406}$. Habitualmente, se o preço da operação vinculada estiver contido no intervalo, não há necessidade de ajustes; se estiver fora dele, o contribuinte pode indicar diferenças nas condições da operação, de modo a proceder a ajustes para enquadrá-la no intervalo.

Esta noção de intervalo de plena concorrência é disciplinada em detalhes na legislação norte-americana, que adota a regra do "interquartile range"; segundo esta norma, o intervalo confiável de plena concorrência deve ser delimitado a partir de critérios estatísticos que garantam que os dados que o compõem tenham $75 \%$ de probabilidade de enquadrar-se naquele intervalo ${ }^{407}$. A sistemática adotada pela legislação brasileira não

405 "Example 3-21. DistCo is distributor of optical products in Euronia that are manufactured by MafCo, its parent company in Mafonia. The resale price method is applied by the tax administration of Euronia based on data of comparable distributor in that country performing similar functions. These data show that the comparable distributors have gross profit percentages, after appropriate adjustments, in a range from 18,6 percent to 23,8 percent.

The differences in the figures that comprise the range in this case may occur because the application of the arm's length principle only produces an approximation of conditions that would have been established between independent enterprises. In addition, the different points in a range may simply indicate that independent enterprises engaged in comparable transactions under comparable circumstances may not establish exactly the same price. Finally, not all comparable transactions will have some degree of comparability. (...) A range of figures is almost bound to occur when more than one method is applied to evaluate a controlled transaction, as Illustration 3-22 shows.

Example 3-22. The situation is the same as in Illustration 3-21, and the CUP method is applied in addition to the resale price method. The CUP method indicates that the gross profit of DistCo should be in the range of 23,9 percent to 36,4 (as opposed to the resale price method range of 18,6 percent to 23,8 percent). The differences in the respected ranges may be caused by differences in the nature and data relevant to each method. Each separate range, however, potentially could be used to define a single acceptable range of arm's length figures. That is, data from theses ranges could be useful to more accurately identify the proper arm's length range. (...)

Example 3-23. The situation is the same as in Illustration 3-22 and it is determined that the arm's length range is 18,6 percent to 34,4 percent. The gross profit percentage of DistCo for the period in question is 19,2 percent. Is this situation, there should be no adjustment for the relevant transactions of DistCo"

(HAMMER, Richard M. et. al. International Transfer Pricing - OCDE Guidelines. op. cit., item 3.03 [8]).

406 "3.62. Extreme results might consist of losses or unusually high profits. Extreme results can affect the financial indicators that are looked at in the chosen method (e.g. the gross margin when applying a resale price, or the net margin when applying a transactional net margin method). They can also affect other items, e.g. exceptional items which are below the line but nonetheless may reflect exceptional circumstances. Where one or more of the potential comparables have extreme results, further examination would be needed to understand the reasons for such extreme results. The reason might be a defect in comparability or exceptional conditions met by an otherwise comparable third party" (OCDE. Proposed Revision of Chapters I-III of the Transfer Pricing Guidelines. $9^{\text {th }}$ September 2009- $9^{\text {th }}$ January 2010. op. cit., p. 67). Item novo, sem correspondente na Diretiva.

407 “ $\$ 1.482-1$ (e) (2) (iii) (A) The arm's length range will consist of the results of all the uncontrolled comparables that meet the following conditions: the information on the controlled transaction and the uncontrolled comparables is sufficiently complete that it is likely that all material differences have been identified, each such difference has a definite and reasonably effect on the price or profit, and an adjustment is made to eliminate the effect of each such difference. 
possibilita, atualmente, a adoção de intervalos de plena concorrência. Com efeito, não há possibilidade de obter-se intervalos a partir da aplicação de um único método, porquanto a lei brasileira compara tão-somente médias aritméticas ponderadas anuais. Poder-se-ia sustentar que a margem de divergência indicada no artigo 38 da Instrução Normativa n. ${ }^{\circ}$ 243/02 formaria uma espécie de intervalo ${ }^{408}$; optamos, contudo, por qualificar tal margem como espécie de safe harbour [cf. subseção 2.9 abaixo]. Também não se formam intervalos se os contribuintes aplicam mais de um método para o "teste" dos seus preços: a lei brasileira reconhece o preço parâmetro que for mais adequado aos interesses dos contribuintes [cf. artigos $18, \S 4^{\circ}$, e $19, \S 5^{\circ}$, da Lei n. ${ }^{\circ} 9.430 / 96$ ].

(VII.) Possibilidade de utilização de dados de períodos fiscais anteriores ou posteriores para a obtenção das transações independentes comparáveis.

Para a adequada compreensão dos fatos e circunstâncias que permearam a transação "testada", por vezes revela-se útil analisar os dados de um determinado ano conjuntamente com dados de períodos precedentes, porque não há dúvidas de que fatos passados podem afetar o exercício corrente. Com efeito, o exame de dados de anos anteriores pode apresentar-se profícuo para ponderar (i.) se as perdas num determinado ano decorreram de circunstâncias econômicas que se iniciaram no passado, mas que ainda geram impactos naquele mercado relevante; (ii.) o ciclo de vida dos bens ${ }^{409}$, (iii.) a

(B) If there are no uncontrolled comparables described in paragraph (e)(2)(ii)(A) of this section, the arm's length range is derived from the results of all the uncontrolled comparables (...) that achieve a similar level of comparability and reliability. In such cases the reliability of the analysis must be increased, where it is possible to do so, by adjusting the range through application of a valid statistical method to the results of all of the uncontrolled comparables so selected. The reliability of the analysis is increased when statistical methods are used to establish a range of results in which the limits of the range will be determined such that there is a 75 percent probability of a result falling above the lower end of the range and a 75 percent probability of a result bellow the upper end of the range. The interquartile range ordinarily provides an acceptable measure of this range; however a different statistical method may be applied if it provides a more reliable method" [26 CFR Ch. I (4-1-09 Edition)].

408 “Art. 38. Será considerada satisfatória a comprovação, nas operações com empresas vinculadas, quando o preço ajustado, a ser utilizado como parâmetro, divirja, em até cinco por cento, para mais ou para menos, daquele constante dos documentos de importação ou exportação.

Parágrafo único. Nessa hipótese, nenhum ajuste será exigido da empresa na apuração do imposto de renda, e na base de cálculo da CSLL".

409 "1.50. Multiple year data will also be useful in providing information about the relevant business and product life cycles of the comparables. Differences in business or product life cycles may have a material effect on transfer pricing conditions that needs to be assessed in determining comparability. The data from earlier years may show whether the independent enterprise engaged in a comparable transaction was affected by comparable economic conditions in a comparable manner, or whether different conditions in an earlier year materially affected its price of profit so that it should not be used as a comparable" (OCDE. Transfer 
necessidade de investimentos extra e margens reduzidas para renovação/recolocação do produto no mercado etc. ${ }^{410}$.

Em algumas hipóteses, dados de anos subseqüentes ao exercício "testado" também podem apresentar utilidade. Seu uso, todavia, deve ser efetivado com cautela, para se evitar os efeitos perversos da análise retrospectiva ${ }^{411}$. De fato, se um determinado contribuinte A inicia a fabricação de um produto X em 2000, evidentemente, em 2005, A possuirá conhecimento acumulado sobre o mercado de $\mathrm{X}$, bem assim sobre a mensuração dos custos, preços etc.; a produção de X tornar-se-á, com o tempo, mais eficiente. Não pode a administração tributária, nesse cenário, pretender ajustar transações de 2000 com amparo em planilhas de custos adotadas a partir de 2004, decorrentes de conhecimentos adquiridos entre 2000 e 2004. Deve a autoridade fiscal "retroagir" seu pensamento e imaginar quais seriam os dados disponíveis para a tomada de decisões comerciais de A em 2000, à época dos fatos.

Pricing Guidelines for Multinational Enterprises and Tax Administrations. op. cit., p. I-20-21). Correspondente ao item 3.76 da Minuta-2009.

410 "Example 3-25. The situation is the same as in Illustration 3-24, where the gross profit of DistCo for 1992 , the year in question, was 12,4 percent and the arm's length range was 18,6 percent to 36,4 percent. The tax administration of Euronia proposes and adjustment because DistCo's gross profit of 12,4 percent was not within the range. Indeed, looking at only 1992, it appears that DistCo had less than arm's length range results. Had the tax administration examined the prior years of DistCo, the situation would look entirely different. The gross profit results of the five prior years are indicated bellow with an average for the six-year period.

$\begin{array}{ccccccc}1987 & 1988 & 1999 & 2000 & 2001 & 2002 & \text { Average } \\ 34,4 \% & 29,6 \% & 17,1 \% & 7 \% & 11,6 \% & 12,4 \% & 18,68 \%\end{array}$

When the DistCo experience over this period is examined, a pattern that indicates a declining gross profit experience emerges. The average of the period of 18,68 percent, however, is within the range of 18,6 percent to a 36,4 percent, indicating that no adjustment is appropriate. From transfer pricing examination standpoint, it is important to determine why the results varied so significantly from year to year.

As indicated by Illustration 3-25, the use of multiple-year data is important, because it can also provide that tax administration with a broader view of the nature of taxpayer's activities over time. This may be beneficial for a variety of reasons, including:

1. Determining whether a taxpayer's reported loss on a transaction flow is part of a history of losses on similar transactions, the result of particular economic conditions in a prior year that increased costs in subsequent year, or a reflection of the fact that a product is at the end of its life cycle;

2. Providing information about the relevant business and product life cycles of the comparables;

3. Using data from earlier years, if possible, to show whether independent enterprise engaged in a comparable transaction was affected by comparable economic conditions In a comparable manner, or whether different conditions in an earlier year materially affected its price or profit so that it should not be used as a comparable" (HAMMER, Richard M. et. al. International Transfer Pricing - OCDE Guidelines. op. cit., item 3.03 [9]).

411 "1.51. Data from years following the year of the transaction may also be relevant to the analysis of transfer prices, but care must be taken by tax administrations to avoid the use of hindsight. For example, data from later years may be useful in comparing product life cycles of controlled and uncontrolled transactions for the purpose of determining whether the uncontrolled transaction is an appropriate comparable to use in applying a particular method. Subsequent conduct by the parties will also be relevant in ascertaining the actual terms and conditions that operate between parties" (OCDE. Transfer Pricing Guidelines for Multinational Enterprises and Tax Administrations. op. cit., p. I-21). Correspondente ao item $3.73 \mathrm{da}$ Minuta-2009. 
A despeito de a Lei n. ${ }^{\circ}$ 9.430/96 não tratar desse assunto ${ }^{412}$, os artigos 11 [PIC] e 18 [métodos aplicáveis às operações de exportação] da Instrução Normativa n. ${ }^{\circ}$ 243/02 413 admitem o emprego de dados aferidos a partir de "operações de venda e compra",414 realizadas em períodos anteriores ou posteriores ao da transação "testada"; para a aplicação desses dados, todavia, é essencial ajustá-los pela variação da cotação do dólar norteamericano entre os dois períodos. Não há previsão expressa de utilização de dados de outros períodos-base em relação aos métodos PVL [PRL] ou ao CPL. Não obstante, entendemos que essa alternativa também deve ser disponibilizada a contribuintes que apenas dispõe do PVL ou do CPL para a comprovação dos seus preços, sempre que não forem obtidos dados do mesmo ano-calendário; deve ser admitida, ademais, a realização de outros ajustes, relacionados às circunstâncias econômicas verificadas em cada um dos períodos, as quais podem ter gerado reflexos materialmente relevantes nos preços das transações testadas.

\subsubsection{Custos administrativos envolvidos na aplicação do princípio da plena concorrência.}

Em 09.09.04, uma comissão da União Européia publicou o documento n. ${ }^{\circ}$ IP/04/1091 ${ }^{415}$, resultado de uma pesquisa sobre custos de compliance no cumprimento de regras tributárias, da qual participaram 700 empresas de 14 países-membros. As principais conclusões de tal pesquisa foram as seguintes: (i.) os custos administrativos médios anuais são da ordem de $€ 202$ mil, equivalente a 2,6\% das receitas de vendas; para grandes companhias, os custos atingem $€ 1,470 \mathrm{mil}$, representativos de $0,02 \%$ das receitas de vendas; (ii.) para companhias com subsidiárias em outros países da Comunidade, o custo é, em média, 5 (cinco) vezes superior aos custos de companhias sem subsidiárias ou filiais

\footnotetext{
${ }^{412}$ Muito ao contrário, da leitura dos artigos 18 e 19 da Lei n. ${ }^{\circ}$ 9.430/96 pode-se inferir que somente seria possível a utilização dos dados comparáveis do mesmo período de apuração "testado" [cf. artigo $18, \S \S 1^{\circ} \mathrm{e}$ $3^{\circ}$, e artigo 19, caput, $\S \S 3^{\circ}$, I, e $\left.4^{\circ}\right]$.

413 "Art. 11. Não sendo possível identificar operações de compra e venda no mesmo período a que se referirem os preços sob investigação, a comparação poderá ser feita com preços praticados em operações efetuadas em períodos anteriores ou posteriores, desde que ajustados por eventuais variações nas taxas de câmbio das moedas de referência, ocorridas entre a data de uma e de outra operação";

"Art. 18. Não sendo possível identificar operações de venda no mesmo período a que se referirem os preços sob investigação, a comparação poderá ser feita com preços praticados em operações efetuadas em períodos anteriores ou posteriores, desde que ajustados por eventuais variações nas taxas de câmbio da moeda de referência, ocorridas entre a data de uma e de outra operação".

${ }^{414}$ Novamente, a regra brasileira alude exclusivamente a "operações de venda e compra", expressão que não se aplica aos serviços ou a operações envolvendo diversos tipos de direitos.

${ }^{415}$ Acessado em 30.11.09, no endereço: http://europa.eu.int/comm/taxation_customs/whatsnew.htm.
} 
estrangeiras; e (iii.) os principais problemas e custos estão relacionados aos preços de transferência, sendo que $82 \%$ das companhias investigadas apontaram dificuldades na obtenção de informações e documentos necessários para o atendimento das regras nacionais para o controle dos preços de transferência.

Após a leitura destes dados, não é difícil concluir que a adoção do princípio da plena concorrência no âmbito do direito tributário internacional, a par de propiciar alguma [limitada] similitude entre as legislações dos países, também foi responsável por um incremento substancial nos custos de compliance das regras tributárias. De fato, como se demonstrou durante o estudo da "análise de comparabilidade", sua concretização é muitíssimo complexa e depende do exame aprofundado de vários fatores e aspectos cuja investigação e comprovação documental são dificílimos. A busca de dados comparáveis é, geralmente, apontada como um processo árduo e custoso. Não por outra razão, os elevados custos administrativos estão entre as principais críticas dos defensores do método da partilha fracionada em relação ao princípio da plena concorrência [cf. CAPÍTULO 6] ${ }^{416}$. No âmbito da Minuta-2009, inclusive, a OCDE incluiu parágrafo com preocupação específica nesse sentido ${ }^{417}$. Pondere-se, a este passo, que estes custos são impostos tanto aos contribuintes, que precisam buscar dados comparáveis e preencher diversos formulários e declarações relacionados ao controle dos preços de transferência, quanto às administrações tributárias, que necessitam de pessoal especializado neste tipo de fiscalização, normalmente trabalhosa e demorada.

A legislação brasileira é bastante mais simplificada, seja porque limita diversos tipos de ajuste, seja porque preestabelece as margens de lucro aplicáveis aos métodos PVL, CPL, PVA, PVV e CAP. Nestes últimos casos, pode-se até afirmar que nossos métodos

\footnotetext{
416 “3.62. Apart from these arguments, advocates contend that a global formulary apportionment approach reduces compliance costs for taxpayers since in principle only one set of accounts would be prepared for the group for domestic tax purposes.

3.69. Contrary to the assertions of its advocates, global formulary apportionment methods may in fact present intolerable compliance costs and data requirements because information would have to be gathered about the entire MNE group and presented in each jurisdiction on the basis of the currency and the book and tax accounting rules for that particular jurisdiction. Thus, the documentation and compliance requirements for an application of a global formulary apportionment would generally be more burdensome that under the separate entity approach of the arm's length principle" (OCDE. Transfer Pricing Guidelines for Multinational Enterprises and Tax Administrations. op. cit., p. III-20 e III-23). Correspondentes aos itens 1-20 e 1-27 da Minuta-2009.

417 "1.7. It is important to put the issue of comparability into perspective in order to emphasize the need for an approach that is balanced in terms of, on the one hand, its reliability and, on the other, the burden it creates for taxpayers and tax administrations" (OCDE. Proposed Revision of Chapters I-III of the Transfer Pricing Guidelines. $9^{\text {th }}$ September 2009- $9^{\text {th }}$ January 2010. op. cit., p. 8). Item novo, sem correspondente na Diretiva.
} 
aproximam-se de fórmulas predeterminadas, porquanto cabe ao contribuinte, para a aplicação do respectivo método, tão-somente introduzir os dados nas "fórmulas legais", sem a necessidade de "tratá-los"; especialmente no caso do PVL e do CAP, é possível que o contribuinte sequer necessite buscar transações comparáveis externas, porque a simples inclusão de seus próprios dados [internos] na fórmula trazida pela lei será suficiente para a aplicação do método. Seguramente, as criticadas normas de "nacionalização" do princípio da plena concorrência, que tornaram-no mais limitado, também contribuíram para a redução dos custos de compliance da legislação brasileira, especialmente se comparada às regras européias e estadunidenses. Apesar desse benefício, sustentamos que esta simplificação pode ser introduzida tão-somente como técnica de presunção relativa, devendo ser admitida, sempre, a prova de que a situação peculiar do contribuinte não é compatível com os parâmetros ali estabelecidos. Entendemos, neste contexto, ser possível a adoção de margens prefixadas ou outros critérios de simplificação e redução de custos de compliance; esta medida de praticabilidade, contudo, não pode se sobrepor ao direito de o contribuinte tributar apenas o seu lucro "real". Desde que garantido o direito à contraprova, assim, parecem-nos apropriadas algumas medidas simplificativas contidas na lei brasileira.

\subsection{Discussão sobre a adoção do princípio da plena concorrência e sua integração ao ordenamento pátrio.}

O princípio da plena concorrência não foi expressamente positivado na Lei n. ${ }^{\circ}$ 9.430/96, mas sua exposição de motivos admite que “(...) em conformidade com as regras adotadas nos países integrantes da OCDE, são propostas normas que possibilitam o controle dos denominados preços de transferência". Ora, tomando-se em consideração que a OCDE consagrou este princípio como instrumento exclusivo para tal controle, a ausência de referência expressa na Lei n. $^{\circ}$ 9.430/96 não impacta o fato de que o critério da plena concorrência, ainda assim, representa relevante orientação para a aplicação do ordenamento jurídico pátrio. Seguramente, a legislação brasileira não segue à risca as orientações da OCDE, em especial na parte da análise de comparabilidade exposta na seção anterior, mas também não há dúvidas de que foi recepcionado o cerne do princípio, i.e., as partes vinculadas devem observar o comportamento de terceiros, como se independentes fossem. O reconhecimento da necessária observância do princípio da plena concorrência para a interpretação das regras brasileiras para o controle dos preços de transferência foi admitido pela maior parte dos doutrinadores que estudaram o tema, 
destacando-se Alberto XAVIER, Paulo de Barros CARVALHO, Ricardo Lobo TORRES, Heleno Taveira TÔRRES e Luís Eduardo SCHOUERI ${ }^{418}$, dentre tantos outros.

Se, por um lado, argumenta-se que o princípio da plena concorrência foi acolhido pelo direito brasileiro, de outro a doutrina nacional tem sido unânime ao sustentar que a Lei n. ${ }^{\circ}$ 9.430/96, na sua formatação atual, limita a busca de um verdadeiro "preço de livre mercado". Com efeito, nossa legislação contém restrições diversas como, v.g., a limitação de ajustes dos preços e das condições comerciais e financeiras das transações; a dificuldade do processo de alteração de margens para os métodos baseados nos custos e nos preços de venda; a fixação de um único parâmetro de juros de mercado aplicável a todas as situações, independentemente do risco suportado pelo mutuante etc.. A despeito de prever mecanismos baseados na comparação de preços, a Lei n. ${ }^{\circ}$ 9.430/96 contém algumas "travas" que impedem os métodos de atender a determinadas situações concretas em que a pessoa jurídica esteja praticando preços "fora do mercado corrente" por justas razões, as quais também seriam levadas em conta por terceiros independentes. Se, por exemplo, a empresa $\mathrm{X}$ precisa cumprir metas estabelecidas num determinado contrato e, para tanto, necessita da matéria-prima A imediatamente, poderá ser obrigada a pagar uma "taxa de urgência" a sua controladora B para a sua aquisição em regime de pronta entrega. Não há dúvidas de que terceiros independentes, operando em regime de plena concorrência, atuariam de forma semelhante; o preço "normal" somado à taxa de urgência seria, assim, um preço de livre concorrência. As normas brasileiras, contudo, não possuem mecanismos para "captar" este tipo de peculiaridade, dado que limitam os ajustes de preço àqueles indicados nos artigos $9^{\circ}$ e 15 da Instrução Normativa n. ${ }^{\circ}$ 243/02. As críticas concentram-se, assim, na "inflexibilidade" da legislação brasileira, que opõe-se à fluidez e maleabilidade típicas do princípio da plena concorrência.

Como decorrência de tal rigidez, alguns autores, dentre os quais se destaca Ricardo MARIZ DE OLIVEIRA, sustentam que a Lei n. ${ }^{\circ}$ 9.430/96 não adotou o princípio da plena concorrência na sua inteireza, pois, em inúmeras hipóteses, sua aplicação, dissociada das práticas negociais que terceiros adotariam, conduzem a resultados

${ }^{418}$ In: XAVIER, Alberto. Direito Tributário Internacional do Brasil. op. cit., p. 362 e ss.; CARVALHO, Paulo de Barros. Preços de Transferência no Direito Tributário Brasileiro. In: Marcelo Magalhães Peixoto (coord.), Tributação, Justiça e Liberdade. Curitiba: Juruá Editora, 2005, p. 547-563; TORRES, Ricardo Lobo. O Princípio Arm's Length, os Preços de Transferência e a Teoria da Interpretação do Direito Tributário. op. cit., p. 122 a 135; TÔRRES, Heleno Taveira. Direito tributário internacional: planejamento tributário e operações transnacionais. op. cit., p. 164 e ss.; e SCHOUERI, Luís Eduardo. Preços de Transferência no Direito Tributário Brasileiro. op. cit., p. 81 e 83 
destoantes daqueles que seriam obtidos se o princípio tivesse sido aplicado adequadamente $^{419}$. Na visão deste autor, falta nas regras para o controle dos preços de transferência previsão semelhante àquela do artigo $464, \S 3^{\circ}$, do RIR- $99^{420}$, o qual admite que o contribuinte prove, por quaisquer meios admitidos em direito, que não praticou distribuição disfarçada de lucros mas, pelo contrário, agiu no seu próprio interesse, sendo que poderia ter contratado nas mesmas condições com quaisquer terceiros. Realmente, inexiste regra semelhante concernente à questão do controle dos preços de transferência; entendemos, contudo, que o contribuinte sempre possui este direito, com fundamento no artigo 148 do Código Tributário Nacional, sendo desnecessária [a despeito de recomendável] a previsão expressa em lei ordinária.

Paulo Ayres BARRETO possui entendimento semelhante àquele exposto no parágrafo anterior, como se depreende da seguinte passagem extraída de sua obra: “contradição há entre a exposição de motivos do referido veículo introdutor de normas [a qual alude às regras da $O C D E]$ e o conteúdo dos enunciados prescritivos dele constantes. (...) Nos termos em que plasmadas estão as normas que regulam os preços de transferência, da comparação entre os preços pactuados e aqueles apurados mediante aplicação dos métodos positivados, obtém-se não o preço que teria sido acordado entre partes nãorelacionadas, mas um outro preço influenciado pelos critérios definidos na própria lei, os quais, longe de identificar um preço sem interferência, levam a um outro valor, que pode ser significativamente superior ou inferior ao de mercado" 421 . Por força da inflexibilidade das regras da Lei n. ${ }^{\circ}$ 9.430/96, argumenta este autor que o princípio da plena concorrência não foi adotado pela legislação pátria.

\footnotetext{
419 “A prévia existência dessas outras normas [DDL e artigo $9^{\circ}$ das convenções para evitar a bitributação da renda celebradas pelo Brasil] presta-se a evidenciar dois fatores da maior importância para afirmar que a Lei n. ${ }^{\circ} 9.430$ não adotou integralmente o princípio arm's length, que são:

- as disposições da Lei n. ${ }^{\circ} 9.430$ são inequivocamente muito mais herméticas e restritivas do que as do Decreto-Lei n. $^{\circ} 1.598$, tornando muito difícil, pela simples comparação entre elas, equivalham à expressão daquele princípio, tão claro no Decreto-Lei n. ${ }^{\circ} 1.598$;

- o legislador sabia da existência do Decreto-Lei n. ${ }^{\circ} 1.598$ e o conhecia perfeitamente e, não obstante, para os negócios internacionais aos quais a Lei n. 9.430 passou a se aplicar, quis introduzir e introduziu normas muito mais rigorosas, fechadas em critérios próprios (...).

Por essa razão, pode-se concluir que, estruturamente, a Lei n. ${ }^{\circ} 9.430$ não adotou na plenitude o sistema 'arm's length', de sorte que a coincidência entre este e o resultado da aplicação de algum dos métodos daquela lei será sempre casuística e acidental" (MARIZ DE OLIVEIRA, Ricardo. Fundamentos do Imposto de Renda. op. cit., p. 843 e 847).

420 " $\$ 3^{\circ}$ A prova de que o negócio foi realizado no interesse da pessoa jurídica e em condições estritamente comutativas, ou em que a pessoa jurídica contrataria com terceiros, exclui a presunção de distribuição disfarçada de lucros".

${ }^{421}$ In: Imposto sobre a Renda e Preços de Transferência. São Paulo: Dialética, 2001, p. 152.
} 
Não obstante a fundamentada crítica de Paulo Ayres BARRETO, filiamo-nos à corrente que sustenta a recepção de tal princípio pela legislação brasileira. De fato, a despeito de suas especificidades, não corroboramos com as afirmações de que o princípio da plena concorrência não tenha sido adotado por nosso ordenamento. Diferenças na compreensão dos métodos são inerentes à temática dos preços de transferência ${ }^{422}$, sendo que cada nação apóia-se na noção de "plena concorrência" mais adequada e, claro, compatível com o seu ordenamento jurídico. Na prática, se este princípio, positivado de maneira "rígida", for aplicado a partir da ponderação com outros princípios e valores constitucionais, pode representar importante medida de Justiça e de atendimento ao princípio da capacidade contributiva. Não se pode pretender aplicar o princípio da plena concorrência de forma isolada; pelo contrário, é mister o reconhecimento de sua constante interação com outros princípios, em especial os princípios da capacidade contributiva, generalidade, universalidade, legalidade, praticabilidade, segurança jurídica, dentre outros.

Este critério da plena concorrência foi, portanto, recepcionado no ordenamento jurídico pátrio como verdadeiro "princípio" ${ }^{423}$, a despeito de não expressamente positivado $^{424}$. Valendo-nos da teoria de Ricardo Lobo TORRES, exposta na seção 1.6, CAPÍTULO 1, pode-se afirmar ser o princípio da plena concorrência vinculado primordialmente ao valor Justiça, estando estreitamente ligado à capacidade

422 Exatamente nesse sentido, cf. TORRES, Ricardo Lobo. O Princípio Arm's Length, os Preços de Transferência e a Teoria da Interpretação do Direito Tributário. op. cit., p. 123. Ainda a esse respeito, na p. 130 desta mesma obra, esse autor assevera que "o arm's length, por exemplo, abre-se para uma pluralidade de normas ou métodos de apuração do preço de transferência, o que torna legítimo que as legislações nacionais adotem pontos de vista específicos e se afastem em alguns aspectos".

423، "Parece-nos que o chamado arm's length principle é realmente um princípio jurídico. A própria circunstância de consubstanciar como cláusula geral já o eleva a esse patamar. Exibe o arm's length características próprias dos princípios, como sejam a generalidade, a abstração, a abertura, a analogia, a vinculação a valores, as múltiplas possibilidades de concretização e a permanente ponderação com outros princípios" (TORRES, Ricardo Lobo. O Princípio Arm's Length, os Preços de Transferência e a Teoria da Interpretação do Direito Tributário. op. cit., p. 129).

${ }^{424}$ Sobre a forma de atuação dos princípios no ordenamento e o conceito de princípio implícito, confira-se, a seguir, trecho de Paulo de Barros CARVALHO:

"Seja como for, os princípios aparecem como linhas diretivas que iluminam a compreensão de setores normativos, imprimindo-lhes caráter de unidade relativa e servindo de fator de agregação num dado feixe de normas. Exercem eles uma reação centrípeta, atraindo em torno de si regras jurídicas que caem sob o seu raio de influência e manifestam a força de sua presença. Algumas vezes constam de preceito expresso, logrando o legislador constitucional enunciá-los com clareza e determinação. Noutras, porém, ficam subjacentes à dicção do produto legislado, suscitando um esforço de feitio indutivo para percebê-los e isolá-los. São os princípios implícitos.

Entre eles e os expressos não se pode falar em supremacia, a não ser pelo conteúdo intrínseco que representam para a ideologia do intérprete, momento em que surge a oportunidade de cogitar-se de princípios e sobre-princípios" (Curso de Direito Tributário, op. cit., p. 147). 
contributiva $^{425}$. Segundo este princípio, deve-se, sempre, interpretar analogicamente os fatos jurídicos, na tentativa de se obter dados para a comparação entre as operações vinculadas e as operações independentes ${ }^{426}$; este cotejo de transações busca, justamente, tributar igualmente capacidades contributivas semelhantes. Em virtude disso, com fundamento na doutrina de Heleno Taveira TÔRRES, sustentamos ser o princípio da plena concorrência um princípio limite-objetivo, que permite a concretização de vários outros princípios, em especial a capacidade contributiva. O quadro abaixo resume o interrelacionamento entre os principais valores, princípios e regras que arrimam os mecanismos para o controle dos preços de transferência:

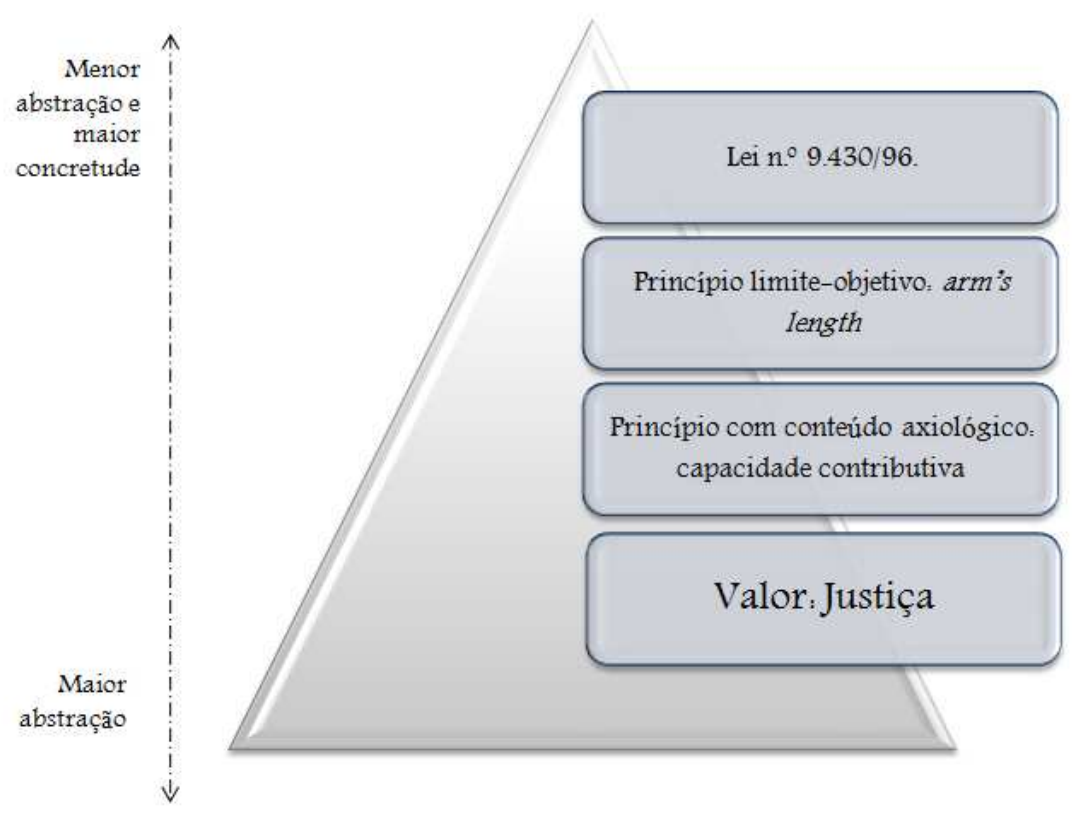

425 “Os princípios jurídicos se vinculam a valores. O arm's length está intimamente ligado à justiça e à capacidade contributiva, eis que tem por objetivo garantir a transferência de bens e serviços pelo preço justo, normal ou de concorrência (...) No campo fiscal, é necessário, para combater a elisão, o permanente equilíbrio e a ponderação entre legalidade e capacidade contributiva. De modo que o princípio arm's length, essencialmente ligado à justiça fiscal, deve se abrir para a ponderação com os princípios vinculados à segurança jurídica, como os da legalidade, proteção da confiança do contribuinte, plena produção da prova, ampla defesa etc.. Em cada hipótese de aplicação o arm's length terá peso diferente, a depender do peso específico que outros princípios apresentem" (TORRES, Ricardo Lobo. Tratado de Direito Constitucional, Financeiro e Tributário. op. cit., p. 362 e 365).

426 “Os princípios jurídicos são analógicos. Constroem-se simultânea e sucessivamente através da dedução a partir de valores e idéias ou de indução. Deles se deduzem as normas. Mas não se situam etereamente no mundo das idéias, pois estão em permanente contato com a facticidade. $\mathrm{O}$ arm's length, do qual se extraem as normas e os métodos, também segue a analogia, eis que se baseia essencialmente na comparação com os preços praticados por empresas independentes, ou seja, procura permanentemente o tertium comparationis" (TORRES, Ricardo Lobo. Tratado de Direito Constitucional, Financeiro e Tributário. op. cit., p. 364). 


\subsection{Ausência de obrigatoriedade de observância das orientações fornecidas pela OCDE frente ao ordenamento tributário brasileiro.}

O Comitê de Assuntos Fiscais da OCDE, principal divisão para o estudo de políticas tributárias no âmbito dessa organização, tem tido atuação ativa nas últimas décadas, mediante a publicação de Diretivas, Documentos, Recomendações, estudos, pesquisas, consultas públicas etc.. Não há dúvidas de que tal Comitê tornou-se um importante foro para a discussão das questões atinentes (i.) à adequada aplicação dos tributos sobre valor agregado; (ii.) à dupla tributação e às convenções bilaterais para afastála; (iii.) ao controle dos preços de transferência, dentre inúmeras outras. A força coercitiva de suas recomendações e orientações, contudo, não é pacificamente reconhecida pelos Estados-Membros.

Segundo Klaus VOGEL, as recomendações da OCDE para a adoção da Convenção-Modelo e de seus Comentários são cada dia mais vinculantes, representando, no mínimo, uma "soft obligation" ${ }^{2} 2$. Na sua percepção, os Estados-Membros são sempre convocados para a discussão do modelo e de seus comentários, sendo possível a indicação de restrições e observações; se nenhum aspecto foi ressalvado pelo Estado-Membro, então ele teria concordado com o documento, devendo, portanto, observá-lo. Seguindo no seu raciocínio, este autor apregoa que essas mesmas considerações aplicam-se à Diretiva, que, na sua visão, tem a mesma importância legal dos Comentários para a aplicação do Artigo $9^{\circ}$ da Convenção-Modelo ${ }^{428}$. Klaus VOGEL reconhece, todavia, que algumas recomendações contêm, no seu próprio texto, a autorização para que os Estados-Membros adotem normas distintas. Entendemos, ousando discordar em parte deste autor, que esse é justamente o caso da Diretiva, a qual contém recomendações não-obrigatórias, mas que

\footnotetext{
427 "Sceptics may certainly ask how one knows that the contracting parties actually intended to incorporate the meaning intended by the MC and MC Commentary as opposed to some other meaning into the particular treaty. That they wanted to follow these OECD documents may, however, be presumed - as long as no particular circumstances indicate to the contrary - because as member States of the OECD, they are legally obliged to follow the Model and Commentary in principle. Both documents were the objects of two important recommendations (...). In OECD practice the legal importance of recommendations is even greater (...), as evidenced by the fact that States filed 'reservations' or included 'observations', regarding their particular interpretations of a recommendation when filling their general consent to the commentary. Such affirmation would not have been necessary, if a recommendation merely obliged the states do examine whether the recommendation was appropriate" (VOGEL, Klaus. Klaus Vogel on Double Taxation Conventions. op. cit., p. 44-45).

428 "The OECD Guidelines are the subject of an OECD Council recommendation and are, therefore, binding upon the member States, but only to a limited extent (...). In regard to the interpretation of MC, they have the same weight as MC Comm." (VOGEL, Klaus. Klaus Vogel on Double Taxation Conventions. op. cit., p. 535).
} 
têm por escopo buscar algum consenso na aplicação das regras para o controle dos preços de transferência, de modo a evitar a bitributação da renda ${ }^{429}$; na prática, a Diretiva empenha-se para influenciar a atuação dos contribuintes e da administração tributária dos países. Além do mais, a própria OCDE, nos seus Comentários sobre a aplicação do Artigo $9^{\circ}$ da Convenção-Modelo, reconhece que muitos países aplicam regras distintas daquelas indicadas na Diretiva, de modo que a concretização do princípio da plena concorrência entre os seus membros ainda mantém alto grau de ambigüidade ${ }^{430}$.

De todo modo, mesmo que a Diretiva contivesse conteúdo obrigatório, este caráter vinculante abrangeria tão-somente os Estados Membros da OCDE e não as demais nações. O próprio Klaus VOGEL reconhece a relevância "muito inferior" das recomendações da $\mathrm{OCDE}$ aos países não-membros ${ }^{431}$. O Brasil, particularmente, não é membro, a despeito de poder participar das reuniões e indicar ressalvas ou observações. Não obstante isso, acreditamos que a Diretiva não tem conteúdo obrigatório no país, seja porque representa mera "recomendação", sem caráter vinculante perante os próprios Estados-Membros da OCDE, seja porque não pode ela ser aplicada em detrimento de lei ordinária promulgada no país. Nesse contexto, as regras para o controle dos preços de transferência brasileiras devem ser aplicadas a partir do conteúdo dos artigos 18 a 22 da Lei n. ${ }^{\circ}$ 9.430/96, sendo que o princípio da plena concorrência deve ser sopesado vis-à-vis outros princípios e valores de nosso ordenamento, todos em constante interação. A Diretiva

429 "16. OECD Members are encouraged to follow these Guidelines in their domestic transfer pricing practices, and taxpayers are encouraged to follow these Guidelines in evaluating for tax purposes whether their transfer pricing complies with the arm's length principle. Tax administrations are encouraged to take into account the taxpayer's commercial judgement about the application of the arm's length principle in their examination practices and to undertake their analysis of transfer pricing from that perspective"

(OCDE. Transfer Pricing Guidelines for Multinational Enterprises and Tax Administrations, op. cit., p. P-5). Veja-se que o texto da Diretiva menciona o termo encourage, cuja tradução seria encorajar, que equivale tãosomente a estimular ou incentivar a prática de um determinado ato.

430 “ 4 . (...) A number of countries interpret the Article in such a way that it by no means bars the adjustment of profits under national law under conditions that differ from those of the Article and that it has the function of raising the arm's length principle at treaty level. (...) However, in some cases the application of the national law of some countries may result in adjustments to profits at variance with the principles of the Article. Contracting States are enabled by the Article to deal with such situations by means of corresponding adjustments (see below) and under mutual agreement procedures" (OECD. Model Tax Convention on Income and Capital. Condensed version. op. cit., p. 147).

431 "In contrast, with regard to the interpretation of treaties with or among non-OECD States, the OECD MC and Commentary are less important. An intention by the contracting parties to adopt a provision within the meaning of the OECD MC can be presumed only where (1) the text of the provision coincides the OECD $\mathrm{MC}$ and (2) its context suggests no other interpretation. The weight to be given to the Commentary in such cases cannot be stated generally, but must be determined according to the circumstances of the individual cases. With regard to recent treaties with developing countries, the UN MC and its official commentary (ST/ESA/102) must be considered, but since both models coincide for the most part, the OECD MC and Commentary can be helpful for such treaties too" (VOGEL, Klaus. Klaus Vogel on Double Taxation Conventions. op. cit., p. 45-46). 
apresenta-se, contudo, como um "repertório doutrinário" muito útil, porque reflete a experiência internacional de diversos países na tentativa de adequada concretização daquele princípio. Com efeito, é mister o reconhecimento da importância que o seu conteúdo assume no estudo do direito tributário: suas posições são relevantes e respeitadas, mas não apresentam qualquer grau de vinculação, seja perante as autoridades tributárias, seja perante o Poder Judiciário; no máximo, representam fonte doutrinária, a ser empregada analogicamente sempre que compatível com a legislação pátria.

Note-se, ainda a respeito, que o fato de o Brasil adotar o conteúdo do Artigo $9^{\circ}$ da Convenção-Modelo em todos os seus acordos para evitar a bitributação também não permite concluir que a Diretiva tenha aplicação obrigatória. Isso porque o Artigo $9^{\circ}$ não remete a métodos ou critérios específicos: apenas expõe, genérica e sucintamente, o princípio da plena concorrência. Ademais, a Diretiva foi publicada tão-somente em jul./95, quando o Brasil já havia firmado 21 dos seus acordos; ora, se as recomendações expostas na Diretiva sequer existiam quando da celebração dos acordos, obviamente elas não podem ser mandatórias ${ }^{432}$.

Por fim, cumpre destacar que este entendimento acerca da função "doutrinária" da Diretiva é partilhado por diversos autores nacionais, incluindo-se Heleno Taveira TÔRRES, que atenta para a função didática das normas editadas pelo Comitê de Assuntos Fiscais da OCDE e, especificamente, da Diretiva ${ }^{433}$ e Ricardo MARIZ DE OLIVEIRA, que frisa a ausência de prevalência da Diretiva sobre o texto da Lei n. ${ }^{\circ}$ 9.430/96 $6^{434}$.

\footnotetext{
432 Confira-se, a respeito, Klaus VOGEL, que sustenta a aplicação dos comentários e normas vigentes no momento da celebração dos acordos:

"When interpreting treaties concluded by OECD member States, only that edition of the MC Commentary which was applicable at the time of the treaty's completion can be binding (...) The 1977 MC Commentary is therefore in principle only significant for treaties which were completed after 11 April 1977, while the 1992 MC Commentary should apply only to those treaties concluded following 23 July 1992. The same pattern applies for future commentaries, of course" (VOGEL, Klaus. Klaus Vogel on Double Taxation Conventions. op. cit., p. 45-46).

433 “(...) tendo presente que o Brasil não faz parte da OCDE. essas referências somente têm relevo didático. Desse modo, os princípios e critérios previstos no art. $9^{\circ}$ das convenções ratificadas pelo Brasil, com base no Modelo OCDE, voltados para definir a retificação de preços, devem acomodar-se à normativa interna, prevista no ordenamento brasileiro, e à luz do texto constitucional. Contudo, é inegável a influência que as recomendações da OCDE exercem" (TÔRRES, Heleno Taveira. Direito tributário internacional: planejamento tributário e operações transnacionais. op. cit., p. 303).

434 "Uma indagação que pode surgir na mente, e efetivamente surge na prática, é sobre se as convenções que o Brasil mantém com inúmeros outros países podem ser interpretadas à luz das recomendações da OCDE ou dos seus comentários para a sua convenção modelo, quando envolvido o princípio do 'arm's length', e uma segunda indagação se estende para saber se tais recomendações e comentários se aplicam para a interpretação das disposições da Lei n. $^{\mathbf{0}} 9.430$ relativas a preços de transferência.
} 


\subsection{Compatibilidade da lei brasileira para o controle dos preços de transferência com os acordos para evitar a bitributação da renda celebrados pelo país.}

$\mathrm{O}$ artigo $5^{\circ}, \S 2^{\circ}$, da Constituição Federal, prevê que os direitos e garantias ali expressos não excluem outros decorrentes dos tratados internacionais de que o Brasil for parte; portanto, sempre que de um tratado se puder extrair um direito ou garantia fundamental, esse será incorporado aos direitos e garantias individuais listados no artigo $5^{\circ}$. Assumindo-se que o controle dos preços de transferência envolve questões atinentes aos direitos individuais ${ }^{435}$ e amparando-nos, ademais, no artigo 98 do Código Tributário Nacional $^{436}$, entendemos não haver dúvidas de que, no âmbito do direito tributário, os tratados, acordos e convenções prevalecem sobre a legislação interna ${ }^{437}$.

Os acordos, convenções e tratados em matéria tributária têm função negativa e são delimitadores de competência; uma convenção para evitar a dupla tributação da renda

(...) Seja como for, a resposta para a primeira indagação é de que, naquilo em que uma convenção for equivalente ao modelo, a sua interpretação poderá guiar-se pelas diretrizes da OCDE, mas não que esteja jungida às mesmas. Os próprios comentários da OCDE são meramente indicativos de rumos, mas não vinculam por qualquer maneira os órgãos judicantes do país.

E a resposta para a segunda indagação é de que as diretrizes da OCDE, que não foram adotadas pela Lei n. ${ }^{\circ}$ 9.430, não têm qualquer prevalência para interpretação desta, exatamente porque são diretrizes não acolhidas pelo legislador e, portanto, não transformadas em lei” (MARIZ DE OLIVEIRA, Ricardo. Fundamentos do Imposto de Renda. op. cit., p. 851).

Paulo Ayres BARRETO, que sustenta a não-adoção do princípio da plena concorrência pelo direito brasileiro, também compartilha dessa posição. Veja-se:

"A organização atua como um corpo consultivo, não tendo suas decisões e pronunciamentos caráter mandatório em relação aos seus países-membros. Nada obstante, gozando a OCDE de largo prestígio e alta reputação entre seus membros e mesmo entre a comunidade internacional de uma forma geral, suas decisões acabam por influir nas diversas ordens jurídicas instaladas, refletindo-se na legislação interna desses países. Daí o relevo do exame de tais decisões. Ressalte-se, por oportuno, que o Brasil não é membro da Organização. Assim, se as decisões da OCDE não têm caráter mandatório em relação aos países-membros, com maior razão não se verifica tal caráter relativamente aos demais países" (BARRETO, Paulo Ayres. op. cit., p. 101).

${ }^{435}$ Nesse sentido, confira-se SCHOUERI, Luís Eduardo. Preços de Transferência no Direito Tributário Brasileiro. op. cit., p. 272. Em sentido oposto, Ricardo Lobo TORRES sustenta que o artigo $5^{\circ}$, $\$ 2^{\circ}$, da Constituição Federal, não se aplica à sistemática dos preços de transferência, porque "aquele princípio constitucional tem por objeto a defesa dos direitos fundamentais, possuindo eficácia inclusive sobre as próprias normas constitucionais que os contrariem, donde resulta que possui extensão muito maior que a do art. 98 do $\mathrm{CTN}$, reservado às questões, como a dos preços de transferência, que não envolvam os direitos humanos" (O Princípio Arm's Length, os Preços de Transferência e a Teoria da Interpretação do Direito Tributário. op. cit., p. 133). Esse mesmo autor discute o assunto em sua obra Tratado de Direito Constitucional, Financeiro e Tributário. op. cit., p. 434.

436 “Art. 98. Os tratados e as convenções internacionais revogam ou modificam a legislação tributária interna, e serão observados pela lei que lhe sobrevenha".

${ }^{437}$ Não serão discutidas as teorias Monista e Dualista, porque ao presente estudo importa constatar, tãosomente, que no direito tributário as convenções internacionais se sobrepõem à lei interna. 
representa, portanto, uma "auto-limitação recíproca de duas soberanias fiscais" "438. No âmbito destas convenções, um determinado Estado se auto-obriga a exercer sua competência segundo os parâmetros ali delimitados ${ }^{439}$. O Artigo $9^{\circ}$ da Convenção-Modelo da OCDE, cujo teor foi adotado pelo Brasil em todos os seus acordos para se evitar a bitributação da renda ${ }^{440}$, prescreve que (a.) quando empresas associadas praticarem (b.) transações com condições diversas daquelas que seriam praticadas por empresas independentes, i.e., condições destoantes do princípio da plena concorrência, (c.) poderá o Estado prejudicado incluir, no lucro da sociedade estabelecida em seu território, os resultados não apropriados em virtude das condições referidas em (b.). Pode-se depreender desse dispositivo que duas empresas associadas precisam estabelecer em seus negócios as mesmas condições que teriam sido estabelecidas por terceiros independentes, sob pena de se sujeitarem a ajustes tributários. Por outras palavras e tomando-se em consideração a "função negativa" desse dispositivo convencional, os Estados contratantes apenas podem efetivar ajustes nos lucros das empresas associadas se não for atendido o princípio da plena concorrência, devendo ser este o critério para a determinação dos preços de transferência nestas hipóteses.

Não entendemos ser possível extrair, do texto dos acordos firmados pelo Brasil, a obrigatoriedade de adoção dos métodos e regramentos específicos recomendados pela OCDE, nem a vedação de instituição de lei interna para o controle dos preços de

\footnotetext{
${ }^{438}$ In: CASELLA, Paulo Borba. et. al. Preços de Transferência: 'Interface’ entre Direito Interno e Direito Internacional. In: Luís Eduardo Schoueri e Valdir de Oliveira Rocha, Tributos e preços de transferência. São Paulo: Dialética, 1999, v. 2, p. 283.

439 "Valendo-se da doutrina de Klaus VOGEL, Luís Eduardo SCHOUERI ensina que "os acordos de bitributação servem como uma máscara, colocada sobre o direito interno, tapando determinadas partes deste. Os dispositivos do Direito Interno que continuarem visíveis (por corresponderem aos buracos recortados no cartão) são aplicáveis; os demais, não. Pouco interessa se a pesquisa inicia-se a partir da máscara ou do texto, já que o resultado é o mesmo; logicamente, inexiste qualquer preferência, devendo a pesquisa seguir, caso a caso, o caminho que for mais prático" (SCHOUERI, Luís Eduardo. Preços de Transferência no Direito Tributário Brasileiro. op. cit., p. 284).

${ }^{440}$ Para facilitar a compreensão do raciocínio, repetimos, abaixo, a transcrição do aludido Artigo:

"Artigo 9. Empresas Associadas.

1. Quando:

a) Uma empresa de um Estado contratante participar, directa ou indirectamente, na direcção, no controle ou no capital de uma empresa do outro Estado contratante, ou

b) As mesmas pessoas participarem, directa ou indirectamente, na direcção, no controle ou no capital de uma empresa de um Estado contratante e de uma empresa do outro Estado contratante,

e em ambos os casos, as duas empresas, nas suas relações comerciais ou financeiras, estiverem ligadas por condições aceites ou impostas que defiram das que seriam estabelecidas entre empresas independentes, os lucros que, se não existissem essas condições, teriam sido obtidos por uma das empresas, mas não o foram por causa dessas condições, podem ser incluídos nos lucros dessa empresa e, conseqüentemente, tributados" Tradução para a língua portuguesa extraída da obra OCDE. Modelo de Convenção Fiscal sobre o Rendimento e o Patrimônio. op. cit., p. 31.
} 
transferência praticados por entes que não se enquadram na noção de "empresas associadas" do Artigo $9^{\circ}$. Pelo contrário, os tratados se sobrepõem ao direito interno apenas naquilo que eles objetivamente disciplinam. Se os tratados não aludem a métodos e sequer mencionam o controle de preços de transferência de empresas não referidas nas alíneas (a.) e (b.) do parágrafo 1 do Artigo $9^{\circ}$, não há porque se inferir esses elementos, que não foram objeto de negociação pelas partes, do seu texto. Entendemos, conseqüentemente, que o regime para o controle dos preços de transferência trazido pela Lei n. ${ }^{\circ}$ 9.430/96 é compatível com os acordos para evitar a bitributação da renda firmados pelo país.

A legislação brasileira prevê métodos inspirados nas metodologias tradicionais recomendadas pela OCDE e, sem dúvidas, recepcionou o princípio da plena concorrência. Não se nega que a Lei n. ${ }^{\circ}$ 9.430/96 é bastante inflexível, o que se agravou com a regulamentação contida na Instrução Normativa n. ${ }^{\circ}$ 243/02, que limitou os ajustes para a obtenção das transações independentes comparáveis ${ }^{441}$. Não se pode afirmar, contudo, ser nossa lei incompatível com o Artigo 9 $9^{\circ}$, simplesmente porque (i.) pretendeu "objetivar" o aludido princípio ou porque (ii.) não previu os métodos baseados na comparação de lucros [cf. CAPÍTULO 5] $]^{442}$. Pelo contrário, mesmo entre os Estados-Membros da OCDE, há países como, v.g., a Alemanha, que são avessos à adoção de métodos não-tradicionais. Os Estados Unidos da América, de outro lado, têm critérios bastante objetivos para a aplicação da plena concorrência, destoando sua legislação da Diretiva. Ademais, o Relatório Geral da "International Fiscal Association" de 1992, elaborado por Guglielmo MAISTO, demonstrou que a maioria dos países admite uma "adaptação" do princípio da plena

\footnotetext{
441 As dificuldades de aplicação da Lei n. ${ }^{\circ}$ 9.430/96 a diversos tipos de transações, principalmente envolvendo serviços e direitos, não devem ser solucionadas com o seu "afastamento", em razão da aparente "contradição" com o teor dos acordos para evitar a bitributação da renda; pelo contrário, a resposta para tais dificuldades deve ser haurida da ponderação de princípios e valores constitucionais que integram o sistema tributário brasileiro quando da interpretação e aplicação da referida norma.

${ }^{442}$ Em sentido contrário, Paulo Borba CASELLA sustenta que não se interpretam as convenções a partir da legislação interna, mas a partir dos comentários e relatórios da OCDE:

"Outro possível conflito entre a Lei 9.430/96 e os acordos de bitributação celebrados pelo Estado brasileiro, quando houver a adoção de texto equivalente ao parágrafo $1^{\circ}$ do artigo $9^{\circ}$ da convenção-modelo da OCDE, poderá ocorrer em eventual restrição ou limitação interna ao princípio arm's length quando este vier a ser interpretado em conformidade com as regras de direito internacional público. Vale dizer, as convenções em matéria de tributação têm de ser situadas no contexto internacional e não se interpretam segundo a legislação de qualquer um dos Estados Contratantes e, em se adotando o modelo do parágrafo $1^{\circ}$ do artigo $9^{\circ}$, os comentários e relatórios da OCDE podem e devem ser utilizados na interpretação e aplicação, como corolário, a legislação brasileira disciplinando os preços de transferência não poderá restringir ou limitar a interpretação do princípio 'arm's length', segundo critérios internacionais, a contribuintes protegidos por acordo de bitributação” (CASELLA, Paulo Borba. et. al. Preços de Transferência: 'Interface' entre Direito Interno e Direito Internacional. op. cit., p. 284).

Esses autores, na p. 280 do mesmo estudo, sustentam que as convenções compõe o direito interno, sendo adeptos do 'monismo'.
} 
concorrência ao seu direito interno, sem que isso represente violação ao texto do Artigo $9^{\mathbf{o}^{443}}$. Transportando-se esta discussão para o direito brasileiro, que possui um sistema tributário constitucional bastante descritivo e peculiar, a situação não poderia ser distinta: o princípio da plena concorrência, como qualquer outro, precisa ser interpretado conforme a Constituição Federal, o que exige a adoção tão-somente dos critérios da Lei n. ${ }^{\circ}$ 9.430/96, sob pena de violação à Segurança Jurídica e à legalidade ${ }^{444}$; os acordos não "criam" métodos ou normas para ajustes em dados comparáveis: eles apenas limitam a implementação de ajustes de preços de transferência que não tenham sido aferidos a partir do princípio da plena concorrência em operações entre empresas associadas.

O aspecto subjetivo das regras para o controle dos preços de transferência não é objeto da tese mas, independentemente disso, importa salientar que o Poder Legislativo brasileiro pode instituir leis para "testar" os preços em quaisquer transações internacionais, sendo legítima a disciplina dos artigos 23, 24 e 24-A da Lei n. ${ }^{\circ}$ 9.430/96 ${ }^{445}$. Como referido anteriormente, ao celebrar uma convenção com o teor do Artigo $9^{\circ}$ da Convenção-Modelo da OCDE, os Estados Contratantes não renunciam ao direito de aplicar normas para o

443 "Most reporters take the view that Art. 9 does not restrict or limit the application of the internal law transfer pricing rules regardless of the method (arm's length or not) which is applied by local tax authority. The most important example of this approach is seen in the USA, where, in the view of the Internal Revenue Service, the treaty rule does not permit a greater flexibility in determining the arm's length price and the order of priority set forth by 482 Regulations is not observed in treaty adjustments. The position of the US tax authority as to the relationship between internal law and Art. 9 of the Convention is reflected in the US Model Convention which expressly states that the rule contained in para. 1 of Art. 9 does not limit the application of the internal law provisions of the contracting States dealing with transfer pricing. In Germany, too, the tax authorities take the view that Art. 9 of the Model does not override the methods to establish the transfer price elaborated under internal law" (MAISTO, Guglielmo. General Report of the Cahiers de Droit Fiscal International. International Fiscal Association. Boston: Kluwer Law and Taxation Issues, v. LXXVIIa, 1992).

444 "É que a atividade de aplicação dos diversos métodos acolhidos pela legislação nacional, predispostos para a determinação de divergências nos preços de transferência, deve ter sempre como principal referência o princípio arm's length. (...)

Não há, pois, e nem poderá haver, como alcançar a construção de um método universal, aplicável a toda e qualquer situação, pelo que a elaboração de métodos, bem como a respectiva aplicação, deverá guardar relação específica com o tipo de operação submetida a confronto.

Mesmo se a OCDE insista em afirmar que as empresas são livres para adotar métodos diversos dos previstos, desde que os preços assim alcançados satisfaçam o princípio arm's length, no direito brasileiro, pelo tipo de sistema (romanístico) e pela aplicação da estrita legalidade, na imposição e exigência de obrigações, isso não pode se concretizar. Os métodos utilizáveis são os que estão contidos na Lei n. ${ }^{\circ}$ 9.430/96, sem concessão para os contribuintes usarem um outro, e muito menos discricionariedade para as autoridades administrativas modificarem os que foram prescritos legalmente. Se há alguma liberdade, esta circunscreve-se aos métodos que a lei permite" (TÔRRES, Heleno Taveira. Direito tributário internacional: planejamento tributário e operações transnacionais. op. cit., p. 211-212).

445 “(...) é nosso entendimento que o Fisco não se encontra impedido de aplicar as regras de preços de transferência, no caso de transações entre empresas que, embora se considerem vinculadas, segundo a definição do art. 23 da Lei 9.430/96, não sejam 'associadas' ou ligadas, como determina a convenção. O teor da convenção, nesse particular, não limita o direito interno" (TÔ̂RRES, Heleno Taveira. Direito tributário internacional: planejamento tributário e operações transnacionais. op. cit., p. 306). 
controle dos preços de transferência em transações não realizadas entre 'empresas associadas', tal como ali definido; na verdade, eles são proibidos tão-somente de implementar ajustes entre empresas associadas que não atendam ao princípio da plena concorrência. Sustentamos, portanto, ser compatível com o Artigo $9^{\circ}$ dos acordos para evitar a bitributação celebrados pelo Brasil a definição de partes vinculadas contida nos artigos 23, 24 e 24-A da Lei n. ${ }^{\circ}$ 9.430/96. Este entendimento, todavia, não é pacífico, existindo muitos defensores, dentre os quais se destacam Luís Eduardo SCHOUERI, Alberto XAVIER, Paulo Borba CASELLA e José Artur LIMA GONÇALVES ${ }^{446}$, da impossibilidade de ampliação do aspecto subjetivo pela lei interna, sob pena de "violação" ao Artigo $9^{\circ}$ dos acordos para evitar a bitributação da renda firmados pelo Brasil ${ }^{447}$.

\subsection{Concretização do princípio da plena concorrência mediante a utilização de métodos. Consistência na aplicação dos métodos.}

A efetivação do princípio da plena concorrência depende da definição dos instrumentos específicos para a sua atuação, os métodos. Portanto, se os contribuintes não pactuarem seus preços segundo as condições de livre mercado, eles poderão ser ajustados pelas autoridades fiscais, em montantes calculados por intermédio dos métodos para o controle dos preços de transferência, de modo que se aproximem dos preços que teriam sido praticados por terceiros independentes, i.e., dos preços de plena concorrência ${ }^{448}$. Como qualquer outro princípio, este possui os requisitos da generalidade, abstração e abertura, além de poder ser concretizado de múltiplas maneiras; essas características que imanam o princípio da plena concorrência tornam-no, assim, dependente de mecanismos mais concretos para sua atuação em cada caso. Os métodos adotados pela Lei n. ${ }^{\circ}$ 9.430/96

${ }^{446}$ In: SCHOUERI, Luís Eduardo. Preços de Transferência no Direito Tributário Brasileiro. op. cit., p. 49; XAVIER, Alberto. Direito Tributário Internacional do Brasil, op. cit., p. 396 e ss.; LIMA GONÇALVES, José Artur. Certos Aspectos da Disciplina dos Preços de Transferência em face do Ordenamento Constitucional Brasileiro. op. cit., p. 227; e CASELLA, Paulo Borba. et. al. Preços de Transferência: 'Interface' entre Direito Interno e Direito Internacional. op. cit., 284.

${ }^{447}$ Por fim, importa ponderar que a Coordenação-Geral do Sistema de Tributação, órgão da Secretaria da Receita Federal do Brasil, manifestou-se no sentido de que não há contradição entre o Artigo 9 da Convenção-Modelo da OCDE e os artigos 18 a 24 da Lei n. ${ }^{\circ}$ 9.430/96. Esse entendimento foi consolidado nos Processos de Consulta n. ${ }^{\circ} 12 / 00,19 / 00,20 / 00$ e 21/00, cujo teor está abaixo transcrito:

“Aplicam-se os ajustes previstos na Lei n. ${ }^{\circ}$ 9.430, de 27 de dezembro de 1996, em matéria de preços de transferência. Não há contradição entre o artigo $9^{\circ}$ do Modelo de Convenção - que trata dos preços de transferência nas convenções -, e os artigos 18 a 24 da Lei n. ${ }^{\circ}$ 9.430/96, que inserem os preços de transferência na legislação fiscal brasileira".

${ }^{448}$ Note-se, por oportuno, que a expressão "plena concorrência” serve para designar tanto o princípio do ordenamento tributário que determina que as partes relacionadas devem utilizar, para a formação de seus preços, as mesmas condições de mercado de que se valem as partes não-relacionadas, quanto o resultado da aplicação dos métodos, sendo o "preço da plena concorrência" também denominado, nessa última acepção, "preço parâmetro" ou "preço de referência". 
serão discutidos no CAPÍTULO 4. Por ora, importa ponderar que as regras que efetivam o princípio da plena concorrência, embora mais "fechadas", ainda apresentam algum grau de abstração. Com efeito, são tantas as possibilidades de transações a serem "testadas" que nenhuma norma seria capaz de listá-las exaustivamente. A lei que disciplina os métodos brasileiros para o controle dos preços de transferência, nesse contexto, define critérios para a mensuração dos preços parâmetros, mas algumas especificidades, como, v.g., os ajustes nas transações independentes comparáveis, precisam ser examinadas a partir da interpretação individualizada de cada caso, desenvolvida a partir (i.) do exame do conteúdo do princípio da plena concorrência, ponderando-o com outros princípios e valores constitucionais; e (ii.) da aplicação analógica da Lei n. ${ }^{\circ}$ 9.430/96.

A aplicação dos métodos consiste na constituição de provas sobre os critérios de definição dos preços praticados pelos contribuintes ${ }^{449}$. São os métodos que demonstram se os contribuintes atuaram com ou sem manipulação de preços; a partir de sua aplicação, obtém-se os preços parâmetro, os quais serão comparados com os preços praticados para fins de verificação da existência de alguma vantagem anormal; detectada eventual vantagem anormal, procede-se ao cálculo do ajuste. O objetivo do emprego dos métodos é, justamente, a aferição do preço de referência ou preço parâmetro. Importa elucidar, a esse passo, que os métodos devem ser aplicados com a estrita finalidade de atendimento do princípio da plena concorrência, e não com o objetivo de aferir uma renda mínima tributável, porque as forças habituais que regem o livre mercado nem sempre possibilitam que os partícipes aufiram esta renda mínima.

No âmbito das normas brasileiras, introduziu-se a noção de "consistência" na aplicação dos métodos. Essa regra, antes disciplinada apenas nos $\operatorname{artigos} 4^{\circ}$, §2 $2^{\circ}$ e 20 , da Instrução Normativa n. 243/02, foi recentemente "transferida" para o texto legal por intermédio da Medida Provisória n. ${ }^{\circ}$ 478/09, que introduziu o artigo 19-B, §2º na Lei n. ${ }^{\circ}$ 9.430/96. Referido dispositivo determina que "a utilização do método de cálculo do preço parâmetro deve ser consistente por bem, serviço ou direito, durante todo o ano-calendário". Para as transações envolvendo um determinado bem, serviço ou direito, portanto, deve ser aplicado um único método durante todo o ano-calendário. Essa norma apresenta-se como importante medida de praticabilidade, porque simplifica a aplicação dos métodos, a partir

\footnotetext{
${ }^{449}$ Note-se que cabe aos contribuintes brasileiros, em virtude da inversão do ônus da prova, angariar provas para demonstrar que seus preços adéquam-se aos métodos e, portanto, atendem ao princípio da plena concorrência.
} 
da comparação de médias, e não de operação a operação [somente se a comparação de médias demonstrar uma vantagem anormal é que, definido o ajuste, ele será aplicado a cada transação]. Essa praticabilidade não pode servir, contudo, para tributar lucro inexistente. Assim, se, num determinado caso concreto, o contribuinte demonstrar que a "consistência" é incompatível com a aplicação do princípio de plena concorrência, deverá a administração tributária avaliar seus argumentos, ponderando-se, caso a caso, possíveis exceções. Em nossa opinião, o fato de a regra da consistência ter alçado ao nível legal não altera as premissas do presente estudo, porque, sempre, as leis devem ser interpretadas à luz dos princípios jurídicos aplicáveis. Não pode o artigo 19-B, §2º da Lei n. ${ }^{\circ}$ 9.430/96, assim, tributar pelo imposto de renda algo do qual não se extrai qualquer capacidade econômica.

\subsection{A "regra do melhor método" e a seleção do método mais apropriado no direito brasileiro.}

Introduzida no direito norte-americano em 1994, a regra do melhor método ["best method rule"] determina que, dentre todos os métodos previstos para uma determinada espécie de transação, deve ser aplicado aquele que produzir os resultados mais confiáveis, amparados na documentação mais adequada ${ }^{450}$. Na prática, isso significa que, nas transações internacionais intra-grupo, precisam ser pesquisados preços, margens brutas e lucros operacionais comparáveis, levando-se em consideração a natureza do bem negociado, as funções desempenhadas pelo vendedor e pelo adquirente, a alocação dos riscos do negócio etc., devendo ser aplicado o método mais fidedigno e que for amparado nos documentos-suporte mais confiáveis. A documentação que evidencia essa pesquisa ampla de dados para subsidiar a aplicação de cada um dos métodos deverá ser arquivada,

450 “\$1.482-1 (c) (1) In general. The arm’s length result of a controlled transaction must be determined under the method that, under the facts and circumstances, provides the most reliable measure of an arm's length result. Thus, there is no strict priority of methods, and no method will invariably be considered to be more reliable than others. An arm's length result may be determined under any method without establishing the inapplicability of another method, but if another method subsequently is shown to produce a more reliable measure of an arm's length result, such other method must be used.

(2) Data based on the results of transactions between unrelated parties provides the most objective basis for determining whether the results of a controlled transaction are arm's length. Thus, in determining which of two or more available methods (or applications of a single method) provides the most reliable measure of an arm's length result, the two primary factors to take into account are the degree of comparability between the controlled transaction (or taxpayer) and any uncontrolled comparables, and the quality of the data and assumptions used in the analysis. (...) (ii) Whether a method provides the most reliable measure of an arm's length result also depends upon the completeness and accuracy of underlying data, the reliability of the assumptions, and the sensitivity of the results to possible deficiencies in the data and assumptions. Such factors are particularly relevant in evaluating the degree of comparability between the controlled and uncontrolled transactions" [26 CFR Ch. I (4-1-09 Edition)]. 
para se demonstrar à administração tributária que o "melhor método" foi aplicado; a ausência de documentação confiável gera, além da cobrança de diferenças tributárias, a imposição de sanções severas pelo físco norte-americano. Os contribuintes norteamericanos precisam, portanto, examinar todas as possibilidades para, em seguida, ponderar qual o método propicia (i.) as mais adequadas transações independentes comparáveis, as quais (ii.) devem estar amparadas nos documentos mais confiáveis. A Argentina contém disciplina semelhante no artigo 15 da Lei n. ${ }^{\circ} 20.268 / 74$, atualizada pela Lei n. ${ }^{\circ}$ 25.784/03, o qual prevê que, para a determinação do preço da plena concorrência, aplicar-se-á o método que resulte mais apropriado para o tipo de operação de que se trate $^{451}$.

Muitas críticas têm sido apontadas contra a sistemática do melhor método, destacando-se (i.) os elevados custos administrativos que essa regra gera aos contribuintes; e (ii.) a ênfase na comparação externa, a qual por vezes afasta-se da realidade econômica do próprio contribuinte; como referido em 2.2.2 (IV), supra, a utilização de comparáveis internos eleva o grau de aproximação entre os negócios confrontados, porque têm o mesmo custo e resultado operacional, além de serem impactados pelas mesmas condições ${ }^{452}$.

\footnotetext{
451، Art. 15. (...) A los fines de la determinación de los precios de las transacciones a que alude el artículo anterior serán utilizados los métodos que resulten más apropiados de acuerdo con el tipo de transacción realizada. La restricción establecida en el artículo 101 de la LEY N. ${ }^{\circ} 11.683$, texto ordenado en 1998 y sus modificaciones, no será aplicable respecto de la información referida a terceros que resulte necesaria para la determinación de dichos precios, cuando la misma deba oponerse como prueba en causas que tramiten en sede administrativa o judicial".

Ainda sobre a adoção da regra do melhor método pelo ordenamento argentino, confira-se:

"La legislación argentina no brinda ni prioridades o una prelación correlativa sino que el mecanismo a utilizar para lograr el precio de mercado normal abierto debe ser a elección del contribuyente a diferencia de cómo lo hacen otras legislaciones.

Esta amplia libertad se ve cercenada cuando deviene obligatorio la adopción del más adecuado de los mismos conforme el quinto parágrafo de artículo 15 de la ley. Sin duda, la adecuación no estará referida una mayor o menor tributación sino que ante los hechos concretos de la operación analizada, se trate del mejor mecanismo que pueda reflejar el precio de mercado del bien o servicio transado o prestado respectivamente. La regla del mejor método (best method rule) es también aplicada por algunas legislaciones, tal el caso de Estados Unidos desde 1993, lo que supone que el contribuyente deberá probar a la Administración Fiscal que la elección del método de precio normal de mercado abierto que utiliza resulta la más apta para el tipo de actividad comercial o de servicios que entre las empresas vinculadas se realiza, definiendo en el amplio campo reglamentario los métodos idealmente aplicables a cada tipo de transacción" (VARELA, Pablo Sergio. op. cit., p. 27).

${ }^{452} \mathrm{Na}$ visão de alguns autores, o temor relacionado às penalidades da legislação norte-americana nas hipóteses de não-adoção do "melhor método" tem acarretado a proliferação da aplicação do CPI [Comparable Profit Method], na medida em que os lucros operacionais de empresas com atividades idênticas ou semelhantes são constantemente divulgados e, por conseguinte, geram documentação mais "confiável" que métodos como o CUP ou métodos amparados em margens brutas. No estudo denominado 2007-2008 Global Transfer Pricing Survey. Global Transfer Pricing Trends, Practices and Analysis, publicado pela Ernst \& Young International Ltd. (op. cit.), verificou-se que de 11\% das transações com bens tangíveis, $14 \%$ das transações com intangíveis e $13 \%$ das transações financeiras foram, nos anos pesquisados, justificadas
} 
No âmbito da Diretiva, a OCDE sustenta que o contribuinte não precisa testar todos os métodos disponíveis para aferir o mais confiável; basta a aplicação de um único método, desde que dele resultem preços parâmetros razoáveis. Nesse contexto, sustentam os Estados-Membros da aludida organização que a regra do melhor método não é essencial para se concretizar do princípio da plena concorrência ${ }^{453}$, mas, pelo contrário, prevêem que, se a aplicação de um único método propiciar um preço de referência confiável, não é necessário o exame de outros; para demonstrar tal fiabilidade, contudo, o método escolhido precisa ser aplicável ao tipo de transação testado e os dados utilizados devem estar amparados em documentação idônea ${ }^{454}$. Assim, v.g., se a empresa X exporta determinados equipamentos com tecnologia exclusiva apenas para sua controladora, inexistindo bens idênticos ou similares disponíveis para comparação, o CPM provavelmente seria mais adequado que o CUP, porque, seguramente, a aplicação deste último envolveria a busca de um bem com características semelhantes, mas cujo preço se sujeitaria a tantos ajustes para torná-lo comparável que, ao final, o resultado não seria confiável. Assim, em algumas

pelo CPI. Ocorre que o lucro operacional ou as margens líquidas não são, como regra geral, os dados que permitem o maior nível de comparabilidade para fins de aplicação do princípio da plena concorrência, porque neles são computados fatores muito específicos de cada contribuinte como a produtividade, eficiências na administração de custos, idade do maquinário etc., os quais têm pouca influência nos preços ou margens brutas. Ademais, terceiros independentes poucas vezes fixam seus preços a partir do cálculo das margens líquidas.

O que os doutrinadores contrários à regra do melhor método sustentam é que a utilização irrestrita do CPI, por receio de questionamentos das autoridades tributárias, pode gerar a tributação de lucros "ficticiamente" obtidos, sendo que Hubert HAMAEKERS aproxima essa circunstância da aplicação de métodos empíricos, extintos desde a Convenção-Modelo da OCDE de 1963. Confira-se:

"The conclusion may, therefore, be drawn that in the United States the old empirical method as described above has returned, not as a method to be used by tax authorities in the absence of reliable accounts, but as a transfer pricing method primarily to be used by taxpayers. As indicated above, however, the empirical method is not an arm's length pricing method" (HAMAEKERS, Hubert. Arm's Length - How Long? op. cit., p. 35). Esse autor, contrário à aplicação irrestrita do princípio da plena concorrência, buscou demonstrar, com esta comparação, que nem mesmo países que apregoam tão fortemente tal princípio como, v.g., os Estados Unidos da América, aplicam-no de forma irrestrita. Neste país, os próprios contribuintes têm migrado para métodos mais objetivamente apurados, como forma de garantir maior segurança jurídica tributária.

453 "I.69. The arm's length principle does not require the application of more than on method, and in fact undue reliance on such an approach could create a significant burden for taxpayers. Thus, this Report does not require either the tax examiner or taxpayer to perform analysis under more than one method" (OCDE. Transfer Pricing Guidelines for Multinational Enterprises and Tax Administrations. op. cit., p. I-27). Correspondente ao item 2.10 da Minuta-2009.

454 " 2.1 . No one method is suitable to every possible situation and the applicability of any particular method need not be disproved. The selection of transfer pricing method always aims at finding the most appropriate method for a particular case. For this purpose, it should take account of the respective strengths and weakness of each of the OECD recognized methods; of the appropriateness of the method considered in view of the nature of the controlled transaction, determined in particular through a functional analysis; of the availability of reasonable reliable information (in particular on uncontrolled comparables) in order to apply the selected method and/or other methods; and of the degree of comparability of controlled and uncontrolled transactions including the reliability of comparability adjustments that may be needed to eliminate differences between them" (OCDE. Proposed Revision of Chapters I-III of the Transfer Pricing Guidelines. $9^{\text {th }}$ September 2009$9^{\text {th }}$ January 2010. op. cit., p. 26). Item alterado, originado de parte do item 1.68 Diretiva. 
hipóteses, pelas próprias particularidades das transações testadas, alguns métodos não são aptos para a produção de resultados confiáveis e, nestes casos, o contribuinte precisa buscar um outro para comprovar os seus preços de transferência. Em alguns casos mais complexos, em que a aplicação dos métodos não gera dados conclusivos, a OCDE sustenta, inclusive, a busca de uma aplicação mais flexível do referido princípio, mediante a aplicação conjugada de métodos ${ }^{455}$. Como regra geral, contudo, devem as administrações tributárias acolher o método escolhido pelo contribuinte, alterando-o apenas se existirem provas de fraude ou de manipulação de dados para fins de redução dos ajustes de preços de transferência ${ }^{456}$.

Originalmente, a Lei n. ${ }^{\circ}$ 9.430/96 não abordou a questão específica da seleção do método mais apropriado; apenas previu que, "na hipótese de aplicação de mais de um método", deveria ser reconhecido o preço parâmetro mais favorável ao contribuinte ${ }^{457}$. Disso se pode concluir que é suficiente, no direito brasileiro, a aplicação de um único método. A Instrução Normativa n. ${ }^{\circ} 243 / 02$ reproduziu esta norma, nos seus artigos $4^{\circ}, \S 2^{\circ}$, e 20 , e complementou a matéria, prevendo, no seu artigo 40, a possibilidade de o fiscal aplicar um dos métodos, a partir dos documentos de que dispuser, sempre que o contribuinte (a.) não indicar um método até o início do procedimento de fiscalização; ou (b.) não apresentar a documentação suporte do preço parâmetro obtido ${ }^{458}$. Na prática,

455 "1.69 (...)While in some cases the choice of a method may not be straightforward and more than one method may be initially considered, generally it is possible to select one method that is apt to provide the best estimation of an arm's length price. However, for difficult cases, where no approach is conclusive, a flexible approach would allow the evidence of various methods to be used in conjunction. In such cases, an attempt should be made to reach a conclusion consistent with the arm's length principle that is satisfactory from a practical viewpoint to all the parts involved, taking into account the facts and circumstances of the case, the mix of evidence available, and the relative reliability of the various methods under consideration" (OCDE. Transfer Pricing Guidelines for Multinational Enterprises and Tax Administrations. op. cit., p. I-27). Correspondente ao item 2.10 da Minuta-2009.

456 "The new OCDE Guidelines start by emphasizing that there is no 'correct' transfer price that can be determined by scientific methods. In principle, the taxpayer, not the revenue authorities, should decide on the appropriate method to be used; its pricing should be scrutinized only when there are sufficient clear indicia that the pricing has being manipulated for tax purposes" (VOGEL, Klaus. Klaus Vogel on Double Taxation Conventions. op. cit., p. 534).

${ }^{457}$ Cf. redação original dos artigos $18, \S 4^{\circ}$, e $19, \S 5^{\circ}$, da Lei n. ${ }^{\circ}$ 9.430/96.

458 “Art. 40. A empresa submetida a procedimentos de fiscalização deverá fornecer aos Auditores-Fiscais da Receita Federal (AFRF), encarregados da verificação:

I - a indicação do método por ela adotado;

II - a documentação por ela utilizada como suporte para determinação do preço praticado e as respectivas memórias de cálculo para apuração do preço parâmetro e, inclusive, para as dispensas de comprovação, de que tratam os arts. 35 e 36 [safe harbours].

Parágrafo único. Não sendo indicado o método, nem apresentados os documentos a que se refere o inciso II, ou, se apresentados, forem insuficientes ou imprestáveis para formar a convicção quanto ao preço, os AFRF encarregados da verificação poderão determiná-lo com base em outros documentos de que dispuserem, aplicando um dos métodos referidos nesta Instrução Normativa”. 
portanto, cabe ao contribuinte a escolha do método, devendo a administração fazê-lo caso ele não o faça, ou o faça sem amparo em documentação razoável ou suficiente. A regulamentação, antes contida apenas no artigo 40 da Instrução Normativa n. ${ }^{\circ}$ 243/02, foi, recentemente, alçada ao patamar de lei, mediante a inclusão do artigo 19-B no texto da Lei n. ${ }^{\circ} 9.430 / 96^{459}$. Segundo as novas regras, o método escolhido pelo contribuinte deve ser declarado em sua DIPJ, a qual não poderá ser alterada após o início de qualquer procedimento de fiscalização concernente à questão dos preços de transferência. Portanto, a lei, na sua atual redação, restringiu temporalmente o direito de o contribuinte livremente adotar o método de sua escolha: esse direito encerra-se com o início do processo, i.e., com o recebimento de notificação, pelo contribuinte, do Mandado de Procedimento Fiscal ("MPF") específico ${ }^{460}$.

Se cabe ao fisco aplicar "um dos métodos indicados nos arts. 18 e 19" sempre que se averiguar a ocorrência das alternativas indicadas nos incisos I a III do artigo 19-B da Lei n. ${ }^{\circ}$ 9.430/96, a questão até então debatida no âmbito doutrinário e jurisprudencial era a seguinte: deve a autoridade fiscal avaliar todos os métodos disponíveis, a fim de aplicar o mais favorável ao contribuinte? Essa dúvida advinha da redação original dos artigos $18, \S 4^{\circ}$, e $19, \S 5^{\circ}$, da Lei n. ${ }^{\circ} 9.430 / 96$, que se referiam tão-somente à "aplicação do método mais favorável ao contribuinte". Como a redação da lei era dúbia, alguns doutrinadores, destacando-se Luís Eduardo SCHOUERI, posicionaram-se no sentido de que "a falta de identificação de método, ou o erro nesta identificação, não afasta o mandamento de que se escolha o mais benéfico ao contribuinte" ${ }^{\text {"461 }}$. Outros, como Heleno Taveira TÔRRES, sustentavam não ser razoável que o fisco despendesse tempo

\footnotetext{
459 “Art. 19-B. A opção por um dos métodos previstos nos arts. 18 e 19 será efetuada na Declaração de Informação Econômico-Fiscais da Pessoa Jurídica (DIPJ) e não poderá ser alterada pelo contribuinte uma vez iniciado o procedimento fiscal.

$\S 1^{\circ}$ A autoridade fiscal responsável pela verificação poderá determinar o preço parâmetro, com base nos documentos de que dispuser, e aplicar um dos métodos previstos nos arts. 18 e 19, quando o sujeito passivo:

I - não indicar, precedentemente ao início do procedimento fiscal, o método de apuração escolhido, observado o disposto no caput deste artigo;

II - não apresentar os documentos que dêem suporte à determinação do preço praticado nem as respectivas memórias de cálculo para apuração do preço parâmetro, segundo o método escolhido;

III - apresentar documentos imprestáveis ou insuficientes para demonstrar a correção do cálculo do preço parâmetro pelo método escolhido".

${ }_{460}$ Esta alteração legislativa está em linha com alguns julgados administrativos, que sustentaram a impossibilidade de escolha do método na apresentação de Impugnação. No acórdão n. ${ }^{\circ}$ 103-22.016, de 06.07.05, v.g., entendeu-se que o contribuinte deveria ter apresentado um método durante o procedimento administrativo, sendo possível fazê-lo após a lavratura da respectiva autuação fiscal. A nova redação legal foi ainda mais restritiva, porque não mais permite a indicação de métodos após o início do procedimento administrativo.

${ }^{461}$ In: Preços de Transferência no Direito Tributário Brasileiro. op. cit., p. 99.
} 
examinando todos os métodos disponíveis: bastaria a aferição do preço parâmetro segundo um único método ${ }^{462}$. Para solucionar esta questão, foi modificado o artigo $18, \S 4^{\circ}$, da Lei n. ${ }^{\circ} 9.430 / 96^{463}$, que passou a prescrever o seguinte: "na hipótese de aplicação de mais de um método, pelo contribuinte, precedentemente ao início do procedimento fiscal, será considerado dedutível o maior valor apurado". As expressões grifadas foram introduzidas pela Medida Provisória n. ${ }^{\text {47 }}$ 478/09 e tiveram como escopo: (a.) deixar claro que o contribuinte pode indicar mais de um método, não sendo obrigação das autoridades administrativas fazê-lo; e (b.) reforçar a noção introduzida pelo artigo 19-B da Lei n. ${ }^{\circ}$ 9.430/96, no sentido de que o direito de escolha do método "termina" com o início do procedimento de fiscalização.

Entendemos serem legítimas as novas normas supra expostas, desde que, obviamente, aplicadas com razoabilidade pela autoridade tributária. Nesse sentido, não está o fisco obrigado a testar todos os métodos, a fim de indicar o mais benéfico; todavia, isso não significa que o contribuinte não possa discutir os critérios por ele adotados. Suponhase, v.g., que o contribuinte escolheu o método PIC, mas não atendeu adequadamente à fiscalização, deixando de apresentar os documentos comprobatórios de preços parâmetros em relação a diversos itens. Durante a fiscalização, as autoridades tributárias afastaram o PIC e aplicaram o PRL, que gerou ajustes dez vezes superiores àqueles que haviam sido originalmente reconhecidos pelo contribuinte. Obviamente, não pode a aplicação do PRL ser efetivada como forma de "punição" ao contribuinte. Se os dados para a aplicação do PIC não foram apresentados pelo contribuinte, deve a administração tributária ponderar a possibilidade de obtê-los por outras vias antes de aplicar diretamente o PRL, cujos resultados, à primeira vista, não foram tão confiáveis ${ }^{464}$. Percebendo o contribuinte que a autoridade administrativa não adotou o método mais adequado, ou que não o aplicou de forma justa, poderá discutir a matéria, demonstrando os possíveis equívocos e o resultado

\footnotetext{
462 “A designação do método, preliminarmente à ação do Fisco, vincularia este àquela opção, mas caso o contribuinte não exerça esse seu direito, caberá ao Fisco a escolha do método que lhe pareça mais adequado. Não se pode exigir que o Fisco deva despender energia à exaustão com a busca do método mais favorável quando o contribuinte, por desídia sua, não o fez. Seria prestigiar uma inércia, com a qual o sistema não pode compadecer" (TÔRRES, Heleno Taveira; UTUMI, e Ana Claudia Akie. O Controle Fiscal dos Preços de Transferência e os Meios de Prova Admitidos para a Definição de Preços e Custos Médios. op. cit., p. 206).

${ }^{463}$ Provavelmente por equívoco do legislador, o $\$ 5^{\circ}$ do artigo 19 , que continha previsão idêntica, não foi modificado pela Medida Provisória n. ${ }^{\circ}$ 478/09.

${ }^{464}$ Desde que, claro, não tenham sido verificados indícios de dolo, fraude ou simulação, hipótese em que o PRL poderá, eventualmente, representar o melhor método.
} 
de outros métodos que seriam mais adequados ao seu caso concreto ${ }^{465}$. Ao contrário da opção do contribuinte por um determinado método, que passou a ser definitiva após a recente alteração legal [cf. artigo 19-B da Lei n. ${ }^{\circ}$ 9.430/96], não pode o método indicado na autuação fiscal ser imodificável: isso representaria ofensa a inúmeros princípios constitucionais, destacando-se a capacidade contributiva e o direito à ampla defesa, os quais são garantia fundamental, não restringível por lei ordinária.

Por fim, importa ponderar que, se um determinado método foi indicado previamente ao início da fiscalização, ele poderá ser ignorado se o contribuinte: (a.) não apresentar os documentos que dêem suporte à determinação do preço praticado nem as respectivas memórias de cálculo para apuração do preço parâmetro; ou (b.) apresentar documentos imprestáveis ou insuficientes para demonstrar seus cálculos [cf. artigo 19-B, II e III, da Lei n. ${ }^{\circ}$ 9.430/96]. Preocupa-nos, a esse passo, a interpretação a ser conferida à expressão “documentos imprestáveis ou insuficientes”. Com efeito, essa expressão, bastante genérica por sinal, deve ser interpretada com máxima cautela, valendo-se a autoridade administrativa, sempre, de razoabilidade. Uma planilha com alguns poucos erros facilmente detectáveis e corrigíveis, v.g., não pode ser considerada imprestável. A ausência de um determinado documento essencial com relação a alguns poucos bens, desde que suprida com outros que produzam fortes indícios da veracidade da informação prestada pelo contribuinte, de outro lado, não é suficiente para se considerar a documentação insuficiente. Evidentemente, a norma não foi editada para as hipóteses em que os documentos apresentados contenham pequenas falhas supríveis, mas, tão-somente, para os casos em que o contribuinte agiu com desdém e não se deu ao trabalho de buscar documentos razoáveis, ou aqueles em que foram verificados indícios de fraude, dolo ou simulação.

\footnotetext{
465 "Ora, se a escolha do método legítimo para a determinação do preço ou custo médio [pelo fisco] não satisfez ao interesse do contribuinte, cumprirá a este demonstrar que a escolha de método praticada pelo Fisco não lhe foi benéfica e indicar aquele que lhe pareça mais congruente. $\mathrm{O}$ que não poderia acontecer, como de fato a lei não consentiu, seria o afastamento do direito do contribuinte de comprovar os motivos do preço efetivamente praticado, com o uso do método que lhe for mais benéfico, como previsto pela Lei 9.430/96, art. 21, inclusive com a aplicação mais extensiva à ampla defesa, quanto aos direitos de prova, como permite o art. 148 do CTN" (TÔRRES, Heleno Taveira. Direito tributário internacional: planejamento tributário e operações transnacionais. op. cit., p. 251).
} 


\subsection{Tratamento tributário nas hipóteses de impossibilidade de aplicação de um dos métodos prescritos na Lei n. ${ }^{\circ}$ 9.430/96.}

Consoante discutido na seção 2.5 acima, a legislação brasileira prevê uma lista exaustiva de métodos para o cálculo dos preços parâmetro, deixando de fornecer orientação para as hipóteses em que as sete sistemáticas ali indicadas forem insuficientes ou inaplicáveis.

Nestas situações específicas, alguns doutrinadores têm sustentado que podem ser aplicadas, subsidiariamente, as normas de DDL. De fato, mesmo após a edição da Lei n. ${ }^{\circ}$ 9.249, de 26 de dezembro de 1995, que eliminou a bitributação econômica dos lucros distribuídos a partir de $1^{\circ}$ de janeiro de 1996, essas normas permaneceram vigentes ${ }^{466}$, devendo ser infligidas sempre que duas "partes ligadas"467 praticarem negócios em condições mais vantajosas que as que prevaleçam no mercado ou em que a pessoa jurídica contrataria com terceiros; as regras de DDL aplicam-se a operações internas e transnacionais. Em dez./96, foi publicada a Lei n. ${ }^{\circ}$ 9.430/96, a qual disciplina o controle dos preços de transferência em operações entre "partes vinculadas"468; estas normas aplicam-se tão-somente a operações transnacionais. Segundo ponderado por Ricardo MARIZ DE OLIVEIRA, ambas as regulamentações estão em vigor, sendo por vezes aplicáveis a um mesmo negócio, o que poderia gerar aparentes antinomias de comandos legislativos. Mas as regras de preços de transferência são normas mais específicas e posteriores, o que justifica sua aplicação prioritária, sempre que possível; as regras de DDL somente devem ser aplicadas a operações transnacionais quando for impossível a

\footnotetext{
${ }^{466}$ A esse respeito, veja-se a seguinte explicação de Luciana Rosanova GALHARDO:

“2.3. Muito se discute sobre a vigência ou utilidade prática das regras de DDL, tendo em vista a eliminação da tributação dos lucros distribuídos a partir de 1996. Não obstante, ainda que o efeito reflexo da DDL (qual seja, o de tributação sobre lucro distribuído disfarçadamente) tenha deixado de existir com a eliminação da tributação dos lucros distribuídos, certo é que remanesce a adição no lucro líquido, para efeitos de IRPJ e CSLL, da diferença entre o valor de mercado e o valor praticado pelas pessoas jurídicas com pessoas ligadas" [Preços de Transferência e Reorganizações Societárias. In: Valdir de Oliveira Rocha (coord.), Grandes Questões Atuais do Direito Tributário. $8^{\circ}$ Volume. São Paulo: Dialética, 2004, p. 325].

${ }^{467}$ A noção de "partes ligadas" consta do artigo 465 do RIR-99. Confira-se

“Art. 465. Considera-se pessoa ligada à pessoa jurídica:

I - o sócio ou acionista desta, mesmo quando outra pessoa jurídica;

II - o administrador ou o titular da pessoa jurídica;

III - o cônjuge e os parentes até o terceiro grau, inclusive os afins, do sócio pessoa física de que trata o inciso I e das demais pessoas mencionadas no inciso II".

${ }^{468}$ As hipóteses de aplicação das regras para o controle dos preços de transferência, que compreendem as "partes vinculadas" [cf. artigo 23 da Lei n. ${ }^{\circ}$ 9.430/96], bem assim as partes indicadas nos artigos 24 e 24-A, são muito mais amplas aquelas atingidas pela noção de "partes ligada", constante do artigo 465 do RIR-99.
} 
implementação das sistemáticas prescritas nos artigos 18 a 22 da Lei n. ${ }^{\circ}$ 9.430/96 ${ }^{469}$. Portanto, nas operações internacionais envolvendo partes vinculadas, aplica-se a Lei n. $^{\circ}$ 9.430/96. Se, contudo, os métodos ali previstos forem insuficientes ou inaplicáveis e as partes envolvidas na transação enquadrarem-se na noção de "partes vinculadas", tal como previsto no artigo 465 do RIR-99, poderão ser aplicadas, subsidiariamente, as regras de DDL. Na ausência de métodos disponíveis, entendemos ser esta, realmente, a conclusão mais adequada a ser extraída da interpretação sistemática da legislação do imposto sobre a renda. Além de Ricardo MARIZ DE OLIVEIRA, também apregoam este entendimento Gerd W. ROTHMAN ${ }^{470}$ e Luciana Rosanova GALHARDO ${ }^{471}$.

Nas hipóteses em que as partes vinculadas sujeitas ao controle dos preços de transferência não se enquadrarem na noção de "partes ligadas", constante do artigo 465 do RIR-99, não se pode sustentar serem aplicáveis subsidiariamente as regras de DDL. Nestes casos, entendemos que devem ser empreendidos esforços para a interpretação da Lei n. ${ }^{\circ}$ 9.430/96 a partir da analogia, da aplicação dos princípios gerais de direito tributário, da aplicação dos princípios gerais de direito público e, ao final, da equidade [cf. artigo 108 do Código Tributário Nacional]. Se, ainda assim, houver hipóteses em que não forem obtidos preços parâmetro razoáveis, devem ser admitidos os custos dedutíveis ou as receitas tributáveis declarados pelos contribuintes. De fato, se, mesmo após a utilização de todos os instrumentos de interpretação disponibilizados pela lei, ainda assim não for viável alcançar uma metodologia para o "teste" dos preços praticados, não pode a administração tributária valer-se de mecanismos arbitrários para se proceder à autuação dos contribuintes. Ressalve-se, todavia, a possibilidade de arbitramento, caso não mereçam fé as declarações ou esclarecimentos prestados pelos contribuintes [cf. artigo 148 do Código Tributário Nacional].

\footnotetext{
469 "Ora, as aparentes antinomias são resolvidas sempre pelos critérios da especialidade, do tempo e da hierarquia. No caso, havendo normas de mesmo grau e não se tratando de hipótese em que o tempo de promulgação das normas exerça papel relevante, resta o critério da especialidade e, por este, inegavelmente, as normas sobre preços de transferência são mais específicas do que as de DDL, quando estejam em cogitação negócios internacionais submetidos à disciplina dos preços de transferência" (MARIZ DE OLIVEIRA, Ricardo. Fundamentos do Imposto de Renda. op. cit., p. 778).

${ }^{470}$ In: Preços de transferência - Método do preço de revenda menos lucro: base CIF (+II) ou FOB. A margem de lucro $(20 \%$ ou $60 \%$ ) em processos de embalagem e beneficiamento. op. cit., p. 44-45.

471 "Assim, entendemos que, com o advento das regras de preços de transferência, as operações internacionais entre pessoas jurídicas brasileiras e pessoas vinculadas, de importação, aquisição, exportação, alienação e de pagamento de juros ficam sujeitas a essa disciplina específica. Não obstante, no caso de impossibilidade de aplicação daquelas regras objetivas, entendemos que permaneceria de forma subsidiária a aplicação das regras de DDL, apenas para os casos específicos por elas disciplinados" (GALHARDO, Luciana Rosanova. Preços de Transferência, Limites à Fiscalização. op. cit., p. 250).
} 


\subsection{Safe harbours.}

A concretização do princípio da plena concorrência, como demonstrado nas seções anteriores deste CAPÍTULO 2, depende de esforços intensivos e custosos tanto dos contribuintes quanto das administrações tributárias. Com o propósito de simplificação de procedimentos tão complexos, alguns países adotaram os denominados safe harbours ou safe havens, que representam normas que excepcionam a aplicação de obrigações legalmente previstas para determinadas espécies de contribuintes e/ou transações ${ }^{472}$. Na prática, os safe harbours podem consistir em uma exoneração da necessidade de atendimento das regras para o controle dos preços de transferência ou na minoração de alguns requisitos/condições previstos na lei $^{473}$. Assim, v.g., ao prever que estas regras não se aplicam às operações de importação envolvendo "royalties e assistência técnica, científica, administrativa ou assemelhada" [cf. artigo $18, \S 8^{\circ}$, da Lei n. ${ }^{\circ}$ 9.430/96], a lei institui uma modalidade de safe harbour que isenta determinadas transações do controle dos preços. De outro lado, ao admitir que os contribuintes cujas operações de exportação não excedam $5 \%$ de sua receita bruta total comprovem seus preços a partir dos documentos das próprias transações, a Instrução Normativa n. ${ }^{\circ}$ 243/02 propicia uma redução das obrigações acessórias previstas na Lei n. ${ }^{\circ}$ 9.430/96.

A instituição de safe harbours fundamenta-se, como sustentado pela OCDE em sua Diretiva, em três fatores principais: (i.) redução dos custos administrativos de compliance, (ii.) maior segurança jurídica aos contribuintes; e (iii.) simplificação dos

\footnotetext{
${ }^{472}$ A definição de safe harbour trazida pela OCDE na sua Diretiva é a seguinte:

"4.95. (...) Formally, in the context of taxation, a safe harbour is a statutory provision that applies to a given category of taxpayers and that relieves eligible taxpayers from certain obligations otherwise imposed by the tax code by substituting exceptional, usually simpler obligations" (OCDE. Transfer Pricing Guidelines for Multinational Enterprises and Tax Administrations, op. cit., p. IV-32).

Confira-se, ainda a respeito, a definição de safe harbour trazida pelo IBFD:

"A safe harbour may be defined as an objective standard or measure, such as a range, percentage, or absolute amount, which can be relied on by a taxpayer as an alternative to a rule based on more subjective or judgmental factors or uncertain facts and circumstances. A safe harbour cannot normally be used to the disadvantage of the taxpayer" (IBFD. International tax glossary, op. cit., p. 353).

473 "4.95 (...) In specific instance of transfer pricing, the administrative requirements of a safe harbour may vary from a total relief of target taxpayers from the obligation to conform with a country's transfer pricing legislation and regulations to the obligation to comply with various procedural rules as a condition for qualifying for the safe harbour. These rules could, for example, require taxpayers to establish transfer pricing or results in a specific way, e.g., by applying a simplified transfer pricing method provided by the tax administration, or satisfy specific information reporting and record maintenance provisions to regard to controlled transactions. Such an approach requires a more substantial involvement from the tax administration, since the taxpayer's compliance with the procedural rules may need to be monitored" (OCDE. Transfer Pricing Guidelines for Multinational Enterprises and Tax Administrations, op. cit., p. IV$32)$.
} 
procedimentos de fiscalização dos preços de transferência pelas autoridades tributárias. Em alguns casos, v.g., as regras muitíssimo complexas para o "teste" dos preços de transferência podem ser incompatíveis com o tamanho da empresa ou com o valor de suas transações internacionais; a instituição de safe harbours, nestes casos, teria por fim garantir uma justa redução dos custos de compliance a estes contribuintes. Quanto à segurança jurídica referida em (ii.), não há dúvidas de que, se o contribuinte se enquadrar numa das hipóteses de safe harbour, terá a garantia de que seus preços serão aceitos sem a necessidade de estudos mais aprofundados ou de discussões com as autoridades tributárias sobre a razoabilidade de ajustes nos dados, a aplicabilidade de um determinado método etc.. Por fim, os safe harbours também servem para reduzir os custos e o prazo de fiscalização dos contribuintes que ali se enquadrarem, porque o exame da sua subsunção àquelas regras é, na maioria dos casos, bastante simples; uma vez reduzidos os esforços para a fiscalização de questões mais simples, sobram mais recursos, humanos e materiais, para que o fisco dedique-se aos casos mais complexos e/ou que envolvam ajustes mais vultosos $^{474}$.

\subsubsection{Compatibilidade da sistemática dos safe harbours com o princípio da plena concorrência.}

Apregoa a Diretiva da OCDE que a questão dos safe harbours suscita muitas discussões relativas (i.) à arbitrariedade de sua instituição, que pode beneficiar contribuintes em situações muito semelhantes às de outros que permanecem aplicando integralmente as normas ${ }^{475}$; (ii.) ao potencial de utilização de tais normas como medida de

${ }^{474}$ In: OCDE. Transfer Pricing Guidelines for Multinational Enterprises and Tax Administrations, op. cit., p. IV-33-34.

475 “4.120. (...) safe harbours raise equity and uniformity issues. By implementing a safe harbour, one would create two distinct sets of rules in the transfer pricing area, one requiring conformity of prices with the arm's length principle and another requiring conformity with a different and simplified set of conditions. Since criteria would necessarily be required to differentiate those taxpayers eligible for the safe harbour, similar and possibly competing taxpayers could, in some circumstances, find themselves on opposite sides of the safe harbour threshold, thus resulting in similar taxpayers enjoying different tax treatment: one meeting the safe harbour rules and the other being obliged to do business exclusively in conformity with the arm's length principle (either because the enterprise in fact deals at arm's length or because it is subject to transfer pricing legislation that is based on the arm's length principle. Preferential tax treatment under safe harbour regimes for a specific category of taxpayers could entail discrimination and competitive distortions" (OCDE. Transfer Pricing Guidelines for Multinational Enterprises and Tax Administrations, op. cit., p. IV-39-40).

Sustenta a OCDE outrossim, que, para a instituição de safe harbours justos, ao invés de arbitrários, as autoridades administrativas teriam que efetivar pesquisas e coletas de dados intensas, o que, ao invés de reduzir os custos administrativos, poderia até elevá-los. Veja-se:

"4.107. Safe harbours are likely to be arbitrary since they rarely fit exactly the varying facts and circumstances even of enterprises in the same trade or business. This arbitrariness could be minimized only with great difficulty by devoting a considerable amount of skilled labour to collecting, collating, and 
planejamento tributário internacional [se, v.g., um contribuinte possuir lucro operacional superior à média de sua indústria, poderá aplicar o safe harbour e, ainda assim, transferir lucros para a sua controladora $]^{476}$; e (iii.) à correta aplicação do princípio da plena concorrência, por vezes incompatível com essas regras simplificadoras. Na verdade, a principal crítica desta organização consiste, justamente, no potencial que os safe harbours têm de afastar a íntegra aplicação do princípio da plena concorrência. Argumenta a OCDE que, se há safe harbours, as transações independentes serão precificadas para se atingir os parâmetros ali determinados, e não de acordo com as condições comerciais e financeiras que seriam adotadas por terceiros independentes em circunstâncias semelhantes; sua utilização seria, nestas hipóteses, incompatível com o princípio cuja aplicação seria obrigatória.

Não obstante as ponderações supra referidas, com as quais concordamos, entende-se, ainda assim, que a instituição de safe harbours apresenta-se muito importante na disciplina do controle dos preços de transferência. Não há dúvidas de que se trata de normas complexas e trabalhosas, especialmente porque o princípio da plena concorrência é muito aberto e abstrato, devendo os parâmetros serem aferidos transação a transação, sendo que cada uma delas exige a busca de dados específicos [e de critérios para o ajuste destes dados]. Este aspecto, somado ao dever da administração tributária de garantir a aplicação da Lei n. ${ }^{\circ}$ 9.430/96 da forma mais eficiente possível ${ }^{477}$, leva à conclusão de que os safe harbours apresentam mais pontos positivos que negativos. Corrobora este entendimento a constatação de que, ponderando-se os princípios da capacidade contributiva, da plena

continuously revising a pool of information for establishing and monitoring safe harbour parameters may therefore impose administrative burdens on tax administrations, because such information may not be readily available and may be accessible only through in-depth transfer pricing inquiries. Therefore, the extensive research necessary to set the safe harbour parameters accurately enough to satisfy the arm's length principle would jeopardize one of the purposes of a safe harbour, that of administrative simplicity" (OCDE. op.cit. nesta nota, p. IV-35 e IV-36).

476 "4.117. If a safe harbour were based on na industry average, tax planning opportunities might exist for taxpayers with better than average profitability. For example, a cost-efficient company selling at the arm's length price must be earning a mark-up of 15 percent on controlled sales. This corporation would have an incentive to elect a safe harbour providing for a 10 percent mark-up. The company would, under the safe harbour, be taxed on a scaled-down profits figure, notwithstanding the fact that the underlying transfer prices on controlled transactions would be significantly below the arm's length prices. Consequently, taxable income would be shifted out of the country. When applied on a large scale, this could mean significant revenue lost for the country offering the safe harbour. By design, the tax administration would have no recourse to counter such instances of profit shifting" (OCDE. Transfer Pricing Guidelines for Multinational Enterprises and Tax Administrations, op. cit., p. IV-38 e IV-39).

477 “A razão de criação das regras de safe harbour não apresenta diferenças fundamentais de outras regras internas que venham, por exemplo, a excluir de execução físcal dívidas limitadas até um certo valor. Apresentam uma utilidade prática simples, mas fundamental para a eficiência da Administração Pública" (SCHOUERI, Luís Eduardo. Preços de Transferência no Direito Tributário Brasileiro. op. cit., p. 234). 
concorrência e da praticabilidade, é mister a admissão de normas simplificadoras, que garantam tributação igual a contribuintes com capacidades econômicas semelhantes, objetivamente mensuradas $^{478}$. A elaboração de normas objetivas, amparadas em critérios razoáveis, tem, nesse cenário, o condão de facilitar o cumprimento das regras para o controle dos preços de transferência, simplificar o procedimento de fiscalização [de modo a reservar recursos humanos para a fiscalização de contribuintes "fora dos parâmetros médios"] e, ainda assim, garantir a aplicação sensata do princípio da capacidade contributiva. Não há dúvidas de que o exame caso a caso, contribuinte por contribuinte, seria mais justo; mas também se sabe que esta providência é impossível e que as normas que possibilitam tamanha "abertura" tornam o sistema complexo e sujeito a arbitrariedades. Sustenta-se, neste cenário, ser a instituição de safe harbours imprescindível para o controle dos preços de transferência; sem medidas para a sua simplificação, estas normas tornam-se muito custosas e trabalhosas, de modo que, se a fiscalização não for intensiva, os contribuintes simplesmente deixarão de aplicá-las.

Como espécies de safe harbours podem ser instituídos, v.g., intervalos de preços ou de margens por tipo de atividade ou de bem, serviço ou direito; os contribuintes que se enquadrassem neste intervalo, estariam sujeitos apenas à comprovação desta circunstância. Os contribuintes que se situassem fora do intervalo, de outro lado, poderiam, sempre, fazer prova do seu preço ou margem efetivo. Este contribuinte não seria, portanto, prejudicado ou tributado por um "lucro inexistente". De outro lado, a grande maioria dos contribuintes enquadráveis nas hipóteses de safe harbours provavelmente se valeriam desta regra, seja por sua simplicidade, seja porque garante maior segurança jurídica, eliminandose os riscos de futuras contingências. Claro que, por outro lado, alguns contribuintes que poderiam registrar custos de importação abaixo da média indicada poderão vislumbrar, nos safe harbours, uma alternativa para elevar os seus preços de importação, "deixando-se" um

\footnotetext{
${ }^{478}$ Com efeito, a praticabilidade é formada por "todos os meios e técnicas utilizáveis com o objetivo de tornar mais simples e viável a execução das leis", e visa "evitar a investigação exaustiva do caso isolado, com o que se reduzem os custos de aplicação da lei; dispensar a colheita de provas difíceis ou mesmo impossíveis em cada caso concreto" (DERSI, Misabel Abreu Machado. Direito Tributário, Direito Penal e Tipo. op. cit., p. 105).

A capacidade contributiva, de outro lado, representa o corolário da igualdade no direito tributário, sendo certo, contudo, que a capacidade econômica pessoal é muito difícil de ser atingida, devendo a lei buscar capacidades semelhantes. Ademais, para se garantir a capacidade contributiva individual, as normas para a sua constatação deveriam ser muito "abertas", possibilitando-se a adoção de fraudes ou evasões, de um lado, e a prática de arbitrariedades, de outro.

Nesse contexto, uma certa "objetivação" da capacidade contributiva, como medida de praticabilidade, apresenta-se como boa solução para o controle da maioria dos preços de transferência.
} 
lucro maior no exterior. Não obstante, entendemos que os ganhos gerados pela instituição dos safe harbours serão suficientes para eliminar estas possíveis perdas de arrecadação ${ }^{479}$. Não temos dúvidas, assim, dos benefícios que os safe harbours podem trazer para o campo das regras para o controle dos preços de transferência.

\subsubsection{Safe harbours admitidos pela legislação brasileira.}

Na legislação brasileira há safe harbours previstos na Lei n. ${ }^{\circ} 9.430 / 96$ [itens (I.) a (III.), abaixo], no artigo 45 da Lei n. ${ }^{\circ} 10.833$, de 29 de dezembro de 2003 [itens (IV.) e (V.)] e, por fim, um último, introduzido pela administração tributária no texto da Instrução Normativa n. ${ }^{\circ}$ 243/02, que garante, por até um ano, a prática de preços desvinculados do princípio da plena concorrência por exportadores que pretendem conquistar novos mercados estrangeiros [item (VI.)]. Foi louvável a introdução destas normas mas, em nossa opinião, deveriam ser estudados outros safe harbours, especificamente no que toca às operações de importação entre partes vinculadas, cujo "teste" tem se mostrado muito complexo nos casos de inaplicabilidade do PIC.

\section{(I.) Exportações por preço médio superior a $90 \%$ do preço médio}

\section{praticado no mercado interno.}

O caput do artigo 19 da Lei n. ${ }^{\circ}$ 9.430/96 prevê que, se um determinado contribuinte praticar exportações controladas, mas, durante o exercício, também vender aqueles mesmos bens no mercado interno, e a média dos preços das primeiras operações for superior a $90 \%$ da média de preços das últimas, não precisará aplicar os métodos para “testar" os preços de transferência nem se sujeitará a qualquer tipo de arbitramento $^{480}$. Se o

\footnotetext{
${ }^{479}$ Note-se que não pode o legislador deixar de instituir uma regra que beneficia a grande maioria dos contribuintes porque alguns poucos poderão utilizá-las como mecanismo de fraude. Nesta situação, seria mais eficiente fiscalizar alterações repentinas de preços ou margens e, nestes casos, pesquisar a existência de possível fraude, dolo ou simulação.

480 “Art. 19. As receitas auferidas nas operações efetuadas com pessoa vinculada ficam sujeitas a arbitramento quando o preço médio de venda dos bens, serviços ou direitos, nas exportações efetuadas durante o respectivo período de apuração da base de cálculo do imposto de renda, for inferior a noventa por cento do preço médio praticado na venda dos mesmos bens, serviços ou direitos, no mercado brasileiro, durante o mesmo período, em condições de pagamento semelhantes.

$\S 1^{\circ}$ Caso a pessoa jurídica não efetue operações de venda no mercado interno, a determinação dos preços médios a que se refere o caput será efetuada com dados de outras empresas que pratiquem a venda de bens, serviços ou direitos, idênticos ou similares, no mercado brasileiro.

$\S 2^{\circ}$ Para efeito de comparação, o preço de venda:
} 
contribuinte não efetuar operações no mercado interno, poderá comparar a média dos preços de suas operações de exportação com a média aferida a partir de dados de outras empresas que pratiquem transações idênticas ou similares [cf. § $1^{\circ}$ do artigo 19].

Note-se que a legislação apresenta uma falha: o caput do artigo 19 prevê que a média dos preços de exportação deve ser comparada com a média de venda "dos mesmos bens, serviços ou direitos, no mercado brasileiro". Não se prevê, aqui, a possibilidade de se aferir uma média a partir de bens, serviços ou direitos similares alienados pelo próprio contribuinte no mercado nacional. De outro lado, no $\S 1^{\circ}$ do mesmo dispositivo, ao discorrer sobre a média obtida a partir de informações externas, garante-se a utilização de "dados de outras empresas que pratiquem a venda de bens, serviços ou direitos, idênticos ou similares, no mercado brasileiro". Essa divergência é sobremaneira injusta. Imagine-se um contribuinte que desenvolveu um produto novo e exclusivo, o qual é produzido em duas versões: (a.) uma primeira, um pouco mais completa, revendida exclusivamente para sua controladora; e (b.) uma segunda destinada ao mercado nacional. As duas versões são similares, não idênticas; uma vez ajustadas as diferenças materialmente relevantes, a versão estrangeira seria alienada por $95 \%$ do preço da versão nacional. Pela dicção legal, este contribuinte não se enquadraria neste safe harbour. Mas o artigo 14 da Instrução Normativa n. ${ }^{\circ}$ 243/02 houve por bem corrigir esta distorção, ao prever que a média dos preços de exportação deve ser comparada com a média de venda "dos bens, serviços ou direitos, idênticos ou similares, no mercado brasileiro" ${ }^{\text {"481 }}$.

Outras inovações trazidas pelo referido normativo foram (i.) a previsão de que as médias a serem comparadas devem ser ponderadas; (ii.) a exigência de que os dados nacionais para cômputo na média precisam ter sido praticados entre "compradores e vendedores não vinculados"; e (iii.) alterações das deduções nos preços de venda do mercado interno, antes de se obter a média ponderada comparável ${ }^{482}$. A previsão de médias

I - no mercado brasileiro, deverá ser considerado líquido dos descontos incondicionais concedidos, do imposto sobre a circulação de mercadorias e serviços, do imposto sobre serviços e das contribuições para a seguridade social - COFINS e para o PIS/PASEP;

II - nas exportações, será tomado pelo valor depois de diminuído dos encargos de frete e seguro, cujo ônus tenha sido da empresa exportadora".

481 "Art. 14. As receitas auferidas nas operações efetuadas com pessoa vinculada, ficam sujeitas a arbitramento quando o preço médio de venda dos bens, serviços ou direitos, nas exportações efetuadas durante o respectivo período de apuração da base de cálculo do imposto de renda e da CSLL, for inferior a noventa por cento do preço médio praticado na venda dos bens, serviços ou direitos, idênticos ou similares, no mercado brasileiro, durante o mesmo período, em condições de pagamento semelhantes"

482 “Art. 14. (...) 
ponderadas parece-nos razoável. O item (iii.) também não apresenta maiores dificuldades porque, na prática, ao aumentar as deduções nos preços internos, o normativo os reduz, o que amplia as possibilidades de o preço médio das exportações superar $90 \%$ da média dos preços internos. Apenas a restrição, para cômputo na média, de dados nacionais hauridos de operações entre "compradores e vendedores não vinculados" gera maiores discussões. Entendemos que a matéria pode ser examinada segundo duas perspectivas. Primeiramente, note-se que a expressão "parte vinculada" é um termo técnico extraído do artigo 23 da Lei n. ${ }^{\circ}$ 9.430/96, o qual exige, necessariamente, a estraneidade da contraparte para que ela caracterize-se como "vinculada"; exigir que as operações internas tenham sido realizadas entre compradores e vendedores não vinculados, assim, parece-nos sem sentido, de modo que o $\$ 3^{\circ}$ do artigo 14 do normativo seria "letra morta". Se, contudo, pretender a administração tributária interpretar a noção de "vínculo" de forma ampla, sem apego à lei que o normativo pretende aplicar, essa norma seria ilegal, porquanto introduz limitações não contidas no texto legal. Pelo contrário, o artigo 19 , $\S 8^{\circ}$, da Lei n. ${ }^{\circ}$ 9.430/96, ao abordar a questão dos compradores não-vinculados, refere-se, exclusivamente, aos dados para a aplicação dos métodos, e não ao safe harbour contido no caput daquele dispositivo ${ }^{483}$.

Por fim, saliente-se que o percentual de $90 \%$ pode ser alterado pelo Ministro de Estado da Fazenda, consoante autorização legal contida no artigo 20 da Lei n. ${ }^{\circ}$ 9.430/96, regulamentado pelos artigos 32 a 34 da Instrução Normativa n. . 243/02.

$\S 1^{\circ} \mathrm{O}$ preço médio a que se refere o caput deste artigo será obtido pela multiplicação dos preços praticados, pelas quantidades relativas a cada operação e os resultados apurados serão somados e divididos pela quantidade total, determinando-se, assim, o preço médio ponderado.

$\$ 2^{\circ}$ Caso a pessoa jurídica não efetue operações de venda no mercado interno, a determinação dos preços médios a que se refere o caput será efetuada com dados de outras empresas que pratiquem a venda de bens, serviços ou direitos, idênticos ou similares, no mercado brasileiro.

$\S 3^{\circ}$ Para efeito do disposto neste artigo, somente serão consideradas as operações de compra e venda praticadas, no mercado brasileiro, entre compradores e vendedores não vinculados.

$\S 4^{\circ}$ Para efeito de comparação, o preço de venda:

I - no mercado brasileiro, deverá ser considerado líquido dos descontos incondicionais concedidos, do ICMS, do ISS, das contribuições Cofins e PIS/Pasep, de outros encargos cobrados pelo Poder Público, do frete e do seguro, suportados pela empresa vendedora;

II - nas exportações, será tomado pelo valor depois de diminuído dos encargos de frete e seguro, cujo ônus tenha sido da empresa exportadora".

483 “Art. 19. (...)

$\S 8^{\circ}$ Para efeito do disposto no $\S 3^{\circ}$, somente serão consideradas as operações de compra e venda praticadas entre compradores e vendedores não vinculados". O $\$ 3^{\circ}$ ora referido é, justamente, o que cita os quatro métodos para o "teste" dos preços de transferência nas operações de exportação. 


\section{(II.) Margens predeterminadas de lucro.}

Os artigos 18, incisos II e III, e 19, §3º, II, III e IV, da Lei n. ${ }^{\circ}$ 9.430/96, predeterminam as margens brutas aplicáveis aos métodos PVL, CPL, PVA, PVV e CAP, respectivamente. Esses métodos são baseados na comparação de margens brutas, de modo que a predeterminação de tais margens deve ser considerada uma modalidade de safe harbour, sob pena de se desvirtuar completamente o conceito de tais sistemáticas. Na prática, as margens prefixadas representam uma espécie de presunção relativa, cuja contraprova pode ser efetivada pelo contribuinte por quaisquer meios disponíveis em direito. A questão da possibilidade de alteração de margens será melhor discutida no CAPÍTULO 4. Por ora, pondere-se que os contribuintes que aplicarem a margem indicada na lei para o cálculo do respectivo preço parâmetro têm segurança de que este percentual não poderá ser alterado em eventual procedimento de fiscalização, além de não necessitarem buscar documentação para a prova de suas margens; são estas, justamente, as características primordiais dos safe harbours.

\section{(III.) Registro da taxa de juros a receber ou a pagar perante o Banco}

\section{Central do Brasil.}

O $\S 4^{\circ}$ do artigo 22 da Lei n. ${ }^{\circ}$ 9.430/96 prevê que os critérios dos juros mínimos tributáveis e máximos dedutíveis ali previstos ${ }^{484}$ não são aplicáveis "nos casos de contratos registrados no Banco Central do Brasil", hipótese em que "serão admitidos os juros determinados com base na taxa registrada". Por intermédio desse safe harbour, a lei transfere para o Banco Central do Brasil o dever de fiscalização das taxas de juros praticadas em operações vinculadas. Preliminarmente, importa ponderar que incumbir o Banco Central do Brasil do controle das taxas de juros estabelecidas entre partes associadas não é uma medida de "justiça tributária". Com efeito, é sabido que, independentemente do nível dos juros praticados mundialmente, o Banco Central do Brasil tem recusado registros de taxas de juros superiores a $4 \%$ ou $5 \%$ ao ano nas hipóteses de captação de mútuos estrangeiros não-bancários. Além disso, são permitidos empréstimos ao exterior sem a cobrança de juros. A fiscalização das autoridades monetárias tem se pautado, fundamentalmente, no controle do ingresso e da saída e divisas, e não na fixação

${ }^{484}$ Estes critérios, em conjunto com a discussão sobre sua interpretação mais adequada, serão abordados no CAPÍTULO 4. 
de juros coerentes com o mercado. Isso tem sido, inclusive, reconhecido expressamente pela $\mathrm{OCDE}^{485}$. Na prática, assim, este safe harbour garante que os mútuos registrados no Banco Central do Brasil podem ser praticados sem qualquer tipo de "teste" ou de aproximação dos os preços que seriam praticados por empresas independentes, tal como determina o princípio da plena concorrência, inaplicável nesta hipótese.

Note-se que o $\S^{\circ}$ do artigo 22, acima referido, alude a contratos "registrados no Banco Central do Brasil". A alusão a "registro" parece-nos, contudo, imprópria. Isso porque apenas os recursos ingressados no país [i.e, nas transações em que a parte vinculada brasileira capta empréstimos] sujeitam-se a registro ${ }^{486}$. A remessa de recursos brasileiros ao exterior [i.e, concessão de empréstimos] não deve ser registrada; pelo contrário, inexistem meios de fazê-lo. Nestas hipóteses, o contribuinte que possui capitais e bens no exterior precisa apenas declará-los, anualmente, ao Banco Central do Brasil [cf. Medida Provisória n. ${ }^{\circ}$ 2.224, de 04.09.01]. Essa declaração não constitui, propriamente, um "registro". Independentemente disso, concordamos com Roberto Quiroga MOSQUERA, o qual sustenta que tal declaração serve também como espécie de "registro" para fins do safe harbour, sob pena de o artigo $22, \S 4^{\circ}$, da Lei n. ${ }^{\circ}$ 9.430/96 tornar-se "letra morta" para as operações de empréstimos de recursos por residentes no país ${ }^{487}$, aplicando-se tão-somente à captação de recursos. Saliente-se, por fim, que este mesmo entendimento foi manifestado no acórdão n. ${ }^{\circ}$ 108-08712, proferido em 22.02.06, pela $8^{\text {a }}$ Câmara do antigo Primeiro Conselho de Contribuintes ${ }^{488}$.

\footnotetext{
485 "Also taxpayers may, in the absence of comparable data from independent parties, bring forward data from transactions with associated enterprises as indirect evidence of compliance with the arm's length principle, based on the fact that the transactions in question have already been scrutinized for non-tax purposes by independent bodies such as financial regulators (...) However, regulators and other users of que accounts may be guided by different principles other than arm's length principle and also may be indifferent to the allocation of profits between jurisdictions" (OCDE. OECD Documents. The Taxation of Global Trading of Financial Instruments. op. cit., p. 33).

${ }^{486}$ Para garantir o livre retorno dos capitais estrangeiros ingressados no país, a Lei n. ${ }^{\text { }} 4.131$, de 03.09.62, instituiu o seu registro. Atualmente, esse registro processa-se por intermédio do Registro Declaratório Eletrônico, no módulo Registro de Operações Financeiras ("RDE-ROF”).

487 MOSQUERA, Roberto Quiroga; e FREITAS, Rodrigo de. Reflexos Financeiros dos Preços de Transferência: Conceito de Registro no Banco Central do Brasil das Operações Inbound e Outbound. In: Luís Eduardo Schoueri (coord.), Tributos e preços de transferência. São Paulo: Dialética, 2009, v. 03, p. 233-238. 488 "IRPJ. REGISTRO DE CAPITAIS NO BACEN. O registro de capitais no BACEN, desde a edição da Lei n. ${ }^{\circ}$ 4.131, de 1962, não contempla um sistema de registro dos capitais brasileiros destinados ao exterior e sim o dever de prestar informações. A Lei n. ${ }^{\circ}$ 9.430/96 ao dispor sobre o registro dos contratos de mútuo no BACEN não trata do registro na forma existente para os capitais estrangeiros, uma vez que o mesmo inexiste. Permanecer a pretensão fiscal equivaleria à norma ter criado uma condição impossível para o contribuinte. Somente com a edição da MP 2.224, de 2001, foi restabelecida a obrigatoriedade de declaração, para o BACEN, de capitais brasileiros detidos no exterior. O Conselho Monetário Nacional e o BACEN instituíram
} 


\title{
(IV.) Lucratividade mínima de $5 \%$ nas operações de exportação ou
}

\author{
receitas de exportação máximas de $5 \%$.
}

Estas duas espécies de safe harbour têm amparo no artigo 45 da Lei n. ${ }^{\circ} 10.833$, de 29 de dezembro de $2003^{489}$. Sua introdução no ordenamento brasileiro, contudo, deu-se com a publicação da Instrução Normativa n. ${ }^{\circ}$ 243/02; a lei que os fundamenta, assim, foi publicada mais de um ano após sua criação pelas autoridades administrativas. Nos termos do artigo 45 da Lei n. ${ }^{\circ}$ 10.833/03, o fisco pode "estabelecer normas, tendo em vista condições especiais de rentabilidade e representatividade de operações da pessoa jurídica" exportadora. As condições especiais de rentabilidade das operações de exportação constam do artigo 35 da Instrução Normativa n..$^{\circ}$ 243/02, ao passo que as exportações com reduzida representatividade se comparada às receitas totais foram disciplinadas pelo artigo 36.

Nos termos do artigo 35, se um contribuinte apurar em suas exportações um lucro líquido, antes da provisão para a CSLL e o IRPJ, superior a 5\% sobre o total das receitas de exportação, "considerando a média anual do período de apuração e dos dois anos precedentes, poderá comprovar a adequação dos preços praticados nas exportações, do período de apuração, exclusivamente com os documentos relacionados com a própria operação" ${ }^{490}$. Trata-se de uma espécie de safe harbour que simplifica os procedimentos administrativos dos contribuintes, que não precisarão buscar dados internos ou externos

a Declaração de Capitais Brasileiros no Exterior, a ser prestada anualmente a partir de 2002" (acórdão n. ${ }^{\circ}$ 108-08712, j. em 22.02.06, pela $8^{\mathrm{a}}$ Câmara do $1^{\mathrm{o}}$ Conselho de Contribuintes do Ministério da Fazenda).

489 “Art. 45. A Secretaria da Receita Federal poderá estabelecer normas, tendo em vista condições especiais de rentabilidade e representatividade de operações da pessoa jurídica, disciplinando a forma de simplificação da apuração dos métodos de preço de transferência de que trata o art. 19 da Lei n. ${ }^{\circ}$ 9.430, de 27 de dezembro de 1996.

$\S 1^{\circ} \mathrm{O}$ disposto no caput não se aplica em relação às vendas efetuadas para empresa, vinculada ou não, domiciliada em país ou dependência com tributação favorecida, ou cuja legislação interna oponha sigilo, conforme definido no art. 24 da Lei n. ${ }^{\circ}$ 9.430, de 27 de dezembro de 1996, e art. $4^{\circ}$ da Lei n. ${ }^{\circ} 10.451$, de 10 de maio de 2002".

490 “Art. 35 A pessoa jurídica que comprovar haver apurado lucro líquido, antes da provisão da CSLL e do imposto de renda, decorrente das receitas de vendas nas exportações para empresas vinculadas, em valor equivalente a, no mínimo, cinco por cento do total dessas receitas, considerando a média anual do período de apuração e dos dois anos precedentes, poderá comprovar a adequação dos preços praticados nas exportações, do período de apuração, exclusivamente com os documentos relacionados com a própria operação.

$\S 1^{\circ}$ Para efeito deste artigo, o lucro líquido correspondente às exportações para empresas vinculadas será apurado segundo o disposto no art. 187 da Lei n. ${ }^{\circ}$ 6.404, de 15 de dezembro de 1976 e na legislação do imposto de renda.

$\S 2^{\circ} \mathrm{Na}$ apuração do lucro líquido correspondente a essas exportações, os custos e despesas comuns às vendas serão rateados em função das respectivas receitas líquidas.

$\S 3^{\circ}$ Não devem ser computadas, para fins de determinação do percentual estabelecido no caput, as operações de venda de bens, serviços ou direitos cujas margens de lucro, previstas nos arts. 24, 25 e 26, tenham sido alteradas nos termos dos arts. 32,33 e 34 ”. 
para justificar seus preços de transferência. Da interpretação literal do caput do artigo 35, pode-se depreender que o lucro de $5 \%$ sobre a receita bruta das exportações precisará ser identificado em cada um dos três anos examinados, especialmente por conta da expressão "média anual", e não trienal. Há, todavia, doutrinadores que sustentam que o artigo deve ser interpretado de modo a se aferir, a partir das médias anuais, uma outra média, ponderada a partir dos volumes e valores de cada ano e que envolva as operações dos três anos, conjuntamente ${ }^{491}$. Entendemos, contudo, que o dispositivo deve ser interpretado de forma restritiva.

O artigo 36 da Instrução Normativa n. ${ }^{\circ}$ 243/02, de outro lado, institui um safe harbour aos contribuintes que praticam esporadicamente operações de exportação, ou que as praticam habitualmente, mas em valores reduzidíssimos: sempre que a receita líquida das operações de exportação num determinado ano-calendário for inferior a $5 \%$ de sua receita líquida total, o contribuinte "poderá comprovar a adequação dos preços praticados nessas exportações, exclusivamente com os documentos relacionados com a própria operação" ${ }^{492}$.

Ressalte-se que os dois safe harbours discutidos nos parágrafos anteriores não se aplicam às operações de exportação destinadas a adquirentes residentes em países ou dependências com tributação favorecida, a cuja legislação interna oponha sigilo, nos termos dos artigos 24 e 24-A da Lei n. ${ }^{\circ}$ 9.430/96. Esta vedação está expressa tanto no artigo $45, \S^{\circ}$, da Lei n. ${ }^{\circ} 10.833 / 03$, quanto no artigo 37 , I, da Instrução Normativa n. ${ }^{\circ}$ $243 / 02^{493}$. Especificamente no que respeita ao safe harbour que trata da representatividade

\footnotetext{
491 “A interpretação literal da referida alteração leva à conclusão rápida de que o contribuinte deva atingir o citado lucro de 5\% por três anos seguidos, independentemente do volume e relevância das operações em cada um dos anos. (...)

Outra interpretação possível seria entender que, a partir das três médias anuais, se deve efetuar uma nova operação, para que se alcance uma média única, aritmética ou ponderada.

A média aritmética também levaria a distorções, tendo em vista a possibilidade de o contribuinte ser obrigado ou desobrigado das demonstrações por conta de um ano com volume mínimo de operações.

Realizar uma operação de média ponderada com as médias anuais, levando-se em conta o volume e o valor das operações é a interpretação que melhor atende à ratio legis da norma e que, por essa razão, deve ser a considerada pelas autoridades fiscais" (SCHOUERI, Luís Eduardo. Preços de Transferência no Direito Tributário Brasileiro. op. cit., p. 243-244).

492 "Art. 36. A pessoa jurídica, cuja receita líquida das exportações, no ano-calendário, não exceder a cinco por cento do total da receita líquida no mesmo período, poderá comprovar a adequação dos preços praticados nessas exportações, exclusivamente com os documentos relacionados com a própria operação.

Parágrafo único. No cálculo da receita líquida de exportação a que se refere o caput devem ser também incluídas as receitas de vendas efetuadas para pessoas físicas ou jurídicas residentes ou domiciliadas em país com tributação favorecida".

${ }_{493}$ "Art. 37. O disposto nos arts. 35 e 36:
} 
das operações de exportação, saliente-se que as transações ora discutidas devem integrar o cálculo da "receita líquida das exportações", para fins de checagem do percentual máximo de $5 \%$. Se o contribuinte que exportou para adquirentes de tais localidades qualificar-se para a aplicação deste safe harbour, contudo, a "dispensa" de documentação das transações independentes comparáveis não se aplicará a estas operações específicas, mas tão-somente a exportações destinadas a contribuintes não indicados nos artigos 24 e $24-\mathrm{A}$ da Lei n. ${ }^{\circ}$ 9.430/96.

Prevê o inciso II do artigo 37 da Instrução Normativa n. ${ }^{0}$ 243/02 que os safe harbours ora discutidos não implicam "a aceitação definitiva do valor da receita reconhecida com base no preço praticado, o qual poderá ser impugnado, se inadequado, em procedimento de ofício, pela SRF". Considerando a amplitude dos poderes conferidos pelo caput do artigo 45 da Lei n. ${ }^{\circ}$ 10.833/03 às autoridades administrativas, não há dúvidas de que esta previsão é legal ${ }^{494}$. Esta disposição, contudo, retira dos safe harbours disciplinados pelos artigos 35 e 36 a segurança jurídica normalmente atrelada a normas deste tipo, especialmente porque o termo "inadequado" é muito vago. Na prática, os preços das transações enquadradas nos safe harbours deveriam ser desqualificados apenas nas hipóteses de fortes indícios de dolo, fraude ou simulação. Ademais, se, por força dos safe harbours, o contribuinte deixar de angariar provas para justificar seus preços à época da transação, dificilmente poderá obtê-las anos mais tarde, quando o fisco iniciar um procedimento de fiscalização tendente a impugná-los.

\section{(V.) Margem de divergência de $5 \%$.}

O $2^{\circ}$ do artigo 45 da Lei n. ${ }^{\circ} 10.833 / 03$, prevê a possibilidade de as autoridades fixarem "margens de divergência" aceitáveis entre os preços praticados e os preços

I - não se aplica em relação às vendas efetuadas para empresa, vinculada ou não, domiciliada em país ou dependência com tributação favorecida, ou cuja legislação interna oponha sigilo, conforme definido no art. 39 ;

II - não implica a aceitação definitiva do valor da receita reconhecida com base no preço praticado, o qual poderá ser impugnado, se inadequado, em procedimento de ofício, pela SRF".

494 "Consoante dispõe o inciso II do artigo 37, o valor da receita reconhecida com base no preço praticado poderá ser impugnado, se inadequado, em procedimento de ofício, pela Secretaria da Receita Federal, a quem caberá o ônus de demonstrar tal inadequação. Não há ilegalidade, já que, como apontado, é faculdade da administração simplificar, ou não, o procedimento de fiscalização dos contribuintes; procedimento simplificado ou não, buscar-se-á, sempre, investigar se os preços praticados são compatíveis com o parâmetro da lei" (SCHOUERI, Luís Eduardo. Preços de Transferência no Direito Tributário Brasileiro. op. cit., p. 241). 
parâmetro $^{495}$; estas margens são aplicáveis tanto às transações de importação quanto às de exportação. O artigo 38 da Instrução Normativa n. ${ }^{\circ} 243 / 02^{496}$ prevê uma margem de divergência de 5\%, para mais ou para menos, a qual foi instituída antes mesmo da lei que a autorizou. Por conta deste safe harbour, assim, o contribuinte deve comparar a média dos preços praticados com o preço parâmetro [também resultante de uma outra média aritmética ponderada]. Se, v.g., num determinado tipo de operação de exportação, o preço parâmetro for inferior à média dos preços praticados, deverá o contribuinte examinar cada uma das transações, a partir dos documentos de importação respectivos. Durante esta análise individualizada, dispensam-se ajustes sempre que a divergência entre o preço parâmetro e o preço praticado for inferior a $5 \%$.

\section{(VI.) Conquista de novos mercados.}

Por fim, importa esclarecer que o artigo 30 da Instrução Normativa n. ${ }^{\circ}$ 243/02 instituiu uma espécie de safe harbour não amparada em lei ${ }^{497}$. Trata-se da possibilidade de

495 "Art. 45. (...)

$\S 2^{\circ}$ A autorização de que trata o caput se aplica também na fixação de percentual de margem de divergência máxima entre o preço ajustado, a ser utilizado como parâmetro, de acordo com os métodos previstos nos arts. 18 e 19 da Lei n. ${ }^{\circ}$ 9.430, de 27 de dezembro de 1996, e o daquele constante na documentação de importação e exportação".

496 “Art. 38. Será considerada satisfatória a comprovação, nas operações com empresas vinculadas, quando o preço ajustado, a ser utilizado como parâmetro, divirja, em até cinco por cento, para mais ou para menos, daquele constante dos documentos de importação ou exportação.

Parágrafo único. Nessa hipótese, nenhum ajuste será exigido da empresa na apuração do imposto de renda, e na base de cálculo da CSLL".

497 “Art. 30. As exportações para empresa vinculada, com o objetivo de conquistar mercado, em outro país, para os bens, serviços ou direitos de produção no território brasileiro, poderão ser efetuadas a preços médios inferiores a noventa por cento dos preços médios praticados no Brasil, independentemente de arbitramento das respectivas receitas, desde que:

I - os bens, serviços ou direitos, objeto da exportação, não tenham sido comercializados no país de destino, pela própria empresa exportadora ou por qualquer outra a ela vinculada, localizada em qualquer parte do mundo;

II - os bens, serviços ou direitos sejam revendidos aos consumidores, por preço inferior ao de qualquer bem, serviço ou direito, idêntico ou similar, comercializado no país de destino;

III - efetuadas com observância das condições fixadas em plano específico de exportação, previamente aprovado pela Coordenação-Geral de Tributação (Cosit) da SRF;

IV - fique demonstrado, no plano de exportação, que a empresa vinculada, domiciliada no país de destino, não terá lucro com as operações e, se houver previsão de prejuízos para a empresa no Brasil, em virtude do preço a ser praticado, o prazo previsto para sua recuperação.

$\$ 1^{\circ}$ Para efeito de comparação, aplicam-se aos preços dos bens, serviços ou direitos, idênticos ou similares, a que se refere o inciso II, as normas de ajuste estabelecidas nos arts. 15 a 18.

$\S 2^{\circ} \mathrm{O}$ plano de exportação a que se refere este artigo deverá conter:

I - a denominação da empresa vinculada, encarregada da distribuição dos bens, serviços ou direitos, no país de destino, com o respectivo endereço;

II - a quantidade de cada bem, serviço ou direito a ser exportado com a finalidade de conquista de mercado;

III - as formas de distribuição no mercado de destino;

IV - as empresas locais por meio das quais será efetuada a distribuição;

$\mathrm{V}$ - a margem, em percentuais, contratada com as distribuidoras; 
o contribuinte exportar bens, serviços ou direitos para empresas vinculadas, com o objetivo de conquistar novos mercados, por preços inferiores a $90 \%$ dos preços praticados nas operações internas, mas sem qualquer arbitramento. Para garantir este direito, o contribuinte precisa apresentar um plano de exportação detalhando sua estratégia e comprovando que (i.) nunca os seus produtos foram vendidos naquele país, diretamente ou por intermédio de partes vinculadas; (ii.) os seus bens serão revendidos naquele país por preço inferior ao de todos os seus concorrentes e similares; e (iii.) a parte vinculada estabelecida naquela localidade não irá auferir lucro com estas operações. Se o contribuinte brasileiro incorrer em prejuízos por conta de tal estratégia de penetração no mercado, deverá apresentar, outrossim, uma estimativa para a sua recuperação. Parece-nos elogiável esta iniciativa da administração tributária. Os requisitos para o enquadramento neste safe harbour, contudo, são complexos e, em alguns caso, não-razoáveis. Mencione-se, por exemplo, a impossibilidade de a parte vinculada auferir lucros no seu país; imagina o fisco que uma empresa estrangeira, do mesmo grupo, desenvolveria as atividades de distribuição e desenvolvimento do mercado consumidor sem qualquer retorno? O normativo deveria ter admitido a possibilidade de algum lucro mínimo, mesmo porque, se esta parte vinculada estiver localizada em nação que possua regras internas para o controle dos preços de transferência, seu fisco não admitirá que ela "trabalhe de graça” para empresa vinculada no Brasil.

VI - o período em que será executado o plano, com as respectivas datas de início e término;

VII - a previsão dos gastos com a promoção, no país de destino, dos bens, serviços ou direitos a serem exportados.

$\S 3^{\circ}$ Somente serão aprovados planos com prazo de execução igual ou inferior a doze meses.

$\S 4^{\circ} \mathrm{O}$ disposto neste artigo não se aplica quando os bens, serviços ou direitos, a serem exportados, tiverem por destino país com tributação favorecida, ou cuja legislação interna oponha sigilo, conforme definido no art. 39". 


\section{CAPÍTULO 3. NEGOCIAÇÃO GLOBAL DE INSTRUMENTOS FINANCEIROS.}

\subsection{Conceito de negociação global de instrumentos financeiros.}

Num sentido amplo, os denominados instrumentos financeiros envolvem ações, títulos diversos, derivativos, fundos de investimento, clubes, aplicações e financiamentos das mais variadas modalidades etc. ${ }^{498}$. Praticamente inexistem sociedades que não captem empréstimos, efetuem investimentos ou pratiquem outras espécies de operações financeiras cotidianamente. De fato, as transações deste tipo tornaram-se inerentes à atuação das companhias, independentemente do seu ramo de negócios. Como referido na INTRODUÇÃO do presente trabalho, os mercados financeiros tornaram-se muito globalizados, o que tem permitido eficiência na alocação/captação de capital: uma companhia brasileira pode angariar recursos mediante a emissão de títulos revendidos em todo o mundo ou, eventualmente, investir de forma mais diversificada, moldando seu portfólio conforme a relação risco-retorno pretendida. A existência de um "mercado global" amplia as possibilidades de negócios que podem ser concebidos pelas companhias em geral, que contam com o auxílio das instituições financeiras, as quais atuam como intermediárias e também como importantes agentes para o desenvolvimento deste mercado global.

${ }^{498}$ Nos termos da Orientação Técnica OCPC-03, com o título "Instrumentos Financeiros: Reconhecimento, Mensuração e Evidenciação", aprovada em 02.10.09 pelo Comitê de Pronunciamentos Contábeis, considerase instrumento financeiro "qualquer contrato que origine um ativo financeiro para uma entidade e um passivo financeiro ou título patrimonial para outra entidade".

Em seguida, o item 6 da OCPC-03 define os ativos e passivos financeiros da seguinte forma:

"Ativo financeiro é qualquer ativo que seja: (a) caixa; (b) título patrimonial de outra entidade; (c) direito contratual: (i) de receber caixa ou outro ativo financeiro de outra entidade; ou (ii) de trocar ativos ou passivos financeiros com outra entidade sob condições potencialmente favoráveis para a entidade; (d) contrato que será ou poderá vir a ser liquidado em títulos patrimoniais da própria entidade e que seja: (i) um instrumento financeiro não derivativo no qual a entidade é ou pode ser obrigada a receber um número variável dos seus próprios títulos patrimoniais; ou (ii) um instrumento financeiro derivativo que será ou poderá ser liquidado por outro meio que não a troca de montante fixo em caixa ou outro ativo financeiro, por número fixo de seus próprios títulos patrimoniais. Para esse propósito os títulos patrimoniais da própria entidade não incluem instrumentos que são contratos para recebimento ou entrega futura de títulos patrimoniais da própria entidade";

"Passivo financeiro é qualquer passivo que seja: (a) obrigação contratual: (i) de entregar caixa ou outro ativo financeiro para outra entidade; ou (ii) de trocar ativos ou passivos financeiros com outra entidade sob condições potencialmente desfavoráveis para a entidade; ou (b) contrato que será ou poderá ser liquidado com títulos patrimoniais da própria entidade e que seja: (i) um não derivativo no qual a entidade é ou pode ser obrigada a entregar um número variável de seus próprios títulos patrimoniais; ou (ii) um derivativo que será ou poderá ser liquidado por outro meio que não a troca de montante fixo de caixa ou outro ativo financeiro por número fixo de títulos patrimoniais da própria entidade. Para esse propósito os títulos patrimoniais da própria entidade não incluem instrumentos que são contratos para recebimento ou entrega futura de títulos patrimoniais da própria entidade". 
Como conseqüência direta do referido no parágrafo anterior, as instituições financeiras que atuam como contrapartes ou intermediárias nas transações globalizadas têm auferido resultados a cada dia mais expressivos. Para proporcionar a seus clientes todo o leque de produtos disponíveis, bem assim para se manterem próximas deles,os grandes e médios grupos financeiros têm constituído subsidiárias, controladas ou filiais em diversas nações; estas entidades, contudo, não desenvolvem suas atividades isoladamente: é muito comum a sua colaboração para (i.) gerar ganhos de eficiência e escala; e (ii.) propiciar maiores lucros ao grupo financeiro. Para a estruturação de um determinado acordo de underwriting, v.g., instituições estabelecidas no Brasil, Inglaterra e Japão podem reunir-se para garantir a implementação do negócio. Também contribuiu para esta "atuação conjunta de instituições" o fenômeno da concentração no mercado financeiro, incentivado pela crise internacional de 2008.

Os preços de transferência praticados nas hipóteses de atuação conjugada de diversas instituições pertencentes a um mesmo conglomerado financeiro são, justamente, o objeto do presente estudo. Não serão estudadas as transações financeiras estabelecidas no livre mercado, mas os negócios entre instituições vinculadas ${ }^{499}$, os quais abrangem desde transações financeiras até a prestação de serviços, cessão do direito de uso de intangíveis etc.. Mais especificamente, pretende-se avaliar as metodologias disponíveis para o cálculo dos preços de transferência em operações de negociação global de instrumentos financeiros estruturados e implementados por empresas associadas. Dada a maior complexidade desta espécie de negócios, muitos dos quais praticados exclusivamente entre empresas vinculadas, entendeu-se que o seu estudo seria apto a demonstrar, com mais propriedade, tanto os benefícios como as fragilidades do princípio da plena concorrência.

A expressão "negociação global" ou "global trading" compreende a capacidade de as instituições executarem ordens de compra ou venda de instrumentos financeiros dadas por seus clientes durante $24 \mathrm{~h}$ por dia, globalmente ${ }^{500}$. Por vezes a negociação global

\footnotetext{
${ }^{499}$ Saliente-se que, se um determinado conglomerado financeiro operar em todo o mundo a partir de um único país [sem filiais ou subsidiárias estrangeiras], não surgirão problemas concernentes aos preços de transferência, mas sim questões relativas à tributação da renda do investidor e/ou da instituição.

500 ' 8 . In the financial sector, the term 'global trading' has become the catch-call phrase that focuses on the capacity of the financial institutions to execute customer's orders in financial products in markets around the world and/or around the clock. This activity includes underwriting and distributing products on a worldwide basis, acting as market-maker in physical securities (i.e. traditional bond and equity markets) and in derivative instruments, acting as a broker for client transactions on stock and commodities exchanges around the world, and developing new products to meet the needs of the financial institution's clients, for example credit derivatives (...).
} 
é referida unicamente por "around the world, around the clock". A proposta de regulamentação do assunto pela legislação norte-americana vale-se da expressão "global dealing" para indicar esta mesma forma de atuação global das instituições financeiras ${ }^{501}$. Note-se, a esse passo, que em 06.03.98 foram editadas as denominadas Proposed Rules, cujo objetivo é a introdução de um novo capítulo na Seção 1.482 do IRC [Seção 1.482-8: "Allocation of income earned in a global securities dealing operations", sendo que a atual Seção 1.482-8 seria convertida em Seção 1.482-9]. A regulamentação final ainda não foi publicada mas, a despeito disso, o IRS recomenda a aplicação das Proposed Rules ${ }^{502}$; para diferenciar a Seção 1.482-8 proposta da versão em vigor, denominá-la-emos "Seção 1.4828/Proposta".

A maior parte dos derivativos pode ser negociado de forma global, sendo que a existência de transações deste tipo depende de um único fator: a sua demanda. Para atender aos clientes, os grupos financeiros desenvolveram a habilidade de atuar durante $24 \mathrm{~h}$ por dia: como decorrência disso, precisam ajustar ou proteger posições assumidas também durante $24 \mathrm{~h}$ por dia. Portanto, a capacidade de atuar em negociações globais, i.e., a capacidade de executar ordens de clientes em mercados no mundo todo e/ou durante as $24 \mathrm{~h}$ do dia, exige que as instituições vinculadas associem-se não apenas para atendê-los como,

9. Enterprises that engage in global trading in this sense may also seek to make profit by correctly forecasting the movement in market variables (such as interest rates, exchange rates or prices) that affect the value of their portfolio. This involves the deliberate exposure of the portfolio to changes in the market variables and is sometimes referred to as taking 'proprietary position' on a global or 24-hour basis but do not make markets. However, in this Report the term 'global trading' refers primarily to those entities that engage in market making on a global or 24-hour basis, but also refer to the dealing or brokering of financial instruments in customer transactions where some part of the business takes place in one or more jurisdiction" (OCDE. Report on the Attribution of Profits to Permanent Establishments. op. cit., p. 121).

No dicionário de direito tributário internacional publicado pelo IBFD, a expressão "global trading" foi explicada da seguinte forma:

'A term used to describe the trading of financial products by associated enterprises in financial markets located throughout the world. Global trading includes execution of customer service transactions, marketing, sales, and pricing and risk management activities in financial products. Investment positions of a dealer and lending activities are not normally included" (IBFD. International tax glossary, op. cit., p. 195).

501 "1.482-8 [proposta] (a) (2) (i) Global dealing operation consists of a execution of customer transactions, including marketing, sales, pricing and risk management activities, in a particular financial product or line of financial products, in multiple tax jurisdictions and/or through multiple participants (...). A global dealing operation may consist of several different business activities engaged in by participants. Whether a separate business activity is a global dealing operation shall be determined with respect to each type of financial product entered on the taxpayer's books and records" (Federal Register/v. 63, no. 44, Friday, March 6, 1988. Department of Treasury, obtido em www.irs.gov).

502 "The Treasury Department and the IRS are working on new global dealing regulations. The intent of the Treasury Department and the IRS is that, when final global dealing regulations are issued, those regulations will govern the evaluation of the activities performed by a global dealing operation. Pending the issuance of new global dealing regulations, taxpayers may rely on the proposed global dealing regulations to govern financial transactions entered into in connection with a global dealing operation as defined in proposed $\S 1.482-8$ " (Federal Register/v. 74, no. 148, Tuesday April 4, 2009. Department of Treasury, obtido em www.irs.gov). 
também, para definir estratégias de hedge e de especulação do grupo. Geralmente, as transações denominadas globais envolvem entidades presentes nas três zonas horárias [“time-zones”], ocorrendo, v.g., a partir de Tóquio, Londres e Nova Iorque, mas, para fins das regras de preços de transferência, é suficiente a participação, na negociação, de empresas estabelecidas em dois países distintos ${ }^{503}$.

Um exemplo muito simples de negociação global seria o seguinte: uma controlada brasileira de instituição financeira com sede nos Estados Unidos vende a uma companhia nacional um contrato de dólar futuro de 3 meses, por $\mathrm{R} \$ 1,80$ cada 1USD. $\mathrm{O}$ presidente do grupo determinou que todo o risco relacionado à cotação do USD deve ser administrado nos Estados Unidos; para o cumprimento desta ordem, no momento subseqüente à venda do futuro, a entidade brasileira transaciona com sua controladora, celebrando uma operação totalmente inversa: a compra de dólar futuro, pelo mesmo preço e prazo; em virtude disso, passa a possuir uma posição "vendida" e uma posição "comprada", podendo honrar, sem riscos, a obrigação assumida perante sua cliente brasileira. Caberá à controladora estadunidense a administração do risco cambial. Como no mercado financeiro a remuneração está rigorosamente vinculada aos riscos assumidos, a empresa brasileira deverá pagar à sua controladora um preço por este hedge. Mas como definir este preço? Qual deve ser a parcela do valor recebido no país pela venda do dólar futuro que deve ser repassado à companhia norte-americana? Estas são apenas algumas questões que surgem nos negócios entre instituições financeiras associadas.

No exemplo supra, facilmente seriam localizados dados comparáveis para o estabelecimento de um adequado preço de transferência. No entanto, nas transações globais envolvendo instrumentos financeiros e, em especial, derivativos negociados em balcão, há situações complexas e de difícil compreensão. Os novos instrumentos financeiros globais põem à prova os ordenamentos tributários tradicionais, em razão da dificuldade de apuração dos ganhos efetivos de cada estabelecimento envolvido nas transações; esta dificuldade eleva-se na mesma medida do grau de integração entre as diversas instituições do grupo financeiro que participaram da operação [cf. subseção 3.2.2, abaixo]. Pondere-se, a esse passo, que as transações intra-grupo podem ser estruturadas de

503 Este entendimento é adotado pela OCDE no Relatório GT-1998 e no Relatório-2008 [cf. $O E C D$ Documents. The Taxation of Global Trading of Financial Instruments. op. cit., p. 12, e Report on the Attribution of Profits to Permanent Establishments. op. cit., p. 121] e pela legislação norte-americana [cf. Seção 1.482-8/Proposta]. 
formas mais variadas e flexíveis que aquelas que seriam pactuadas entre instituições financeiras independentes ${ }^{504}$, o que dificulta ainda mais a obtenção de "dados comparáveis". É indubitável que este tipo de operação representa um desafio para as autoridades regulatórias $^{505}$ e fiscais ${ }^{506}$. Estas últimas, em especial, podem não dispor de mecanismos suficientes e aptos para captar o preço de transferência adequado à remuneração de cada uma das funções executadas pelos membros de um grupo.

Adicionalmente, note-se que também é árdua a tarefa de entender os derivativos inovadores negociados em mercado de balcão pelas vias contábil e jurídica. Se a regulamentação contábil é essencial para a apuração dos tributos que incidem sobre a renda, não há exceção à regra neste caso: a adequada escrituração dos instrumentos financeiros negociados em bases globais, por cada ente que atua na operação, também é imprescindível, a despeito de muitíssimo complexa. Não obstante as incessantes tentativas de harmonização das regras contábeis internacionais, a contabilização de instrumentos muito específicos pode gerar dúvidas e ser interpretada de forma dissonante pelos países e/ou contribuintes. Na sistemática do controle dos preços de transferência, tal

504 "I.39 Associated enterprises are able to make a much greater variety of contracts and arrangements than can unrelated parties because the normal conflict of interest which would exist between independent parties is often absent. Associated enterprises may and frequently do conclude arrangements of a specific nature that are not or are very rarely encountered between unrelated parties. This may be done for various economic, legal, or fiscal reasons dependent on the circumstances in a particular case" (OCDE. Transfer Pricing Guidelines for Multinational Enterprises and Tax Administrations. op. cit., p. I-16). Correspondente ao item 1.66 da Minuta-2009.

505 "For a variety of reasons, therefore, adequate supervision of foreign banking establishments, without unnecessary overlapping, calls for contact and cooperation between host and parent supervisory authorities. It is one of the Committee's purposes to foster cooperation of that kind among its member countries" (WILLIAMS, Richard C. at. all. Supervision of Banks Foreign Establishments. In International Capital Markets, Recent Developments and Short-Term Prospects. Washington: International Monetary Fund, 1981, p. 29).

506 "O segundo desafio se refere às operações financeiras nos mercados futuros ou derivativos. Se a precificação de ativos, produtos e operações no mercado financeiro à vista, obedecendo ao princípio de preços sem interferência (arm's length), apresenta uma série de dificuldades, já podemos antever as complexidades da aplicação dos métodos de preços de transferência nos mercados futuros.

É de conhecimento de todos o que o mercado de derivativos representa na economia mundial. A possibilidade de que os participantes assumam e façam transferências de riscos significa que lucros ou prejuízos possam ocorrer. (...)

A princípio, as operações de derivativos efetuadas por empresas vinculadas poderiam ser comparadas com operações realizadas entre instituições não-vinculadas. Ou seja, o método de Preços Independentes Comparados (PIC) poderia ser aplicado, devido ao fato de que as operações de mercado futuro são em grande parte efetuadas em bolsas de futuros.

Existe, porém, a possibilidade de uma instituição financeira efetuar uma operação de derivativos no chamado mercado de balcão (Over the Counter), apresentando características únicas de prazos, taxas e ativos objeto. (...) Acreditamos, então, que ficaria difícil a aplicação de métodos tradicionais. Mais uma vez seria necessária a identificação dos participantes da operação, os compromissos assumidos por cada um deles e a análise dos resultados, para se determinar o resultado tributável de cada um dos participantes e verificar uma eventual transferência de resultados" (CARNEIRO, Paulo Baltazar. Preços de transferência no setor financeiro. Secretaria da Receita Federal. Disponível em www.receita.fazenda.gov.br e acessado em 31.10.08). 
complexidade é particularmente relevante, porque parcela substancial dos dados para aferição do preço de referência e do preço praticado é extraída justamente destes registros; se os países não possuírem interpretações semelhantes, o confronto de registros contábeis tornar-se-á impossível. No que respeita às provações de ordem jurídica para a compreensão dos derivativos, cumpre destacar que, a cada dia, para o atendimento das inovações tecnológicas, econômicas, regulatórias e da própria dinâmica do mercado, surgem novos tipos de contratos ou são atribuídas funcionalidades distintas a tipos existentes; nem sempre, contudo, os operadores do direito estão preparados para lidar com as complexidades trazidas por estas inovações ${ }^{507}$.

\subsection{Fatores que afetam a condução e estruturação de transações envolvendo a negociação global de instrumentos financeiros.}

\subsubsection{Partícipes das transações envolvendo a negociação global.}

As empresas e grupos transnacionais são um fator muito relevante para a evolução das transações financeiras globais, porque ambos se estimulam e completam-se mutuamente: de fato, se as transações globais têm evoluído e diversificado, isso serve para atender às empresas e entes multinacionais dos mais variados tipos; de outro lado, estes últimos não teriam se voltado tanto para o comércio e investimento estrangeiros não fosse a possibilidade de proteção contra variações cambiais. Os grupos multinacionais em geral valem-se das transações globais tanto para a captação de recursos a custos mais reduzidos ou em condições não disponíveis no seu mercado local, quanto para desenvolver estratégias de hedge ou diversificar investimentos ${ }^{508}$.

\footnotetext{
507 "Mercados, definidos como estruturas ou supra-estruturas de regras (jurídicas ou não jurídicas), mudam, transformam-se, conforme mudam os costumes, sobrem os efeitos dos avanços da tecnologia, do aparecimento de novos produtos e serviços, assim como de novas necessidades. Sem dúvida, as modificações dos mercados também se processam por influência de regras jurídicas ou de políticas econômicas. (...) Admitida a autonomia privada como princípio cardeal da dinâmica jurídica, a autonomia contratual dos particulares é o princípio que valida seu poder de autodeterminação. Esse poder conferido às pessoas não se limita a modificar os modelos legalmente previstos, mas permite determinar o fato-pressuposto da circulação e seus efeitos, além das consequiências jurídicas no plano da atribuição de direitos e obrigações" (SZTAJN, Rachel. Futuros e swaps: uma visão jurídica. São Paulo: Cultural Paulista, 1999, p. 143).

508 "Capital users (e.g. corporate borrowers) use financial instruments for liability management, incorporating them in financing decisions to lower funding costs (for example, they may take advantage of market opportunities by issuing a debt instrument in a foreign market, or by creating a synthetic that would replicate such an issuance) and to diversify funding sources out of concern about their ability to obtain funds in the future, particularly in a market or company crisis. A corporation's hedging strategy also may call for products on overseas exchanges" (PLAMBECK, Charles T. Transfer Pricing Analysis of Global Trading Operations and Procedural Alternatives. Taxes. v. 74, dez. 1996, p. 1131).
} 
O crescimento das transações globais têm relação estreita, outrossim, com a diversificação e globalização dos negócios dos denominados "investidores institucionais" ${ }^{509}$, dentre os quais incluem-se companhias de seguro, fundos de pensão, bancos comerciais e de investimento, governos, fundos de hedge etc.. Essas instituições investidoras têm a sofisticação, a habilidade e o interesse para acessar todos os mercados via variados instrumentos financeiros, incluindo-se complexos derivativos. O crescimento dos tipos e variedades de transações globais possibilitou a formação, no âmbito dos investidores institucionais, de grupos de gerentes específicos, educados profissionalmente em modernas gerências de carteiras de investimento e dispostos a vislumbrar investimentos globais com maior retorno ou mais diversificados ${ }^{510}$. Da mesma forma, para atender a este grupo de investidores a cada dia mais exigente, as instituições precisam estar aptas a fornecer produtos cada vez mais sofisticados.

Tradicionalmente, as instituições financeiras sempre atuaram como intermediárias entre investidores e captadores. Cada vez mais, contudo, aspiram a outros ganhos além da mera comissão de intermediação: pretendem obter renda administrando diretamente riscos de seu portfólio; este objetivo pode ser atingido, e.g., na negociação global de derivativos. Com o objetivo de ampliar suas zonas de atuação, as instituições financeiras em geral passaram operar segundo quatro modalidades distintas ${ }^{511}$ : (i.) atuação

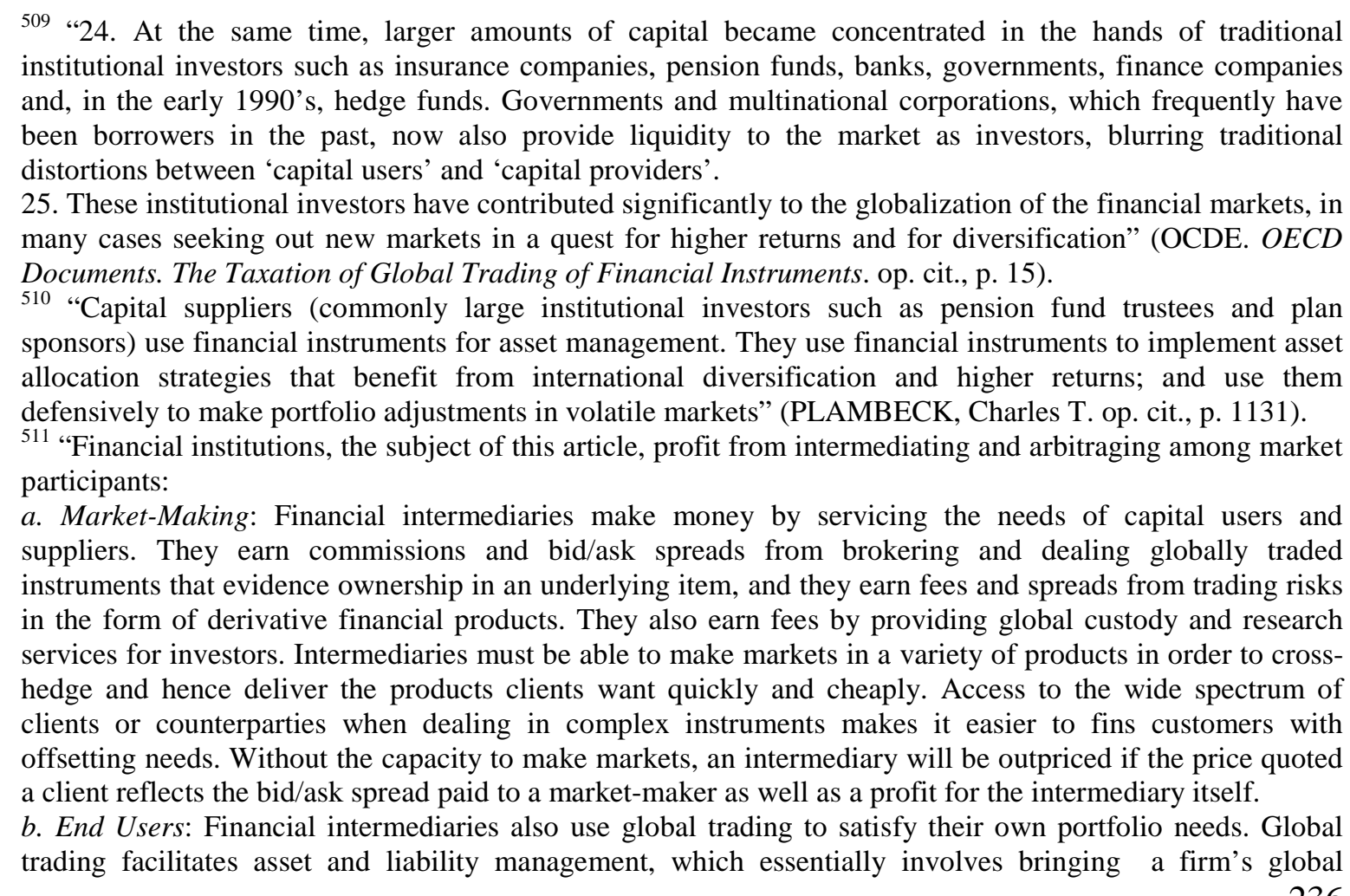


direta no mercado ["market-makers"], adquirindo instrumentos financeiros para revenda a seus clientes [ou vice-versa] com um determinado spread e mediante a cobrança de comissão $^{512}$; (ii.) na condição de usuárias finais, comprando e/ou vendendo ativos para proteção de sua própria carteira [v.g., quando desenvolvem suas próprias estratégias de hedge]; (iii.) como especuladoras, adquirindo e revendendo títulos de seu próprio portfólio; e (iv.) na condição de meras intermediárias de negócios entre terceiros, sem assunção de posição proprietária dos ativos financeiros ["brokers"].

Diante deste novo rol de atividades a serem desempenhadas pelas instituições, seus rendimentos podem ser gerados por (i.) juros ou dividendos pagos pelo seu estoque de ativos [necessário para atuar na negociação de derivativos de balcão]; (ii.) ganhos na alienação do estoque; (iii.) derivativos de balcão ou contratos de principal hipotéticos [“notional principle contracts" ${ }^{513}$ ]; (iv.) comissão de estruturação de transações; (v.) ganho para lidar com contingências; (vii.) intermediação por atuação em bolsas ou outros negócios, (viii.) desenvolvimento de novos produtos, em especial derivativos para a captação de crédito no mercado etc..

balance sheet under unified management, maximizing profit (by maximizing the return on assets and minimizing the cost of liabilities) and minimizing risk (by matching the denomination, interest sensitivity, and maturity of assets with liabilities). Global trading also facilitates access to a variety of funding sources, thereby diversifying the risk that a bank may be unable to tap a particular source of capital to meet its continuing obligations.

c. Proprietary Trading: Financial intermediaries also profit in the global market by trading operation is form speculating and taking positions with respect to movements in prices (including interest rates and exchange rates). This means that operating revenues of a global trading operation are essentially a function of price movements and the size of positions. In addition, intermediaries' access to capital and investment in communications and data processing places them in an advantageous position to capitalize upon arbitrage opportunities, including tax and regulatory arbitrage" (PLAMBECK, Charles T. op. cit., p. 1131-1132).

512 "Some banks distinguish five market-making lines:

- treasury;

- foreign exchange (FX) and FX derivatives;

- government bonds and interest rate derivatives;

- credit derivatives, credit bonds, and equity derivatives; and

- emerging market debt/western Europe high yield" (BAKKER, Anuschka J. Global Trading. International Transfer Pricing Journal. Amsterdã: IBFD, mar./abr. 2006, p. 97).

513 "Notional principle contracts (NPCs) include swaps, caps, floors and collars whereby one or more parties agree to make periodic payments reflecting the value of a specified variable index applied to a 'notional' agreed-upon principle amount. The counterparty agrees to either make periodic payments based on a different index or pay a fixed premium for the contract (a cap or floor). Caps are contracts whereby a seller makes periodic payments equal to the product of a notional principle amount and any excess of a specified index over the agreed level (the cap rate). The buyer pays a single premium or makes a series of fixed periodic payments for the contract. Floors are contracts whereby a seller makes periodic payments equal to the product of a notional principal amount and any amount by which a specified index falls below a specific level (the floor rate). The buyer pays a single premium or makes a series of fixed periodic payments for the contract. Combinations of caps and floors, whereby purchases a cap and sells a floor, or purchases a floor and sell a cap, are known as collars. An option to enter into a notional principal contract is not considered a notional principal contract” (BAKKER, Anuschka J. Global Trading. op. cit. p. 95-96). 
Para que seja vitoriosa a sua estratégia de atuação na negociação global, as instituições financeiras concluíram que não poderiam atuar apenas em sua sede, por meio de computadores, celebrando-se virtualmente todos os negócios. Pelo contrário, merece ser ressaltada a tendência de atuação global por intermédio de subsidiárias [ou estabelecimentos permanentes], porque isso possibilita o conhecimento do mercado local e, por conseguinte, a atuação competitiva em determinada nação ${ }^{514}$. Sabe-se que a presença "física" num certo país aumenta a lucratividade da instituição, dada a proximidade com os clientes, o que permite conhecê-los melhor, entender profundamente suas expectativas e compreender as peculiaridades do mercado local, atendendo-os de modo mais eficiente. Por conta das dificuldades impostas pela legislação interna, conglomerados financeiros estrangeiros normalmente constituem subsidiárias no Brasil, e não filiais ou escritórios ${ }^{515}$, o que amplia a importância das regras para o controle dos preços de transferência, em detrimento da aplicação do Artigo $7^{\circ}$ da Convenção-Modelo, refletido nos acordos para evitar a bitributação da renda assinados pelo Brasil. Da mesma forma, companhias subsidiárias são também preferíveis em países como Estados Unidos e Inglaterra; no Japão,

\footnotetext{
514 “28. The main task of a bank operating multinationally, whether through branches or through subsidiaries may be seen as the efficient and profitable provision of funds and services to meet the needs of customers in the areas where they are located. Despite the development of rapid communications systems, it is generally recognized in the banking business that for efficient international operation of a multinational bank a good deal of decentralization of responsibility is required and it is important that local entities should have the ability to deal directly in the money market centres of the world both locally and further afield. Management controls appear to be generally at their most effective when the local operation is set up as a profit centre with approved budgets against which performance can be measured. In such a case the local office, while also operating further afield, would normally, in all probability, maintain an active presence in the local interbank market, particularly in the foreign exchange and money dealing, and might also participate in the local bullion market. The ability of the local office to provide a fully competitive service to its customers may be very dependent upon its access and reputation in these local markets" (OCDE. Report of the Committee on Fiscal Affairs on Transfer Pricing and MNEs. Three Taxation Issues. op. cit.).

515 "Em relação às sociedades estrangeiras, tal como qualificadas pelo citado art. 60 [do Decreto-Lei n. ${ }^{\circ}$ 2.627, de 26 de setembro de 1940], colocam-se dois problemas teoricamente distintos: o problema de reconhecimento, que consiste em saber se o Direito brasileiro reconhece a personalidade jurídica das sociedades estrangeiras e, portanto, a sua capacidade de gozo e exercício de direitos; e o problema logicamente subseqüente do funcionamento ou do direito de estabelecimento e que consiste em saber se, apesar de se reconhecer a personalidade jurídica das sociedades estrangeiras, podem elas exercer no Brasil os direitos próprios do seu objeto social. No que se refere ao primeiro dos aludidos problemas, o Direito brasileiro consagra o reconhecimento pleno e automático da personalidade jurídica das sociedades estrangeiras, nos termos do art. 114 da Lei de Introdução ao Código Civil; todavia, no que concerne ao segundo tal automatismo não existe, pelo que as sociedades estrangeiras que pretendem 'funcionar' no país (não se limitando ao mero exercício isolado de direitos) deverão obter prévia autorização governamental (art. $11, \S 1^{\circ}$, da Lei de Introdução ao Código Civil e art. 64 do Decreto-Lei 2.627). Nos termos do art. 64 do Decreto-Lei 2.627 as sociedades estrangeiras autorizadas pelo Governo a funcionar no país podem fazê-lo por dois modos distintos: 'por si mesmas' ou por 'filiais, sucursais, agências ou estabelecimentos' que as representem" (XAVIER, Alberto. Problemas Jurídicos das Filiais de Sociedades Estrangeiras no Brasil e de Sociedades Brasileiras no Exterior. Revista de Direito Mercantil. São Paulo: Editora Revista dos Tribunais, ano XIX (nova série), n. ${ }^{\circ}$ 39, jul./set,/1980, p. 77).
} 
de outro lado, somente são admitidos escritórios de instituições financeiras nãojaponesas $^{516}$, sendo vedada a incorporação de um ente com personalidade jurídica distinta.

Normalmente, as operações de negociação global são desenvolvidas via bancos comerciais ou de investimento, mas isso não significa que elas não possam ser conduzidas por quaisquer espécies de instituições ${ }^{517}$; devem ser confirmadas tão-somente eventuais restrições regulatórias em cada país. Os derivativos de balcão, v.g., possuem risco de crédito maior que operações em bolsa, dependendo de elevada base de capital e de boa classificação/rating. Se a instituição não tiver base de capital suficiente, a contraparte exigirá garantia colateral, o que pode eliminar a lucratividade do negócio. Por conseguinte, derivativos de balcão são recorrentemente estruturados por bancos comerciais ou de investimento ${ }^{518}$.

Para simplificar, no âmbito do presente estudo, os entes responsáveis pela estruturação e/ou consecução das negociações globais serão designados "instituições financeiras", ainda que não se enquadrem juridicamente nesta noção.

516 "Regulatory considerations directly affect the corporate structure of the global securities business. Securities regulators in the United States, United Kingdom and Japan generally require broker-dealers serving customers in their jurisdictions to register with them as broker-dealers. Once the broker-dealer registers in a particular jurisdiction, that jurisdiction's regulations become applicable to that broker-dealer and its personnel and set standards regarding capital, recordkeeping and reporting, custody of customer funds and securities, and supervision of personnel. Because of the complications that would arise from endeavoring to comply with overlapping and sometimes inconsistent or conflicting regulation, most global broker-dealers have organized separate corporate entities to operate in the United Stated, the United Kingdom and Japan. In addition, the securities regulators usually require market makers to maintain their inventory in the entity that makes the market. Consequently, a broker-dealer normally cannot hold itself ou as willing to deal in securities positions that are held in any entity that is not regulated. Generally, a US broker-dealer cannot maintain its inventory in an affiliate that is not also registered as a broker-dealer.

In case of the United States and the United Kingdom, broker-dealers generally have incorporated in the jurisdiction where they operate. (...) The pattern in Japan is different. Japanese owned securities firms generally are incorporated in Japan (...). However, non-Japanese financial institutions have not been permitted to organize Japan subsidiaries to operate their business in Japan. Generally these firms have incorporated in a low- or zero-tax jurisdiction a subsidiary which operates a branch office in Japan. (...) The typical structure, therefore, is a US corporation registered as a UB broker-dealer, one or more corporations operating in London and a foreign corporation incorporated outside Japan operation a branch form in Tokyo. This corporate structure is not universal, specially with respect to nonregulated business (such as interest rate and currency swaps or foreign currency transactions) where branches or subsidiaries in various jurisdictions may conduct their business" (SAMUELS, Leslie B; BROWN, Patricia A. Observations on the Taxation of Global Securities Trading. Tax Law Review. v. 45, Summer 1990, p. 527).

517 "The financial intermediaries that trade globally are primarily banks (both commercial and investment) and securities dealers. Global trading also is conducted by other financial intermediaries, such as insurance companies and commodities brokers, and by suppliers and users of capital or goods" (PLAMBECK, Charles T. op. cit., p. 1132).

${ }^{518}$ In: OCDE. OECD Documents. The Taxation of Global Trading of Financial Instruments. op. cit., p. 16. 


\subsubsection{Estruturas principais de atuação das instituições financeiras e organização das atividades de trading.}

Os serviços ou funções que podem compor uma operação de negociação global de instrumentos financeiros foram sistematizados pela OCDE, para fins estritamente analíticos, nos seguintes grupos: (i.) vendas e marketing; (ii.) negociação [trading ${ }^{519}$ ] e gerenciamento cotidiano de riscos; (iii.) tesouraria; e (iv.) serviços gerais de apoio [suporte, back-office e middle-office], que compreendem desenvolvimento de sistemas, análise de crédito, estratégia de riscos da instituição, contabilidade e controle de produtos, dentre outras ${ }^{520}$. Cada uma destas funções será examinada no estudo da análise funcional constante da subseção 2.3, abaixo.

Por ora, importa tão-somente ponderar que as atividades de trading e gerenciamento de riscos podem desenvolver-se de forma totalmente integrada, totalmente segregada, ou de inúmeras maneiras intermediárias. Segundo classificação proposta pela OCDE, que avalia exclusivamente o nível de integração das funções de trading e de administração de riscos, normalmente determinantes da estratégia de atuação das instituições, estas últimas podem ser divididas entre instituições de: (i.) negociação integrada ["Integrated Trading"]; (ii.) administração centralizada de produtos ["Centralised Product Management”]; (iii.) negociação por entidades segregadas [“Separate Enterprise Trading”]; ou (iv.) atuação flexível [“Dynamic and flexible nature of global trading”], sendo que este último tipo pode representar uma combinação dos demais modelos de estruturação.

Note-se que, quando se alude à integração, refere-se à localização dos "centro de lucros" ou "books", na linguagem financeira ${ }^{521}$. Nesse contexto, a negociação integrada ou "24-hour trading" 522 indica, literalmente, a atuação conjugada das empresas associadas de um determinado conglomerado econômico. Um exemplo de atuação integrada seria,

\footnotetext{
${ }^{519}$ Considerando que as traduções localizadas não refletem adequadamente o conteúdo do termo, ele será mantido em sua língua original.

${ }^{520}$ In: OCDE. OECD Documents. The Taxation of Global Trading of Financial Instruments. op. cit., p. 2127; e OCDE. Report on the Attribution of Profits to Permanent Establishments. op. cit., p. 127-136.

521 "The basic unit of organization of global trading is generally the book, defined essentially as the firm's trading position with respect to a particular type of instrument., risk, or other class of transaction. The profits and losses from a book are recorded in a profit center, defined in accounting literature as 'the smallest unit of activity for which revenue and expense information is accumulated for internal planning and control purposes" (PLAMBECK, Charles T. op. cit., p. 1134).

${ }_{522}$ A negociação integrada é também denominada "single profit center". In: PLAMBECK, Charles T. op. cit., p. 1134.
} 
assim, o de uma determinada empresa londrina que atua até o fechamento do horário de negociação naquele país e, em seguida, transfere as posições em aberto para uma subsidiária norte-americana, que por sua vez transmite suas posições para uma subsidiária em Hong Kong. Na prática, cada empresa associada [Londres, Nova York e Hong Kong] estipula preços e negocia o portfólio do book no seu horário comercial; quando termina seu horário, transfere aquela exata posição para o centro seguinte; este tipo de negociação é denominado book-passing ${ }^{523}$. A titularidade dos ativos normalmente é retida em um ente; nesta hipótese, não há vários centros de lucros ou books que assumem sucessivamente as posições de outros, mas um centro só, gerenciado a partir de diversas unidades distintas com poderes típicos de um trader $^{524}$. Na atuação integrada, normalmente um comitê da instituição financeira estipula parâmetros e limites para a atuação dos traders de cada localidade envolvidos nas operações integradas ${ }^{525}$. Este tipo de estrutura é muito utilizado para a negociação de opções de venda ou compra de moedas estrangeiras.

As operações totalmente integradas ou "24-hour trading" representam a estrutura adotada para a negociação global que apresenta mais desafios às regras para o controle dos preços de transferência. Conseqüentemente, este será o exemplo de operação mais recorrente nos CAPÍTULOS 5 e 6, que abordarão os exemplos mais complexos para a concretização do princípio da plena concorrência. Pela mesma razão, a regulamentação norte-americana contém regras específicas para a tributação destas operações totalmente integradas ["fully integrated operations"] de commodities ou de produtos derivativos,

\footnotetext{
523 "When the markets close in a particular location, responsibility for trading the book is passed to the next trading location where the open positions form the starting point for trading. Traders in the new location may close positions passed to them and open new ones. In addition to the book-passing method described above, trading is increasingly being conducted in a more seamless manner, with traders in one location trading at the same time from the same book as traders in another location" (OCDE. Report on the Attribution of Profits to Permanent Establishments. op. cit., p. 124).

524 "When trading authority is passed, the receiving center usually is not a distinct profit center operating wholly autonomously because, among other reasons, of the fear of passing a well crafted position only to 'receive it back next morning in a real mess'. Instead, most firms tend to operate in a 'one profit center mode'. A profit center that crosses national boundaries and operates as a unit maximizes the worldwide profits of the book. A centralized book also provides the advantages of 24 hour service, integration of all risk management products, and access to the bank's global network. In order to encourage teamwork, traders are compensated based on the profits of the entire book. A single global profit center is most common for global options" (PLAMBECK, Charles T. op. cit., p. 1134)

525 "Overall trading limits are generally set by a committee which may or may not also centrally manage the trading operations. There may be a head trader in each location (or a single head trader for the book), whose participation may vary with the circumstances. For example, at one end of the spectrum, a head trader could directly exercise discretionary authority to enter into specific transactions, or the head trade might only apportion aggregate risk limits among individual traders" (OCDE. Report on the Attribution of Profits to Permanent Establishments. op. cit., p. 125).
} 
caracterizadas, justamente, pela transferência da competência para negociar um certo book de posições de uma entidade para outra ${ }^{526}$.

A estrutura da administração centralizada indica que apenas uma sociedade do grupo é responsável pela negociação e administração de riscos de um determinado produto, i.e., o book é gerenciado por um único ente. A definição da localização deste único trader depende de inúmeras considerações comerciais como, v.g., a liquidez do produto no mercado, a facilidade de contratação de hedge, a localização dos principais clientes, a existência de pessoal capacitado etc.. O book normalmente está situado na localização "natural" do produto ${ }^{527}$, se houver, ou no seu mercado primário. Trata-se da estrutura mais difundida dentre as instituições que se dedicam à negociação global de instrumentos financeiros. Nesta hipótese, os vendedores ou marketers alienam determinados produtos e, em seguida, celebram as transações opostas com o ente responsável pelo book; alternativamente, também é possível que a contabilização da operação se dê diretamente pelo trader. O objetivo é concentrar naquele (único) trader a maior parte das funções economicamente relevantes das transações globais ${ }^{528}$. Se for o

526 "Global trading operations of companies that are functionally fully integrated are characterized by the centralized management of risk and personnel. The business is managed as one global position for purposes of risk management rather than several discrete business. Thus, a trading book is not independently maintained for each trading location. Rather, one book is maintained and the trading authority for that book is 'passed' from trading location to trading location at the close of each trading day for that trading location (the 'global book'). To assist in the management of the risk, a central credit department monitors the creditrelated exposure of the transactions entered into by the traders. This information is used by the home office to establish credit guidelines and customer credit limits to be applied by traders throughout the company.

The book of each product, or group of product, typically has one head trader or book manager who allocates trading limits for each trading location and determines guidelines for the book. The head trader is responsible for the economic performance of that book. The head trader is responsible for the economic performance of that book. Accordingly, the head trader is in frequent communication with other traders employed by the company. The head trader, therefore, acts as overseer of the trading personnel.

In a functionally fully integrated operation each office may be capable of performing the same function as any other subject to limits, procedures and guidelines imposed by the home office. For example, it is common for one office to locate a seller of a commodity or derivative financial product and another office to locate a buyer, while either of those offices or a third office hedges the transaction. Each office in such a transaction contributes to the overall profitability of the global business" [UNITED STATES OF AMERICA. DEPARTMENT OF TREASURY. IRS. Notice 94-40, de 25.04.94, referência: 1994-1 C.B. 351; 1994 IRB LEXIS 213; 1994-17 I.R.B. 22; Notice 94-40, extraída do sítio eletrônico www.irs.gov].

527 "Some products such as government securities, may have a primary trading market - sometimes called a 'natural home' - where the bulk of trading in that product occurs" (OCDE. Report on the Attribution of Profits to Permanent Establishments. op. cit., p. 126).

528 "The financial institution will rely on marketing operations in its other trading centres but will require the marketing location (referred to below as the originating office) to transfer responsibility for managing the market risk to the centralized trading location (back-to-back transactions). This is achieved by either:

- Booking the transaction directly in the centralized trading location. Under this booking practice, credit risk in addition to market risk will be reported in the centralized trading location;

- Having the marketing location reverse the transaction with a trader in the centralized trading location through an inter-branch (or inter-company) transaction (back-to-back transactions), thus, transferring responsibility for managing the market risk to that location. Under this booking practice, credit risk will still 
caso, os marketers podem ter atuação mais ampla, devendo conhecer melhor os produtos, hipótese em que poderão ser denominados traders remotos ${ }^{529}$.

Por fim, no modelo por atuação de entidades segregadas, cada subsidiária ou filial possui um centro de lucros ou book próprios para cada produto e, na medida do possível, atua com os outros entes do mesmo grupo em condições de plena concorrência $^{530}$. Para facilitar a compreensão das três estruturas e estratégias possíveis de atuação das instituições em operação de negociação de instrumentos financeiros, confirase a representação gráfica abaixo, que indica, na seqüência, desde o modelo menos integrado até a integração total ou "24-hour trading":

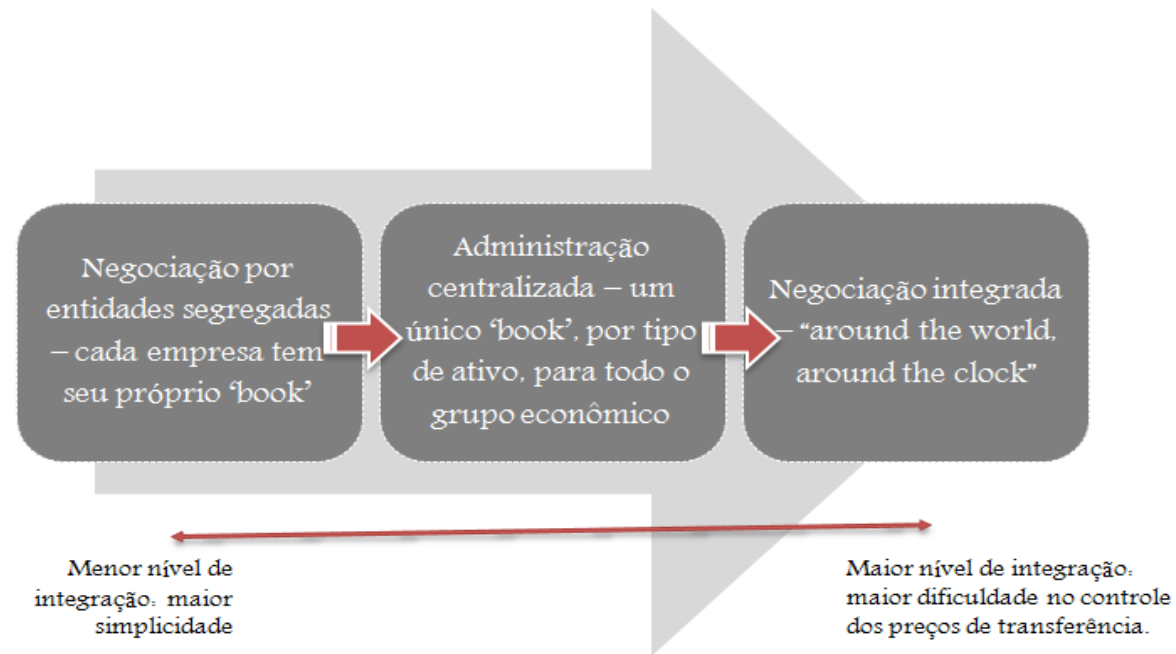

Estas três formas de organização das instituições foram assim definidas pela OCDE somente para fins didáticos, sendo certo que a maioria delas mescla elementos para melhor administrar seus riscos ${ }^{531}$. O grau de integração das empresas multinacionais

be reported in the originating office" (OCDE. Report on the Attribution of Profits to Permanent Establishments. op. cit., p. 125).

529 "Centralized Trading with Remote Trading Authority. For perhaps the bulk of financial products, financial intermediaries concentrate traders in a single jurisdiction - sometimes referred to as its 'natural home'. For example, the natural home for a U.S. dollar swap book would be New York, for a yen book would be Tokyo, etc. Thus, the most common organization structure for global trading is one in which trading authority is concentrated in one jurisdiction and, if necessary, remote locations (i.e., locations outside the 'natural home') are manned by persons with limited trading authority - termed variously remote traders, super sales-man or watchdogs. Marketers are deployed throughout the world according to the firm's client base, and capital is provided from the location where concentrated or where regulatory or client demand require" (PLAMBECK, Charles T. op. cit., p. 1134).

${ }^{530}$ In: OCDE. Report on the Attribution of Profits to Permanent Establishments. op. cit., p. 126. Ainda a respeito deste tipo de estrutura, note-se que:

"Many banks organize their trading in spot and forward transactions of the most heavily traded currencies on a separate enterprise basis" (op. cit. nesta nota, p. 126).

531 "36. Also, it is important to emphasize that while these trading models are a convenient means of describing how trading activities can be carried out in different ways, the organization of the trading activities of a given enterprise may not fall neatly within any of the models. For example, trading authority may be neither completely transferred to one particular location nor located in only one jurisdiction. Thus, 
depende tanto das características da transação e/ou do derivativo transacionado quanto do histórico e da estratégia particular de cada uma delas. Adicionalmente, o fato de a função trading ser integrada não indica que as outras funções também o sejam: as atividades praticadas pelas instituições em operações envolvendo a negociação global de instrumentos financeiros podem ser combinadas de formas infinitas ${ }^{532}$.

\subsubsection{Tipos de produtos oferecidos a clientes.}

Praticamente todos os produtos financeiros podem ser negociados globalmente; mas são a sua liquidez e eficiência na implementação de estratégias de hedge que servem como medida do quão global é, efetivamente, sua negociação. As moedas como, v.g., o dólar norte-americano, são reconhecidas como os produtos mais globalizados, sendo possível sua liquidação, mediante a conversão em diversas outras moedas, durante $24 \mathrm{~h}$, em qualquer localidade ou "24-hour trading"533. As moedas são seguidas pelo ouro, derivativos, outros metais preciosos, e commodities como, v.g., o petróleo. Outro produto financeiro cuja negociação global é de extrema relevância é o título do tesouro norteamericano. Este tipo de instrumento é denominado "physical security", porque existe um mercado "natural" onde as liquidações do produto "físico" ocorrem; assim, o mercado primário dos títulos emitidos por governos estão nos respectivos países. Por mais que os títulos do tesouro norte-americano [Treasury Bills ou T-Bills] possam ser negociados em São Paulo, Londres ou Tóquio, seu mercado primário permanece em Nova Iorque, sendo estes outros os mercados secundários ${ }^{534}$. Os mercados de ações, ao contrário destes outros,

there could be close co-operation between the head office and the PE in making trading decisions or the primary responsibility for the performance of the book may be located in one jurisdiction, with limited authority to trade the book passed to another jurisdiction. In the latter case, the head of trading may still have to be consulted by traders in another location if major decisions have to be taken or trades executed over a pre-set limit - even if it means he or she has to be woken up in the middle of the night" (OCDE. Report on the Attribution of Profits to Permanent Establishments. op. cit., p. 126).

532 " 27 . In addition to a diversity of legal structures, there is an almost limitless number of different business structures that firms engaged in global trading can employ regardless of the legal structure adopted. (...) The classification of a particular global trading business under one of the above models not therefore mean that other activities, such as marketing and support, are organized in the same manner as trading as risk management activities. Indeed, the business dynamic is towards de-centralization of those functions so as to be geographically chose to customer" (OCDE. Report on the Attribution of Profits to Permanent Establishments. op. cit., p. 124).

533 "Foreign exchange is widely regarded as the most globally traded product, though liquidity in many currencies drops at various times within a 24-hour period, particularly between nine to 11 o'clock p.m. G.M.T., when market-moving news rarely emerges from London, New York or Tokyo. Gold, silver and U.S. treasury bonds are next, followed by oil, money market instruments, securitized assets, derivative products and certain equities" (PLAMBECK, Charles T. op. cit., p. 1132).

534 "Some products, particularly physical securities, have a primary trading market where the bulk of trading in that product occurs. Traders will be drawn to that market because its greater liquidity will allow the traders to hedge their portfolios most efficiently. Accordingly, secondary markets for those products are relatively 
normalmente são transacionados apenas em bolsas de valores específicas e, por conseguinte, são mais “concentrados”.

Em sentido oposto ao das physical securities, os derivativos não possuem um "mercado natural", podendo ser globalmente negociados. Derivativos representam os ativos financeiros cujos valores e características de negociação estão ligados aos ativos que lhes servem de referência; a expressão "derivativos" decorre, justamente, da circunstância de que o preço de um ativo é derivado de um outro ${ }^{535}$. Trata-se de um direito contratual que tem seu valor derivado do valor de outro bem, direito ou índice. Ao contrário dos títulos de débito ou investimento [equity] mais tradicionais, os derivativos não envolvem um retorno sobre um investimento inicial ${ }^{536}$. Os tipos mais disseminados são os swaps, as opções ${ }^{537}$ e os futuros. Justamente em virtude de suas características, os derivativos têm

unimportant unless there is a major market disruption when the primary market is closed. The products most frequently described as having a primary market (sometimes called natural home) are government securities. Although it is possible to trade US Treasury securities outside the United States, the primary market remains New York, just as the primary market for UK government bonds ("Gilts") remains in London and the primary market for Japanese government bonds in Tokyo" (OCDE. OECD Documents. The Taxation of Global Trading of Financial Instruments. op. cit., p. 17).

${ }^{535}$ Nesse mesmo sentido, Rachel SZTAJN define o derivativo como sendo um "contrato cujo valor deriva, decorre, do valor de seu substrato, que pode ser outro contrato ou ativo (posição financeira) sujeito a risco de flutuação de preço. Alguns dos instrumentos assim designados são contratos sociais e legalmente tipificados. Assim, os contratos a termo, as opções, as permutas ou swaps. Outros, decorrentes de combinações de modelos legais, de modificações que se lhes introduziram, ou, ainda, de completa inovação negocial, devem ser analisados em seus elementos e ajustados ao sistema jurídico segundo sua natureza jurídica” (op. cit., p. 15-16).

Ainda a respeito, veja-se a definição oferecida pela OCDE:

"A 'derivative' instrument is a contractual right that derives its value from the value of something else, such as debt security, equity, commodity, or a specified index. The most common derivative instruments are forwards, futures, options and notional principal contracts, such as swaps, caps, floors and collars. Unlike traditional debt and equity securities, these instruments generally do not involve a return on an initial investment" (OCDE. OECD Documents. The Taxation of Global Trading of Financial Instruments. op. cit., p. 11).

${ }^{536}$ A Orientação Técnica OCPC-03, do Comitê de Pronunciamentos Contábeis, conceitua "derivativo" no seu item 7, abaixo transcrito:

"Derivativo é um instrumento financeiro ou outro contrato dentro do alcance desta Orientação que possui todas as três características seguintes: (a) seu valor se altera em resposta a mudanças na taxa de juros específica, no preço de instrumento financeiro, preço de commodity, taxa de câmbio, índice de preços ou de taxas, avaliação (rating) de crédito ou índice de crédito, ou outra variável, às vezes denominada "ativo subjacente", desde que, no caso de variável não financeira, a variável não seja específica a uma parte do contrato; (b) não é necessário qualquer desembolso inicial ou o desembolso inicial é menor do que seria exigido para outros tipos de contratos onde seria esperada uma resposta semelhante às mudanças nos fatores de mercado; e (c) deve ser liquidado em data futura".

${ }^{537}$ Vejam-se, abaixo, exemplificativamente, apenas alguns tipos de opções negociadas por empresas que se dedicam à negociação global de derivativos:

"First generation ('vanilla') options: plain vanilla options can be either exchange traded options (ETOs) or over the counter (OTC) options. ETOs are typically only available in a limited number of currencies, notional amounts, strike prices and maturities. They are traded on recognized exchanges as contracts worldwide. OTC options are subject to negotiation between buyer and seller, and therefore are not limited as ETOs with regard to the terms of the option. OTC options are traded by international banks and other financial institutions (with the OTC market being regulated by central banks). ETOs carry little risk of counter party default whilst 
mercado menos localizado; diz-se, inclusive, que os contratos nocionais de USD são mais negociados em Londres que Nova York; isso não significa, contudo, que este último mercado não seja relevante para garantir a liquidez desta espécie de derivativo ${ }^{538}$. Não obstante, importa consignar que aos derivativos não se aplica a noção de mercado primário. Os produtos derivativos com mercados mais globalizados são os futuros de moedas.

Mas há outras diferenças relevantes entre os mercados de derivativos e de physical secutiries, sendo a mais importante a forma de estruturação da operação: enquanto nestas últimas a instituição financeira aliena sua posição e deixa de ser parte da transação, nos derivativos age como verdadeiro operador do mercado de balcão [dealer], mantendo o produto no seu balanço até o término [normal ou antecipado] da transação; neste momento final, tem-se o pagamento em dinheiro para compensar o ganho ou perda da posição. A

OTC options are traded on the basis of line of credit to the counter party. Plain vanilla options are either American or European (...).

Second generation ('exotic') options: these can be sub-divided into five basic groups: averages, barriers, binaries, compounds and optimals.

‥ Averages: Where the pricing of the option is dependent on as averaging process - fixing either the underlying spot market or on the underlying forward market. There are two types:

- $\quad$ average rate options: cash settled at expiry through comparison of the difference between the strike price and the average of a pre-set determined series of spot rates. Sometimes also known as an 'Asian' style option;

- $\quad$ average strike options: same as the average rate options except the strike price is not set until the expiry date. It is then set to the average level over the life of the option and then exercised. It can either be cash or physically settled.

a Barriers: These tend to be the most actively traded of exotic option. They terminate (knock-out) or are activated (knock-in) when the specific trigger level is reached before or on the exercise date. There are two forms of barrier options:

- $\quad$ standard knock-out and knock-in options: barrier level would be below the spot rate for a call and above the spot rate of a put;

- $\quad$ reverse knock-out and knock-in options: barrier level would be above the spot rate for a call and below the spot rate for a put.

a Binaries: These deliver a pay-out on exercise but none at expiration. Three main types exist:

- digital: once certain pre-set conditions are met, the pay-out remains fixed, regardless of where the underlying currency subsequently trades. There is no pay-out if the conditions are not met;

- $\quad$ no touch: these are the opposite of digital options with a pay-out only if the underlying spot rate is bellow the strike price (for calls) or above the strike prices (for puts) at expiry;

- $\quad$ one touch: a fixed pay-out if the spot rate trades above (or below) a certain level at any time up to and including the expiry date. The payout can be at that time or at expiry.

- Compounds: These confer the right to buy or sell an underlying option at a pre-determined date in the future pro a pre-set amount of premium payable in a pre-set currency.

- Optimals: Also known as 'look-back' options allowing the holder to look back over the duration of the option lifetime and trans-act at the most favourable rate. Three main types exist:

optimal rate look-back option: where the strike price is fixed on the initial deal date;

- optimal strike look-back option: where the strike price is not fixed until the expiry date of the option and is then the fixed as the high (put) or the low (call) of the spot rate over the lifetime of the option"

(FAIFERLICK, Chris; LABRUM, Stephen; RAFIQ, Aamer. Transfer Pricing for Financial Institutions: Global Trading. Derivatives and Financial Instruments. Amsterdã: IBFD, set./out. 2000, p. 246).

${ }^{538}$ In: OCDE. OECD Documents. The Taxation of Global Trading of Financial Instruments. op. cit., p. 17. 
instituição pode também atuar como mera intermediária na bolsa [broker], mas, neste caso, apenas cobra comissões e não atua como parte da transação. Sem dúvidas, os tipos de instrumentos financeiros aptos à negociação global e que mais apresentam desafios para o cálculo dos preços de transferência são os derivativos, especialmente nas hipóteses em que as instituições desenvolvem-nos exclusivamente para atender a determinados clientes, no mercado de balcão.

\subsubsection{Estratégias empresariais.}

Diferenças nas estratégias adotadas pelas instituições financeiras afetam onde e como suas transações globais são conduzidas. Assim, v.g., algumas instituições podem pretender atuar em todos os mercados possíveis, enquanto outras concentram-se, geograficamente, nos locais onde está sua base de clientes, limitando-se a constituir subsidiárias e filiais nestes últimos. A política de assunção de riscos também é um fator relevante, porque enquanto algumas instituições preferem suportar riscos reduzidos e auferir lucratividade limitada a comissões, outras assumem posições proprietárias sem hedge específico, com o intuito de especular e ampliar sua rentabilidade. Neste cenário, enquanto algumas instituições dedicam-se fortemente ao desenvolvimento de derivativos sofisticados, investindo em pessoal qualificado e sistemas, outras dedicam-se à negociação de derivativos tão-somente porque esta atividade é essencial para o oferecimento de um serviço amplo e completo [full-service] a seus clientes ${ }^{539}$.

\footnotetext{
539 "22. Institutions also differ in their choices of instruments to market and trade. In some cases, the institution may believe that it will be more competitive if it develops a specialty, such as structuring OTC derivatives transactions to meet the individualized needs of the institution's customer. This strategy, which has been followed by some of the best-known derivatives houses, employs a wide range of highly skilled paid individuals and requires a large spread on each transaction in order to be profitable.

23. Other institutions that are market-makers aim to enter into a large number of fairly 'plain vanilla' transactions. Although the profit on each transaction is reasonably low, there is also a relatively small level of risk and they can count on earning a fairly steady profit from the sheer volume of transactions. Yet other institutions combine elements of both strategies.

24. Finally, other financial institutions do not view themselves as being primarily 'market-makers' but view their derivatives transactions as a necessary part of their business of being a full-service financial intermediary. Some of the products offered by such full-serviced financial intermediaries may be loss leaders or in loss making positions, in order to facilitate other business activities. In that case, a financial institution would normally hedge its customers' positions and any profits would come from the institutions' ability to provide its customers with any of the basic products that a customer can expect" (OCDE. Report on the Attribution of Profits to Permanent Establishments. op. cit., p. 123).
} 


\subsection{Análise de comparabilidade.}

A OCDE e a legislação norte-americana têm sustentado que o princípio da plena concorrência deve ser aplicado também às operações de negociação global de instrumentos financeiros. Conseqüentemente, para o controle dos preços de transferência desde tipo de transação associada entre membros de um mesmo conglomerado financeiro, deve ser implementada a "análise de comparabilidade", nos mesmos moldes discutidos no CAPÍTULO 2, subseção 2.2. Esta análise envolve, substancialmente, (i.) o exame detalhado das transações controladas [operações "testadas"]; (ii.) a procura de operações não-controladas que sejam suficientemente semelhantes [ou que se tornem suficientemente semelhantes após ajustes acurados e precisos] e que possam ser confrontadas com as transações controladas; e (iii.) a comparação das transações independentes comparáveis com as transações controladas, de modo a aferir a necessidade de reconhecimento de ajustes na renda tributável.

Devem ser ponderados, outrossim, os cinco fatores determinantes de comparabilidade [cf. subseção 2.2.1]. Com efeito, a sofisticação e exclusividade do instrumento transacionado têm importante impacto na definição dos preços das transações. Para o entendimento das atividades desempenhadas pelas empresas associadas, devem ser compreendidas as funções desenvolvidas por cada uma delas, os ativos empregados, os riscos assumidos, bem assim a importância relativa de tal função, ativo ou risco na estruturação da operação. Adicionalmente, devem ser examinadas as condições dos contratos celebrados ${ }^{540}$, as circunstâncias econômicas ${ }^{541}$ e as estratégias empresariais

${ }^{540}$ As condições contratuais que precisam ser examinadas, nos termos da legislação norte-americana proposta em 1998, são as seguintes:

“1.482-8 [proposta] (a) (3) (ii) (A) Sales and purchase volume;

(B) Rights to modify or transfer the contract;

(C) Contingencies to which the contract is subject or that are embedded in the contract;

(D) Length of the contract;

(E) Settlement date;

(F) Place of settlement (or delivery);

(G) Notional principal amount;

(H) Specified indices;

(I) The currency or currencies in which the contract is denominated;

(J) Choice of law and jurisdiction governing the contract to the extend chosen by the parties; and

(K) Dispute resolution, including binding arbitration" (Federal Register/v. 63, no. 44, op. cit.).

${ }^{541}$ As circunstâncias econômicas referidas pela proposta de legislação norte-americana são as seguintes:

"1.482-8 [proposta] (a) (3) (iv) (A) The similarity of geographic markets;

(B) The relative size and sophistication of the markets;

(C) The alternatives reasonably available to the buyer and seller;

(D) The volatility of the market; and

(E) The time the particular transaction is entered into" (Federal Register/v. 63, no. 44, op. cit.). 
adotadas. O Relatório GT-1998 e o Relatório-2008 não oferecem um guia detalhado para a aplicação dos cinco fatores, mas dispõem preponderantemente a respeito da análise funcional, a ser abordada em 3.4, infra.

Idealmente, é preciso analisar cada transação isolada [transação a transação], mas, por vezes, pode-se examinar operações semelhantes conjuntamente; essa flexibilidade é importante neste tipo de negócio porque, e.g., o risco por ser administrado via hedge líquido ou net hedge, hipótese em que uma determinada empresa associada soma todas as suas posições ativas e passivas num determinado período, repassando para o book tãosomente a diferença que necessita de proteção ${ }^{542}$. Da mesma forma, como sustentado pelas autoridades fiscais estadunidenses, é possível que uma única operação de negociação global seja dividida, de modo que se possam obter dados comparáveis para cada uma de suas partes ${ }^{543}$.

\subsection{Análise funcional de operações de negociação global de instrumentos} financeiros.

Os desafios que devem permear a análise funcional nestas hipóteses de negociação global são os seguintes: (i.) qual a importância relativa das funções desempenhadas, riscos assumidos ou ativos, tangíveis e intangíveis, empregados, para o sucesso ou fracasso do negócio? (ii.) qual parte relacionada desenvolve cada função, assume cada risco ou emprega cada ativo crítico para o sucesso do negócio? Para facilitar a obtenção de respostas a estas questões, nas subseções 3.4.1 a 3.4.3 serão examinadas, respectivamente, as principais funções, ativos e riscos envolvidos.

\footnotetext{
542 “121. (...) Ideally, the comparability analysis should be performed at the transactional level, i.e. separately for each particular transaction. Methods which attempt an analysis based on consolidated results from a number of distinct derivative trading activities are unlikely to meet the standard point of reliability required by the Guidelines. However, the analysis can be made on a combined group of a similar transactions, where they are so closely linked or continuous that they cannot be evaluated adequately on a separate basis. This flexibility is very helpful in the context of global trading where, for example, risk is often managed not at the level of individual transactions but at the level of a book or portfolio consisting of similar and closely linked transactions" (OCDE. OECD Documents. The Taxation of Global Trading of Financial Instruments. op. cit., p. 32).

543 "Where a taxpayer is engaged in more than one global dealing operation, it will be necessary to segregate each activity and determine on a transaction-by-transaction basis within each activity which method provides the most reliable measure of an arm's length price. It may be appropriate to apply the same method to multiple transactions of the same type within a single business activity entered into as part of a global dealing operation. For example, if a taxpayer operates its global dealing activity in notional principal contracts differently than its foreign exchange trading activity, then the income from notional principal contracts may be allocated using a different methodology than the income from foreign exchange trading" (Federal Register/v. 63, no. 44, op. cit., "Explanation of Provisions").
} 
Antes, porém, confiram-se as etapas a partir das quais a análise funcional nas transações envolvendo a negociação global de instrumentos financeiros pode ser desenvolvida:

\begin{tabular}{|c|c|c|c|}
\hline $\begin{array}{l}\text { Estudo do caso } \\
\text { concreto } \\
\text { Ponderação dos } \\
\text { fatos e } \\
\text { circunstâncias } \\
\text { principais que } \\
\text { devem ser } \\
\text { avaliados. }\end{array}$ & $\begin{array}{l}\text { Análise funcional- } \\
\text { funções } \\
\text { desempenhadas. } \\
\text { - Exame das funções } \\
\text { de cada ente e } \\
\text { verificação do seu } \\
\text { valor relativo. }\end{array}$ & $\begin{array}{l}\text { Análise funcional- } \\
\text { ativos e riscos } \\
\text { - Exame do capital } \\
\text { empregados e } \\
\text { intangíveis, bem } \\
\text { assim dos riscos da } \\
\text { transação. }\end{array}$ & $\begin{array}{l}\text { Definição da } \\
\text { remuneração de } \\
\text { cada empresa, de } \\
\text { acordo com a } \\
\text { análise funcional. } \\
\text { - Definição dos } \\
\text { métodos aplicáveis. }\end{array}$ \\
\hline
\end{tabular}

\subsubsection{Principais funções desempenhadas na negociação global de instrumentos financeiros.}

Nos termos do Relatório-2008, as principais funções que podem ser desempenhadas pelas instituições financeiras na negociação global de instrumentos financeiros são as seguintes (i.) vendas e marketing; (ii.) trading e gerenciamento cotidiano de riscos; (iii.) tesouraria; e (iv.) serviços gerais de apoio [suporte, back-office e middleoffice], que compreendem desenvolvimento de sistemas, análise de crédito, estratégia de riscos da instituição, contabilidade e controle de produtos, dentre outras ${ }^{544}$. Esta classificação, contudo, não é pacífica ${ }^{545}$, sendo que a proposta de redação da Seção 1.4828/Proposta (a)(3)(i) da legislação norte-americana alude às seguintes cinco funções principais: (a.) pesquisa e desenvolvimento de produtos; (b.) marketing; (c.) precificação; (d.) corretagem/brokering; e (e.) administração de riscos. Veja-se que a legislação norteamericana não contempla os serviços gerais de apoio em suas regras de "global dealing",

\footnotetext{
${ }^{544}$ In: OCDE. Report on the Attribution of Profits to Permanent Establishments. op. cit., p. 127-136.

545 Chris FAIFERLICK et. al. reconhecem seis tipos distintos de funções desempenhadas nas operações envolvendo a negociação global de instrumentos financeiros, segregando algumas das atividades-base indicadas pela OCDE. Confira-se a seguinte passagem:

"Within a global trading perspective, we have found that the business may be broken into six discrete parts (with variations suited to individual business):

- pre-sales: the identification of the opportunity and relevant research into markets, products and customers;

- sales: selling of the products and financial instruments to potential and/or current customers;

- pricing and structuring: tailoring a product to meet customer requirements, effectively hedging company risk and pricing the product;

- execution: completing the transaction with the customer or counter-party;

- operations and settlement: providing the necessary support after execution either from middle office, backoffice and other support services including deal capture and settlement services; and

- risk management: ensuring the risk of transactions and portfolios is effectively managed, including meeting regulatory and commercial requirements" (FAIFERLICK, Chris et. al. op. cit., p. 242).
} 
porque estes últimos devem ter seus preços calculados a partir das regras que disciplinam os preços de transferência em transações envolvendo serviços ou a cessão de ativos intangíveis. Portanto, antes de se aplicar a Seção 1.482-8/Proposta, devem ser adequadamente remuneradas, a partir dos métodos pertinentes, as funções de middle-office e back-office. As demais funções são, em seguida, integradas na análise funcional própria da negociação global, a qual abrange tão-somente os serviços principais ou front-office. Não obstante as abordagens aparentemente diversas entre a OCDE [cf. Relatório-GT 1998 e Relatório-2008], de um lado, e o fisco norte-americano, de outro, a aplicação de suas regras gera, ao final, resultados muito próximos.

Independentemente do critério classificatório adotado, saliente-se que as funções podem ser combinadas de múltiplas formas entre as empresas associadas de um mesmo grupo econômico, mediante a repartição de tarefas. Daí a necessidade de se ponderar, sempre caso a caso, o melhor mecanismo para o controle dos preços de transferência, porque os grupos financeiros podem alocar aquelas funções [ou parte delas], entre suas empresas, segundo milhares de maneiras possíveis. Importa sopesar, ademais, que, em inúmeros casos, especialmente naqueles envolvendo a estruturação de um instrumento inovador, (a.) algumas modalidades de "repartição" de atividades verificam-se tão-somente entre empresas do mesmo grupo; empresas independentes não repartiriam funções estratégicas com terceiros, mas apenas serviços gerais de apoio; e, (b.) ainda que pudessem ser desenvolvidas entre partes não-relacionadas, algumas estruturas de divisão de funções somente são implementadas, na prática, em operações intra-grupo, porque neste âmbito não se sujeitam a conflitos de interesse.

\section{(I.) Vendas e marketing.}

Como esclarecido anteriormente, os serviços de vendas e marketing ${ }^{546}$ tendem à descentralização, de forma que os vendedores especializam-se em regiões e produtos específicos, sempre com o objetivo de conhecer melhor seus clientes e atender mais adequadamente a suas expectativas. De acordo com a estrutura e o porte da instituição ${ }^{547}$,

\footnotetext{
${ }^{546}$ Em conjunto, os vendedores e os marketers são designados “delivery channels". In: DIAKONOVA, Irina. et. al. Where Do Financial Services Meet Transfer Pricing? Derivatives and Financial Instruments. Amsterdã: IBFD, mar./abr. 2000, p. 68.

547 "70. For example, those institutions whose strategy is to earn a fairly large spread on a few highly customized derivatives transactions generally maintain a dedicated sales force, the members of which are very familiar with the products. In many cases, these marketers understand the rudiments of pricing and hedging and can work with the traders to develop new products. At the other extreme are those institutions
} 
há dois tipos de vendedores. Os primeiros, denominados vendedores gerais [general sales] e responsáveis pelo contato inicial com os clientes, verificam seu interesse e transferem a condução da negociação, em seguida, para um segundo tipo de vendedor, mais especializado e apto a negociar com o cliente [marketers], mas sempre dentro dos limites demarcados pelos operadores [traders]. Seria o caso, v.g., de um gerente de conta corporativa que apresenta uma operação de hedge a um grande cliente de um banco comercial, transferindo o contato, em seguida, para o marketer responsável por este tipo de transação no seu país/localidade. O marketer não precifica as operações, mas possui alguma margem de negociação com o cliente, podendo impor preços além daqueles estipulados pelo trader. Geralmente, o trader inicia a estruturação do negócio e fornece um preço indicativo, o marketer negocia transação e, quando ela evolui, o trader indica o preço final mínimo ${ }^{548}$. A maior contribuição dos marketers para os negócios envolvendo a negociação global de derivativos é, justamente, o conhecimento profundo do cliente e do mercado local, bem assim a aferição do quanto um determinado cliente está disposto a pagar por um certo produto financeiro. A atuação do departamento de vendas e marketing é tanto mais relevante quanto mais específico e customizado for o derivativo negociado ${ }^{549}$. Em derivativos muito comuns, há preços fixados pelo próprio mercado e os vendedores praticamente não conseguem agregar valor no momento da venda. Nos instrumentos mais sofisticados, os clientes dispõem de alternativas mais limitadas e, portanto, de margem [um pouco] menor para negociação.

that treat derivatives as just another of the basis banking products they offer their customers. These institutions largely rely on their general sales force, with very few, if any, dedicated marketers to act as a liaison to the traders" (OCDE. OECD Documents. The Taxation of Global Trading of Financial Instruments. op. cit., p. 22).

548 "73. The extend of the mark-up over the trader's final price depends in large part on the sophistication of the client. One of the marketer's most significant contributions is determining the price that a client will be willing to pay. It is reasonably clear that there is not one single market price at the retail level at any particular time. The price prevailing in the inter-bank or 'wholesale', market often (but not always) is more consistent. Accordingly, the role of marketers in the wholesale market is much more limited. Some institutions committed to market-making dedicate one or more marketers to handle the entire wholesale market while other institutions do not use marketers in their wholesale business, but allow traders to speak directly to other institution" (OCDE. OECD Documents. The Taxation of Global Trading of Financial Instruments. op. cit., p. 22).

549 "The conventional wisdom has always been to view the sales personnel in a financial institution as simply that - sales people who should be remunerated by a sales credit or a cost plus mark-up. The real value drivers were perceived to be the traders. As such, the model which came to be adopted was one where sales were remunerated on a sales credit basis or a cost plus basis, and trader compensation was used to allocate the residual profit between locations. (...) In certain circumstances, the traders are not the primary drivers of the business - all they may do is provide an execution service. The appropriate model then would be remunerate them on a sots-plus basis and to divide the residual profit (if this was an integrated trading model) according to sales compensation" (FAIFERLICK, Chris et. al. op. cit. p. 243). 
Os marketers e os vendedores gerais são, normalmente, responsáveis por todos os contratos com os clientes. Na maioria das grandes instituições eles são alocados por área e, por vezes, especializados por tipo de indústria, para entender melhor às necessidades dos clientes. Ao contrário dos traders, cuja atividade torna-se mais integrada a cada dia, a atividade de vendas tende à descentralização, porque assim se torna mais acessível aos clientes; em virtude disso, os marketers mais especializados podem familiarizar-se com produtos e, em alguns casos, auxiliar os traders na customização de derivativos para determinada demanda dos clientes de sua região. Por mais que os marketers envolvam-se na estruturação da operação, sua atuação, na maioria dos casos, é limitada ${ }^{550}$. Não obstante, durante o desenvolvimento da análise funcional, um fator importante para a alocação dos lucros é a forma de compensação dos marketers. Se, v.g., eles são remunerados a partir de percentuais da transação, bônus ou opções de compra de ações de companhias do grupo, obviamente isso deve ser refletido na remuneração da empresa associada responsável pelo desenvolvimento da atividade de marketing numa determinada transação ${ }^{551}$.

\section{(II.) Trading e administração cotidiana de riscos.}

O trader, sinteticamente, atua na compra e administração de posições proprietárias, fornece os preços mínimos para os marketers e administra cotidianamente os riscos de mercado. Ao trader também incumbe, segundo as estratégias globalmente definidas no âmbito de determinada instituição, a opção por proteger ou não determinadas posições e, com isso, elevar os lucros de determinada transação ou eventualmente, incorrer em perdas elevadas ${ }^{552}$. Nesse contexto, sua atuação afeta diretamente a rentabilidade da

\footnotetext{
550 "69. Sales or marketing personnel are distinguished from traders as, normally, they are not allowed to price and trade in a product directly. On the other hand, some marketers/structurers may have a role in trading with customers, although their role is limited because the final responsibility for pricing and accepting the trade rests with the trader" (OCDE. OECD Documents. The Taxation of Global Trading of Financial Instruments. op. cit., p. 22).

551 "The definition of compensation for trader and sales personnel needs to be clarified and fully understood. The following are a number of issues which will need to be considered:

- bonuses: bonuses are typically the major component of trader and sales compensation. Any transfer pricing model which seeks to allocate profit based on compensation must consider how these bonuses are defined and calculated. In particular, the more closely the transfer pricing models follows the business model, the more credible it will be;

- stock options: financial services companies typically grant their professionals stock options grants for the performance of services. Stock options are considered to be compensation for US tax purposes. The determination of the value of options and allocation for activities related to a particular trading book must be considered" (FAIFERLICK, Chris et. al. op. cit., p. 246-247).

552 "74. (...) Traders are often given the opportunity to earn trading profits by running unhedged positions that may result in substantial gain (or loss), while keeping the ultimate risk incurred by the institution within risk limits that are set by the institution's management" (OCDE. OECD Documents. The Taxation of Global Trading of Financial Instruments. op. cit., p. 23).
} 
instituição, razão pela qual os traders são, normalmente, remunerados por bônus ou participações nos resultados. Os traders são agrupados por tipos de produtos ${ }^{553}$. De um único derivativo estruturado por várias empresas de um mesmo grupo, todavia, podem surgir vários tipos de riscos: se um determinado trader eventualmente suportar um risco não relacionado ao seu book, contudo, deverá transferi-lo para o trader responsável, mediante transferências internas opostas. Assim, suponha-se, v.g., que o trader T envolvase junto ao marketer M para desenvolver um derivativo específico para uma empresa de gás natural; nesta operação, o grupo assume riscos de variação cambial da moeda estadunidense e do preço do gás no mercado internacional. Se T for uma companhia norteamericana, responsável pelo book de tal moeda, deverá administrar o risco de variação cambial, transferindo o risco relacionado ao preço do gás natural para o trader responsável. Uma vez lançadas nos livros próprios as operações respectivas, os traders administram o risco e, se optarem por não proteger suas posições [via hedge], podem gerar lucros especulativos [trader profit], que são distintos da comissão e margem do negócio [dealer spread].

Durante este processo cotidiano de administração de riscos, os traders podem (i.) buscar hedges a cada transação; ou, o que é bastante mais difundido, (ii.) desenvolver suas estratégias de hedge a partir do saldo líquido no final do dia [net hedging ou portfólio hedging]. Nesta hipótese, o trader compensa todas as posições compradas e vendidas em seu livro e, em seguida, apenas protege eventuais diferenças líquidas. Esta estratégia, muitíssimo razoável sob a perspectiva financeira, dificulta a análise funcional para a definição dos preços de transferência: será complicado identificar os custos da transação

553 "Traders generally are grouped according to broad product types and are articulated more and more finely until at the individual level a trader is very specialized in a product and has broad discretion in its pricing" (PLAMBECK, Charles T. op. cit., p. 1132).

Ainda a este respeito, confira-se o seguinte trecho do Relatório-GT 1998:

"A trader can perform those functions only if the risks incurred by the bank are organized into trading portfolios (or books) of similar risks. For example, a trader responsible for US dollar risks should not have Swedish Kroner liabilities included in his trading book. The Swedish Kroner risks must be allocated to the trader who is responsible for Swedish Kroner risks.

This process is fairly straightforward in the case of physical securities. For example, one trader may be responsible for European equities, which may further be down into baskets of equities relating to high tech industries, transportations industries etc. Similarly, in the case of commodities, one trader may be responsible for precious metals and another for oil, or the responsibilities may be further broken down into gold, silver and platinum, on the one hand and West Texas crude and North Sea oil on the other. However, in either case, once the books are established, it is fairly easy to assign securities and commodities to the appropriate book.

The process is somewhat more complicated in the case of derivative instruments, largely because the cash flows in such instruments are not necessarily limited into a single type of risk. Therefore, in order to manage the risks arising from a transaction, the transaction must be unbundled into separate risks components so that they can be assigned to the appropriate trading books" (OCDE. OECD Documents. The Taxation of Global Trading of Financial Instruments. op. cit., p. 23). 
que tenha servido como hedge dos riscos assumidos por uma determinada companhia numa determinada operação global.

O limite dos riscos que podem ser assumidos pelo trader de um determinado livro depende da estratégia do conglomerado financeiro. Normalmente, o risco é medido simulando-se movimentações extremas de mercado e calculando-se as perdas possíveis ${ }^{554}$. Instituições com relevantes atividades de trading calculam o risco diariamente, sendo o limite diário imposto por grupo de trabalho distinto. O limite pode ser global, por book ou por trader. De modo geral, desde que respeitados os parâmetros impostos, seja pelo estrategista ou gerente de sua área, seja pela diretoria do grupo, os traders são bastante autônomos. A atividades de trading [market-making] e de administração de riscos posteriormente à operação, em especial a definição das estratégias de hedge da instituição, podem ser desenvolvidas por empresas associadas distintas, apesar de normalmente serem vinculadas a um mesmo grupo de trabalho ${ }^{555}$.

\footnotetext{
554،"The trader's discretion is limited to a greater or lesser degree by the market risk limits that are imposed by all well-run financial institutions and the level of control depends upon choice of business model and the nature of the financial products being traded. At one extreme there may be a highly detailed master hedging strategy the implementation of which may be relatively straightforward. An analysis of how such an approach works in a given case may show that the master strategy intrudes directly on the day-to-day risk management function. Other master hedging strategies, where they exist, may be less intrusive. A highly intrusive master hedging strategy may be more suitable for some products than for others. For example, it may be more likely to be found in a forex book, say, than an equities book. In either event, a financial institution will usually measure several different aspects of the risk in order to establish limits on the amount of market risk to which the institution can be exposed. [Common measures include outright interest rate risk, foreign exchange risk, yield curve risk, swap spread risk or basis risk, and several different options risks, including volatility risk]" (OCDE. Report on the Attribution of Profits to Permanent Establishments. op. cit., p. 130).

555 Este tipo de estrutura não constava do Relatório GT-1998 e foi introduzida pelo Relatório-2008 nos seguintes termos:

“(...) The dealing or market-making functions and the day-to-day risk management functions described in this section may be carried out by the same person. Or they may be performed by different people in different parts of the global trading business, either though institutional choice or because a functional separation between trading and risk management is imposed by the regulatory authorities.

Where the initial assumption of risk is performed in a different place from the ongoing management of risk the two functions may still be integrated to a greater or lesser extent, depending on such factors as business organization and the nature of the traded product. Different products require different amounts of continuing effort to manage the ongoing risk. For example, the risk profile of a simple forward contract is far less complicated, and thus ordinarily may be more easily managed, than the risk profile of an option contract. And some financial products are so complex that it is not possible to fully manage the risks assumed when the contract is written. Moreover, the price quoted by the trader in writing the contract must take into account assumptions about the firm's ability to manage the resulting risk. It may therefore be difficult in practice to segregate the risk assumption from the risk management function and the Report uses the term 'trader' or 'trading' to cover both" (OCDE. Report on the Attribution of Profits to Permanent Establishments. op. cit., p. 129).
} 


\section{(III.) Outras funções.}

As funções de vendas, marketing, trading e administração de riscos são as atividades-chave da estruturação de transações globais envolvendo derivativos; elas formam o denominado front office ${ }^{556}$ e se relacionam com as atividades enquadradas no middle office e no back office, que doravante serão designados "serviços gerais de apoio". $\mathrm{Na}$ legislação norte-americana, também compõe a lista de atividades principais a pesquisa e desenvolvimento de produtos, por sua proximidade com a geração direta de lucros. Os serviços gerais de apoio são centralizados na maioria das instituições, como medida de redução de custos; por vezes, todavia, estão centralizados em ente distinto daquele onde são desenvolvidas as atividades de marketing e trading, sujeitando-se, neste último caso, ao controle dos preços de transferência. A maioria dos serviços gerais de apoio não apresenta muitas complexidades porque, em virtude do fenômeno da terceirização, podem ser localizadas transações independentes comparáveis ou, eventualmente, transações que se tornem comparáveis após a implementação de ajustes razoavelmente precisos e acurados. Justamente por este motivo é que apenas alguns deles serão indicados, sucintamente, nesta subseção.

(1.) Tesouraria. A tesouraria [Treasury] garante, a um mesmo tempo, que a instituição disponha de caixa suficiente para quitar suas obrigações e que não existam recursos não aplicados, sem gerar rendimentos. A necessidade de caixa flutua muito e está relacionada a diversos fatores como, v.g., os tipos de derivativos transacionados e a necessidade de cobertura de margens, no caso das transações em bolsas ${ }^{557}$. Em algumas instituições, o book da tesouraria é considerado um centro de lucros segregado, que empresta recursos, mediante a cobrança de juros "gerenciais" para outros books; o lucro da tesouraria é representado pela diferença entre o custo de captação de recursos no mercado e

\footnotetext{
556 "The traders and/or sales personnel tend to be the drivers of the business and as such, the level of interaction between these personnel in different locations needs to be precisely understood. Roles may vary in significance. For example, in an equities business, the trader may be providing only execution services with regard to agency trades, but in primary distribution the role may be much more significant" (FAIFERLICK, Chris et. al. op. cit. p. 242).

557 " 88 . The task of the Treasury book traders is complicated by the fact that the cash needs of the business fluctuate a great deal. This volatility results in part from the use of exchange-traded contracts and securities to hedge OTC positions. In that case, the cash needs of a particular book (and therefore the business) will depend on whether the exchange-traded or the OTC contracts are in the money. If the book has losses on the exchange-traded contracts and gains on the OTC contracts, its cash needs will be greater than in the opposite case because the institution will be required to meet margin calls with respect to the exchange-traded contracts that it would not be required to make if the losses were with respect to the OTC contracts. Thus, the cash needs of the book are not necessarily related to its overall profitability" (OCDE. OECD Documents. The Taxation of Global Trading of Financial Instruments. op. cit., p. 25).
} 
os juros/despesas decorrentes das transações com outros books. O lucro da tesouraria decorre, basicamente, da economia gerada pelo melhor aproveitamento do caixa. Se, ao final do dia, faltarem recursos, a tesouraria capta o suficiente no mercado e, se há excedentes, empresta-os no overnight para outras instituições. A tesouraria também se dedica a uma espécie de hedge interno, i.e., transaciona com outros books, tentando delimitar sua exposição ao risco de curto prazo na moeda do país principal do banco; a tesouraria também pode ingressar em operações de hedge com terceiros, mas esta medida é desaconselhável porque não maximiza resultado interno da instituição.

(2.) Desenvolvimento de sistema de informação. A tecnologia da informação e os sistemas de comunicação são fatores críticos nas instituições que se dedicam à negociação global $^{558}$. Algumas instituições mantêm grandes equipes de técnicos e especialistas para desenvolver sistemas ou customizar modelos disponíveis, ao passo que outras contratam serviços terceirizados. Em alguns casos, os sistemas transformam-se em intangíveis valiosíssimos, devendo ser avaliados como tal durante a análise funcional, ao passo que, em outros, a tecnologia da informação, a despeito de relevante, não depende de ativos tão exclusivos, de modo que esta atividade, mesmo que desenvolvida por equipe de uma determinada empresa associada, pode ser comparada com serviços semelhantes disponíveis no livre mercado.

(3.) Análise de crédito. Este departamento é o principal responsável pela análise dos limites de crédito dos clientes e das contrapartes nas transações, antes da operação e durante toda a sua duração. Com efeito, dependendo do tipo de derivativo e do mercado, o risco pode variar muito durante o prazo em que a instituição ainda for titular de posição ativa ou passiva numa determinada transação global. Este departamento normalmente é responsável também pela avaliação dos limites impostos por autoridades regulatórias à própria instituição 559 .

558 "The valuation of products, the development of new products, the processing and settlement of trades, the
real-time global risk management of the portfolio, the management of credit and corporate accounting and
reporting are all dependent on the availability of sophisticated computer-based systems" (OCDE. Report on
the Attribution of Profits to Permanent Establishments. op. cit., p. 132).
559 "Credit limits imposed by regulators or by the institution's directors may limit the ability of the institution
to write new business. In that case, the credit department and marketers may suggest terminating some
existing transactions with the counterparty in order to enter into new transactions. As credit limits have
become more of a problem, some institutions have decided to dedicate traders to 'credit risk management' to
eliminate those transactions with a relatively lower profit (i.e. those with the smallest spread) to allow the
institution to enter into other transactions with the counterparty where the profit margin may be higher. Some 
(4.) Função de gerenciamento estratégico de riscos. Esta função não constou do Relatório GT-1998, tendo sido indicada como relevante para a análise funcional das transações globais tão-somente a partir do Relatório- $2008^{560}$. Neste item devem ser considerados os serviços prestados por gestores que se responsabilizem pela alocação estratégica de capital e/ou risco no âmbito do grupo, seja em virtude do cumprimento de metas internas, seja garantir o atendimento às regulamentações do setor financeiro. Os objetivos dos acionistas [aumento do lucro] e dos reguladores [proteção a clientes] não são coincidentes, mas ambos criam demanda para um recurso escasso no interior do grupo econômico: o capital. A função desta gerência é a alocação do capital da instituição, de forma que seu uso seja eficiente a ponto de gerar bons resultados e, a um mesmo tempo, obter os índices exigidos pelas autoridades regulatórias. Normalmente, este gerente aloca o capital entre as áreas de negócio e, em seguida, entre os produtos de cada área, entre as diversas localidades que desenvolvem tal produto etc.. Esta alocação de capital é efetivada sob a forma de limitação de riscos. Como regra geral, esta atividade não está diretamente relacionada à administração de riscos desenvolvida pelo trading e, por conseguinte, não vincula a rentabilidade da operação ${ }^{561}$.

institutions use credit derivatives to effectively manage and reduce credit risk" (OCDE. Report on the Attribution of Profits to Permanent Establishments. op. cit., p. 133).

${ }^{560}$ Charles T. PLAMBECK sustenta a necessidade de exame segregado desta atividade para fins da análise funcional desde 1996, como se depreende da seguinte passagem de texto publicado nesse ano:

"Management. Overseeing the trader is the strategist or trading manager, who might himself be a head trader, a risk manager or a senior manager. The strategist is responsible for coordinating and implementing the worldwide strategy of the firm and continually attempts to identify market themes. Based on his determinations he might direct salesman to push particular products, or direct traders to limit or extend a particular position. The strategist also is responsible for controlling and monitoring the level of risk to which the institution is exposed. He may manage this by setting absolute trading limits or by restricting trading in individual products, issuers, economic sectors or national markets. In some organizations some of the decisions that require less immediate reaction time are made by senior management, who also make decisions regarding the use and compensation of human resources, the shifting of managerial authority overseas, and cooperation among trading centers" (PLAMBECK, Charles T. op. cit., p. 1133).

A preocupação específica da OCDE acerca desta função de gerenciamento global de riscos surgiu a partir das últimas crises envolvendo a falta de transparência em operações envolvendo derivativos, como se pode depreender do seguinte item:

"As part of their duty to the shareholders of the financial institutions, senior management will share the goal of the regulators but will also be concerned with maximizing the return on the capital raised by the institution. Conventional finance theory suggests that the larger the risk to which an asset is exposed, the larger the expected profit should be. In order to attempt to make more profits, more risks would have to be assumed and more capital would be needed. It should be noted that, theoretically, the assumption of greater risk should increase the expected profits. As can be seen from recent experience, the assuming of more risks can lead to the realization of actual losses, rather than expected profits" (OCDE. Report on the Attribution of Profits to Permanent Establishments. op. cit., p. 133).

561 "78. In determining whether and, if so, how the parameter-setting function should be rewarded, the authorized OECD approach is to follow, by analogy, the guidelines that apply to this issue in as associated enterprises context under Article 9. For purposes of this paragraph, 'parameter setting' consists of 


\subsubsection{Ativos empregados nas transações de negociação global de instrumentos financeiros.}

\section{(I.) Capital e funding.}

O capital representa um ativo importante tanto para suprir necessidades de caixa quanto para possibilitar a assunção de riscos nas transações globais ${ }^{562}$. Sem capital disponível, nem o trader mais talentoso obtém resultados favoráveis em ambiente regulamentado, porque necessita dele para a prestação das garantias exigidas. O capital das instituições financeiras, como regra geral, pode ser analisado a partir de três perspectivas: (i.) capital disponível [available capital]: composto pelos recursos que a instituição financeira pode livremente dispor num determinado momento; (ii.) capital regulamentado [regulatory capital]: índice de capital mínimo que as instituições precisam manter, por exigência das autoridades regulatórias ${ }^{563}$; este índice é variável e pode ser um dos

establishing general parameters regarding the risks to be borne in a particular trading business, as opposed to the active monitoring and adjustment of such risks on an ongoing basis. (...)

79. As always the identity of the key entrepreneurial risk-taking function for a particular business needs to be determined through a detailed functional and factual analysis. There may be cases where the analysis show that the senior management are simultaneously performing both the parameter-setting and the riskmanagement function. For example, the responsibilities of the trading locations may be so narrowly prescribed that traders are in fact acting as no more than 'night watchmen' for the senior management team. (...) such limited activity would not constitute the key entrepreneurial risk-taking function. Where the 'traders' are performing such a limited function one would expect to see this reflected in lower salaries and bonuses than traders who are authorized to built up significant market exposures" (OCDE. Report on the Attribution of Profits to Permanent Establishments. op. cit., p. 134).

${ }^{562}$ Sobre a importância no capital para a atuação das instituições financeiras tradicionais, cf. OCDE. Report on the Attribution of Profits to Permanent Establishments. op. cit., p. 81-85.

Especificamente a respeito das instituições envolvidas em transações globais, veja-se o trecho abaixo:

“107. (...) In short, global trading enterprises will also need capital in order to assume the risks arising from their business, whether that will be market-making or taking proprietary positions. Similarly, they will also use a wide variety of financial instruments including repos and swaps, to fund their trading positions. One special feature of many derivatives is that they create potential funding obligations for the financial institution over the life of the instrument, e.g. the need to make periodic payments under an interest rate swap. Such instruments also create an ongoing need for capital to cover the ongoing risks" (OCDE. Report on the Attribution of Profits to Permanent Establishments. op. cit., p. 140).

563 "33. Importantly, to protect customers and to maintain the integrity of the financial system, banks are regulated by Governments and are required to have minimum amounts of 'regulatory' capital (regulatory minimum capital) based on the risks they assume in conducting business. (...) The Basel Committee on Banking Supervision of the Bank for International Settlements (BIS) is the body that sets internationally accepted standards for capital adequacy (...). The Basel Accord sets minimum levels of capital to cover credit risk for internationally active banks while permitting national authorities to adopt arrangements that set higher capital levels. (...)

35. Regulatory capital is classified into different Tiers of capital, based broadly on the permanency of the capital invested. The most permanent capital is Tier 1 capital and consists of items such as paid-up ordinary shares, non-cumulative and non-redeemable preference shares, non-repayable share premiums, disclosed reserves and retained earnings. Tier 2 capital includes items such as subordinated debt instruments, longdated debt, and certain reserves (e.g. certain undisclosed, asset revaluation, and general loan-loss reserves). One other matter interest is that, in calculating Tier 1 and Tier 2 capital, a deduction is normally made for capital invested in affiliated banks in order to discourage the banking system as a whole for creating cross- 
parâmetros para a definição do local de implantação do centro de lucros/book; e (iii.) capital econômico [economic capital]: calculado a partir dos sistemas de mensuração de riscos da instituição, devendo ser suficiente para a cobertura das perdas potenciais decorrentes das posições assumidas num determinado momento ${ }^{564}$. As transferências de capital entre instituições financeiras pertencentes a um mesmo conglomerado financeiro devem, obviamente, ser remuneradas, mediante a aplicação do princípio da plena concorrência; normalmente, há critérios disponíveis para comparação. Na definição do "custo do capital", todavia, deve-se tomar em conta, além dos prazos e condições financeiras, a reputação da instituição que "capta empréstimo"; o custo de capital de uma instituição AAA, obviamente, é menor que o custo que seria imposto a instituição com classificação inferior $^{565}$.

\section{(II.) Outros ativos.}

As instituições que se dedicam à negociação global de instrumentos financeiros, como quaisquer outras, necessitam, para o desenvolvimento de suas atividades, de ativos tangíveis [sede, instalações etc.], mas, especialmente, intangíveis. A mensuração do preço de utilização de ativos "físicos", se for o caso, não deve apresentar maiores dificuldades. Mesmo a divisão dos custos de modernos e sofisticados servidores e equipamentos de

holdings of capital rather drawing capital from outside sources" (OCDE. Report on the Attribution of Profits to Permanent Establishments. op. cit., p. 83).

564 "Economic capital is calculated through internal capital allocation systems which determine the amount of risk-based capital required to cover potential losses. Two concepts are paramount: value at risk (VAR) and capital at risk (CAR). These two differences effectively quantify possible losses generated by various risks. The difference between the two is that VAR derives a value of potential losses and will not be exceeded in more than a given fraction events. VAR can be applied to all levels of risk management, capturing, diversifying effects. CAR measures the potential losses for the entire portfolio of a bank and is the capital necessary to absorb the unexpected losses. As such, CAR is usually referred to as 'risk-based capital' or economic capital. (...)

Since the capital is risk-based, it requires a rate of return. (...) This led to the development of measures such as RAROC or RORAC, which are variants of risk-adjusted ratios. RAROC (Risk-Adjusted Return on Capital) adjusts the return for risks, e.g. through calculating margins net of statistical default. RORAC (Return on Risk-Adjusted Capital) is a profitability calculated on risk-based capital. Both adjustments are required as net margins should be related to the capital necessary to absorb expected losses and the expected loss should be deducted from expected margins" (FAIFERLICK, Chris et. al. op. cit. p. 247-248).

565 "The creditworthiness of a global trading enterprise is a crucial factor as a minimum credit rating may be required by some counterparties as a condition to do business with the global trading enterprise and also in the ability to make a profit on its activities. Like banks, global trading enterprises have to fund their operations and their creditworthiness affects the rate at which they can borrow. This has an obvious effect on the profitability of transactions where the global trading enterprise has to borrow, for example to fund the payments it is obliged to make under an interest rate swap contract. Moreover, (...) the price of an interest rate swap vary according to the credit risk inherent in the transaction. Moreover, certain products (particularly long dated and exotic instruments) can effectively only be sold by the most creditworthy financial institutions, AAA-rated entities may be able to sell a much wider range of products than lower rated institutions" (OCDE. Report on the Attribution of Profits to Permanent Establishments. op. cit., p. 140-141). 
informática [hardware] não deve apresentar maiores dificuldades, porque normalmente este tipo de equipamento é adquirido de terceiros. Maiores complexidades surgem a partir da utilização compartilhada de intangíveis, que podem abranger desde os intangíveis de marketing ${ }^{566}$ aos softwares e sistemas desenvolvidos por técnicos altamente especializados contratados pela instituição ${ }^{567}$. Também pode oferecer dificuldades o cálculo do preço de transferência relativo à utilização de eventual banco de dados útil a todo o grupo empresarial, na medida em que, por mais que ele tenha sido desenvolvido por uma única empresa associada, provavelmente foi "alimentado" por todo o grupo ${ }^{568}$; trata-se de um ativo dinâmico, cujo valor pode estar justamente relacionado a este aspecto.

\subsubsection{Riscos assumidos.}

As instituições financeiras disponibilizam a seus clientes uma gama de serviços, mas um dos mais significativos é a habilidade de "conformar" os riscos por eles assumidos até um limite considerado adequado pelo cliente. Praticamente todas as empresas multinacionais desenvolvem suas próprias estratégias de hedge e diversificam riscos cambiais, de juros, de crédito ou de mercado ${ }^{569}$. A diferença entre o nível máximo de risco que o cliente entende suportável e os riscos advindos de seus negócios são absorvidos pelas instituições, mediante transações financeiras dos mais diversos tipos. Não obstante os mecanismos de administração de riscos e de hedge, inexistem estratégias para a total

\footnotetext{
566 "In the global trading area a common intangible is likely to be the marketing intangible represented by the name, reputation, trademark or logo of the global trading firm. Such intangible property will be particularly important for the performance of the marketing function" (OCDE. Report on the Attribution of Profits to Permanent Establishments. op. cit., p. 136).

567 "Other intangible would be more akin to manufacturing intangibles, such as proprietary (software) systems for pricing financial instruments on prospective third party deals, allocating capital, measuring, monitoring and managing various types of risk. These intangibles result from the efforts of highly skilled personnel and are of particular relevance to the performance of the trading and risk management functions and the middle office control functions (...)"(OCDE. Report on the Attribution of Profits to Permanent Establishments. op. cit., p. 136).

568 "The technology and information developed and used by a global securities business raises the issue of how the costs and benefits of valuable information should be shared by the various affiliates of the international group. From a practical standpoint, members of the group may benefit from systems and information that other members of the group may have developed. These systems and information include economic models, pricing methodologies, computer software and data bases. Moreover, a data base is not static; each affiliate involved in global trading may add market information regarding purchases and sales, identify of investors and similar marketing information that will be used by the group. In addition, affiliates might adapt and improve computer software and related models" (SAMUELS, Leslie B; BROWN, Patricia A. op. cit., p. 527).

569،Financial institutional customers, including banks and investment banks, mutual funds, pension funds, hedge funds and insurance companies may have more sophisticated needs, such as the desire to take positions in financial instruments that present particular investment characteristics, such as derivatives providing exposure (or hedging) of the volatility (as well as the absolute level) or financial instruments" (FAIFERLICK, Chris et. al. op. cit., p. 247).
} 
eliminação de riscos assumidos pelas instituições financeiras; seus portfólios normalmente estão sujeitos a uma variedade de riscos que compreende, v.g., os riscos de mercado, de crédito, legais, regulatórios, operacionais, riscos de capital, riscos relativos a garantias prestadas etc. ${ }^{570}$.

As funções desempenhadas têm relação direta com os riscos assumidos por cada empresa de um determinado grupo multinacional ${ }^{571}$. Como regra geral, se a empresa associada que empreendeu a operação diretamente com o cliente [i.e., aquela que assumiu determinada posição contratual] suportar todos os riscos da transação, não transferindo nenhum deles, via contrato, para outras empresas do mesmo grupo, merecerá praticamente todo o retorno gerado. Uma empresa que meramente revende o produto, sem assumir nenhuma outra responsabilidade ou risco, deverá ser remunerada exatamente por essa função e, portanto, sua participação nos resultados, se houver, será reduzida. Nas transações envolvendo a negociação global de instrumentos financeiros, o fornecimento de capital e de serviços pode ser combinado no mínimo segundo três estruturas, com distintos resultados no que concerne à alocação de riscos: (i.) prestador de serviços obtém empréstimo; como a sociedade que suprirá os recursos necessários para a operação praticamente não assume riscos, será remunerada com amparo em juros de mercado; (ii.) prestador de serviços e fornecedor de capital repartem riscos e lucros da operação; e (iii.) fornecedor de capital desenvolve a operação isoladamente, apenas contratando uma consultoria especializada; nessa hipótese, o primeiro assumirá todos os riscos e, portanto,

\footnotetext{
570 “ $a$. Market Risk: One significant source of risk is market risk, which is the risk that the market value of a particular position or portfolio of positions will move adversely to the institution.

b. Credit Risk. Another source of risk is credit risk, the risk that if the market value of a particular position (or portfolio of positions) move in favor of the institution, the counterparty will be unable to satisfy its obligations to the institution and will default.

c. Other Risks. Other risks inherent in a global trading include legal risks, regulatory risks, valuation or 'model' risks, operational risks, enterprise risks, and franchise risks.

d. Risk capital versus Funding. The capital needed to absorb these risks is distinct from capital needed for funding. The latter simply covers the cash needs of the business and the investment in fixed assets.

e. Guarantees. Capital provision and risk-absorption within an affiliated group is a function not only of the transaction with the counterparty but also of any transaction that transmit risks to other entities, such as guarantee arrangements, loss underwriting agreements, mirror transactions, and even APAs or intercompany service arrangements" (PLAMBECK, Charles T. op. cit., p. 1133).

Maiores informações sobre cada um destes riscos podem ser obtidas em OCDE. Report on the Attribution of Profits to Permanent Establishments. op. cit., p. 136-140.

${ }^{571}$ In: OCDE. Transfer Pricing Guidelines for Multinational Enterprises and Tax Administrations. op. cit., p. I-11, item 1.25. Correspondente ao item 1.47 da Minuta-2009.
} 
fará jus a remuneração substancial, ao passo que o segundo receberá apenas por serviços, segundo o padrão de mercado ${ }^{572}$.

\subsection{Exame de outras operações financeiras que apresentam desafios às regras para o controle dos preços de transferência.}

São vários os exemplos de transações estruturadas por instituições financeiras que impõem desafios às autoridades tributárias, destacando-se os acordos de subscrição [underwriting], operações de securitização, serviços intra-grupo em geral e acordos de repartição de despesas, transações cambiais, outorga de garantias, descontos por empresas de factoring, administração global de caixa, constituição de sindicatos para a realização de empréstimos, transações virtuais em geral, desenvolvimento de estratégias de hedge e gerenciamento de riscos das próprias instituições etc. ${ }^{573}$. Especificamente no que toca à legislação brasileira, que praticamente não contém dispositivos sobre o controle dos preços em operações envolvendo serviços ou direitos, a problemática a ser superada apresenta-se ainda mais complexa. Este estudo pretende discutir os métodos e critérios atualmente adotados para o controle dos preços de transferência a partir, especialmente, das transações globais envolvendo instrumentos financeiros. Independentemente disso, não há dúvidas de que a legislação pátria não está apta para lidar sequer com operações financeiras um pouco menos sofisticadas ${ }^{574}$, razão pela qual, abaixo, são apresentados outros dois exemplos de operações financeiras nas quais há diversos tipos de transações intra-grupo, com variadas funções que precisam ser adequadamente remuneradas ${ }^{575}$.

\footnotetext{
572 "The provider of capital and the provider of services can combine their resources in at least three different ownership structures with different results:

(1) Capital Provider as Lender. The capital provider might accept only the limited role of lender to a global trading operation owned by the service provider. By bearing limited risk (the credit risk of the service providers), it would earn a limited return (the risk free time value of money plus a credit premium);

(2) Capital and Service Provider as Profit Sharers. The capital and service providers might instead jointly share in the profits and risks of the operation. This form of the combination is widely observed in the market place - the capital source generally receives more than half the profits and losses, the talented team of traders usually less than half.

(3) Service Provider as Investment Advisor. A third alternative is for the capital provider to own the entire venture, and hence its risks and rewards, but retain and pay the service provider for consulting services" (PLAMBECK, Charles T. op. cit., p. 1136).

${ }^{573}$ In: DIAKONOVA, Irina. et. al. Where Do Financial Services Meet Transfer Pricing? op. cit., p. 55.

${ }^{574}$ Como referido anteriormente, todos os esforços de regulamentação estão voltados para a importação e exportação de bens, deixando-se os serviços e direitos para um "segundo plano".

${ }^{575}$ Esquemas inspirados em DIAKONOVA, Irina. et. al. Where Do Financial Services Meet Transfer Pricing? op. cit., p. 56 e 62.
} 
Exemplo 1. Acordo de subscrição; Underwriting.

Suponha-se que uma determinada companhia estabelecida em Hong Kong solicite a um banco de investimentos no seu país que estruture uma determinada operação de captação de recursos mediante a colocação de títulos no mercado internacional, conjuntamente com um acordo de subscrição residual ${ }^{576}$. A instituição de Hong Kong contata outras instituições de seu grupo econômico, estruturando a transação de modo que: (a.) a controladora norte-americana seja a subscritora dos títulos, caso não sejam adquiridos no prazo de três meses [underwriting stand-by]; e (b.) além da controladora, instituições associadas no Japão e na Holanda também participarão do processo de colocação dos títulos, sendo responsáveis pelo relacionamento direto com os clientes daqueles respectivos países. Esta transação pode ser melhor compreendida a partir do esquema abaixo:

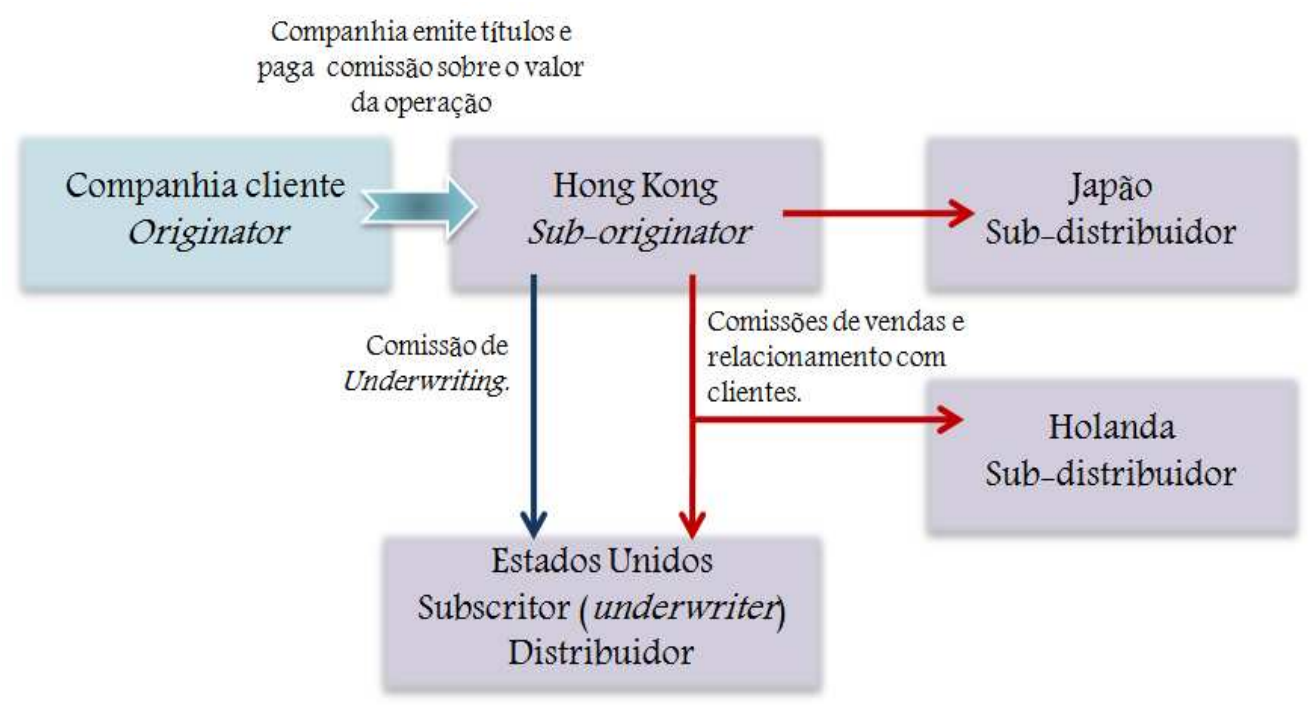

A comissão do negócio será paga pelo emitente dos títulos à instituição financeira em Hong Kong, responsável pela estruturação da operação. Essa deverá reter a remuneração por suas atividades ${ }^{577} \mathrm{e}$, em seguida, mensurar os seguintes preços de

\footnotetext{
576 "Underwriting can be defined as 'an arrangement whereby one party (usually a bank) agrees to take up securities in an offer for sale if the issue is not fully subscribed for by third parties in the market.

Such 'guarantee' is formalized by an underwriting agreement and is a subject to fee. This commission is usually based on a percentage of capital raised. When the total value of the issued securities is substantial, in order to spread the risk other banks or institutions may be invited to participate in a syndicate. The risk of underwriting is that the issue will not be fully taken up by the third parties in the market; therefore, under the agreement, the underwriter must take the remainder at the issue price. If eventually the market price appears to be less than the issue price the underwriter will bear a loss. Securities taken up under the underwriting agreement may be held by the bank in both dealing or investment portfolios" (DIAKONOVA, Irina. et. al. Where Do Financial Services Meet Transfer Pricing? op. cit., p. 56).

${ }^{577}$ Remuneração normalmente aferida a partir da soma de uma margem bruta adequada aos custos totais.
} 
transferência: (i.) qual a comissão de underwriting mais adequada? (ii.) qual o valor a ser pago a título de comissão de vendas às instituições nos Estados Unidos, Japão e Holanda? Para dirimir estas questões, este grupo financeiro multinacional deverá buscar transações semelhantes praticadas por terceiros independentes. A comissão de underwriting normalmente é calculada a partir de um percentual da transação; como parcela importante dos riscos foi alocada na controladora estadunidense, parte relevante da comissão deverá ser repassada de Hong Kong a primeira; deve-se buscar a margem bruta que seria praticada em operações semelhantes [valores com mesma ordem de grandeza, mesmas condições econômicas, mesmo nível de risco de crédito etc.]. A definição das comissões de vendas, por seu turno, possivelmente poderão ser aferidas a partir do exame das margens brutas que terceiros independentes praticariam em situações semelhantes; como a atividade de distribuição praticamente não suporta riscos, a remuneração deverá ser reduzida. Se todas as partes forem remuneradas conforme os critérios de plena concorrência e, ainda assim, restar um lucro residual a ser partilhado, o ideal é que se busque um critério para dividi-lo entre as empresas de Hong Kong, que gerou e estruturou o negócio, e dos Estados Unidos, que assumiu os riscos mais relevantes. Terceiros independentes que atuam como distribuidores e não assumem riscos inerentes à operação de subscrição, como as associadas no Japão e na Holanda, em regra geral não têm direito à percepção de parcela do lucro da operação.

\section{Exemplo 2. Empréstimo via sindicato com garantia prestada por controladora.}

Imagine-se que uma subsidiária brasileira de um grupo multinacional inglês necessita de um empréstimo de USD100milhões. Esta subsidiária dirige-se a uma instituição brasileira, também pertencente a um grupo inglês, e solicita a estruturação de um financiamento de tal monta, mas desde logo informa que ainda não dispõe, no país, de bens suficientes para a garantia do empréstimo, pois ainda está iniciando suas atividades; as garantias do empréstimo seriam, assim, prestadas por sua controladora, com sede na Inglaterra. Com amparo nestas informações, a instituição brasileira desenvolve a seguinte transação: (a.) considerando os riscos do empréstimo, a ser disponibilizado para empresa brasileira que, a despeito de pertencer a um grande grupo multinacional, inicia um novo ramo de atividades no país, a operação será sindicalizada ${ }^{578}$, de modo que os recursos serão

578 "A syndicated loan transaction involves two or more banks contracting with a borrower to provide credit
on common terms and conditions. Banks usually participate in syndication activity to share credit risk,
especially when risk is too large to be taken on a single bank's balance sheet. In a syndicate, each bank acts 
providos, em igual proporção, tanto pela instituição brasileira quanto por sua controladora inglesa; (b.) a controladora da mutuária prestará as garantias exigidas diretamente na Inglaterra, perante a instituição bancária controladora ${ }^{579}$; e (c.) a comissão de estruturação do negócio será paga no país, à instituição brasileira.

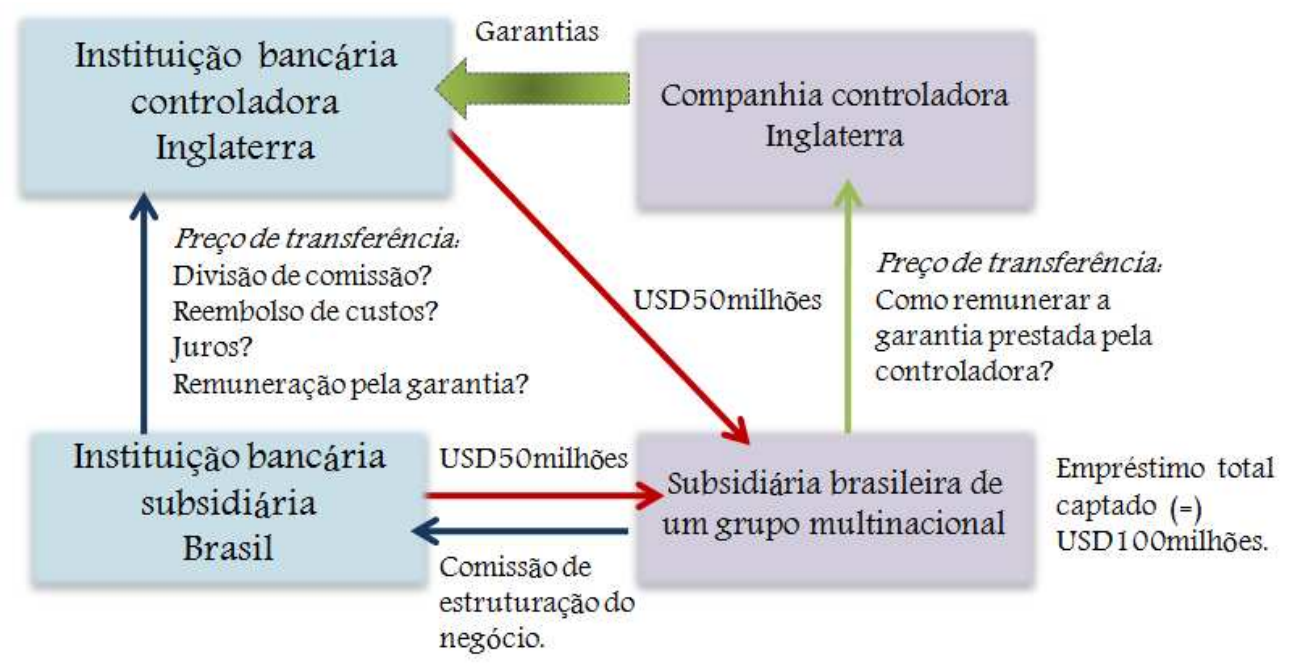

Primeiramente, pondere-se que a companhia controladora inglesa prestou garantias, gratuitamente, em nome de sua controlada brasileira. Terceiros independentes cobrariam um preço pela prestação de tal garantia? Com certeza, sim. Precisa ser examinada, portanto, uma alternativa para que a empresa brasileira remunere sua controladora $^{580}$. Mas a prestação de garantias também tem impacto no relacionamento

on its own and does not bear any responsibility for another member if that member fails to honour its obligations.

Syndicated loan are usually of medium-term maturity and carry variable rates which are indexed above appropriate benchmark rates (e.g. Libor). Syndicated loans can be of various types (for example: term loan, revolving credit facility, stand-by facility, letter of credit)" (DIAKONOVA, Irina. et. al. Where Do Financial Services Meet Transfer Pricing? op. cit., p. 62).

579 "Related companies may support each other when borrowing money from third parties. Such support may take the form of a guarantee. Usually a subsidiary of a multinational is able to obtain better borrowing terms, because the parent company is known to the financial world as a highly credible counterparty (e.g. AAAranking).

A guarantee can be achieved in two ways, by providing an explicit or an implicit guarantee for funding: - issuance of an explicit guarantee, i.e., a statement in writing that the guarantor will guarantee the repayment of a subsidiary's debt If that company cannot meet its obligations. This statement is communicated to the third party lender and needs to be noted in the guarantor's balance sheet; or

- issuance of an implicit guarantee. From a legal point of view, this statement does not constitute an obligation to repay the loan, but only indicates the guarantor's intention to keep its subsidiary in a good financial condition. In practice, the use of an implicit guarantee is viable, as multinationals cannot allow themselves to fail to repay a debt to a third party because this would serious damage its reputation and ability to obtain funding on financial markets" (DIAKONOVA, Irina. et. al. Where Do Financial Services Meet Transfer Pricing? op. cit., p. 60).

${ }^{580}$ Há vários aspectos tributários que devem ser ponderados a esse passo, sendo que alguns deles estão refletidos nas questões a seguir: qual a forma de mensuração do valor devido pela garantia prestada, de modo 
entre as duas instituições financeiras associadas: a instituição inglesa negociou e obteve garantias. Deve ser remunerada por esta atividade? Claro, tendo em vista que o planejamento das estruturas de garantia são imprescindíveis para que os riscos da operação como um todo tornem-se suportáveis para ambas as instituições. Note-se, outrossim, que toda a comissão da operação foi paga no país, à instituição financeira aqui localizada. Além da adequada remuneração da instituição inglesa em virtude da negociação das garantias, a parte remanescente da comissão deve ser com ela repartida? Deve ser adotada a estratégia do reembolso de custos ou a efetiva divisão da comissão segundo determinados critérios? ${ }^{581}$. A resposta a essa última questão depende, obviamente, da natureza da atuação de cada uma das partes na estruturação do negócio, na captação do cliente etc.. Os riscos (de crédito) assumidos pelas partes não devem ser examinados nesta repartição de receitas, porque sua remuneração está embutida nos juros cobrados da mutuária, não no custo de implementação da operação.

\subsection{Distinções principais entre as transações envolvendo a negociação global de instrumentos financeiros implementadas intra-grupo e intra- companhia.}

Como referido em 3.2.1, supra, as instituições financeiras constataram que sua presença física nos países onde estão estabelecidos os seus clientes-alvo representa uma medida importante para o sucesso de sua estratégia global. Como conseqüência, os conglomerados que se dedicam à negociação de instrumentos financeiros deste tipo expandiram-se via constituição de subsidiárias, controladas, filiais, agências, escritórios etc.. A escolha da estrutura jurídica para a sua atuação numa determinada jurisdição é, normalmente, amparada em razões de ordem regulatória ou comercial, e não tributária. Assim, v.g., os investimentos no Brasil ocorrem mediante a incorporação de controladas, dada a dificuldade de constituição regular de filiais de sociedades estrangeiras no país. Considerando, portanto, que a estrutura a ser adotada pelas instituições varia conforme o ambiente regulatório, algumas nações sustentam que as filiais e as sociedades controladas devem ter tratamento idêntico, sem distinções de natureza tributária. A legislação interna

que este valor reflita um preço de plena concorrência? A subsidiária obteria outras garantias isoladamente? Qual seria o seu custo? Este valor pago seria dedutível no Brasil?

${ }^{581}$ With respect to loan transactions transfer pricing issues become relevant when loan origination and syndication transactions involve more than one affiliate of a bank. A common and often overlooked transfer pricing issue with respect to bank lending transactions involves one bank affiliate using its existing relationship with a borrower in the local market to originate business for another bank affiliate" (DIAKONOVA, Irina. et. al. Where Do Financial Services Meet Transfer Pricing? op. cit., p. 62). 
do Brasil, v.g., vale-se da técnica da ficção para tributar as filiais como se sociedades fossem [cf. artigo 143, II, do RIR-99, e subseção 1.10 da tese], a despeito de não reconhecer sua personalidade jurídica para outros fins de direito ${ }^{582}$. Outros países, todavia, sustentam que é imprescindível o reconhecimento de que a estrutura jurídica adotada afeta a substância econômica do negócio ${ }^{583}$. Assim, v.g., a celebração de uma transação global envolvendo determinado derivativo com uma filial de instituição financeira seria distinta da celebração do mesmo negócio com uma subsidiária; na primeira hipótese, existe a garantia implícita da matriz, ao passo que, na segunda, tal garantia somente pode ser exigida da controladora se esta última tiver assumido formalmente este compromisso; segundo a compreensão destes países, esta diferença econômica deveria ser refletida nas regras de direito tributário.

Para os fins do presente estudo, importa esclarecer que, tanto nas hipóteses de negociação global de instrumentos financeiros intra-grupo [cf. Artigo $7^{\circ}$ da ConvençãoModelo ${ }^{584}$ ], quanto nos casos de negociação intra-companhia [cf. Artigo $9^{\circ}$ da ConvençãoModelo], deve ser aplicado o princípio da plena concorrência ${ }^{585}$ para a definição dos preços de transferência. Por outras palavras, as normas para o controle destes preços também são utilizadas para a aferição de lucros de estabelecimentos permanentes de uma

\footnotetext{
${ }^{582}$ As relações entre uma determinada matriz e suas filiais "surgem de necessidades de economia e disciplina interna das organizações, podendo traduzir-se em movimentos de dinheiro, de mercadorias ou de pessoa de um para outro estabelecimento de uma pessoa jurídica. Todavia, tais relações não revestem a natureza de relações jurídicas, precisamente porque esse conceito pressupõe logicamente a existência de dois sujeitos de direito e no caso concreto existe apenas um. Assim, onde se nos depara a aparência de uma compra e venda, de um mútuo, ou de um depósito entre matriz e filial está-se na realidade perante figuras não-contratuais, desprovidas de relevância jurídica. (...) $\mathrm{O}$ fato de por vezes certas autoridades administrativas, designadamente o Banco Central, reconhecerem a forma de um empréstimo, até titulado por nota promissória, entre filial e matriz deve ter-se como simplificação administrativa, aliás imprópria, por não existirem instrumentos generalizados que exprimam este tipo singular de relações" (XAVIER, Alberto. Problemas Jurídicos das Filiais de Sociedades Estrangeiras no Brasil e de Sociedades Brasileiras no Exterior. op. cit., p. 82).

${ }^{583}$ In: OCDE. OECD Documents. The Taxation of Global Trading of Financial Instruments. op. cit., p. 57.

584 “Artigo 7. Lucros das empresas. (...)

2. Com a ressalva do disposto no n. 3 , quando uma empresa de um Estado contratante exercer a sua atividade no outro Estado contratante por meio de um estabelecimento estável aí situado, serão imputados, em cada Estado contratante, a esse estabelecimento estável, os lucros que este obteria se fosse uma empresa distinta e separada que exercesse as mesmas actividades ou actividades similares, nas mesmas condições ou em condições similares, e tratasse com absoluta independência com a empresa de que é estabelecimento estável" (tradução para a língua portuguesa extraída da obra OCDE. Modelo de Convenção Fiscal sobre o Rendimento e o Patrimônio. op. cit., p. 30).

585 Sobre o empréstimo das regras dos preços de transferência para a determinação dos lucros dos estabelecimentos permanentes, veja-se, também, o seguinte trecho do verbete "transfer pricing" do dicionário do IBFD:

"Transfer pricing principles may also be applied in the context of transactions - or dealings between different parts of a single enterprise, e.g., between a head office and permanent establishment or between different permanent establishments of the same enterprise" (IBFD, International tax glossary. op. cit., p. 422).
} 
mesma sociedade, situados em duas jurisdições distintas. Logo, em princípio, as regras sobre análise de comparabilidade e cabimento de métodos nas transações de negociação global podem ser aplicadas às duas hipóteses. Nesse sentido, tanto o Relatório GT-1998, que trata especificamente das transações intra-grupo, quanto o Relatório-2008, que aborda os negócios intra-companhia, servem para o estudo dos preços de transferência nas negociações globais.

A despeito da necessária aplicação do princípio da plena concorrência a transações intra-grupo e intra-empresa, a OCDE sustenta a existência de algumas distinções materiais que precisam ser ponderadas. Basicamente, as dessemelhanças de tratamento sugeridas referem-se ao uso de intangíveis, ao custo do capital e à assunção de riscos. No âmbito do Relatório GT-1998, sustentou-se que um estabelecimento permanente não poderia pagar royalties pelo uso de intangíveis de sua matriz, porque o ativo pertence à companhia globalmente considerada, e não a uma parte dela ${ }^{586}$. Quanto ao capital, seu uso poderia ser remunerado entre estabelecimentos de bancos comerciais, que se valem dele para auferir juros, mas o mesmo não poderia verificar-se entre estabelecimentos industriais, v.g.. No caso dos estabelecimentos dedicados à negociação global de instrumentos financeiros, as posições adotadas pelos Estados-Membros ainda seriam controversas $^{587}$. A questão da remuneração pela assunção de riscos apenas foi abordada sob a perspectiva da sua transferência via operações-espelho [mirror swap], mas, também

\footnotetext{
586 "243. With respect to intangible rights, the Commentary on the OECD Model Convention states that 'the rules concerning the relations between enterprises of the same group (e.g. payment of royalty) cannot be applied in respect of the relations between parts of the same enterprise'. This is because legal ownership of the intangible cannot be attributed to any particular part of the enterprise. Accordingly, the costs of creating intangible rights are regarded as attributable to all parts of the enterprise making use of the intangible. Therefore, the current view reflected in the OECD Model Convention and its Commentary is that internal or intra-entity payments made by a PE in considerations for the use of intangibles (as opposed to a contribution towards the cost of developing an intangible) are not recognized" (OCDE. OECD Documents. The Taxation of Global Trading of Financial Instruments. op. cit., p. 61).

587 "247. Unlike a traditional bank, global traders in financial products do not engage in raising and lending interest bearing funds. Rather they borrow money just to cover their trading and inventory positions like any non financial trading or manufacturing concern. For this reason some countries believe that internal 'interest' payments incurred in connection with global trading should not be recognized, even if they accept the majority view of the treatment of lending institutions.

248. The variation in treatment seems to be widen with respect to internal payments made pursuant to innovative financial instruments. Several countries that recognize internal 'interest' payments would not recognize payments on internal 'notional principal' contracts, while some that do not recognize internal interest payments will recognize internal swap payments in appropriate circumstances. Is has also been suggested that all countries should recognize arm's length internal global trading 'transactions', for the purposes of computing the arm's length profits of a permanent establishment, even if they would not do so for internal 'interest' payments" (OCDE. OECD Documents. The Taxation of Global Trading of Financial Instruments. op. cit., p. 62).
} 
neste caso, ainda não havia uma posição definida entre os Estados-Membros para a avaliação da assunção de riscos por filiais ${ }^{588}$.

As mesmas questões foram, dez anos mais tarde, novamente abordadas pelo Relatório-2008. Neste último, o tratamento das transações intra-companhia aproximou-se das negociações intra-grupo. Consoante consignado pela OCDE, o Artigo $7^{\circ}$, parágrafo 2, da Convenção-Modelo, prevê que os estabelecimentos devem ser tratados como se fossem empresas independentes; hipoteticamente, assim, deveria ser simulada a remuneração relativa aos intangíveis e ao capital providos por um estabelecimento em favor de outro, bem assim o preço a ser pago em virtude da assunção de riscos por um determinado estabelecimento $^{589}$. Ainda há, obviamente, distinções de tratamento, devendo ser os três

588 “250. One popular form of internal notional principal is the so-called 'mirror swap'. In a mirror swap, the branch marketing a transaction with a third party enters the real transaction on its books and then enters into a matching internal transaction with the trading location that will manage the trading or the market risk arising from the real transaction.

252. (...) The internal transfers of risk may not always be acceptable for tax purposes (...) and may create further problems where the purported transfer of responsibility for managing risk under the internal swap does not reflect where that risk is actually managed. (...)

254. However, in other circumstances the internal transactions match equivalent real transactions with third parties, and so the application of this direct method of determining the profits of the permanent establishment is straightforward. For example, if the price of each internal 'swap' is set individually and after a full evaluation of the specific function performed, assets employed and risks assumed, then there should be no theoretical problem in deciding whether or not it is at arm's length" (OCDE. OECD Documents. The Taxation of Global Trading of Financial Instruments. op. cit., p. 62-63).

589 “17. (...) in a separate enterprise context no issues generally arise over determining which enterprise possesses the capital. The factual, legal position in a PE context, on the other hand, is that there is no single part of an enterprise which legally owns the assets, assumes the risks, possesses the capital or contracts with separate enterprises. The legal position is thus unhelpful in a PE context, since Article 7(2) requires the PE to be treated as if it were a distinct and separate enterprise, performing its own functions, assuming its own risk and owing or using assets on its own. It is therefore necessary under the arm's length principle of Article 7 to develop a mechanism for attributing risks, economic ownership of assets and capital to the hypothetically distinct and separate PE, for associating with the hypothetically distinct and separate PE the rights and obligations arising out of transactions between separate enterprises and the enterprise of which the PE is a part and for recognizing and determining the nature of the dealings (i.e. the intra-enterprise equivalents of separate enterprise transactions) between the hypothetically distinct and separate PE and other parts of the enterprise of which the PE is part.

18. As it is not possible to use a legal analysis as the required mechanism, another solution must be sought. After careful consideration, the OECD decided that a functional analysis should be used, as this concept underpins the application of the arm's length principle under Article 9 and there is already considerable guidance on how to conduct this analysis in the Guidelines. However, in order to address the issues created by the fact that legally the assets, risks, capital and rights and obligations arising out of transactions with separate enterprises belong to the enterprise as a whole rather than to any part of the enterprise and that there is no legal transaction between different parts of a single entity, it proved necessary to supplement the functional analysis of Article 9. Accordingly, the authorized OECD approach attributes to PE those risks for which the significant functions relevant to the assumption and/or management (subsequent to the transfer) of risks are performed by people in the PE and also attributes to the PE economic ownership of assets for which the significant functions relevant to the economic ownership of assets are performed by people in the PE" (OCDE. Report on the Attribution of Profits to Permanent Establishments. op. cit., p. 13-14). 
fatores referidos remunerados apenas em situações específicas ali discriminadas ${ }^{590}$. De todo modo, reconhece a OCDE que, não obstante as questões "legais", devem ser buscados mecanismos para, na medida do possível, garantir-se a aplicação das regras desenvolvidas no âmbito do Artigo $9^{\circ}$ às situações previstas no Artigo $7^{\circ}$, parágrafo 2 , da ConvençãoModelo.

Nesta tese serão indicados exemplos e orientações extraídos tanto do Relatório GT-1998 quanto do Relatório-2008. No entanto, sempre que for utilizado um exemplo relativo a operações intra-companhia, serão tecidas, se for o caso, as ressalvas necessárias a respeito da remuneração pelo uso de intangíveis, pelo provimento de capital e pela assunção de riscos.

${ }^{590}$ Detalhes sobre as distinções entre os tratamentos que devem ser conferidos às transações intra-grupo e às transações intra-companhia no que se refere à negociação global de instrumentos financeiros podem ser estudados em OCDE. Report on the Attribution of Profits to Permanent Establishments. op. cit., p. 160-170. 


\section{CAPÍTULO 4. MÉTODOS TRADICIONAIS.}

\subsection{Considerações preliminares.}

Dentre as metodologias propostas pela OCDE para a concretização do princípio da plena concorrência, os métodos tradicionais são, indubitavelmente, os mais difundidos entre os países que, cada qual com suas particularidades, consagraram a comparabilidade dos preços praticados em operações vinculadas com os preços negociados em operações não-vinculadas como a principal forma de controle os preços de transferência. Os três métodos referidos sob a designação tradicionais são os seguintes: (i.) Método dos Preços Independentes Comparados ["Comparable Uncontrolled Price Method" ou "CUP”; cf. seção 4.2]; (ii.) Método do Preço de Revenda [“Resale Price Method" ou "RPM”; cf. seção 4.3]; e (iii.) Método do Custo mais Lucro [“Cost Plus Method” ou “CPM”; cf. seção 4.4].

Os métodos tradicionais foram elaborados com o objetivo de refletir o processo de formação de preços desenvolvido por empresas independentes ${ }^{591}$, as quais analisam as diferentes opções realisticamente disponíveis no mercado e comparam-nas, examinando, principalmente, as diferenças suscetíveis de alteração de seu valor. Uma empresa independente sempre buscará, de um lado, adquirir bens, serviços ou direitos pelo menor preço possível e, de outro, vender bens, serviços e direitos para os clientes dispostos a pagar o maior preço; seu objetivo é maximizar seu lucro. Sabe-se, v.g., que empresas independentes efetuam uma "pesquisa de mercado" antes de efetivar quaisquer negócios, examinando-se os preços praticados por seus concorrentes antes de definir sua própria estratégia de preços; da observação deste raciocínio resultou o CUP [método da comparatividade direta de preços]. Este método busca comparar o preço cobrado nas operações vinculadas de venda de bens ou serviços com o preço praticado nas operações não-vinculadas realizadas em circunstâncias comparáveis. Sempre que for possível a sua

\footnotetext{
591 “Há, com efeito, uma grande semelhança entre os métodos fixados pelo legislador e os métodos clássicos ensinados pela Administração de Marketing para a fixação dos preços de uma empresa.

O método CPL e o PRL assemelham-se ao mais simples dos métodos de precificação, que é chamado por Kotler de Cost-Plus Pricing, onde o empresário fixa seu preço de olho na margem de lucro a ser atingida. Outro método de precificação que pode se assemelhar ao PRL ou ao CPL é o Breakeven Pricing ou Target Profit Pricing. Já o PIC assemelha-se ao método Competition-based Pricing, no qual o empresário baseia-se na concorrência para fixar seus preços.

É claro que os elementos de precificação ensinados pelos manuais de Marketing podem se mostrar mais complicados e até mesmo combinar métodos diferentes de precificação, mas guardam evidentemente uma grande semelhança com aqueles indicados pelo legislador, pois só pode ser no mercado que o legislador baseia-se para fixar métodos de precificação. Assim, apresentam-se como uma presunção legal de que uma empresa em regime de mercado calcula seus preços segundo uma daquelas três formas" (SCHOUERI, Luís Eduardo. Preços de Transferência no Direito Tributário Brasileiro. op. cit., p. 74).
} 
aplicação, i.e., sempre que estiverem disponíveis operações independentes com grau razoável de comparabilidade, o CUP é preferível a quaisquer outros métodos, justamente por refletir melhor e mais diretamente as condições de plena concorrência ${ }^{592}$. Não obstante o empenho dos contribuintes e/ou das administrações tributárias para viabilizar a sua aplicação, contudo, o CUP não é útil [ou confiável] em inúmeras situações. Como via alternativa, o contribuinte pode se valer do RPM ou do CPM, métodos tradicionais que atuam a partir da comparação das margens de lucros brutas, ou dos métodos baseados na comparação de lucros operacionais, sendo que estes últimos serão discutidos no CAPÍTULO 5.

O cálculo do preço parâmetro mediante a aplicação do RPM inicia-se com a aferição do preço pelo qual um produto/serviço adquirido de parte vinculada é revendido para uma parte não-vinculada; desse preço é deduzida uma margem bruta [resale price margin], calculada a partir da remuneração segundo a função desempenhada (ativos e riscos). A partir da diferença entre [preço praticado (-) margem bruta], obtém-se o preço de referência. A adequada determinação da margem bruta representa, assim, o "cerne" para uma adequada aplicação do RPM. O cálculo do preço parâmetro via CPM advém de raciocínio bastante semelhante, mas ao invés da comparação do resultado do cálculo [preço praticado (-) margem bruta], utiliza-se a fórmula dos custos incorridos (+) margem bruta. Com efeito, o método do CPM inicia-se com a aferição dos custos incorridos pelo fornecedor de bens/serviços numa operação vinculada. Em seguida, soma-se uma margem bruta [cost plus mark up], apurada a partir das funções desempenhadas e das condições de mercado, obtendo-se o preço de plena concorrência. Tanto no RPM quanto no CPM, a margem bruta ideal para comparação seria aquela aferida pelo mesmo ente em operações não-vinculadas; apenas subsidiariamente devem ser adotadas margens de outras empresas [cf. seção 2.2.2(IV) do CAPÍTULO 2, na qual foram discutidos os benefícios da comparação interna em relação à comparação externa].

O RPM e o CPM têm uma esfera de aplicação mais abrangente se comparados ao CUP, porque as margens brutas são, em geral, menos afetadas por diferenças físicas ou

\footnotetext{
${ }^{592}$ Confira-se a posição da OCDE sobre a predileção do CUP em relação aos demais métodos: "Moreover, where taking account of the criteria described at paragraph 2.1, the comparable uncontrolled price method (CUP) and another transfer pricing method can be applied in an equally reliable manner, the CUP method is to be preferred" OCDE. Proposed Revision of Chapters I-III of the Transfer Pricing Guidelines. 9th September 2009- 9th January 2010. op. cit., p. 26). Item alterado, correspondente a parte do item 2.49 da Diretiva.
} 
materiais entre produtos e, por conseguinte, esses métodos podem ser de grande utilidade na ausência de bens idênticos ou similares [passíveis de ajuste razoável], mas que decorrem de processos produtivos semelhantes a outros cujos dados podem ser obtidos. Os preços dos produtos, ao contrário das margens, são modificados por quaisquer alterações mínimas no produto final; se não for possível determinar adequadamente ajustes precisos para eliminar diferenças materialmente relevantes nos preços, os resultados obtidos via CUP serão menos confiáveis que os preços parâmetro indicados pelo RPM ou pelo $\mathrm{CPM}^{593}$.

Como regra geral, os métodos tradicionais são prioritariamente adotados para fins de aplicação das regras para o controle dos preços de transferência. Segundo a versão original da Diretiva da OCDE, as metodologias tradicionais seriam preferíveis, sendo que os métodos baseados na comparação de lucros operacionais teriam aplicação subsidiária e restrita tão-somente às hipóteses em que os mecanismos tradicionais, mesmo após realizados todos os ajustes para tornar os dados disponíveis no mercado comparáveis, ainda assim não fossem suficientes para o pleno atendimento dos ditames do aludido princípio $^{594}$. No âmbito da Minuta-2009, os métodos tradicionais apenas são preferíveis se

593 "In making comparisons for purposes of the resale price method, fewer adjustments are normally needed to account for product differences than under de CUP Method, because minor product differences are less likely to have as material an effect on profit margins as they do on price.

In a market economy, the compensation for performing similar functions would tend to be equalized across different activities. In contrast, prices for different products would tend to equalize only to the extent that those products were substitutes for one another. Because gross profit margins represent gross compensation, after the cost of sales for specific functions performed (taking into account assets used and risks assumed), product differences are less significant. For example, the facts may indicate that a distribution company performs the same functions (taking into account assets used and risks assumed) selling toasters as it would selling blenders, and hence in a market economy there should be a similar level of compensation for the two activities. However, customers would not consider toasters and blenders to be particularly close substitutes, and hence there would be no reason to expect their prices to be the same" (OCDE. Transfer Pricing Guidelines for Multinational Enterprises and Tax Administrations. op. cit., p. II-5 e II-6). Texto não alterado pela Minuta-2009.

594 “3.1. Part B of this Chapter provides a discussion of other approaches that might be used to approximate arm's length conditions when traditional transaction methods cannot be applied alone or exceptionally cannot be applied at all. The other approaches are referred to in the discussion here as 'transactional profit methods', i.e., methods that examine the profits that arise from particular transactions among associated enterprises (...).

3.2. (...) In fact, enterprises rarely if ever use transactional profit method to establish their prices. Nonetheless, profit arising from a controlled transaction can be a relevant indicator of whether the transaction was affected by conditions that differ from those that would have been made by independent enterprises in otherwise comparable circumstances. Thus, in those exceptional cases in which the complexities of real life business put practical difficulties in the way of the application of the traditional transaction methods and provided all the safeguards set out in this Chapter are observed, application of the transactional profit methods (profit split and transactional net margin method) may provide an approximation of transfer pricing in a manner consistent with the arm's length principle. However, the transactional profit methods may not be applied automatically simply because there is a difficult in obtaining data. The same factors that led to the conclusion that it was not possible to reliably apply a traditional transaction method may be reconsidered 
propiciarem resultados melhores ou idênticos àqueles obtidos via aplicação dos métodos amparados na comparação de lucros. Reconhece-se, contudo, que em inúmeras situações como, v.g., o cálculo dos preços parâmetro em operações envolvendo intangíveis exclusivos e valiosos ou empresas de um mesmo grupo que atuam com elevado grau de integração ${ }^{595}$, os métodos baseados na comparação de lucros podem apresentar-se como os mais adequados. Com efeito, a aplicação dos métodos tradicionais apresenta dificuldades práticas que advêm de seu próprio fundamento: a existência de preços e margens para comparação extraídos de operações não-controladas. A antiga relação de absoluta preferência dos métodos tradicionais vis-à-vis os métodos baseados na comparação de lucros foi, portanto, alterada no âmbito da Minuta-2009 ${ }^{596}$.

No âmbito da Lei n. ${ }^{\circ}$ 9.430/96, foram prescritas apenas formas adaptadas dos métodos tradicionais preconizados pela OCDE, os quais envolvem, necessariamente, a comparabilidade de preços ou margens brutas das transações ${ }^{597}$. Note-se que tanto o PIC quanto o PVEx têm relativa proximidade com o CUP, porque permitem o confronto direto entre os preços praticados nas transações com partes relacionadas e os preços cobrados com partes independentes em condições semelhantes. Da mesma forma, o PVL, o PVA e o PVV são análogos ao RPM, porque todos eles partem do preço de venda, deduzindo-se

when evaluating the reliability of a transactional profit method" (OCDE. Transfer Pricing Guidelines for Multinational Enterprises and Tax Administrations. op. cit., p. III-1 e III-2). Texto não alterado pela Minuta2009.

${ }^{595}$ Ressalte-se, a este passo, que as operações envolvendo a negociação global de instrumentos financeiros denominadas "24-hour trading" enquadram-se perfeitamente nesta condição. A aplicação dos métodos baseados na comparação de lucros a esta espécie de operação será discutida no CAPÍTULO 5.

596 "2.2. Traditional transaction methods are regarded as the most direct means of establishing whether conditions in the commercial and financial relations between associated enterprises are arm's length. As a result, where, taking account of the criteria described at paragraph 2.1 , a traditional transactional method and a transactional profit method can be applied in an equally reliable manner, the traditional transactional method is preferable to the transactional profit method. (...)

2.3. There are situations where transactional profit methods are found to be more appropriate than traditional transactional methods. One example is where, considering the functional analysis of the controlled transaction under review and an evaluation of the comparable uncontrolled transactions, it is found that a net profit margin analysis is more reliable than a gross margin analysis, e.g. because there are material differences in functions between the tested and the uncontrolled transaction which are reflected only in operating expenses below the gross margin level. Another example relates to cases where the presence of significant unique intangibles contributed by each of the parties to the controlled transaction or the engagement is highly integrated activities makes a transactional profit split more appropriate than a one-sided method. Furthermore, where there is no or limited publicly available reliable gross margin information on third parties, traditional transactional methods might be difficult to apply in cases other than those where there are reasonably reliable comparables, and a transactional profit method might be the most appropriate method in view of the availability of reasonably reliable information" (OCDE. Proposed Revision of Chapters I-III of the Transfer Pricing Guidelines. $9^{\text {th }}$ September 2009- $9^{\text {th }}$ January 2010. op. cit., p. 26). Itens novos, sem correspondente na Diretiva.

${ }^{597}$ Consoante discutido na seção 2.5 do CAPÍTULO 2, não há, até o momento, previsão legal específica a respeito da possibilidade de aplicação de outros métodos. 
uma margem bruta razoável que seria praticada por terceiros independentes. Por fim, o CPL e o CAP podem ser assemelhados ao CPM, por testarem os preços praticados em operações vinculadas a partir da demonstração do custo, acrescida da mesma margem bruta de lucro que seria cobrada por partes independentes. Como demonstrado no CAPÍTULO 2, os métodos brasileiros não oferecem toda a gama de mecanismos existentes para a aplicação do CUP, do RPM ou do CPM [porque há limitação dos ajustes nos preços e/ou condições das transações para torná-las comparáveis à transação testada], mas, claramente, foram neles inspirados ${ }^{598}$.

Considerando que o cálculo do preço parâmetro representa tão-somente um “teste" para ponderar se os preços praticados estão em consonância com o princípio da plena concorrência, ele atua como limite máximo à dedutibilidade de custos ou limite mínimo de receitas tributáveis nas operações de exportação. Justamente em virtude disso é que a atual redação do $\$ 5^{\circ}$ do artigo 18 da Lei n. ${ }^{\circ}$ 9.430/96 prevê que "se os valores apurados segundo os métodos mencionados neste artigo forem superiores aos de aquisição, constante dos respectivos documentos, a dedutibilidade, para fins de determinação do lucro real, fica limitada ao montante deste último". Por outras palavras, o valor a ser deduzido será aquele indicado nos respectivos documentos de importação, e não o preço parâmetro propriamente dito; este último tem a função de limite. Regras idênticas aplicam-se as operações de exportação, nos termos do artigo $19, \S 7^{\circ}$ da lei ${ }^{599}$.

\subsection{Método da comparação direta de preços.}

Antes de abordar especificamente as características do CUP, importa destacar a principal distinção conceitual entre este método tradicional direto [CUP] e os métodos tradicionais indiretos [RPM e CPM]. Este tipo de distinção é sustentado por diversos

\footnotetext{
${ }^{598}$ No mesmo sentido do quanto sustentado neste parágrafo, confira-se:

"Para se concluir que os preços praticados nas transações entre empresas vinculadas estão dentro do princípio arm's length price, são necessários parâmetros para a verificação desses preços, calculados mediante metodologias específicas. (...) Existem duas metodologias primordiais: as baseadas no custo e as baseadas no lucro. Há três métodos baseados no custo: CUP, RPM e CPM. Os métodos baseados nos lucros são dois: PSM e CPM (...). O Brasil adotou os chamados métodos baseados nos custos, mas tratou de forma separada as importações e as exportações" (SECRETARIA DA RECEITA FEDERAL. Tributação da Renda no Brasil Pós-Real. Brasília: Dupligráfica, 2001, p. 89 e 95).

599 “Art. 19 (...)

$\$ 7^{\circ}$ A parcela das receitas, apurada segundo o disposto neste artigo, que exceder ao valor já apropriado na escrituração da empresa deverá ser adicionada ao lucro líquido, para determinação do lucro real, bem como ser computada na determinação do lucro presumido e do lucro arbitrado".
} 
doutrinadores, destacando-se Klaus VOGEL ${ }^{600}$ e Heleno Taveira TÔRRES ${ }^{601}$. No método de comparação direta, são confrontados os preços das operações vinculadas com os preços praticados nas operações não-vinculadas; diz-se comparação direta porque há confronto direto de preços. Nos métodos de comparação indireta, de outro lado, não são comparados os preços propriamente ditos; pelo contrário, devem ser localizadas margens de lucro brutas praticadas por partes independentes que sejam comparáveis às margens adotadas por partes associadas que exerçam funções assemelhadas [considerando-se os ativos empregados e os riscos incorridos]; em seguida, o valor resultante da soma da margem bruta aos custos de produção ou da dedução de tal margem do preço de venda formam o preço parâmetro, o qual é comparado com o preço efetivamente praticado pela parte “testada”. Segundo salientado por Gerd W. ROTHMAN ${ }^{602}$ e Luís Eduardo SCHOUERI ${ }^{603}$, os métodos indiretos possibilitam uma espécie de comparação hipotética, ao contrário do CUP, método baseado em comparação concreta. Por decorrência destas considerações é que o CUP é preferível aos demais métodos tradicionais e aos baseados na comparação de lucros $^{604}$.

${ }^{600}$ In: Klaus Vogel on Double Taxation Conventions. op. cit., p. 530.

${ }^{601}$ Este autor classifica os métodos entre diretos ou simples (CUP) e indiretos ou complexos (RPM e CPM). Confiram-se os seus fundamentos:

"Os métodos adotados pela legislação brasileira para efetuar o controle das transferências de preços podem ser repartidos entre os métodos de comparação simples ou direta e os métodos de comparação complexa ou indireta, que só permitem comparação entre o preço praticado na operação controlada e o preço de referência, obtido mediante levantamento de dados e a aplicação de margens de referência.

Esta classificação toma como critério a necessidade ou desnecessidade de coleta de dados e ou de definição de margens de lucro, e conseqüente equiparação, respectivamente, entre operações concretas (comparação direta) ou entre uma operação concreta e a transação que poderia ter sido praticada na situação concreta se não concorressem as condições vantajosas e anormais para as partes, em função da vinculação (comparação indireta)" (TÔRRES, Heleno Taveira. Direito tributário internacional: planejamento tributário e operações transnacionais. op. cit., p. 216).

602 "b) O método do preço de revenda menos lucro (PRL) parte do preço pelo qual a sociedade coligada revende a mercadoria a um terceiro. Trata-se de uma comparação hipotética, visto que a adequação do preço de revenda acordado com este terceiro não está sujeito a exame e comprovação. É, pois, completamente diferente da comparação realizada no PIC, que se baseia numa comparação concreta" [ROTHMAN, Gerd W. Preços de transferência - Método do preço de revenda menos lucro: base CIF (+II) ou FOB. A margem de lucro (20\% ou 60\%) em processos de embalagem e beneficiamento. op. cit., p. 38].

603 "Dos três métodos propostos pela OCDE, este é o único que efetivamente compara uma transação entre pessoas ligadas com transações de fato ocorridas entre pessoas independentes (Ist-Ist-Vergleich), já que, nos demais métodos, a investigação sempre parte da indagação de como teriam agido pessoas independentes em igual situação" (SCHOUERI, Luís Eduardo. Preços de Transferência no Direito Tributário Brasileiro. op. cit., p. 121).

604 "A strict order of preference of the three methods mentioned cannot be established because their utility tends do vary according to which of the different types of goods, services, etc., are involved (...). Provided the necessary data is capable of being ascertained, the comparable uncontrolled price method should invariably be given precedence over the other two and any further methods, as the former method is exclusively based on prices which the goods, services etc., fetch, or could fetch, the market. In contrast, the resale price methods involve the calculation in retrospect of margins, based on elements of costs, and of costing, that are not readily ascertainable. The last method to be resorted should usually be the cost plus 


\subsubsection{Comparable Uncontrolled Price Method (“CUP”).}

O método dos preços independentes comparáveis ou CUP, disciplinado pela OCDE no âmbito de sua Diretiva e adotado por todas as nações que dispõem de regras para o controle dos preços de transferência, concretiza-se a partir da comparação do preço praticado nas operações vinculadas envolvendo bens, serviços ou direitos, com o preço estipulado em operações não-vinculadas relativas a bens, serviços ou direitos, idênticos ou similares, em circunstâncias semelhantes ${ }^{605}$. Para a obtenção de uma transação independente comparável ${ }^{606}$ e, conseqüentemente, para a adequada aplicação do CUP, podem ser utilizados comparáveis internos ou externos, como explicado na subseção seção 2.2.2 (IV) do CAPÍTULO 2. São comparáveis internos as transações praticadas entre o contribuinte "testado" e empresas independentes. Já os comparáveis externos podem ser alcançados a partir do exame de transações não-vinculadas praticadas entre duas partes independentes, sem envolvimento do contribuinte examinado, ou "a partir de informações de bolsas, ou de costumes comerciais arraigados no mercado, ou de listas de preços publicadas por associações de classe ou entidades profissionais (tabelas de honorários, por exemplo)" "607. A legislação norte-americana denomina "evidências indiretas de transações independentes comparáveis" aqueles dados disponíveis em bolsas ou outros tipos de

method, because it is based on cost accounting where attribution is often extremely difficult" (VOGEL, Klaus. Klaus Vogel on Double Taxation Conventions. op. cit., p. 532).

${ }^{605}$ "2.6. The CUP method compares the price charged for property or services transferred in a controlled transaction to the price charged for property or services transferred in a comparable uncontrolled transaction in comparable circumstances. If there is any difference between the two prices, this may indicate that the conditions of the commercial and financial relations of the associated enterprises are not arm's length, and the price in the uncontrolled transaction may need to be substituted for the price in the controlled transaction" (OCDE. Transfer Pricing Guidelines for Multinational Enterprises and Tax Administrations. op. cit., p. II-2). Texto não alterado pela Minuta-2009.

Ainda sobre a caracterização do CUP, veja-se posição de Juan Ignacio Moreno FERNÁNDEZ:

"Consiste em determinar el precio de mercado del bien o servicio entre partes independientes. Esto es, se trata de fijar el precio de un bien o servicio en concreto o de otros de características similares, efectuando, en este caso, las correcciones necesarias para obtener la equivalencia, así como para considerar las particularidades de la operación. Para ello, la comparación del precio de mercado entre partes independientes debe hacerse tomando en consideración la misma mercancía, en la misma fase y momento de producción o distribución (fabricante y mayorista, mayorista y minorista, o minorista y consumidor final), con las mismas condiciones de venta, con mercados geográficos similares y en volúmenes parecidos. Todo ello sin olvidar si la transferencia conlleva además la prestación de algún tipo de servicios o la transmisión de activos inmateriales incorporados a los bienes, tales como patentes, marcas, know-how, etc. Es decir, los atributos de las transacciones que deben compararse son cuatro: las características del producto o los servicios, el análisis funcional, los términos contractuales y, las circunstancias económicas y la estrategia del negocio" (op. cit., p. 72-75).

${ }^{606}$ Expressão extraída de OCDE. Proposed Revision of Chapters I-III of the Transfer Pricing Guidelines. $9^{\text {th }}$ September 2009- $9^{\text {th }}$ January 2010. op. cit., p. 7, parágrafo 1.6.

${ }^{607}$ In: SCHOUERI, Luís Eduardo. Preços de Transferência no Direito Tributário Brasileiro. op. cit., p. 122. 
instituições que divulgam e publicam informações sobre determinado produto e/ou $\operatorname{mercado}^{608}$.

O CUP deve ser aplicado se uma das duas condições seguintes for cumprida: (a.) se não houver diferenças entre as transações comparadas ou, se houver, constatar-se que estas diferenças não teriam efeitos materiais sobre o preço praticado; ou (b.) se forem constatadas dessemelhanças materialmente relevantes entre a transação praticada e a transação independente comparável, houver ajustes razoavelmente precisos que possam ser implementados para eliminar possíveis efeitos econômicos das diferenças materiais ${ }^{609}$. Os ajustes admitidos são aqueles indicados na seção 2.2 do CAPÍTULO 2, destacando-se aqueles relativos aos cinco fatores de comparabilidade, i.e., (I.) características dos bens, serviços e direitos objeto da transação; (II.) análise funcional; (III.) análise contratual; (IV.) circunstâncias econômicas; e (V.) estratégias empresariais. A extensão e a qualidade dos ajustes afetam a relativa confiabilidade da análise dos preços de transferência via CUP. Por vezes, pode ser complicado efetuar ajustes acurados para eliminar efeitos de circunstâncias distintas nos preços praticados, mas esta dificuldade, per se, não é suficiente para se afastar uma possível aplicação do CUP. Consoante a orientação atual da OCDE, devem ser reunidos todos os esforços para a realização de ajustes que possibilitem a aplicação deste método $^{610}$.

\footnotetext{
${ }^{608}$ As evidências indiretas de transações independentes comparáveis podem ser utilizadas para a aplicação do CUP, desde que preenchidos os requisitos abaixo transcritos:

"\$1.482-3 (b) (5) (i) (A) The data is widely and routinely used in the ordinary course of business in the industry to negotiate prices for uncontrolled sales;

(B) The data derived from public exchanges or quotation media is used to set prices in the controlled transactions in the same way it is used by uncontrolled taxpayers in that industry; and

(C) The amount charged in the controlled transaction is adjusted to reflect differences in product quality and quantity, contractual terms, transportation costs, market conditions, risks borne, and other factors that affect the price that would be agreed to by uncontrolled taxpayers" [26 CFR Ch. I (4-1-09 Edition)].

609 "Application of this method by means of a 'direct' price comparison presupposes that in all essential details the concrete business relations are identical to those of the relations with which the comparison is made" (VOGEL, Klaus. Klaus Vogel on Double Taxation Conventions. op. cit., p. 530).

610 "2.9. Where differences exist between the controlled and uncontrolled transactions or between enterprises undertaking those transactions, it may be difficult to determine reasonably accurate adjustments to eliminate the effect on price. The difficulties that arise in attempting to make reasonably accurate adjustments should not routinely preclude the possible application of the CUP method. Practical considerations dictate a more flexible approach to enable the CUP method to be used and to be supplemented as necessary by other appropriate methods, all of which should be evaluated according to their relative accuracy. Every effort should be made to adjust the data so that it may be used appropriately in a CUP method. As for any method, the relative reliability of the CUP method is affected by the degree of accuracy with which adjustments can be made to achieve comparability" (OCDE. Transfer Pricing Guidelines for Multinational Enterprises and Tax Administrations. op. cit., p. II-3). Texto não alterado pela Minuta-2009.
} 
Em sua Diretiva, a OCDE expõe alguns exemplos de ajustamentos possíveis para a aplicação do CUP. No primeiro deles, discute os efeitos do local de produção dos bens e o impacto respectivo no preço. Neste exemplo, confronta-se o preço do café colombiano com o café brasileiro, sendo ambos sem marca e de igual espécie, qualidade e quantidade. Para aferir se as transações são realmente comparáveis, deve ser ponderado o efeito do local de produção dos grãos no preço. Deve-se, questionar se, no mercado internacional, o fato de o café comparável ser proveniente do Brasil ou da Colômbia gera um aumento ou uma redução no seu preço; esta informação pode ser obtida, v.g., perante bolsas de mercadorias, fabricantes que adquirem café no mercado internacional etc.. Uma vez constatada qualquer diferença material no preço, devem ser efetivados os ajustes necessários no preço do café brasileiro, para tornar a operação envolvendo-o uma transação independente comparável com a transação praticada, relativa ao café colombiano. Se ajustes razoavelmente precisos não puderem ser efetivados, reduz-se a fiabilidade do CUP, podendo ser o caso, inclusive, de combiná-lo com outros métodos, ou de simplesmente aplicar outros métodos, isoladamente ${ }^{611}$. Um outro exemplo oferecido pela OCDE seria o seguinte: o contribuinte $\mathrm{Z}$ aliena a pessoa vinculada 1.000 toneladas do produto $\mathrm{X}$ a $\$ 80$ por tonelada, e, no mesmo período, $\mathrm{Z}$ aliena a parte não-vinculada 500 toneladas de $\mathrm{X}$ por $\$ 100$ a tonelada. Neste exemplo, para uma venda 50\% maior, foi

${ }^{611}$ In: OCDE. Transfer Pricing Guidelines for Multinational Enterprises and Tax Administrations. op. cit., p. II-4, item 2.11. Texto não alterado pela Minuta-2009.

Este exemplo foi melhor explicado da seguinte forma por Richard M. HAMMER:

"Example 4-3. CoffCo is a Dominian producer of an unbranded coffee beans harvested on its plantations in Dominia. It combines the beans to produce Blend A, which has become the standard blend from the famous Dominian mountains. CoffCo sells Blend A to related parties and unrelated enterprises for the same price, always cash paid for delivery at the blending plant in Foronia.

In this situation, the CUP method is clearly applicable, because the same product is sold on the same terms to independent and associated enterprises. Such situations are actually quite rare, although there have been cases like this in which the CUP method was found to be applicable.

Unfortunately, the international business world is more complex, and even commodities like coffee have variations that must be taken into account to apply the CUP method. The Guidelines illustrates the application of the CUP method in situations where adjustments to uncontrolled transactions are required to make them comparable uncontrolled transactions. Consider Illustration 4-4.

Example 4-4. The situation is the same as in Illustration 4-3, except that CoffCo produces coffee beans in Dominia as well as Foronia. Beans from different countries are of a similar type, quality and quantity. The coffee blended from Dominia beans is sold only to associated enterprises, and coffee from Foronian beans is sold only to independent parties.

The controlled and uncontrolled transactions each involve similar goods (blends from coffee beans) sold in transactions that occur at about the same time as controlled transactions, at the same stage in the productiondistribution chain, and under similar conditions. Thus, the CUP method should apply. The Guidelines notes appropriately that, if the only available uncontrolled transaction involved unbranded coffee beans from a different country, it would be appropriate to inquire whether the 'difference in the coffee beans from Country A to Country B has a material effect on the price'. For example, it could be asked whether the source of coffee beans command a premium or requires a discount generally in the open market. Such information may be obtainable from commodity markets or may be deduced from dealer prices" (HAMMER, Richard M. et. al. International Transfer Pricing - OCDE Guidelines. op. cit. item 4.02). 
praticado um desconto de 20\%; para tornar os preços das duas transações comparáveis, a transação entre $\mathrm{Z}$ e a parte não-vinculada deverá ser ajustada a partir dos descontos por quantidade que teriam sido concedidos por empresa independente. Se, após o cômputo dos descontos, o preço da transação entre $\mathrm{Z}$ e a parte não-vinculada for semelhante a $\$ 80$ por tonelada, consideram-se comprovados os preços de transferência praticados por $Z^{612}$.

A Seção 1.482-3 do IRC norte-americano também expõe inúmeros exemplos de ajustes possíveis para a aplicação do CUP, incluindo-se ajustes envolvendo transações com fixação do preço para entrega no chão da fábrica comparadas com transações $\mathrm{FOB}^{613}$, ajustes relativos a diferenças mínimas nos produtos, ajustes referentes ao mercado relevante onde as transações são efetivadas etc.. Entende o fisco norte-americano, contudo, que os efeitos materiais que as marcas e outros intangíveis geram nos preços dos produtos não são passíveis de ajustes razoáveis; pelo contrário, nestes casos envolvendo bens materiais acrescidos de intangíveis, o CUP não propiciaria resultados confiáveis e que atendessem ao princípio da plena concorrência ${ }^{614}$. Nestas hipóteses, deveria ser aplicado o Comparable Uncontrolled Transaction Method ("CUT"), método específico para a aferição de preços parâmetro envolvendo intangíveis. A OCDE, de outro lado, apregoa que o CUP pode ser aplicado em operações envolvendo bens que incorporam intangíveis; nesta hipótese, deve ser efetivada uma análise de comparabilidade e, dentre os ajustes necessários, computar-se o valor agregado pela marca. Assim, v.g., se um tênis com a marca A for vendido por $\mathrm{Z}$ exclusivamente para partes relacionadas e $\mathrm{Z}$ pretender

${ }^{612}$ In: OCDE. Transfer Pricing Guidelines for Multinational Enterprises and Tax Administrations. op. cit., p. II-4, item 2.13. Texto não alterado pela Minuta-2009.

613 "\$1.482-3 (b) (4) Example 1. Comparable Sales of Same Product. USM, a US manufacturer, sells the same product to both controlled and uncontrolled distributors. The circumstances surrounding the controlled and uncontrolled transactions are substantially the same, except that the controlled sales price is a delivered price and the uncontrolled sales are made at f.o.b. USM's factory. Differences in the contractual terms of transportation and the insurance generally have a definite and reasonably ascertainable effect on price, and adjustments are made to the results of the uncontrolled transaction to account for such differences. No other material difference has been identified between the controlled and uncontrolled transactions. Because USM sells in both the controlled and uncontrolled transactions, it is likely that all material differences between the two transactions have been identified. In addition, because the comparable uncontrolled price method is applied to an uncontrolled comparable with no product differences, and there are only minor contractual differences that have a definite and reasonably ascertainable effect on price, the results of this application on the comparable uncontrolled price method will provide the most direct and reliable measure of arm's length result" [26 CFR Ch. I (4-1-09 Edition)].

614 "\$1.482-3 (b) (4) Example 2. Minor Product Differences. The facts are the same as in Example 1, except that USM affixes its valuable trademark to the property sold in the controlled transactions, but does not affix its trademark to the property sold in the uncontrolled transactions.

Under the facts of this case, the effect on price of the trademark is material and cannot be reliably estimated. Because there are material product differences for which reliable adjustments cannot be made, the comparable uncontrolled price method is unlikely to provide reliable measure of the arm's length result" [26 CFR Ch. I (4-1-09 Edition)]. 
compará-lo com tênis muito semelhantes, da mesma linha, mas sem marca, pode fazê-lo. Um dos mecanismos para se obter o ajuste adequado seria o seguinte: verificar se $\mathrm{Z}$ tem outras linhas de tênis, vendidos com marca e sem marca a terceiros independentes; se esta informação estiver disponível, pode-se calcular o "prêmio" do tênis com marca sobre o tênis sem marca e aplicar este percentual para ajustar o preço do tênis semelhante àquele comercializado com a marca A, de modo a torná-lo comparável ao tênis com marca e, assim, controlar estes preços de transferência ${ }^{615}$. A despeito desta posição manifestada pela OCDE, entende-se ser muito complexa esta sistemática, porque ela prevê a comparação do valor adicionado por uma determinada marca a um tipo de tênis, a qual pode possuir maior ou menor impactos sobre o preço em relação à marca A, numa outra linha de tênis. Deve ser reconhecido que, como regra geral, marcas distintas têm impacto distintos nos preços.

Em muitos casos, como no exemplo supracitado e nas transações globais entre instituições financeiras envolvendo instrumentos derivativos, é complexa a localização de operações idênticas ou similares entre partes não-vinculadas para subsidiar a adequada aplicação do CUP; na prática, sabe-se que qualquer diferença mínima nos produtos, serviços ou direitos, pode gerar efeitos no preço. Independentemente disso, como referido nesta seção 4.2., sempre que possível a sua aplicação, o CUP é preferível aos outros métodos, por refletir melhor e mais diretamente as condições de plena concorrência.

615 "6.24. In the sale of goods incorporating intangible property, it may also be possible to use the CUP or resale price method following the principles in Chapter II. When marketing intangibles (e.g. a trademark) are involved, the analysis of comparability should consider the value added by the trademark, taking into account consumer acceptability, geographical significance, market shares, sales volume, and other relevant factors. When trade intangibles are involved, the analysis of comparability should moreover consider the value attributable to such intangibles (patent protected or otherwise exclusive intangibles) and the importance of the ongoing R\&D functions).

6.25. For example, it may be the case that a branded athletic shoe transferred in a controlled transaction is comparable to an athletic shoe transferred under a different brand name in an uncontrolled transaction both in terms of the quality and specification of the shoe itself, and also in terms of customer acceptability and other characteristics of the brand name in the market. Where such a comparison is not possible, some help may also be found, if adequate evidence is available, by comparing the volume of sales and the prices chargeable and profits realized for trademarked goods with those for similar goods that do not carry the trademark. It therefore may be possible to use sales of unbranded products as comparable transactions to sales of branded products that are otherwise comparables, but only to the extent that adjustments can be made to account for any value added by the trademark. For example, branded athletic shoe A may be comparable to an unbranded shoe in all respects (after adjustments) except for the brandname itself. In such a case, the premium attributable to the brand might be determined by comparing an unbranded shoe with different features, transferred in an uncontrolled transaction, to its branded equivalent, also transferred in an uncontrolled transaction. Then it may be possible to use this information as an aid in determining the price of branded shoe A, although adjustments may be necessary for the effect of difference in features on the value of brand. However, adjustments may be particularly difficult where a trademarked product has a dominant market position such that the generic product is in essence trading in a different market, particularly where sophisticated products are involved" (OCDE. Transfer Pricing Guidelines for Multinational Enterprises and Tax Administrations. op. cit., p. VI-9 e VI-10). Texto não alterado pela Minuta-2009. 
Baseando-se neste argumento, a OCDE sustenta que este método pode ser usado de forma mais "flexível" e, dependendo do caso, ser complementado por outros métodos, sendo que cada um deles deverá ser avaliado segundo sua confiabilidade e quantidade de ajustes efetivados. Não obstante a necessidade de se tentar aplicar o CUP nestas circunstâncias, conforme recomendado pela OCDE, deve ser reconhecido que este método, sem os ajustes acurados necessários para tornar as transações comparáveis, provavelmente não produzirá resultados seguros e que atendam adequadamente ao princípio da plena concorrência ${ }^{616}$.

Como regra geral, as commodities, por suas próprias características, permitem a localização de dados comparáveis que, com poucos ajustes, prestam-se à aplicação do CUP. No âmbito do mercado financeiro, em que as transações relevantes também se tornaram espécies de commodities, este método também é muito empregado. No campo dos serviços e intangíveis únicos e exclusivos, todavia, o CUP apresenta problemas em muitas situações práticas ${ }^{617}$. Note-se, a este passo, que as transações globais envolvendo instrumentos financeiros não se enquadram nas espécies de negociações-commodities. Pelo contrário, como se demonstrará ao longo deste CAPÍTULO 4, sua aplicação é viável apenas em alguns tipos de transações rotineiras, assumindo os métodos indiretos e, especialmente, os métodos baseados na comparação de lucros, maior importância em relação ao CUP.

616 "\$1.482-3 (b) (2) (ii) (A) Although all the factors described in §1.482-1(d)(3) [este item refere-se à análise functional] must be considered, similarity of products generally will have the greatest effect on comparability under this method. In addition, because even minor differences in contractual terms or economic conditions could materially affect the amount charged in an uncontrolled transaction, comparability under this method depends on close similarity with respect to these factors, or adjustments to account for any differences. The results derived from applying the comparable uncontrolled price method generally will be the most direct and reliable measure of an arm's length price for the controlled transaction if an uncontrolled transaction has no differences with the controlled transaction that would affect the price, or if there are only minor differences that have a definite and reasonably ascertainable effect on price or for which appropriate adjustments are made. If such adjustments cannot be made, of if there are more than minor differences between the controlled and uncontrolled transactions, the comparable uncontrolled price method may be used, but the reliability of the results as a measure of the arm's length price will be reduced. Further, if there are material product differences for which reliable adjustments cannot be made, this method ordinarily will not provide a reliable measure of an arm's length result" [26 CFR Ch. I (4-1-09 Edition)].

${ }^{617}$ Em pesquisa realizada pela Ernst \& Young International Ltd., denominada 2007-2008 Global Transfer Pricing Survey. Global Transfer Pricing Trends, Practices and Analysis, constatou-se que o CUP seria aplicado, dentre as companhias pesquisadas, a 32\% das transações com bens tangíveis, $19 \%$ dos serviços e $56 \%$ das operações financeiras. No caso dos bens intangíveis, a pesquisa envolveu o CUP e o Comparable Uncontrolled Transaction Method ("CUT") norte-americano, sendo que a inclusão na pesquisa dos contribuintes norte-americanos, obrigados à aplicação do CUT, distorceu o resultado. Segundo apurado, 54\% das transações envolvendo intangíveis seriam mensuradas pelo CUP ou CUT; não foi indicado, todavia, o resultado relativo a cada método, isoladamente. Não obstante a inclusão conjunta dos dados relativos ao CUP e ao CUT, a própria empresa pesquisadora questiona este percentual, nos seguintes termos:

"However, the inherent uniqueness of intangible property raises a question as to whether, in practice, taxpayers are adhering to a fairly strict comparability criteria associated with qualifying intellectual property transactions as CUP/CUT" (Ernst \& Young International Ltd., dez./99, p. 16). 
Para se garantir uma adequada aplicação do CUP, sustenta-se que seria útil a constituição de um banco de dados internacional, formado a partir de uma ampla base de informações de caráter indicativo do preço de produtos, serviços ou direitos considerados commodities $^{618}$. No âmbito da II Jornada Tributária do Mercosul, realizada em out./97 em São Paulo, v.g., a resolução n. 9 tratava justamente dessa questão, nos seguintes termos: “para a aplicação adequada das regras do preço de transferência no âmbito dos países do Mercosul, o estabelecimento de uma organização supra nacional para formação de uma ampla base de dados (estatísticas) de caráter somente indicativo das atividades estatísticas relevantes para as transações internacionais se apresenta de notável importância, conquanto seja preservado o necessário sigilo comercial das operações e práticas negociais adotadas pelos contribuintes" $" 619$.

Qualquer banco de dados deveria ser, obviamente, aplicado em conjunto com uma predeterminada margem de divergência, de modo a suprir eventuais fragilidades em suas informações. Saliente-se, ainda a respeito, que os bancos de dados em geral não podem conter preços parâmetro "obrigatórios"; pelo contrário, devem ser vislumbrados como espécies de safe harbours, para fins de simplificação das técnicas para o controle dos preços de transferência, cabendo ao contribuinte, evidentemente, a possibilidade de demonstrar seus preços, a partir do princípio da plena concorrência, via quaisquer métodos e procedendo-se a todos os ajustes necessários para que seja obtida uma transação independente efetivamente comparável. Com efeito, pode-se constatar, intuitivamente, que o processo de formação de um banco de dados oficial com preços de diversos bens, serviços e direitos é bastante complexo; também é complicada a alimentação constante do banco de dados, de forma que reflita sazonalidades, crises específicas num setor etc.. Seguramente, um banco de dados desta natureza apresenta deficiências, mesmo porque é impossível provê-lo com todos os tipos de condições comerciais ou financeiras das transações; não é viável, assim, que ele tenha efeitos além daqueles típicos dos safe harbours em geral.

\footnotetext{
${ }^{618}$ Seria impossível montar um banco de dados com preços parâmetro relativos a serviços específicos e especializados, diretos sobre marcas ou patentes etc.. Nestas hipóteses, o preço das transações sujeitam-se ao conhecimento específico e reputação do prestador, ou aos impactos de determinada marca ou tecnologia perante o consumidor, fatores de difícil quantificação ou mensuração.

619 As Resoluções sobre o tema "O preço de transferência (transfer pricing) no Mercosul" constam de RODRIGUES DO AMARAL, Antonio Carlos. O preço da transferência (transfer pricing) no Mercosul - II Jornada Tributária do Mercosul. op. cit., p. 242-243.
} 
As fragilidades destas espécies de bancos de dados, apontadas pela OCDE na Minuta-2009, foram analisadas na seção 2.2.2(IV), do CAPÍTULO 2. Não obstante as inúmeras falhas ali indicadas, entendemos que medidas deste tipo seriam importantes, como espécies de safe harbour, para garantir maior segurança jurídica aos contribuintes. Poderia ser constituído, v.g., um banco de dados com preços em USD (dólares norteamericanos), de modo a evitar o impacto da variação cambial nos preços ali consignados.

A obtenção de documentação externa para a comprovação das transações independentes é sempre complexa; esta constatação, aliada ao fato de que as administrações tributárias podem desconsiderar documentos imprestáveis ou insuficientes, leva-nos à conclusão de que este tipo de safe harbour reduziria os custos de compliance da maioria dos contribuintes que negociam commodities, além de garantir maior segurança jurídica aos cidadãos. Este tipo de medida, a despeito da posição da OCDE se afastaria, em alguma medida, do princípio da plena concorrência ${ }^{620}$, deve ser incentivado, como medida de praticabilidade, reservando-se os recursos econômicos e humanos disponíveis das administrações tributárias para o exame de operações realmente complexas.

$\mathrm{O}$ argumento de que este tipo de safe harbour pode levar à redução de receitas tributáveis [porque os contribuintes poderiam manipular seus preços de modo a tributar o mínimo possível em determinado país] também não merece prosperar; os ganhos com a simplificação de procedimentos e o aumento da quantidade de contribuintes que, espontaneamente, aplicarão as regras para o controle dos preços de transferência, sem dúvidas justificam qualquer possível perda de arrecadação.

\subsubsection{Método dos Preços Independentes Comparados (“PIC”).}

A Lei n. ${ }^{\circ}$ 9.430/96 prevê, no seu artigo 18, I, o método CUP para as operações de importação, conhecido no Brasil pela sigla PIC [preços independentes comparados]. A redação atual do referido dispositivo legal, considerando-se as alterações promovidas pela Medida Provisória n. 478/09, é a seguinte: "PIC: definido como a média aritmética ponderada dos preços de bens, serviços ou direitos, idênticos ou similares, apurados no mercado brasileiro ou de outros países, em operações de compra e venda, empreendidas

\footnotetext{
${ }^{620}$ OCDE. Transfer Pricing Guidelines for Multinational Enterprises and Tax Administrations, op. cit., p.
} IV-35 a IV-40. Confiram-se ponderações mais detalhadas sobre este assunto no CAPÍTULO 2, seção 2.9.1. 
pela própria interessada ou por terceiros com não vinculadas, em condições de pagamento semelhantes".

Os itens sublinhados indicam as inclusões trazidas pela Medida Provisória n. ${ }^{\circ}$ 478/09 em relação ao texto original da Lei n. ${ }^{\circ}$ 9.430/96. A referência às médias ponderadas consta desde 2002 do teor da Instrução Normativa n. ${ }^{\circ}$ 243/02; de fato, sempre que a lei aludia a "média aritmética", referido normativo traduzia-a como "média aritmética ponderada". Diante das discussões que surgiram em virtude da "inovação" da legislação regulamentar, o texto legal foi alterado por intermédio da Medida Provisória n. ${ }^{\circ}$ 478/09, que alçou ao patamar de lei a sistemática infralegal das médias ponderadas. As considerações sobre os prós e contras relacionados à adoção das médias, aritméticas e ponderadas, constam da seção 2.2.1, do CAPÍTULO 2.

A inclusão da expressão "empreendidas pela própria interessada ou por terceiros com não vinculadas" no inciso I do artigo 18 decorre de mera reformulação sistemática do artigo. Com efeito, previsão semelhante estava contida no $§ 2^{\circ}$ do artigo 18 da redação original da Lei n. ${ }^{\circ}$ 9.430/96, revogado pela Medida Provisória n. ${ }^{\circ}$ 478/09 ${ }^{621}$. Especificamente no que concerne a esta regra, importa ponderar que ela foi disciplinada pelo artigo $8^{\circ}$, parágrafo único, da Instrução Normativa n. $^{\circ}$ 243/02, que prevê a comparação dos preços praticados em operações envolvendo determinados bens, serviços ou direitos, com os preços parâmetro obtidos a partir das seguintes operações, envolvendo bens, serviços ou direitos idênticos ou similares: (a.) venda pela mesma exportadora para partes não-vinculadas, no Brasil ou no exterior; (b.) aquisição, pelo contribuinte, de partes não-vinculadas, no Brasil ou no exterior; ou (c.) transação entre dois terceiros nãovinculados, no Brasil ou no exterior ${ }^{622}$. A respeito da interpretação conferida por este normativo ao texto legal, Luís Eduardo SCHOUERI aponta que ali "não está prevista a possibilidade de utilização no cálculo do PIC das operações de aquisição do mesmo

${ }^{621}$ A antiga redação do artigo $18, \S 2^{\circ}$, da Lei n. ${ }^{\circ} 9.430 / 96$, era a seguinte:

"Art. 18 (...)

$\$ 2^{\circ}$ Para efeito do disposto no inciso I, somente serão consideradas as operações de compra e venda praticadas entre compradores e vendedores não vinculados".

622،A Art. $8^{\circ}(\ldots)$.

Parágrafo único. Por esse método, os preços dos bens, serviços ou direitos, adquiridos no exterior, de uma empresa vinculada, serão comparados com os preços de bens, serviços ou direitos, idênticos ou similares:

I - vendidos pela mesma empresa exportadora, a pessoas jurídicas não vinculadas, residentes ou nãoresidentes;

II - adquiridos pela mesma importadora, de pessoas jurídicas não vinculadas, residentes ou não-residentes;

III - em operações de compra e venda praticadas entre outras pessoas jurídicas não vinculadas, residentes ou não-residentes". 
produto pela exportadora ou de venda pela importadora. Essa restrição não possui base no

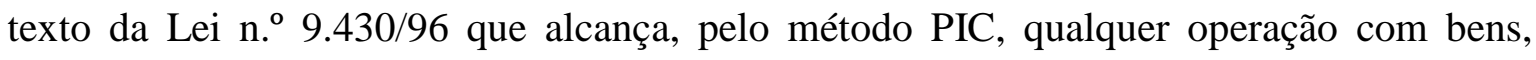
serviços ou direitos, idênticos ou similares, desde que praticadas entre compradores e vendedores não-vinculados" ${ }^{623}$.

No que respeita à análise de comparabilidade envolvida na aplicação do PIC, reporta-se (i.) à seção 2.2.1(I), do CAPÍTULO 2, que discute as noções de bens, serviços ou direitos idênticos ou similares, bem assim as limitações trazidas pelo artigo 10 da Instrução Normativa n. ${ }^{\circ}$ 243/02; (ii.) à seção 2.2.2(VII), que trata da possibilidade de utilização de dados de anos anteriores e posteriores, (iii.) à seção 2.2.2(V), que aborda a proibição de utilização de comparáveis secretos pela administração tributária, bem assim (iv.) à seção 2.2.1, no âmbito da qual se conclui que quaisquer distinções nas condições das transações, que afetem materialmente os preços ou margens de transações similares, devem ser ajustadas, de modo a torná-las comparáveis às transações "testadas"; sustenta-se, ali, que a Lei n. ${ }^{\circ}$ 9.430/96 admite a implementação de quaisquer ajustes para a aplicação do PIC, não obstante as limitações indicadas no artigo $9^{\circ}$ da Instrução Normativa n. $^{\circ}$ $243 / 02^{624}$.

Especificamente no tocante ao item (iv.), acima, saliente-se que, como a lei não fixou limites à implementação de ajustes relacionados às condições comerciais ou financeiras das transações, não pode um normativo infra-legal fazê-lo. Com efeito, se um normativo cria situação que impõe ao contribuinte tributação maior que a aceitável,

\footnotetext{
${ }^{623}$ In: SCHOUERI, Luís Eduardo. Preços de Transferência no Direito Tributário Brasileiro. op. cit., p. 123. $\mathrm{O}$ autor continua seu raciocínio da seguinte forma:

"Uma vez sem suporte legal expresso, essa restrição somente poderia ser aceita se decorresse de mera interpretação legal. Um possível argumento nesse sentido seria dizer que aceitar operações de venda da empresa importadora como limite de preço de importação permitiria à revendedora trabalhar com lucro zero no país, o que seria contrário ao objetivo da legislação de preços de transferência. De fato, ainda que atualmente s legislação de preços de transferência não mais se confunda com a distribuição de lucros entre as unidades de uma empresa multinacional, utilizar o método PIC de forma a permitir que o preço de compra de um produto seja idêntico ao seu preço de venda não parece atingir o objetivo de tratar a transação de compra como praticada entre empresas independentes" (op. cit., p. 123).

${ }^{624} \mathrm{O}$ aludido artigo $9^{\circ}$ e seu $\S 1^{\circ}$ prescrevem que:

“Art. $9^{\circ}$ Os valores dos bens, serviços ou direitos serão ajustados de forma a minimizar os efeitos provocados sobre os preços a serem comparados, por diferenças nas condições de negócio, de natureza física e de conteúdo.

$\S 1^{\circ}$ No caso de bens, serviços e direitos idênticos, somente será permitida a efetivação de ajustes relacionados com (...)".

Note-se, por relevante, que estes dispositivos referem-se tão-somente às limitações de ajustes concernentes às condições comerciais ou financeiras das transações. Os ajustes relacionados à natureza do bem, serviço ou direito objeto da transação, i.e., os ajustes exigidos para que um bem similar torne-se comparável, estão disciplinados no artigo 10 do normativo, sendo que as limitações previstas, porque aplicáveis a todos os métodos, foram discutidas na seção 2.2.1(I), do CAPÍTULO 2.
} 
exigindo-se, a partir de um ajuste na base tributável pelo IRPJ e pela CSLL, um lucro muito acima do real, evidentemente essa interpretação da lei não cumpre sua principal finalidade, i.e., a tributação da renda de acordo com a capacidade econômica de cada contribuinte; pelo contrário, o normativo impõe a tributação pelo imposto sobre a renda a algo que não configura materialmente "renda", de modo que, a par de ilegal, o artigo $9^{\circ}$ do normativo também é inconstitucional, por violar os princípios da capacidade contributiva, a noção constitucional de renda, dentre outros. Não obstante os seus vícios, os ajustes contidos no artigo $9^{\circ}$ da Instrução Normativa n. ${ }^{\circ}$ 243/02 podem ser vislumbrados como exemplos dos ajustes mais comuns nas condições comerciais ou financeiras das transações assemelhadas, de modo a torná-las transações independentes comparáveis para fins da aplicação do PIC. Unicamente em virtude de seu aspecto ilustrativo é que, abaixo, estão indicados os principais ajustes disciplinados pelo artigo $9^{\circ}$ do mencionado normativo, os quais se referem a:

I. prazo para pagamento ${ }^{625}$;

II. quantidades negociadas ${ }^{626}$;

III. obrigação por garantia de funcionamento do bem ou da aplicabilidade do serviço ou direito $^{627}$;

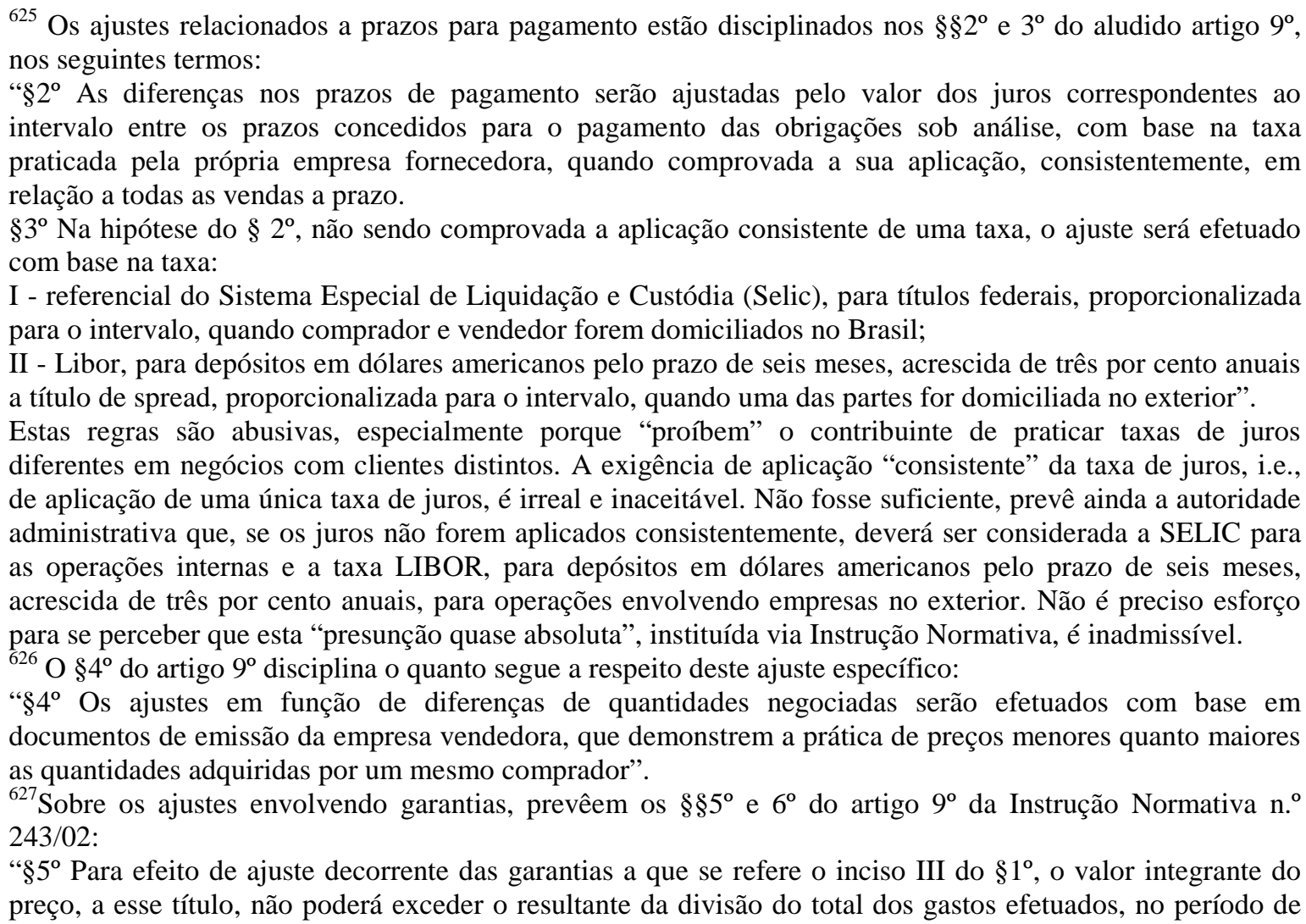


IV. obrigação pela promoção, junto ao público, do bem, serviço ou direito, por meio de propaganda e publicidade ${ }^{628}$;

V. obrigação pelos custos de fiscalização de qualidade, do padrão dos serviços e das condições de higiene ${ }^{629}$;

VI. custos de intermediação, nas operações de compra e venda, praticadas pelas empresas não vinculadas, consideradas para efeito de comparação dos $\operatorname{preços}^{630}$;

apuração anterior, pela quantidade de bens, serviços ou direitos, com garantia em vigor, no mercado nacional, durante o mesmo período.

$\S 6^{\circ} \mathrm{Na}$ hipótese do $\S 5^{\circ}$, se o bem, serviço ou direito não houver, ainda, sido vendido no Brasil, será admitido o custo, em moeda nacional, correspondente à mesma garantia, praticado em outro país".

$\mathrm{O}$ §5 $5^{\circ}$ apresenta limitação repreensível, porque a inclusão de garantias nos preços dos bens ou serviços não se processa a partir dos gastos no último ano. Partes independentes não atuam deste modo e, por decorrência, partes dependentes também não devem adotar este procedimento. Suponha-se, v.g., que num determinado ano A1 sejam vendidas 1.000 unidades do produto $\mathrm{Y}$ no país, ao passo que, para o ano A2, estimam-se vendas de 10.000 unidades. Se a empresa brasileira for a responsável pela prestação de assistência técnica e garantia, obviamente não exigirá um desconto no preço relativo aos gastos no ano A1, mas verificará um custo percentual médio por unidade e, em seguida, multiplicará tal custo pela quantidade de unidades que se estima vender no ano A2. A legislação brasileira, ao invés de comparar as transações controladas com as transações independentes, no âmbito das quais o valor relativo à garantia é estimado e cobrado da contraparte, podendo o garantidor incorrer em lucros ou prejuízos, compara-as a transações controladas "manipuladas", porque apenas partes vinculadas aceitariam um contrato amparado nestas condições econômicas.

${ }^{628}$ Especificamente quanto aos efeitos da obrigação de implementação de estratégias de propaganda e publicidade, prevêem os $\S \S 7^{\circ}$ e $8^{\circ}$ da Instrução Normativa n. ${ }^{\circ} 243 / 02$ :

" $\$ 7^{\circ}$ Nos ajustes em virtude do disposto nos incisos IV e $\mathrm{V}$ do $\S 1^{\circ}$, o preço do bem, serviço ou direito adquirido de uma empresa vinculada, domiciliada no exterior, que suporte o ônus da promoção do bem, serviço ou direito no Brasil, poderá exceder o de outra que não suporte o mesmo ônus, até o montante despendido, por unidade do produto, pela empresa exportadora, com a referida obrigação.

$\S 8^{\circ}$ Para efeito do $\S 7^{\circ}$, no caso de propaganda e publicidade que tenha por finalidade a promoção:

I - do nome ou da marca da empresa, os gastos serão rateados para todos os bens, serviços ou direitos vendidos no Brasil, proporcionalizados em função das quantidades e respectivos valores de cada tipo de bem, serviço ou direito;

II - de um produto, o rateio será em função das quantidades deste".

Novamente, a autoridade administrativa brasileira desvirtua a aplicação do PIC, ao proibir a comparação com as práticas adotadas por terceiros independentes; o que o transcrito $\S 7^{\circ}$ possibilita é uma espécie de rateio de custos, típica de transações vinculadas.

Outro aspecto reprimível desta regulamentação é que o contribuinte brasileiro apenas saberá se deverá ou não reconhecer ajustes após o término do ano-calendário, momento a partir do qual será possível verificar "o montante despendido, por unidade do produto, pela empresa exportadora". Este tipo de regra é totalmente incompatível com o princípio da segurança jurídica, mesmo condiciona o cálculo do tributo de um contribuinte brasileiro à prática de um ato por empresa no exterior; com o fundamento de limitar sem razoabilidade as deduções no país, o fisco brasileiro estimula a manipulação de preços, ao invés de trabalhar para aboli-la.

${ }^{629} \mathrm{O} \S 7^{\circ}$ do artigo $9^{\circ}$ faz referência ao inciso $\mathrm{V}$ do $\S 1^{\circ}$, que se refere aos custos de fiscalização de qualidade, do padrão dos serviços e das condições de higiene, mas este aspecto não foi discutido, naquele parágrafo ou em qualquer outro dispositivo da Instrução Normativa n. ${ }^{\circ}$ 243/02.

${ }^{630}$ Este ajuste foi disciplinado pelo $\$ 9^{\circ}$ do artigo $9^{\circ}$, que dispõe:

" $\$ 9^{\circ}$ Quando forem utilizados dados de uma empresa adquirente que houver suportado os encargos de intermediação na compra do bem, serviço ou direito, cujo preço for parâmetro para comparação com o praticado na operação de compra efetuada com uma empresa vinculada, não sujeita a referido encargo, o preço do bem, serviço ou direito desta poderá exceder o daquela, até o montante correspondente a esse encargo". 
VII. acondicionamento; e

VIII. frete e seguro ${ }^{631}$.

\subsubsection{Método do Preço de Venda nas Exportações ("PVEx").}

Preliminarmente, é relevante frisar que as operações de exportação somente se sujeitam à aplicação dos métodos se não superarem o seu primeiro “teste". Por outras palavras, nos termos do 19, caput, da Lei n. ${ }^{\circ}$ 9.430/96, o contribuinte estará dispensado das regras de arbitramento ali prescritas se comprovar que os preços dos bens, serviços ou direitos exportados para empresas vinculadas foram superiores a 90\% (noventa por cento) do preço médio praticado na venda de bens, serviços ou direitos, idênticos ou similares, no mercado brasileiro, durante o mesmo período. Somente se não configuradas as condições necessárias para o enquadramento nesta espécie de safe harbour é que o contribuinte deve passar à aplicação dos métodos. Detalhes a respeito da aplicação deste safe harbour constam da seção 2.9.2(I) do CAPÍTULO 2.

Enfrentada esta primeira questão preliminar, pondere-se que o método do preço de venda nas exportações [PVEx] equivale ao CUP, a exemplo do PIC. Esta denominação distinta advém da diferenciação que a legislação brasileira fez entre os métodos aplicáveis às operações de importação e os métodos aplicáveis às operações de exportação. Nos

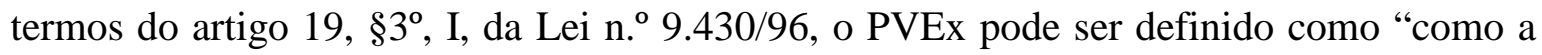
média aritmética dos preços de venda nas exportações efetuadas pela própria empresa, para outros clientes, ou por outra exportadora nacional de bens, serviços ou direitos, idênticos ou similares, durante o mesmo período de apuração da base de cálculo do imposto de renda e em condições de pagamento semelhantes",632. Em qualquer hipótese, as vendas

Este parágrafo possui redação confusa e aplicação bastante complexa: exige-se que a parte envolvida na transação independente comparável demonstre o valor exato dos encargos de intermediação por ela pagos. Se a empresa intermediadora não for do grupo econômico da sociedade "testada", dificilmente este custo será obtido. Deveria a norma prever tão-somente que a parte deveria comprovar os encargos médios praticados no mercado, para aquela espécie de bem, serviço ou direito.

631 Nestes incisos específicos, as previsões do $\S 10^{\circ}$ do artigo $9^{\circ}$ da Instrução Normativa n. ${ }^{\circ} 243 / 02$ são bastante razoáveis e sem a previsão de limitações esdrúxulas. Confira-se o seu teor:

“\$10. Para efeito de comparação, os preços dos bens, serviços e direitos serão, também, ajustados em função de diferenças de custo dos materiais utilizados no acondicionamento de cada um e do frete e seguro incidente em cada caso".

${ }^{632}$ A despeito de a Lei n. ${ }^{\circ}$ 9.430/96 aludir a "média aritmética", o artigo 23 da Instrução Normativa n. 243/02 refere-se a "média aritmética ponderada". Ao contrário do que se deu em relação aos métodos aplicáveis às operações de importação, em que a noção de média ponderada foi incluída no texto legal via Medida Provisória n. ${ }^{\circ}$ 478/09 [cf. artigo 18, incisos I, II e III], os métodos relativos às exportações, previstos no artigo $19, \S 3^{\circ}$, da Lei n. ${ }^{\circ}$ 9.430/96, não tiveram seu texto modificado. Prevalece, neste cenário, a dissonância entre a lei e o normativo infra-legal. 
comparáveis praticadas pelo contribuinte ou por outros exportadores nacionais deverão, sempre, ser extraídas de transações não-vinculadas ${ }^{633}$.

Para a aplicação do PVEx, os preços praticados pelos contribuintes nas exportações devem ser calculados a partir da taxa de câmbio de compra, fixada no boletim de abertura do BACEN, em vigor no dia do embarque dos bens ${ }^{634}$, devendo estes preços serem comparados com os preços praticados em operações efetivadas pelo próprio contribuinte ou por outros exportadores, com partes não-vinculadas. Este critério de utilização do PVEx apresenta muitas impropriedades. De fato, não está claro se apenas podem ser comparadas as transações em que o contribuinte brasileiro e outros exportadores vendem para contribuintes não-vinculados no exterior, ou se transações internas nãovinculadas podem servir de parâmetro. Quando a lei refere-se a "exportadora nacional de bens, serviços ou direitos, idênticos ou similares" [cf. artigo 19, $\S 3^{\circ}$, I, da Lei n. ${ }^{\circ}$ 9.430/96], parece restringir as transações comparáveis a outras operações de exportação, proibindo-se a utilização de dados de outra empresa nacional que opere tão-somente no mercado interno. Esta restrição, contudo, não se justifica: se o PVEx deve ser preferencialmente aplicado, porque representa o método que melhor concretiza o princípio da plena concorrência, quaisquer transações semelhantes devem ser admitidas como parâmetro. Também não existe razão para a vedação de comparáveis externos [v.g., a utilização de dados de uma empresa Argentina, que fabrica produto idêntico e exporta apenas a empresas não-vinculadas]. Para evitar injustiças, devem ser admitidas, para fins de aplicação do PVEx, quaisquer transações idênticas ou semelhantes, desde que passíveis de ajustes razoavelmente precisos ${ }^{635}$.

\footnotetext{
${ }^{633}$ Confira-se, a respeito, o $\$ 8^{\circ}$ do artigo 19 da Lei n. ${ }^{\circ}$ 9.430/96:

“§ $8^{\circ}$ Para efeito do disposto no $\S 3^{\circ}$, somente serão consideradas as operações de compra e venda praticadas entre compradores e vendedores não vinculados".

634 “Art. 22. A receita de vendas de exportação de bens, serviços e direitos será determinada pela conversão em reais à taxa de câmbio de compra, fixada no boletim de abertura do Banco Central do Brasil, em vigor na data:

I - de embarque, no caso de bens;

II- da efetiva prestação do serviço ou transferência do direito.

$\S 1^{\circ}$ A data da efetiva prestação do serviço ou transferência do direito é a data do auferimento da receita, assim considerada o momento em que, nascido o direito à sua percepção, a receita deva ser contabilizada em observância ao regime de competência".

635 “.(...) no PVEx o parâmetro interno de comparação limita-se a dados do exportador nacional. Irrelevante, assim, para a aplicação do PVEx, a demonstração de que o exportador, no exterior, adquiriu de partes independentes produtos idênticos ou semelhantes, em condições e preços comparáveis. Nota-se, aqui, uma limitação, imposta pelo legislador nacional, às alternativas oferecidas ao contribuinte para a apuração do parâmetro arm's length, o que oferece ao contribuinte prejudicado a possibilidade de vir a discutir os critérios do legislador nacional, quando este se desvia do arm's length.
} 
Os ajustes para a aplicação do PVEx, comuns a todos os métodos para o "teste" dos preços de transferência nas operações de exportação, constam dos artigos 15 a 18 da Instrução Normativa n. ${ }^{\circ}$ 243/02. Para o fim de se evitar repetições indevidas, importa destacar que: (i.) as noções de bens, serviços ou direitos idênticos ou similares, bem assim as limitações trazidas pelo artigo 17 da Instrução Normativa n. ${ }^{\circ}$ 243/02, foram discutidas na seção 2.2.1(I), do CAPÍTULO 2; (ii.) a possibilidade de utilização de dados de períodos anteriores ou posteriores aos das transações, referida no artigo 18 do referido normativo, foi tratada na seção 2.2.2(VII); (iii.) a proibição de comparáveis secretos foi exposta na seção 2.2.2(V); e, por fim, (iv.) consta da seção 2.2.1 o debate a respeito da legalidade das limitações de ajustes sobre as condições que afetarem materialmente os preços ou margens de transações similares.

A discussão referida em (iv.) é idêntica àquela tratada na subseção anterior, com respeito ao PIC. Com efeito, as limitações trazidas pelo artigo $9^{\circ}, \S 1^{\circ}$, da Instrução Normativa n. ${ }^{\circ}$ 243/02, são incoerentes com a previsão legal do PIC [cf. artigo 18, I, da Lei n. ${ }^{\circ}$ 9.430/96], assim como as limitações do artigo $15, \S 1^{\circ}$, do mesmo normativo ${ }^{636}$, são incompatíveis com a previsão do PVEx, i.e., com o artigo $19, \S^{\circ}$, I, da Lei n. ${ }^{\circ}$ 9.430/96. Assim como exposto em 4.2.2, supra, os ajustes prescritos no $\S 1^{\circ}$ do artigo 15 devem ser compreendidos como exemplos, e não como os únicos ajustes admitidos para a concretização do PVEx. Os ajustes indicados no $\S 1^{\circ}$, do artigo 15 , do normativo ora discutido, são os seguintes:

I. prazo para pagamento;

II. quantidades negociadas;

III. obrigação por garantia de funcionamento do bem ou da aplicabilidade do serviço ou direito;

De igual modo, a comparação externa admitida para o PVEx apenas leva em conta dados de 'outra exportadora nacional', afastando-se, daí, a possibilidade de o contribuinte demonstrar os parâmetros arm's length de sua transação a partir de dados do mercado internacional" (SCHOUERI, Luís Eduardo. Preços de Transferência no Direito Tributário Brasileiro. op. cit., p. 125).

${ }^{636} \mathrm{O}$ aludido artigo $15^{\circ}$, caput e $\S 1^{\circ}$, que possuem teor idêntico ao do artigo $9^{\circ}$, caput e $\S 1^{\circ}$, discutido na seção 4.2.2, supra, prescrevem que:

"Art. $9^{\circ}$ Os valores dos bens, serviços ou direitos serão ajustados de forma a minimizar os efeitos provocados sobre os preços a serem comparados, por diferenças nas condições de negócio, de natureza física e de conteúdo.

$\S 1^{\circ}$ No caso de bens, serviços e direitos idênticos, somente será permitida a efetivação de ajustes relacionados com (...)". 
IV. obrigação pela promoção, junto ao público, do bem, serviço ou direito, por meio de propaganda e publicidade;

V. obrigação pelos custos de fiscalização de qualidade, do padrão dos serviços e das condições de higiene;

VI. custos de intermediação, nas operações de compra e venda, praticadas pelas empresas não vinculadas, consideradas para efeito de comparação dos preços;

VII. acondicionamento;

VIII. frete e seguro; e

IX. riscos de crédito.

A regulamentação aplicável aos itens I a VIII, supra, é idêntica àquela examinada na subseção anterior, com relação aos ajustes previstos nos incisos I a VIII do $\S^{\circ}$ do artigo $9^{\circ}$ da Instrução Normativa n. ${ }^{\circ} 243 / 02$; na realidade, o artigo $9^{\circ}$ [PIC] tem conteúdo muito semelhante ao do artigo 15 [aplicável a todos os métodos para comprovação dos preços de transferência nas operações de exportação]. Em virtude de tal similitude, não serão abordadas, novamente, as críticas tecidas com relação à regulamentação federal expedida em relação a cada um dos itens de comparabilidade indicados no normativo infra-legal. A única distinção entre os artigos $9^{\circ}$ e $15^{\circ}$ é a de que, especificamente nas operações de exportação, a Instrução Normativa n. ${ }^{\circ}$ 243/02 prevê também ajustes relacionados a riscos de crédito. A disciplina a respeito desse ajuste, todavia, não segue o princípio da plena concorrência e apresenta aplicação muito complicada $^{637}$. Com efeito, prevê o $§ 10^{\circ}$ do artigo 15 da Instrução Normativa n. ${ }^{\circ}$ 243/02 que os ajustes por riscos de crédito apenas podem ser aplicados (a.) se as transações independentes tiverem sido praticadas no país; e (b.) se forem baseados no percentual de perdas aferido pela parte "testadas" no ano-calendário anterior.

Novamente, desvirtua-se o normativo infra-legal dos fins da lei: devem ser admitidos ajustes em quaisquer tipos de transações comparáveis, e não apenas aquelas estabelecidas entre dois residentes. Ademais, a necessidade de os ajustes serem calculados a partir das perdas reais do ano anterior desconsidera totalmente o sentido econômico da

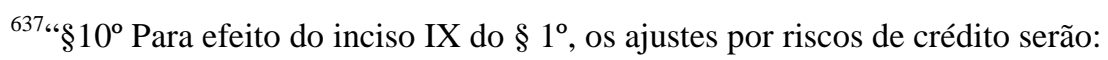

I - admitidos exclusivamente em relação às operações praticadas entre comprador e vendedor domiciliados no Brasil;

II - efetuados com base no percentual resultante da comparação dos totais de perdas e de créditos relativos ao ano-calendário anterior". 
assunção de riscos. Com efeito, uma parte assume riscos porque, com isso, pode obter ganhos maiores. Assim, se um exportador vende para adquirente estrangeiro em situação financeira bastante complicada, provavelmente exigirá um preço maior, ainda que tenha quase certeza de que o preço será pago, sob pena de o seu cliente paralisar suas atividades industriais. O risco pode não ser materializado, mas, ainda assim, a parte que o assumiu deve ser remunerada. Por outras palavras, o ajuste refere-se a riscos, e não à materialização de perdas. Ao vincular o primeiro critério a este segundo, equivocou-se a autoridade tributária.

\subsubsection{Comparable Uncontrolled Financial Transactions (“CUFT"), proposto pelas autoridades norte-americanas para o controle das negociações globais.}

Consoante indicado na seção 3.1 do CAPÍTULO 3, o IRS norte-americano propôs uma minuta de Seção 1.482, capítulo 8, do IRC [Seção 1.482-8/Proposta], a qual contém regras específicas para o controle dos preços de transferência praticados por instituições financeiras em transações envolvendo a negociação global. Estas regras, a despeito de publicadas originalmente em 1998, ainda não foram aprovadas; provavelmente o serão durante o ano-calendário 2010. Independentemente disso, o IRS recomenda que as instituições que praticarem esta espécie de negócio devem, desde logo, amparar o teste dos seus preços nas aludidas normas ${ }^{638}$. Para a aplicação da nova Seção 1.482/Proposta, o contribuinte norte-americano deve pautar-se nas regras gerais de comparabilidade, previstas na Seção 1.482-1 e discutidas na seção 2.2 do CAPÍTULO 2, e, em seguida, complementá-las [ou modificá-las] a partir das normas propostas na Seção 1.4828/Proposta ${ }^{639}$. Nesta última, foram previstos métodos exclusivos para as transações globais [ou "global dealings", como referido na legislação estadunidense e explicado na seção 3.1 do CAPÍTULO 3], além de regras específicas sobre a análise funcional, a regra do melhor método e o intervalo de plena concorrência; há, outrossim, ponderações sobre os

\footnotetext{
${ }^{638}$ In: Federal Register/v. 74, no. 148; texto explicado na seção 3.1 do CAPÍTULO 3.

639 "Section 1.482-8(a)(1) lists specified methods that may be used to determine if global dealing transactions entered into between controlled taxpayers are at arm's length. The enumerated methods must be applied in accordance with all of the provisions of $\S 1.482-1$, including the best method rule of $\S 1.482-1(\mathrm{c})$, the comparability analysis of $\$ 1.482-1(\mathrm{~d})$, and the arm's length range rule of $\$ 1.482-1(\mathrm{e})$. The section further requires that any modifications or supplemental considerations applicable to a global dealing operation set forth in $\$ 1.482-8(\mathrm{a})(3)$ be taken into account when applying any of the transfer pricing methods. Specific modifications to the factors for determining comparability and the arm's length range rule are provided in $\$ 1.482-8(\mathrm{a})(3) "$ (Federal Register/v. 63, no. 44. op. cit, Explanation of provisions, Supplementary Information).
} 
documentos exigidos para a comprovação dos preços de transações vinculadas entre instituições financeiras.

As regras da Seção 1.482-8/Proposta, no entanto, aplicam-se tão-somente aos serviços principais ou ao front-office ${ }^{640}$ das negociações globais praticadas por instituições financeiras associadas, ao passo que a OCDE considera que também as atividades de middle-office e back-office integram este tipo de transação. Nesse sentido, a principal distinção entre a legislação proposta pelas autoridades tributárias estadunidenses, de um lado, e pela OCDE [Relatório GT-1998 e Relatório-2008], de outro, está na abrangência do estudo. Enquanto a OCDE vislumbra uma transação de negociação global que envolve todas as atividades, do trading ao apoio contábil, a lei norte-americana sustenta que os serviços gerais de apoio devem ter seus preços calculados a partir das regras que disciplinam os preços de transferência em transações envolvendo serviços ou a cessão de ativos intangíveis. Portanto, antes de se aplicar a Seção 1.482-8/Proposta, devem ser adequadamente remuneradas, a partir dos métodos pertinentes, as funções de middle-office e back-office. As demais são, em seguida, integradas na análise funcional própria da negociação global, a qual abrange tão-somente dos serviços principais ou front-office, que, segundo a aludida seção proposta, são os seguintes: (a.) pesquisa e desenvolvimento de produtos; (b.) marketing; (c.) precificação; (d.) corretagem/brokering; e (e.) administração de riscos.

Ponderadas estas questões preliminares que respeitam a todos os métodos tratados na Seção 1.482-8/Proposta, assinale-se que o CUFT, especificamente, representa uma variação do CUP que prevê o confronto direto dos preços das operações vinculadas "testadas" com os preços de transações não-vinculadas que sejam idênticas ou similares e tenham sido praticadas em condições análogas, de modo a examinar se as primeiras estão consonantes com o princípio da plena concorrência ${ }^{641}$.

\footnotetext{
640 “\$1.482-8 [proposta] (B) For purposes of paragraph (a)(2)(ii)(A)(2) of this section, such related activities are marketing, sales, pricing, risk management or brokering activities. Such related activities do not include credit analysis, accounting services, back office services, general supervision and control over the policies of the controlled taxpayer, or the provision of a guarantee of one or more transactions entered into by a regular dealer in securities or other participant" (Federal Register/v. 63, no. 44. op. cit).

641 "\$1.482-8 [proposta] (b) (1) General rule. The comparable uncontrolled financial transaction (CUFT) method evaluates whether the amount charged in a controlled financial transaction is arm's length by reference to the amount charged in a comparable uncontrolled financial transaction" (Federal Register/v. 63, no. 44. op. cit).
} 
Para o emprego do CUFT, assim como no CUP, devem ser localizadas transações similares, passíveis de se tornarem "transações independentes comparáveis". Durante esta busca, devem ser adotados os critérios e procedimentos referidos na seção 2.2 do CAPÍTULO 2. Devem ser ponderadas, especialmente, as cinco funções de comparabilidade, sendo que a seção 1.482-8/Proposta (a) prevê regras específicas e/ou adicionais para a aplicação de cada uma delas.

Em relação às características dos instrumentos financeiros ou direitos que forem o objeto da transação, é importante examinar detalhadamente sua natureza, sua relativa relevância no mercado financeiro mundial, sua oferta, sua demanda, a existência de produtos substitutos etc.. Com efeito, a sofisticação e exclusividade do instrumento transacionado têm importante impacto na definição dos preços das transações; diferenças mínimas podem afetar a confiabilidade dos resultados do CUFT. Em exemplo trazido pela legislação norte-americana, discute-se a possibilidade de comparação de transações envolvendo contratos derivativos baseados na cotação internacional de moedas como o USD (dólar norte-americano), o € (euro), a £ (libra esterlina), dentre outros, com contratos amparados na moeda malasiana. Entendeu-se não ser possível a comparação destes tipos de transações, ainda que o derivativo elaborado fosse idêntico em todas as suas demais características $^{642}$. A diferença, na espécie, reside nos riscos trazidos em negociações com distintas moedas. Com efeito, negociações envolvendo o USD, o $€$ ou a $£$ apresentam riscos, sendo impossível, como se viu nos últimos anos com relação ao dólar, prever com exatidão a variação da cotação destas moedas; há, contudo, um maior grau de previsibilidade ou uma certa "delimitação" dos riscos, porque há muitos dados disponíveis para a precificação destes tipos de contrato, há estudos elaborados em diversos ramos de negócios em todo o mundo, além de outros subsídios. Com relação à moeda malasiana, pouco negociada no cenário internacional, há tão poucas informações que provavelmente a

642 "\$1.482-8 [proposta] (a) (4) Example 4. Dissimilar products. The facts are the same as in Example 1 [B is a foreign bank that acts as a market maker in foreign currency in country $X$, the country of which it is a resident. $C$, a country, $Y$ resident corporation, D, a country Z resident corporation, and USFX, a U.S. resident corporation are all members of a controlled group of taxpayers with $B$, and each acts as a market maker in foreign currency] but B, C, D, and USFX also act as a market maker in Malaysian ringgit-U.S. dollar cross-currency options in the United States and countries X, Y, and Z. The ringgit is not widely traded throughout the world and is considered a thinly traded currency. The functional analysis required by $\S 1.482-$ 8(a)(3)(i) shows that the development, marketing, pricing, and risk management of ringgit-U.S. dollar crosscurrency option contracts are different than that of other foreign currency contracts, including option contracts. Moreover, the contractual terms, risks, and economic conditions of ringgit-U.S. dollar crosscurrency option contracts differ considerably from that of other foreign currency contracts, including option contracts. See $\S 1.482-8($ a)(3)(ii) through (iv). Accordingly, the ringgit-U.S. dollar cross-currency option contracts are not comparable to contracts in other foreign currencies" (Federal Register/v. 63, no. 44. op. cit). 
elaboração de um derivativo amparado em sua cotação frente ao USD seria muitas vezes superior a um contrato envolvendo USD e €. A natureza do objeto da transação seria, neste caso, o principal fator de modificação material do preço em determinada negociação envolvendo a negociação global.

A análise funcional, segundo a Seção 1.482-8/Proposta, deve ser efetivada a partir do exame das funções desempenhadas, i.e., (a.) pesquisa e desenvolvimento de produtos; (b.) marketing; (c.) precificação; (d.) corretagem/brokering; e (e.) administração de $\operatorname{riscos}^{643}$. Lembre-se que as funções de middle-office e back-office sujeitam-se ao CUP, ao RPM, ao CPM ou ao PSM, conforme o caso. Ademais, ao contrário do quanto prescrito pela OCDE, a legislação norte-americana não admite, no âmbito da análise funcional das transações envolvendo a negociação global de derivativos, o exame dos ativos utilizados para o desenvolvimento das funções. Também a adequada remuneração do capital e intangíveis eventualmente envolvidos, neste contexto, deve ser testada a partir dos métodos específicos para estas transações, e não via CUFT ou qualquer um dos outros métodos referidos na Seção 1.482-8/Proposta. Esta norma disciplina, ademais, os riscos que, dentre outros, devem ser examinados nestas transações ${ }^{644}$ e as condições econômicas ${ }^{645}$; não há referência à comparabilidade entre distintas estratégias empresariais.

Especificamente no que respeita à análise contratual, além do exame de certas cláusulas específicas dos contratos envolvendo instrumentos financeiros ${ }^{646}$, como, v.g., o

${ }^{643}$ In: Federal Register/v. 63, no. 44. op. cit., $\$ 1.482-8$ [proposta] (a) (3) (i).

644 " $\$ 1.482-8$ [proposta] (a) (3) (iii) Risk. In lieu of the list set forth in $\$ 1.482-1(\mathrm{~d})(3)$, significant risks that could affect the prices or profitability include -

(A) Market risks, including the volatility of the price of the underlying property;

(B) Liquidity risks, including the fact that the property (or the hedges of the property) trades in a thinly traded market;

(C) Hedging risks;

(D) Creditworthiness of the counterparty; and

(E) Country and transfer risk" (Federal Register/v. 63, no. 44. op. cit).

645 " $\$ 1.482-8$ [proposta] (a) (3) (iv) Economic conditions. In lieu of the list set forth in $\S 1.482-1(\mathrm{~d})(3)(\mathrm{iv})$

(A) through $(\mathrm{H})$, significant economic conditions that could affect the prices or profitability include -

(A) The similarity of geographic markets;

(B) The relative size and sophistication of the markets;

(C) The alternatives reasonably available to the buyer and seller;

(D) The volatility of the market; and

(E) The time the particular transaction is entered into" (Federal Register/v. 63, no. 44. op. cit).

646 " $\$ 1.482-8$ [proposta] (a) (3) (ii) Contractual terms. In addition to the terms set forth in $\S 1.482-$ 1(d)(3)(ii)(A), and subject to $\S 1.482-1(\mathrm{~d})(3)(\mathrm{ii})(\mathrm{B})$, significant contractual terms for financial products transactions include -

(A) Sales or purchase volume;

(B) Rights to modify or transfer the contract;

(C) Contingencies to which the contract is subject or that are embedded in the contract; 
volume, a data e o local, apresenta grande importância o seu prazo de duração, haja vista a enorme volatilidade no mercado financeiro. Sabe-se que contratos futuros para compra de USD pelo prazo de 30 dias têm menores taxas que contratos idênticos, mas com o prazo de 180 dias; os riscos assumidos pela instituição, neste último caso, são muitas vezes mais elevados. Nas negociações globais, estas diferenças de prazo são mais reduzidas, pela própria natureza das operações, sendo que, em alguns períodos específicos, podem ocorrer várias alterações relevantes num intervalo inferior $\mathrm{a} 1 \mathrm{~h}^{647}$. Adicionalmente, ressalte-se que, para a avaliação da viabilidade de ingresso em determinadas operações globais nãovinculadas, as instituições financeiras elaboram modelos de precificação estatísticos para calcular o preço dos seus produtos com amparo em dados de mercado, como, v.g., taxas de juros, cotações, riscos de mercado etc.. Estes modelos são, inclusive, um importante ativo das instituições que transacionam neste mercado. Mas, por mais que os modelos

(D) Length of the contract;

(E) Settlement date;

(F) Place of settlement (or delivery);

(G) Notional principal amount;

(H) Specified indices;

(I) The currency or currencies in which the contract is denominated;

(J) Choice of law and jurisdiction governing the contract to the extent chosen by the parties; and

(K) Dispute resolution, including binding arbitration" (Federal Register/v. 63, no. 44. op. cit).

647 "\$1.482-8 [proposta] (a) (4) Example 5. Relevant time period. (i) USFX is a U.S. resident corporation that is a regular dealer in securities acting as a market maker in foreign currency by buying from and selling currencies to customers. C performs marketing and pricing activities with respect to USFX's foreign currency operation. Trading in Deutsche marks (DM) is conducted between 10:00 a.m. and 10:30 a.m. and between 10:45 a.m. and 11:00 a.m. under the following circumstances.

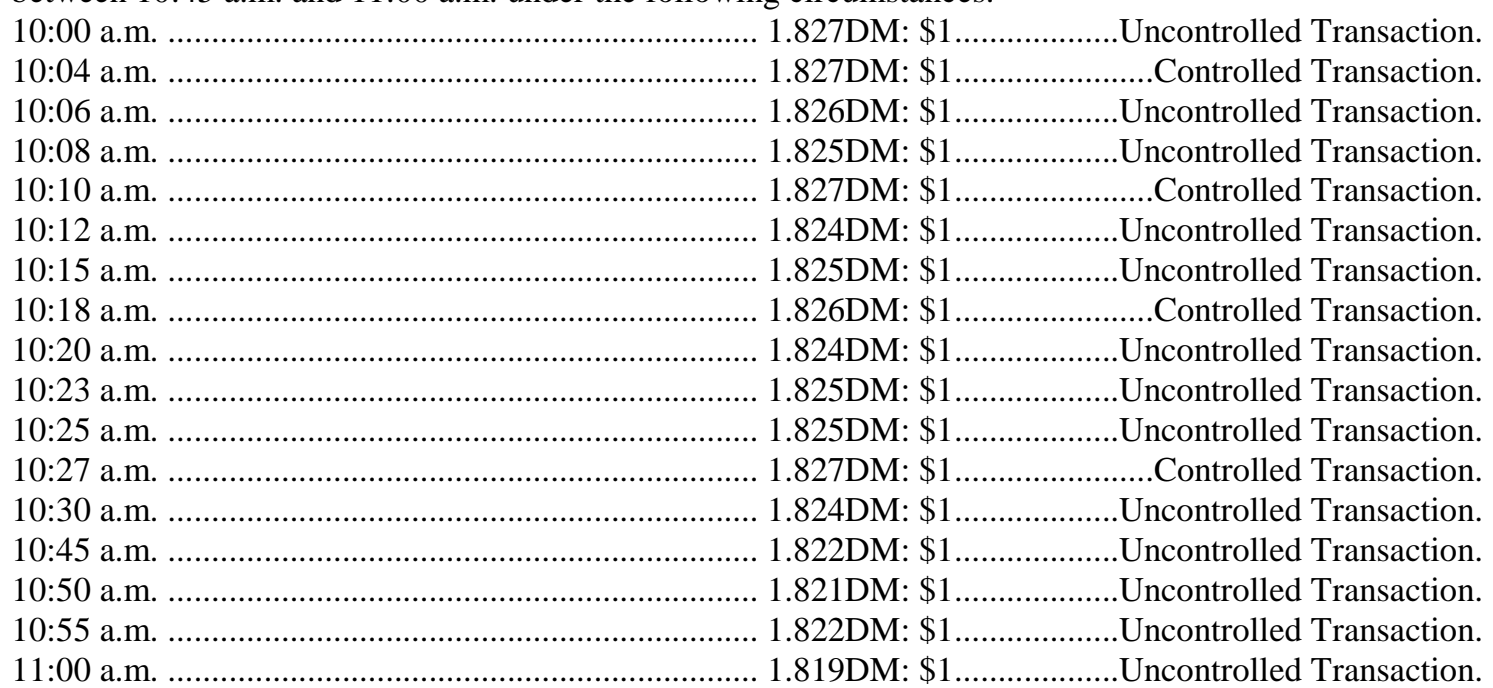

(ii) USFX and $\mathrm{C}$ are participants in a global dealing operation under $\S 1.482-8(\mathrm{a})(2)(\mathrm{i})$. Therefore, USFX determines its arm's length price for its controlled DM contracts under $\S 1.482-8(\mathrm{a})(4)$. Under $\S 1.482-$ $8(a)(4)$, the relevant arm's length range for setting the prices of USFX's controlled DM transactions occurs between 10:00 a.m. and 10:30 a.m. Because USFX has no controlled transactions between 10:45 a.m. and 11:00 a.m., and the price movement during this later time period continued to decrease, the 10:45 a.m. to 11:00 a.m. time period is not part of the relevant arm's length range for pricing USFX's

controlled transactions" (Federal Register/v. 63, no. 44. op. cit). 
estatísticos sejam sofisticados e muito bem elaborados, se não forem alimentados com dados contemporâneos às transações, deixam de ser adequados para a aplicação do CUFT ou de qualquer outro método para o "teste" de transações globais ${ }^{648}$.

A questão dos modelos estatísticos de precificação referida no parágrafo anterior traz à tona a discussão sobre os comparáveis internos e externos para a aplicação do CUPF. A explicação sobre estas duas espécies de comparáveis consta da subseção seção 2.2.2(IV) do CAPÍTULO 2. São comparáveis internos as transações praticadas entre o contribuinte "testado" e empresas independentes; transmudando-se para a questão da negociação global, se uma instituição norte-americana $\mathrm{X}$ celebra dezenas de contratos futuros de dólar com seus clientes e, a um mesmo tempo, contrata em idênticas condições com suas subsidiárias em todo o mundo, por ser a responsável pelo "book" dos riscos relativos àquela moeda, será possível aferir comparáveis internos bastante confiáveis ${ }^{649}$. De outro lado, se a mesma instituição X celebrar apenas transações vinculadas, apenas poderá aplicar o CUPF a partir de comparáveis externos. Uma alternativa muitas vezes disponível neste mercado é a utilização de dados de bolsas de mercadorias e futuros, dados coletados e disponibilizados pelos reguladores ou agentes do sistema bancário etc.. Estes dados são denominados "evidências indiretas de transações financeiras independentes comparáveis". No campo da negociação global, estas evidências indiretas são inseridas nos modelos estatísticos de precificação e, uma vez processados os modelos, obtém-se os preços

648 “\$1.482-8 [proposta] (a) (4) (ii) Reliability. In determining the reliability of an arm's length range, it is necessary to consider the fact that the market for financial products is highly volatile and participants in a global dealing operation frequently earn only thin profit margins. The reliability of using a statistical range in establishing a comparable price of a financial product in a global dealing operation is based on facts and circumstances. In a global dealing operation, close proximity in time between a controlled transaction and an uncontrolled transaction may be a relevant factor in determining the reliability of the uncontrolled transaction as a measure of the arm's length price. The relevant time period will depend on the price volatility of the particular product" (Federal Register/v. 63, no. 44. op. cit).

649 " $\$ 1.482-8$ [proposta] (b) (5) Example 1. Comparable uncontrolled financial transactions. (i) B is a foreign bank resident in country $\mathrm{X}$ that acts as a market maker in foreign currency in country $\mathrm{X}$. $\mathrm{C}$, a country $\mathrm{Y}$ resident corporation, D, a country $\mathrm{Z}$ resident corporation, and USFX, a U.S. resident corporation are all members of a controlled group of taxpayers with B, and each acts as a market maker in foreign currency. In addition to market marking activities conducted in their respective countries, C, D, and USFX each employ marketers and traders, who also perform risk management with respect to their foreign currency operations. In a typical business day, B, C, D, and USFX each enter into several hundred spot and forward contracts to purchase and sell Deutsche marks (DM) with unrelated third parties on the interbank market. In the ordinary course of business, B, C, D, and USFX also each enter into contracts to purchase and sell DM with each other. On a typical day, no more than $10 \%$ of USFX's DM trades are with controlled taxpayers. USFX's DM-denominated spot and forward contracts do not vary in their terms, except as to the volume of DM purchased or sold. The differences in volume of DM purchased and sold by USFX do not affect the pricing of the DM. USFX maintains contemporaneous records of its trades, accounted for by type of trade and counterparty. The daily volume of USFX's DM-denominated spot and forward contracts consistently provides USFX with third party transactions that are contemporaneous with the transactions between controlled taxpayers" (Federal Register/v. 63, no. 44. op. cit). 
comparáveis. Pequenos ajustes nas transações também podem ser efetivados via modelo. Como os modelos são privados e as fontes de dados para a sua alimentação podem não conter informações suficientemente detalhadas, as autoridades tributárias estadunidenses preocupam-se sobremaneira com esta situação. Em virtude disso, para que possa utilizar este tipo de comparáveis externos, a instituição financeira deverá armazenar registros para comprovar a sua contemporaneidade; ademais, caso o diretor distrital fiscal exija esta providência, deverá explicar seu modelo estatístico de precificação ${ }^{650}$. O contribuinte deverá também comprovar que o uso de dados desta espécie é rotineiro naquele determinado mercado ${ }^{651}$ e que os resultados obtidos atendem ao princípio da plena concorrência ${ }^{652}$. De fato, por mais que exista uma importante corrente na doutrina norteamericana que sustenta que a negociação global de instrumentos financeiros seria o campo adequado para a aplicação de fórmulas predeterminadas de lucros ["formulary apportionment”], bem assim outra corrente que acusa a prática adotada no território norteamericano de desvirtuar-se daquele princípio, o IRS apregoa que o princípio da plena concorrência permanece sendo o único critério aplicável para o teste dos preços de transferência, em quaisquer tipos de transações.

650 " $\$ 1.482-8$ [proposta] (b) (3) Indirect evidence of the price of a comparable uncontrolled financial transaction (i) In general. The price of a CUFT may be derived from data from public exchanges or quotation media if the following requirements are met -

(A) The data is widely and routinely used in the ordinary course of business in the industry to negotiate prices for uncontrolled sales;

(B) The data derived from public exchanges or quotation media is used to set prices in the controlled transaction in the same way it is used for uncontrolled transactions of the taxpayer, or the same way it is used by uncontrolled taxpayers; and

(C) The amount charged in the controlled transaction is adjusted to reflect differences in quantity,

contractual terms, counterparties, and other factors that affect the price to which uncontrolled taxpayers would agree" (Federal Register/v. 63, no. 44. op. cit).

651 " $\$ 1.482-8$ [proposta] (b) (2) (iii.) (...) In the case of a global dealing operation in which the CUFT is set through the use of indirect evidence, participants generally must establish data from a public exchange or quotation media contemporaneously to the time of the transaction, retain records of such data, and upon request furnish to the district director any pricing model used to establish indirect evidence of a CUFT, in order for this method to be a reliable means of evaluating the arm's length nature of the controlled transactions" (Federal Register/v. 63, no. 44. op. cit).

652 "§1.482-8 [proposta] (a) (4) (iii) The district director may, notwithstanding $§ 1.482-1(\mathrm{e})(1)$, adjust a taxpayer's results under a method applied on a transaction-by-transaction basis if a valid statistical analysis demonstrates that the taxpayer's controlled prices, when analyzed on an aggregate basis, provide results that are not arm's length. See $§ 1.482-1$ (f)(2)(iv). This may occur, for example, when there is a pattern of prices in controlled transactions that are higher or lower than the prices of comparable

uncontrolled transactions" (Federal Register/v. 63, no. 44. op. cit). 


\subsection{Métodos de comparação indireta baseados no preço de revenda deduzido de determinada margem bruta de revenda.}

\subsubsection{Resale Price Method ("RPM").}

O método do preço de revenda menos lucro ou RPM, concretiza-se a partir da comparação dos preços e das margens brutas de lucro obtidas em operações vinculadas com os preços e margens aferidos em operações não-vinculadas relativas a bens, serviços ou direitos, idênticos ou similares, em circunstâncias análogas. Por se tratar de um dos métodos tradicionais indiretos para se atingir o princípio da plena concorrência, o emprego do RPM desenvolve-se em duas etapas ${ }^{653}$. Primeiramente, examina-se o preço do produto, serviço ou direito, adquirido de parte vinculada e revendido para parte não-vinculada. Desse preço, em seguida, é deduzida a margem bruta de revenda, aferida a partir da função desempenhada, dos ativos empregados e dos riscos assumidos; devem ser efetivados, outrossim, os ajustes necessários, obtendo-se, ao final, o preço de plena concorrência.

A margem bruta de revenda corresponde à divisão do lucro operacional bruto ou lucro bruto, demonstrado a partir das disposições do artigo 187 da Lei n. ${ }^{\circ}$ 6.404/76, pela receita líquida de venda dos bens, serviços ou direitos. Assim, [margem bruta] (=) [lucro bruto] (/) [receita líquida]. Em síntese, o contribuinte escritura todas as suas receitas brutas, deduzindo-se deste valor as vendas canceladas, os descontos incondicionais e os tributos sobre vendas, em especial o ICMS [ou o ISS, se for o caso], o PIS e a Cofins; o resultado obtido corresponde à receita líquida. Deste valor são descontados os custos dos produtos vendidos ou dos serviços prestados; estes custos devem compreender os custos dos bens adquiridos de partes relacionadas e, ademais, quaisquer custos relativos ao valor agregado pelo contribuinte ${ }^{654}$. A diferença entre a receita líquida e estes custos forma o lucro bruto.

\footnotetext{
653 "2.14 The resale price method begins with the price at which a product that has been purchased from an associated enterprise is resold to an independent enterprise. This price (the resale price) is then reduced by an appropriate gross margin (the 'resale price margin') representing the amount out of which the reseller would seek to cover its selling and other operating expenses and, in the light of the functions performed (taking into account assets used and risks assumed), make an appropriate profit. What is left after subtracting the gross margin can be regarded, after adjustment for other costs associated with the purchase of the product (e.g. customs duties), as an arm's length price for the original transfer of property between the associated enterprises" (OCDE. Transfer Pricing Guidelines for Multinational Enterprises and Tax Administrations, op. cit., p. II-5).

${ }^{654}$ Nos termos do artigo 187 da Lei n. ${ }^{\circ}$ 6.404, de 15 de dezembro de 1976, que disciplina os itens que devem compor a demonstração do resultado do exercício, o lucro bruto seria formado da seguinte forma:

Receita bruta de vendas

(-) devoluções e abatimentos

(-) descontos incondicionais
} 
A partir deste lucro é que se calcula a margem de revenda adequada. Tecnicamente, contudo, o RPM não se vale da "margem" propriamente dita, mas do valor em moeda corrente correspondente à multiplicação da margem pela receita líquida, i.e., do valor do lucro operacional bruto ${ }^{655}$. Com efeito, para a definição do cálculo do preço parâmetro via aplicação do RPM, deve-se efetivar o seguinte cálculo:

$$
\text { Preço parâmetro (=) }
$$

Preço de revenda líquido (-) custo do produto vendido ou dos serviços prestados, incluindose valor agregado pelo revendedor (-) lucro operacional bruto.

O RPM pode ser aplicado tão-somente se uma das duas condições seguintes for cumprida: (a.) se não houver diferenças entre as transações comparadas ou, se houver, constatar-se que estas diferenças não têm efeitos materiais sobre o preço praticado; ou (b.) se forem constatadas dessemelhanças materialmente relevantes entre a transação praticada e a transação independente comparável, elas possam ser alvo de ajustes razoavelmente precisos para a eliminação dos efeitos econômicos das diferenças materiais. Estes requisitos devem ser atendidos tanto no processo de busca dos preços de operações de revenda entre partes não-vinculadas, quanto no exame da margem bruta de lucro mais adequada, o qual representa o ponto mais crítico na aplicação do RPM ${ }^{656}$.

Para que se possa proceder ao confronto de preços e margens, podem ser buscados comparáveis internos ou externos, como explicado na subseção 2.2.2(IV) do CAPÍTULO 2. São comparáveis internos as transações praticadas entre o contribuinte “testado" e empresas independentes. O exemplo clássico deste tipo de comparável no RPM

(-) tributos sobre vendas

(=) Receita líquida

(-) custo das mercadorias vendidas ou custo dos serviços prestados (=) Lucro bruto ou Lucro operacional bruto.

655 “\$1.482-3 (c) (2) (i) Determination of arm's length price. The resale price method measures an arm's length price by subtracting the appropriate gross profit from the applicable resale price for the property involved in the controlled transaction under review";

“\$1.482-3 (c) (2) (iii) Appropriate gross profit. The appropriate gross profit is computed by multiplying the applicable resale price by the gross profit margin (expressed as a percentage of total revenue derived from sales) earned in comparable uncontrolled transactions" [26 CFR Ch. I (4-1-09 Edition)].

656 "The critical element in applying the resale price method is determining the resale price margin, which is based on the general comparability criteria of the Guidelines. The resale price margin of the reseller in the controlled transaction may be determined by reference to the resale price margin that the same reseller earns on items purchased ad sold in comparable uncontrolled transactions. It is also appropriate to use (where such data are available) the resale price margin that an independent enterprise earned in comparable uncontrolled transactions, provided that the reseller performs the same or similar functions as in the controlled transaction" (HAMMER, Richard M. et. al. International Transfer Pricing - OCDE Guidelines. op. cit. item 4.03). 
seria o seguinte: (a.) uma determinada empresa adquire produtos de empresa associada e, em seguida, (b.) revende-os para partes não-vinculadas e para partes vinculadas; estas vendas não-vinculadas permitem um exame adequado dos preços de revenda a partes vinculadas. Especialmente no RPM, os comparáveis internos são os mais recomendados porque os preços e margens externos normalmente são formulados segundo distintas estratégias empresariais, graus de eficiência administrativa, de controles de estoques etc. $^{657}$; as diferenças materialmente relevantes geradas por estes aspectos precisam ser adequadamente medidas e ajustadas nas margens.

Em adição, saliente-se que, normalmente, os comparáveis externos estão "viciados" por divergências entre os critérios contábeis, que podem afetar o lucro operacional bruto; nem sempre estas diferenças são facilmente detectáveis e/ou ajustáveis. Suponha-se, v.g., que a empresa $\mathrm{X}$ contabilize os seus projetos de pesquisa e desenvolvimento ("P\&D") como custo do produto vendido, ao passo que a empresa Y contabiliza-os integralmente como despesas operacionais; para que as transações de $\mathrm{X}$ e $\mathrm{Y}$ sejam comparáveis, este fator deverá ser ajustado. Ressalte-se, a este passo, que a existência de uma "consistência contábil" entre as transações que se pretende comparar tem sido objeto de bastante preocupação por parte das autoridades estadunidenses que, inclusive, introduziram na Seção $1.482-3$ regra específica sobre esta questão ${ }^{658}$.

657 " 2.20 . When the resale price margin used is that of an independent enterprise in a comparable transaction, the reliability of the resale price method may be affected if there are material differences in the ways the associated enterprises and independent enterprises carry out their business. Such differences could include those that affect the level of costs taken into account (e.g., the differences could include the effect of management efficiency on levels and ranges of inventory maintenance), which may well have an impact on the profitability of an enterprise but which may not necessarily affect the price at which it buys or sells its goods or services in the open market. These types of characteristics should be analyzed in determining whether an uncontrolled transaction is comparable for purposes of applying the resale price method" (OCDE. Transfer Pricing Guidelines for Multinational Enterprises and Tax Administrations. op. cit., p. II-7). Texto não alterado pela Minuta-2009.

658 “\$1.482-3 (c) (3) (iii) (B) Consistency in accounting. The degree of consistency in accounting practices between the controlled transaction and the uncontrolled comparables that materially affect the gross profit margin affects the reliability of the result. Thus, for example, if differences in inventory and other cost accounting practices would materially affect the gross profit margin, the ability to make reliable adjustments for such differences would affect the reliability of the results. Further, the controlled transaction and the uncontrolled comparable should be consistent in the reporting of items (such as discounts, returns and allowances, rebates, transportation costs, insurance, and packaging) between cost of goods sold and operating expenses";

"§1.482-3 (c) (4) Example 4. Example 4. USSub, a U.S. corporation, is the exclusive distributor of widgets for its foreign parent. To determine whether the gross profit margin of $25 \%$ earned by USSub is an arm's length result, the district director considers applying the resale price method. There are several uncontrolled distributors that perform similar functions under similar circumstances in uncontrolled transactions. However, the uncontrolled distributors treat certain costs such as discounts and insurance as cost of goods sold, while USSub treats such costs as operating expenses. In such cases, accounting reclassifications, 
Consoante referido na seção 4.1, acima, as margens brutas são, em relação aos preços, menos afetadas por diferenças físicas ou materiais dos produtos, bens ou direitos transacionados; por decorrência, o RPM e o CPM podem apresentar maior utilidade que o CUP nas hipóteses em que não forem localizados bens, serviços ou direitos idênticos. Isso não significa, contudo, que as margens não reflitam a natureza do objeto da transação ou que sejam totalmente desvinculadas desse último; o que se pode constatar é que diferenças mínimas entre os bens, serviços ou direitos, têm menor impacto no lucro bruto que no preço final da transação, possibilitando-se, em determinados casos, a aplicação mais adequada do princípio da plena concorrência ${ }^{659}$. Consoante salientado pela OCDE, no livre mercado, a remuneração por funções semelhantes tende a ser próxima em diferentes atividades; já os preços apenas se aproximam se um produto for substituto do outro ${ }^{660}$. Claro que quanto mais semelhantes os produtos, melhor a confiabilidade dos resultados obtidos com o RPM, especialmente se há ativos intangíveis de elevado valor por ele adicionados ao produto; é, de fato, complexa a mensuração de margens nestes $\operatorname{casos}^{661}$. De

pursuant to $\S 1.482-3(\mathrm{c})(3)(\mathrm{iii})(\mathrm{B})$, must be made to ensure consistent treatment of such material items. Inability to make such accounting reclassifications will decrease the reliability of the results of the uncontrolled transactions" [26 CFR Ch. I (4-1-09 Edition)].

659 " $\$ 1.482-3$ (c) (3) (ii) (B) Other comparability factors. Comparability under this method is less dependent on close physical similarity between the products transferred than under the comparable uncontrolled price method. For example, distributors of a wide variety of consumer durables might perform comparable distribution functions without regard to the specific durable goods distributed. Substantial differences in the products may, however, indicate significant functional differences between the controlled and uncontrolled taxpayers. Thus, it ordinarily would be expected that the controlled and uncontrolled transactions would involve the distribution of products of the same general type (e.g., consumer electronics). Furthermore, significant differences in the value of the distributed goods due, for example, to the value of a trademark, may also affect the reliability of the comparison" [26 CFR Ch. I (4-1-09 Edition)].

${ }_{660}$ In: OCDE. Transfer Pricing Guidelines for Multinational Enterprises and Tax Administrations. op. cit., p. II-6, item 2.17. Texto não alterado pela Minuta-2009.

${ }^{661}$ "Product vs. Functional Differences. In making comparisons for purposes of the resale price method, fewer adjustments are normally needed to account for product differences than under the CUP method, because minor product differences are less likely to have as material an effect on profit

margin as they do on price.

Although broader product differences can also be allowed in the resale price method, the property transferred in the controlled transaction still must be compared with the property being transferred in the uncontrolled transaction. Broader product differences are more likely to be reflected in differences in functions performed between the parties to the controlled and uncontrolled transactions. Although less product comparability may be required in using the resale price method, closer comparability of products will nonetheless produce better results. For example, where there is a high-value or relatively unique intangible involved in a transaction, product similarity may assume a greater importance and particular attention should be paid to it to ensure that the comparison is valid. In some cases, it may also be appropriate to give more weight to other attributes of comparability (such as functions performed, economic circumstances, risks assumed, contractual provisions, and related matters) when the profit margin relates primarily to these other attributes and only secondarily to the particular product being transferred. This circumstance usually exists where the profit margin is determined for an associated enterprise that does not use relatively unique assets (i.e., highly valuable intangibles) to add significant value to the product being transferred. In other words, where uncontrolled and controlled transactions are comparable in all characteristics other than the product itself, the resale price method might produce a more reliable measure of arm's length conditions than the CUP method, unless 
todo modo, ao contrário do que se sucede em relação ao CUP, centrado essencialmente nas características dos bens, serviços ou direitos transacionados, o emprego do RPM deve voltar-se para o exame dos outros fatores, muitos dos quais sequer afetam os preços, como, v.g., as estruturas de custo, as eficiências administrativas, o panorama econômico etc. ${ }^{662}$. Devem ser aplicados, outrossim, os demais fatores de comparabilidade, i.e., (I.) a análise funcional [atividades desempenhadas, ativos empregados e riscos envolvidos]; (II.) a análise contratual; (III.) as circunstâncias econômicas; e (IV.) as estratégias empresariais $^{663}$. Cada um dos fatores de comparabilidade, bem assim os ajustes respectivos, foram expostos na seção 2.2 do CAPÍTULO 2. Será a extensão e a qualidade dos ajustes relativos a cada um dos cinco fatores de comparabilidade que afetará a relativa confiabilidade da análise dos preços de transferência mediante a aplicação do RPM.

Especificamente no que concerne à análise funcional, ressalte-se que a margem de lucro bruta está diretamente vinculada à quantidade e relevância das atividades desempenhadas pelo revendedor. Assim, v.g., uma determinada empresa atua como mero "agente" e adquire bens de sociedade controladora para revenda em seu país, sem assumir quaisquer responsabilidades concernente a garantias, variações cambiais etc., certamente auferirá margem bruta de lucro inferior à de outro revendedor que, além de assumir riscos de câmbio e responsabilizar-se pela assistência técnica do produto no país, também será o responsável por toda a estratégia de marketing para o fortalecimento da marca ${ }^{664}$.

reasonably accurate adjustments could be made to account for differences in the products transferred" (HAMMER, Richard M. et. al. International Transfer Pricing - OCDE Guidelines. op. cit. item 4.03[2]).

662 "\$1.482-3 (c) (3) (ii) (B) (...) Finally, the reliability of profit measures based on gross profit may be adversely affected by factors that have less effect on prices. For example, gross profit may be affected by a variety of other factors, including cost structures (as reflected, for example, in the age of plant and equipment), business experience (such as whether the business is in a start-up phase or is mature), or management efficiency (as indicated, for example, by expanding or contracting sales or executive compensation over time). Accordingly, if material differences in these factors are identified based on objective evidence, the reliability of the analysis may be affected" [26 CFR Ch. I (4-1-09 Edition)].

663 " $\$ 1.482-3$ (c) (3) (ii) (C) (...) Specific examples of the factors that may be particularly relevant to this method include -

(1) Inventory levels and turnover rates, and corresponding risks, including any price protection programs offered by the manufacturer;

(2) Contractual terms (e.g., scope and terms of warranties provided, sales or purchase volume, credit terms, transport terms);

(3) Sales, marketing, advertising programs and services, (including promotional programs, rebates, and co-op advertising);

(4) The level of the market (e.g., wholesale, retail, etc.); and

(5) Foreign currency risks" [26 CFR Ch. I (4-1-09 Edition)].

664 " $2.24(\ldots)$ This level of activities can range widely from the case where the reseller performs only minimal services as a forwarding agent to the case where the reseller takes on the full risk of ownership together with the full responsibility for and the risks involved in advertising, marketing, distributing and guaranteeing the goods, financing stocks, and other connected services. If the reseller in the controlled 
Especificamente quanto à publicidade, importa consignar que apenas faz jus a uma margem superior de lucro aquele contribuinte que desembolsa recursos próprios e/ou incorre em riscos. Nesse sentido, se uma empresa emprega recursos para o custeio de comerciais de tevê, mas estes recursos são descontados do preço pago ao fornecedor pelo fornecimento dos bens, esta empresa não tem direito a uma margem mais elevada, porque não assumiu riscos; no máximo, pode cobrar do fornecedor um preço pelos serviços prestados. Já o contribuinte que contribui para a propaganda com recursos próprios, com o objetivo de elevar sua renda futura, sem descontos no preço [ou com descontos reduzidos], provavelmente praticará uma maior margem bruta na venda dos produtos. Sob a perspectiva da análise funcional, são situações totalmente distintas e que somente podem ser comparadas após a implementação [se possível] de ajustes razoavelmente precisos.

Se, por exemplo, uma determinada empresa vende produtos sem garantia, não pode ter suas margens comparadas a transações de terceiros que prestam assistência técnica, porque as margens destes últimos serão superiores ${ }^{665}$. Também se espera uma elevação das margens brutas nas hipóteses em que um revendedor possui acordos de exclusividade. Os efeitos materiais destes acordos nas margens, contudo, demanda o exame de sua extensão geográfica, da competitividade dos substitutos naquele determinado mercado etc. ${ }^{666}$. Ambas as situações justificam a implementação de ajustes nos preços e/ou

transaction does not carry on a substantial commercial activity but only transfers the goods to a third party, the resale price margin could, in light of the functions performed, be a small one. The resale price margin could be higher where it can be demonstrated that the reseller has some special expertise in the marketing of such goods, in effect bears special risks, or contributes substantially to the creation or maintenance of intangible property associated with the product" (OCDE. Transfer Pricing Guidelines for Multinational Enterprises and Tax Administrations. op. cit., p. II-8). Texto não alterado pela Minuta-2009.

${ }^{665}$ Confira-se, a respeito, o seguinte exemplo, extraído da Diretiva da OCDE:

"2.29 Assume that there are two distributors selling the same product in the same market under the same brand name. Distributor A offers a warranty; Distributor B offers none. Distributor A is not including the warranty as part of a pricing strategy and so sells its product at a higher price resulting in a higher

gross profit margin (if the costs of servicing the warranty are not taken into account) than that of Distributor $\mathrm{B}$, which sells at a lower price. The two margins are not comparable until an adjustment is made to account for that difference" (OCDE. Transfer Pricing Guidelines for Multinational Enterprises and Tax Administrations. op. cit., p. II-10). Texto não alterado pela Minuta-2009.

666 "2.27 The resale price margin should also be expected to vary according to whether the reseller has the exclusive right to resell the goods. Arrangements of this kind are found in transactions between independent enterprises and may influence the margin. Thus, this type of exclusive right should be taken into account in any comparison. The value to be attributed to such an exclusive right will depend to some extent upon its geographical scope and the existence and relative competitiveness of possible substitute goods. The arrangement may be valuable to both the supplier and the reseller in an arm's length transaction. For instance, it may stimulate the reseller to greater efforts to sell the supplier's particular line of goods. On the other hand, such an arrangement may provide the reseller with a kind of monopoly with the result that the reseller possibly can realize a substantial turn over without great effort. Accordingly, the effect of this factor upon the appropriate resale price margin must be examined with care in each case" (OCDE. Transfer Pricing 
margens antes da obtenção do preço parâmetro. Ainda a respeito, ressalte-se que muitas situações práticas exigirão a implementação de vários ajustamentos a um mesmo tempo como, v.g., relativos à prestação de garantia, a critérios contábeis, a despesas de marketing etc. ${ }^{667}$.

Remonta a 1973 um exemplo famoso de tentativa de imposição tributária a partir da comparação de margens brutas por parte das autoridades inglesas; à época, os supostos abusos cometidos pela indústria Hoffman La Roche representaram um importante fator político para a introdução de regras para o controle dos preços de transferência na Inglaterra. Consoante resumido por Sol PICCIOTTO, a Hoffman La Roche comercializava no território inglês dois recém lançados anti-barbitúricos, denominados Valium e Librium. Os princípios ativos destes medicamentos eram adquiridos de afiliada localizada na Suíça, e revendidos para o Sistema Nacional de Saúde da Inglaterra; os preços pagos pelos referidos insumos, contudo, era mais de quarenta vezes superior aos preços praticados por pequenas indústrias italianas, não atingidos pela patente de tal indústria farmacêutica. A Comissão de Investigação de Monopólios questionou esta situação e requereu à Hoffman La Roche uma explicação sobre estes abusos; ao final, a companhia foi obrigada a pagar multa ao Sistema Nacional de Saúde pelos prejuízos a ele causados. A um mesmo tempo, iniciou-se fiscalização tributária, com o intuito de apurar desvio de lucros do território

Guidelines for Multinational Enterprises and Tax Administrations. op. cit., p. II-9). Texto não alterado pela Minuta-2009.

${ }^{667}$ A respeito da realização de diversos ajustes numa única análise de comparabilidade, confira-se o exemplo abaixo transcrito, extraído de Richard M. HAMMER, et. al.:

"The mechanics of the resale price method are shown in Illustration 4-8.

EXAMPLE 4-8. Manufacturer P manufactures Product X, an unbranded widget, and sells it to Subsidiary S, its wholly owned subsidiary. Subsidiary S acts as a distributor of Product X in Country M, and sells it to uncontrolled taxpayers in that country. Uncontrolled distributors A, B, and C distribute competing products in Country M. All such products are unbranded, and the resale price in Country M is 100x per unit. Based on an analysis of the functions performed and risks assumed by Subsidiary S and by A, B, and C and a review of their financial statements, the tax administration has determined the following adjustments for the year's question:

$\begin{array}{lcccc} & \mathrm{S} & \mathrm{A} & \mathrm{B} & \mathrm{C} \\ \text { Reported gross profit } & 18 & 22 & 14 & 16 \\ \text { Accounting reclassifications } & & (2) & 4 & 1 \\ \text { Inventory } & & 2 & (1) & - \\ \text { Advertising } & & (3) & 2 & 1 \\ \text { Warranty } & 1 & (3) & (1) \\ \text { Volume } & & - & (1) & (1) \\ \text { Adjusted gross profit } & 18 & 20 & 15 & 16\end{array}$

Applying the resale price method to test the arm's length character of the amount paid by Manufacturer P for the distribution functions performed by Subsidiary S, the tax administration determines that any gross profit between 15 and 20 will produce an arm's length margin, and any price for the widget between 80 and 85 would be an arm's length price" (HAMMER, Richard M. et. al. International Transfer Pricing - OCDE Guidelines. op. cit. item 4.03). 
inglês. As autoridades fiscais sustentaram a aplicação de um mecanismo próximo ao RPM, mediante a aplicação de margem bruta de $12 \%$, recorrentemente encontrada em indústrias farmacêuticas inglesas similares. A Hoffman La Roche questionou a aplicação de tal margem, mas recusou-se a apresentar documentação para justificar seus argumentos. Não se sabe, ao certo, o deslinde da questão na esfera tributária. Não obstante, pouco tempo mais tarde foram introduzidas as normas para o controle dos preços de transferência na Inglaterra, de modo que o fisco local passou a dispor de mecanismos para combater mais eficazmente situações deste tipo ${ }^{668}$.

Ainda no que respeita ao RPM, pondere-se, por fim, que se trata de método que se adéqua mais facilmente às hipóteses em compra e revenda de bens ou direitos, sem o seu emprego em processo industrial ou o acréscimo de valor agregado no país. Isso não significa, contudo, que o RPM seja aplicado tão-somente às operações de revenda; pelo contrário, desde que produza resultados com o princípio da plena concorrência, pode ser aplicado a quaisquer tipos de situações ${ }^{669}$. Como referido no início desta seção, os custos incorridos pelo importador-revendedor devem ser computados dentre os custos dos

\footnotetext{
${ }^{668}$ Some of these generalized concern was brought to a head by the cause célèbre of Hoffman La Roche. A report by the British Monopolies Commission in 1973 revealed that Roche UK was paying grossly inflated prices to its Swiss affiliate for the active ingredients for drugs to be packaged for sale; these drugs were librium and valium, wonderful new non-barbiturate tranquilizers, sold on prescriptions and therefore most paid for by the National Health Service. Roche's transfer-price was $£ 370$ a kilo for librium and $£ 922$ for valium, while the same active ingredients could be obtained from small companies in Italy (where Roche's patents were not protected) for $£ 9$ and $£ 20$ per kilo respectively. The company told the Monopolies Commission that its pricing policy for drugs was based on what the market could bear in each country, although in the UK the price was negotiated with the government under the then-voluntary price regulation scheme for pharmaceuticals. The British subsidiary's accounts showed directed payments to its parent company for overheads, especially for the heavy research program in its Swiss and US laboratories. These were determined by what the Inland Revenue would allow by comparison with similar UK pharmaceutical firms - about 12 per cent of sales. But Roche's UK business was concentrated on a few, highly-profitable items - tranquilizers and vitamins. Thus, Roche argued that it was not fair to look at the profitability of individual drugs, especially such highly successful ones as librium and valium, since these must finance the company's overall research effort. However, it refused to provide the Commission with data on its worldwide activities (UK Monopolies Commission, 1973). The dispute was eventually settled by the payment of an agreed sum to the NHS; but the case led to investigations in many other countries of Roche's pricing policies. It is not publicly known whether the Inland Revenue had itself taken any action on Roche's transfer prices under its own powers, or did so subsequently" (PICCIOTTO, Sol. op. cit., p. 188-189).

669 “2.22. An appropriate resale margin is easiest to determine where the reseller does not add substantially to the value of the product. In contrast, it may be more difficult to use the resale price method to arrive at an arm's length price where, before sale, the goods are further processed or incorporated into a more complicated product so that their identify is lost or transformed (e.g. where components are joint together in finished or semi-finished goods). Another example where the resale price margin requires particular care is where the reseller contributes substantially to the creation or maintenance of intangible property associated with the product (e.g. trademarks or tradenames) which are owned by an associated enterprise. In such cases, the contribution of the goods originally transferred to the value of the final product cannot be easily evaluated" (OCDE. Transfer Pricing Guidelines for Multinational Enterprises and Tax Administrations, op. cit., p. II-7).
} 
produtos vendidos ou dos serviços prestados, sendo que quaisquer acréscimos relativos a funções ou riscos devem, outrossim, interferir na delimitação das margens. No entanto, a medição do valor agregado é mais complexa quanto maior forem as modificações introduzidas no bem ou direito importado ${ }^{670}$. Nas hipóteses de intangíveis aplicados a bens tangíveis, v.g., a aplicação do RPM torna-se sobremaneira mais complexa, a despeito de ser admitida pela $\mathrm{OCDE}^{671}$; de fato, podem ser vislumbrados alguns exemplos mais simples envolvendo a comparação de margens brutas de revenda em operações com intangíveis ${ }^{672}$. A legislação estadunidense, contudo, desestimula o emprego do RPM nestas situações $^{673}$. Particularmente, nas operações envolvendo tão-somente intangíveis, este

670 "As already noted, an appropriate resale price margin is easiest to determine where the reseller does not add substantially to the value of the product. In contrast, it may be more difficult (if not impossible) to use the resale price method to arrive at an arm's length price where there are other substantial elements in the functions performed prior to resale. One such situation would occur when, before resale, the goods are further processed or incorporated into a more complex product so that the identity of these goods is lost or transformed (e.g., components are joined together in finished or semi finished goods).

The resale price margin also requires particular care when the reseller contributes substantially to the creation or maintenance of intangible property associated with the product (e.g., trademarks or tradenames) that is owned by an affiliate (whether or not it is the affiliate that produced the products). In such cases, the contribution of the goods originally transferred to the final product cannot be easily valued" (HAMMER, Richard M. et. al. International Transfer Pricing - OCDE Guidelines. op. cit. item 4.03 [4] [b]).

671 "6.24 In the sale of goods incorporating intangible property, it may also be possible to use the CUP or resale price method following the principles in Chapter II. When marketing intangibles (e.g. a trademark) are involved, the analysis of comparability should consider the value added by the trademark, taking into account consumer acceptability, geographical significance, market shares, sales volume, and other relevant factors. When trade intangibles are involved, the analysis of comparability should moreover consider the value attributable to such intangibles (patent protected or otherwise exclusive intangibles) and the importance of the ongoing R\&D functions" (OCDE. Transfer Pricing Guidelines for Multinational Enterprises and Tax Administrations, op. cit., p. VI-9 e VI-10).

672 "EXAMPLE 4-9. The situation is the same as that in Illustration 4-8, except that the widget is a branded widget, the resale price in Country A is 110x, and Manufacturer P owns the worldwide rights to the brand name. What is the effect of the 10x higher resale price in this situation, where Manufacturer $\mathrm{P}$ owns the intangible (the brand name)? Specifically, the question is whether any part of the additional 10x gross profit should inure to the distributor Subsidiary S. The answer would appear to be no, because Manufacturer P is the owner of the intangible. Subsidiary S is merely performing the functions of a distributor. Accordingly, Subsidiary S's margin would remain unchanged, and Manufacturer P would earn the incremental 10x. (...)

EXAMPLE 4-11. The situation is the same as that in Illustration 4-8, except that Product X does carry a brand name that is not well known in Country M. Manufacturer P and Subsidiary S decide to undertake market development efforts to cause the brand name to become well known in Country M. The cost of the project is $5 x$ per unit, which Subsidiary $\mathrm{S}$ incurs as advertising and promotional activity expenses, but Manufacturer P reduces the transfer price of Product X. This has the effect of maintaining Subsidiary S's gross profit margin. What effect would this additional $5 \mathrm{x}$ of gross margin have on the comparability analysis noted in Illustration 4-8 ? The result should be merely to increase the gross profit margin of the comparables by the same amount in order for the controlled and uncontrolled transactions to be comparable (the other distributors being deemed to perform the same activity as Subsidiary S). The net effect is that Manufacturer P incurs the cost of the name-recognition project and should receive the economic benefit of the brand-name identification program once it becomes profitable" (HAMMER, Richard M. et. al. International Transfer Pricing - OCDE Guidelines. op. cit. item 4.03 [4] [b]).

673 " $\$ 1.482-3$ (c) (1) The resale price method measures the value of functions performed, and is ordinarily used in cases involving the purchase and resale of tangible property in which the reseller has not added substantial value to the tangible goods by physically altering the goods before resale. For this purpose, packaging, repackaging, labeling, or minor assembly do not ordinarily constitute physical alteration. Further 
método é vedado, consoante se depreende da seção 1.482-4 do IRC, a qual prevê que o cálculo dos preços de transferência nestas hipóteses apenas pode se desenvolver via CUT, CPM e PSM; os intangíveis são, naquele país, examinados a partir da renda potencialmente gerada [mediante o exame do valor presente líquido dos benefícios econômicos do intangível], sistemática incompatível com os métodos baseados em margens brutas. $\mathrm{O}$ RPM também possui aplicação restrita no controle dos preços em transações envolvendo serviços; isso porque, normalmente, eles não se compatibilizam com a noção de "revenda" "674.

\subsubsection{Método do Preço de Venda menos Lucro ("PVL").}

O preço de venda menos lucro ou PVL, atual denominação do preço de revenda menos lucro ou PRL, teve sua sistemática modificada por intermédio da Medida Provisória n. ${ }^{\circ}$ 478/09, que trouxe nova redação para o artigo 18, III, da Lei n. ${ }^{\circ}$ 9.430/96. Até a edição desta regra, em dez./09, o PRL era disciplinado no artigo 18, II, da Lei n. ${ }^{\circ}$ 9.430/96, com redação trazida pela Lei n. ${ }^{\circ}$ 9.959/00. Neste caso, o preço parâmetro obtido via PRL correspondia à média aritmética ponderada ${ }^{675}$ dos preços de revenda dos bens ou $\underline{\text { direitos }}^{676}$, diminuídos dos descontos incondicionais, dos tributos sobre vendas e das comissões e corretagens, bem assim de margem de lucro de (a.) 60\%,calculada sobre o preço de revenda, após deduzidos os abatimentos legais, e o valor agregado no país, na hipótese de bens importados aplicados à produção; ou de (b.) $20 \%$, calculada sobre o preço de revenda, nas demais hipóteses. Frise-se que as margens de $60 \%$ ou $20 \%$ aplicavam-se, até dez./09, conforme o bem fosse, ou não, "aplicado à produção". Em síntese, o PRL poderia ser calculado das seguintes sistemáticas legais:

Preço parâmetro no PRL-20\% (=) [Receita líquida] (-) [20\% (x) preço de revenda]; ou

the resale price method is not ordinarily used in cases where the controlled taxpayer uses its intangible property to add substantial value to the tangible goods" [26 CFR Ch. I (4-1-09 Edition)].

${ }_{674}$ Em pesquisa realizada pela Ernst \& Young International Ltd., constatou-se que $73 \%$ das empresas pesquisadas comprovam os preços de transferência em operações desta natureza mediante a aplicação do CPM ou métodos decorrentes do exame dos custos; $19 \%$ das consultadas declararam a utilização do CUP; não tendo nenhuma delas apontado o emprego do RPM nestas hipóteses (2007-2008 Global Transfer Pricing Survey. Global Transfer Pricing Trends, Practices and Analysis, op. cit.).

${ }^{675}$ Note-se que a referência à "média aritmética ponderada" consta tão-somente da Instrução Normativa n. ${ }^{\circ}$ 243/02, sendo que a Lei n. ${ }^{\circ}$ 9.430/96, até a edição da Medida Provisória n. ${ }^{\circ}$ 478/09, aludia tão-somente à "média aritmética".

${ }^{676}$ Ressalve-se que não existe a previsão de aplicação do PRL para transações envolvendo serviços. 
Preço parâmetro no PRL-60\% (=) [Receita líquida] (-) \{60\% (x) [receita líquida (-) valor agregado no país]\}.

O artigo 18, II, da Lei n. ${ }^{\circ}$ 9.430/96, com redação trazida pela Lei n. ${ }^{\circ}$ 9.959/00, foi disciplinado pelo artigo 23 da Instrução Normativa n. ${ }^{\circ} 243 / 02$. O $\S 9^{\circ}$ do referido dispositivo determina que a margem de lucro de $20 \%$ deve ser aplicada sobre o preço de revenda, constante da nota fiscal, excluídos os descontos incondicionais. O cálculo do PRL-20\%, neste contexto, era efetivado da seguinte forma:

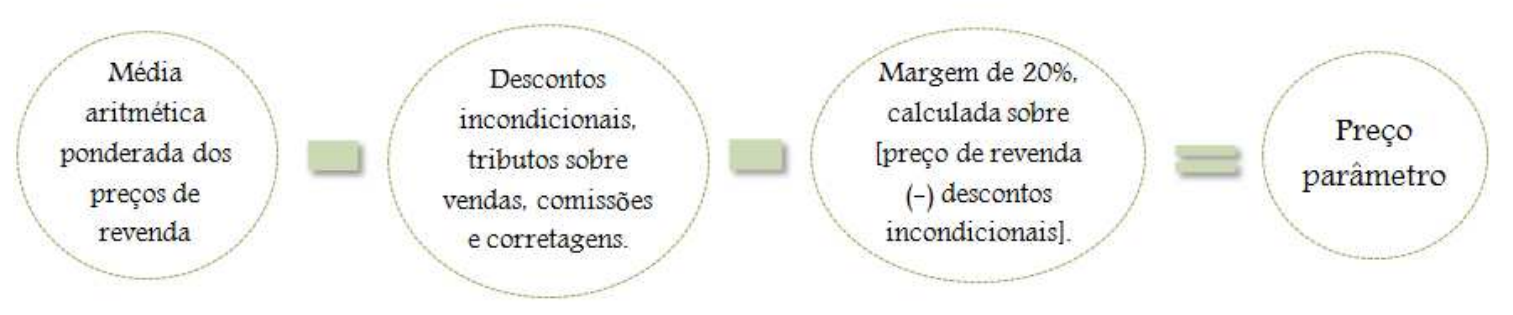

De outro lado, o PRL-60\%, nos termos estritos da lei [cf. fórmula acima] e do

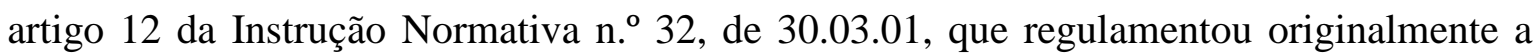
matéria, deveria ser calculado a partir da receita líquida, deduzida de um fator, calculado a partir da multiplicação do percentual de $60 \%$ sobre a própria receita líquida, deduzida "valor agregado ao bem produzido no país"677. O procedimento para a obtenção do preço parâmetro seria, em síntese, o seguinte:

677 “Art. 12. (...)

§11. Na hipótese do parágrafo anterior, o preço a ser utilizado como parâmetro de comparação será a diferença entre o preço líquido de venda e a margem de lucro de sessenta por cento, considerando-se, para este fim:

I - preço líquido de venda, a média aritmética dos preços de venda do bem produzido, diminuídos dos descontos incondicionais concedidos, dos impostos e contribuições sobre as vendas e das comissões e corretagens pagas;

II - margem de lucro, o resultado da aplicação do percentual de sessenta por cento sobre a média aritmética dos preços de venda do bem produzido, diminuídos dos descontos incondicionais concedidos, dos impostos e contribuições sobre as vendas, das comissões e corretagens pagas e do valor agregado ao bem produzido no País".

Ressalve-se que o texto do normativo alude tão-somente aos "bens", desprezando-se a necessidade de se controlar os preços de transferência também dos serviços ou direitos. 


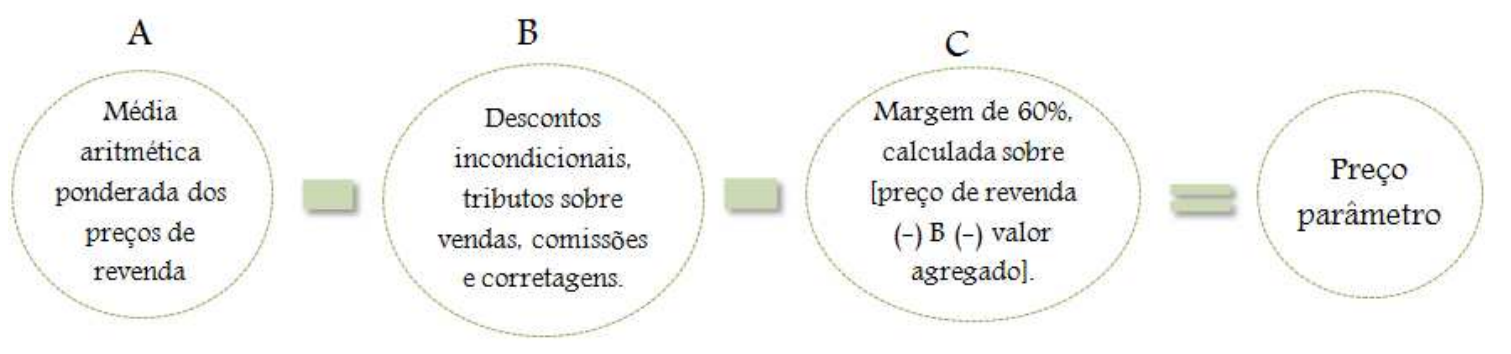

Por intermédio da fórmula supra, o valor mínimo do preço parâmetro seria equivalente a 40\% da receita líquida, i.e., [Receita líquida] (-) [60\% (x) Receita líquida] (=) [40\% (x) Receita líquida]. A metodologia acima continha uma relevante imprecisão, tendo em vista que a noção de "valor agregado" não está expressamente definida no direito tributário brasileiro $^{678}$. Independentemente disso, esta sistemática era adequada sob a perspectiva da política tributária, porque, quanto maior fosse o valor agregado no país ao bem ou direito importado, menor seria o valor do item $\mathrm{C}$ da fórmula e, por conseqüência, maior seria o preço parâmetro. Por outras palavras, esta forma de compreensão do PRL$60 \%$ estimula a agregação de valor no país, garantindo-se um nível mais adequado de dedutibilidade dos preços dos bens importados, mesmo diante de uma margem predeterminada de $60 \%$. Na grande maioria dos casos, a agregação de valor no país não gerará apenas maior dedução tributária em relação às operações envolvendo empresas vinculadas, mas, também, envolverá a elevação do número de atividades aqui desenvolvidas, de empregados para desempenhá-las etc.; trata-se de mecanismo não apenas recomendável, mas obrigatório, diante do determinado pelos artigos $3^{\circ}$, II, e 170, ambos da Constituição Federal.

Pouco mais de um ano após a edição da Instrução Normativa n. ${ }^{\circ}$ 32/01, contudo, ela foi revogada pela Instrução Normativa n. ${ }^{\circ}$ 243/02, que instituiu, não obstante os parâmetros estabelecidos pelo texto legal, disciplina completamente distinta para o

678 "Aparentemente, o posicionamento mais adequado para a determinação do quantum a ser considerado como valor agregado ao bem produzido no país (VA) poderia considerar três hipóteses:

1) $\mathrm{VA}=$ preço líquido de venda menos custo do bem importado;

2) $\mathrm{VA}=$ custo total - custo do bem importado;

3) VQA = custo de fatores locais (mão-de-obra, materiais secundários etc.).

(...) Em primeiro lugar, parece que 'valor agregado' é expressão que tem alcance muito superior a 'custo'. Valor agregado é, como o próprio nome diz, todo o valor que se soma a um valor inicial para compor um valor final ou provisório. (...) Em segundo lugar, não faz muito sentido supor que o legislador queira dizer ‘custo' com a expressão valor agregado. (...) Ademais, a expressão valor agregado no país, que consta da lei, indica uma intenção de separar o valor de um bem importado do valor somado a ele, no Brasil. Tudo o que não for 'agregado no país' ao bem, portanto, é algo que compõe o seu próprio custo" (SCHOUERI, Luís Eduardo. Preços de Transferência no Direito Tributário Brasileiro. op. cit., p. 157). 
cálculo do PRL-60\%. Com efeito, referido normativo abandonou a noção de receita líquida para se valer do conceito de "participação dos bens, $\underline{\text { serviços }}^{679}$ ou direitos importados no preço de venda do bem produzido" ${ }^{680}$. Segundo a mencionada norma regulamentar, o contribuinte deve obter o valor dos custos dos bens ou serviços importados sobre o valor total do custo do produto vendido. Este percentual deve ser multiplicado pela receita líquida, para fins de obtenção da denominada "participação de itens importados no preço de venda do bem produzido". Em seguida, o cálculo do preço parâmetro é efetivado a partir da seguinte operação de subtração: [Participação do bem importado no preço de venda final] (-) [60\% (x) Participação do bem importado no preço de venda final]. $\mathrm{O}$ esquema abaixo resume os novos critérios introduzidos pelo artigo 12 , §11, da Instrução Normativa n. ${ }^{\circ}$ 342/02, na aplicação do PRL-60\%:

\begin{tabular}{|l|}
\hline \multicolumn{1}{|c|}{ (I.) Preçolíquido de } \\
venda
\end{tabular}
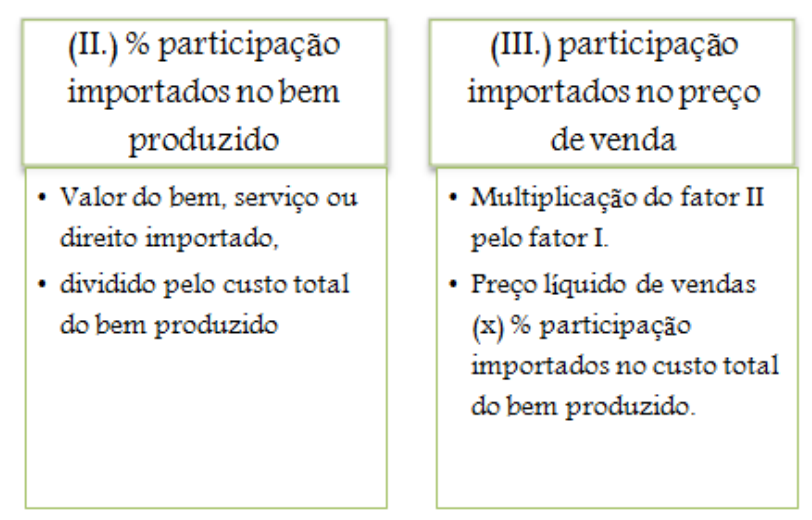

\footnotetext{
${ }^{679}$ Ressalve-se que, na Lei n. ${ }^{\circ}$ 9.430/96, artigo 18, II, não foi expressamente permitida a aplicação do PRL para os serviços, tendo sido mencionados tão-somente os bens e os direitos.

680 “Art. 12. (...)
}

$\S 11$. Na hipótese do $§ 10$, o preço parâmetro dos bens, serviços ou direitos importados será apurado excluindo-se o valor agregado no País e a margem de lucro de sessenta por cento, conforme metodologia a seguir:

I - preço líquido de venda: a média aritmética ponderada dos preços de venda do bem produzido, diminuídos dos descontos incondicionais concedidos, dos impostos e contribuições sobre as vendas e das comissões e corretagens pagas;

II - percentual de participação dos bens, serviços ou direitos importados no custo total do bem produzido: a relação percentual entre o valor do bem, serviço ou direito importado e o custo total do bem produzido, calculada em conformidade com a planilha de custos da empresa;

III - participação dos bens, serviços ou direitos importados no preço de venda do bem produzido: a aplicação do percentual de participação do bem, serviço ou direito importado no custo total, apurado conforme o inciso II, sobre o preço líquido de venda calculado de acordo com o inciso I;

IV - margem de lucro: a aplicação do percentual de sessenta por cento sobre a 'participação do bem, serviço ou direito importado no preço de venda do bem produzido', calculado de acordo com o inciso III;

$\mathrm{V}$ - preço parâmetro: a diferença entre o valor da 'participação do bem, serviço ou direito importado no preço de venda do bem produzido', calculado conforme o inciso III, e a margem de lucro de sessenta por cento, calculada de acordo com o inciso IV". 

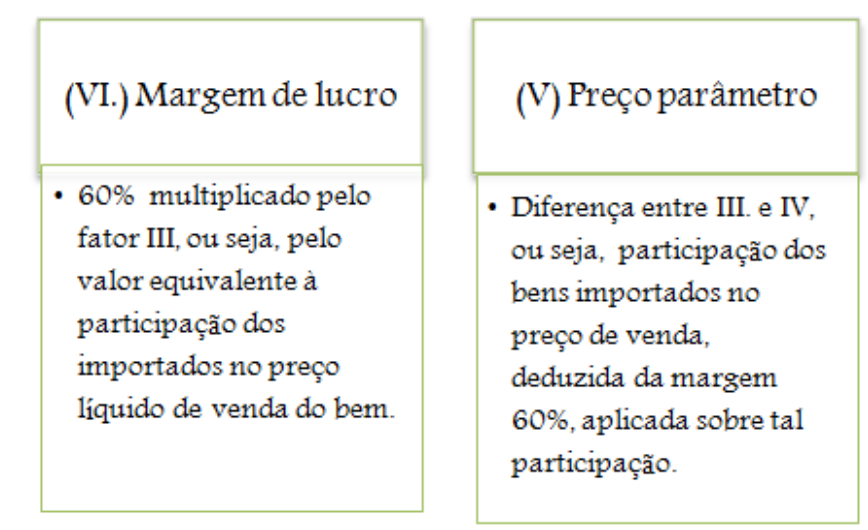

Como se pode depreender, no âmbito da nova sistemática "regulamentar" deixou de ser relevante a agregação de valor no país, e, ao contrário, passou a ser crucial uma relação elevada entre o custo dos bens, serviços ou direitos importados e o custo total do produto vendido. De acordo com as novas regras, por sinal ilegais, quanto maior o custo do produto importado em relação ao produto total [i.e., quanto menor o valor agregado no país], maior a participação percentual dos produtos importados no custo do bem produzido e, por conseguinte, maior a participação do bem importado no preço de venda final. Considerando que o preço parâmetro corresponde a 40\% da participação do bem importado no preço de venda, i.e., [Participação do bem importado no preço de venda] (-) [60\% (x) Participação do bem importado no preço de venda] (=) [40\% (x) Participação do bem importado no preço de venda], pode-se concluir que, quanto mais insumos e produtos importados no bem revendido, maior será o preço parâmetro. Inverteu-se, assim, toda a lógica econômica do PRL-60\%. De fato, segundo esta sistemática, é mais benéfico aos contribuintes processar ao máximo os produtos no exterior, trazendo-os ao país com mera finalidade de revenda; por outras palavras, há um total desestímulo à manipulação e/ou produção de bens no Brasil. Esta questão de política fiscal é grave porque, como se sabe, os grandes grupos multinacionais têm bastante liberdade para processar seus produtos em qualquer país. Como medida de economia legítima, assim, optarão por retirar do país a maior quantidade de atividades possível, deixando para processar no Brasil tão-somente o mínimo necessário para o desenvolvimento de suas atividades. Esta medida, obviamente, não visa ao crescimento econômico e está em desacordo com todos os fins e direitos prescritos no texto constitucional. Sob a perspectiva de supostamente aumentar a arrecadação, criou-se um grave desestímulo para a introdução de novas atividades industriais no Brasil. 
Além das críticas de natureza econômica supra referidas, esta "diferenciação" da fórmula do PRL-20\% em relação ao PRL-60\% trouxe inúmeras discussões doutrinárias. De fato, o artigo 18, II, 'd', 2, da Lei n. ${ }^{\circ}$ 9.430/96, com redação trazida pela Lei n. ${ }^{\circ}$ 9.959/00, determinava que o PRL-60\% deveria ser aplicado tão-somente "na hipótese de os bens importados serem aplicados à produção". A noção de "aplicação à produção", todavia, não foi expressamente disciplinada no direito tributário brasileiro. Não obstante, os $\S \S 9^{\circ}$ e 10 do artigo 12 da Instrução Normativa n. ${ }^{\circ}$ 243/02 prescreveram que seria aplicado o PRL-60\% sempre que houvesse "agregação de valor ao custo dos bens, serviços ou direitos importados"; o PRL-20\%, de outro lado, seria empregado apenas nos "simples processos de revenda" ${ }^{681}$. Como o texto do normativo, mais uma vez, ultrapassou os seus limites de norma regulamentar, diversos doutrinadores, destacando-se Heleno Taveira TÔRRES $^{682}$ e Gerd W. ROTHMAN ${ }^{683}$, passaram a sustentar que, para a aplicação do PRL$60 \%$, o bem importado deveria perder suas características originais ou sofrer modificações, a ponto de alterar-se na sua funcionalidade, emprego ou utilidade. ; mínimas alterações nos produtos, que resultem em reduzido valor agregado, deveriam permanecer na esfera do PRL-20\%. Consoante afirmado por Gerd W. ROTHMAN, "seria completamente absurdo não admitir o método PRL 20\% nas hipóteses em que o revendedor adiciona somente valor relativamente pequeno ao produto importado, elevando a 'margem de lucro' para $60 \%$.

\footnotetext{
681 “Art. 12. (...)

$\S 9^{\circ} \mathrm{O}$ método do Preço de Revenda menos Lucro mediante a utilização da margem de lucro de vinte por cento somente será aplicado nas hipóteses em que, no País, não haja agregação de valor ao custo dos bens, serviços ou direitos importados, configurando, assim, simples processo de revenda dos mesmos bens, serviços ou direitos importados.

§10. O método de que trata a alínea 'b’ do inciso IV do caput será utilizado na hipótese de bens, serviços ou direitos importados aplicados à produção".

${ }^{682}$ In: TÔRRES, Heleno Taveira. Garantias constitucionais aplicadas ao controle sobre preços de transferência (legalidade e uso de presunções no arbitramento da base de cálculo dos tributos, a partir do controle de preços de transferência. O direito ao emprego do melhor método. Um caso: limites ao uso do PRL-60 na importação. op. cit., p. 107.

683 “Daí decorre que: a) pela adoção do conceito de 'produção' a lei continua rejeitando os conceitos específicos da legislação do IPI como 'industrialização', 'transformação' etc., dando assim, flexibilidade à interpretação; b) dependendo da profundidade da produção realizada pelo revendedor com utilização da mercadoria importada de sua coligada no exterior, pode ser escolhido, pelo contribuinte, o método PRL na sua modalidade de $20 \%$, já existente anteriormente, ou a nova modalidade do PRL de $60 \%$. Essas conclusões estão em perfeita harmonia com o direito previsto no parágrafo $4^{\circ}$ do art. 18 da Lei n. ${ }^{\circ} 9.430 / 96$, que permite ao contribuinte escolher o método que lhe for mais conveniente. Não há nada na lei que possa fundamentar, nem sistemática nem teleologicamente, a conclusão de que o método com margem de $20 \%$ não seja mais aplicável às hipóteses de "produção local'” [ROTHMANN, Gerd W. Preços de Transferência. Método do Preço de Revenda menos Lucro: Base CIF (+II) ou FOB. A margem de lucro (20\% ou 60\%) em Processos de Embalagem e Beneficiamento. op. cit., p. 47].
} 
Somente quem estiver alheio à realidade econômica poderia chegar a defender interpretação tão falaciosa, que leva a resultados simplesmente absurdos"684.

Como o objetivo de eliminar a ilegalidade do critério de aplicação do PRL-60, bem assim de afastar-se das discussões sobre o conceito de "aplicação à produção" e das acusações de que a margem de $60 \%$ seria absurdamente elevada, as autoridades tributárias apresentaram pedido de alteração do texto legal à Presidência da República, sendo que, em dez./09, foi editada a Medida Provisória n. ${ }^{\circ}$ 478/09, que alçou ao patamar de lei as arbitrariedades relativas ao PRL-60\%. Com efeito, a nova redação do artigo 18, III, da Lei n. ${ }^{\circ} 9.430 / 96$, é praticamente idêntica à do artigo $12, \S 11^{\circ}$, da Instrução Normativa n. ${ }^{\circ}$ 243/02 685 . Para reforçar que este método aplica-se também às atividades industriais, sua denominação foi alterada, passando o método a se chamar preço de venda menos lucro ou PVL; foi substituído o termo "revenda". Além da nomenclatura do método, a única modificação substancial foi a substituição do percentual de $60 \%$ pelo percentual único de $35 \%{ }^{686}$. Foi extinta a distinção entre o PRL-20\% e o PRL-60\%; atualmente, existe um único PVL, aplicável a todos e quaisquer tipos de transações. A elevação ao patamar de lei do PRL-60\%, como não poderia deixar de ser, garantiu a perpetuação da ausência de razoabilidade econômica do método, que afronta totalmente aos objetivos e fins da nação brasileira, desestimulando os investimentos no país. Para facilitar a compreensão do "novo" método, vejam-se os dois exemplos abaixo:

${ }^{684}$ In: ROTHMANN, Gerd W. Preços de Transferência. Método do Preço de Revenda menos Lucro: Base CIF (+II) ou FOB. A margem de lucro (20\% ou 60\%) em Processos de Embalagem e Beneficiamento. op. cit., p. 47.

685 "Art. 18 (...)

III - Método do Preço de Venda menos Lucro - PVL: definido como a média aritmética ponderada dos preços de venda no País dos bens, direitos ou serviços importados e calculado conforme a metodologia a seguir:

a) preço líquido de venda: a média aritmética ponderada dos preços de venda do bem, direito ou serviço produzido, diminuídos dos descontos incondicionais concedidos, dos impostos e contribuições sobre as vendas e das comissões e corretagens pagas;

b) percentual de participação dos bens, direitos ou serviços importados no custo total do bem, direito ou serviço vendido: a relação percentual entre o custo médio ponderado do bem, direito ou serviço importado e o custo total médio ponderado do bem, direito ou serviço vendido, calculado em conformidade com a planilha de custos da empresa;

c) participação dos bens, direitos ou serviços importados no preço de venda do bem, direito ou serviço vendido: aplicação do percentual de participação do bem, direito ou serviço importado no custo total, apurada conforme a alínea 'b', sobre o preço líquido de venda calculado de acordo com a alínea 'a';

d) margem de lucro: a aplicação do percentual de trinta e cinco por cento sobre a participação do bem, direito ou serviço importado no preço de venda do bem, direito ou serviço vendido, calculado de acordo com a alínea 'c';

e) preço parâmetro: a diferença entre o valor da participação do bem, direito ou serviço importado no preço de venda do bem, direito ou serviço vendido, calculado conforme a alínea 'c', e a 'margem de lucro', calculada de acordo com a alínea 'd"'.

${ }^{686}$ Além disso, a expressão "média aritmética ponderada", antes prescrita apenas na Instrução Normativa n. 243/02, também foi alçada ao texto legal. 
Exemplo 1. Aquisição de bem importado para revenda, com agregação mínima de valor no país.
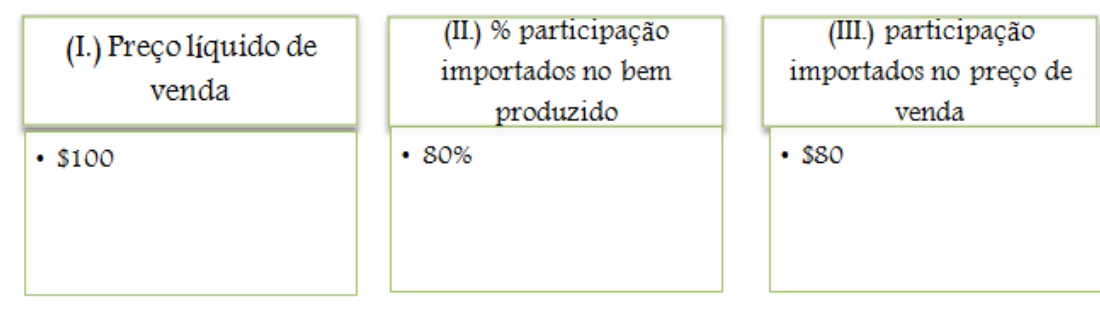

(VI.) Margem de lucro - $35 \%(\mathrm{x}) \$ 80(=) \$ 28$.
(V) Preço parâmetro

- $\$ 80(-) \$ 28(=) \$ 52$.

Neste primeiro exemplo, em que os custos dos bens importados correspondem a $80 \%$ do preço líquido de venda dos produtos revendidos, o preço parâmetro apurado equivale a $52 \%$ do preço líquido de vendas.

Exemplo 2. Aquisição de bem importado para aplicação em processo produtivo, com agregação de valor no país equivalente a $80 \%$ do preço do produto final.
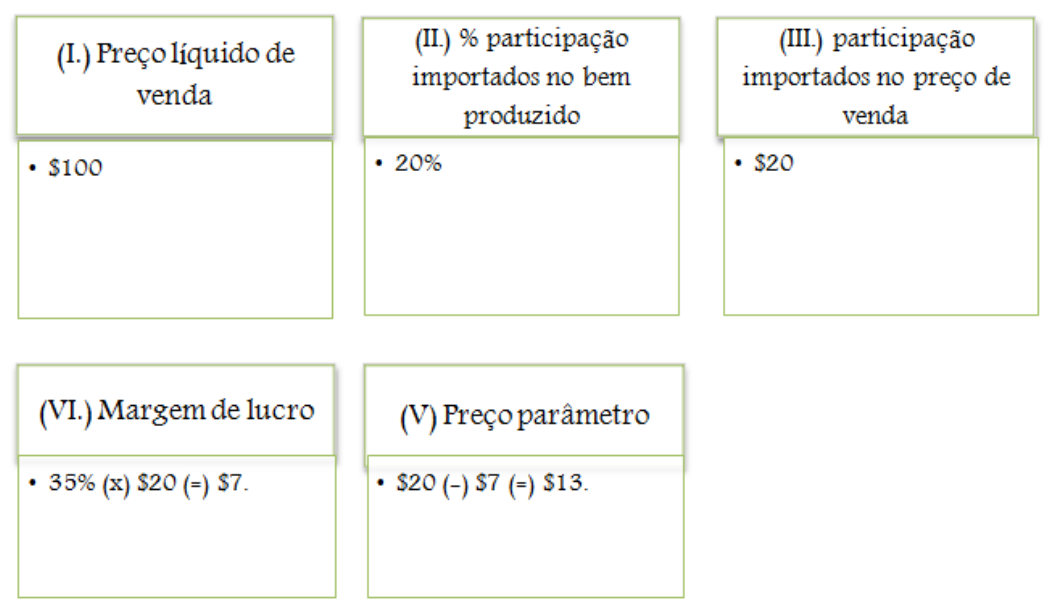

(V) Preço parâmetro

- $\$ 20(-) \$ 7(=) \$ 13$.

No Exemplo 2, os custos dos bens importados correspondem a tão-somente $20 \%$ do preço líquido de venda dos produtos revendidos, tendo sido a matéria-prima adquirida processada no território nacional, convertendo-se em um novo produto. O preço parâmetro apurado, nesta hipótese, equivale a $13 \%$ do preço líquido de vendas. A relação entre os dois exemplos é simples: a participação dos bens ou direitos importados no preço final do bem reduziu-se em 4 vezes, de modo que o preço parâmetro respectivo também reduziu-se em 4 vezes. Na visão da administração tributária, parece haver alguma 
razoabilidade neste raciocínio; não se percebe, todavia, que este tipo de regra apresenta um enorme desestímulo a investimentos no país, não sendo raros os exemplos de multinacionais que, justamente em razão das normas para o controle dos preços de transferência, instalam-se em outros países da América Latina para produzir bens destinados ao mercado consumidor brasileiro.

No que respeita à análise de comparabilidade empreendida para a aplicação do PVL, ressalte-se que não há referência expressa à utilização de transações "idênticas ou similares", seja no artigo 18, III, da Lei n. ${ }^{\circ}$ 9.430/96, seja no artigo 12 da Instrução Normativa n. ${ }^{0}$ 243/02. Inexiste, outrossim, vedação à utilização dados de transações similares. Nesta ordem de idéias, não parece ser possível a proibição de utilização de transações similares para a aplicação do PVL, especialmente se inexistir outro método disponível. Suponha-se, v.g., que um determinado contribuinte brasileiro X importe um certo produto exclusivo de $\mathrm{X} 1$, processe-o, e revenda para partes vinculadas no exterior [X2 e X3] e partes não-vinculadas no país [Y e Z], sendo que os produtos alienados a estes últimos contém algumas adaptações exigidas por normas técnicas nacionais. Os produtos não serão idênticos, mas, como provavelmente o PVL será o único método aplicável, deve ser admitido o seu emprego, mediante a efetivação de ajustes concernentes às características do bem ou direito objeto das transações comparadas. Como discutido na seção 2.2.1(I) do CAPÍTULO 2, devem ser admitidos quaisquer ajustes razoáveis para tornar as transações similares comparáveis.

Ainda a respeito deste fator de comparabilidade [características dos bens ou direitos objeto da transação], importa consignar que também não está admitida expressamente na lei a possibilidade de utilização dos comparáveis externos. Pelo contrário, existe esta vedação no artigo $12, \S^{\circ}$, da Instrução Normativa n. ${ }^{\circ} 243 / 02^{687}$; a nova redação do $\$ 3^{\circ}$ do artigo 18 da Lei n. ${ }^{\circ}$ 9.430/96, de outro lado, contém previsão bastante ambígua $^{688}$. Independentemente disto, por todas as razões expostas na seção 2.2.

687 “Art. 12. (...)

$\S 1^{\circ}$ Os preços de revenda, a serem considerados, serão os praticados pela própria empresa importadora, em operações de venda a varejo e no atacado, com compradores, pessoas físicas ou jurídicas, que não sejam a ela vinculados".

688 "Art. 18. (...)

$\S 3^{\circ}$ Para efeito do disposto no inciso III, somente serão considerados, para fins de cálculo do preço parâmetro, os preços de venda obtidos pela pessoa jurídica importadora do bem, direito ou serviço, exclusivamente, em operações com não vinculadas, empreendidas no período de apuração".

Note-se que o texto legal alude a preços de venda "obtidos", e não a preços "praticados", termo que seria mais adequado para expressamente vedar a utilização de comparáveis externos. 
do CAPÍTULO 2, não é razoável esta proibição. Suponha-se, v.g., que a empresa X importe uma determinada matéria-prima bastante rara, processe-a no país, gerando-se um produto final que possua substitutos, fabricados a partir de outros insumos; toda a produção é vendida para as empresas vinculadas X2 e X3, ambas do seu grupo econômico. A empresa Y, contudo, aliena bens similares no mercado nacional. Se o PVL for o único método disponível para o controle dos preços de X, por qual razão seu uso seria vedado, simplesmente porque os dados foram extraídos de fontes externas? Os comparáveis internos, de fato, são mais confiáveis na aplicação deste método; não se pode, todavia, proibir o uso dos comparáveis externos, ainda mais diante da inexistência de outros métodos.

Quanto aos demais fatores de comparabilidade envolvidos na aplicação do PVL, reporta-se à seção 2.2.1, no âmbito da qual se conclui que, não obstante a ausência de previsão legal específica, quaisquer distinções nas condições das transações, que afetem materialmente os preços ou margens de transações similares, devem ser ajustadas, de modo a torná-las comparáveis às transações "testadas". No âmbito da Instrução Normativa n. 243/02, existe, em relação ao PRL, tão-somente a previsão de ajuste em relação ao impacto das vendas à vista e à prazo nos preços comparáveis; ainda assim, esta previsão contêm arbitrariedades como, v.g., a obrigatória utilização de SELIC ou LIBOR acrescida de spread anual de três por cento, sempre que não for praticada a mesma taxa para todos os clientes, "consistentemente", ao longo de todo o ano-calendário. Trata-se, na verdade, de instituição de "presunção absoluta" via Instrução Normativa, o que certamente é inadmissível. Por fim, no que se refere ao percentual prefixado de $35 \%$ para a determinação da "margem" meios de prova admitidos para sua alteração, bem assim a seção 4.6, abaixo.

\subsubsection{Método do Preço de Venda por Atacado do País de Destino, diminuído do Lucro ("PVA").}

Por intermédio do emprego do método do preço de venda por atacado no país de destino, diminuído de margem bruta de lucro, ou PVA, obtém-se preço parâmetro representado pela "média aritmética dos preços de venda de bens, idênticos ou similares,

\footnotetext{
${ }^{689}$ Nesta nova sistemática de cálculo, deixou de ser aplicável a noção de "margem bruta de revenda"; pelo contrário, existe apenas a aplicação de um percentual fixo de $35 \%$ sobre o valor da participação do produto importado sobre o preço final de venda.
} 
praticados no mercado atacadista do país de destino, em condições de pagamento semelhantes, diminuídos dos tributos incluídos no preço, cobrados no referido país, e de margem de lucro de quinze por cento sobre o preço de venda no atacado" [cf. artigo 19, $\S 3^{\circ}$, II, da Lei n. ${ }^{\circ}$ 9.430/96]. Em síntese, este método é implementado a partir da seguinte fórmula:

Preço parâmetro (=) [Preço de venda no atacado] (-) [tributos sobre vendas nos países de destino] $(-)[15 \%(\mathrm{x})$ preço de venda no atacado].

O "preço de venda no atacado", supra aludido, deve ser aferido a partir da média aritmética ponderada dos preços de atacado ${ }^{690}$. No âmbito da Instrução Normativa n. ${ }^{\circ}$ 243/02, as autoridades tributárias esclareceram que os tributos sobre vendas no país de destino são aqueles que guardam semelhanças com o ICMS [ou ISS] e com o PIS e a Cofins; trata-se dos mesmos tributos deduzidos da receita bruta para a obtenção da receita líquida $^{691}$. Determinou-se, ademais, a incidência da margem predeterminada de $15 \%$ sobre o "preço bruto de venda no atacado" 692 , i.e., sobre a receita bruta de vendas. A incidência do percentual de $15 \%$ sobre o preço bruto de venda no atacado pode gerar impactos no preço parâmetro mediante a aplicação do PVA, os quais não têm qualquer relação com a questão dos preços de transferência. De fato, como consignado por Luís Eduardo SCHOUERI, quanto maiores forem os tributos incluídos no preço atacadista do país de destino, ou seja, quanto maior for o impacto dos tributos na receita bruta de vendas naquele país, maior será a redução referente à margem de $15 \%$ e menor será o preço parâmetro; o preço parâmetro será, assim, variável em função da carga tributária no país de destino, o que não se apresenta razoável $^{693}$. Suponha-se, v.g., que dois contribuintes, A e B,

\footnotetext{
${ }^{690}$ A despeito de a Lei n. ${ }^{\circ}$ 9.430/96 aludir a "média aritmética", o artigo 24 da Instrução Normativa n. ${ }^{\circ}$ 243/02 refere-se a "média aritmética ponderada". Ao contrário do que se deu em relação aos métodos aplicáveis às operações de importação, em que a noção de média ponderada foi incluída no texto legal via Medida Provisória n. ${ }^{\circ}$ 478/09 [cf. artigo 18, incisos I, II e III], os métodos relativos às exportações, previstos no artigo $19, \S 3^{\circ}$, da Lei n. ${ }^{\circ}$ 9.430/96, não tiveram seu texto modificado. Prevalece, neste cenário, a dissonância entre a lei e o normativo infra-legal.

691 “Art. 24. (...)

$\S 1^{\circ}$ Consideram-se tributos incluídos no preço, aqueles que guardem semelhança com o ICMS e o ISS e com as contribuições Cofins e PIS/Pasep".

692 “Art. 24. (...)

$\S 2^{\circ}$ A margem de lucro a que se refere este artigo será aplicada sobre o preço bruto de venda no atacado".

693 "Noutras palavras, as margens de $15 \%$ e $30 \%$ são calculadas sobre o preço de venda 'cheio'; tributos incluídos no preço no país de destino, conquanto sejam parcela a deduzir na apuração do PVV e do PVA, não são deduzidos da base de cálculo da margem. Daí se constatar que quanto maiores forem os tributos incluídos no preço do vendedor e cobrados localmente (que, portanto, aumentam aquele preço), tanto maior será a própria margem de lucro a ser deduzida. Como o incremento da margem de lucro implica diminuição do preço-parâmetro, vê-se que quanto maior o montante de tributos locais incluídos no preço, menor será o
} 
fabriquem produtos muito semelhantes, revendendo-os para os países $\mathrm{X}$ e $\mathrm{Y}$, respectivamente. Se o preço de venda no atacado, em ambos os países, for de $\$ 100$, mas os tributos sobre vendas incluídos no preço forem de $20 \%$ em X e $40 \%$ em Y, o preço parâmetro de A será 65, ao passo que o preço parâmetro em B será de 45; neste exemplo, B foi prejudicado, podendo até se sujeitar a ajustes de preços de transferência se não obtiver dados para a aplicação do PVEx ou do CAP, apenas porque a carga tributária em Y é elevada.

No que respeita à análise de comparabilidade envolvida na aplicação do PVV, saliente-se que, nos termos do $\$ 3^{\circ}$ do artigo 24 da Instrução Normativa n. ${ }^{\circ}$ 243/02, aplicam-se a este método as mesmas normas expostas com relação ao PIC, na seção 4.2.2, supra. Adicionalmente à seção 4.2.2 deste capítulo, deve-se reportar (i.) à seção 2.2.1(I), do CAPÍTULO 2, que discute as noções de bens, serviços ou direitos idênticos ou similares; bem assim (iv.) à seção 2.2.1, no âmbito da qual foram discutidos os ajustes exigidos para a aplicação do princípio da plena concorrência. Por fim, cumpre ponderar que não há, na Lei n. ${ }^{\circ}$ 9.430/96 ou nos normativos que a disciplinam, regras específicas para a obtenção dos "preços do mercado atacadista no país de destino". Obviamente, as fontes de dados não são exclusivamente aquelas referidas no artigo 21 da lei ou no artigo 29 da Instrução Normativa n. ${ }^{\circ}$ 9.430/96 [cf. seção 1.9.1 do CAPÍTULO 1]. Pelo contrário, os preços podem ser provados por quaisquer meios admitidos em direito, inclusive pelos dados da própria parte vinculada/adquirente, se ela efetivar vendas para partes não-independentes no seu país $^{694}$.

\subsubsection{Método do Preço de Venda a Varejo no País de Destino, diminuído do Lucro ("PVV").}

O método do preço de venda a varejo no país de destino, diminuído do lucro, previsto no artigo $19, \S 3^{\circ}$, III, da Lei n. ${ }^{\circ} 9.430 / 96$, e disciplinado pelo artigo 25 , c.c. artigos 15 a 18 e $24, \S \S 1^{\circ}$ e $2^{\circ}$, todos da Instrução Normativa n. $^{\circ} 243 / 02$, emprega-se de forma idêntica ao PVA, descrito na seção 4.3.3 deste CAPÍTULO. As únicas distinções estão

preço parâmetro exigido do importador" (SCHOUERI, Luís Eduardo. Preços de Transferência no Direito Tributário Brasileiro. op. cit., p. 187).

694 "Outro ponto a notar é que, quando o legislador se refere à média dos preços no mercado atacadista ou varejista, não está ele a exigir que se faça um levantamento de todos os preços ali praticados. Afinal, se o importador revende seus produtos localmente a terceiros independentes, a média desses preços refletirá, já por ela mesma, a média do mercado" (SCHOUERI, Luís Eduardo. Preços de Transferência no Direito Tributário Brasileiro. op. cit., p. 187). 
relacionadas à fonte dos preços independentes comparáveis no mercado do país de destino [atacado vis-à-vis varejo], bem assim a margem bruta prefixada, que com relação a este método é de $30 \%$, ao invés dos $15 \%$ verificados no mercado atacadista.

\subsubsection{Gross Margin Method, proposto pelas autoridades norte- americanas para o controle das negociações globais.}

O "método da margem bruta de revenda" corresponde a uma variação ao RPM, disciplinada pela Seção 1.482-8/Proposta do IRC, aplicável especificamente às negociações globais. Na seção 4.3.5, supra, demonstrou-se que o RPM adéqua-se melhor à compra e revenda de mercadorias, sem agregação de valor ao bem ou direito pelo adquirente. Este mesmo raciocínio reflete-se no campo das negociações globais: o método da margem bruta pode ser aplicado às hipóteses de compra e revenda de produtos financeiros, de títulos, de posições contratuais ativas ou passivas etc. ${ }^{695}$. Neste campo de análise é possível, ademais, a comparação "direta" de margens brutas para o exame do preço de plena concorrência de alguns tipos de comissões ou remunerações baseadas em margens brutas ou em percentuais sobre o valor total transacionado ${ }^{696}$. Assim como o RPM, a fórmula para de aplicação deste método é a seguinte:

Preço parâmetro (=) [preço de revenda do produto financeiro] (-) [lucro bruto].

Lucro bruto (=) [margem bruta] (x) [preço de revenda do produto financeiro] ${ }^{697}$.

Os dados necessários à obtenção do preço parâmetro a partir do "método da margem bruta de revenda" próprio das transações globais são, assim, (i.) o preço de

695 “\$1.482-8 [proposta] (c) (1) General rule. The gross margin method evaluates whether the amount allocated to a participant in a global dealing operation is arm's length by reference to the gross profit margin realized on the sale of financial products in comparable uncontrolled transactions. The gross margin method may be used to establish an arm's length price for a transaction where a participant resells a financial product to an unrelated party that the participant purchased from a related party. The gross margin method may apply to transactions involving the purchase and resale of debt and equity instruments" (Federal Register/v. 63, no. 44. op. cit).

696 " $\$ 1.482-8$ [proposta] (c) (1) (...) The method may also be used to evaluate whether a participant has received an arm's length commission for its activities in a global dealing operation when the participant has not taken title to a security or has not become a party to a derivative financial product (Federal Register/v. 63, no. 44. op. cit).

697 " $\$ 1.482-8$ [proposta] (c) The gross margin method measures an arm's length price by subtracting the appropriate gross profit from the applicable resale price for the financial product involved in the controlled transaction under review. (...)The appropriate gross profit is computed by multiplying the applicable resale price by the gross profit margin, expressed as a percentage of total revenue derived from sales, earned in comparable uncontrolled transactions" (Federal Register/v. 63, no. 44. op. cit). 
revenda do produto financeiro, aferido em transações não-vinculadas ${ }^{698}$; e (ii.) a margem adequada de lucro bruto para a remuneração das atividades desempenhadas e riscos assumidos pela instituição financeira. Para a aferição da margem, é relevante o exame do objeto da transação financeira mas, essencialmente, deve ser efetivada uma aprofundada análise funcional $^{699}$; trata-se de situação idêntica à exposta em 4.3.1, em relação ao RPM. Para que seja viável o confronto entre transações, a margem bruta comparável precisa ter sido estabelecida em transações idênticas ou similares às transações "testadas", sob pena de os resultados obtidos via "método da margem bruta" não serem fidedignos ou confiáveis; a legislação estadunidense ressalva, a este passo, sua extrema preocupação na aplicação deste método às hipóteses em que uma determinada instituição adquire um instrumento financeiro, desenvolve o produto para atender às solicitações de seu cliente, tornando-o mais sofisticado, e, em seguida, "revende-o"; este tipo de transação envolve outros fatores, além da simples mensuração da margem bruta de venda.

Ainda no que respeita à busca de dados para o confronto de transações, sustentam as autoridades norte-americanas que os comparáveis internos são preferíveis aos comparáveis externos ${ }^{700}$; não há dúvidas de que, se existirem comparáveis externos e internos numa determinada situação, estes últimos devem ser preferencialmente utilizados. Ademais, como salientado em 4.3.1 em relação ao RPM, este país demonstra extrema preocupação com a consistência dos critérios contábeis adotados nas comparações de transações envolvendo operações globais de uma determinada instituição com transações praticadas por outras; de fato, este tipo de operação normalmente envolve derivativos muito específicos e inovadores, os quais, por sua natureza híbrida, podem ser contabilizados de diversas formas; o método apenas pode ser aplicado se existirem critérios

698 “\$1.482-8 [proposta] (c) (2) (ii) The applicable resale price is equal to either the price at which the financial product involved is sold in an uncontrolled sale or the price at which contemporaneous resales of the same product are made" (Federal Register/v. 63, no. 44. op. cit).

699 "\$1.482-8 [proposta] (c) (3) (i) The gross margin method considers whether a participant has earned a sufficient gross profit margin on the resale of a financial product (or line of products) given the functions performed by the participant. A reseller's gross profit margin provides compensation for performing resale functions related to the product or products under review, including an operating profit in return for the reseller's investment of capital and the assumption of risks. Accordingly, where a participant does not take title, or does not become a party to a financial product, the reseller's return to capital and assumption of risk are additional factors that must be considered in determining an appropriate gross profit margin" (Federal Register/v. 63, no. 44. op. cit).

700 “ $\$ 1.482-8$ [proposta] (c) (3) (i) (...) An appropriate gross profit margin primarily should be derived from comparable uncontrolled purchases and resales of the reseller involved in the controlled sale. This is because similar characteristics are more likely to be found among different resales of a financial product or products made by the same reseller than among sales made by other resellers. In the absence of comparable uncontrolled transactions involving the same reseller, an appropriate gross profit margin may be derived from comparable uncontrolled transactions of other resellers" (Federal Register/v. 63, no. 44. op. cit). 
acurados para o ajuste das escriturações das instituições com relação a um determinado e específico produto financeiro $^{701}$. Um exemplo interessante trazido pela Seção 1.4828/Proposta, item (c), advém da possibilidade de um mesmo produto ser, sucessivamente, transacionado entre as diversas empresas de um mesmo conglomerado financeiro; isto poderia ocorrer, e.g., com alguns tipos de instrumentos utilizados para fins de hedge, muitas vezes transacionados entre os responsáveis pelos books, que preferem o "hedge interno", economicamente mais vantajoso. Nestas hipóteses, sustenta o fisco estadunidense que, sempre, deve ser buscado como parâmetro uma transação independente; o critério para a "divisão" do lucro gerado pelas instituições deve ser aferido a partir do exame da função exercida por cada uma delas naquela série de transações ${ }^{702}$.

Por fim, saliente-se que a este "método da margem bruta de revenda" também são aplicáveis todas as peculiaridades concernentes aos cinco fatores de comparabilidade específicos para as transações envolvendo a negociação global de instrumentos financeiros, os quais foram disciplinados na Seção 1.482-8/Proposta, item (a). Por outras palavras, devem ser aplicadas as regras gerais descritas na Seção 1.482-1 do IRC, as quais foram

701 “\$1.482-8 [proposta] (c) (3) (iv) (B) Consistency in accounting. The degree of consistency in accounting practices between the controlled transaction and the uncontrolled transactions may affect the reliability of the gross margin method. For example, differences as between controlled and uncontrolled transactions in the method used to value similar financial products (including methods of accounting, methods of estimation, and the timing for changes of such methods) could affect the gross profit. The ability to make reliable adjustments for such differences could affect the reliability of the results" (Federal Register/v. 63, no. 44. op. cit).

702 "\$1.482-8 [proposta] (c) (2) (ii) (...) If the product purchased in the controlled sale is resold to one or more related parties in a series of controlled sales before being resold in an uncontrolled sale, the applicable resale price is the price at which the product is resold to an uncontrolled party, or the price at which contemporaneous resales of the same product are made. In such case, the determination of the appropriate gross profit will take into account the functions of all members of the controlled group participating in the series of controlled sales and final uncontrolled resales, as well as any other relevant factors described in paragraph (a)(3) of this section";

"\$1.482-8 [proposta] (c) (5) Example 1. Gross margin method. (i) T is a U.S. resident financial institution that acts as a market maker in debt and equity instruments issued by U.S. corporations. Most of T's sales are to U.S.-based customers. TS, T's U.K. subsidiary, acts as a market maker in debt and equity instruments issued by European corporations and conducts most of its business with European-based customers. On occasion, however, a customer of TS wishes to purchase a security that is either held by or more readily accessible to T. To facilitate this transaction, T sells the security it owns or acquires to TS, who then promptly sells it to the customer. T and TS generally derive the majority of their profit on the difference between the price at which they purchase and the price at which they sell securities (the bid/offer spread). On average, TS's gross profit margin on its purchases and sales of securities from unrelated persons is $2 \%$. Applying the comparability factors specified in $\$ 1.482-8(\mathrm{a})(3)$, T's purchases and sales with unrelated persons are comparable to the purchases and sales between T and TS.

(ii) Since T's related purchases and sales are comparable to its unrelated purchases and sales, if TS's gross profit margin on purchases and sales of comparable securities from unrelated persons is $2 \%$, TS should also typically earn a $2 \%$ gross profit on the securities it purchases from T. Thus, when TS resells for $\$ 100$ a security that it purchased from T, the arm's length price at which TS would have purchased the security from T would normally be $\$ 98$ ( $\$ 100$ sales price minus (2\% gross profit margin x \$100))" (Federal Register/v. 63, no. 44. op. cit). 
complementadas/modificadas pela Seção 1.482-8/Proposta; estas regras foram abordadas na seção 4.2.4, juntamente com as normas concernentes ao CUFT. Também se aplicam a este método as preocupações expostas em 4.2.4, relativamente ao fator "tempo" na comparação de transações globais, porque, diante da elevada volatilidade dos mercados, transações próximas podem não ser comparáveis, por terem sido praticadas em condições econômicas muito distintas.

\subsection{Métodos de comparação indireta baseados no custo de aquisição, acrescido de margem bruta calculada sobre este custo.}

\subsubsection{Cost Plus Method (“CPM").}

O método do custo acrescido de uma margem de lucro bruta ou CPM, concretiza-se a partir da comparação das margens brutas obtidas em operações vinculadas com as margens brutas aferidas em operações não-vinculadas, relativas a bens, serviços ou direitos, idênticos ou similares, em circunstâncias análogas ${ }^{703}$. Considerando que, a exemplo do RPM, o CPM é um dos métodos tradicionais indiretos para se atingir o princípio da plena concorrência, seu emprego desenvolve-se em duas etapas. Primeiramente, examina-se o custo de produção do bem, serviço ou direito fabricado/prestado. Em seguida, calcula-se uma margem bruta de lucro [referida como "gross profit markup"], aferida a partir das funções desempenhadas, dos ativos empregados e dos riscos assumidos; devem ser efetivados, outrossim, os ajustes necessários para tornar as margens examinadas efetivamente comparáveis. Ao final, os custos de produção dos bens e direitos ou dos serviços prestados, somados ao lucro bruto calculado a partir da margem bruta "comparável”, correspondem ao preço de plena concorrência ${ }^{704}$.

A margem bruta, neste caso, corresponde à divisão do lucro operacional bruto ou lucro bruto, pelo custo de produção dos bens, serviços ou direitos. Assim, [margem bruta] (=) [lucro bruto] (/) [custo de produção]. Tecnicamente, contudo, o CPM não se vale

\footnotetext{
703 “\$1.482-3 (d) (2) Determination of arm’s length price. (i) In general. The cost plus method measures an arm's length price by adding the appropriate gross profit to the controlled taxpayer's costs of producing the property involved in the controlled transaction" [26 CFR Ch. I (4-1-09 Edition)].

704 "The cost-plus method begins with the identification of the costs that the supplier of property or services incurs in a controlled transaction with respect to property transferred or services provided to a related purchaser. An appropriate mark-up is then added to this cost to make an appropriate profit in light of the functions performed and the market conditions. In essence, the cost-plus method is the reciprocal of the resale price method. After this mark-up is added, the aggregate amount may be regarded as an arm's length price of the original controlled transaction" (HAMMER, Richard M. et. al. International Transfer Pricing OCDE Guidelines. op. cit. item 4.04).
} 
da "margem bruta" propriamente dita, mas do valor em moeda corrente correspondente à multiplicação desta margem bruta sobre o custo de produção, i.e., do valor do lucro operacional bruto $^{705}$. De fato, para a definição do preço parâmetro via CPM, podem ser efetivados, simplificativamente, os seguintes cálculos:

Preço parâmetro (=) Custo de produção (+) [margem bruta (x) Custo de produção]; ou

Preço parâmetro (=) Custo de produção (+) [Lucro operacional bruto]; ou

Preço parâmetro (=) Custo de produção (x) [1 (+) margem bruta].

O CPM pode ser aplicado tão-somente se uma das duas condições seguintes for atendida: (a.) se não houver diferenças entre as transações comparadas ou, se houver, constatar-se que elas não têm efeitos materiais sobre a margem bruta; ou (b.) se forem constatadas dessemelhanças materialmente relevantes entre a margem bruta da transação praticada e a margem da transação independente comparável, elas possam ser alvo de ajustes, razoavelmente precisos, para a eliminação dos efeitos econômicos das diferenças materiais entre as margens. Note-se que, ao contrário do RPM, que exige a comparação dos preços e das margens brutas de revenda, o CPM envolve, tão-somente, a comparação de margens. Os custos apenas precisam ser examinados na hipótese de comparáveis externos, para sopesar os critérios contábeis adotados pelos contribuintes confrontados. Desse modo, se, no CPM, a margem bruta for prefixada por lei ou por autoridades tributárias, automaticamente este método será transformado num método formular. Como demonstrado acima, \{Preço parâmetro (=) Custo de produção (x) [1 (+) margem bruta]\}. Suponha-se, v.g., que a margem foi fixada em 10\%. Nesta hipótese, [Preço parâmetro (=) 1,1 (x) Custo de produção]; com esta fórmula, razoavelmente simples, o preço parâmetro poderá ser calculado em planilhas de Excel.

Para que se possa proceder ao confronto de margens entre transações vinculadas e transações não-vinculadas, podem ser empregados comparáveis internos ou externos, os quais foram definidos na subseção 2.2.2(IV) do CAPÍTULO 2. No CPM, mais que em qualquer outro método, os comparáveis internos são mais apropriados ${ }^{706}$;

705 " $\$ 1.482-3(\mathrm{~d})(2)$ (ii) Appropriate gross profit. The appropriate gross profit is computed by multiplying the
controlled taxpayer's cost of producing the transferred property by the gross profit markup, expressed as a
percentage of cost, earned in comparable uncontrolled transactions" [ 26 CFR Ch. I (4-1-09 Edition)].
706 " 2.33 The cost plus mark up of the supplier in the controlled transaction should ideally be established by
reference to the cost plus mark up that the same supplier earns in comparable uncontrolled transactions. In
addition, the cost plus mark up that would have been earned in comparable transactions by an independent 
idealmente, assim, o método produziria efeitos mais confiáveis naquelas hipóteses em que um determinado contribuinte fabrica certo bem e revende-o tanto para partes vinculadas quanto a partes não-vinculadas. Neste exemplo específico, a base de custos sobre a qual se aplica a margem bruta é idêntica, porque uma empresa certamente se vale dos mesmos critérios contábeis em todas as suas transações semelhantes; para a comparação de margens, é imprescindível a existência de uma "base de custos" comparável. Nesse contexto, suponha-se, v.g., que dois contribuintes, A e B, fabricam produtos idênticos; ocorre que A possui maquinário moderno, que demanda menor número de funcionários e garante menor desperdício de matéria-prima e insumos; $\mathrm{B}$, de outro lado, possui maquinário antigo, o qual, passa ser operado adequadamente, depende de muitos funcionários qualificados. Estas diferenças claramente afetam os custos de produção e, conseqüentemente, a margem bruta de lucro; devem, conseqüentemente, ser alvo de ajustes antes de as margens de A e B tornarem-se comparáveis, para fins de aplicação do CPM.

Além da distinta composição de custos entre os produtores de bens, serviços e direitos semelhantes, reforça a maior fidedignidade dos comparáveis internos a questão da "consistência contábil" ${ }^{707}$, abordada exaustivamente na seção 4.3.1, acima, no exame do RPM. No âmbito do CPM, todavia, a situação é muito mais grave: enquanto no RPM a consistência contábil presta-se para a definição de margens em operações preponderantemente de revenda, ou com reduzido valor agregado, o CPM parte dos custos de produção de bens ou de prestação de serviços, que se sujeitam a regras mais intrincadas. As inconsistências contábeis, seguramente, multiplicam-se na aplicação do CPM, porque a seara da contabilidade de custos é muito mais complexa nas atividades industriais em geral. Há diferenças entre as regras para o registro de custos entre os países, entre os

enterprise may serve as a guide" (OCDE. Transfer Pricing Guidelines for Multinational Enterprises and Tax Administrations. op. cit., p. II-11). Texto não alterado pela Minuta-2009.

No mesmo sentido, veja-se o teor da legislação norte-americana:

"\$1.482-3 (d) (3) (ii) (A) (...)If possible, the appropriate gross profit markup should be derived from comparable uncontrolled transactions of the taxpayer involved in the controlled sale, because similar characteristics are more likely to be found among sales of property by the same producer than among sales by other producers. In the absence of such sales, an appropriate gross profit markup may be derived from comparable uncontrolled sales of other producers whether or not such producers are members of the same controlled group" [26 CFR Ch. I (4-1-09 Edition)].

707 “\$1.482-3 (d) (3) (iii) (B) Consistency in accounting. The degree of consistency in accounting practices between the controlled transaction and the uncontrolled comparables that materially affect the gross profit markup affects the reliability of the result. Thus, for example, if differences in inventory and other cost accounting practices would materially affect the gross profit markup, the ability to make reliable adjustments for such differences would affect the reliability of the results. Further, the controlled transaction and the comparable uncontrolled transaction should be consistent in the reporting of costs between cost of goods sold and operating expenses. The term cost of producing includes the cost of acquiring property that is held for resale" [26 CFR Ch. I (4-1-09 Edition)]. 
setores produtivos, entre as empresas de um mesmo setor etc.; todas estas diferenças afetam o cálculo da margem bruta de lucro. Tanto não bastasse, o enquadramento de determinados tipos de dispêndios nas três categorias possíveis [custos diretos, custos indiretos ou despesas operacionais] ainda é muito discutido na doutrina contábil ${ }^{708}$. Independentemente disso, pode-se afirmar que os custos diretos e indiretos compõem o "custo de produção do bem ou de prestação do serviço", e possibilitam a aferição da "margem bruta", ao passo que as despesas operacionais são deduzidas do lucro bruto, para a formação do lucro operacional, e possibilitam o cálculo da "margem líquida", como se depreende do artigo 187 da Lei n. ${ }^{\circ}$ 6.404/76. Em apertadíssima síntese, a estrutura de custos e seu impacto na formação das margens seria a seguinte:

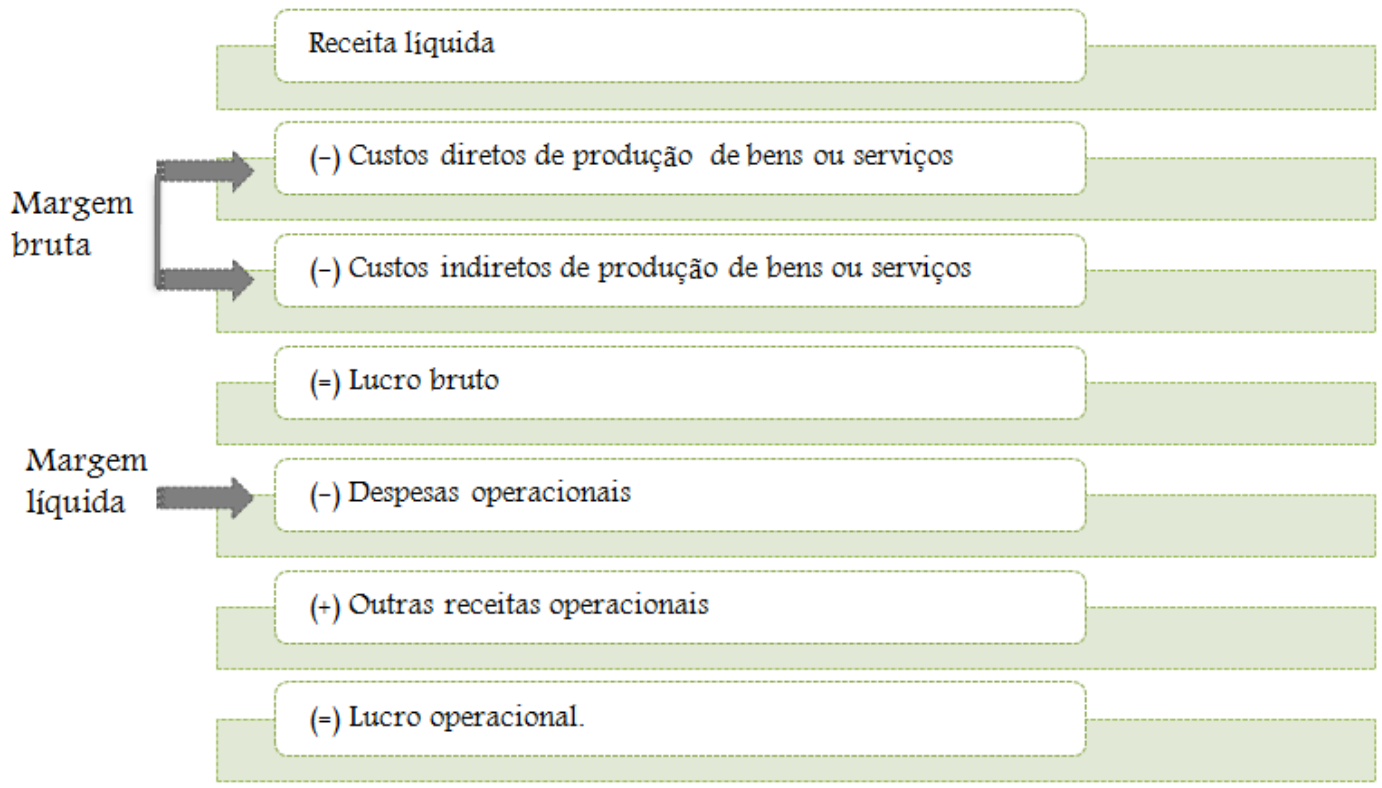

O CPM representa um método tradicional amparado na comparação de margens brutas [baseadas nos custos de produção], e não de margens líquidas [baseadas nos custos de produção $(+)$ receitas operacionais $]^{709}$. Esta constatação é relevante porque, como se

\footnotetext{
708، 2.40 . While precise accounting standards and terms may vary, in general the costs and expenses of an enterprise are understood to be divisible into three broad categories. First, there are the direct costs of producing a product or service, such as the cost of raw materials. Second, there are indirect costs of production, which although closely related to the production process may be common to several products or services (e.g. the costs of a repair department that services equipment used to produce different products). Finally, there are the operating expenses of the enterprise as a whole, such as supervisory, general, and administrative expenses.

2.41. (...) It must be recognized that because of the variations in practice among countries, it is difficult to draw any precise lines between the three categories described above" (OCDE. Transfer Pricing Guidelines for Multinational Enterprises and Tax Administrations. op. cit., p. II-14). Texto não alterado pela Minuta2009.

709 "2.41 The distinction between gross and net margin analyses may be understood in the following terms. In general, the cost plus method will use margins computed after direct and indirect costs of production, while a
} 
verificará no CAPÍTULO 5, há muitas críticas à utilização de margens líquidas ou do lucro operacional (líquido) para o controle dos preços de transferência. De fato, se as margens brutas são afetadas por aspectos como eficiência administrativa, distintos critérios contábeis, estratégias empresariais etc., as margens líquidas são impactadas por uma gama de outros fatores, ainda mais peculiares entre as companhias de um mesmo ramo, como, e.g., estrutura de capital, despesas administrativas, dentre outros. Por este motivo, na opinião de alguns doutrinadores e administrações tributárias, os resultados obtidos a partir da comparação de margens líquidas afastam-se de um preço de plena concorrência. Não obstante, como se ponderará no CAPÍTULO 5, a comparação de lucros operacionais, dados mais divulgados que as margens brutas, vem se tornando uma tendência, influenciada pelos resultados obtidos nos Estados Unidos da América com a aplicação do CPI [“Comparable Profit Method"].

Superada a questão técnico-contábil, pondere-se que, se inexistirem comparáveis internos, as margens brutas do contribuinte "testado" podem ser confrontadas com margens brutas de terceiros, desde que adotados os procedimentos típicos da análise de comparabilidade, bem assim os ajustes contábeis necessários ${ }^{710}$.

net margin method will use margins computed after operating expenses of the enterprise as well. It must be recognized that because of the variations in practice among countries, it is difficult to draw any precise lines between the three categories described above". (OCDE. Transfer Pricing Guidelines for Multinational Enterprises and Tax Administrations. op. cit., p. II-14). Texto não alterado pela Minuta-2009.

Este método é calculado com amparo na margem bruta mas, se algumas despesas operacionais precisarem ser computadas para fins de comparação, isso não desnatura o método, consoante salientado pela OCDE em sua Diretiva:

"2.39. (...) In some cases it may be necessary to take into account certain operating expenses in order to achieve consistency and comparability; in these circumstances the cost plus method starts to approach a net rather than gross margin. To the extent that the analysis takes into account operating expenses, the reliability of the analysis may be adversely affected (...) 2.41. Thus, for example, an application of the cost plus method may in a particular case include the consideration of some expenses that might be considered operating expenses, as discussed in paragraph 2.39. Nevertheless, the problems in delineating with mathematical precision the boundaries of the three categories described above do not alter the basic practical distinction between the gross and net margin approaches" (OCDE. op. cit. nesta nota, p. II-14).

${ }^{710}$ Confira-se, abaixo, exemplo de ajuste contábil bastante simples, trazido por Richard M. HAMMER:

"EXAMPLE 4-18 - Manufacturer A is a domestic manufacturer of timing mechanisms for mass-market clocks. It sells this product to its foreign subsidiary, B. Manufacturer A earns a 5 percent gross profit markup with respect to its manufacturing operation. Manufacturers $\mathrm{X}, \mathrm{Y}$, and $\mathrm{Z}$ are unrelated domestic manufacturers of timing mechanisms for mass-market watches. Manufacturers $\mathrm{X}, \mathrm{Y}$, and $\mathrm{Z}$ sell to unrelated foreign purchasers, and they earn gross profit mark-ups with respect to their manufacturing operations that range from 3 to 5 percent. Manufacturer A accounts for supervisory, general, and administrative costs as operating expenses, and thus these costs are not reflected in cost of goods sold. The gross profit mark-ups of Manufacturers X, Y, and Z, however, reflect supervisory, general, and administrative costs as part of costs of goods sold. In order to provide accounting consistency, the gross profit mark-ups of Manufacturers X, Y, and $\mathrm{Z}$ must be adjusted for the handling of supervisory, general, and administrative costs" (HAMMER, Richard M. et. al. International Transfer Pricing - OCDE Guidelines. op. cit. item 4.04[2] [a]). 
A exemplo do que se apontou quanto ao RPM na seção 4.3.1, acima, também no CPM a identidade ou similitude das características do bem, serviço ou direito que forem objeto da transação não são imprescindíveis para a determinação das margens brutas ${ }^{711}$, que estão mais diretamente vinculadas à quantidade e relevância das atividades desempenhadas pelo produtor dos bens/prestador dos serviços; na prática, outros fatores de comparabilidade podem ser mais relevantes. É possível, v.g., comparar margens aferidas em outros produtos, mas com processo produtivo semelhante. Por este motivo, todos os demais fatores de comparabilidade também devem ser exaustivamente ponderados. A definição da comparabilidade de margens deve envolver, portanto: (I.) a análise funcional [atividades desempenhadas, ativos empregados e riscos envolvidos] ${ }^{712}$; (II.) a análise contratual; (III.) as circunstâncias econômicas; e (IV.) as estratégias empresariais. Cada um dos fatores de comparabilidade foram expostos seção 2.2 do CAPÍTULO 2. Ao final, será a extensão e a qualidade dos ajustes relativos a cada um dos cinco fatores de comparabilidade que afetará a relativa fiabilidade da análise dos preços de transferência mediante a aplicação do CPM.

Ajustes contábeis simples, como a exclusão de despesas de leasing na comparação das margens de um contribuinte que utiliza esta modalidade de financiamento com outro que se valeu de recursos acumulados para a compra à vista de maquinário,

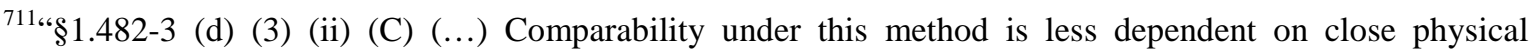
similarity between the products transferred than under the comparable uncontrolled price method. Substantial differences in the products may, however, indicate significant functional differences between the controlled and uncontrolled taxpayers. Thus, it ordinarily would be expected that the controlled and uncontrolled transactions involve the production of goods within the same product categories. Furthermore, significant differences in the value of the products due, for example, to the value of a trademark, may also affect the reliability of the comparison. Finally, the reliability of profit measures based on gross profit may be adversely affected by factors that have less effect on prices. For example, gross profit may be affected by a variety of other factors, including cost structures (as reflected, for example, in the age of plant and equipment), business experience (such as whether the business is in a start-up phase or is mature), or management efficiency (as indicated, for example, by expanding or contracting sales or executive compensation over time). Accordingly, if material differences in these factors are identified based on objective evidence, the reliability of the analysis may be affected" [26 CFR Ch. I (4-1-09 Edition)].

${ }^{712}$ Confira-se, abaixo, um exemplo em que as transações estudadas têm diferentes riscos de estoque: "\$1.482-3 (d) (4) Example 3. The facts are the same as in Example1 [USP, a domestic manufacturer of computer components, sells its products to FS, its foreign distributor. UT1, UT2, and UT3 are domestic computer component manufacturers that sell to uncontrolled foreign purchasers] except that under its contract with FS, USP uses materials consigned by FS. UT1, UT2, and UT3, on the other hand, purchase their own materials, and their gross profit markups are determined by including the costs of materials. The fact that USP does not carry an inventory risk by purchasing its own materials while the uncontrolled producers carry inventory is a significant difference that may require an adjustment if the difference has a material effect on the gross profit markups of the uncontrolled producers. Inability to reasonably ascertain the effect of the difference on the gross profit markups will affect the reliability of the results of UT1, UT2, and UT3” [26 CFR Ch. I (4-1-09 Edition)].
} 
podem ser efetivadas sem prejuízos à fiabilidade dos resultados do método ${ }^{713}$. De outro lado, pode não ser possível a efetivação de ajustes suficientes para garantir a comparabilidade de margens brutas entre empresas com graus muito distintos de eficiência e níveis de produtividade ${ }^{714}$.

No caso da prestação de serviços, a avaliação do nível das atividades desempenhadas e do risco suportado pelo prestador é imprescindível para a definição das margens brutas. Assim, suponha-se que uma determinada empresa A dedique-se a pesquisas inovadoras no mercado eletrônico, mas que seu contrato com B prevê que A contratará técnicos e adquirirá equipamentos, com recursos fornecidos por A, que reembolsará quaisquer dispêndios, independentemente do sucesso da pesquisa; neste exemplo, A provavelmente cobraria de B uma margem reduzida sobre os custos totais do projeto, mas não participaria de seus resultados. De outro lado, se B contrata a empresa C, que recebe um valor fixo inicial e desenvolve pesquisas às suas expensas, esta última exigirá uma remuneração bastante mais elevada na hipótese de a pesquisa resultar em produtos lucrativos. O caso Westreco Inc. V. Commissioner, envolvendo uma empresa do grupo Nestlé estabelecida nos Estados de Ohio e Connecticut, assemelha-se bastante a este exemplo $^{715}$; neste caso, a Nestlé constituiu uma companhia denominada Nestec, a qual

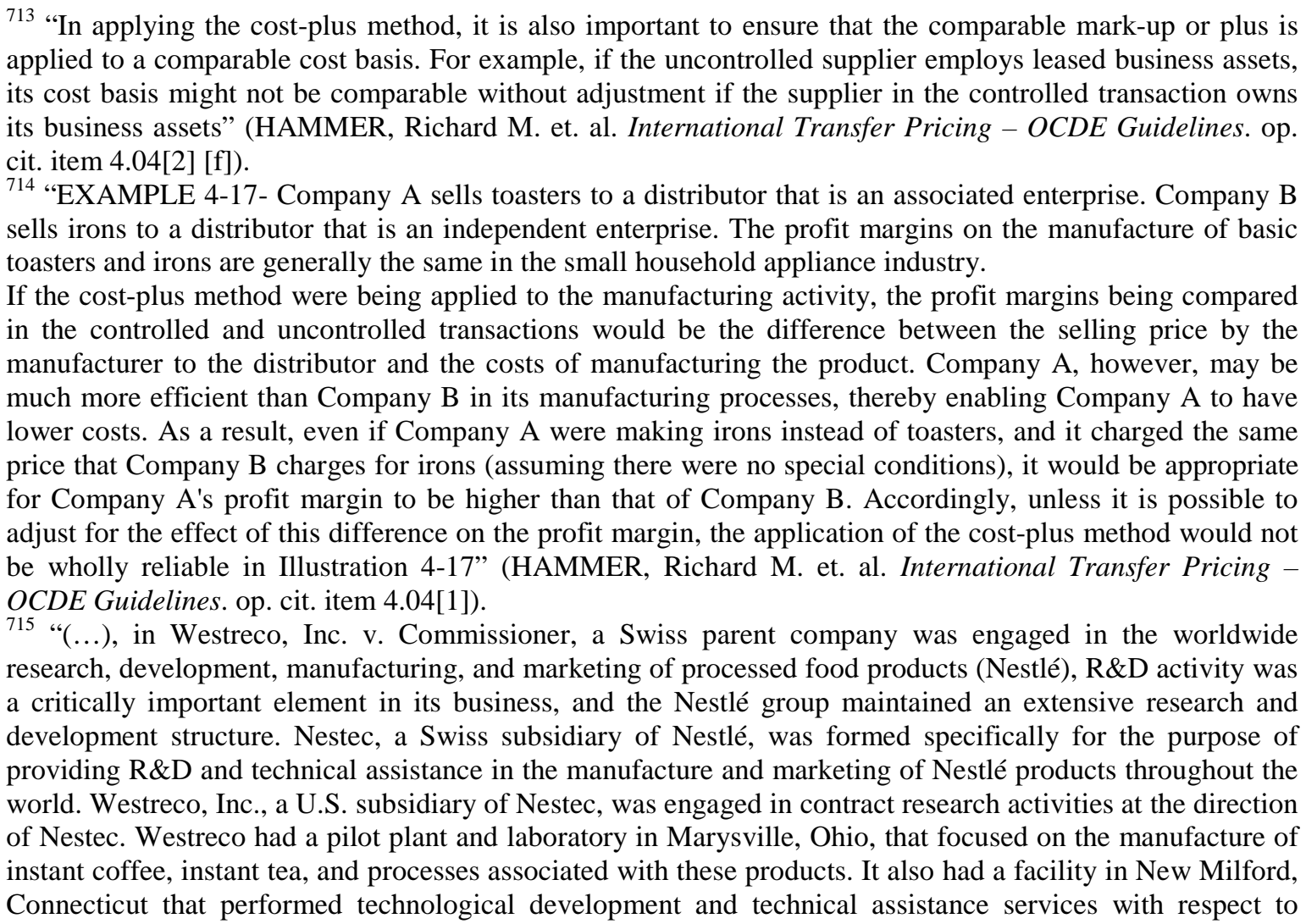


tinha por objeto a manutenção de extensas pesquisas para o aperfeiçoamento ou desenvolvimento de produtos. A Nestec constituiu, no território estadunidense, a Westreco, com o objetivo de pesquisas no setor de café instantâneo. Esta companhia, contudo, não assumia nenhum risco: era sempre remunerada pelo valor dos seus custos, acrescidos de margem bruta de lucro [7,5\% a 3,5\%]; as autoridades fiscais norte-americanas buscavam aumentar a margem tributável no seu país mas, ao final, o tribunal reconheceu que a ausência de riscos assumidos seria um fator relevante para a redução da remuneração da Westreco, comparativamente a outras companhias que desenvolviam atividades assemelhadas.

Por fim, importa esclarecer que o CPM é um método bastante utilizado na revenda de produtos semi-acabados entre empresas do mesmo grupo e, especialmente, no setor de serviços ${ }^{716}$; trata-se do método "por excelência" aplicado a este setor e, por

culinary products. Westreco was compensated on the basis of cost plus a profit of 7.5 percent of the first $\$ 350,000$ of certain expenses, 5 percent of the next $\$ 1$ million, and 3.5 percent of additional expenses. Research contracts were terminable on three months notice by either party.

The Service conducted an examination that covered 1978 through 1982, and it proposed deficiencies without identifying a methodology to support the alleged deficiency. The engineer who conducted the examination of Westreco had used a methodology based on a so-called salary multiplier method, which was apparently a common means of compensating large construction and engineering firms.

The Tax Court suggested that this method was not an appropriate method for determining the arm's length level of fees that Westreco would have received in dealing with unrelated parties.

The taxpayer offered the testimony of an economist as an expert witness, who compared Westreco's margins with those of four corporations that also provided contract research services, and concluded that Westreco's earnings 'were comparable to such income from services performed for unrelated corporations'. The Service also offered the testimony of economists as expert witnesses, who compiled a group of 15 corporations from a data base organized by Standard Industrial Classification (SIC) codes. The court found that this grouping of potential comparables was defective because there was no indication in the record that the 15 companies were comparable to Westreco.

The court noted, however, that the record reflected several reasons that supported a lower level of profitability in Westreco than in the group of companies that the Service offered. One reason for lower gross income in Westreco was the fact that there was a 'great deal less economic and business risk for Westreco'. Research and other downstream risk was found to be virtually nonexistent, because Westreco was paid regardless of success or failure on its projects. The court noted a fundamental economic principle that firms that do not take risks can and should expect to earn a lower rate of return. This concept can readily be seen from the standpoint of a consumer as the difference between a passbook savings account (a safe but low return) and a junk bond (speculative but a much higher return).

Finally, the court noted that even the Service's own experts at trial had indicated that Westreco was within an acceptable range of profitability. It then concluded that the fees that Nestec paid to Westreco for Westreco's research and development services 'clearly reflected income under section 482'. The essence of the conclusion in Westreco is that the margins that unrelated parties earned can be used to determine an arm's length charge, provided that the circumstances are sufficiently similar or comparable (including the level of economic risk)" (HAMMER, Richard M. et. al. International Transfer Pricing - OCDE Guidelines. op. cit. item 4.04[3]).

${ }_{716 ،}$ The cost-plus method seeks to determine the transfer price as a percentage of the cost that the seller incurs in a controlled sale. This method is typically appropriate where the seller uses little of its own intangible property and otherwise takes little economic risk in the overall transaction. (...) This method probably is most useful where semi-finished goods are sold between related parties, where related parties have concluded joint facility agreements or long-term buy-and-supply arrangements, or where the controlled transaction is 
conseqüência, trata-se de método bastante difundido para o "teste" das operações globais envolvendo a negociação de instrumentos financeiros, como se verificará em 4.4.4, abaixo. De fato, em pesquisa realizada pela Ernst \& Young International Ltd., constatou-se que 73\% das empresas pesquisadas comprovam os preços de transferência em operações desta natureza mediante a aplicação do CPM ou métodos decorrentes do exame dos $\operatorname{custos}^{717}$.

\subsubsection{Método do Custo de Produção mais Lucro (“CPL”).}

A Lei n. ${ }^{\circ}$ 9.430/96 prevê, no seu artigo 18, II, um equivalente ao método CPM para as operações de importação, conhecido no Brasil pela sigla CPL [custo de produção mais lucro]. A redação atual do referido dispositivo legal, considerando-se as alterações promovidas pela Medida Provisória n. ${ }^{\circ}$ 478/09, é a seguinte: "CPL: definido como o custo médio ponderado de produção de bens, serviços ou direitos, idênticos ou similares, no país onde tiverem sido originariamente produzidos, acrescido dos impostos e taxas cobrados pelo referido país na exportação e de margem de lucro de vinte por cento, calculada sobre o custo apurado" 718 . Em resumo, a fórmula para o cálculo do preço parâmetro mediante o emprego do CPL seria a seguinte:

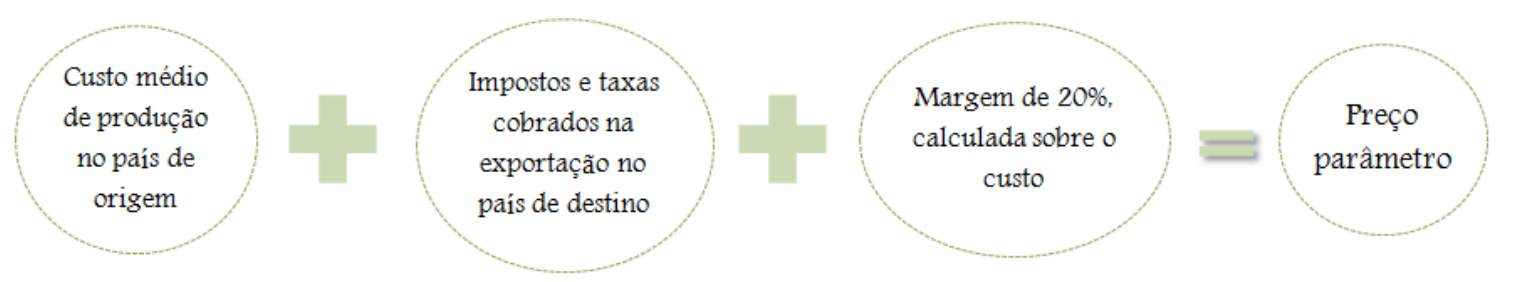

Veja-se que o preço parâmetro equivale a [Custos de produção (+) Tributos incidentes na exportação (+) Lucro operacional bruto], sendo o último elemento da fórmula correspondente a [Margem bruta de lucros (x) Custo de produção ${ }^{719}$ ]. A margem, como se

the provision of services" (HAMMER, Richard M. et. al. International Transfer Pricing - OCDE Guidelines. op. cit. item 4.04).

${ }^{717}$ In: 2007-2008 Global Transfer Pricing Survey. Global Transfer Pricing Trends, Practices and Analysis, op. cit..

${ }^{718}$ O termo sublinhado foi incluído na redação original da Lei n. ${ }^{\circ}$ 9.430/96 pela Medida Provisória n. ${ }^{\circ}$ 478/09. As considerações sobre os prós e contras relacionados à adoção das médias, aritméticas e ponderadas constam da seção 2.2.1, do CAPÍTULO 2.

Ressalte-se, outrossim, que, após a alteração por aludida medida, o CPL passou a ser previsto no inciso II do artigo 18 da Lei n..$^{\circ}$ 9.430/96, ao invés do inciso III, agora reservado ao PVL.

${ }_{719}$ A respeito do cálculo da margem, o $\$ 7^{\circ}$ do artigo 13 da Instrução Normativa n. $.^{\circ} 243 / 02$ apregoa que:

"Art. 13. (...) 
depreende do próprio texto legal, foi prefixada por lei em $20 \%$. O cálculo do preço parâmetro poderia ser, portanto, o seguinte: \{Preço Parâmetro (=) [1,2 (x) Custo de Produção] (+) Tributos incidentes na exportação\}. Sem a necessidade de busca da margem mais adequada pelo contribuinte, o CPL perde o "cerne" da comparabilidade e aproximase, como referido em 4.4.1, de um método formular.

O artigo 18, II, da Lei n. ${ }^{\circ}$ 9.430/96, não prevê detalhes sobre a aplicação do método. No âmbito do artigo 13 da Instrução Normativa n. ${ }^{\circ}$ 243/02, todavia, a administração tributária indica uma lista supostamente exaustiva de dispêndios que devem compor o "custo de produção",720. Os custos de produção deverão ser rateados, proporcionalmente às quantidades destinadas à empresa brasileira; na hipótese de a produtora dedicar-se também a atividades distintas que compartilhem dos custos indiretos, contudo, não foi indicado o parâmetro para rateio ${ }^{721}$. Independentemente das incertezas da norma, é certo que, para a aplicação do CPL, os contribuintes brasileiros deverão solicitar, à empresa associada no exterior, a elaboração de nova planilha de custos, a partir dos

$\S 7^{\circ}$ A margem de lucro a que se refere o caput será aplicada sobre os custos apurados antes da incidência dos impostos e taxas cobrados no país de origem, sobre o valor dos bens, serviços e direitos adquiridos pela empresa no Brasil".

720 "Art. 13. (...)

$\S 1^{\circ} \mathrm{Na}$ apuração de preço por esse método serão considerados exclusivamente os custos a que se refere o $\S 4^{\circ}$, incorridos na produção do bem, serviço ou direito, excluídos quaisquer outros, ainda que se refira a margem de lucro de distribuidor atacadista. (...)

$\S 4^{\circ}$ Para efeito de determinação do preço por esse método, poderão ser computados como integrantes do custo:

I - o custo de aquisição das matérias-primas, dos produtos intermediários e dos materiais de embalagem utilizados na produção do bem, serviço ou direito;

II - o custo de quaisquer outros bens, serviços ou direitos aplicados ou consumidos na produção;

III - o custo do pessoal, aplicado na produção, inclusive de supervisão direta, manutenção e guarda das instalações de produção e os respectivos encargos sociais incorridos, exigidos ou admitidos pela legislação do país de origem;

IV - os custos de locação, manutenção e reparo e os encargos de depreciação, amortização ou exaustão dos bens, serviços ou direitos aplicados na produção;

V - os valores das quebras e perdas razoáveis, ocorridas no processo produtivo, admitidas pela legislação fiscal do país de origem do bem, serviço ou direito".

${ }^{721}$ A exigência quanto à proporcionalização dos custos nas vendas para o Brasil consta do $§ 5^{\circ}$ do artigo 13 da Instrução Normativa n. ${ }^{\circ}$ 243/02. Confira-se:

“Art. 13 (...)

$\S 5^{\circ} \mathrm{Na}$ determinação do custo do bem, serviço ou direito, adquirido pela empresa no Brasil, os custos referidos no $\S 4^{\circ}$, incorridos pela unidade produtora no exterior, serão considerados proporcionalmente às quantidades destinadas à empresa no Brasil"

Ainda sobre o rateio dos custos indiretos, confira-se o entendimento de Luis Eduardo SCHOUERI:

“A norma administrativa brasileira não esclarece qual o critério de rateio de custos indiretos. Tendo em vista que também internamente o legislador brasileiro não impôs critérios rígidos, parece correto entender que o contribuinte tem, aqui, liberdade de atuação, desde que mantenha consistência em sua prática.

Vale lembrar, outrossim, que se o contribuinte pretender valer-se da aplicação de margens de lucro diversas daquelas previstas pelo legislador, deverá demonstrar que as transações comparadas adotam critérios de rateio semelhantes" (SCHOUERI, Luís Eduardo. Preços de Transferência no Direito Tributário Brasileiro. op. cit., p. 198). 
critérios-base definidos pela regulamentação brasileira, para fins de comprovação dos preços de transferência praticados. Há previsão, ainda, de que "os custos de produção deverão ser demonstrados, discriminadamente, por componente, valores e respectivos fornecedores" [cf. artigo 13, §2º da Instrução Normativa n. ${ }^{\circ}$ 243/02]. Da leitura destas regras pode-se depreender, com facilidade, que a questão documental atinente à aplicação do CPL é bastante complexa. Com efeito, a documentação de empresa associada no exterior nem sempre é facilmente "adaptável" aos critérios contábeis brasileiros; a prova de cada uma das operações da exportadora estrangeira, com os custos divididos por componentes e respectivos fornecedores, também é custosa. Estas dificuldades, aliadas ao teor do artigo 19-B da Lei n. ${ }^{\circ}$ 9.430/96, que permite a desconsideração de "documentos imprestáveis ou insuficientes" pela administração tributária ${ }^{722}$, comprovam porque a aplicação deste método pelos contribuintes brasileiros ainda gera insegurança, sendo, portanto, restrita.

No que respeita à análise de comparabilidade envolvida na aplicação do CPL, convém, inicialmente, esclarecer que este método aplica-se a transações envolvendo bens idênticos ou similares. Na hipótese de comparação das margens brutas de produção dos produtos similares, "o custo de produção deverá ser ajustado em função das diferenças entre o bem, serviço ou direito adquirido e o que estiver sendo utilizado como parâmetro" [cf. artigo 13, $\S 6^{\circ}$, da Instrução Normativa n. $243 / 02$ ]. A redação deste dispositivo, se comparada ao teor dos artigos 10 e 17 do mesmo normativo, demonstra que, especificamente no CPL, os ajustes relativos à similaridade não são alvo de limitações abusivas. Sobre as noções de bens, serviços ou direitos idênticos ou similares, reporta-se à seção 2.2.1(I), do CAPÍTULO 2.

Importa consignar, a este passo, que o $\$ 3^{\circ}$ do artigo 13 da Instrução Normativa n. . 243/02 determina que "poderão ser utilizados dados da própria unidade fornecedora [exportadora para o Brasil] ou de unidades produtoras de outras empresas, localizadas no país de origem do bem, serviço ou direito". O conteúdo desta norma gera margens a dúvidas: devem ser utilizados apenas os dados das exportadoras [ou de outras fabricantes dos produtos que ela vendeu ao Brasil], ou podem ser utilizados dados externos? ${ }^{723}$

\footnotetext{
${ }^{722}$ As principais dificuldades relacionadas à aplicação do artigo 19-B da Lei n. ${ }^{\circ}$ 9.430/96 foram indicadas e discutidas na seção 2.7 do CAPÍTULO 2.

${ }^{723}$ A este respeito, Luís Eduardo SCHOUERI pondera que:
} 
Também não está claro o sentido da expressão "país onde tiverem sido originariamente produzidos".

Não obstante o conteúdo do artigo 18, II, da Lei n. ${ }^{\circ}$ 9.430/96 ou do artigo 13 do normativo, por todas as razões expostas na seção 2.2. do CAPÍTULO 2, sustenta-se não ser razoável a proibição de utilização de dados externos ou de outros países, além do país exportador. Suponha-se, v.g., que a instituição financeira $X$ contrate serviços de contabilidade e controladoria de outra empresa do seu grupo econômico, a X1; sabe-se que, neste ramo, os serviços de contabilidade são remunerados por [custo (+) $50 \%$ de margem bruta], em razão de pesquisas publicadas por associações contábeis. X1, contudo, recusa-se a fornecer seus custos para que $\mathrm{X}$ possa comprovar os seus preços de transferência. Se o PIC não for aplicável, por especificidades do próprio serviço, e não sendo o PVL compatível com a transação, por que proibir a utilização de tal indicador externo? Os comparáveis internos, de fato, são mais confiáveis na aplicação deste método se comparados aos comparáveis externos [dados de outras empresas ou indícios externos do mercado]; não se pode, todavia, proibir o seu uso, ainda mais diante da inexistência de outros métodos.

Quanto aos demais fatores de comparabilidade envolvidos na aplicação do PVL, reporta-se à seção 2.2.1, no âmbito da qual se conclui que, não obstante a ausência de previsão legal ou regulamentar específica, quaisquer distinções nas condições das transações, que afetem materialmente os preços ou margens de transações similares, devem ser ajustadas, de modo a torná-las comparáveis às transações "testadas". Por fim, no que se refere ao percentual prefixado de $20 \%$ para a determinação da "margem", confiram-se as seções 1.9.1 do CAPÍTULO 1, que trata dos meios de prova admitidos para sua alteração, bem assim a seção 4.6, abaixo.

\footnotetext{
"O parágrafo $3^{\circ}$ do artigo 13 da IN 243/02 admite a utilização de dados da própria unidade fornecedora ou de unidades produtoras de outras empresas, localizadas no país de origem do bem, serviço ou direito. À primeira vista, esta autorização poderia significar estarem as autoridades administrativas cogitando de médias de custos de fabricantes.

Na verdade, o que o dispositivo contempla é a circunstância de que nem sempre o fornecedor (vinculado) é o próprio fabricante. Apenas em tal caso é que, em vez de considerar-se a estrutura de custos do vendedor, tomar-se-á o custo do fabricante, no país de origem do bem, serviço ou direito" (SCHOUERI, Luís Eduardo. Preços de Transferência no Direito Tributário Brasileiro. op. cit., p. 197).
} 


\subsubsection{Método do Custo de Aquisição ou de Produção mais Tributos e Lucro ("CAP").}

Por intermédio do emprego do método do custo de aquisição ou de produção mais tributos e lucros, ou CAP, obtém-se preço parâmetro representado pela "média aritmética [ponderada ${ }^{724}$ ] dos custos de aquisição ou de produção dos bens, serviços ou direitos, exportados, acrescidos dos impostos e contribuições cobrados no Brasil e de margem de lucro de quinze por cento sobre a soma dos custos mais impostos e contribuições" [cf. artigo 19, $\$ 3^{\circ}$, III, da Lei n. ${ }^{\circ}$ 9.430/96]. Este método é concretizado a partir da seguinte fórmula:

Preço parâmetro (=) [Custo médio de produção ou aquisição] (+) [tributos cobrados no Brasil] (+) [15\% (x) Custo médio de produção ou aquisição]; ou

Preço parâmetro (=) [1,15 (x) Custo médio de produção ou aquisição] (+) [tributos].

No âmbito da Instrução Normativa n. ${ }^{\circ}$ 243/02, as autoridades tributárias esclareceram que, para a determinação do custo médio ponderado de aquisição ou produção dos bens, serviços ou direitos exportados, devem ser (i.) somados os valores de frete e seguro pagos pela adquirente, relativamente aos bens, serviços ou direitos exportados $^{725}$; e (ii.) deduzidos os saldos de crédito presumido de IPI [cf. artigo 26, $\S 2^{\circ}$ ]. A margem, de outro lado, deve ser multiplicada pelo [Custo médio de produção ou aquisição (-) crédito presumido de IPI]. Também se previu, como não poderia deixar de ser, que o método aplica-se indistintamente às vendas diretas e às vendas via companhias trading ou empresas comerciais exportadoras ${ }^{726}$. Especificamente quanto ao percentual prefixado de 15\% para a determinação da "margem", confiram-se as seções 1.9.1 do CAPÍTULO 1, que trata dos meios de prova admitidos para sua alteração, bem assim a seção 4.6, abaixo.

\footnotetext{
${ }^{724}$ A despeito de a Lei n. 9 9.430/96 aludir a "média aritmética", o artigo 26 da Instrução Normativa n. ${ }^{\circ}$ 243/02 refere-se a "média aritmética ponderada". Ao contrário do que se deu em relação aos métodos aplicáveis às operações de importação, em que a noção de média ponderada foi incluída no texto legal via Medida Provisória n. ${ }^{\circ}$ 478/09 [cf. artigo 18, incisos I, II e III], os métodos relativos às exportações, previstos no artigo $19, \S^{\circ}$, da Lei n. ${ }^{\circ} 9.430 / 96$, não tiveram seu texto modificado.

${ }^{725}$ In: artigo $26, \S 1^{\circ}$, da Instrução Normativa n. ${ }^{\circ} 243 / 02$.

726 “Art. 26. (...)

$\S 4^{\circ} \mathrm{O}$ preço determinado por este método, relativamente às exportações diretas efetuadas pela própria empresa produtora, poderá ser considerado parâmetro para o preço praticado nas exportações efetuadas pela empresa, por intermédio de empresa comercial exportadora, não devendo ser considerado o novo acréscimo a título de margem de lucro da empresa comercial exportadora".
} 
Ao se referir a "custos de aquisição ou de produção dos bens (...) exportados", o legislador indica que tão-somente os custos relacionados às operações de exportação testadas é que devem ser computados nos cálculos ${ }^{727}$; inexiste, portanto, a necessidade/possibilidade de comparação de custos. O contribuinte apenas definirá o seu custo para fins de sobre ele fazer incidir a margem bruta e, em seguida, obter o preço parâmetro; não precisará compará-lo com outros custos, nem estudar margens em transações idênticas ou semelhantes. Trata-se, assim, de mais um método brasileiro que se aproxima de critérios semelhantes a "fórmulas predeterminadas", porque sua aplicação depende, tão-somente, do adequado preenchimento de planilha de Excel com os custos médios ponderados de aquisição ou produção. A legislação brasileira supõe, por conseguinte, que o CAP poderá ser aplicado apenas nas hipóteses em que um determinado contribuinte revender seus bens ou direitos, ou prestar seus serviços, tanto a partes vinculadas quanto a partes não vinculadas, no exterior ou no país. Se, e.g., um contribuinte brasileiro fabricar determinado produto e revendê-lo com exclusividade a sua controladora no exterior, o CAP não tem utilidade. Como decorrência desta restrição à aplicação do CPM às operações de exportação, (a.) não existe referência à possibilidade de utilização de dados de transações "similares", (b.) nem se prevê a adoção de comparáveis externos.

\subsubsection{Gross markup method, proposto pela legislação norte-americana para o controle das negociações globais.}

O "método da margem bruta sobre o custo" ou "gross markup method"728, corresponde a uma variação do CPM, disciplinada pela Seção 1.482-8/Proposta do IRC e aplicada tão-somente a negociações globais. O preço parâmetro é calculado, neste caso, a partir do confronto das margens brutas auferidas em transações vinculadas com as margens de transações não-vinculadas. Este método aplica-se tanto às hipóteses de negociação de instrumentos financeiros [e do "markup" mínimo que seria exigido por terceiros

\footnotetext{
727 “(...) enquanto no método CPL havia a possibilidade de descobrirem-se custos (de fabricação) de bens idênticos ou similares, no método CAP encontra-se a referência ao custo dos próprios bens exportados. Verifica-se, portanto, que para o método CAP, o legislador, ao referir-se ao 'custo médio', exigiu a apuração do custo imputável diretamente àquela exportação. Noutras palavras, se o exportador efetua vendas no mercado interno, ou até mesmo no mercado externo a pessoas não-ligadas ou a outras pessoas ligadas, o método CAP desconsidera tais circunstâncias, exigindo a apuração do custo médio, para o exportador, dos bens que foram exportados na transação controlada" (SCHOUERI, Luís Eduardo. Preços de Transferência no Direito Tributário Brasileiro. op. cit., p. 199).

${ }^{728}$ A expressão "markup" ou "mark up" indica quanto do preço de um determinado produto está acima do seu custo de produção e distribuição; o "markup" pode ser expressado como uma quantia fixada ou como um percentual.
} 
independentes, em condições análogas], quanto a serviços nesta área, remunerados via comissão $^{729}$. Como referido em 4.4.1, supra, em relação ao CPM, este é, por excelência, o método aplicável às transações envolvendo serviços. A fórmula para de aplicação deste método, tal como prescrito na legislação estadunidense, é a seguinte:

Preço parâmetro (=) Custo de estruturação do produto financeiro (+) [margem bruta (x) Custo de estruturação do produto].

Preço parâmetro (=)Custo de estruturação do produto financeiro (+) [Lucro bruto] ${ }^{730}$.

Para o cálculo do preço parâmetro a partir do "método da margem bruta sobre o custo", deve-se adotar o seguinte procedimento: (i.) primeiramente, examina-se o custo de estruturação do instrumento financeiro e, se for o caso, também o custo estimado de manutenção de determinada posição até sua maturação [i.e., até a "maturity date"]; (ii.) em seguida, calcula-se uma margem bruta de lucro, aferida a partir das funções desempenhadas, dos ativos empregados e dos riscos assumidos; devem ser efetivados, outrossim, os ajustes necessários para tornar as margens examinadas efetivamente comparáveis. Ao final, os custos de estruturação e acompanhamento do produto financeiro, somados ao lucro bruto calculado a partir da margem bruta comparável, propiciam o preço de plena concorrência.

Para a aferição da margem bruta sobre o custo, é relevante o exame do objeto da transação financeira mas, essencialmente, deve ser efetivada uma análise funcional minuciosa, examinando-se as funções desempenhadas [ou que serão desempenhadas durante o período de maturação do instrumento], os ativos empregados e os riscos

729 “\$1.482-8 [proposta] (d) (1) General rule. The gross markup method evaluates whether the amount allocated to a participant in a global dealing operation is arm's length by reference to the gross profit markup realized in comparable uncontrolled transactions. The gross markup method may be used to establish an arm's length price for a transaction where a participant purchases a financial product from an unrelated party that the participant sells to a related party. This method may apply to transactions involving the purchase and resale of debt and equity instruments. The method may also be used to evaluate whether a participant has received an arm's length commission for its role in a global dealing operation when the participant has not taken title to a security or has not become a party to a derivative financial product" (Federal Register/v. 63, no. 44. op. cit).

730 " $\$ 1.482-8$ [proposta] (d) (2) The gross markup method measures an arm’s length price by adding the appropriate gross profit to the participant's cost or anticipated cost, of purchasing, holding, or structuring the financial product involved in the controlled transaction under review (or in the case of a derivative financial product, the initial net present value, measured by the anticipated cost of purchasing, holding, or structuring the product). (...)The appropriate gross profit is computed by multiplying the participant's cost or anticipated cost of purchasing, holding, or structuring a transaction by the gross profit markup, expressed as a percentage of cost, earned in comparable uncontrolled transactions" (Federal Register/v. 63, no. 44. op. cit). 
assumidos pela instituição financeira "testada"731; trata-se de situação idêntica à exposta em 4.4.1, em relação ao CPM. Para a aplicação deste método, assim como se sucede em relação a quaisquer métodos de comparação indireta, sustentam as autoridades norteamericanas que os comparáveis internos são preferíveis aos comparáveis externos ${ }^{732}$. É possível, entretanto, a utilização de dados disponíveis no mercado como, v.g., cotações em bolsas $^{733}$, ou de terceiros, pertencentes ou não ao mesmo grupo financeiro, desde que produzam resultados compatíveis com o princípio da plena concorrência. Nas hipóteses de comparação externa, assim como explicado em 4.4.1, a consistência dos critérios contábeis adotados pelos contribuintes comparados é muitíssimo relevante, porque quaisquer dessemelhanças mínimas afetam a composição dos custos de estruturação dos instrumentos e, por conseguinte, a margem bruta sobre estes custos ${ }^{734}$. Adicionalmente, assevere-se que a contabilidade de custos envolvida na escrituração de serviços sofisticados, como aqueles desenvolvidos nas transações globais, pode afetar a comparabilidade das transações, porquanto, nesta área, há diversas modalidades de avaliação dos ativos financeiros, de apropriação dos custos e de simulação dos custos estimados até a maturação do instrumento, se for o caso.

731 “\$1.482-8 [proposta] (d) (3) (i) (...) The gross markup method considers whether a participant has earned a sufficient gross markup on the sale of a financial product, or line of products, given the functions it has performed. A participant's gross profit markup provides compensation for purchasing, hedging, and transactional structuring functions related to the transaction under review, including an operating profit in return for the investment of capital and the assumption of risks. Accordingly, where a participant does not take title, or does not become a party to a financial product, the reseller's return to capital and assumption of risk are additional factors that must be considered in determining the gross profit markup" (Federal Register/v. 63, no. 44. op. cit).

732 “ $\$ 1.482-8$ [proposta] (d) (3) (i) (...) An appropriate gross profit markup primarily should be derived from comparable uncontrolled purchases and sales of the participant involved in the controlled sale. This is because similar characteristics are more likely to be found among different sales of property made by the same participant than among sales made by other resellers. In the absence of comparable uncontrolled transactions involving the same participant, an appropriate gross profit markup may be derived from comparable uncontrolled transactions of other parties whether or not such parties are members of the same controlled group" (Federal Register/v. 63, no. 44. op. cit).

733، $\$ 1.482-8$ [proposta] (d) (3) (iv) (A) The reliability of the results derived from the gross markup method is affected by the completeness and accuracy of the data used and the reliability of the assumptions made to apply the method. See $\S 1.482-1$ (c)(2)(ii). A participant may establish the gross markup by comparing the bid and offer prices on a public exchange or quotation media. In such case, the prices must be contemporaneous with the controlled transaction, and the participant must retain records of such data" (Federal Register/v. 63, no. 44. op. cit).

734 " $\$ 1.482-8$ [proposta] (d) (3) (iv) (B) Consistency in accounting. The degree of consistency in accounting practices between the controlled transaction and the uncontrolled transactions may affect the reliability of the gross markup method. For example, differences as between controlled and uncontrolled transactions in the method used to value similar financial products (including methods in accounting, methods of estimation, and the timing for changes of such methods) could affect the gross profit. The ability to make reliable adjustments for such differences could affect the reliability of the results" (Federal Register/v. 63, no. 44. op. cit). 
Por fim, pondere-se que as regras gerais do CPM, expostas em 4.4.1, são o fundamento para a aplicação do "método da margem bruta sobre o custo", desde que, claro, sejam adaptadas a esta espécie específica de transação. Adicionalmente, também devem ser empregadas durante a implementação da análise de comparabilidade exigida por este método todas as peculiaridades concernentes aos cinco fatores específicos para as transações envolvendo a negociação global de instrumentos financeiros [Seção 1.482-1 do IRC, c.c. Seção 1.482-8/Proposta, item (a) ${ }^{735}$, conforme analisado em 4.2.4, item específico concernente à aplicação do CUFT.

\subsection{Análise funcional e aplicação dos métodos tradicionais às transações intra-conglomerados bancários envolvendo a negociação global de instrumentos financeiros.}

Nesta seção, pretende-se identificar (i.) as principais contribuições de cada atividade desempenhada, ativo empregado ou risco assumido na precificação das transações de negociação global de instrumentos financeiros, de modo a determinar (ii.) possível(is) método(s) para o controle dos preços de transferência respectivos ${ }^{736}$. Os principais fundamentos teóricos para o exame das atividades, ativos e riscos, foram discutidos na seção 3.4 do CAPÍTULO 3. Já a definição da estrutura para a organização das atividades de trading implementada em cada grupo econômico [negociação integrada, administração centralizada de produtos e negociação por entidades segregadas], que também auxilia sobremaneira neste processo, foi discutida na subseção 3.2.2, também do CAPÍTULO 3.

$\mathrm{Na}$ maioria das transações globais, os métodos tradicionais discutidos neste CAPÍTULO 4 podem ser empregados sem muitas dificuldades, sendo viável a obtenção de preços ou margens brutas comparáveis para a aplicação do CUP, RPM ou CPM. Na administração centralizada de produtos ["Centralised Product Management”], e.g., adquire-

\footnotetext{
$735 \S 1.482-8$ [proposta] (d) (3) (i) The provisions of $\S 1.482-1$ (d), as modified by paragraph (a)(3) of this section, apply in determining whether a controlled transaction is comparable to a particular uncontrolled transaction. All of the factors described in paragraph (a)(3) of this section must be considered in determining the comparability of two financial products transactions, including the functions performed" (Federal Register/v. 63, no. 44. op. cit).

736 " 115 . (...)In the global trading context, the carrying out of a careful functional analysis will be particularly important because of the wide range of significant functions potentially involved, the variety of risks that can be assumed or transferred, the global dispersal of the performance of many functions and the wide variation in business structures and organization" (OCDE. Report on the Attribution of Profits to Permanent Establishments. op. cit., p. 142).
} 
se de partes associadas tão-somente serviços de apoio [middle office e back office] e de vendas; as funções de mensuração mais delicada como a atividade de trading e a administração de riscos são centralizados na esfera de uma única pessoa jurídica do mesmo grupo econômico e, por conseguinte, não precisam ser "testadas"; também eventuais intangíveis de elevado valor costumam ser de titularidade da empresa "centralizadora", afastando-se a necessidade de mensurar uma remuneração por seu uso. Habitualmente, portanto, a estrutura da administração centralizada adéqua-se aos métodos tradicionais, na maioria dos casos suficientes para o controle dos preços de transferência das entidades que operam desta maneira ${ }^{737}$. Na estrutura de negociação por entidades segregadas ["Separate Enterprise Trading"], que praticamente não gera a integração de funções, a não ser algumas atividades de back-office, a questão dos preços de transferência apresenta-se mais simples $^{738}$.

Apenas a atuação integrada ou "Integrated Trading" costuma apresentar maiores dificuldades, em especial relacionadas à forma de avaliação dos serviços dos traders e de administração de riscos, que podem ser repartidos entre várias instituições de um mesmo grupo econômico. Como exemplificado na seção 3.4 do CAPÍTULO 3, numa estrutura de negociação ininterrupta durante $24 \mathrm{~h} / \mathrm{dia}$, normalmente as atividades de trading e administração de riscos transferem-se entre instituições localizadas em países distintos, de acordo com o fuso horário respectivo [são os negócios designados "around the world, around the clock"]. A atuação integrada exige a repartição do resultado de tal atividade específica entre mais de uma instituição; a busca de dados comparáveis para a aplicação do princípio da plena concorrência, neste caso, não é trivial, porque este tipo de estrutura não é praxe entre partes independentes que, se for o caso, reúnem-se em "joint ventures" para

\footnotetext{
737 “ $116 .(\ldots)$ This is because, where a business is organized on pure centralized product management model lines, many of the functions apart from marketing (i.e. trading and risk management functions) may all be centralized in one location. The profit attributable to those functions is largely produced from transactions with independents. Most controlled transactions will be in respect of simpler functions performed by associated enterprises, such as support and sales, though where arrangements exist between associated enterprises whereby the capital necessary to support the risks resides in a different legal enterprise from the enterprise which performs the functions giving rise to the risks (whether or not a PE is found) it will be necessary to determine a reward for supplying that capital. Comparable market data may be readily available to determine an arm's length price for support and sales functions as long as these functions are not linked to valuable intangibles" (OCDE. Report on the Attribution of Profits to Permanent Establishments. op. cit., p. 142).

738 "Similarly, where a business is organized on pure separate enterprise trading model lines, with no integration of functions or locations, it may be reasonably straightforward to find comparables for the controlled transactions in sales and support which, again, may be appropriately characterized as service provision" (OCDE. Report on the Attribution of Profits to Permanent Establishments. op. cit., p. 142).
} 
desenvolvê-las ${ }^{739}$. De todo modo, se for possível obter os critérios de repartição de resultados das "joint ventures" entre terceiros independentes, bem assim sopesar as funções, ativos e riscos ali envolvidos, pode ser viável a aplicação dos métodos tradicionais. Cumpre notar, contudo, que em alguns negócios altamente integrados, partes independentes também podem optar pela repartição de resultados [ao invés de remunerar isoladamente as funções] e, nestes casos, o método PSM [adotado pelas partes independentes] será o mais adequado para o controle dos preços de transferência em atividades de trading $^{740}$.

Mesmo na estrutura de negociação integrada, entretanto, importa esclarecer que as transações globais precisam ser "divididas", de modo a obter a remuneração própria de cada função, ativo ou risco; desta repartição em "remunerações distintas" geralmente se conclui que apenas as funções de trading e administração de riscos são realmente integradas, sendo as demais atividades passíveis de mensuração a partir da aplicação dos métodos tradicionais. De fato, o "teste" de todas as funções não-integradas é, como regra geral, possível pela via dos métodos tradicionais. Esta comparação, ademais, não precisa ser sempre com outras transações idênticas, ou sequer com outras transações globais. Consoante esclarecido na subseção 2.2.1(I), do CAPÍTULO 2, podem ser obtidas transações similares que, se sujeitas a ajustes razoavelmente precisos, transformam-se em "transações independentes comparáveis". Desde de que efetivada uma minuciosa análise funcional, portanto, podem ser dados comparáveis as remunerações praticadas nos

\footnotetext{
739 "119. There will be other cases where there may be real difficulty in reliably applying traditional transaction methods. This is particularly likely to be the case when evaluating the trading/risk management function in the fully integrated trading model. In such a case, the trading and risk management function may itself be split between different entities. Comparable data may be difficult to find as such a trading structure is unlikely to be found amongst independent parties without some kind of formal arrangement to govern the integrated activities. The arrangement can be made in a variety of legal forms, e.g. a joint venture, a partnership or an incorporated body. However, under such arrangements, the independent parties may well not attempt to divide the profits from each transaction but instead may well attempt to determine the overall profits for each party. For example, where the legal form is that of an incorporated body or a partnership, the arrangement may divide the profits from the venture at the shareholder or partnership level respectively" (OCDE. Report on the Attribution of Profits to Permanent Establishments. op. cit., p. 143).

${ }^{740}$ Este tipo de situação pode ser detectado a partir, por exemplo, dos critérios de remuneração dos traders, como se depreende do seguinte trecho do Relatório-2008 da OCDE:

"120 (...) A question arises as to how to evaluate the level of integration of functions in respect of a particular transaction or transactions. The behavior of the parties may help in this analysis. For example, if the traders in each location are remunerated out of different bonus pools and their performance evaluated by reference to completely different criteria in each location, it should be possible to similarly evaluate the trading transactions in which they are involved, without reference to the other trading locations. Conversely, if the performance of a trader is judged to a significant extent by reference to how well he or she co-operates with traders in the other location, this may be good evidence that, in reality, the trading function is highly integrated across the locations of the co-operating traders" (OCDE. Report on the Attribution of Profits to Permanent Establishments. op. cit., p. 143).
} 
mercados derivativos locais, os juros no mercado interbancário de determinada nação, os custos de administração de fundos de investimento ou clubes de ações etc. ${ }^{741}$.

Ponderadas as principais distinções e problemáticas relacionadas a cada uma das três estruturas que podem ser implementadas pelos conglomerados financeiros que se dedicam à negociação global de derivativos, passa-se, a seguir, a expor exemplos de aplicação dos métodos tradicionais a cada uma das funções desempenhadas, ativos empregados e riscos envolvidos nesta atividade.

A remuneração da função de vendas e marketing, exposta na subseção 3.4 .1 (I.) do CAPÍTULO 3, varia conforme o tipo e a quantidade de serviços prestados pelo contribuinte "testado". As vendas de produtos padronizados normalmente são remuneradas via comissão, estando as margens respectivas disponíveis para comparação. Se, de outro lado, localizar-se um marketer muitíssimo envolvido com o desenvolvimento do produto, em conjunto com o trader, é possível que sua remuneração aproxime-se da deste último e, portanto, que ele receba um percentual do lucro total da transação. Mas, obviamente, a maioria das situações está entre estes dois extremos ${ }^{742}$. A remuneração das atividades de vendas de produtos financeiros mais difundidos pode, na maior parte das vezes, ser "testada" via CUP. Pode também ser utilizado o RPM para a comparação de margens brutas de revenda de produtos. Nesta hipótese, contudo, é imprescindível a certificação de que os riscos assumidos contratualmente nas transações vinculadas e nas transações independentes sejam semelhantes; no caso de diferenças materialmente relevantes, pode-se

\footnotetext{
741 117. Transactions between independents may still be comparable even though there are some differences from the controlled transaction, provided that 'reasonably accurate adjustments can be made to eliminate the material effects of such differences'. For example, a transaction may be found which is similar except that in the controlled transaction there may be no assumption of credit risk. The price of the uncontrolled transaction may still be able to be used if it is possible to make reasonably accurate adjustments to reflect the differences in the assumption of credit risk, perhaps by using third party data for the pricing of credit derivatives.

118. The Guidelines are intended to be applied flexibly and so the search for comparable data may not be restricted to the derivatives market. Thus third party data on pricing credit risk from, say, the bond markets could be used provided it meets the "reasonably accurate adjustment" (OCDE. Report on the Attribution of Profits to Permanent Establishments. op. cit., p. 142-143).

742 "For example, some general sales personnel merely act as brokers in respect of standardized products and so do not assume any credit risk from the sales transaction. They are likely to be rewarded by a simple fee or commission, e.g. a number of basis points, which does not depend on the profitability of the particular deal. At the other end of the spectrum, some marketers are so highly specialized and closely involved in the process of developing and structuring products that they perform functions leading to the assumption of credit risk and carry out some aspects of the trading function leading to the assumption of market risk. They are likely to insist on a share of the trading profits and losses (although, in the former case, the parties they have taken on. In the middle of this spectrum are those marketers who, as a functional analysis shows, act as more than simple brokers and so assume credit risk but who are not as involved in structuring products and so are unlikely to be treated as assuming significant market risk (...)" (OCDE. Report on the Attribution of Profits to Permanent Establishments. op. cit., p. 144-145).
} 
efetivar ajustes razoavelmente precisos. É possível, outrossim, a comparação de determinada remuneração de vendas com margens de produtos assemelhados, aplicandose, com maior flexibilidade, o princípio da plena concorrência; mas as operações apenas serão comparáveis após a análise funcional e, em especial, após o exame dos riscos ${ }^{743}$.

Mesmo com certa flexibilização dos métodos tradicionais, contudo, pode ser necessária a utilização do $\operatorname{PSM}^{744}$ para a mensuração de atividades mais complexas desempenhadas pelos marketers ${ }^{745}$. Este método, bem assim sua aplicação às transações globais, serão objeto do CAPÍTULO 5. Por ora, importa salientar tão-somente que a partição de lucros precisa ser dividida em duas etapas: (i.) lucro inicial, resultante do ganho [spread] com a venda do instrumento derivativo; e (ii.) lucro de trading, que decorre do adequado manejo dos riscos e do resultado final da transação, incluindo-se os ganhos/perdas na data de maturação do derivativo, se for o caso. Considerando que a função do marketer é, justamente, descobrir o quanto um contribuinte está disposto a pagar por certo produto [além do preço mínimo estipulado pelo trader, cf. subseção 3.4.1 (I.) do CAPÍTULO 3], nestas hipóteses pouco frequientes ele pode fazer jus a uma parcela do lucro inicial; raramente, contudo, participa da divisão dos lucros de trading.

\footnotetext{
743،128. (...) A careful comparison of the risks assumed and borne in both the controlled and uncontrolled transaction will be necessary, based on an analysis of the contractual arrangements. A component of the value added by marketing personnel may in certain circumstances be measured by reference to the difference between the price at which a trader would undertake a transaction with a customer and the price actually obtained by the marketer. However, even where there is this relationship, care must be taken to ensure that the rewards attributable to the trader and marketer correctly reflect the functions performed by each, especially taking into account the risks assumed.

129. Flexibility may be needed in order to make reasonably accurate adjustments for any differences between the controlled and uncontrolled transactions under any of the above approaches, perhaps by looking for independent data concerning reasonably comparable marketing functions leading to the assumption of reasonably comparable risks outside the global trading field. It is likely to be easier to find comparables where the function does not give rise to the assumption of significant risk. For example, the search for comparable data for the marketing of a derivative product need not be restricted to the derivative markets" (OCDE. Report on the Attribution of Profits to Permanent Establishments. op. cit., p. 145).

${ }^{744}$ Relembre-se que, a partir da edição da Minuta-2009, os métodos amparados na comparação de lucros deixaram de possuir caráter subsidiário, devendo ser aplicados sempre que produzirem resultados mais confiáveis que os métodos tradicionais. Maiores considerações sobre a revisão da OCDE acerca da relevância dos métodos de confronto de lucros constam da seção 4.1 deste capítulo.

745 " 130 . (...) This is likely to be more common in businesses where the strategy is to encourage the sale of more complex high margin transactions rather than one where the strategy is to pursue simpler and lower margin transactions with the volume of transactions being the key to profitability. The business strategy should therefore be considered when evaluating the appropriateness of rewarding the marketer in a controlled transaction by a profit share" (OCDE. Report on the Attribution of Profits to Permanent Establishments. op. cit., p. 145).
} 
A remuneração das atividades trading e de administração de riscos ${ }^{746}$, de outro lado, tem relação intrínseca com os três modelos de estruturas de instituições dedicadas à negociação global, acima discutidos. Na negociação por entidades segregadas, e.g., os dados para a aplicação do CUP geralmente estão disponíveis; com efeito, neste tipo de estratégia, as instituições transacionam tanto com partes independentes quanto com partes dependentes, sendo possível, em muitos casos, a obtenção de comparáveis internos ${ }^{747}$. Há, todavia, alguns tipos de hedge intra-grupo, os quais não seriam praticados por terceiros independentes, que apresentam maiores dificuldades; nestas hipóteses, recomenda-se a aplicação do $\mathrm{PSM}^{748}$. Na administração centralizada de produtos, normalmente apenas a instituição "centralizadora" dedica-se às atividades de trading e administração de riscos, desenvolvendo-as diretamente com terceiros ${ }^{749}$. Considerando que as atividades de vendas e de apoio são mais facilmente "testáveis", a aplicação dos preços de transferência, nesta estrutura, é razoavelmente mais simples, mediante a aplicação do CUP ou do RPM. Quanto mais a estrutura do grupo financeiro centralizado tende a alguma integração, contudo,

\footnotetext{
${ }_{746}^{74}$ Estas atividades foram melhor definidas na subseção 3.4.1 (II) do CAPÍTULO 3.

747 "149. (...) For example, institutions engaging in foreign currency transactions (spot and forward) frequently act on this basis. In such cases, there generally is no need to consider methods other than traditional transaction methods, as each location should earn the appropriate overall profit provided that all trading and hedging transactions, whether third party, intra-company, inter-branch or inter-company, are undertaken under arm's length conditions, and it should be relatively straightforward to test this, because of the availability of comparable transactions with unrelated parties. (...)

150. In many cases the comparable uncontrolled price (CUP) can be applied by reference to market data, without the need for any adjustments because there are no material differences in the way the controlled transactions are carried out. In other cases, adjustments by reference to market data can be reliably made to account for any material differences between the controlled and uncontrolled conditions" (OCDE. OECD Documents. The Taxation of Global Trading of Financial Instruments. op. cit., p. 38).

748 "As noted in paragraph 33, under the separate enterprise trading model, one trading location may enter into trades with another trading location. At another level, a question might arise in some situations involving financial transactions (particularly hedging transactions) between associated enterprises in different trading locations as to whether an independent trader would have entered into such a transaction. If the expected dealer spread on the transaction between trading locations is negative or if the NPV [valor presente líquido] on a financial transaction from the perspective of the trading location under examination is negative, then the circumstances surrounding the transaction would need to be examined. It will be important to consider the business strategies of each trading location and of the MNE group as a whole. For example, it may be that the transaction was entered into for a purpose other than the normal trading function of the particular location, e.g. an internal hedging transaction made at the request of a central committee managing overall risk limits within the MNE group. In such cases, it may be necessary to eliminate the effect on trading profits of such transactions and to reward the function performed by the trading location by other means (...) Problems also arise where financial institutions use 'net' hedging strategies so that it is impossible to trace the gain or loss from any particular transaction to the offsetting gain or loss on the customer transaction it hedges" (OCDE. Report on the Attribution of Profits to Permanent Establishments. op. cit., p. 145). A questão dos hedge líquidos foi discutida na seção 3.3 do CAPÍTULO 3.

749 "Any profits identified with the management of a particular class of risk must be attributable to the single jurisdiction in which that risk is managed. Thus, one possible TPM [transfer pricing method] would attribute to traders all value associated with market-making (e.g., bid/ask spreads) and all revenue associated with portfolio management (e.g., the change in value of the portfolio from the beginning of the year to the end of the year)" (PLAMBECK, Charles T. op. cit., p. 1139).
} 
maiores as complexidades para a aplicação das regras para o controle dos preços de transferência via métodos tradicionais ${ }^{750}$. Por fim, no que respeita à estrutura de negociação integrada, note-se que a atividade de trading pode ser dividida entre estabelecimentos [e terceiros independentes não atuam dessa forma] ${ }^{751}$; por isso, geralmente, numa hipótese de atuação totalmente integrada, recomenda-se o PSM [cf. CAPÍTULO 5]. Em geral, contudo, a estrutura adotada é híbrida, e, quanto mais próxima da centralização, maiores as possibilidades de aplicação do CPM, ao invés do PSM $^{752}$.

Para a mensuração da remuneração das atividades que integram os denominados back-office e middle-office, normalmente os métodos tradicionais são suficientes $^{753}$. Para algumas atividades tipicamente internas das empresas, contudo, pode ser complicada a aplicação do CUP ${ }^{754}$. Nestas hipóteses, o CPM pode apresentar-se útil; o exame da remuneração das equipes pode ser, inclusive, um elemento relevante para a

\footnotetext{
750 "This raises the issue of how to reward the trading function taking place outside the central location. A similar need also arises if risk management is centralized in a different location from the trading location. There is a problem in deciding whether a location which starts to undertake some kind of limited trading or risk management activity under the control of the central location, can still be appropriately rewarded by traditional transaction methods, as opposed to receiving a share of the overall profits. (...)The flexibility provided for in the Guidelines may again be helpful as there may be reasonably comparable situations outside the global trading field. For example, the role of a fund manager involves the exercise of highly specialized skills and discretion as well as more routine trading functions. Independent parties often reward the fund manager by paying a performance related element (e.g. in the form of a share of any increase in value of the fund) on top of a basic commission or fee" (OCDE. OECD Documents. The Taxation of Global Trading of Financial Instruments. op. cit., p. 38-39). Saliente-se, contudo, que os administradores de fundos, como regra geral, não participam das perdas dos investimentos, devendo ser efetivado ajuste relativo aos riscos assumidos nas transações globais.

751 “142. (...)The difference is that in the integrated trading model, the trading and risk management functions with respect to a particular third party transaction may be split between locations and the gross profit arising from that transaction may be recognized in any or all of the locations. Trading or risk management in integrated form is unlikely to be found between independents and so it may not be possible to make 'reasonably accurate adjustments' to make the data comparable. Additionally, in the integrated trading model each location cannot act independently but must co-operate with the others in order to successfully enter into a transaction and subsequently manage the resulting risk. Therefore, it may not be possible that traditional transaction methods could be applied reliably and so consideration should be given to transactional profit methods" (OCDE. Report on the Attribution of Profits to Permanent Establishments. op. cit., p. 148).

752 " 155 . In reality, the actual trading or risk management operations may be a hybrid that does not fall completely within one of the three models but may include aspects of the others. It is more likely that traditional methods, for example the cost plus method, could be reliably adapted the closer the trading pattern is to the centralized product management rather than the fully integrated trading model" (OCDE. OECD Documents. The Taxation of Global Trading of Financial Instruments. op. cit., p. 39).

${ }^{753}$ Estas atividades foram melhor definidas na subseção 3.4.1 (III) do CAPÍTULO 3.

754،"145. Back office activities include various types of activities, some of which constitute significant parts of global trading, and some of which are quite remote from its main activity. Since activities of key back office staff such as product control staff (sometimes called 'middle office' staff) play significant roles in determining the profitability of the whole operation, for example by trying to minimize operational risks, it may be necessary to give further consideration to those activities. CUPs may not be available as a reliable benchmark to evaluate the contribution made by such staff but one possible measure of the contribution of such activities is the amount of compensation to key staff, especially to the extent that their compensation is performance related. The cost plus method may be particularly applicable to such situations" (OCDE. Report on the Attribution of Profits to Permanent Establishments. op. cit., p. 148).
} 
definição das margens brutas. Como regra geral, o CUP e CPM estão disponíveis para as atividades "não-financeiras", incluindo-se a formação de intangíveis exclusivos. De fato, nas transações globais, os pesquisadores costumam tem funções semelhantes àquelas desempenhadas nas demais indústrias, sendo viável a utilização do CPM para intangíveis desenvolvidos pelo back-office ou middle-office. Não é praxe que terceiros independentes repartam os lucros da atividade com os responsáveis pela formação desta espécie de intangível $^{755}$; não obstante, em hipóteses remotíssimas, nas quais restar comprovada a participação daquela função no lucro global, pode-se aplicar o PSM.

Especificamente no que concerne aos ativos empregados nas operações de negociação global [cf. subseção 3.4.2 do CAPÍTULO 3], importa ponderar que há duas situações em que a influência do capital precisa ser analisada. A primeira delas tem relação com a análise funcional, posto que os ativos empregados nas transações comparadas precisam ser equivalentes ou, se não o forem, o impacto disso nas margens precisa ser ajustado $^{756}$. Mas o capital fornecido para a consecução das transações globais também precisa ser remunerado, mediante a aplicação do princípio da plena concorrência. $\mathrm{Na}$ prática, se o capital empregado é de titularidade da empresa que desempenha as atividades de trading e de administração de riscos, a questão não apresenta dificuldades, porque o restante das atividades têm custo de capital insignificante. De outro lado, se o capital for proveniente de outras instituições do mesmo grupo, precisará ser remunerado ${ }^{757}$. Nesta

\footnotetext{
755 “146. (...)In the non-financial sector both the CUP and cost plus methods have often been used to measure the role of such staff, although profit methods have had to be used in some cases, especially where the development of highly valuable and unique intangibles is involved. In the global trading situation, the role of the support staff may often be similar to the contract researchers found in other industry sectors and it may be possible to use a cost plus methodology. In other cases any intangibles will have been developed by the "front office staff" and so have already been taken into account when evaluating their contribution (OCDE. Report on the Attribution of Profits to Permanent Establishments. op. cit., p. 148).

756 " 151 . A possible approach to making adjustments for differences in capital or risk assumption between the controlled and uncontrolled conditions could be based on the capital 'used' or 'put at risk' in the transaction. Financial businesses need capital to be able to cover the risks they assume and there is a cost to maintaining this capital base. The more risky a transaction the more capital has to be set aside to cover it and the price charged for entering into the transactions should be greater to take account of the increased capital cost. Often such data may be available from independents or the taxpayer may bring forward its own contemporaneous data on the basis that the data have been created for business and management purposes and have been validated by the regulatory authorities, although such data require careful analysis and evaluation" (OCDE. Report on the Attribution of Profits to Permanent Establishments. op. cit., p. 150).

757 “153. (...)This may take one of two forms: the capital possessor may provide a guarantee or other arrangement by which it provides credit support with respect to transactions entered into by a second enterprise; or it may directly book the transactions onto its own balance sheet or enter into back-to-back transactions with the second enterprise mirroring the transactions the second enterprise has with its customers. It should be noted that in neither case does the enterprise possessing the capital contribute actual debt or equity capital to the associated enterprise carrying on the functions giving rise to the risk" (OCDE. Report on the Attribution of Profits to Permanent Establishments. op. cit., p. 150).
} 
última hipótese, o capital pode ter sido transferido apenas a título de empréstimo, sendo a sua respectiva remuneração remunerada a partir do RPM. Mas se o fornecedor do capital participar das perdas, fará jus a uma remuneração superior à média de mercado. O PSM apenas deve ser aplicado nas hipóteses em que terceiros independentes também determinariam a remuneração do capital segundo a sistemática da partição de resultados ${ }^{758}$.

\subsection{Margens preestabelecidas para aplicação dos métodos de comparação indireta no direito brasileiro.}

Não há dúvidas de que a questão da prefixação de margens para os métodos PVL, PVA, PVV, CPL e CAP, nos termos dos artigos 18 e 19 da Lei n. ${ }^{\circ}$ 9.430/96, é um dos pontos mais criticados da legislação brasileira para o controle dos preços de transferência; tal prefixação pode, sem dúvidas, limitar sobremaneira os mecanismos para a aplicação do princípio da plena concorrência. Consoante se discutiu nas seções 4.2.3 [RPM] e 4.2.4 [CPM], ambos os métodos são baseados essencialmente nas comparações de margens, aferidas a partir do confronto das atividades desempenhadas, ativos empregados e riscos assumidos. Se as margens deixam de ser comparáveis, estes métodos transformam-se em espécies de fórmulas predeterminadas; sua aplicação basear-se-á numa planilha de Excel e não na análise funcional, que representa o fator de comparabilidade mais relevante para a mensuração de margens brutas de lucros. O CAP, e.g., não passa de um método formular, posto que, para a sua aplicação, não são admitidos comparáveis externos ou o uso de transações similares; basta a aplicação da fórmula \{Preço parâmetro (=) $[1,15 \text { (x) Custo médio de produção ou aquisição] (+) tributos }\}^{759}$; não há considerações sobre a realidade econômica da transação. Mesmo na nova sistemática do PVL, segundo a qual [Margem bruta de venda (=) 35\% (x) Participação de importados no preço de venda dos bens], sustenta-se haver uma margem prefixada, porque o percentual, a ser

\footnotetext{
758 " 164 . It is very important to examine the facts and circumstances surrounding the provision of capital in order to evaluate exactly what function is being undertaken. At one end of the spectrum, the capital provider may simply be lending money and so can be rewarded by the use of a CUP, an arm's length interest rate. At the other extreme, the capital provider may be acting as the entrepreneur and so by underwriting all the risks of the activity is likely to demand a large share of the profits. In between these extremes are capital providers whose function may be more that of an intermediary or a portfolio investor and where it may be possible to apply traditional transaction methods reliably.

165. However, in some circumstances it may not be possible to reliably make such adjustments and so profit split methods may have to be used as a last resort. Even in such cases third party data may well be available to help decide on how the profits could be split. For example, where the provision of capital is not in the same location as the traders and risk managers, data may be available showing the division of profits in joint ventures between independent traders and capital providers as described in Section II" (OCDE. OECD Documents. The Taxation of Global Trading of Financial Instruments. op. cit., p. 41).

${ }^{759}$ Este ponto foi objeto de considerações mais específicas na seção 4.4 .3 deste capítulo.
} 
multiplicado sobre outra conta matemática dependente exclusivamente da análise contábil, também é prefixado.

Como sustentado na subseção 2.9.2 (II.) do CAPÍTULO 2, a prefixação de margens deve ser reconhecida como uma espécie de safe harbour, na medida em que se fixa, via presunção relativa, um patamar de máxima segurança jurídica para os contribuintes. Se, nesta hipótese, se comprovar a aplicação do CPL com margem pouco inferior a $20 \%$, a administração tributária não poderá questionar tal operação e sustentar que a margem efetiva do exportador estrangeiro foi próxima a 5\%; uma vez abrangida pelas condições do safe harbour, considera-se que a transação do contribuinte está "protegida" contra questionamentos relativos àquele patamar legal. Esta espécie de providência é bastante recomendável, porque as normas para a concretização do princípio da plena concorrência são bastante "fluidas". Se o contribuinte dispõe de um "patamar" [máximo ou mínimo] que lhe garante segurança jurídica e redução dos custos administrativos envolvidos na obtenção de documentos, nos cálculos de margens etc., não há dúvidas de que a iniciativa da legislação brasileira é digna de aclamação. De fato, tratase de prática vinculada à segurança jurídica, à legalidade e à praticabilidade, dentre outros valores e princípios constitucionais.

Mas seu mérito está estritamente vinculado à sua condição de presunção relativa ou de safe harbour, que tem tão-somente o condão de inversão do ônus da prova. Se, como parece denotar a atuação das autoridades tributárias até a presente data, as margens fossem absolutamente fixas, sem a possibilidade prática de o contribuinte afastar a presunção com amparo em todos os meios de provas admitidos no direito brasileiro, esta técnica deveria ser considerada, a par de absurda, incompatível com o sistema constitucional tributário $^{760}$. Segundo discutido à exaustão na seção 1.9 do CAPÍTULO 1 , não se permite a utilização da técnica da presunção absoluta para a instituição ou definição da base de cálculo de tributos. Isso significaria tributar pelo imposto sobre a renda algo que não é renda; adicionalmente, por mais que os negócios visem lucro, nem sempre obtém lucro, devendo o direito tributário conviver com tal realidade; os lucros mínimos são

\footnotetext{
760 "Fossem as margens absolutas, teríamos, irredutivelmente, a imposição de limites à dedutibilidade, no caso das importação, ou de receitas mínimas, no caso das exportações, gerando rendas fictícias, superando a noção constitucional de renda, como acréscimo patrimonial de um período, e o próprio princípio da capacidade contributiva, na medida em que o limite objetivo arm's length não alcança suas finalidades equiparativas" (TÔRRES, Heleno Taveira. Direito tributário internacional: planejamento tributário e operações transnacionais. op. cit., p. 290).
} 
sempre um objetivo, mas nem sempre alcançado. Da leitura dos termos legais, como se verificará nas seções 4.6.1 e 4..6.2., abaixo, não se pode depreender que há presunção absoluta de margens; a ausência de sua alteração após mais 12 anos da data da publicação da Lei n. ${ }^{\circ}$ 9.430/96, contudo, demonstra uma realidade prática não compatível com as prescrições legais.

Ainda no que respeita às margens prefixadas como técnica de presunção relativa, é importante destacar a posição de Renato Fernandes BACCARO, segundo o qual qualquer presunção deve ser, sempre, fundamentada em uma probabilidade elevada de ocorrência do fato presumido. Na visão desse autor, a razoabilidade e a proporcionalidade devem ser refletidas na formulação da norma presuntiva, a qual deve possuir verossimilhança com a realidade; a presunção legal deve, neste contexto, ser razoável e proporcional $^{761}$. Não obstante a aproximação do fato presuntivo com a realidade, deve sempre ser resguardado ao contribuinte o direito de ilidir a presunção, via quaisquer provas admitidas em direito. Com efeito, a presunção tributária, ainda que fundada em sólidos estudos econômicos, nunca pode ser absoluta. Transmudando-se este raciocínio para as normas brasileiras, pode-se constatar, com relativa facilidade, que as margens de $15 \%$ [PVV e CAP], 20\% [CPL] e 30\% [PVV], bem assim o percentual de 35\% [PVL], não decorrem de estudos econômicos específicos, mesmo porque inexistem margens ou percentuais que possam a ser aplicados a todos os setores da economia, incluindo-se bens, serviços ou direito. Estes percentuais prefixados não têm, claramente, amparo na razoabilidade.

Uma possível solução para minorar os efeitos danosos que as margens prefixadas, ainda que sujeitas a contraprova, podem gerar, é a formulação de presunções baseadas, na medida do possível, em dados reais de mercado. Nesse sentido, e.g., a segregação das margens fixas por atividade e/ou ramos de atuação, baseada em estudos econômicos e não em meros apontamentos sem qualquer referência feitos pelo legislador, poderia aproximar as margens prefixadas da realidade dos contribuintes e, por decorrência, reduzir as distorções que atualmente maculam a aplicação das regras para o controle dos preços de transferência no direito brasileiro. Quanto maior a quantidade e nível de detalhamento das margens prefixadas, maior sua proximidade com a capacidade

761 In: Manual de Preços de Transferência. Uma aplicação prática ante as margens de lucro predeterminadas. São Paulo: IBPT, 2002, p. 59 e ss.. 
contributiva efetiva dos contribuintes. Sob outra perspectiva, quanto mais adequadas as margens, maior será sua utilização como safe harbours e, por conseqüência, maiores os seus efeitos como medida de praticabilidade e a simplificação. De fato, se fossem estipuladas margens setoriais diversas, os procedimentos tendentes à sua modificação tornar-se-iam úteis tão-somente em hipóteses excepcionais, e não "em quase todas as situações", como via de regra ocorre atualmente, haja vista que os percentuais previstos em lei somente são aplicáveis a pouquíssimos setores econômicos.

\subsubsection{Possibilidade de alteração de margens pelo Ministro de Estado da Fazenda [cf. artigos 19-A e 20, da Lei n. ${ }^{\circ}$ 9.430/96].}

Em princípio, os percentuais prefixados para os métodos CPL, CAP, PVL, PVV e PVA, supra discutidos, podem ser alterados por duas vias distintas, sendo uma delas prevista nos artigos 19-A e 20, da Lei n. ${ }^{\circ}$ 9.430/96, com redação determinada pela Medida Provisória n. ${ }^{\circ}$ 478/09, e outra com prescrição no artigo 21 , $§ 2^{\circ}$, da mesma lei. Nesta subseção 4.6.1, será examinada a primeira destas hipóteses.

O artigo 20 da Lei n. ${ }^{\circ}$ 9.430/96, que ainda mantém sua redação original, determina que, "em circunstâncias especiais, o Ministro de Estado de Estado da Fazenda poderá alterar os percentuais" relativos aos métodos PVL, CPL, PVA, PVV e CAP, bem assim o percentual de $90 \%$ estipulado como safe harbour nas operações de exportação, previsto no artigo 19, caput, da Lei n. ${ }^{0}$ 9.430/96, e estudado na seção 2.9.2(I.) do CAPÍTULO 2. Para a regulamentação do artigo 20 da lei, foram editados os artigos 32 a 34 da Instrução Normativa n..$^{\circ}$ 243/02. Em suma, no artigo 32, foi previsto que os percentuais poderiam ser alterados pelo Ministro de Estado da Fazenda, mediante atuação de ofício, solicitação de entidade de classe representativa de setor da economia, ou mesmo via pedido individualizado de determinado contribuinte. Neste contexto, as alterações poderiam ser em caráter geral, setorial ou específico ${ }^{762}$. Recentemente, parte do $\S 1^{\circ}$ do artigo 32 da

\footnotetext{
762 "Art. 32. Os percentuais de que tratam os arts. 12, 13, 14, 24, 25 e 26 poderão ser alterados por determinação do Ministro de Estado da Fazenda.

$\S 1^{\circ}$ As alterações de percentuais a que se refere este artigo serão efetuadas em caráter geral, setorial ou específico, de ofício ou em atendimento a solicitação de entidade de classe representativa de setor da economia, em relação aos bens, serviços ou direitos objeto de operações por parte das empresas representadas, ou, ainda, em atendimento a solicitação da própria empresa interessada.

$\S 2^{\circ}$ Aos pedidos de alteração de percentuais, efetuados por setor econômico ou por empresa, aplicam-se as normas relativas aos processos de consulta de que trata o Decreto n. ${ }^{\circ} 70.235$, de 6 de março de 1972 (Processo Administrativo Fiscal), com alteração dada pelos arts. 48 a 50, da Lei n. ${ }^{\circ} 9.430$, de 27 de dezembro de 1996".
} 
Instrução Normativa n. ${ }^{\circ}$ 243/02 foi transferida para o texto legal, mediante a inserção do artigo 19-A por intermédio da Medida Provisória n. ${ }^{\circ}$ 478/09, cujo conteúdo é o seguinte: "O Ministro de Estado da Fazenda poderá fixar margens de lucro diferentes por setor ou ramo de atividade econômica para fins de apuração dos preços parâmetros relativos aos métodos de que tratam os arts. 18 e 19”. Esta é uma das alterações mais relevantes promovidas pela referida Medida Provisória, porque, como se demonstrou em 4.6 acima, a criação de margens setoriais pode representar um instrumento importante para que as normas brasileiras para o controle dos preços de transferência garantam, a um mesmo tempo, os Valores da Segurança Jurídica e da Justiça, por intermédio dos princípios da razoabilidade, praticabilidade, etc.. Espera-se, portanto, a imediata utilização de tal prerrogativa legal.

Saliente-se, a este passo, que, sempre que o Ministro de Estado da Fazenda constatar uma "circunstância especial”, i.e., uma situação prática à qual as margens ou percentuais prefixados não se adéquam, deverá alterá-los; não se trata de hipótese de uso discricionário desta autorização legal, mas de medida obrigatória para a implementação de normas tributárias mais justas ${ }^{763}$. Como a lei não pode disciplinar minúcias, e tendo em vista que as margens alteram-se constantemente, o que é incompatível com a dinâmica do processo legislativo, recebeu o Ministro de Estado da Fazenda um comando genérico para estudar os diferentes tipos de transações e garantir que recebam uma disciplina específica e distinta da regra geral prevista em lei.

Mas as margens não são alteradas apenas de ofício pelo Ministro de Estado da Fazenda; pelo contrário, prevê o artigo 32 da Instrução Normativa n. o 243/02 que tal alteração também poderá decorrer de pedido dos contribuinte ou de entidades de classe representativas de determinado setor. Nestas hipóteses, devem ser observadas as regras do Decreto n. ${ }^{\circ}$ 70.235, de 06.03.72, bem assim a disciplina dos artigos 33 e 34 do mesmo normativo $^{764}$, que exigem a apresentação de tantos documentos que, por vezes, o pedido de

\footnotetext{
763، Ainda a respeito dos atos ministeriais que devem alterar as margens porcentuais previstas na lei, há necessariamente que se afirmar serem eles de emissão obrigatória todas as vezes em que se verificar a existência das 'circunstâncias especiais', eis que a obrigação tributária está sempre e inelutavelmente submetida ao princípio da legalidade tributária. (...) Na verdade, a autoridade não apenas tem o dever de adaptar situações concretas atingidas por circunstâncias especiais a um critério de comparação que, sem fugir do que está previsto na norma estabelecedora do critério (método) em geral, faça o seu ajustamento a uma margem de lucro ou a uma porcentagem do preço interno compatível com a realidade" (MARIZ DE OLIVEIRA, Ricardo. Fundamentos do Imposto de Renda. op. cit., p. 637-638).

764 “Art. 33. A Cosit fica incumbida da análise dos pleitos de alteração de percentual a que se refere o $\$ 2^{\circ}$ do art. 32, devendo, para cada caso, propor, ao Secretário da Receita Federal, a solução a ser submetida à
} 
alteração de margens será inviável, exigindo verdadeiras provas impossíveis ou diabólicas. O assunto está regulamentado, outrossim, pela Portaria do Ministério da Fazenda n. ${ }^{\circ} 22$ de 24.09.08, a qual também contém exigências documentais exageradas, não dotadas de razoabilidade ou proporcionalidade. Na prática, devem ser admitidos quaisquer meios para comprovar a necessidade de alteração das margens prefixadas, consoante explicado na seção 1.9 do CAPÍTULO 1.

Note-se que, em virtude destas limitações, os mecanismos para o afastamento das presunções instituídas via margens prefixadas não têm tido eficácia prática, seja pela dificuldade de demonstração das margens efetivas à administração tributária, seja pelo temor dos contribuintes, que se recusam a elaborar pedidos com receio de início de fiscalização tributária específica naquele setor da economia. Independentemente disso, sabe-se que, até o momento, os pleitos de alteração de margens foram (i.) não-conhecidos, por falta de documentação; ou (ii.) não foram analisados, sendo que inúmeros aguardam,

aprovação do Ministro de Estado da Fazenda.

$\S 1^{\circ}$ A decisão, se denegatória, será exarada em despacho, formalizado no próprio processo de solicitação; se concessória, será formalizada por meio de Portaria Ministerial, publicada, em seu inteiro teor, no Diário Oficial da União.

$\S 2^{\circ}$ Os meios para formalização das decisões do Ministro de Estado da Fazenda, a que se refere o $\S 1^{\circ}$, serão aplicados inclusive nos casos de atendimento parcial.

$\S 3^{\circ}$ Nas hipóteses de atendimento ao pleito, a Cosit deverá informar se concorda com o prazo de vigência das novas margens, sugerido pela entidade ou empresa interessada, ou, caso contrário, propor o prazo que julgar mais adequado".

A exigência de publicação da decisão concessória no Diário Oficial da União pode representar quebra de sigilo industrial de determinado contribuinte; por conta disso, apenas a decisão, e não as razões decisórias, pode ser publicado.

"Art. 34. As solicitações de alteração de percentuais, efetuadas por entidades de classe ou por empresa, deverão conter indicação do prazo para vigência das margens sugeridas e ser instruídas com os seguintes documentos:

I - demonstrativo dos custos de produção dos bens, serviços ou direitos, emitidos pela empresa fornecedora, domiciliada no exterior;

II - demonstrativo do total anual das compras e vendas, por tipo de bem, serviço ou direito, objeto da solicitação;

III - demonstrativo dos valores pagos a título de frete e seguros, relativamente aos bens, serviços ou direitos;

IV - demonstrativo da parcela do crédito presumido do IPI, como ressarcimento das contribuições PIS/Pasep e Cofins, correspondente aos bens objeto da solicitação.

$\S 1^{\circ}$ Os demonstrativos deverão ser corroborados com os seguintes documentos:

I - cópia dos documentos de compra dos bens, serviços ou direitos e dos demais documentos de pagamento dos impostos incidentes na importação e outros encargos computáveis como custo, relativos ao anocalendário anterior;

II - cópia dos documentos de pagamento dos impostos e taxas incidentes na exportação, cobrados no país exportador;

III - cópia de documentos fiscais de venda emitidos no último ano-calendário, nas operações entre a empresa vinculada, domiciliada no exterior, e as empresas atacadistas, não vinculadas, distribuidoras dos bens, serviços ou direitos, objeto da solicitação;

IV - cópia de documentos fiscais de venda a consumidores, emitidos por empresas varejistas, localizadas nos países de destino dos bens, serviços ou direitos, com indicação do respectivo preço cobrado.

$\S 2^{\circ}$ Os documentos a que se refere o $\S 1^{\circ}$ não serão anexados ao processo, devendo ser mantidos à disposição da Cosit, no domicílio fiscal da empresa solicitante ou representada pela entidade de classe". 
há anos, uma solução. Somando-se a isto a constatação de que, em estudos econômicos recentes, restou comprovado que os percentuais legais, definitivamente, estão distantes das taxas reais praticadas na grande maioria dos setores da economia ${ }^{765}$, pode-se concluir que ainda é necessário estruturar mecanismos mais eficazes para garantir as alterações das margens prefixadas.

\subsubsection{Regras de alteração de margens previstas no artigo $21, \$ 2^{\circ}$, da Lei n. $^{\circ}$ 9.430/96.}

O artigo 21, $2^{\circ}$, da Lei n. ${ }^{\circ}$ 9.430/96, prevê que são admitidas "margens de lucro diversas das estabelecidas nos arts. 18 e 19, desde que o contribuinte as comprove, com base em publicações, pesquisas ou relatórios elaborados de conformidade com o disposto neste artigo". A lista dos documentos indicados no artigo 21 da lei, bem assim as dificuldades inerentes a sua obtenção e a previsão de seu afastamento arbitrário contida no $\S 3^{\circ}$ deste mesmo dispositivo legal, foram discutidos na subseção 1.9.1 do CAPÍTULO 1, tendo sido concluído, ali, que esta "limitação dos meios de prova" é incompatível com os princípios da ampla defesa e do contraditório [cf. artigos 150, LIV e LV, da Constituição Federal].

\subsection{Vedação de aplicação das regras de preços de transferência a royalties em operações de importação, conforme artigo 18, §9 $^{\circ}$, da Lei n. ${ }^{\circ}$ 9.430/96.}

Especificamente com relação ao controle dos preços de transferência nas operações de importação, prevê o artigo $18,9^{\circ}$, da Lei n. ${ }^{\circ}$ 9.430/96, que "o disposto neste artigo não se aplica aos casos de royalties e assistência técnica, científica, administrativa ou assemelhada, os quais permanecem subordinados às condições de dedutibilidade constantes da legislação vigente". Isto significa que permanecem aplicáveis as regras do artigo 355 do RIR-99, as quais limitam a dedutibilidade dos pagamentos de royalties ao exterior a $5 \%$ da receita líquida das vendas do produto fabricado ou vendido ${ }^{766}$;

\footnotetext{
${ }^{765}$ Cf., a respeito, estudo da DELOITTE TOUCHE TOHMATSU, publicado no ano 2003 em sua página eletrônica Para a hipótese de aplicação da margem de $60 \%$ do antigo PRL-60\%, por exemplo, apurou-se uma margem média no mercado de apenas 31,6\% (Margem Bruta de Lucro das Empresas Brasileiras, Pesquisa 2003, p. 11-13.

766 “Art. 355. As somas das quantias devidas a título de royalties pela exploração de patentes de invenção ou uso de marcas de indústria ou de comércio, e por assistência técnica, científica, administrativa ou semelhante, poderão ser deduzidas como despesas operacionais até o limite máximo de cinco por cento da receita líquida das vendas do produto fabricado ou vendido (art. 280), ressalvado o disposto nos arts. 501 e 504, inciso V.
} 
especificamente no caso dos pagamentos de royalties pela cessão do direito de uso de marcas, o percentual é de $1 \%$. Potencialmente, como inexiste qualquer vedação no artigo 19, poderia ser aplicado o controle dos preços de transferência para o recebimento de royalties por brasileiros. O artigo 43 da Instrução Normativa n. ${ }^{\circ}$ 243/02, todavia, retirou da administração tributária esta possibilidade ${ }^{767}$.

Não parece adequada a manutenção de tais regras após a edição de normas para o controle dos preços de transferência no direito brasileiro. Com efeito, os limites às dedutibilidades de royalties ou de pagamentos a título de assistência técnica, científica, administrativa ou assemelhada, remontam a 1964, período em que o Brasil encontrava-se em situação econômica totalmente distinta, com menor nível de globalização e com um alto grau de controle das saídas de recursos ao exterior; ademais, estas normas tinham por escopo evitar a transferência indevida de resultados para filiais ou subsidiárias estabelecidas em países com tributação favorecida da renda. Após 1995, com a instituição do princípio da universalidade no campo do IRPJ, este tipo de regra deixou de ser necessária ${ }^{768}$. Ademais, após 1997, faz muito mais sentido conferir aos royalties o mesmo tratamento dispensado a quaisquer pagamentos ao exterior. Estas regras gerais de indedutibilidade representam, na prática, uma elevação dos custos de produção de bens no país, podendo representar, por vezes, restrição a novos investimentos no território nacional. Suponha-se, v.g., que uma determinada companhia pretenda instalar uma unidade

$\S 1^{\circ}$ Serão estabelecidos e revistos periodicamente, mediante ato do Ministro de Estado da Fazenda, os coeficientes percentuais admitidos para as deduções a que se refere este artigo, considerados os tipos de produção ou atividades reunidos em grupos, segundo o grau de essencialidade".

767 "Art. 43. As normas sobre preços de transferência de que trata esta Instrução Normativa não se aplicam aos casos de royalties e assistência técnica, científica, administrativa ou assemelhada".

Veja-se que este dispositivo não alude especificamente às operações de importação ou de exportação, mas a todas as normas para o controle dos preços de transferência.

${ }^{768}$ Luís Eduardo SCHOUERI sustenta, também neste sentido, que as normas que impunham limites à dedutibilidade dos royalties tinham relação direta com a tributação de lucros e dividendos na esfera jurídica dos sócios e acionistas. Como esta bitributação econômica foi afastada em 1995, o limite à dedutibilidade dos royalties também deveria ter sido extinto. Confira-se:

“Com efeito, as normas acima reproduzidas são datadas de período anterior a 1995. Até aquele ano, vigia em nosso ordenamento o regime da bitributação econômica, pelo imposto de renda. De acordo com aquele regime, os lucros auferidos pela pessoa jurídica deveriam ser tributados tanto nessa quanto na pessoa de seus sócios. Dado que muitos contribuintes buscavam fugir desta incidência, mediante pagamentos exagerados, via-se o legislador tributário obrigado a limitar aqueles pagamentos, a fim de assegurar fosse o critério da bitributação jurídica alcançado plenamente. É em tal conceito que se encontrava a indedutibilidade dos royalties e pagamentos por assistência técnica e assemelhados.

O ano de 1995 marca, com a entrada em vigor do artigo 10 da Lei n. ${ }^{\circ}$ 9.249/95, a renúncia, pelo legislador do imposto de renda, à opção pela bitributação econômica. A partir daí, os lucros distribuídos pelas pessoas jurídicas tributadas pelo lucro real, presumido ou arbitrado, deixavam de sofrer nova tributação. (...) Diante dessa nova realidade, revelavam-se anacrônicas as normas que buscavam assegurar uma bitributação econômica que já não era mais desejada pelo legislador tributário" (SCHOUERI, Luís Eduardo. Preços de Transferência no Direito Tributário Brasileiro. op. cit., p. 230-231). 
industrial, onde fabricará bens de produção com utilização de uma certa patente. O titular da patente, renomada empresa de tecnologia no exterior, exige uma remuneração de $10 \%$ sobre a receita líquida, certo este o valor pago por todos os outros licenciados independentes. Se a unidade industrial for instalada no país, os custos relativos à patente serão de $10 \%$, somados ao custo tributário advindo da indedutibilidade; de fato, $50 \%$ do valor devido será indedutível. Portanto, ao preço negociado deverá ser acrescido um valor adicional a título de tributos devidos no país, equivalente a \{5\% (x) 34\% [IRPJ (+) CSLL] (=) $1,7 \%$; o custo para a utilização da patente no país será, assim, de 11,7\%. Considerando que este percentual é multiplicado pela receita líquida, esta indedutibilidade fiscal pode ser importante fator para a tomada de decisão do investidor estrangeiro nesta situação. Assim como discutido com relação à metodologia para aplicação do PVL [cf. seção 4.3.2, acima], trata-se de prática tributária que desestimula novos investimentos no país.

Por fim, especificamente no que concerne à necessidade de reconhecimento de receitas mínimas a título de royalties pelos brasileiros titulares de marcas, patentes ou processos industriais "exportados", pode-se afirmar que inexiste a possibilidade de arbitramento de receita mínima com amparo nas normas para o controle dos preços de transferência. É possível, todavia, a aplicação das regras mais genéricas de DDL, para autuar contribuintes que atuem em desacordo com as práticas estabelecidas no livre mercado $^{769}$. A respeito da aplicação subsidiária das regras de DDL, veja-se a seção 2.8 do CAPÍTULO 2, que discute as hipóteses de inexistência de método aplicável para a determinação do preço parâmetro.

\subsection{Metodologia para o controle dos juros praticados intra-grupo, conforme previsto no artigo 22 da Lei n. ${ }^{\circ}$ 9.430/96.}

Consoante referido na subseção 2.9.2 (III.), o registro de contratos perante o Banco Central do Brasil representa uma espécie de safe harbour, hipótese em que são "admitidos os juros determinados com base na taxa registrada"; inexiste, assim, a necessidade de busca de um preço parâmetro, a partir da aplicação das regras do artigo 22

\footnotetext{
769 “(...) a DDL pode atingir pagamentos de royalties, e assistência técnica, os quais estão expressamente excluídos das regras de preços de transferência” (MARIZ DE OLIVEIRA, Ricardo. Fundamentos do Imposto de Renda. op. cit., p. 776).
} 
da Lei n. ${ }^{0} 9.430 / 96^{770}$, c.c. artigo 27 da Instrução Normativa n. ${ }^{\circ} 243 / 02^{771}$. Se, de outro lado, não houver o registro do contrato perante a autoridade cambial, deverá o contribuinte brasileiro, na posição ativa, reconhecer juros equivalentes a, no mínimo, o valor calculado com base na taxa Libor, para depósitos em dólares americanos pelo prazo de seis meses, acrescida de $3^{\circ}$ anuais a título de spread, proporcionalizados em função do período a que se referirem os juros. Se o mesmo contribuinte estiver na posição passiva, esta taxa será considerada o maior valor dedutível; os tributos cujo ônus foram assumidos pela fonte brasileira, contudo, não se sujeitam a esta limitação ${ }^{772}$. Economicamente, não é razoável a previsão de taxas idênticas [e fixas] para as operações ativas e passivas; poderia o legislador prever, e.g., um intervalo de plena concorrência, o qual seria considerado um safe harbour. Independentemente da instituição de safe harbours vinculados a taxas de juros, sempre deve ser garantido ao contribuinte o direito à contraprova. A discussão sobre a interpretação que deve ser conferida aos juros fixos determinados neste artigo 22, bem

\footnotetext{
770 “Art. 22. Os juros pagos ou creditados a pessoa vinculada, quando decorrentes de contrato não registrado no Banco Central do Brasil, somente serão dedutíveis para fins de determinação do lucro real até o montante que não exceda ao valor calculado com base na taxa Libor, para depósitos em dólares dos Estados Unidos da América pelo prazo de seis meses, acrescida de três por cento anuais a título de spread, proporcionalizados em função do período a que se referirem os juros.

$\S 1^{\circ}$ No caso de mútuo com pessoa vinculada, a pessoa jurídica mutuante, domiciliada no Brasil, deverá reconhecer, como receita financeira correspondente à operação, no mínimo o valor apurado segundo o disposto neste artigo.

$\S 2^{\circ}$ Para efeito do limite a que se refere este artigo, os juros serão calculados com base no valor da obrigação ou do direito, expresso na moeda objeto do contrato e convertida em reais pela taxa de câmbio, divulgada pelo Banco Central do Brasil, para a data do termo final do cálculo dos juros.

$\$ 3^{\circ} \mathrm{O}$ valor dos encargos que exceder o limite referido no caput e a diferença de receita apurada na forma do parágrafo anterior serão adicionados à base de cálculo do imposto de renda devido pela empresa no Brasil, inclusive ao lucro presumido ou arbitrado.

$\S 4^{\circ}$ Nos casos de contratos registrados no Banco Central do Brasil, serão admitidos os juros determinados com base na taxa registrada".

771 “Art. 27. Os juros pagos ou creditados a pessoa vinculada, quando decorrentes de contrato não registrado no Banco Central do Brasil, somente serão dedutíveis para fins de determinação do lucro real e da base de cálculo da CSLL até o montante que não exceda ao valor calculado com base na taxa Libor, para depósitos em dólares americanos pelo prazo de seis meses, acrescida de três por cento anuais a título de spread, proporcionalizados em função do período a que se referirem os juros.

$\$ 1^{\circ}$ No caso de mútuo com pessoa vinculada, a pessoa jurídica mutuante, domiciliada no Brasil, deverá reconhecer, como receita financeira correspondente à operação, no mínimo o valor apurado segundo o disposto neste artigo.

$\$ 2^{\circ}$ Para efeito do limite a que se refere este artigo, os juros serão calculados com base no valor da obrigação ou do direito, expresso na moeda objeto do contrato, e convertidos em reais pela taxa de câmbio, divulgada pelo Banco Central do Brasil, para a data do termo final do cálculo dos juros.

$\S 3^{\circ} \mathrm{O}$ valor dos encargos que exceder o limite referido no caput e a diferença de receita apurada na forma do $\$ 2^{\circ}$ serão adicionados ao lucro real, presumido ou arbitrado e à base de cálculo da CSLL. (...)

$\S 6^{\circ}$. O cálculo dos juros a que se refere o artigo poderá ser efetuado por contrato ou conjunto de operações financeiras com datas, taxas e prazos idênticos. (...)

$\S 8^{\circ}$ Para efeito dos limites a que se referem o caput deste artigo e o $\$ 1^{\circ}$ deverá ser utilizada a taxa Libor vigente na data do termo inicial do contrato, devendo ser alterada a cada 183 dias, até a data do termo final do cálculo dos juros".

${ }^{772}$ In: artigo $23, \S 7^{\circ}$, da Instrução Normativa n. ${ }^{\circ} 243 / 02$.
} 
assim sobre a impossibilidade de instituição de presunção absoluta no direito tributário brasileiro, consta da seção 1.9 do CAPÍTULO 1.

Veja-se que o caput do artigo 22 da Lei n. ${ }^{\circ} 9.430 / 96$ não indica a natureza das posições passivas sujeitas a este controle, ao passo que o $\$ 1^{\circ}$ alude a "mútuos ativos". No artigo 27 da Instrução Normativa n. ${ }^{\circ}$ 243/02, permanece esta aparente distinção: (a.) o $1^{\text {o }}$, que trata das posições ativas, menciona apenas "mútuo com pessoa vinculada"; de outro lado, (b.) o $\S 7^{\circ}$ do mesmo dispositivo prevê que "para efeito deste artigo, são consideradas operações financeiras aquelas decorrentes de contratos, inclusive os de aplicação de recursos e os de capitalização de linha de crédito, celebrados com pessoa física ou jurídica residente ou domiciliada no exterior não registrados no Banco Central do Brasil, cuja remessa ou ingresso de principal tenha sido conduzido em moeda estrangeira ou por meio de transferência internacional em moeda nacional". O conceito de "operações financeiras" do $\S 7^{\circ}$ é mais amplo que a noção de "mútuo" consignada no $\S 1^{\circ}$; em virtude disso, surgiu a seguinte questão: para as operações ativas, apenas seria necessário o cálculo dos preços de transferência caso restem caracterizados todos os requisitos de um contrato típico de mútuo? De outro lado, o $\$ 7^{\circ}$ alude a "para efeito deste artigo", e não para efeito do caput ou de qualquer parágrafo específico. Esta norma, cujo teor é bastante confuso, tem viabilizado dois tipos de entendimentos dissonantes a respeito da aplicação do artigo 22 da Lei n. ${ }^{\circ}$ 9.430/96 às operações ativas ${ }^{773}$. No âmbito desta tese, sustenta-se que o tratamento distinto entre operações ativas e passivas é apenas aparente, sendo resultado de imprecisões no texto legal. A noção de operações financeiras do $\S 7^{\circ}$ do artigo 27 , assim, seria aplicável a quaisquer operações ativas ou passivas não enquadradas no safe harbour relacionado ao seu registro no Banco Central do Brasil.

Na hipótese de pagamento de juros a controlada ou coligada no exterior que tenham lucros a distribuir para a sócia brasileira, não deve ser aplicado o artigo 22 da Lei n. ${ }^{\circ} 9.430 / 96$, tendo em vista a existência de regra posterior e mais específica no artigo $1^{\circ}$, $\S 3^{\circ}$, da Lei n. ${ }^{\circ}$ 9.532, de 10 de dezembro de 1997, segundo a qual "não são dedutíveis na determinação do lucro real, os juros pagos ou creditados a empresas controladas ou coligadas, domiciliadas no exterior, relativos a empréstimos contraídos, quando, no balanço da coligada ou controlada, constar a existência de lucros não disponibilizados para

\footnotetext{
${ }^{773}$ Confira-se, abaixo, entendimento de Ricardo MARIZ DE OLIVEIRA:

“(...) aqui cabe o reparo de que o controle para os juros ativos somente é exigido pela lei sobre os contratos de mútuo" (Ricardo. Fundamentos do Imposto de Renda. op. cit., p. 804).
} 
a controladora ou coligada no Brasil". Devem ser observadas, outrossim, as recentes regras de indedutibilidade trazidas pelos artigos 24 a 26 da Medida Provisória n. ${ }^{\circ}$ 476, de 15 de dezembro de 2009. Estas normas introduziram, no país, a limitação da dedutibilidade de juros pagos a sociedades do mesmo grupo, mediante o estabelecimento de critérios amparados no capital investido pela receptora dos juros na fonte pagadora brasileira [também conhecidas internacionalmente como regras de thin capitalization].

Saliente-se, por fim, que a efetivação de ajustes relativos a despesas de juros nas sociedades optantes pelo regime do lucro presumido e do lucro arbitrado foi discutida na seção 1.1 do CAPÍTULO 1. 


\section{CAPÍTULO 5. MÉTODOS BASEAdOS NA COMPARAÇÃO DE LUCROS.}

\subsection{Considerações preliminares.}

Os métodos baseados na comparação de lucros ou "Transactional Profit Methods" confrontam os lucros operacionais resultantes de operações controladas com os lucros auferidos em operações não-controladas. Geralmente, o "lucro operacional" não é uma condição imposta por empresas controladoras, ao contrário do que se sucede em relação a preços ou margens brutas; não obstante, a lucratividade representa um indicativo de que a transação pode ter sido afetada pelo grupo. Os métodos baseados nos lucros, recomendados pela OCDE tanto em sua Diretiva quanto na Minuta-2009, são o PSM e o TNMM. Na legislação norte-americana, há a previsão do PSM, do CPI [que conceitualmente é idêntico ao TNMM], além do PSM específico para as operações de negociação global, os quais estão previstos, respectivamente, nas Seções 1.482-5, 1.482-6 e 1.482-8 [proposta](e).

Consoante esclarecido na seção 4.1, supra, enquanto na Diretiva os métodos baseados na comparação de lucros eram considerados excepcionais e poderiam ser empregados tão-somente se os métodos tradicionais não propiciassem resultados confiáveis isoladamente, ou se não fossem aplicáveis ${ }^{774}$, na Minuta-2009 eles têm tratamento distinto. Nos termos desta última, os métodos tradicionais apenas são preferíveis se propiciarem resultados melhores ou idênticos àqueles obtidos via aplicação dos métodos amparados na comparação de lucros. Passou a admitir-se, neste novo estudo, que há situações em que esta espécie de métodos apresenta-se como a mais adequada, produzindo resultados que melhor atendem ao princípio da plena concorrência; dentre estas situações estão os intangíveis raros e exclusivos, a atuação integrada de instituições que se dedicam à negociação global de instrumentos financeiros, bem assim as hipóteses em que as margens brutas não são comparáveis, diante da ausência de ajustes razoavelmente precisos para eliminar os impactos econômicos das dessemelhanças localizadas entre as margens "testadas" e as margens praticadas por terceiros independentes.

\footnotetext{
${ }^{774}$ In: OCDE. Transfer Pricing Guidelines for Multinational Enterprises and Tax Administrations. op. cit., p. III-1, itens 3.1 e 3.2. Correspondentes aos itens 2.60 e 2.61 da Minuta-2009.
} 
A aplicação dos métodos tradicionais apresenta dificuldades que advêm de seu próprio fundamento, i.e., a necessária existência de preços e margens para comparação extraídos de operações não-controladas. Sol PICCIOTTO sustenta que o princípio da plena concorrência assume a existência de uma comparação "natural" que não é, na maioria dos casos, vislumbrada na prática; isso tem gerado uma grande difusão dos métodos de repartição de lucros baseados no princípio da plena concorrência ${ }^{775}$ em países como Inglaterra, Alemanha, Austrália, Estados Unidos, dentre outros. Acrescenta Klaus VOGEL, que os métodos tradicionais são de difícil aplicação porque foram delineados para atender a certos tipos de negócios e não está em sua formulação lidar com intangíveis ou direitos imateriais em geral $^{776}$.

Entretanto, a despeito do reconhecimento da maior importância dos métodos baseados na comparação dos lucros pelos Estados-Membros da OCDE, eles não devem ser aplicados simplesmente porque há dificuldades na obtenção de dados comparáveis; pelo contrário, os mesmos fatores que levaram à exclusão da aplicação dos métodos tradicionais precisam ser "testados" vis-à-vis os métodos baseados nos lucros, para verificar se eles não estão sujeitos aos mesmos obstáculos ${ }^{777}$. Sua aplicabilidade deve ser examinada da mesma

\footnotetext{
775 "It became increasingly plain that the problem was not merely that firms could avoid tax by fixing prices which were other than the 'true' ones; the underlying issue was the need to establish criteria to determine a fair allocation of costs and profits. The arm's length criterion assumed that this question could be resolved 'naturally', by reference to market prices set for comparable transactions between unrelated parties. (...) transactions that are strictly comparable are hard to find, and such a procedure can be complex and difficult. In practice, administrators have resorted to an arm's length profit criterion, comparing the profitability of the entity with that of comparable independent firms. While this approach was authorized as a fall-back technique or a check on the validity of price adjustments, it has come to be increasingly relied upon as a primary method, especially in the absence of comparable transactions. Furthermore, profit-comparison has tended to become profit-split, since tax authorities are naturally concerned that the local entity should show a reasonable proportion of the total profits to the enterprise as a whole" (PICCIOTTO, Sol. op. cit., p. 172).

776 "The three conventional methods are difficult to apply where goods are delivered, services rendered, or licenses granted among associated enterprises of which there is no comparable market. Further, prices for goods, which are not passed on to third parties (semi-finished products, tailored manufacture, transfer of technology, etc.) cannot be determined by application of the comparable uncontrolled price method. The resale price method must be ruled out where services and licenses are involved because that method is tailored to be used in connection with supplies of goods. The cost plus method is particularly problematic with licenses because it largely would shift the profits from newly developed technology and procedures, but also the risks as well, of course, to the licensee, which would seldom occur among independent enterprises" (VOGEL, Klaus. Klaus Vogel on Double Taxation Conventions. op. cit., p. 532-533).

777 "2.1. (...)No one method is suitable in every possible situation and the applicability of any particular method need not be disproved. The selection of a transfer pricing method always aims at finding the most appropriate method for a particular case. For this purpose, it should take account of the respective strengths and weaknesses of each of the OECD recognized methods; of the appropriateness of the method considered in view of the nature of the controlled transaction, determined in particular through a functional analysis; of the availability of reasonably reliable information (in particular on uncontrolled comparables) in order to apply the selected method and / or other methods; and of the degree of comparability of controlled and uncontrolled transactions including the reliability of comparability adjustments that may be needed to eliminate differences between them" (OCDE. Proposed Revision of Chapters I-III of the Transfer Pricing
} 
forma que um contribuinte pondera a aplicação de qualquer método: analisam-se (a.) os aspectos positivos e negativos da aplicação do método naquele caso concreto; (b.) se o método é compatível com a natureza da transação, determinada a partir de análise funcional; (c.) se há informações razoáveis e confiáveis para a aplicação do método; (d.) se eventuais ajustes para a obtenção dos dados comparáveis são confiáveis etc.. Note-se que a OCDE não adota a regra do melhor método ${ }^{778}$; por este motivo, não é necessária aplicação de todos os métodos para a escolha do método mais adequado. Se foi examinado um único método, nos moldes do processo de comparabilidade descrito na subseção 2.2.2 do CAPÍTULO 2, e ele for considerado adequado, isto deve ser suficiente para satisfazer às exigências das autoridades tributárias ${ }^{779}$.

Ressalte-se, a este passo, que os métodos amparados na repartição de lucros somente são aceitáveis pela OCDE se compatíveis com o Artigo $9^{\circ}$ da Convenção-Modelo, especialmente no que diz respeito à comparabilidade: devem ser confrontados lucros de operações vinculadas com lucros de operações independentes. Na prática, reconhece-se que quaisquer métodos baseados nos lucros podem ser aplicados, desde que compatíveis com o princípio da plena concorrência ${ }^{780}$. Exatamente por conta disto é que não podem as administrações tributárias, sob qualquer argumento, valer-se destes métodos para tributar lucros de empresas que têm resultados inferiores à média com amparo numa certa "lucratividade da média"; o princípio da plena concorrência não pode representar justificativa para tributação adicional decorrente de insucesso e/ou ineficiência; nesse

Guidelines. $9^{\text {th }}$ September 2009- $9^{\text {th }}$ January 2010. op. cit., p. 26). Item alterado, correspondente a parte do item 1.68 da Diretiva.

${ }_{778}$ A "regra do melhor método", bem assim a posição da OCDE e da regulamentação brasileira sobre esta questão, foram estudados na seção 2.7 do CAPÍTULO 2.

779 " 2.7 The guidance at paragraph 2.1 [veja-se nota anterior] that the selection of a transfer pricing method always aims at finding the most appropriate method for each particular case does not mean that all the transfer pricing methods should be analyzed in depth or tested in each case in arriving at the selection of the most appropriate method. As a matter of good practice, the selection of the most appropriate method and comparables should be evidenced and can be part of a typical search process as proposed at paragraph 3.5 [processo de comparabilidade]" (OCDE. Proposed Revision of Chapters I-III of the Transfer Pricing Guidelines. $9^{\text {th }}$ September 2009- $9^{\text {th }}$ January 2010. op. cit., p. 27). Item novo, sem correspondente na Diretiva.

780 "2.5. Methods that are based on profits can be accepted only insofar as they are compatible with Article 9 of the OECD Model Tax Convention, especially with regard to comparability. This is achieved by applying the methods in a manner that approximates arm's length pricing" (OCDE. Proposed Revision of Chapters IIII of the Transfer Pricing Guidelines. $9^{\text {th }}$ September 2009- $9^{\text {th }}$ January 2010. op. cit., p. 27). Item alterado, correspondente ao item 3.3 da Diretiva. 
cenário, tem o contribuinte o direito de comprovar suas dessemelhanças e pleitear ajustes no lucro operacional comparável ${ }^{781}$.

Por sua maior praticidade e diante da existência de uma maior quantidade de dados comparáveis, posto que os lucros operacionais por produto/atividade normalmente são dados divulgados ao mercado, ao passo que margens brutas e preços podem sujeitar-se a maior sigilo, os métodos baseados na comparação de lucros têm se difundido. Não obstante, ainda há quem sustente que estes métodos "poluem" o princípio da plena concorrência, transformando-o em mera comparação de dados externos, sem seu escopo inicial de "atuar como terceiros independentes o fariam"; sua utilização constante, nesse contexto, seria uma afronta àquele princípio $^{782}$.

A evolução destes métodos no âmbito da legislação norte-americana foi discutida na seção 1.4 do CAPÍTULO 1. Mas não é apenas no âmbito deste último país que esta espécie de método teve grande aceitação. A Austrália, e.g., aplica métodos amparados na comparação de lucros desde o início da década de 90. Em reunião informal realizada pela OCDE em 7-8 abr./94 em Seul, o representante do grupo de legislação australiano, Jim KILLALY, ponderou que os métodos tradicionais apresentam muitas dificuldades, seja para a sua comprovação documental, seja por conta do seu procedimento custoso; em virtude disso, a Austrália vinha estudando a ampliação da aplicação dos métodos baseados nos lucros, de modo a reduzir custos de compliance e, ainda assim, obter um resultado razoavelmente próximo do preço de plena concorrência ${ }^{783}$ Neste país é aplicado um

781 "2.6 In no case should transactional profit methods be used so as to result in over-taxing enterprises mainly because they make profits lower than the average, or in under-taxing enterprises that make higher than average profits. There is no justification under the arm's length principle for imposing additional tax on enterprises that are less successful than average or, conversely, for under-taxing enterprises that are more successful than average, when the reason for their success or lack thereof is attributable to commercial factors" (OCDE. Proposed Revision of Chapters I-III of the Transfer Pricing Guidelines. $9^{\text {th }}$ September 2009- $9^{\text {th }}$ January 2010. op. cit., p. 27). Item alterado, correspondente ao item 3.4 da Diretiva.

782 "After 70 years the arm's length principle seems to have reached the limits of its development. The main reason for this is that the emphasis in the legislation and regulations of many countries and in the OECD Guidelines 1995 is no longer on the taxpayer itself but on comparables, i.e. external factors and data, which as usually difficult to obtain and apply. In particular, methods based on net income comparison, such as the CPM and the TNMM, which are in fact sophisticated versions of the old empirical method, have polluted the arm's length principle. As the 1979 OECD Report indicated, methods of that kind should not be looked upon as a transfer pricing methods but as selection methods for auditing by the tax authorities" (HAMAEKERS. Arm's Length - How Long? op. cit., p. 39).

${ }^{783 ،}$ 'The first three methodologies for determination of arm's length prices are presenting difficulties in terms of the extent of the work of identifying, collecting and analyzing all the relevant documentation. They tend to require separate consideration of each transaction or multiple of transactions in each product or service against the arm's length principle. If this approach is continue to be the mainstream methodology, it is difficult to see, especially as world trade within multinational enterprises continues to grow and innovation continues, how tax administrations can effectively address transfer pricing issues in the longer term thought 
método denominado "profit comparison method", semelhante ao TNMM, além do PSM, este último empregado em menor grau. Na Alemanha, os métodos tradicionais não são "preferíveis", sendo os métodos baseados nos lucros amplamente recomendados pelas autoridades tributárias, dada a sua maior facilidade. A Inglaterra, por seu turno, aceita o uso dos métodos baseados nos lucros de forma subsidiária, desde que os dados para a aplicação confiável dos métodos tradicionais não estejam disponíveis. Reconhece-se, expressamente, que estes métodos devem ser empregados nas negociações altamente integradas entre várias empresas de um mesmo grupo econômico ${ }^{784}$, incluindo-se as transações globais.

O Brasil, como indicado no CAPÍTULO 4, não adota estes métodos em sua legislação, nem reconhece sua aplicação subsidiária, com fundamento na Diretiva ou na Convenção-Modelo.

Para demonstrar o grau de aplicação dos métodos baseados na comparação de lucros confira-se, abaixo, planilha elaborada a partir de pesquisa da Ernst \& Young International Ltd., desenvolvida entre os anos-calendário 2007 e 2008, em dezenas de países que adotam regras para o controle dos preços de transferência:

traditional after-the-event enforcement approaches, given the number of skilled resources that would be require. (...)

These three approaches are also very costly to taxpayers, requiring them to provide all the relevant documentation in relation to each transaction or multiple of transactions in each product or service line. (...) Australia it therefore giving consideration to approaches that would keep compliance costs to a minimum for both tax administrations and taxpayers, while at the same time achieving a reliable approximation of the arm's length result and taking account of the facts and merits of each case" (KILLALY, Jim. Transfer Pricing: the Allocation of Income and expenses the experience of OECD an Dynamic Non-Member economies. Profit Methods in Theory and Practice. Seoul: OCDE, The Seoul DNME Workshop on Taxation. Issue Paper n. ${ }^{\circ}$ 6, abr. 1994, p. 6).

784 "The most common reasons for applying a profit-based method in the United Kingdom are a combination of the following:

- there is no CUP;

- the data on which to base a gross margin method, such as resale price, are less reliable that the data for using a profit-based method; and

- in connection with the profit split in particular, the nature of the activities of the company being tested are too complex to lend themselves to the use of resale price or cost plus methods.

Aggregation of transactions at the broadest level is common in applying profit-based methods - often the aggregation of all transactions between two parties. However, the taxpayer should have regard to all the types of groups of transactions in question, even if it is not possible to apply a transfer pricing method to each group of transactions separately, in order to demonstrate that all relevant transactions and conditions were taken into account in arriving at an arm's length price" (CASLEY, Andrew; HORROCKS, Victoria. United Kingdom. Practical Application of Transactional Profit Methods. International Transfer Pricing Journal. Amsterdã: IBFD, jul./ago. 2000, p. 136). 


\begin{tabular}{|c|c|c|c|c|c|}
\hline & $\begin{array}{l}\text { Bens } \\
\text { tangíveis }\end{array}$ & Serviços & $\begin{array}{l}\text { Propriedade } \\
\text { intangível }\end{array}$ & $\begin{array}{l}\text { Operações } \\
\text { financeiras }\end{array}$ & $\begin{array}{l}\text { Acordos de } \\
\text { repartição } \\
\text { de custos }\end{array}$ \\
\hline CUP/CUT & $32 \%$ & $19 \%$ & $54 \%$ & $56 \%$ & \\
\hline $\begin{array}{l}\text { Método baseado no } \\
\text { preço de revenda }\end{array}$ & $17 \%$ & & & & \\
\hline CPI/TNMM & $11 \%$ & & $14 \%$ & $13 \%$ & \\
\hline Custo & & $13 \%$ & & & $29 \%$ \\
\hline $\begin{array}{l}\text { Método baseado no } \\
\text { custo mais lucro }\end{array}$ & $29 \%$ & $60 \%$ & & & $49 \%$ \\
\hline PSM & $4 \%$ & & $10 \%$ & $7 \%$ & \\
\hline Outros & $6 \%$ & $7 \%$ & $22 \%$ & $24 \%$ & $22 \%$ \\
\hline
\end{tabular}

Fonte: Ernst \& Young International Ltd.. 2007-2008 Global Transfer Pricing Survey. Global Transfer Pricing Trends, Practices and Analysis. Dez./99, p. 16.

Veja-se que o CUP/CUT ${ }^{785}$ permanece sendo o método mais utilizado, por sua simplicidade e por ser compatível com a grande maioria das situações [especialmente commodities, que representam parcela substancial do comércio mundial]. Este método prevalece também no âmbito das operações financeiras, visto que há um grande número de operações-padrão. Especificamente quanto a estas operações, note-se que o CUP prevalece, mas o RPM e o CPM praticamente não são aplicados; na verdade, em substituição, são utilizados o CPI/TNMM e o PSM, os quais, conjuntamente, amparam $20 \%$ das transações. Mais de $24 \%$ destes negócios, contudo, são amparados em "outros métodos", em especial aquelas baseados em fórmulas predeterminadas, que serão explicados no CAPÍTULO 6.

Os métodos amparados na comparação de lucros também são relevantes no campo das transações envolvendo bens tangíveis, sendo empregado em $15 \%$ do total de transações pesquisadas, bem assim em operações com intangíveis. Neste último caso, o emprego do CPM e do RPM não é viável, porque não servem para avaliar operações com custo reduzido e não suscetíveis a compra e venda constante. Se o CUP ou o CUT não forem aplicáveis, assim, podem sê-lo o CPI/TNMM ou o PSM. A seção "outros métodos", que inclui os métodos de partilha fracionada, congrega $22 \%$ do total das negociações praticadas pelos contribuintes questionados.

\footnotetext{
785 O "Comparable Uncontrolled Transactions" representa uma variação do CUP, formulado pela legislação norte-americana exclusivamente para o "teste" de operações envolvendo intangíveis.
} 
Os dados supra comprovam que os métodos tradicionais, em especial o CUP, solucionam grande parte das questões concernentes aos preços de transferência. Demonstram, outrossim, que as metodologias tradicionais, a despeito de adequadas à maioria das situações, não se prestam ao controle dos preços em alguns tipos de transações. Como referido anteriormente, a ausência de dados comparáveis e o alto grau de integração nos grupos multinacionais apresentam desafios aos métodos tradicionais e precisam ser pensados segundo novas metodologias. Dentre os tipos de transações que apresentam desafios aos métodos tradicionais estão as operações financeiras ${ }^{786}$, e, em especial, as transações integradas entre instituições que se dedicam à negociação global de instrumentos financeiros [cf. subseção 3.2.2 do CAPÍTULO 2].

Como demonstrado na seção 4.5 do CAPÍTULO 4, há muitas atividades inseridas nas negociações globais de caráter mais simplificado e que podem ser "testadas" a partir dos métodos tradicionais ${ }^{787}$; inúmeros exemplos de aplicação destes métodos foram discutidos na mencionada seção. Ali, contudo, constatou-se que, sempre que não fosse

\footnotetext{
${ }^{786}$ Confira-se, a respeito, passagem que demonstra as dificuldades de aplicação dos métodos tradicionais ao controle dos preços de transferência de instituições financeiras:

"Acreditamos que existem alguns desafios na aplicação dos métodos de preços de transferência em instituições financeiras. Destacamos e comentamos os que consideramos mais relevantes. O primeiro deles se refere a operações internacionais, tais como financiamentos de comércio exterior, colocação de títulos (underwriting), transferências de fundos, cartões de crédito e demais operações em que uma determina instituição se utiliza de sua rede mundial de estabelecimentos vinculados para atender as necessidades de seus clientes. Sob o ponto de vista da instituição como um todo, um serviço é prestado, representando receitas e custos. Como identificar as atividades desempenhadas em cada estabelecimento do grupo e, conseqüentemente, as receitas e custos de cada uma? É perfeitamente possível que o pagamento por tais serviços ou operações de empréstimos seja feito em uma unidade do grupo, instalada em qualquer país, enquanto que os custos poderiam ser absorvidos por unidades localizadas em outros países. (...)

Existem dificuldades para se calcular o resultado por divisão ou unidade, nessas situações. A grande razão é que as unidades estabelecidas em cada país executam uma série de atividades, sendo difícil a vinculação de cada uma delas com operações específicas que, na prática, são executadas por mais de uma unidade do grupo. Uma questão adicional que surge é que a distribuição dos resultados é feita, de uma maneira geral, gerencialmente. Ou seja, muitas vezes o lucro, ou prejuízo, de uma operação pode ficar concentrado em um determinado país, permitindo dessa forma uma transferência de resultados para países com tributação menor. Se internamente, dentro de uma corporação, não é fácil identificar a participação de cada unidade no resultado de um negócio, podemos imaginar o que significa essa situação para as administrações tributárias. Acreditamos que a aplicação dos métodos tradicionais, baseados em custos, fica difícil, pois na maioria das vezes o produto negociado é específico, não é uma commodity, é 'fabricado' por várias empresas de um grupo financeiro, e a participação de cada uma delas é de difícil mensuração" (CARNEIRO, Paulo Baltazar. Preços de Transferência no Setor Financeiro. Disponível no site www.receita.fazenda.gov.br, p. 4).

787 "134. This paper spends most time discussing these difficult cases but it should be noted that a large number of global trading problems are capable of solution without any need to consider, as a last resort, use of the profit split method. However, the use of some kind of profit split approach in appropriate cases may be easier to justify in the global trading of financial instruments than in other industry sectors. This is because the way the business is organized is more akin to joint venture profit sharing arrangements of a type which can be found between independents in the financial sector. In addition, independent parties may reward the performance of complex functions, e.g. risk management of investment funds, with an arrangement which, whilst not strictly a profit split, is calculated by reference to the profits of the funds" (OCDE. OECD Documents. The Taxation of Global Trading of Financial Instruments. op. cit., p. 34).
} 
aplicado um determinado método tradicional, seria recomendável o PSM para auxiliar na concretização do princípio da plena concorrência. De fato, há negócios envolvendo transações globais em que terceiros independentes também adotam uma fórmula de repartição de resultados semelhante ao PSM; daí ser recomendada a sua aplicação. O emprego deste método, no entanto, pode trazer dificuldades, seja por conta da ausência de um consenso a respeito de sua aplicação entre as nações ${ }^{788}$, seja porque o PSM não pode ajustar resultados a ponto de impactar regras regulatórias, em especial dos países onde se situam os books ${ }^{789}$.

Recorde-se, a este passo, que, se a estratégia de que se vale a instituição "testada" para a negociação global de instrumentos financeiros puder ser reproduzida entre partes não-relacionadas, os métodos tradicionais serão de grande valia. De outro lado, se for implementada uma estratégia integrada muitíssimo específica, os métodos tradicionais não serão suficientes ou serão imprestáveis, por uma razão: a inexistência de operações comparáveis ou passíveis de ajuste razoavelmente precisos que produzam resultados confiáveis. Além da estrutura de atuação do conglomerado bancário, também é essencial o exame da maneira de divisão das funções desempenhadas pelas partes. Com efeito, os serviços de trading e gerenciamento de riscos no âmbito das instituições financeiras que se dedicam à negociação global de derivativos são, sem dúvidas, os mais suscetíveis a uma possível abordagem pelo PSM, embora todas as funções desempenhadas na transação global possam sê-lo, como se verificou seção 4.5 do CAPÍTULO 4. Com efeito, os traders são os responsáveis tanto pelo desenvolvimento de produtos específicos e customizados para atender à demanda dos clientes da instituição, quanto pela administração do risco

\footnotetext{
788، 135. Although the broad basis for using profit split methods as described in Chapter III of the Guidelines is clear, there can be considerable practical problems in achieving an international consensus as to how and when they are to be applied to particular global trading cases" (OCDE. OECD Documents. The Taxation of Global Trading of Financial Instruments. op. cit., p. 34).

789 "137. One issue which requires attention is the regulatory consequences of adopting a profit split approach. Regulatory capital will normally be located and regulated in the jurisdiction where the transaction is booked and the regulator will continually monitor the capital requirements throughout the year. However, the profit split method may be applied at, or after, the year end and will result in an allocation of profits or losses away from the booking jurisdiction. This potentially raises a number of regulatory issues where application of the profit split methodology leads to movements of funds or capital. If losses are allocated to another location will the regulators in that location also insist on the provision of regulatory capital? Would this have to be additional capital or would the regulatory authorities of the booking jurisdiction agree to the transfer of an appropriate amount of capital to the other location or agree that less capital be provided in the booking location to reflect the allocation of losses. This situation is likely to be particularly problematical where the profit split method has been chosen without considering in advance the regulatory framework. However, whilst the potential interests of the regulatory authorities need to be borne in mind, there seems no reason why their concerns or possible problems in themselves should prevent tax authorities from sanctioning the use of a profit split method in appropriate circumstances" (OCDE. OECD Documents. The Taxation of Global Trading of Financial Instruments. op. cit., p. 35).
} 
assumido, mediante o cálculo do risco do mercado. São os traders que decidem para quais posições em aberto a instituição financeira fará hedge e para quais posições o risco será assumido [i.e. posições que a instituição não se protege, porque aposta em ganhos futuros elevados]. Considerando os elevados custos de quaisquer operações de hedge, são os traders os geradores de parcela substancial do lucro na negociação global de derivativos. A decisão de afastamento de uma operação de hedge [ou a escolha adequada das posições que serão mantidas "em aberto"], nesse contexto, é potencial geradora de lucros elevados para a instituição ${ }^{790}$. Quando a atividade de trading divide-se entre mais de uma instituição do mesmo grupo, especialmente se ambas atuam de forma integrada, o PSM provavelmente será utilizado, isolada ou conjuntamente com outros métodos.

Normalmente os riscos são divididos entre diversos portfólios, pela sua semelhança, e cada portfólio é atribuído a um trader. Os riscos são transferidos de cada estabelecimento para o portfólio do trader responsável mediante a estruturação de operações inversas entre as filiais ou afiliadas [transações inter-branch ou inter-company]. A possibilidade de utilização dos métodos tradicionais para o controle dos preços de transferência nesse tipo de serviço depende da estratégia de atuação da instituição financeira. Com efeito, se a instituição financeira negociar derivativos globalmente, de forma integrada ["Integrated Trading" ou 24h/dia], vendendo um mesmo tipo de produto financeiro a partir de diversos países e permitindo que as posições em aberto de um estabelecimento sejam, após o fechamento do horário de negociação do seu país, transferidas para o estabelecimento subseqüente, a mensuração do valor dos serviços dos traders é sobremaneira complexa. Normalmente, somente as funções de traders mais simples são prestadas por partes não-relacionadas e, por conseguinte, raramente esse tipo de serviço apresenta similares comparáveis. Quanto mais complexa a atuação dos traders, menor o grau de referibilidade dos dados disponíveis no mercado e menores as possibilidades de controle dos preços de transferência a partir dos métodos tradicionais. Novamente, o PSM seria o método recomendável pela OCDE para o "teste" da remuneração da administração de risco.

\footnotetext{
${ }^{790} \mathrm{Na}$ prática, a instituição desenvolve um produto para seu cliente e, por um determinado preço, assume uma posição compradora ou vendedora que apresenta riscos. A instituição, assim, cobra um preço para suportar aquele risco transferido pelo cliente; mas esse risco precisa ser administrado pela instituição, mediante: (i.) realização de operações de hedge inter-branch; ou (ii.) aquisição de proteção em outras instituições. Se os traders optarem por não proteger esse risco, há uma economia de custos para a instituição; se, ao final, sua "aposta" for correta, além de uma redução de custos, pode-se obter ganhos em suas posições no mercado. Se a "aposta" não se concretizar, contudo, a economia provavelmente foi um mau negócio, porque as perdas da instituição naquelas posições em aberto podem ser elevadas.
} 
A dificuldade de aplicação dos métodos tradicionais na mensuração do valor da atividade dos traders não se resume aos casos nos quais a instituição atua de forma integrada. Em qualquer forma de estruturação do negócio, sempre que uma função relevante dos traders for desempenhada fora da subsidiária em que os lucros são reconhecidos, haverá dificuldades de avaliação de seu preço de plena concorrência. Essa dificuldade decorre, em essência, da ausência de negócios similares entre partes nãorelacionadas que possam ser utilizados como parâmetro. Ademais, mesmo nos casos em que a transação se dá entre partes não-ligadas, o trader, considerando a relevância de sua atuação, exige como remuneração parte dos lucros (ou prejuízos) gerados pelo derivativo. Não haveria, portanto, um preço parâmetro para a aplicação dos métodos tradicionais. Dada a escassez de referências para se proceder à comparação, a OCDE propõe a análise da atuação de traders em outros tipos de negócios [e.g. administração de fundos de investimento] e, como medida residual, a adoção do PSM.

Comprovada a relevância do PSM para a aferição dos preços de transferência em operações envolvendo a negociação global de instrumentos financeiros, passa-se, abaixo, a descrevê-lo. Na subseção 5.2.1, serão examinadas as regras gerais para a aplicação do método, especialmente segundo a concepção trazida pela OCDE na Diretiva e na Minuta-2009, e pela legislação norte-americana [Seção 1.482-6] ao passo que, na subseção 5.2.2, o método será examinado vis-à-vis as regras das transações globais, a partir da perspectiva da OCDE [Relatório GT-1998 e Relatório-2008] e das autoridades estadunidenses [Seção 1.482-8 [proposta](e)].

\subsection{Profit Split Method ('PSM").}

\subsubsection{Regras gerais para aplicação do método.}

O método da divisão de lucros [ou "Profit Split Method" ou "PSM"] destina-se a eliminar os impactos nos lucros operacionais [ou nos prejuízos operacionais] que as condições impostas em transações controladas possam ter acarretado, mediante a divisão dos lucros [ou prejuízos] de forma semelhante àquela que terceiros independentes o teriam repartido $^{791}$. Na prática, a aplicação deste método resume-se à questão: como terceiros

791 "\$1.482-6 (a) In general. The profit split method evaluates whether the allocation of the combined operating profit or loss attributable to one or more controlled transactions is arm's length by reference to the relative value of each controlled taxpayer's contribution to that combined operating profit or loss. The combined operating profit or loss must be derived from the most narrowly identifiable business activity of the 
independentes repartiriam este lucro? Em primeiro lugar, deve-se identificar o lucro a ser partilhado para, em seguida, buscar os critérios que empresas independentes utilizaram ou utilizariam para tal divisão. A “contribuição" de cada parte para o lucro operacional total da transação deve ser buscada a partir da efetivação de análise funcional, mensurada segundo dados externos disponíveis no mercado, que podem compreender, v.g., o percentual de divisão de lucros ou o retorno esperado entre terceiros para o desenvolvimento de atividades comparáveis ${ }^{792}$.

Segundo manifestado pela OCDE em sua Diretiva e na Minuta-2009, há duas perspectivas para a aplicação do PSM, denominadas análise de contribuição [“contribution

controlled taxpayers for which data is available that includes the controlled transactions (relevant business activity)" [26 CFR Ch. I (4-1-09 Edition)].

792 "2.70 Under the transactional profit split method, the combined profits are to be split between the associated enterprises on an economically valid basis that approximates the division of profits that would have been anticipated and reflected in an agreement made at arm's length. In general, the determination of the combined profit to be split and of the splitting factors should:

- Be consistent with the functional analysis of the controlled transaction under review, and in particular reflect the allocation of risks among the parties,

- Be consistent with the determination of the combined profit to be split and of the splitting factors which would have been agreed between independent parties,

- Be consistent with the type of profit split approach (e.g. contribution analysis, residual analysis, or other; ex ante or ex post approach, as discussed at paragraphs 2.72-2.99 below), and

- Be capable of being measured in a reasonably reliable manner.

2.71 In addition,

- If a transactional profit split method is used to set transfer pricing in controlled transactions (ex ante approach), it would be reasonable to expect the criteria or allocation keys to be agreed in advance of the transaction,

- The person using a transactional profit split method (taxpayer or tax administration) should be prepared to explain the appropriateness of the method as well as the way it is implemented, and in particular the criteria or allocation keys used to split the combined profit, and

- The determination of the combined profit to be split and of the splitting factors should generally be used consistently over the life-time of the arrangement, including during loss years, unless independent parties at arm's length would have agreed otherwise and the rationale for using differing criteria or allocation keys is documented, or if specific circumstances would have justified a re-negotiation between independent parties"

(OCDE. Proposed Revision of Chapters I-III of the Transfer Pricing Guidelines. $9^{\text {th }}$ September 2009- $9^{\text {th }}$ January 2010. op. cit., p. 31-32). Itens novos, sem correspondentes na Diretiva.

A legislação norte-americana também é clara no sentido de que a análise funcional é essencial para a obtenção de critérios para a partição de lucros:

"§1.482-6 (b) Appropriate share of profits and losses. The relative value of each controlled taxpayer's contribution to the success of the relevant business activity must be determined in a manner that reflects the functions performed, risks assumed, and resources employed by each participant in the relevant

business activity, consistent with the comparability provisions of $\S 1.482-1(\mathrm{~d})(3)$ [cf. CAPÍTULO 2 da tese]. Such an allocation is intended to correspond to the division of profit or loss that would result from an arrangement between uncontrolled taxpayers, each performing functions similar to those of the various controlled taxpayers engaged in the relevant business activity. The profit allocated to any particular member of a controlled group is not necessarily limited to the total operating profit of the group from the relevant business activity. For example, in a given year, one member of the group may earn a profit

while another member incurs a loss. In addition, it may not be assumed that the combined operating profit or loss from the relevant business activity should be shared equally, or in any other arbitrary proportion" [26 CFR Ch. I (4-1-09 Edition)]. 
analysis"] ou análise residual ["residual analysis"], as quais não são exaustivas nem mutuamente exclusivas. Na legislação norte-americana, estas duas possibilidades de aplicação do PSM são denominadas divisão de lucros comparáveis [“comparable profit split"] e divisão de lucros residuais ["residual profit split"].

$\mathrm{Na}$ análise da contribuição, parte-se do lucro total da transação [“combined profits"], o qual deve ser dividido entre as empresas associadas com base no valor relativo das funções desenvolvidas por cada uma, complementando-se na medida do possível com dados externos que indicam como empresas independentes dividiriam os lucros em circunstâncias análogas; quaisquer formas de repartição devem, sempre, ser compatíveis com o princípio da plena concorrência. Em alguns casos, o valor relativo da contribuição da parte pode ser diretamente medido, não sendo necessário estimar valores de mercado. Normalmente, o lucro a ser dividido desta forma é o operacional, o que gera resultados mais consistentes com a aplicação do método. Existem, contudo, casos nos quais não é possível determinar com precisão a qual empresa determinadas despesas, incorridas por uma delas, pertence, porque tal despesa é necessária para todo o negócio integrado. Nestes casos, parte-se do lucro bruto e, em seguida, deduzem-se as despesas atribuíveis a cada empresa [a repartição das despesas precisa ser consistente com as atividades desenvolvidas e os riscos incorridos] $]^{793}$.

A análise residual, de outro lado, é aplicada em duas etapas: (1.) na primeira delas, aloca-se o lucro cabível a cada parte, de acordo com as funções desempenhadas, ativos empregados e riscos envolvidos; observa-se, na prática, o retorno de mercado [obtido ou esperado] de operações não-vinculadas comparáveis; (2.) na segunda etapa, o lucro residual, i.e., o lucro não distribuído a partir da remuneração fundada na análise

\footnotetext{
793 " 2.85 . Generally, the profit to be combined and divided under the contribution analysis is operating profit. Applying the transactional profit split in this manner ensures that both income and expenses of the MNE are attributed to the relevant associated enterprise on a consistent basis. However, occasionally, it may be appropriate to carry out a split of gross profits and then deduct the expenses incurred in or attributable to each relevant enterprise (and excluding expenses taken into account in computing gross profits). In such cases, where different analyses are being applied to divide the gross income and the deductions of the MNE among associated enterprises, care must be taken to ensure that the expenses incurred in or attributable to each enterprise are consistent with the activities and risks undertaken there, and that the allocation of gross profits is likewise consistent with the placement of activities and risks. For example, in the case of an MNE that engages in highly integrated worldwide trading operations, involving various types of property, it may be possible to determine the enterprises in which expenses are incurred (or attributed), but not to accurately determine the particular trading activities to which those expenses relate. In such a case, it may be appropriate to split the gross profits from each trading activity and then deduct from the resulting overall gross profits the expenses incurred in or attributable to each enterprise, bearing in mind the caution noted above" (OCDE. Proposed Revision of Chapters I-III of the Transfer Pricing Guidelines. $9^{\text {th }}$ September 2009$9^{\text {th }}$ January 2010. op. cit., p. 36). Item praticamente alterado, correspondente ao item 3.17 da Diretiva.
} 
funcional referida em (1.), deve ser repartido conforme o contexto ${ }^{794}$. Este 'resíduo' para repartir também pode surgir da aplicação de outros métodos. Esta sistemática é útil na valoração de intangíveis usados em operações vinculadas, bem assim na divisão de lucros em casos de economia de escala ou outros fatores decorrentes de elevação de eficiências; normalmente, inexistem dados comparáveis para a repartição destes "ganhos extra" decorrentes das transações intra-grupo.

Uma forma de divisão do lucro residual seria replicar a negociação no livre mercado; o retorno básico seria o preço máximo que uma empresa independente estaria disposta a pagar ou o mínimo a que estaria disposta a vender. Eventual diferença remanescente poderia, numa terceira etapa, ser dividida, também conforme fatores buscados no livre mercado. O fluxo de caixa descontado também pode ser usado na partição de lucros residuais, mas seria muito complicado utilizá-lo sozinho; idealmente, o fluxo de caixa descontado deveria ser usado apenas a partir de informações obtidas via outros métodos. A principal questão, neste caso, seria a definição da taxa de desconto, que depende do nível de risco dos negócios, do porte da empresa etc. ${ }^{795}$.

794 “\$1.482-6 (c) (3) (ii) (B) Comparability. The first step of the residual profit split relies on market benchmarks of profitability. Thus, the comparability considerations that are relevant for the first step of the residual profit split are those that are relevant for the methods that are used to determine market returns for the routine contributions. The second step of the residual profit split, however, may not rely so directly on market benchmarks. Thus, the reliability of the results under this method is reduced to the extent that the allocation of profits in the second step does not rely on market benchmarks" [26 CFR Ch. I (4-1-09 Edition)]. 795 "2.76 An alternative approach to how to apply a residual analysis could seek to replicate the outcome of bargaining between independent enterprises in the free market. In this context, in the first stage, the initial remuneration provided to each participant would correspond to the lowest price an independent seller reasonably would accept in the circumstances and the highest price that the buyer would be reasonably willing to pay. Any discrepancy between these two figures could result in the residual profit over which independent enterprises would bargain. In the second stage, the residual analysis therefore could divide this pool of profit based on an analysis of any factors relevant to the associated enterprises that would indicate how independent enterprises might have split the difference between the seller's minimum price and the buyer's maximum price.

2.77 In some cases an analysis could be performed, perhaps as part of a residual profit split or as a method of splitting profits in its own right, by taking into account the discounted cash flow to the parties to the controlled transactions over the anticipated life of the business. One of the situations in which this may be an effective method could be where a start-up is involved, cash flow projections were carried out as part of assessing the viability of the project, and capital investment and sales could be estimated with a reasonable degree of certainty. However, the reliability of such an approach will depend on the use of an appropriate discount rate, which should be based on market benchmarks. In this regard, it should be noted that industrywide risk premiums used to calculate the discount do not distinguish between particular companies let alone segments of businesses, and estimates of the relative timing of receipts can be problematic. Such an approach, therefore, would require considerable caution and should be supplemented where possible by information derived from other methods" (OCDE. Proposed Revision of Chapters I-III of the Transfer Pricing Guidelines. $9^{\text {th }}$ September 2009- $9^{\text {th }}$ January 2010. op. cit., p. 34). Correspondentes aos itens 3.21 e 3.22 da Diretiva. 
Para a definição dos lucros a serem partilhados, eles devem, primeiramente, ser avaliados numa mesma moeda e segundo critérios contábeis consistentes; apenas após estes ajustes preliminares os lucros totais auferidos pelas partes podem ser somados. Em seguida, devem ser avaliados as particularidades de cada caso concreto, de modo a se definir um critério de alocação [“allocation keys”]. Não há uma lista de fórmulas de aplicação do PSM para cada ocasião; pelo contrário, em respeito ao princípio da plena concorrência, sempre deve ser buscado o critério que mais se aproximar daquele que foi [ou teria sido] escolhido por empresas independentes para a repartição daquele mesmo lucro. Os critérios mais comuns, segundo sustentado pela OCDE na Minuta-2009, são baseados em ativos/capital [lucros operacionais, ativos fixos, ativos intangíveis, capital empregado etc.] ou custos [despesas com pesquisas e desenvolvimento, marketing etc.] ${ }^{796}$. Em cada caso concreto, devem ser ponderados os fatores mais relevantes para a formação do lucro. Se forem intangíveis exclusivos, v.g., aplicam-se critérios amparados nestes ativos; se o lucro tiver forte relação com o valor agregado pela parte, de outro lado, podem ser aplicados métodos amparados nos custos ${ }^{797}$.

796 "2.88 In practice, allocation keys based on assets/capital (operating assets, fixed assets, intangible assets, capital employed) or costs (relative spending and/or investment in key areas such as research and development, engineering, marketing) are the most common. Other allocation keys based for instance on incremental sales, headcounts (number of individuals involved in the key functions that generate value to the transaction), time spent by a certain group of employees if there is a strong correlation between the time spent and the creation of the combined profits, number of servers, data storage, floor area of retail points, etc. are also sometimes encountered" (OCDE. Proposed Revision of Chapters I-III of the Transfer Pricing Guidelines. $9^{\text {th }}$ September 2009- $9^{\text {th }}$ January 2010. op. cit., p. 37). Item novo, sem correspondente na Diretiva.

797 "2.89 Asset-based or capital-based allocation keys can be used where there is a strong correlation between tangible or intangible assets or capital employed and creation of value in the context of the controlled transaction. (...)

2.90 One particular circumstance where the transactional profit split method may be found to be the most appropriate method is the case where both parties to the transaction contribute significant unique intangibles. Intangible assets pose difficult issues in relation both to their identification and to their valuation. Identification of intangibles can be difficult because not all valuable intangible assets are legally protected and registered and not all valuable intangible assets are recorded in the accounts. An essential part of a transactional profit split analysis is to identify what intangible assets are owned by each party to the transaction and what their relative value is. (...)

2.91 An allocation key based on expenses may be appropriate where it is possible to identify a strong correlation between relative expenses incurred and relative value added.

For example, marketing expenses may be an appropriate key for a distributor-marketer if advertising generates material marketing intangibles, e.g. in consumer goods where the value of marketing intangibles is affected by advertising. Research and development expenses may be suitable for a manufacturer if they relate to the development of significant trade intangibles such as patents. However, if, for instance, both parties contribute different valuable intangibles, then it is not appropriate to use a cost-based allocation key unless cost is a reliable measure of the relative value of both intangibles. Remuneration is frequently used in situations where people functions are the primary factor in generating the combined profit.

2.92 Cost-based allocation keys have the advantage of simplicity. It is however not always the case that a strong correlation exists between relative expenses and relative value. One possible issue with cost-based allocation keys is that they can be very sensitive to accounting classification of costs. It is therefore necessary 
Os lucros operacionais precisam ser fiscalizados com cautela pelas autoridades tributárias; isto porque, durante a fiscalização, será efetivado o exame de fatos que, quando da prática das transações, não poderiam ter sido vislumbrados pelas partes. A atribuição de maior peso a estas circunstâncias [que não poderiam ter sido previstas à época da definição dos preços] representa impor ao contribuinte uma penalidade contrária ao princípio da plena concorrência ${ }^{798}$; terceiros independentes também não teriam sopesado fatores totalmente desconhecidos e imprevisíveis à época da contratação do negócio.

Um dos principais diferenciais do PSM é que, ao contrário de outros métodos, ele pode ser aplicado a operações intra-grupo altamente integradas; este foi, inclusive, o motivo que levou a OCDE e as autoridades tributárias norte-americanas a atribuírem tamanha importância ao PSM no âmbito de seus estudos a respeito da negociação global de instrumentos financeiros [cf. seção 5.2.2, infra]. Por se tratar de um mecanismo que exige, necessariamente, a participação de todas as empresas vinculadas envolvidas numa determinada transação, ele possibilita a repartição de resultados que não seriam "captados" pelos métodos "unilaterais", i.e., passíveis de aplicação a partir do exame tão-somente das informações disponibilizadas pelo(s) contribuinte(s) de uma determinada nação. Também por conta desta característica é que o PSM destaca-se como importante método para a determinação dos preços de transferência em operações com intangíveis únicos e exclusivos. Claro que o exame de "dados externos" relativos a operações praticadas no

to clearly identify in advance what costs will be taken into account in the determination of the allocation key and to determine the allocation key consistently among the parties. Cost-based allocation keys can also pose consistency problems where they are applied to parties situated in countries with significantly different levels of costs (e.g. a high labour-cost country and a low labour-cost country)" (OCDE. Proposed Revision of Chapters I-III of the Transfer Pricing Guidelines. $9^{\text {th }}$ September 2009- $9^{\text {th }}$ January 2010. op. cit., p. 37-38). Itens novos, sem correspondente na Diretiva.

798 " 2.82 When a tax administration examines the application of the method used ex ante to evaluate whether the method has reliably approximated arm's length transfer pricing, it is critical for the tax administration to acknowledge that the taxpayer could not have known what the actual profit experience of the business activity would be at the time that the conditions of the controlled transaction were established. Without such an acknowledgement, the application of the transactional profit split method could penalize or reward a taxpayer by focusing on circumstances that the taxpayer could not reasonably have foreseen. Such an application would be contrary to the arm's length principle, because independent enterprises in similar circumstances could only have relied upon projections and could not have known the actual profit experience. $(. .$.

2.84 Where the associated enterprises have determined the conditions in their controlled transactions on a basis other than the transactional profit split method, the tax administration would evaluate such conditions on the basis of the actual profit experience of the enterprise. However, care would need to be exercised to ensure that the application of a transactional profit split method is performed in a context that is similar to what the associated enterprises would have experienced, i.e. on the basis of information known or reasonably foreseeable by the associated enterprises at the time the transactions were entered into, in order to avoid the use of hindsight" (OCDE. Proposed Revision of Chapters I-III of the Transfer Pricing Guidelines. $9^{\text {th }}$ September 2009- $9^{\text {th }}$ January 2010. op. cit., p. 35-36). Correspondentes aos itens 3.12 e 3.14 da Diretiva. 
mercado é importante para mensurar a contribuição de cada um dos agentes na aferição do lucro operacional total ${ }^{799}$. De todo modo, outra vantagem deste método é que, mesmo se não houver transações semelhantes entre partes independentes, ainda assim o PSM pode ser aplicado, a partir do exame das funções, ativos e riscos que podem ser atribuídos a cada uma das empresas envolvidas na transação "testada" 800 . Trata-se de metodologia flexível, mas que, ainda assim, atende ao princípio da plena concorrência. Adicionalmente, sua aplicação dificilmente gera lucros extremos para uma parte em detrimento da outra, porquanto as contribuições de ambas as partes são avaliadas.

Mas o PSM não está isento de críticas. Habitualmente, os dados externos disponíveis no mercado sobre a contribuição de cada empresa são menos próximos das operações reais, se comparados aos outros métodos. E, se os dados não forem de operações semelhantes, podem gerar uma alocação "subjetiva" de lucros. Há outros aspectos que também devem ser analisados para ponderar se o PSM é aplicável em cada caso concreto: (i.) dificuldade de acesso aos dados de empresas vinculadas no exterior; (ii.) as empresas independentes, como regra geral, não usam o PSM para determinar seus preços de transferência [exceto em joint ventures]; (iii.) pode ser complexo mensurar receitas e despesas de todas as empresas a partir de critérios contábeis unificados [necessitar-se-ia de muitos ajustes contábeis]; e (iv.) pode ser complicado segregar os custos corretos na contabilidade das empresas associadas, haja vista uma possível inconsistência contábil entre as regras dos países das partes envolvidas.

\footnotetext{
799 A diferença do PSM para os métodos da partilha fracionada reside justamente nisso: no PSM, dados externos [ou amparados na divisão de funções efetivamente realizadas pelas partes] são utilizados para a montagem de fórmula de alocação de lucros, ao passo que, na partilha fracionada, a fórmula é predeterminada e independe das funções de cada parte no caso concreto.

800 "2.64 Where reasonably reliable comparables data are available, they can be relevant in the profit split analysis to support the division of profits that would have been achieved between independent parties at arm's length. Comparables data can also be relevant in the profit split analysis to assess the value of the contributions that each associated enterprise makes to the transactions. In effect, the assumption is that independent parties would have split the combined profit in proportion to the value of their respective contributions to the generation of profit in the transaction. On the other hand, the external market data considered in valuing the contribution each associated enterprise makes to the controlled transactions will be less closely connected to those transactions than is the case with the other available methods. The more tenuous the nature of the external market data used when applying the profit split method, the more subjective will be the resulting allocation of profits.

2.65 However, in those cases where there is no more direct evidence of how independent parties at arm's length would have split the profit in comparable transactions, the allocation of profits may be based on the division of functions (taking account of the assets used and risks assumed) between the associated enterprises themselves" (OCDE. Proposed Revision of Chapters I-III of the Transfer Pricing Guidelines. $9^{\text {th }}$ September 2009- $9^{\text {th }}$ January 2010. op. cit., p. 31). Itens alterados, correspondentes a partes dos itens 3.6 e 3.8 da Diretiva.
} 
Por fim, destaque-se que o PSM tornou-se muito relevante em países como Japão e Canadá. Na América Latina, a Argentina prevê os métodos da "participación de utilidades e residual de participación de utilidades" ${ }^{801}$, baseados no PSM. Nos Estados Unidos da América, a despeito da utilização maciça do CPI, o PSM é, provavelmente, o método mais utilizado em APA, discussões administrativas em geral e, também, perante o Poder Judiciário.

\subsubsection{Aplicação do PSM às transações envolvendo a negociação global de instrumentos financeiros.}

\section{(I.) Regras gerais propostas pela OCDE.}

No âmbito do Relatório GT-1998 e do Relatório-2008, a OCDE discute os fatores da fórmula para alocação de lucros das atividades altamente integradas desenvolvidas no âmbito das transações de negociação global de instrumentos financeiros. Antes de se proceder à aplicação do PSM, deve-se remunerar as funções não integradas [vendas, back office (alguns ou todos) etc.], mediante a aplicação dos métodos tradicionais, para, em seguida, partilhar o lucro operacional remanescente, da mesma forma que terceiros independentes partilhariam. O procedimento a ser adotado para o emprego do PSM, o qual necessariamente deve ser compatível com o princípio da plena concorrência será, resumidamente, o seguinte: (1.) verifica-se o lucro/prejuízo a ser repartido e as funções, ativos e riscos que contribuíram para o lucro/prejuízo operacional; (2.) mede-se a participação de cada função/ativo/risco no lucro/prejuízo total; e (3.) divide-se o valor relativo a cada função/ativo/risco pelas partes atuaram integradamente ${ }^{802}$. O PSM pode ser

801 "A los efectos previstos en el tercer párrafo, serán de aplicación los métodos de precios comparables entre
partes independientes, de precios de reventa fijados entre partes independientes, de costo más beneficios, de
división de ganancias y de margen neto de la transacción, en la forma y entre otros métodos que, con
idénticos fines, establezca la reglamentación" [Artículo 15, párrafo 5, Ley n. ${ }^{\circ} 20.628 / 97$, Texto vigente según
Ley n. . $^{\circ} 5.784 / 03$ ].
802 " 175 . To apply a profit split method to global trading first of all requires an identification of the functions
that need to be rewarded by a profit method following the guidance in Section C-2 [cf. subseção 3.4 .1 do
CAPÍTULO 3]. It should be noted that when the residual profit method is applied it is only the functions
producing the residual profit or loss that need to be included in the profit allocation. The reward for
performing the other functions will have already been deducted in calculating the residual profit or loss.
176 . Once the relevant functions have been identified, it will be necessary to determine the relative
contribution of each function to the earning of the combined profit from global trading. The final step is to
determine the relative contribution of each location to the performance of the function. As with all transfer
pricing, the above determination of the reward for particular functions should consider the assets used and
risks assumed in the performance of those functions. A common approach to applying the profit split method
(a multi-factor formula) is to select factors to represent one or more of the relevant functions, to weight the
factors to determine the relative contribution of the function(s) represented by each factor and to use the 
aplicado segundo a perspectiva da análise de contribuição ou da análise residual; somente podem ser incluídos nesta última, todavia, as funções/ativos/riscos que contribuírem para o lucro residual.

Cada uma das funções desempenhadas nas transações entre instituições envolvendo a negociação global de instrumentos derivativos foi estudada na seção 3.4 do CAPÍTULO 3, bem assim na seção 4.5 do CAPÍTULO 4. Na prática, qualquer uma das funções podem sujeitar-se ao PSM, em maior ou menor grau.

Como referido na seção 5.1, supra, as atividades de trading e administração de riscos são as que mais necessitam ser examinadas pelo PSM, como decorrência da nãoconfiabilidade dos resultados obtidos via métodos tradicionais. Há grande correlação entre resultado das transações globais e os salários/bônus dos responsáveis por estas funções; a remuneração dos traders pode, nesse sentido, ser um fator para alocação de lucros; obviamente, contudo, precisa ser excluída eventual parcela fixa dos salários, que não tenha relação com o resultado das transações. Este mesmo critério de partição de lucros pode ser aplicados aos marketers ${ }^{803}$. Como discutido seção 4.5 do CAPÍTULO 4, contudo, é importante definir se estes últimos fazem jus apenas à parte inicial do lucro, resultado do ganho na transação com o cliente, ou se participam do resultado global do negócio ${ }^{804}$. Em cada caso concreto, deve ser ponderada inclusão, na fórmula, dos administradores de mais alto escalão, dos responsáveis por administração estratégica ou de funcionários que exercem funções de middle-office. Adicionalmente, se, num caso mais específico, os traders e/ou marketers tiverem salários fixos, o que é incomum neste ramo de negócios,

factors to allocate the profit to the locations performing those functions" (OCDE. Report on the Attribution of Profits to Permanent Establishments. op. cit., p. 155).

803 "184. The performance of both traders and specialized marketers is the key to the profitability of global trading. They require adequate compensation for their performance and, if not rewarded adequately, often move to an enterprise which does so reward them. In the rather specialized field of global trading, the compensation negotiated with wholly independent enterprises would also seek to measure the relative contribution of traders to the realized profits. Therefore, the traders' and marketers' compensation generally reflects the arm's length value of the function that the traders perform. However, if this relationship breaks down for any reason, then an alternative way of measuring this function, such as the number of employees, may need to be considered" (OCDE. OECD Documents. The Taxation of Global Trading of Financial Instruments. op. cit., p. 45).

804 " 183 . In cases where the marketing function is also to be rewarded by inclusion as a factor in the profit split formula then, if there is a similar link between specialized marketers' compensation and the contribution of the marketing function, it would be appropriate to include the marketers' compensation as well as that of traders as an allocation factor. It is only the compensation of marketers who share in the total profits who need to be considered in the factor formula. The ones who share in the initial profit would already have been rewarded by a fee which effectively reduces the profits available to be shared" (OCDE. OECD Documents. The Taxation of Global Trading of Financial Instruments. op. cit., p. 45). 
pode-se utilizar na fórmula de partição de resultados um outro critério, como, v.g., o número de empregados.

A atividade de administração de riscos é, provavelmente, a de mais complexa mensuração para fins de aplicação das regras para o controle dos preços de transferência. A capacidade de assumir riscos é a função mais relevante para garantir a rentabilidade global do negócio e há uma óbvia relação entre o risco e o lucro esperado; inexiste, contudo, consenso sobre inclusão na fórmula do PSM de critérios relativos à remuneração da exposição ao risco, da administração de risco ou de ambos.

Alguns países são contra a inclusão de fator concernente à utilização da exposição ao risco na fórmula do PSM, com fundamento nas seguintes alegações: (i.) seria difícil determinar quem assume o risco, porque ele pode ser facilmente transferido ou repartido [por intermédio garantias, e.g.]; (ii.) a medição da exposição ao risco em derivativos complexos é difícil; ademais, as autoridades tributárias não dispõem da mesma gama de recursos que as instituições financeiras para fazê-lo; (iii.) assumir muito risco pode representar especulação; dividir com amparo neste critério pode sobrevalorizar especuladores, que por vezes trazem prejuízos ao invés de lucro. Países favoráveis à inclusão do fator "exposição ao risco" na fórmula para medir a contribuição do capital para a lucratividade da instituição apresentam os seguintes argumentos: (a.) na maioria dos casos, é possível determinar quem assume o risco, via análise funcional [e rastreando-se sua transferência entre entes]; mas mera alocação arbitrária de riscos [v.g., todo o risco em filial sem recursos] não deve ser considerada; (ii.) pode-se usar os sistemas das próprias instituições e dali partir para calcular nível de exposição ao risco; e (iii.) há correlação entre exposição ao risco e lucro, de modo que a especulação precisa ser adequadamente remunerada. No Relatório GT-1998, os Estados-Membros da OCDE ainda discutiam este impasse entre as nações; neste relatório, a OCDE esclareceu que esta questão merecia maiores discussões, mas sugeriu a adoção do fator risco nas fórmulas do $\operatorname{PSM}^{805}$. No Relatório-2008, contudo, a OCDE esclareceu que os riscos assumidos precisam ser incluídos na fórmula do PSM, assim como qualquer outro fator envolvido na análise

\footnotetext{
805 " 197 . There seems to be a need for further discussion of the factors that could capture the contribution made by the risk management function. Suggested measures include initial risk exposure, compensation of dedicated risk managers (as opposed to traders) and the financial institution's risk limits" (OCDE. OECD Documents. The Taxation of Global Trading of Financial Instruments. op. cit., p. 45).
} 
funcional $^{806}$. Este novo Relatório-2008 trouxe, inclusive, um exemplo de mensuração do risco de mercado assumido em operação de negociação global, que envolve também intangíveis $[\text { know-how }]^{807}$.

Parte relevante das atividades de apoio ou back-office, consoante esclarecido na seção 4.5 do CAPÍTULO 4, pode ter seus preços comprovados a partir dos métodos tradicionais ali indicados. Apenas se estas atividades (a.) influírem diretamente no resultado; (b.) forem integradas às demais; e (c) não puderem ser comprovadas pelos métodos tradicionais após a implementação de ajustes, é que se admite a aplicação do PSM para a comprovação dos respectivos preços de transferência. Nestas hipóteses, a remuneração dos funcionários mais importantes costuma ser o fator mais adequado para inclusão na fórmula do $\mathrm{PSM}^{808}$. Eventuais despesas administrativas, incluindo-se a depreciação de bens, devem ser remuneradas pelos métodos tradicionais. Já os programas computação, sistemas ou modelos de negociação podem, desde que seja impossível sua

806 "198. Finally, just as in the situation where traditional transaction methods are applied, it will also be necessary when weighting or measuring factors to consider whether 'risks assumed' or 'assets used' have been appropriately taken into account when measuring the contribution of the functions included in the profit split. To illustrate, suppose that the relative contribution of each location to the trading and market risk management functions is determined by the use of a single measure, the 'front office' factor, based on the compensation of the marketers, traders and market risk managers. Following the guidance in the Guidelines, it will be necessary when undertaking a functional analysis of the trading and market risk management function in each location to analyze what intangibles were used and what risks were assumed in that location" (OCDE. Report on the Attribution of Profits to Permanent Establishments. op. cit., p. 159).

807 " 199 . Suppose that differences are found between the various locations, perhaps because the trading and market risk management function is organized not on fully integrated trading lines but more as a hybrid between the integrated trading and centralized product management models. The traders in location $\mathrm{X}$ are found to use an intangible ("trader know-how") which was developed by them. Further, they are found to have higher risk limits, and have accordingly assumed more market risk. The profit split methodology must ensure that the differences in the "assets used" and "risks assumed" in location X are reflected appropriately in the reward given to the performance of the trading and risk management function in location X.

200. There are a number of possible ways of doing this. For example, it might be that the traders and market risk managers in location $\mathrm{X}$ are paid more than those in other locations to reflect their 'know-how'

and greater ability to assume market risk. In that case, using their compensation as the measurement of the 'front office' factor should ensure that location X gets a greater share of the profits. However, if for some reason these differences are not appropriately reflected in the compensation of the traders and market risk managers in location X, these differences would have to be taken into account in some other way. Perhaps the traders in location X should have their compensation multiplied by an appropriate amount so as to give it more weight in the calculation? Perhaps, as well as the 'front office factor', there would have to be appropriately weighted 'intangible' and 'risk assumption' factors, provided that doing so would not result in a double counting of these functions. Another possibility may be to reward the owner of the intangible by way of a royalty. Again, this determination would have to be made on a case-by-case basis" (OCDE. Report on the Attribution of Profits to Permanent Establishments. op. cit., p. 159-160).

808 " 199 . (...)The most likely way to measure the contribution of such activities is to use the compensation of such key staff who, because their functions are essential for global trading, will have their compensation largely determined by performance in a similar manner to that used to determine traders' and marketers' compensation. The relationship between other activities (such as employee training and clerical functions) and profitability may be more remote, which indicates that these activities should not be reflected in an allocation factor" (OCDE. OECD Documents. The Taxation of Global Trading of Financial Instruments. op. cit., p. 49). 
"remuneração" pelos métodos tradicionais, ser incluídos na fórmula do PSM, método que também se destina à avaliação de intangíveis exclusivos ${ }^{809}$.

Além dos fatores supra indicados, diversos outros podem ser ponderados para a partilha de lucros resultantes de transações globais ${ }^{810}$. Na prática, os fatores devem ser sopesados caso a caso, inexistindo fórmulas predeterminadas para cada transação; todas as funções devem ser necessariamente avaliadas, porque a exclusão de quaisquer fatores pode afetar o resultado de aplicação da fórmula. Não há regra para a ponderação de fatores, mas devem ser examinadas as circunstâncias econômicas, os comparáveis externos e internos, especialmente relatórios de lucratividade, dentre outros.

Após a verificação das funções/ativos/riscos que contribuíram para a geração do lucro/prejuízo operacional a ser partilhado, mediante a realização da análise de funções constante da seção 3.4 do CAPÍTULO 3, da seção 4.5 do CAPÍTULO 4 e desta seção 5.2.2 (I), deve-se examinar a efetiva receita que compõe o lucro a ser partilhado. Para tanto, devem ser excluídos os valores (i.) não referentes às transações globais propriamente ditas [deve-se comparar tão-somente os lucros operacionais advindos de transações globais ${ }^{811}$ ]; e (ii.) que puderam ser "comprovados" a partir dos métodos tradicionais. Geralmente, reparte-se o lucro líquido; a Diretiva admite, todavia, a repartição do lucro bruto, seguida da dedução das despesas operacionais que não puderam ser vinculadas a uma empresa específica. Na divisão a partir do lucro líquido, reparte-se o lucro ou prejuízo global, o que reflete a real cooperação e integração das atividades que compõem a transação global. Na

809 "201. In order to compete in a cut throat environment, financial enterprises engaging in global trading stress the need to develop proprietary intangibles, e.g. computer programs, systems, or trading methods. Therefore, such items might be reflected in the factors to ensure that an appropriate amount of profits are allocated to the location which actually developed these programs, systems or methods" (OCDE. OECD Documents. The Taxation of Global Trading of Financial Instruments. op. cit., p. 49).

810 "203. Several countries have suggested that factors other than those described above could be used in allocating profits from global trading operations. For instance, countries have suggested that factors include a measure of volume (such as number of transactions or notional amounts of contracts written at a particular location), capital, and management" (OCDE. OECD Documents. The Taxation of Global Trading of Financial Instruments. op. cit., p. 50).

811 "212. The most common problem is in deciding whether the revenues of a treasury book should be taken into account in the global profit split. As noted above, these revenues could include interest or other income from investing surplus cash or capital and gains or losses from hedging transactions. The resolution of these issues affects the aggregate amount of profits from global trading which is to be allocated among the locations. If the decision is taken to exclude the treasury book from the scope of the profit split, it is essential that the transactions with the global trading book are undertaken under arm's length conditions. This is a transfer pricing issue if the treasury book is in a different legal entity to the global trading book and it should normally be possible to apply traditional transaction methods because comparable market data should be available. However, if the treasury book is in the same legal entity as the trading book this raises the issue of how to treat the internal 'transactions' between the books for tax purposes (OCDE. OECD Documents. The Taxation of Global Trading of Financial Instruments. op. cit., p. 54). 
divisão do lucro bruto, de outro lado, divide-se um determinado resultado bruto e, em seguida, são alocadas as despesas operacionais entre os envolvidos; é possível, neste caso, que determinados membros do grupo bancário tenham lucro, ao passo que outros incorram em prejuízos $^{812}$.

Nas transações globais, diferentemente de outros ramos de negócios, o PSM não tem o condão de elevar os custos de compliance, visto que apenas é aplicado se há negociações em um mesmo book; o lucro global, neste contexto, é mais facilmente perceptível $^{813}$. A aplicação deste método, todavia, não é simples nestas espécies de transações: trata-se de campo em que há muitos critérios contábeis aceitos [marcação a mercado, competência, realização, caixa etc.]; ademais, ainda que se utilizem os mesmos critérios, cada localidade tem regras próprias, o que também interfere na definição do lucro a partilhar. A este respeito, alguns países sustentam que o lucro deve ser "uniformizado" a partir dos critérios contábeis do país do book; outros discordam sob o argumento de que esta prática seria ilógica e impraticável ${ }^{814}$.

812 "213. The Guidelines state that profit split methods generally are to be applied to associated enterprises by combining and dividing their operating profits. Applying the profit split in this manner ensures that 'both income and expenses of the MNE are attributed to the relevant associated enterprises on a consistent basis'. Therefore, to the extent that expenses properly relate to global trading, so that they should be allocated in the same manner as income, it seems appropriate to deduct these expenses from the gross trading profit and then allocate the net profits. The Guidelines continue, however, that 'occasionally it may be appropriate to carry out a split of gross profits and then deduct the expenses incurred in or attributable to each relevant enterprise (and excluding expenses taken into account in computing gross profits)'. Using the latter method also ensures that one jurisdiction does not have to make enquiries where expenses have been incurred in another jurisdiction in order to check that they are allowable under its tax rules.

214. One consequence of choosing a gross, rather than a net, profit split method concerns the uniformity of treatment of locations. If a net method is chosen, where the overall result is a profit then each location sharing in the result will make a profit, and where the overall result is a loss then each location will make a loss. However, if a gross profit split is used, where the overall result is a profit it would still be possible for a particular location to make a loss, if its share of the gross profit did not exceed its operating expenses. This is used by some as a reason for generally favoring a gross profit split, as they feel such a result is more in accordance with what would happen between independent parties who, when deciding whether expenses should be shared or borne individually, are most likely to agree that expenses should be borne by those that can best control the expense. Others feel that the net profit method more accurately reflects the integrated and co-operative nature of a global business so that it would not be appropriate for one location to make a loss when others make a profit" (OCDE. OECD Documents. The Taxation of Global Trading of Financial Instruments. op. cit., p. 54).

813 "220. There is an issue as to whether the application of profit split methods increases the burden on taxpayers since it is difficult to get enough relevant information. However, global trading is different from other businesses where this argument may carry more weight, because the profit split method is only used where each location trades off a common book. Accordingly it should not be difficult to determine the worldwide trading profits" (OCDE. OECD Documents. The Taxation of Global Trading of Financial Instruments. op. cit., p. 55).

814 "221. (...) Even if all countries adopt mark-to-market accounting for taxation purposes, there are differences in the way it might be applied which could result in some degree of under, over, or double 


\section{(II.) Método específico proposto pelas autoridades norte-americanas para o controle das negociações globais.}

Além dos três métodos tradicionais discutidos no CAPÍTULO 4, a Seção 1.4828/Proposta do IRC também prevê a aplicação do PSM às transações envolvendo a negociação global de instrumentos financeiros ${ }^{815}$. Por intermédio deste método, os lucros e prejuízos que não puderam ser atribuídos aos agentes a partir dos métodos tradicionais são repartidos, de acordo com o exame das funções/ativos/riscos envolvidos. Por outras palavras, o valor relativo da contribuição de cada participante numa determinada transação global precisa ser aferido a partir da análise funcional, nos moldes discutidos na seção 2.2.1 (II.) do CAPÍTULO 2, bem assim na seção 3.4 do CAPÍTULO 3; deve-se ponderar como terceiros independentes efetivariam tal divisão de resultados. Não precisa haver, necessariamente, uma alocação de resultados positivos entre os envolvidos: se, e.g., o lucro da transação global integrada, desenvolvida pelas empresas A e B, foi \$100, é possível a atribuição, desde que amparada na análise funcional, de \$120 para A e de um prejuízo de $\$ 20$ para $\mathrm{B}^{816}$. As fórmulas definidas pelas partes para a divisão do lucro operacional podem, ademais, envolver vários fatores, desde que comprovado que terceiros independentes procederam [ou procederiam] desta forma.

Para a definição do resultado a ser partilhado, a proposta de regulamentação estadunidense alude a "lucro operacional", regulamentando-o na Seção 1.482-8/Proposta (e) (3). O lucro operacional corresponde ao lucro bruto ${ }^{817}$, deduzido das despesas

taxation. For example, differences in the way in which credit risk is reflected in the valuation will result in different measures of profits.

222. Despite these limitations, it is desirable to reach a general consensus, because the calculation of the profit to be split is the starting point of the application of any profit split method. Some countries believe that one way to resolve the problem is to respect the method used in the jurisdiction in which the book is kept (i.e. where legal ownership with respect to the positions is located) and apply the profit split to the amount of profits calculated by that method. Others do not see this as either logical or practical" (OCDE. OECD Documents. The Taxation of Global Trading of Financial Instruments. op. cit., p. 56).

815 "\$1.482-8 [proposta] (e) (1) General rule. The profit split method evaluates whether the allocation of the combined operating profit or loss of a global dealing operation to one or more participants is at arm's length by reference to the relative value of each participant's contribution to that combined operating profit or loss. The combined operating profit or loss must be derived from the most narrowly identifiable business activity of the participants for which data is available that includes the controlled transactions (relevant business activity)" (Federal Register/v. 63, no. 44. op. cit).

816 "\$1.482-8 [proposta] (e) (2) (i) The profit allocated to any particular participant using a profit split method is not necessarily limited to the total operating profit from the global dealing operation. For example, in a given year, one participant may earn a profit while another participant incurs a loss, so long as the arrangement is comparable to an arrangement to which two uncontrolled parties would agree. In addition, it may not be assumed that the combined operating profit or loss from the relevant business activity should be shared equally or in any other arbitrary proportion" (Federal Register/v. 63, no. 44. op. cit).

${ }^{817}$ Veja-se a formação do "lucro bruto", extraída do artigo 187 da Lei n. ${ }^{\circ}$ 6.404/76: 
operacionais; apenas devem ser computadas as receitas, despesas, ganhos ou perdas relacionados às atividades que serão remuneradas via PSM; não devem ser computados resultados relativos a outras atividades ou a ganhos ou perdas extraordinários; ou seja, deve ser aferido o lucro operacional específico das atividades cujo preço de transferência será examinado via PSM. O fator "despesas operacionais", de outro lado, deve compreender todos os dispêndios não computados nos custos, à exceção dos juros, impostos sobre a renda e despesas não relacionadas diretamente às atividades de negociação global ${ }^{818}$. Em síntese, o lucro a ser partilhado é o seguinte:

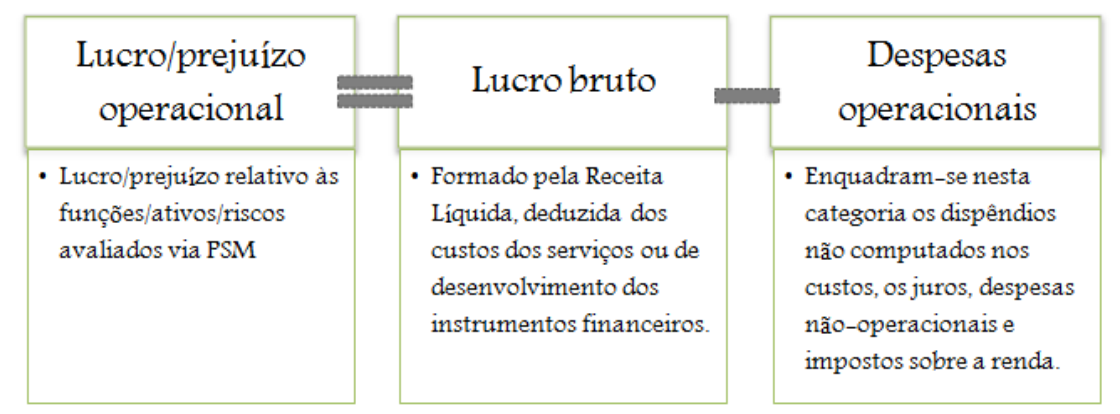

Uma vez delimitado o lucro a ser partilhado, deve-se optar por uma das duas variantes do método: a divisão de lucros total ["total profit split"] ou a divisão dos lucros residuais ["residual profit split"].

Na divisão de lucros totais, examina-se o lucro da transação global para repartilo, segundo as funções desempenhadas, ativos empregados e riscos assumidos pelos participantes; deve-se ponderar como terceiros independentes, naquela mesma situação,

Receita bruta de vendas

(-) devoluções e abatimentos

(-) descontos incondicionais

(-) tributos sobre vendas

(=) Receita líquida

(-) custo das mercadorias vendidas ou custo dos serviços prestados

(=) Lucro bruto ou Lucro operacional bruto.

818 "\$1.482-8 [proposta] (e) (3) Definitions. The definitions in this paragraph (e)(3) apply for purposes of applying the profit split methods in this paragraph (e).

Gross profit is gross income earned by the global dealing operation.

Operating expenses includes all expenses not included in the computation of gross profit, except for in $\$ 1.901-2(\mathrm{a})$, domestic income taxes, and any expenses not related to the global dealing activity that is evaluated under the profit split method.

Operating profit or loss is gross profit less operating expenses, and includes all income, expense, gain, loss, credits or allowances attributable to each global dealing activity that is evaluated under the profit split method. It does not include income, expense, gain, loss, credits or allowances from activities that are not evaluated under the profit split method, nor does it include extraordinary gains or losses that do not relate to the continuing global dealing activities of the participant" (Federal Register/v. 63, no. 44. op. cit). 
repartiriam os seus lucros. Para orientar a obtenção dos critérios de repartição, deve ser efetivada a análise funcional, conforme discutido na seção 2.2.1 (II.) do CAPÍTULO 2 e na seção 3.4 do CAPÍTULO 3. Se houver diferenças entre as transações "testadas" e as transações comparáveis que sejam aptas a afetar os critérios de divisão do lucro operacional entre as partes, deve-se implementar ajustes aptos a eliminar tais distorções. Se não forem localizados parâmetros para comparação no mercado externo [i.e., se não forem localizadas transações similares praticadas via joint ventures por terceiros independentes], podem ser examinadas as próprias transações e suas respectivas contribuições relativas para o lucro global. Os bônus e remunerações variáveis pagos a funcionários ${ }^{819}$, a participação de todas as sociedades envolvidas na transação global, dentre outros, aumentam a fiabilidade dos resultados obtidos ${ }^{820}$; esta confiabilidade depende, outrossim, da consistência contábil dos dados examinados.

${ }^{819}$ A respeito da divisão dos lucros com amparo na remuneração de traders e marketers, confira-se o seguinte exemplo trazido pela legislação norte-americana:

"\$1.482-8 [proposta] (e) (8) Example 1. Total profit split. (i) P, a U.S. corporation, establishes a separate U.S. subsidiary (USsub) to conduct a global dealing operation in over-the-counter derivatives. USsub in turn establishes subsidiaries incorporated and doing business in the U.K. (UKsub) and Japan (Jsub). USsub, UKsub, and Jsub each employ marketers and traders who work closely together to design and sell derivative products to meet the particular needs of customers. Each also employs personnel who process and confirm trades, reconcile trade tickets and provide ongoing administrative support (back office services) for the global dealing operation. The global dealing operation maintains a single common book for each type of risk, and the book is maintained where the head trader for that type of risk is located. Thus, notional principal contracts denominated in North and South American currencies are booked in USsub, notional principal contracts denominated in European currencies are booked in UKsub, and notional principal contracts denominated in Japanese yen are booked in Jsub. However, each of the affiliates has authorized a trader located in each of the other affiliates to risk manage its books during periods when the booking location is closed. This grant of authority is necessary because marketers, regardless of their location, are expected to sell all of the group's products, and need to receive pricing information with respect to products during their clients business hours, even if the booking location is closed. Moreover, $\mathrm{P}$ is known for making a substantial amount of its profits from trading activities, and frequently does not hedge the positions arising from its customer transactions in an attempt to profit from market changes. As a result, the traders in 'off-hours' locations must have a substantial amount of trading authority in order to react to market changes.

(ii) Under § 1.482-8(a)(2), USsub, UKsub and Jsub are participants in a global dealing operation in over-thecounter derivatives. P determines that the total profit split method is the best method to allocate an arm's length amount of income to each participant. P allocates the operating profit from the global dealing operation between USsub, UKsub and Jsub on the basis of the relative compensation paid to marketers and traders in each location. In making the allocation, $\mathrm{P}$ adjusts the compensation amounts to account for factors unrelated to job performance, such as the higher cost of living in certain jurisdictions. Because the traders receive significantly greater compensation than marketers in order to account for their greater contribution to the profits of the global dealing operation, $\mathrm{P}$ need not make additional adjustments or weight the compensation of the traders more heavily in allocating the operating profit between the affiliates" (Federal Register/v. 63, no. 44. op. cit).

820 "\$1.482-8 [proposta] (e) (5) (iii) In a global dealing operation, however, the absence of external market benchmarks (for example, joint ventures between uncontrolled taxpayers) on which to base the allocation of operating profits does not preclude use of this method if the allocation of the operating profit takes into account the relative contribution of each participant. The reliability of this method is increased to the extent that the allocation has economic significance for purposes other than tax (for example, satisfying regulatory standards and reporting, or determining bonuses paid to management or traders). The reliability of the 
A divisão de lucros residuais, de outro lado, é efetivada em duas etapas. Primeiramente, o lucro operacional das funções mais simples ou rotineiras é atribuído a cada uma delas ${ }^{821}$; este resultado preliminar pode também ser repartido mediante a aplicação de outros métodos. Este primeiro passo deve, necessariamente, atender ao princípio da plena concorrência, i.e., deve ser efetivada uma detalhada análise funcional, de modo que a remuneração de cada parte se dê segundo os mesmos parâmetros de retribuição exigidos por terceiros independentes que desenvolvam atividades similares. Em seguida, após a remuneração das funções ditas "rotineiras", aloca-se o lucro residual entre os participantes, amparando-se na contribuição relativa das funções "não-rotineiras" de cada um deles; diz-se que as funções são "não-rotineiras" porque contribuem de forma tão integrada para o resultado da negociação global que não é possível segregá-las para buscar um retorno de mercado esperado isolado para cada uma delas. Normalmente estão compreendidas neste tipo de função a precificação das operações, a administração de riscos, a atividade dos marketers estritamente vinculados ao desenvolvimento do instrumento e, eventualmente, a atividade de desenvolvimento de sistemas e modelos, que se enquadram no middle-office. Mais raramente, algumas atividades de back-office também podem ter seus preços de transferência avaliados desta forma, como se explicou na seção 4.5 do CAPÍTULO $4^{822}$. Para o desenvolvimento da análise de comparabilidade em cada um dos passos supra mencionados, deve-se buscar, primeiramente, parâmetros de rentabilidade no mercado. Há maior possibilidade de obtenção de parâmetros para as atividades rotineiras. No caso das atividades não-rotineiras, deve-se, ainda assim, tentar

analysis under this method may also be enhanced by the fact that all parties to the controlled transaction are evaluated under this method. The reliability of the results, however, of an analysis based on information from all parties to a transaction is affected by the reliability of the data and assumptions pertaining to each party to the controlled transaction. Thus, if the data and assumptions are significantly more reliable with respect to one of the parties than with respect to the others, a different method, focusing solely on the results of that party, may yield more reliable results" (Federal Register/v. 63, no. 44. op. cit).

821 "\$1.482-8 [proposta] (e) (6) (ii) Routine contributions are contributions of the same or similar kind as those made by uncontrolled taxpayers involved in similar business activities for which it is possible to identify market returns. Routine contributions ordinarily include contributions of tangible property, services, and intangibles that are generally owned or performed by uncontrolled taxpayers engaged in similar activities. For example, transactions processing and credit analysis are typically routine contributions. In addition, a participant that guarantees obligations of or otherwise provides credit support to another controlled taxpayer in a global dealing operation is regarded as making a routine contribution" (Federal Register/v. 63, no. 44. op. cit).

822 "\$1.482-8 [proposta] (e) (6) (iii) (...) Nonroutine contributions are contributions so integral to the global dealing operation that it is impossible to segregate them from the operation and find a separate market return for the contribution. Pricing and risk managing financial products almost invariably involve nonroutine contributions. Similarly, product development and information technology are generally nonroutine contributions. Marketing may be a nonroutine contribution if the marketer substantially participates in developing a product or in tailoring the product to the unique requirements of a customer" (Federal Register/v. 63, no. 44. op. cit). 
obter comparáveis externos e, se necessário, ajustá-los. Se isto não for viável, devem ser examinados os fatores de comparabilidade específicos indicados na Seção 1.4828/Proposta, item (a), os quais foram abordados nas seções 3.3 e 3.4 do CAPÍTULO 2; em suma, deve ser examinada uma lista de funções, termos contratuais, riscos e condições econômicas que normalmente afetam a remuneração nas transações globais envolvendo instrumentos financeiros. A consistência dos critérios contábeis de todas as partes envolvidas [empresas do mesmo grupo e terceiros independentes comparáveis], frise-se, é imprescindível para que o PSM produza resultados confiáveis.

As autoridades estadunidenses, a despeito da inexistência de regulamentações definitivas acerca das transações envolvendo a negociação global de instrumentos financeiros, têm bastante experiência na aplicação do PSM a estes casos, em especial via APA. A este respeito, importa salientar que, em 25.04.94, o IRS publicou a "Notice 9440", a qual contém uma espécie de "guia” para a condução de APA envolvendo transações globais com elevado grau de integração; esta Notice 94-40 aplica-se, portanto, a transações "24-hour basis", nos moldes explicados na subseção 3.2.2 do CAPÍTULO $3^{823}$. No âmbito

823 "In each of these APAs, the Service, the taxpayer, and a treaty partner agreed that the worldwide income for each global book to be covered by the APA should be allocated among the taxpayer's trading locations pursuant to a profit split method. The method was intended to measure the economic activity of each trading location and its contribution to the overall profitability of the worldwide business. Three critical factors were identified: 1) the relative value of the trading location (the 'value factor'), 2) the risk associated with a trading location (the 'risk factor'), and 3) the extent of the activity of each trading location (the 'activity factor'). Each of the factors was weighted to reflect its relative contribution to the overall profitability of a taxpayer's worldwide business. Moreover, the APAs did not adopt a uniform measurement of these factors; rather, different measurements were adopted in each APA to reflect the taxpayer's particular facts and circumstances as closely as possible. Relevant considerations in adopting a measurement for each factor included: the taxpayer's management structure and management information system capability, the functions performed, risks assumed, and capital employed by each trading location.

The value factor is a direct measure of the contribution of a trading location to the worldwide profits of that business. Trading commodities or derivative financial products generates the profit and loss for the business. For the taxpayers covered by these APAs, traders were the most significant resource in generating trading profit or loss for the company because they typically had customer lists and knowledge of the market. Traders are responsible for negotiating prices at which trades will be made, executing the transactions, and determining the hedging strategies to be used. Their compensation often is based upon a salary and a discretionary incentive bonus that depends upon their contribution to the profitability of the book. The sum of the compensation paid to traders in a particular trading location is a direct indication of the trading location's contribution to the profitability of the worldwide book. Thus, the Service, the taxpayer, and the participating treaty partner viewed compensation of the traders at a trading location as the best measure of the value of a trading location. Accordingly, this factor was weighted more heavily than others.

The risk factor measures the potential risk to which a particular trading location exposes the worldwide capital of the organization. This factor provides an important indication of the contribution of that trading location to the production of gross profits of the business. Based on the unique characteristics of each taxpayer, the risk factor was measured in several different ways, such as the maturity weighted volume of swap transactions (determined by multiplying the notional amount of each swap transaction entered into by its maturity) or open commodity positions at the end of the year entered into in that trading location. Sometimes this factor was weighted more heavily than others. 
de tal regulamentação, sustenta-se que a remuneração das atividades trading precisa ser mensurada a partir de três fatores: (a.) fator valor [da atividade de trading], que mede a contribuição de cada sociedade trader na negociação global; (b.) fator risco, que mede o risco suportado pelas entidades; e (c.) fator atividade, que permite a valoração das atividades de trading a partir da remuneração dos agentes e do valor presente líquido das transações ali negociadas. Em cada caso concreto, estes fatores são sopesados e compõem uma determinada fórmula, a ser adotada por conglomerado bancário que mantenha empresa associada no território estadunidense. Em muitos casos concretos, todavia, inexistem dados para ponderar como terceiros independentes sopesariam os componentes da fórmula; nestas hipóteses, os contribuintes e as autoridades fiscais norte-americanas acordam uma determinada regra. Esta regulamentação e, principalmente, a forma de consecução dos APA nos termos da Notice 94-40, é alvo de críticas entre os EstadosMembros da OCDE, porque conteria simplificações incompatíveis com o princípio da plena concorrência. Na prática, existem elementos formulares nos APA relativos a transações globais ${ }^{824}$, sendo este o principal aspecto gerador das críticas. Não há dúvidas,

The activity factor serves as another measure of a trading location's contribution to the production of gross profits of the business. This factor was measured by reference to the compensation of key support people at a trading location (for example, back office support) or the net present value of transactions executed at a trading location (determined by aggregating the present values of the cash flows computed at the inception of each transaction for each trading location).

APPLICATION OF THE METHOD.

The first step in applying the agreed upon method is to determine the amount of trading profits or losses to which the method will apply. Typically, this includes worldwide profits and losses from trading the class of commodities or derivative financial products and related hedges that the taxpayer and the Service have agreed to include within the APA, less expenses that are directly related to the production of trading income or loss, such as compensation of certain personnel, trading computer systems, and broker commissions (the 'worldwide net income or loss'). Other expenses, including office supplies, rent, and communications, were allocated to the trading locations that incurred them. However, expenses that are required to be computed under specific Code or regulatory rules, such as interest expense deductions under $\$ 1.861-9 \mathrm{~T}$ of the Temporary Regulations or $\$ 1.882-5$ of the regulations, were allocated under the appropriate provisions.

The second step in applying the method is to calculate the ratio that results from each factor. For example, to determine the ratio for the value factor, the total U.S. trader compensation is divided by the total worldwide trader compensation. That result, possibly multiplied by a weighting factor, is the ratio for the value factor. Once the three ratios are determined, the percentage of worldwide net income or loss attributable to the U.S. is calculated by taking the sum of the three factors and dividing them by the sum of the weights given to each factor. Finally, to determine the amount of worldwide net income or loss attributable to the U.S., the worldwide profit or loss is multiplied by the percentage described above" (UNITED STATES OF AMERICA. DEPARTMENT OF TREASURY. IRS. Notice 94-40, op. cit.).

${ }^{824}$ Sobre a combinação entre o PSM e critérios formulares nestas espécies de operações, confira-se:

"E. Combination of direct and formula approaches.

Formulary apportionment is not incompatible with the methods described in Case I [single profit centers]. Indeed, the residual profit split approach, in with functional approaches are used until no longer reliable and profit split is applied to the residual, combines the two. This combined method can compensate for some or all of the capital through a guarantee fee or a risk-adjusted return on equity capital. Similarly, support may be eliminated as a factor and included as a charge. These charges can be based on cost or cost-plus.

F. APA Experience. 
contudo, de que se trata de regulamentação que, na prática, garante segurança às instituições que atuam naquele país; não por outra razão as instituições bancárias com subsidiária/controlada/coligada no território norte-americano normalmente optam pela condução de APA. Claro que a simples divisão dos lucros, sem amparo em dados comparáveis, não está totalmente adequada ao princípio da plena concorrência. Os adeptos à adoção fidedigna deste último, todavia, não conseguiram, até o momento, apresentar respostas para a mensuração dos preços de transferência nestes casos.

\subsection{Transactional Net Margin Method ("TNMM").}

O método da comparação das margens líquidas [ou “Transactional Net Margin Method" ou "TNMM"] examina o lucro operacional de um determinado contribuinte ${ }^{825}$, dividido por um certo parâmetro [vendas, custos, ativos etc.], comparando este índice com índices semelhantes que seriam obtidos por partes independentes em transações análogas. Sob o aspecto procedimental, o TNMM é semelhante ao RPM ou CPM: compara-se a margem líquida aferida nas transações "testadas" com (i.) a margem obtida pelo mesmo contribuinte em operações não-vinculadas; ou (ii.) a margem de empresas independentes. Preferencialmente, devem ser utilizados os comparáveis internos ao invés dos externos, pelas mesmas razões expostas nas seções 4.3.1 e 4.4.1 do CAPÍTULO 4, as quais examinam, respectivamente, o RPM e o $\mathrm{CPM}^{826}$.

Os preços dos bens, serviços ou direitos normalmente são afetados por diferenças nestes objetos das transações; as margens brutas utilizadas para a aplicação do

The first four APAs used a formulary apportionment approach, including, it is reported, Barclays and Sumitomo. A majority of cases currently in the system propose this type of TPM. Options trading is most frequently handled on a formulary basis" (PLAMBECK, Charles T. op. cit., p. 1141).

${ }^{825}$ O lucro operacional é definido da seguinte forma:

Receita líquida

(-) custo das mercadorias vendidas ou custo dos serviços prestados

(=) Lucro bruto ou Lucro operacional bruto.

(-) despesas operacionais, incluindo-se despesas de vendas e administrativas.

(=) Lucro operacional.

826 "2.100. (...)Thus, a transactional net margin method operates in a manner similar to the cost plus and resale price methods. This similarity means that in order to be applied reliably, the transactional net margin method must be applied in a manner consistent with the manner in which the resale price or cost plus method is applied. This means in particular that the net margin of the taxpayer from the controlled transaction (or transactions that are appropriate to aggregate under the principles of paragraphs 3.9-3.12) should ideally be established by reference to the net margin that the same taxpayer earns in comparable uncontrolled transactions, i.e. by reference to 'internal comparables'. Where this is not possible, the net margin that would have been earned in comparable transactions by an independent enterprise ('external comparables') may serve as a guide" (OCDE. Proposed Revision of Chapters I-III of the Transfer Pricing Guidelines. $9^{\text {th }}$ September 2009- $9^{\text {th }}$ January 2010. op. cit., p. 40). Correspondente ao item 3.26 da Diretiva. 
RPM e do CPM são impactadas pelas funções exercidas pelas partes; o lucro operacional, de outro lado, é menos influenciado por diferenças nos objetos das transações comparadas e/ou nas funções desempenhadas. No desempenho de uma mesma função, contudo, podese aferir lucratividade operacional distinta, de acordo com o setor da economia e ou mercado em que atua a empresa utilizada como parâmetro. Os dados comparáveis externos, neste contexto, precisam ser examinados a partir de várias perspectivas, para fins de viabilizar qualquer confronto de margens líquidas ${ }^{827}$. Com efeito, as margens líquidas podem ser afetadas por novos entrantes naquele mercado, posição competitiva da parte, eficiência administrativa, estratégia empresarial, custos estruturais [fábricas/manutenção] e de capital, dentre outros; se estes itens gerarem impactos materialmente relevantes nas margens, devem ser implementados ajustes para tornar as margens líquidas de terceiros comparáveis com as margens líquidas "testadas". No entanto, os ajustes exigidos nestas hipóteses são mais complicados que os ajustes diretos nos preços de bens, serviços ou direitos. Assim como nos demais métodos, a fiabilidade dos resultados do TNMM depende da razoabilidade e precisão destes ajustes nas margens líquidas ${ }^{828}$. Claro que algumas das distinções supra referidas podem ser mitigadas a partir do emprego da técnica do intervalo da plena concorrência ${ }^{829}$, mas esta metodologia não tem utilidade se a lucratividade for afetada por um fator único que afeta tão-somente o contribuinte testado.

Em resumo, o TNMM somente pode ser empregado se: (i.) a margem líquida for extraída de operações não-vinculadas do mesmo contribuinte em circunstâncias

\footnotetext{
827 "2.111. Assuming similar functions can be isolated from among the wide range of functions that enterprises may exercise, in order to apply the method, the profit margins related to such functions may still not be automatically comparable where, for instance, the enterprises concerned carry on those functions in different economic sectors or markets with different levels of profitability. When the comparable uncontrolled transactions being used are those of an independent enterprise, a high degree of similarity is required in a number of aspects of the associated enterprise and the independent enterprise involved in the transactions in order for the controlled transactions to be comparable; there are various factors other than products and functions that can significantly influence net margins" (OCDE. Proposed Revision of Chapters I-III of the Transfer Pricing Guidelines. $9^{\text {th }}$ September 2009- $9^{\text {th }}$ January 2010. op. cit., p. 43). Correspondente ao item 3.34 da Diretiva.

828 "2.114. Assume, for example, that a taxpayer sells top quality audio players to an associated enterprise, and the only profit information available on comparable business activities is on generic medium quality audio player sales. Assume that the top quality audio player market is growing in its sales, has a high entry barrier, has a small number of competitors, and is with wide possibilities for product differentiation. All of the differences are likely to have material effect on the profitability of the examined activities and compared activities, and in such a case would require adjustment. As with other methods, the reliability of the necessary adjustments will affect the reliability of the analysis. It should be noted that even if two enterprises are in exactly the same industry, the profitability may differ depending on their market shares, competitive positions, etc." (OCDE. Proposed Revision of Chapters I-III of the Transfer Pricing Guidelines. $9^{\text {th }}$ September 2009- $9^{\text {th }}$ January 2010. op. cit., p. 43). Correspondente ao item 3.37 da Diretiva.

${ }^{829}$ Sobre o intervalo de plena concorrência, confira-se a subseção 2.2.2 (VI) do CAPÍTULO 2.
} 
análogas [comparáveis internos]; ou (ii.) se as diferenças nas empresas que forem aptas a gerar efeitos materiais nas margens líquidas puderem ser razoavelmente ajustadas [comparáveis externos]; a extensão e confiabilidade dos ajustes afeta a qualidade dos resultados obtidos pelo método. Em qualquer um dos casos, a seleção de uma margem líquida confiável para se proceder ao teste dos preços de transferência depende da implementação de exaustiva análise de comparabilidade, incluindo-se o passo a passo do processo de comparabilidade, nos moldes da seção 2.2.2 do CAPÍTULO 2.

Como o TNMM deixou de ser considerado a "ultima ratio" para se tornar um método que, em algumas situações, pode ser o mais adequado, a Minuta-2009 explicou melhor os procedimentos para a sua aplicação. Primeiramente, deve ser aferido o lucro operacional comparável para, em seguida, ponderar-se o índice mais adequado para a comparação de margens líquidas em cada caso concreto.

Para a definição do lucro operacional comparável, deve-se incluir apenas os itens direta ou indiretamente relacionados às transações globais que precisam ser "testadas". Receitas, custos e despesas não-relacionados devem ser excluídos, formando-se um resultado operacional específico para a comparação. Também não podem ser incluídos neste lucro operacional itens não-operacionais ou excepcionais ${ }^{830}$, juros e tributos sobre a renda. Este "lucro operacional" a ser examinado deve corresponder ao EBIT [lucro antes dos juros e tributos sobre a renda ou "earnings before income and tax"], que representa o indicador mais comum para o exame de negócios não-financeiros; se o TNMM for utilizado em transações financeiras, contudo, devem remanescer os juros no cálculo, porque, neste caso, representam receitas operacionais ${ }^{831}$. Em seguida, deve-se selecionar o “denominador" da fórmula; de fato, a comparação envolve um índice calculado a partir do

\footnotetext{
830 "2.120 Non-operating items such as income taxes should be excluded from the determination of the net profit margin indicator. Exceptional and extraordinary items of a non-recurring nature should generally also be excluded. This however is not always the case as there may be situations where it would be appropriate to include them, depending on the circumstances of the case and on the functions being undertaken and risks being borne by the tested party (see for instance discussion of termination costs below). Even where exceptional and extraordinary items are not taken into account in the determination of the net margin, it will generally be useful to review them because they can provide valuable information for the purpose of comparability analysis (for instance by reflecting that the tested party bears a given risk)" (OCDE. Proposed Revision of Chapters I-III of the Transfer Pricing Guidelines. $9^{\text {th }}$ September 2009- $9^{\text {th }}$ January 2010. op. cit., p. 45). Item novo, sem correspondente na Diretiva.

831 "2.124 For financial activities where interest is trade interest, as well as in other situations where the capital structure may heavily influence the prices, it will generally be appropriate to consider the effect of interest when determining the net profit margin" (OCDE. Proposed Revision of Chapters I-III of the Transfer Pricing Guidelines. $9^{\text {th }}$ September 2009- $9^{\text {th }}$ January 2010. op. cit., p. 46). Item novo, sem correspondente na Diretiva.
} 
seguinte cálculo: [lucro operacional (/) fator escolhido]. Este fator deve ser consoante com a análise funcional; neste contexto, atividades com uso intensivo de capital podem ser comparadas, v.g., a partir do retorno sobre os ativos ou sobre o capital empregado. Este fator deve, contudo, ser ajustado caso existam diferenças entre os riscos [de perda do capital] assumidos nas transações "testadas" e nas transações independentes ${ }^{832}$. Estes índices são, normalmente, divulgados aos seus acionistas e ao mercado, que se vale deles para a avaliação de suas ações; por conseguinte, há maior quantidade de dados públicos, o que justifica o apego exacerbado a este tipo de método nos países onde eles estão disciplinados.

O TNMM pode representar a única solução prática para alguns casos complexos de definição dos preços de transferência ${ }^{833}$. Se, v.g., pretender-se comparar as transações vinculadas praticadas por A com as transações não-vinculadas de B, C e D, mas perceber-se que, nas margens brutas destes últimos, foram computadas despesas administrativas diversas, não sendo possível o ajuste contábil, o TNMM pode ser aplicado em substituição ao RPM ou ao CPM. Num outro exemplo, A adquire produtos de A1 a um preço reduzido, porque desenvolve toda a assistência técnica e garantia do produto no território nacional. De outro lado, B e C, que praticam transações semelhantes, adquirem de A1 os produtos a um preço superior, mas não se responsabilizam por quaisquer custos com assistência no país. Suponha-se que não sejam possíveis ajustes concernentes aos custos de garantia e assistência técnica. Nesta hipótese, os preços não são comparáveis e também não o são as margens brutas; resta, como alternativa, a aplicação do TNMM.

Mas o TNMM também apresenta fragilidades, devendo ser aplicado com máxima cautela, para evitar o desrespeito ao princípio da plena concorrência ou a geração de hipótese de bitributação econômica da renda. Ao contrário do PSM, por exemplo, este

\footnotetext{
832 " 2.128 The denominator should be focused on the relevant indicator(s) of the value of the functions performed by the tested party in the transaction under review, taking account of its assets used and risks assumed. Typically, and subject to a review of the facts and circumstances of the case, sales or distribution operating expenses may be an appropriate base for distribution activities, full costs or operating expenses may be an appropriate base for a service or manufacturing activity, and operating assets may be an appropriate base for capital-intensive activities such as certain manufacturing activities or utilities. Other bases can also be appropriate depending on the circumstances of the case" (OCDE. Proposed Revision of Chapters I-III of the Transfer Pricing Guidelines. $9^{\text {th }}$ September 2009- $9^{\text {th }}$ January 2010. op. cit., p. 46-47). Itens novos, sem correspondentes na Diretiva.

833 "2.116 The transactional net margin method may afford a practical solution to otherwise insoluble transfer pricing problems if it is used sensibly and with appropriate adjustments to account for differences of the type referred to above" (OCDE. Proposed Revision of Chapters I-III of the Transfer Pricing Guidelines. $9^{\text {th }}$ September 2009- $9^{\text {th }}$ January 2010. op. cit., p. 44). Correspondente ao item 3.39 da Diretiva.
} 
método é unilateralmente aplicável, sendo desnecessário o exame dos lucros e margens líquidas dos demais partícipes estrangeiros das operações controladas; por este motivo, o TNMM pode gerar resultados não-confiáveis, tributando-se um lucro total maior ou menor que o lucro global do grupo; ademais, este exame da lucratividade global pode ser útil para confirmar os resultados obtidos com o método. Imagine-se, adicionalmente, que um determinado contribuinte A adquire bens de sua controladora A1 e revende-os para outra empresa estrangeira do grupo, A2. Se o TNMM for aplicado e, ao final, a administração tributária entender que são necessários ajustes, qual seria a transação vinculada a ser ajustada: a de importação de produtos de A1 ou a de exportação para A2? A aplicação do TNMM não oferece resposta a esta questão. Mas se tal "unilateralidade", de um lado, sujeita-se às críticas supra, de outro, apresenta benefícios, porque o método pode ser aplicado independentemente do exame, exigido pelo PSM, dos livros e da contabilidade de todas as partes envolvidas [as quais podem não estar disponíveis]. O emprego do TNMM é efetivado a partir do exame apenas das transações da parte "testada", as quais têm suas margens líquidas confrontadas com outras transações comparáveis, internas ou externas. Há uma limitação de escopo, a qual, a despeito de garantir maior praticabilidade, pode afetar a perfeita concretização do princípio da plena concorrência.

Há, ainda, outras críticas ao TNMM, como, e.g., (i.) o fato de as margens líquidas poderem ser impactadas por fatores que não teriam [ou teriam pouco] efeito sobre os preços ou margens brutas; (ii.) a dificuldade de implementação de ajustes e de obtenção de índices de terceiros à época da transação, porque estas informações apenas serão publicadas nos períodos subseqüentes ${ }^{834}$; (iii.) os índices publicados por terceiros podem não conter os mesmos grupos de transações/produtos exigidos para a aplicação do método, ou podem não conter elementos suficientes para a implementação de uma adequada análise de comparabilidade etc. ${ }^{835}$.

Inspirando-se no TNMM, a Argentina prevê o método da "margen neto de la transacción" ${ }^{836}$. A Inglaterra também disciplina método semelhante, sendo que o seu uso

\footnotetext{
${ }^{834}$ Uma possível solução para a ausência de dados contemporâneos às transações seria a adoção de dados de períodos fiscais anteriores, conforme discutido na subseção 2.2.2 (VII.) do CAPÍTULO 2.

${ }_{835}$ Outras críticas à aplicação do TNMM constam dos itens 2.104 a 2.109 da Minuta-2009.

836 “A los efectos previstos en el tercer párrafo, serán de aplicación los métodos de precios comparables entre partes independientes, de precios de reventa fijados entre partes independientes, de costo más beneficios, de división de ganancias y de margen neto de la transacción, en la forma y entre otros métodos que, con idénticos fines, establezca la reglamentación" [Artículo 15, párrafo 5, Ley n. ${ }^{\circ}$ 20.628/97, Texto vigente según Ley n. $\left.{ }^{\circ} 25.784 / 03\right]$.
} 
tem sido muito disseminado, especialmente por conta da existência de dados comparáveis, que podem ser extraídos de demonstrações financeiras públicas de concorrentes, normalmente consolidadas em bancos de dados elaborados para finalidades comerciais ${ }^{837}$; segundo sustentado por Andrew CASLEY, a obtenção dos custos diretos e indiretos para a aplicação do CPM é complexa, o que leva alguns contribuintes à adoção do TNMM ao invés deste último ${ }^{838}$; adicionalmente, o TNMM apresenta vantagens práticas como, e.g., (a.) menores inconsistências contábeis, dado que a noção de lucro operacional é assemelhada em praticamente todos os países; (b.) maiores amostras para comparação; e (c.) com a maior quantidade de dados de terceiros, diluem-se as possíveis situações excepcionais captadas no livre mercado ${ }^{839}$. A administração tributária australiana também tem incentivado a aplicação de um método semelhante, com o objetivo de redução de

837 "It is also worth noting that The increasing use of company financial statements from commercial databases as the basis for a comparability analysis has lead to a fairly widespread adoption of TNMM as a means of applying the cost-plus method. For the reasons given bellow, it is rarely possible to identify direct rather than indirect costs in the financial statements in the public domain and, as a result, the analysis of third party data is often based simply on full cost.

Because mark-up on full cost is arithmetically identical to net margin in absolute terms (and very similar in percentage terms), this manner of applying the cost-plus method is, in effect, the same as TNMM. It is not clear that this is what is envisaged when the OECD Guidelines refer to cost-plus - particularly in the paragraphs relating to the manufacture of semi-finished goods or long-term by and supply contracts.

In fact, then, in many cases where cost-plus (as applied to direct costs) and resale minus are the "default methods, for practical purposes it is TNMM that is used both by taxpayers and by Inland Revenue" (CASLEY, Andrew; HORROCKS, Victoria. United Kingdom. Practical Application of Transactional Profit Methods. op. cit., p. 137).

${ }^{838}$ Sobre os itens que compõem o cálculo do CPM, confira-se a subseção 4.1.1 do CAPÍTULO 4.

839 "Again bearing in mind the OECD's comments, but this time on TNMM, the advantages of this method in the circumstances include:

- the problem of business description is overcome if functional comparability is more important that product comparability;

- the problem of accounting policies is overcome if one is looking at operating profit rather than gross profit;

- the number of private companies on which data are available means that the sample is likely to satisfy the transactional requirements of TNMM (i.e. that different activities are not being aggregated);

- because a larger sampler is often possible in these circumstances, the range will not be unduly distorted by any companies which are not, in fact, comparable but impossible to identify; and

- again because of a large sample is possible, the use of an interquartile range to eliminate extreme results will usually yield a reliable range of arm's length profitability.

Although these are essentially practical rather than technical issues, they are in reality the conditions under which TNMM is likely to prove acceptable in the United Kingdom. (...)

Taking into account the other factors outlined above, the additional constrains a taxpayer should meet are that (1) an examination of gross margin data should also be made; and (2) some explanation will be needed of why those data make application of resale price unreasonable or unreliable.

Provided these constrains are met, experience to date in the United Kingdom is that TNMM is becoming fairly widely accepted, at least for distribution companies. Similarly, the manner in which cost-plus is often applied (for example to a simple service provider) comes very close to TNMM" (CASLEY, Andrew; HORROCKS, Victoria. United Kingdom. Practical Application of Transactional Profit Methods. op. cit., p. 139-140). 
custos de compliance; o método denomina-se "profit comparison method" 840 ; este método examina o retorno global das atividades do contribuinte testado, mas, obrigatoriamente, vale-se da análise funcional, da comparação das condições comerciais, econômicas e estratégias empresariais $^{841}$.

Consoante referido na seção 5.2.2, supra, tanto a OCDE quanto a Seção 1.4828/Proposta sustentam a aplicação do PSM a transações integradas envolvendo a negociação global de instrumentos financeiros. No que respeita ao TNMM, contudo, inexiste regra expressa na legislação estadunidense; mas também não há, de outro lado, vedação expressa, de modo que o TNMM pode ser aplicado dentre os "métodos não especificados" [Seção 1.482-8/Proposta (f) $]^{842}$. Não foram localizados exemplos de aplicação do TNMM a esta espécie de negócios na doutrina ou na jurisprudência. A OCDE, por seu turno, argumenta que o método apenas seria aplicável a funções de back-office ou middleoffice $^{843}$. Seguindo-se esta mesma linha de entendimento, na Alemanha, as autoridades administrativas sugerem a aplicação deste método às denominadas funções rotineiras

${ }^{840}$ A despeito da semelhança da nomenclatura entre o "Comparable profit method" norte-americano e o "profit comparison method" australiano, este último tem características mais próximas do TNMM. Confirase, a respeito, Jim KILLALY:

"The profit comparisons method used in Australia also differs from the comparable profits method in that is has regard to rates of return on assets, risks and functions for the particular enterprise on a more detailed basis than the comparable profits method, and should therefore produce a higher level of comparability that has regard to the particular facts and circumstances of the taxpayer" (KILLALY, Jim. op. cit., p. 14-15).

841 “Australia's current exploration of profit methods primarily involves the use of profit comparisons based on rates of return for functions, assets and risks in comparable markets. These techniques follow the basic approaches of cost plus and resale minus on the more macro level of the overall operations of an enterprise, using economic functional analysis and taking account of wider commercial, economic and market factors affecting the particular enterprise. Some might argue that this is just an application of cost plus and resale minus, but we draw a distinction between the application at the transaction level and the enterprise level since the latter produces an overall rate of return on an investment, much the way shareholders seek from their investment in a publicly listed company, rather than a profit margin on a particular product line or service" (KILLALY, Jim. op. cit., p. 12).

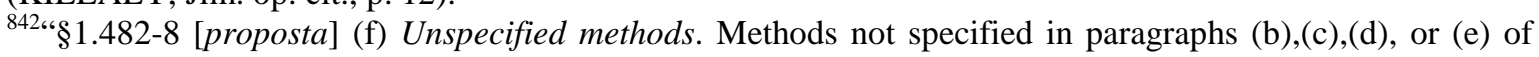
this section may be used to evaluate whether the amount charged in a controlled transaction is at arm's length. Any method used under this paragraph (f) must be applied in accordance with the provisions of $\S 1.482-1$ as modified by paragraph (a)(3) of this section" (Federal Register/v. 63, no. 44. op. cit).

843 "174. The sheer diversity of the organization, business strategies, products and functions of global trading businesses has meant that to date taxpayers and tax authorities have been reluctant in global trading cases to use the other acceptable profit method described in Chapter III of the Guidelines, the transactional net margin method (TNMM). In the core trading function particularly, such diversity makes it very difficult to be sure that the net margins of the uncontrolled transactions are indeed comparable to those found in the controlled transactions. There may be greater scope for using the TNMM when considering middle and back office support functions though there remain problems in that area. In respect of support functions, it might be possible to use TNMM in conjunction with other methods. For example, if it is decided to reward a support function by a traditional cost plus method based on the gross margin of the transaction, in some circumstances it may be useful to also compare the net margin on the transaction, especially where it is not entirely clear exactly what functions are covered by, or what costs are deducted in arriving at, the gross margin found in the independent transactions" (OCDE. Report on the Attribution of Profits to Permanent Establishments. op. cit., p. 154). 
["routine functions"] das transações globais. Com efeito, na regulamentação alemã, as atividades envolvendo as transações globais são divididas em três tipos, quais sejam: (i.) atividades rotineiras, como back-office ou vendedores que não assumem riscos; se o CUP, ou CPM ou o RPM não puderem ser aplicados pela ausência de dados comparáveis, emprega-se o TNMM; (ii.) atividades estratégicas, normalmente associadas a intangíveis exclusivos e, portanto, sujeitas ao CUP ou a PSM; e (iii.) atividades de middle office, também sujeitas ao CUP, RPM, CPM ou, em última instância, ao PSM. Consoante as autoridades tributárias alemãs, o TNMM não pode ser aplicado às atividades qualificadas em (ii.) e (iii.), $\operatorname{supra}^{844}$.

844 "However, it will likely be useful to also take into account certain specific aspects of the new Administrative Principles-Procedure in light of the selection of transfer pricing methods relative to the entrepreneurial characteristics of a taxpayer. The regulations identify three types of companies for the application of the transfer pricing method.

The first group of companies perform only routine functions, for example as limited-risk distributors, or contract manufacturers. Pure service providers (e.g. in the back office) are also likely to be classified as performing such low-risk routine functions. The tax authorities assume that this type of company will derive a rather steady profit from its activities. From this group of companies, the transactional net margin method (TNMM) is fully applicable if no CUP, cost-plus or resale price method can be used. A proper benchmarking for those functions is essential to determine the arm's length remuneration.

The second group of companies consists of the so-called entrepreneurs or strategy leaders. These companies own substantial non-routine intangibles and their profits are determined by these specific intangibles. Therefore, no reliably comparable companies are available for the application of the TNMM or the traditional, transactional-based methods. The entrepreneur typically receives the residual income from the transaction. If more than one entrepreneur is evolved and no CUPs are available, a profit split could apply.

The third group of companies is the so-called middle companies. It seems that in other industries, a fully fledged distributor or a manufacturer licensing its intellectual property will fall into this category. The TNMM is not applicable to such companies, according the tax authorities, because allegedly no comparable data are available. If no other method could be used, the arm's length price must be determined based on the company's budget data. Otherwise the taxpayer might be exposed to transfer pricing sanctions. (...)

In line with Sec. $123 \mathrm{ff}$. of the OECD draft, routine activities and functions should normally fall under the scope of standard methods like the CUP method or the cost-plus method if the necessary third-party data are available. However, as indicated above, the new German regulations also allow the use of the TNMM in the case of low-risk, routine activities. As a first precondition for the application of the TNMM, it must be verified that standard methods will not be applicable because of a lack of usable third-party data. Second, the regulations indicate that the activities to be benchmarked must be limited to routine transactions that can also be consolidated to one uniform activity or transaction. Finally, it must be documented that the comparable companies used in the benchmark are sufficiently comparable to the tested party. In the financial services industry these three conditions will be met in a large number of cases. Hence, there is some expectation that in line with the trend in other industries Germany will witness and increasing number of global-trading transfer pricing systems that will rely on net margins or the TNMM as the method of choice for routine support activities" (NIENTIMP, Axel; ROEDER, Achim. op. cit., p. 308-309). 


\subsection{Comparable Profits Method ("CPI"), aplicável no direito norte- americano.}

O "Comparable Profits Method" ou ("CPI") ${ }^{845}$ avalia se o preço de uma determinada transação controlada atende ao princípio da plena concorrência, mediante o exame de um indicador de lucro objetivo, haurido de contribuintes independentes que se dedicam a negócios semelhantes em condições análogas. Como mencionado na seção anterior em relação ao TNMM, o lucro operacional comparável ${ }^{846}$ é obtido a partir de um determinado índice financeiro de contribuinte não-vinculado; as diferenças entre os lucros operacionais comparados indicarão se houve, ou não, manipulação de preços em operações controladas e inobservância do aludido princípio.

O procedimento para a aplicação do CPI seria, em suma, o seguinte: (1.) seleciona-se, dentre os participantes da transação, a parte a ser testada, que deve ser aquela (a.) cujo lucro operacional pode ser demonstrado a partir dos documentos mais confiáveis; e (b.) cujas atividades mais se assemelham àquelas desenvolvidas pelas transações independentes possivelmente comparáveis, de modo que o confronto entre elas gere menores ajustes ou ajustes mais acurados; em virtude destes requisitos, normalmente a parte "testada" será a empresa envolvida na transação que desenvolveu as atividades mais simples ou que não contribuiu com intangíveis únicos e exclusivos ${ }^{847}$. O lucro operacional da parte testada pode sujeitar-se a quaisquer ajustes relativos à análise de comparabilidade,

845 Consoante referido na seção 1.4 do CAPÍTULO 1, o "Comparable Profit Method", a despeito de normalmente conhecido pela sigla CPL, será referido nesta tese como CPI, de modo a evitar confusão com o "Cost-Plus Method", também conhecido, entre os Estados-Membros da OCDE, pela sigla CPM.

846 “ $\$ 1.482-5$ (d) (4) Operating profit means gross profit less operating expenses. Operating profit includes all income derived from the business activity being evaluated by the comparable profits method, but does not include interest and dividends, income derived from activities not being tested by this method, or extraordinary gains and losses that do not relate to the continuing operations of the tested party" [26 CFR Ch. I (4-1-09 Edition)].

847 "\$1.482-5 (b) (2) Tested party - (i) In general. For purposes of this section, the tested party will be the participant in the controlled transaction whose operating profit attributable to the controlled transactions can be verified using the most reliable data and requiring the fewest and most reliable adjustments, and for which reliable data regarding uncontrolled comparables can be located. Consequently, in most cases the tested party will be the least complex of the controlled taxpayers and will not own valuable intangible property or unique assets that distinguish it from potential uncontrolled comparables" [26 CFR Ch. I (4-1-09 Edition)].

"More specifically, the CPM is applied by selecting a tested party, which is generally the 'simpler' of the related parties involved in the intercompany transaction at issue. For example, suppose that a manufacturer of widgets, Company A, produces finished goods, ready for sale to the end user, using intellectual property (e.g. technology, patents, know-how or trademarks) owned by it. Suppose, further, that the manufacturer sells the goods to related company B (the reseller), which functions as a distributor and marketer for the products. If the reseller owns no intellectual property beyond what an independent distributor would own (e.g. a trained sales force or customer list), then the reseller is the simpler of the two related parties and is ordinarily the tested party under CPM" (WRIGHT, Deloris R. Practical Application of Transactional Profit Methods. International Transfer Pricing Journal. Amsterdã: IBFD, set./out. 2000, p. 198). 
indicados na seção 2.2 do CAPÍTULO 2. Em seguida, (2.) obtém-se o indicador de nível de lucros [ou "Profit Level Indicator" ou "PLI"]; não existe um PLI que seja o mais adequado; como regra geral, o indicador deve ser escolhido a partir da natureza das atividades da parte testada, da confiabilidade dos dados obtidos de terceiros e da capacidade do índice de produzir resultados razoáveis, tendo em vista os fatos e circunstâncias do caso concreto. A legislação estadunidense exige que o PLI seja obtido a partir de dados de períodos superiores a 3 anos; os dados contábeis para o seu cálculo, portanto, devem compreender ao menos o ano da transação examinada e os dois anos anteriores $^{848}$. Após a definição do PLI mais adequado, (3.) calcula-se o intervalo de plena concorrência $^{849}$. O resultado do contribuinte testado deverá ser comparado com este intervalo.

Especificamente no que respeita à mensuração do intervalo de plena concorrência, importa recordar o quanto discutido na subseção 2.2.2 (VI) do CAPÍTULO 2 a respeito do "interquartile range", segundo o qual o intervalo confiável de plena concorrência deve ser delimitado a partir de critérios estatísticos que garantam que os dados que o compõem tenham, no mínimo, $75 \%$ de probabilidade de enquadrar-se naquele intervalo. Este cálculo de intervalo é distinto daquele proposto pela OCDE. Na aplicação do TNMM, v.g., se forem obtidos dados de 1 a 100, este deve ser considerado o intervalo de plena concorrência, sem a possibilidade de sua redução - não importa, para a OCDE, a amplitude do intervalo. A adoção do "interquartile range" pela legislação estadunidense é muito criticada por diferir deste entendimento, especialmente no âmbito do CPI, que foi o método que mais gerou, e ainda gera, controvérsias no cenário internacional. Sobre as críticas à sua definição do intervalo de plena concorrência, os norte-americanos defendem-

\footnotetext{
848 " $\$ 1.482-5$ (b) (4) Profit level indicators. Profit level indicators are ratios that measure relationships between profits and costs incurred or resources employed. A variety of profit level indicators can be calculated in any given case. Whether use of a particular profit level indicator is appropriate depends upon a number of factors, including the nature of the activities of the tested party, the reliability of the available data with respect to uncontrolled comparables, and the extent to which the profit level indicator is likely to produce a reliable measure of the income that the tested party would have earned had it dealt with controlled taxpayers at arm's length, taking into account all of the facts and circumstances. The profit level indicators should be derived from a sufficient number of years of data to reasonably measure returns that accrue to uncontrolled comparables. Generally, such a period should encompass at least the taxable year under review and the preceding two taxable years" [26 CFR Ch. I (4-1-09 Edition)].

849 “\$1.482-5 (b) (3) Arm's length range. See $\$ 1.482-1$ (e)(2) for the determination of the arm's length range. For purposes of the comparable profits method, the arm's length range will be established using comparable operating profits derived from a single profit level indicator" [26 CFR Ch. I (4-1-09 Edition)].
} 
se, sob o argumento de que este critério é inerente a qualquer análise estatística básica, sendo, regularmente, utilizado em vários setores da economia ${ }^{850}$.

No âmbito da Seção 1.482-5 do IRC, há sugestão de alguns indicadores de nível de lucros para a aplicação do $\mathrm{CPI}^{851}$. São ali discutidos os (A.) índices de retorno sobre o capital ["rate of return on capital employed"] e índices financeiros, destacando-se (B.) o lucro operacional sobre vendas ["ratio of operating profits to sales"] e (C.) o lucro bruto sobre despesas operacionais ["ratio of gross profit to operating expenses", também conhecido como "Berry ratio"].

O índice de retorno sobre o capital, referido em (A.) é calculado a partir da seguinte fórmula: [Lucro operacional] (/) [Ativos operacionais ${ }^{852}$ ]. Este PLI produz melhores resultados nas hipóteses em que os ativos operacionais desempenham um papel

850 "The interquartile range is regarded as a mystery by some and an article faith by others. It roots lies in basis statistic analysis and, specifically, hypothesis testing. If one knows the distribution of a given that set, a population, and one observes a specific result, an observation, how does one know whether one has spotted something normal or abnormal?

The origins of this are in engineering and an oft-quoted example is of sampling products coming off a production line. With each sample the engineer needs to know whether the results he or she observes are a sign that production is running within normal parameters, for example that products are of appropriate quality or not. The hypothesis the engineer tests is that the results he or she has observed could reasonably be expected to have been found from any random sample from the underlying population. If, for example, the engineer's population is normally distributed and the engineer's sample lies more than 1.96 standard deviations from the population mean, the engineer concludes that there is only a $5 \%$ chance of this being a normal result and, on this basis, the engineer may choose to recall the production run.

A similar process is being applied when the interquartile range is used on a set of potential comparables for transfer pricing purposes. If the affiliated company whose results are being tested falls at the extreme end of the comparable set. The question that needs to be asked is whether it is reasonable to suppose that such results could be obtained by third parties acting at arm's length" (CASLEY, Andrew; KRITIKIDES, Artemis. Transactional Net Margin Method, Comparable Profits Method and the Arm's Length Principle. International Transfer Pricing Journal. Amsterdã: IBFD, set./out. 2003, p. 167).

${ }^{851}$ Sobre o caráter sugestivo dos índices ali discutidos, confira-se:

“\$1.482-5 (b) (4) (iii) Other profit level indicators. Other profit level indicators not described in this paragraph (b)(4) may be used if they provide reliable measures of the income that the tested party would have earned had it dealt with controlled taxpayers at arm's length. However, profit level indicators based solely on internal data may not be used under this paragraph (b)(4) because they are not objective measures of profitability derived from operations of uncontrolled taxpayers engaged in similar business activities under similar circumstances" [26 CFR Ch. I (4-1-09 Edition)].

852 " $\$ 1.482-5$ (d) (6) Operating assets. The term operating assets means the value of all assets used in the relevant business activity of the tested party, including fixed assets and current assets (such as cash, cash equivalents, accounts receivable, and inventories). The term does not include investments in subsidiaries, excess cash, and portfolio investments. Operating assets may be measured by their net book value or by their fair market value, provided that the same method is consistently applied to the tested party and the comparable parties, and consistently applied from year to year. In addition, it may be necessary to take into account recent acquisitions, leased assets, intangibles, currency fluctuations, and other items that may not be explicitly recorded in the financial statements of the tested party or uncontrolled comparable. Finally, operating assets must be measured by the average of the values for the beginning of the year and the end of the year, unless substantial fluctuations in the value of operating assets during the year make this an inaccurate measure of the average value over the year. In such a case, a more accurate measure of the average value of operating assets must be applied." [26 CFR Ch. I (4-1-09 Edition)]. 
fundamental na geração do lucro operacional da parte "testada" e do terceiro comparável; ademais, sua confiabilidade está estritamente vinculada a uma consistência dos critérios de reconhecimento dos ativos operacionais empregados por ambas as partes. Se as transações envolvem ativos de difícil mensuração como, v.g., intangíveis exclusivos e valiosos, não é recomendável a adoção deste índice ${ }^{853}$. Os índices financeiros [Lucro operacional (/) Receitas de vendas ${ }^{854}$ ] e [Lucro bruto ${ }^{855}$ (/) despesas operacionais ${ }^{856}$ ] são mais sensíveis a diferenças funcionais entre as partes que o índice de retorno de capital. A análise de comparabilidade implementada nestas hipóteses precisa, portanto, ser ainda mais aprofundada.

A respeito de tal análise, devem ser examinados todos os aspectos indicados na seção 2.2 do CAPÍTULO 2. Considerando que os dados para confronto de lucros operacionais são comparáveis externos, maior atenção deve ser conferida aos fatos e circunstâncias específicas das partes e das transações ${ }^{857}$. Deve também ser examinada uma análise funcional para exame das funções desempenhadas, porquanto o emprego de ativos e a assunção de riscos estão diretamente vinculados ao exercício das funções. Consoante

${ }^{853}$ Confira-se, abaixo, exemplo de aplicação deste PLI trazido pela legislação norte-americana, na hipótese de prévios ajustes contábeis:

“\$1.482-5 (e) Example 5. Adjusting operating assets and operating profit for differences in accounts receivable. (i) USM is a U.S. company that manufactures parts for industrial equipment and sells them to its foreign parent corporation. For purposes of applying the comparable profits method, 15 uncontrolled manufacturers that are similar to USM have been identified.

(ii) USM has a significantly lower level of accounts receivable than the uncontrolled manufacturers. Since the rate of return on capital employed is to be used as the profit level indicator, both operating assets and operating profits must be adjusted to account for this difference. Each uncontrolled comparable's operating assets is reduced by the amount (relative to sales) by which they exceed USM's accounts receivable. Each uncontrolled comparable's operating profit is adjusted by deducting imputed interest income on the excess accounts receivable. This imputed interest income is calculated by multiplying the uncontrolled comparable's excess accounts receivable by an interest rate appropriate for short-term debt" [26 CFR Ch. I (4-1-09 Edition)].

854 " $\$ 1.482-5$ (d) (1) Sales revenue means the amount of the total receipts from sale of goods and provision of services, less returns and allowances. Accounting principles and conventions that are generally accepted in the trade or industry of the controlled taxpayer under review must be used" [26 CFR Ch. I (4-1-09 Edition)].

855 "\$1.482-5 (d) (2) Gross profit means sales revenue less cost of goods sold" [26 CFR Ch. I (4-1-09 Edition)].

856 “\$1.482-5 (d) (3) Operating expenses includes all expenses not included in cost of goods sold except for interest expense, foreign income taxes (as defined in $\S 1.901-2(a)$ ), domestic income taxes, and any other expenses not related to the operation of the relevant business activity. Operating expenses ordinarily include expenses associated with advertising, promotion, sales, marketing, warehousing and distribution, administration, and a reasonable allowance for depreciation and amortization" [26 CFR Ch. I (4-1-09 Edition)].

857 " $\$ 1.482-5$ (c) (2) (i) (...)The determination of the degree of comparability between the tested party and the uncontrolled taxpayer depends upon all the relevant facts and circumstances, including the relevant lines of business, the product or service markets involved, the asset composition employed (including the nature and quantity of tangible assets, intangible assets and working capital), the size and scope of operations, and the stage in a business or product cycle" [26 CFR Ch. I (4-1-09 Edition)]. 
referido em relação ao TNMM, o exame das funções, no CPI, não é tão aprofundado quanto no RPM ou no CPM, porque as margens líquidas são alteradas em menor grau por pequenas diferenças funcionais. Neste mesmo raciocínio, deve-se efetivar o confronto do objeto das transações "testada" e comparável, ainda que reduzidas distinções não tenham tanto impacto no preço. É importante, todavia, o exame da maior quantidade de fatores possível, para se obter a maior quantidade de provas e/ou indícios de que as transações confrontadas são realmente comparáveis.

Ressalve-se que, conceitualmente, o CPI e TNMM são o mesmo método ${ }^{858}$; de fato, foram as autoridades estadunidenses que exerceram pressão para que a OCDE reconhecesse este método na Diretiva, em 1995, e que garantiram sua maior importância na Minuta-2009. Há distinções na aplicação dos métodos, destacando-se as seguintes: (i.) no TNMM existe a possibilidade de adoção de comparáveis internos, não sendo esta opção regulamentada no CPI; (ii.) no CPI, sugere-se que o PLI seja composto por dados de três anos consecutivos; para o TNMM, a OCDE tão-somente sugere a busca de dados de múltiplos anos, sem indicação de quantidade; e (iii.) no CPI o cálculo do intervalo de plena concorrência é efetivado a partir do "interquartile range" ${ }^{859}$, dentre outros ${ }^{860}$. As principais críticas à aplicação do CPI vis-à-vis o TNMM, contudo, referem-se à obtenção dos indicadores de nível de lucratividade comparáveis, conforme será explanado na seção

858 "En efecto, das diferencias entre ambos métodos, CPM americano de 1994 y TNMM, son mínimas. Ambos se establecen como métodos de última instancia; se fijan en la parte de la operación vinculada (sea el contribuyente o no) con menos funciones; utilizan un margen de franja de plena competencia creado con los beneficios independientes comparables; comparan el nivel de beneficios de varios anos, establecen el mismo estándar de comparabilidad, resaltando los factores que afectan directamente al nivel de beneficios; exigen la práctica de ajustes en los comparables independientes teniendo en cuenta estos factores y las diferencias de tratamiento contable a la hora de ser aplicados y satisfaces así el principio arm's length; y toman como punto de referencia los beneficios netos obtenidos por la empresa vinculada exclusivamente a raíz de la operación vinculada y no los beneficios netos totales de la empresa vinculada obtenidos por toda su actividad. Así, tanto el Reglamento final americano como la exposición del TNMM de la OCDE cierran el círculo de críticas vertidas sobre los métodos de comparación de beneficios, estableciendo, de un lado, su subsidiariedad y su estándar de comparabilidad para que arrojen resultados de acuerdo con al principio arm's length y, de otro, restringiendo su base de aplicación a los beneficios netos por operaciones vinculadas de una sola parte de la transacción" (GALVAÑ, Gemma Sala. op. cit., p. 124-126).

859 "Applying the conditions formulated by the OECD Guidelines for TNMM to the CPM, it is evident that CPM does not satisfy the arm's length principle.

In the first place, CPM is not used in exceptional cases but has become a prominent transfer pricing method in the United States. (...) Moreover, criticism of the diverging quality of comparables remains ineffective because of the application of the interquartile range. The third condition is not met because it is indeed possible that a controlled taxpayer which is performing less than other companies in a broad sector will have to pay tax on profits it has not made in reality"

(HAMAEKERS, Hubert. The Comparable Profits Method and the Arm's Length Principle. International Transfer Pricing Journal. Amsterdã: IBFD, mai./jun. 2003, p. 91).

${ }^{860}$ In: FEINSCHREIBER, Robert. Transfer Pricing Methods. An Application Guide. New York: John Wiley \& Sons, Inc., 2004, p. 237-241. 
5.4.1, infra. Contribui para estas críticas a importância que o método assumiu no território norte-americano $^{861}$; os demais países temem que o CPI seja sempre aplicado para a precificação de transações vinculadas envolvendo empresas norte-americanas, de modo a alocar nesse país maiores lucros e, portanto, reduzindo-se as bases tributáveis de suas contrapartes, nas respectivas residências fiscais.

Há, ainda, quem sustente que, mesmo em teoria, há incompatibilidade entre o princípio da plena concorrência e os métodos amparados em lucros operacionais ou índices financeiros. Klaus VOGEL, e.g., sustenta que o CPI não é compatível com o Artigo $9^{\circ}$ da Convenção-Modelo, porque confronta lucros, e não "condições que diferem daquelas praticadas por terceiros independentes" ${ }^{862}$; o Artigo $9^{\circ}$, nesse contexto, exigiria, sempre, a comparação de preços ou margens brutas. Hubert HAMAEKERS, de outro lado, sustenta ser o CPI uma espécie de método empírico, não mais aceito pela OCDE desde a Convenção-Modelo de $1963^{863}$. Com efeito, os métodos empíricos, segundo relato de Mitchell B. CARROL, previam a estimativa/presunção da renda a partir da comparação

${ }^{861}$ Confira-se, a respeito, a seguinte passagem de Robert FEINSCHREIBER, segundo o qual, na prática, as regras para o controle dos preços de transferência nos Estados Unidos resumem-se ao CPI:

"In practice, transfer pricing in the United States is based on the comparable profits method (CPM), which focuses on the U.S. activities of the business. This approach seek comparative data between ostensibly similarly situated enterprises in the United States. Three comparable profits methods are in widespread use:

1. The ratio of operating profits to sales;

2. The ratio of gross profits to sales;

3. The ratio operating profits to operating assets.

Economists make a number of adjustments to establish the CPM, including the following:

- inventory adjustments;

- accounts receivable;

- accounts payable;

- foreign exchange risk" (FEINSCHREIBER, Robert. Transfer Pricing Methods. An Application Guide. op. cit., p. 52-53).

862 "The new standard pricing method postulated for both tangible and as well as for intangible assets is the comparable profit method (Final Treas. Regs. $§ 1.482-5$ ). Under this method, there will be a profit comparison undertaken in such a way that for each comparable operation, a profit level indicator is determined. This indicators then constitute an arm's length range (...). A profit adjustment is undertaken when the indicator of the enterprise under scrutiny is outside of the range or framework. Thus, profits are now being compared with one another, rather than prices. According to Art. 9 MC, however, it is decisive whether the 'conditions' - and not profits - 'are made or imposed which differ from those which would be made between independent enterprises'. A profit distribution deviating from the normal may be based on multiple underlying causes; it should in no way indicate conclusively that there were non-market conditions. Therefore, the comparable profit method as a standard pricing method is not in accordance with Art. 9 MC; it may, if necessary, be considered in exceptional cases when all other methods fail" (VOGEL, Klaus. Klaus Vogel on Double Taxation Conventions. op. cit., p. 533-534).

863 "Because of the reference to external levels of profitability, the working of the arm's length range under the US Regulations, the adjustment to median of the range and the burden of proof laying on the taxpayer, CPM has clear characteristics of presumptive taxations. It is not a transfer pricing method or the result of application of transfer pricing methods but the resurrection of the empirical/presumptive method included in multilateral treaty and model treaty drafts of the League of Nations which was not taken over by the OECD" (HAMAEKERS, Hubert. The Comparable Profits Method and the Arm's Length Principle. op. cit., p. 93). 
com empresas similares ou levando-se em consideração ativos, taxa de retorno, dentre outros fatores; ainda segundo aquele autor, estes métodos eram frequientemente empregados pelas administrações tributárias nas hipóteses em que os demonstrativos contábeis apresentados continham dados insuficientes ou falsos ${ }^{864}$. Este tipo de presunção, portanto, era utilizado como forma de "penalidade", e não como o método prioritário para a repartição de resultados entre empresas estabelecidas em nações distintas. Por sua similaridade com o CPI, este último não poderia ser mais empregado após 1963, porque incompatíveis com o princípio da plena concorrência.

Por fim, recorde-se que, num primeiro momento, o Japão e a Alemanha ${ }^{865}$, foram os principais opositores da instituição do CPI pela legislação estadunidense. O Japão, em especial, sustentava que, em virtude de tal método, as subsidiárias de empresas japonesas estabelecidas nos Estados Unidos da América, em especial do ramo automotor, à época ainda não lucrativas, suportavam elevados tributos. Para contornar esta questão específica, foram celebrados APA "híbridos" entre os dois países; diz-se "híbridos" porque aplicavam, conjuntamente, o PSM e o CPI. Na prática, se os lucros da matriz japonesa superassem um predeterminado "patamar de tolerância", o CPM seria aplicável; se eles fossem inferiores a tal limite, empregar-se-ia o PSM - a forma de aplicação deste último, contudo, foi alvo de críticas, porque muitas vezes o APA previa critérios predeterminados para repartição dos resultados, tornando o PSM próximo de um método de partilha fracionada. Ainda que o conteúdo destes APA não tenha sido divulgado, pelas empresas ou pelas administrações tributárias envolvidas, à comunidade internacional, ainda assim foram alvos de muitas críticas ${ }^{866}$.

${ }^{864} \mathrm{O}$ histórico sobre o afastamento dos métodos empíricos, originalmente estudados por Mitchell B. CARROLL, constam da seção 1.2 do CAPÍTULO 1.

Ainda a respeito a impossibilidade de cogitar-se, atualmente, da aplicação de métodos empíricos, confira-se Hubert HAMAEKERS:

"From the history of Arts. 7 and 9 of the OECD Model, its League of Nations predecessors, and the OECD Transfer Pricing Report and Guidelines the following conclusions can be drawn:

- transfer pricing applying the arm's length principle is the only acceptable method for the allocation of income to parts of multinational enterprises located in different countries;

- (global) formulary apportionment is rejected;

- in this context the third possible allocation method, presumptive taxation, does not even deserve mention anymore" (HAMAEKERS, Hubert. The Comparable Profits Method and the Arm's Length Principle. op. cit., p. 91).

${ }^{865}$ Como referido na seção anterior, a Alemanha atualmente aplica o TNMM; permanece, contudo, sua discordância em relação ao CPI.

866 “50.7. Various practitioners made public statements during 1996 and 1997 about 'hybrid-method' advance pricing agreements (APAs) between Japan and the United States that combined CPM method with profit split. The profit split was generally described as relying on allocation factors, such as expenses and fixed 


\subsubsection{Obtenção de comparáveis para a aplicação do CPI. A questão dos SIC codes.}

O CPI, como qualquer outro método norte-americano para o controle dos preços de transferência, sujeita-se ao estrito atendimento do princípio da plena concorrência, examinado na seção 2.1 do CAPÍTULO 2 e expressamente previsto na Seção 1.482-1 (b) do IRC. Imprescindível, assim, a demonstração de que a transação "controlada" tenha sido praticada nas mesmas condições que foram [ou teriam sido] contratadas por terceiros independentes, em condições análogas. A constatação de que o CPI representa um método baseado na comparação de lucros, o qual compara o resultado operacional e não cada transação isolada, não tem o condão de afastar tal obrigação. Pelo contrário, as normas estadunidenses sequer diferem entre métodos tradicionais e métodos de comparação de lucros: quaisquer metodologias devem sujeitar-se à análise de comparabilidade e a testes de confiabilidade dos dados, adequação dos ajustes, consistência de critérios contábeis etc..

Se, de um lado, há muitas exigências procedimentais no âmbito da Seção 1.482 do IRC, de outro, as autoridades tributárias estadunidenses são conhecidas por sua rigorosidade na aplicação das regras para o controle os preços de transferência. Em virtude destes fatores, os contribuintes normalmente se apegam às sistemáticas de mais fácil emprego e comprovação documental. A busca de dados comparáveis para a aplicação do CPI não diverge desta realidade. Exatamente por este motivo é que foi bastante difundido naquele país o "CPI formular" [ou "formulary CPM"], segundo denominação atribuída por Robert FEINSCHREIBER. Na aplicação do CPI formular, ao invés de um contribuinte efetivar toda a análise de comparabilidade descrita na Seção 1.482-1 do IRC, ele apega-se

assets, to determine how the profits should be split, and thus would be an application of formula apportionment.

Descriptions (by anonymous sources quoted in Tax Management's Transfer Pricing Report) of the first hybrid-method APA, for transactions between Komatsu America International and Komatsu Ltd., indicated that CPM would be applied to determine the US subsidiary's profits whenever the parent's consolidated profits were above a given 'tolerance level'. Bellow the tolerance level, 'a separate range will be drawn as long as [the parent's consolidated profit] remains in the range, the profit split method will be used'. The anonymous sources did not specify what method would be used for profits bellow both the tolerance level and the separate range, but commentators have suggested that the hybrid method could result in the sharing of losses.

The use of CPM when profits are above a given level would cap the US profits during good times. The hybrid method also put a floor under the subsidiary's profits when consolidated profits were low or negative, then it would be appropriately characterized as risk sharing within a band" (FEINSCHREIBER, Robert. Transfer Pricing Handbook, $3^{\mathrm{a}}$ ed. Nova York: John Wiley \& Sons, Inc., 2002, p. 403-404). 
ao código SIC ["Standard Industry Classification"] ${ }^{867}$ mais semelhante às atividades por ele exercidas. Determinado o código SIC, são obtidos, em bancos de dados públicos ou $\operatorname{privados}^{868}$, as informações e índices de nível de lucratividade (PLI) médios para aquele código; obtidas as informações, aplica-se o $\mathrm{CPI}^{869}$. Ao mesmo tempo em que se disseminou esta sistemática de aplicação do CPI, ampliaram-se os serviços de bancos de dados, destacando-se Robert Morris Associates, Amadeus, Dun \& Bradstreet and Moody's, que também são utilizados pelo fisco norte-americano em autuações fiscais nas quais não dispõem de mais detalhes para a autuação do contribuinte, o qual, v.g., pode ter se recusado a fornecer maiores informações.

Deloris R. WRIGHT, em virtude desta prática recorrente, discrimina duas distintas possibilidades de aplicação do CPI: (i.) "layers of evidence" [busca, via análise de comparabilidade, o preço de plena concorrência mais adequado]; e (ii.) "database dump" [busca dos comparáveis num certo banco de dados, sem exame e confronto específico das transações comparadas], sendo este último o CPI formular descrito por Robert FEINSCHREIBER. Na visão desta autora, impactam a decisão do contribuinte acerca da modalidade a ser aplicada fatores como custos de compliance, o porte da empresa, o impacto das operações associadas no seu negócio, a proximidade dos resultados efetivos com aqueles obtidos via código SIC etc. ${ }^{870}$.

${ }^{867}$ Em certa medida, o código SIC assemelha-se ao número de registro na Classificação Nacional das Atividades Econômicas (“CNAE”). Esta classificação é dividida em Seção, divisão, grupo, classe e subclasse. A Seção é formada por uma letra, a divisão por um número de dois dígitos, o grupo por um número de três dígitos e a classe por um número de quatro dígitos; cada classe pode possuir inúmeras subclasses. Confira-se, abaixo, um exemplo de classificação no CNAE.

Seção:(A) AGRICULTURA, PECUÁRIA, PRODUÇÃO FLORESTAL, PESCA E AQÜICULTURA.

Divisão: $\quad$ 01. AGRICULTURA, PECUÁRIA E SERVIÇOS RELACIONADOS

Grupo: $\quad$ 011. PRODUÇÃO DE LAVOURAS TEMPORÁRIAS

Classe: $\quad$ 0111-3 CULTIVO DE CEREAIS

Subclasse 0111-3/01CULTIVO DE ARROZ

A obtenção do código CNAE adequado não é providência simples, a despeito de muito menos complicada que a obtenção do código SIC.

${ }^{868}$ Maiores ponderações sobre a utilização de comparáveis hauridos de bancos de dados constam da seção 2.2.2 (IV.) do CAPÍTULO 2.

869 "The taxpayer or the IRS frequently applies the easiest transfer pricing method, which is often formulary CPM. The taxpayer or the IRS auditor often applies the CPM procedure by going to the Standard Industrial Classification (SIC) code and doing the following:

- Using the four-digit SIC code applicable to the business;

- Including other business in that SIC code;

- Preparing and utilizing CPM comparative formulas" (FEINSCHREIBER, Robert. Transfer Pricing Methods. An Application Guide. op. cit., p. 53).

870 "Companies that choose not to obtain an APA (the majority of companies) must decide whether to take the 'database dump' CPM approach or to do the 'layers of evidence' approach described above. This decision is largely a function of which advisor the company uses and is also related to the size and types of 
Pondere-se, a este passo, que a aplicação do CPI via código SIC não representa uma espécie de safe harbour no direito norte-americano; pelo contrário, a Seção 1.482-1 do IRC mantém a exigência de que todos os contribuintes são obrigados a aplicar a análise de comparabilidade e a efetivar os testes de confiabilidade dos resultados obtidos. A despeito de se tratar de prática recorrente tanto entre os contribuintes quanto entre as autoridades tributárias, assim, a utilização deste único parâmetro para comparação pode ser questionada. Trata-se, portanto, de simplificação que, a despeito de muito difundida, não está autorizada por regulamentos.

Como reconhecido por diversos doutrinadores estadunidenses, esta prática, além de não totalmente segura, viola o princípio da plena concorrência ${ }^{871}$; de fato, o CPI formular é muito distinto do TNMM, esse sim compatível com o princípio ${ }^{872}$; no CPI formular claramente não se busca comparar as transações "testadas" com transações independentes comparáveis, mas sim justificar as transações testadas a partir de médias obtidas em bancos de dados, sem exame das circunstâncias específicas da transação, das empresas, de sua estratégia, mercado relevante etc.. Em sua Diretiva, a OCDE expressamente rejeita o uso de médias por indústrias ou resultados agregados por

intercompany transactions. Companies with very small intercompany transactions involving high tax jurisdictions probably have the flexibility to do the 'database dump' approach simply because it is cheaper and requires much less talent to apply. The exposure that such a company has is small enough that spending considerably more money to "do it right" is nos cost effective. Companies that have large volumes of intercompany transactions involving countries that have active transfer pricing auditors probably do not have such flexibility. The APA route is obviously the approach that provides the most certainty, although at a price (i.e. making the government one's business partner limits one's flexibility in using this very powerful international tax planning tool)" (WRIGHT, Deloris R. Practical Application of Transactional Profit Methods. op. cit., p. 201).

871 "Both taxpayers and IRS auditors most often apply the comparable profits method (CPM) for transfer pricing purposes by selecting the relevant Standard Industrial Classification (SIC) code and then using the data for companies that classify themselves in that SIC code as the comparison. This shortcut approach ignores whether the SIC classification is correct for the company or its comparables, functional analysis, risk, contract terms, economic conditions, and the like, as well as the nature of the firm evaluated. As such, the shortcut approach deviates most strongly from the transfer pricing regulations resulting invalid approaches and results. The essential ingredient in applying the comparable profits method is finding and applying arm's length comparables" (FEINSCHREIBER, Robert. Transfer Pricing Handbook. op. cit., p. 72).

872 "It is clear that the US 'database dump' approach to the CPM is not consistent with the proper application of the TNMM. This means that while this approach may be useful in the United States (although there are those who contend that the 'database dump' will not withstand US Tax Courts scrutiny), it is not helpful in most countries outside the United States" (WRIGHT, Deloris R. Practical Application of Transactional Profit Methods. op. cit., p. 201). 
diferentes atividades; este é um dos motivos pelos quais diversos Estados-Membros não reconhecem a compatibilidade entre o CPI e o Artigo $9^{\circ}$ da Convenção-Modelo ${ }^{873}$.

Por fim, pondere-se que, na visão de Robert FEINSCHREIBER, o CPI formular, ao invés de simplificar o teste dos preços de transferência, está sujeito a inúmeras complexidades, relativas à obtenção do código SIC, à adequada classificação dos contribuintes, à alteração de códigos na eventual alteração do objeto social etc. ${ }^{874}$. Ao contrário do CNAE brasileiro, que possui um regime razoavelmente simples, o código SIC é complexo e possui tantas subdivisões que muitos contribuintes permanecem enquadrados incorretamente por longos períodos. Justamente em virtude das dificuldades geradas por um critério que deveria ser simples, o CPI formular é alvo de muitas críticas, inclusive de economistas, que pregam sua extinção [i.e., a vedação de sua adoção pelos contribuintes por intermédio de regulamentação do IRS].

\footnotetext{
873 'In particular, so-called 'comparable profits method' or 'modified cost plus/resale price methods' are acceptable only to the extent that they are consistent with these Guidelines" (OCDE. Proposed Revision of Chapters I-III of the Transfer Pricing Guidelines. $9^{\text {th }}$ September 2009- $9^{\text {th }}$ January 2010. op. cit., p. 30).

874 "At present time, the SIC approach for transfer pricing is being abused and is fraught with difficulty. The six most serious transfer pricing problems for the taxpayer or the IRS examiners are as follows:

1. The initial selection of SIC may be determined by a staff person in the company who is unfamiliar with the ramifications of the SIC selection or with transfer pricing.

2. Such an individual may not be adequately familiar with the operations of the business to adequately select the SIC code.

3. A four-digit SIC code is too broad-based and encompasses activities vastly different from the taxpayer under examination.

4. The SIC process does not adequately effect changes in the taxpayer's business. Many business continue on with the SIC code by habit rather than by further analysis.

5. The SIC process does not contain an established process for changing a business's SIC code.

6. The SIC code may become obsolete or obsolescent as high technology moves rapidly. Multiyear data would not be available under any event" (FEINSCHREIBER, Robert. Transfer Pricing Methods. An Application Guide. op. cit., p. 53).
} 


\section{CAPÍTULO 6. CRÍTICAS AO PRINCÍPIO DA PLENA CONCORRÊNCIA E PONDERAÇÕES SOBRE ALTERNATIVAS DE SIMPLIFICAÇÃO COMPATÍVEIS COM O ORDENAMENTO TRIBUTÁRIO BRASILEIRO.}

\subsection{Considerações preliminares e principais críticas ao princípio da plena concorrência.}

O princípio da plena concorrência apregoa que, nos negócios jurídicos celebrados entre partes relacionadas, os preços e as condições comerciais e financeiras estabelecidos devem ser aqueles esperados em transações idênticas ou similares, realizadas [ou que teriam sido realizadas] sob as mesmas circunstâncias, entre partes nãorelacionadas. Se este princípio pudesse ser reduzido a um único termo, ele seria a "comparação" [de transações vinculadas com transações não-vinculadas]. Sob a perspectiva teórica, a metodologia derivada do princípio da plena concorrência é bastante adequada, porque possibilita uma aproximação dos preços vinculados com os preços de mercado e produz resultados aceitáveis na maioria das situações ${ }^{875}$. Sob a perspectiva prática, de outro lado, é esta mesma "comparação", intrínseca à própria existência do princípio, que é alvo de críticas por tributaristas e economistas.

A própria OCDE reconhece que este princípio apresenta algumas fragilidades, destacando-se (i.) a ausência de dados comparáveis, porque há realmente transações que não são desenvolvidas por partes não-vinculadas ${ }^{876}$; (ii.) a dificuldade de aplicação prática dos métodos, dada a enorme quantidade de informações, muitas vezes indisponíveis, que

\footnotetext{
875 “ $1.14(\ldots)$ The arm's length principle is sound in theory since it provides the closest approximation of the workings of the open market in cases where property (such as goods, other types of tangible assets, or intangible assets) is transferred or services are rendered between associated enterprises. While it may not always be straightforward to apply in practice, it does generally produce appropriate levels of income between members of MNE groups, acceptable to tax administrations. This reflects the economic realities of the controlled taxpayer's particular facts and circumstances and adopts as a benchmark the normal operation of the market" (OCDE. Proposed Revision of Chapters I-III of the Transfer Pricing Guidelines. $9^{\text {th }}$ September 2009- $9^{\text {th }}$ January 2010. op. cit., p. 8). Correspondente ao item 1.13 da Diretiva.

876 “'A practical difficulty in applying the arm's length principle is that associated enterprises may engage in transactions that independent enterprises would not undertake. Such transactions may not necessarily be motivated by tax avoidance but may occur because in transacting business with each other, member of an MNE group face different commercial circumstances than would independent enterprises. Where independent enterprises seldom undertake transactions of the type entered into by associated enterprises, the arm's length is difficult to apply because that is little or no direct evidence of what conditions would have been established by independent enterprises. The mere fact that a transaction may not be found between independent parties does not itself means that is not arm's length" (OCDE. Proposed Revision of Chapters IIII of the Transfer Pricing Guidelines. $9^{\text {th }}$ September 2009- $9^{\text {th }}$ January 2010. op. cit., p. 8). Baseado no parágrafo 1.10 da Diretiva.
} 
precisam ser pesquisadas pelos contribuintes ${ }^{877}$; o que, conseqüentemente, propicia (iii.) a geração de custos administrativos para o cumprimento de suas regras [compliance] muito elevado em circunstâncias não-rotineiras ${ }^{878}$.

Não obstante as deficiências práticas inerentes ao princípio da plena concorrência, a OCDE insiste que ele deve ser mantido como uma espécie de dogma no direito tributário internacional, porque (a.) o controle dos preços de transferência nunca será uma ciência exata, sendo que quaisquer metodologias alternativas dependerão de análises minuciosas e custosas - este tipo de crítica deve, assim, ser ignorada, porque se aplicaria a qualquer hipótese de controle de preços; (b.) há muita experiência acumulada na sua aplicação, de modo que existem precedentes de mecanismos para a solução de uma enorme gama de situações; e (c.) por ser amplamente aceito entre as diversas jurisdições fiscais, o princípio da plena concorrência não deve apenas ser mantido, mas se deve buscar maior consenso acerca de sua aplicação, o que possibilitaria a redução dos casos de bitributação econômica da renda ${ }^{879}$. Neste sentido, abandonar o princípio da plena

877 "1.13 Both tax administrations and taxpayers often have difficulty in obtaining adequate information to apply the arm's length principle. Because the arm's length principle usually requires taxpayers and tax administrations to evaluate uncontrolled transactions and the business activities of independent enterprises, and to compare these with the transactions and activities of associated enterprises, it can demand a substantial amount of data. The information that is accessible may be incomplete and difficult to interpret; other information, if it exists, may be difficult to obtain for reasons of its geographical location or that of the parties from whom it may have to be acquired. In addition, it may not be possible to obtain information from independent enterprises because of confidentiality concerns. In other cases information about an independent enterprise which could be relevant may simply not exist, or there may be no reasonably reliable comparable independent enterprises, e.g. if that industry has reached a high level of vertical integration. It is important not to lose sight of the objective to find a reasonable estimate of an arm's length outcome based on reasonably reliable information" (OCDE. Proposed Revision of Chapters I-III of the Transfer Pricing Guidelines. $9^{\text {th }}$ September 2009- $9^{\text {th }}$ January 2010. op. cit., p. 9). Baseado no parágrafo 1.12 da Diretiva.

878 "1.12 In certain cases, the arm's length principle may result in an administrative burden for both the taxpayer and the tax administrations of evaluating significant numbers and types of cross-border transactions. Although associated enterprises normally establish the conditions for a transaction at the time it is undertaken, at some point the enterprises may be required to demonstrate that these are consistent with the arm's length principle. (...) The tax administration may also have to engage in this verification process perhaps some years after the transactions have taken place. The tax administration would then attempt to gather information about comparable uncontrolled transactions, the market conditions at the time the transactions took place, etc., for numerous and varied transactions. Such an undertaking usually becomes more difficult with the passage of time" (OCDE. Proposed Revision of Chapters I-III of the Transfer Pricing Guidelines. $9^{\text {th }}$ September 2009- $9^{\text {th }}$ January 2010. op. cit., p. 9). Baseado no parágrafo 1.11 da Diretiva.

879 "1.15 A move away from the arm's length principle would abandon the sound theoretical basis described above and threaten the international consensus, thereby substantially increasing the risk of double taxation. Experience under the arm's length principle has become sufficiently broad and sophisticated to establish a substantial body of common understanding among the business community and tax administrations. This shared understanding is of great practical value in achieving the objectives of securing the appropriate tax base in each jurisdiction and avoiding double taxation. This experience should be drawn on to elaborate the arm's length principle further, to refine its operation, and to improve its administration by providing clearer guidance to taxpayers and more timely examinations. 
concorrência equivaleria a elevar as hipóteses de bitributação da renda, porque, além de métodos distintos [como atualmente se verifica], os países passariam a defender, também, fundamentos teóricos distintos. Ao final, sustenta a OCDE que, mesmo com todas as dificuldades práticas envolvidas na concretização do princípio da plena concorrência, inexiste, até o presente momento, alternativa que realisticamente possa substituí-lo.

Entretanto, o princípio da plena concorrência, na sua concepção "pura", tal como indicada pela OCDE em sua Diretiva e mantida na Minuta-2009, apresenta outros defeitos que o maculam, como se passa a explicar.

Primeiramente, sob a perspectiva econômica, o princípio da plena concorrência é alvo de críticas porque não permite visualizar o grupo multinacional em sua uma inteireza, avaliando-se sinergias, ganhos de escala e eficiências. Os critérios da entidade segregada por unidade empresarial e da ficção de independência, nos quais se ampara ${ }^{880}$, não são compatíveis com a realidade econômica própria das operações internacionais intragrupo. Na prática, um agente no mercado não atua como uma empresa isolada, mas como um grupo multinacional; estas situações são economicamente distintas ${ }^{881}$. Por se basear na

In sum, OECD member countries continue to support strongly the arm's length principle. In fact, no legitimate or realistic alternative to the arm's length principle has emerged" (OCDE. Proposed Revision of Chapters I-III of the Transfer Pricing Guidelines. $9^{\text {th }}$ September 2009- $9^{\text {th }}$ January 2010. op. cit., p. 9-10). Baseado no parágrafo 1.14 da Diretiva.

${ }^{880}$ Os critérios da entidade segregada e da ficção de independência, bem assim sua relação com o princípio da plena concorrência, foram discutidos na seção 1.9 do CAPÍTULO 1.

881 "On the most fundamental level, the basic criticism of the ALS is that it does not reflect economic reality. As the courts and Congress have stated, multinational corporations do not regard each subsidiary as a separate entity which bargains with other subsidiaries at arm's length. Multinationals are usually integrated entities to which each subsidiary contributes, and the transfer prices among the constituent subsidiaries are fully under control of the multinational which naturally considers the tax implications in setting such prices. (...) Moreover, the very existence of integrated multinationals is evidence that the ALS does not reflect economic reality. The predominant explanation for the existence of multinationals is the internalization theory, which posits that, like any organization, multinational exist because of the market and non-market advantages that are derived from their structure. The multinational's structure allows to avoid (internalize) transaction costs, which increases efficiency in raising capital, advertizing products, achieving economies of scale, and protecting valuable intangibles. Thus, if one applies a market rate of return separately to each of the components of multinational, the result is less than the actual return of the organization as a whole. This residual, the result of the interaction among the constituent parts of the organization, cannot be assigned to any component. Any transfer pricing rule which arbitrarily assigns the residual to one part of the organization distorts economic reality. No single correct transfer price exists in this situation; instead, there is a continuum which depends on how the residual is split among the parties, and any price on this continuum is correct" (AVI-YONAH, Reuven. The Rise and Fall of Arm's Length: A Study in the Evolution of US International Taxation. Virginia Tax Review. v. 15, p. 148);

"According to a number of economists, the arm's length principle is contrary to economic reality. It starts from the fiscal myth that every subsidiary and permanent establishment within a group is a separate entity which conducts trade under free-market conditions with other entities in the group. The essence of an MNE, however, is the potential to act as one entity in the world market and so to gain competitive advantages. The higher efficiency usually realized within the MNEs is not recognized by the arm's length principle. Advantages of scale and synergy-effects which are inherent in MNEs cannot be divided amongst the group in 
ficção de independência de entes dependentes, o princípio da plena concorrência gera um problema de avaliação dos lucros marginais gerados pelas sinergias, ganhos de escala e eficiências. Esta renda marginal não captada teoricamente pelo princípio da plena concorrência vem sendo denominada na doutrina como o problema do "continuum price", segundo denominação haurida da ciência econômica a ele atribuída por Stanley I. LANGBEIN $^{882}$. De fato, se o princípio da plena concorrência for implementado de forma perfeita, cada empresa vinculada tributará o mesmo que um terceiro independente, em condições e circunstâncias comparáveis, tributaria. O lucro tributável do grupo será, assim, o lucro que teria sido haurido se ele não fosse um grupo, mas um conjunto de empresas segregadas. O lucro marginal decorrente das eficiências geradas pela atuação conjunta dos membros do grupo, nesse contexto, não será tributado em nenhuma localidade; daí a "falha" econômica do princípio. Esse lucro marginal é, como regra geral, deduzido dos custos administrativos da holding do grupo; também esta despesa não é mensurável pelo princípio da plena concorrência.

Saliente-se que, se nos grupos econômicos transnacionais em geral, o princípio da plena concorrência não capta os ganhos com eficiências e escala, nos grupos que atuam de forma altamente integrada a situação é ainda mais grave. De fato, mesmo na União Européia, onde residem os principais defensores da aplicação pura e exclusiva do princípio da plena concorrência, há autores que reconhecem que a união dos mercados e, conseqüentemente, a atuação integrada das empresas, tem dificultado a aplicação de tal princípio e, por conseguinte, concordam com as críticas supra referidas. Ben J. TERRA e Peter J. WATTEL sustentam que "it is increasingly difficult to apply the arm's length principle. In the first place, companies and markets become increasingly integrated as a result of, precisely, the single European market and globalization in general" 883 . Estes autores sustentam que o princípio da plena concorrência, no contexto específico da União

as objective way via arm's length principle, according to those economists" (HAMAEKERS. Arm's Length How Long? op. cit., p. 34).

882، The 'continuum price' problem is generated when the aggregate returns on a 'remuneration of services' basis are less than the actual combined return to the integrated group. And I believe that if one uses any 'single component' method, one will determine the return to the measured component on what will in substance be a 'remuneration of services' basis. (...) How and why the continuum price problem deranges the separate enterprise system is not difficult to discern. Let us denominate the (assumed) excess of combined income over the aggregate of separate incomes (determined under single component methods), the 'marginal product of the entrepreneur' or, alternatively, the 'marginal return to organization" (LANGBEIN, Stanley I. The Unitary Method and the Myth of Arm's Length. op. cit., 654).

${ }^{883}$ In: TERRA, Ben J. M; WATTEL, Peter J. European Tax Law. Abridged Student Edition. $5^{\mathrm{a}}$ ed. The Netherlands: Kluwer Law International, 2008, p. 285. 
Européia, apresenta problemas relacionados às distintas interpretações que podem ser a ele conferidos por cada um dos Países-Membros, bem assim à impossibilidade de se mensurar todas as compensações intra-grupo e à complexidade de obtenção de documentos para a prova dos dados comparáveis, quando estes forem localizados ${ }^{884}$.

Diante de todas as ponderações do CAPÍTULO 2, não há dúvidas de que o princípio da plena concorrência têm aplicação complexa e custosa. Apenas na análise de comparabilidade discutida na seção 2.2, foram demonstradas dezenas de aspectos que precisam ser examinados e de possíveis ajustes para a obtenção de uma "transação independente comparável". Há, sem dúvidas, uma enorme quantidade de informações, muitas vezes de acesso difícil ou indisponíveis, que precisam ser pesquisadas pelos contribuintes; na prática, mesmo nos países onde o princípio da plena concorrência foi recepcionado expressamente pela lei interna, há questionamentos sobre sua efetiva eficiência ${ }^{885}$, dada a sua complexidade, abertura e fluidez de conteúdo. Não são apenas os contribuintes que se sujeitam a tais dificuldades: também a administração tributária precisa empreender esforços, despender recursos e treinar pessoal para propiciar a adequada compreensão de todos os mecanismos e especificidades do princípio da plena concorrência, que demanda o exame caso-a-caso de cada uma das transações, de cada um dos contribuintes que negociam internacionalmente. Estas dificuldades geram, conseqüentemente, enormes custos administrativos $[\text { compliance }]^{886}$, especialmente se estes

\footnotetext{
884 "Formula apportionment within the EU for European groups of companies would rid European industry of at least three major tax (compliance) headaches: (i.) transfer pricing and connected problems of transactionbased profit attribution (such as depressing documentation requirements), (ii.) having to deal with 27 different tax base determination systems and the ensuing mismatches, and (iii) the very limited possibilities for horizontal cross-border loss compensation between group companies" (TERRA, Ben J. M; WATTEL, Peter J. European Tax Law. Abridged Student Edition. 5 ${ }^{\mathrm{a}}$ ed. The Netherlands: Kluwer Law International, 2008, p. 285-286).

885 "I have been concerned for several years, first as a government official and later in private practice, with transfer pricing questions. In these capacities, I have, like many, if not most, practitioners and academic students of the subject, experienced considerably difficulty with the existing federal regulations implementing the arm's length standard. Like many, if not most, academics and lawyers who have written on the subject in the last 20 years, I have been frustrated by the complexity and impenetrability of the rules and the uncertainty they generate and I have come to question their viability as a long term solution to the problem of allocating the income multinational enterprises" (LANGBEIN, The Unitary Method and the Myth of Arm's Length. op. cit., p. 627).

886 "Beyond the theoretical critique of the ALS, which may explain some of its practical problems, one is left with the fact that the experience of the last twenty-five years indicate that the ALS creates a climate of uncertainty and an immense administrative burden for the taxpayers, the IRS and the courts and provides ample opportunity of abuse. The burden imposed by the ALS has been documented and commented upon extensively. This burden results from the need to apply the ALS on a factual case-by-case basis without any general rules in the majority cases in which there are no comparables. (...)

Former chief Judge Nims of the Tax Court has stated that transfer pricing cases have absorbed a substantial part of the Tax Court pretrial, trial and post-trial resources.
} 
custos forem comparados com aqueles demandados em regimes envolvendo fórmulas, como será discutido em 5.2, infra. Saliente-se, por oportuno, que na subseção 2.2.3 do CAPÍTULO 2 também foram discutidos os elevados custos administrativos envolvidos na aplicação deste princípio. O exame casuístico de cada transação exigido quando da implementação do princípio da plena concorrência também produz um outro efeito: a possibilidade de atuação discricionária das autoridades fiscais e a geração de insegurança aos contribuintes. De fato, se as regras são fluidas e abertas, estes últimos nunca estarão seguros de que o método escolhido ou sua implementação serão, ao final, suficientes para a administração tributária. Percebendo que, por maior que seja o seu esforço, ainda haverá questionamento por parte das autoridades tributárias, os contribuintes simplesmente não dedicarão mais enormes esforços para a aplicação das regras para o controle dos preços de transferência; simplesmente aguardarão a posição a ser adotada pelo fisco ${ }^{887}$.

The dollar amount of tax in controversy in section 482 cases docketed in Tax Court in 1992 was $\$ 32$ billion, twice the amount it was in 1989, The figures in the appeals process are even more substantial. The costs of the government in such cases are very high and are likely to be even higher if the IRS is allowed to hire outside counsel to aid it in litigation, as has been proposed. The IRS spent about $\$ 15$ million on expert witnesses in section 482 cases in 1992, and a recent Treasury report recommends increased use of such experts. The Treasury report concludes that 'if the IRS has not being widely successful in developing and litigating section 482 cases', and '(f)or the foreseeable future, transfer pricing will place a heavy burden on the Service and the Tax Court" (AVI-YONAH, Reuven. The Rise and Fall of Arm's Length: A Study in the Evolution of US International Taxation. op. cit., p. 150-151).

"All these are symptoms of the breakdown of the arm's length pricing adjustment system, which:

* costs de federal and state treasuries billions of dollars annually in unjustified and unnecessary revenue losses: a public policy failure that borders on the scandalous;

* diverts too many scarce resources, both public and private, to tax planning, complex accounting and auditing practices, and lengthy litigation;

* creates inequities in tax payments and thereby tilts the competitive playing field by allowing global corporations to play transfer pricing games that entirely domestic firms are not even eligible to enter; and

* fails to guarantee any substantial degree of international uniformity in the division of income for tax purposes.

The theoretical and practical shortcomings of the arm's length system have been described and illustrated much better than I can possibly do in the space available here.

However, no one has described the inherent futility of the arm's length approach more straightforwardly than the anonymous practitioners quoted in the cover story of International Tax Review, October 1993 which aired corporations' opinions of various global tax issues. As one corporate tax specialist said: 'When you multiply a situation by hundreds of thousands of transactions, conducted in different economic situations, involving a range of different products, than the problems, the cracks in the theory, really start to show" (MAZEROV, Michael. Why arm's length falls short. International Tax Review. London: v. 5, issue 2, fev. 1994, p. 28).

887 “The arm's length standard has often been criticizes as difficult to apply and unjust. Is poses three major problems. First, from the practical standpoint of compliance, it remains almost impossible to establish an arm's length price because reasonable people may differ over the appropriate price for a particular transaction. Determining a transfer price is a subjective factual judgement that, in most situations, involves the exercise of a certain amount of business judgement and discretion. The good faith determination of a transfer price by a taxpayer may be very different from the price estimated by the Service's experts years after the transaction. In fact, taxpayers sometimes may have no incentive to set a correct price. The common perception is that regardless of how hard taxpayer tries to find the 'correct price', the Service may nevertheless challenge it. 
Até este momento foram discutidas, nesta seção, as críticas mais comuns à aplicação do princípio da plena concorrência. Cumpre ponderar, todavia, que há muitas hipóteses nas quais este princípio não pode ser sequer aplicado; dentre estas alternativas, destacam-se as transações intra-grupo com elevado grau de integração e, também, as negociações envolvendo intangíveis de elevado valor.

Para exemplificar esta situação, veja-se o exemplo abaixo, relativo a transação global de instrumentos financeiros. Suponha-se que um determinado grupo multinacional realize uma transação de balcão extremamente complexa para um certo cliente; para o desenvolvimento da transação, atuaram as empresas A1, nos Estados Unidos da América; A2, na Inglaterra e A3, em Tóquio. Em síntese, as funções desempenhadas foram as seguintes: back-office e middle-office, incluindo-se os necessários aprimoramentos de softwares, foram realizados na controladora A1; A3 atuou como mero vendedor de títulos, sem influência na sua estruturação, ao passo que os traders e marketers de A1 e A2 responsabilizaram-se por todo o restante da estruturação do negócio, de forma intrinsecamente vinculada; estes últimos trabalharam numa única equipe, de forma totalmente integrada. Para a determinação dos preços de transferência no exemplo supra, uma metodologia possível seria a seguinte: (1.) remuneração das funções de back-office e middle-office, via RPM, método muito utilizado para o "teste" dos preços de serviços mais rotineiros; (2.) remuneração da equipe de vendas de Tóquio pelo RPM, tendo em vista que aquela instituição financeira também desenvolve serviços deste tipo para instituições de outros grupos, sem filial ou sede no Japão.

Resta a remuneração dos traders e marketers. Admitindo-se que nenhuma de suas atividades possa ser remunerada pelo CUP, RPM ou CPM, resta o PSM, método bastante utilizado nestes casos, como se explicou na seção 5.2 do CAPÍTULO $5^{888}$. Note-se que esta foi exatamente a sistemática descrita na Notice 94-40, que instituiu regras para a consecução de APA envolvendo a negociação global de instrumentos financeiros no

This encourages taxpayers to honestly understate income by choosing the lowest sustainable arm's length price, thereby promoting ad hoc determinations in that grey area. This, in turn, determines the predictability that companies need when planning transactions. For example, a global trader using the centralizes product management model might have difficulty finding the arm's length service charge for foreign sales representatives, an integral part of the parent corporation's operation" (LEUNG, Kevin K. Taxing Global Trading: an Appropriate Testing Ground for Formula Apportionment? Minnesota Journal of Global Trade. v. 01, Fall, 1992).

${ }^{888}$ Como se demonstrou na seção 5.3 do CAPÍTULO 5, o TNMM é pouquíssimo utilizado para a comprovação dos preços de transferência na negociação global de instrumentos financeiros por instituições intra-grupo. 
território estadunidense [veja-se a subseção 5.2.2 do CAPÍTULO 5]. Em alguns casos, percebeu o fisco norte-americano que o próprio PSM não seria suficiente; de fato, a análise funcional e os outros itens da análise de comparabilidade devem ser empregados até que, a partir de um certo ponto, não são mais confiáveis. Para este lucro residual [pós-aplicação do PSM], a administração tributária norte-americana previu a repartição segundo fórmulas predeterminadas e negociadas entre o fisco e os contribuintes. Haveria, neste sentido, a aplicação do princípio da plena concorrência até um limite a partir do qual não seriam mais obtidos resultados confiáveis; dali por diante, deveriam ser ajustados critérios não hauridos do "mercado", simplesmente porque inexiste um "mercado" para angariar comparáveis. Não seria uma hipótese de afronta ao princípio da plena concorrência, mas de suprimento de lacuna. Para facilitar a compreensão deste exemplo e da técnica empregada no território norte-americano, veja-se o seguinte esquema, dividido nos Passos 1 a 5:

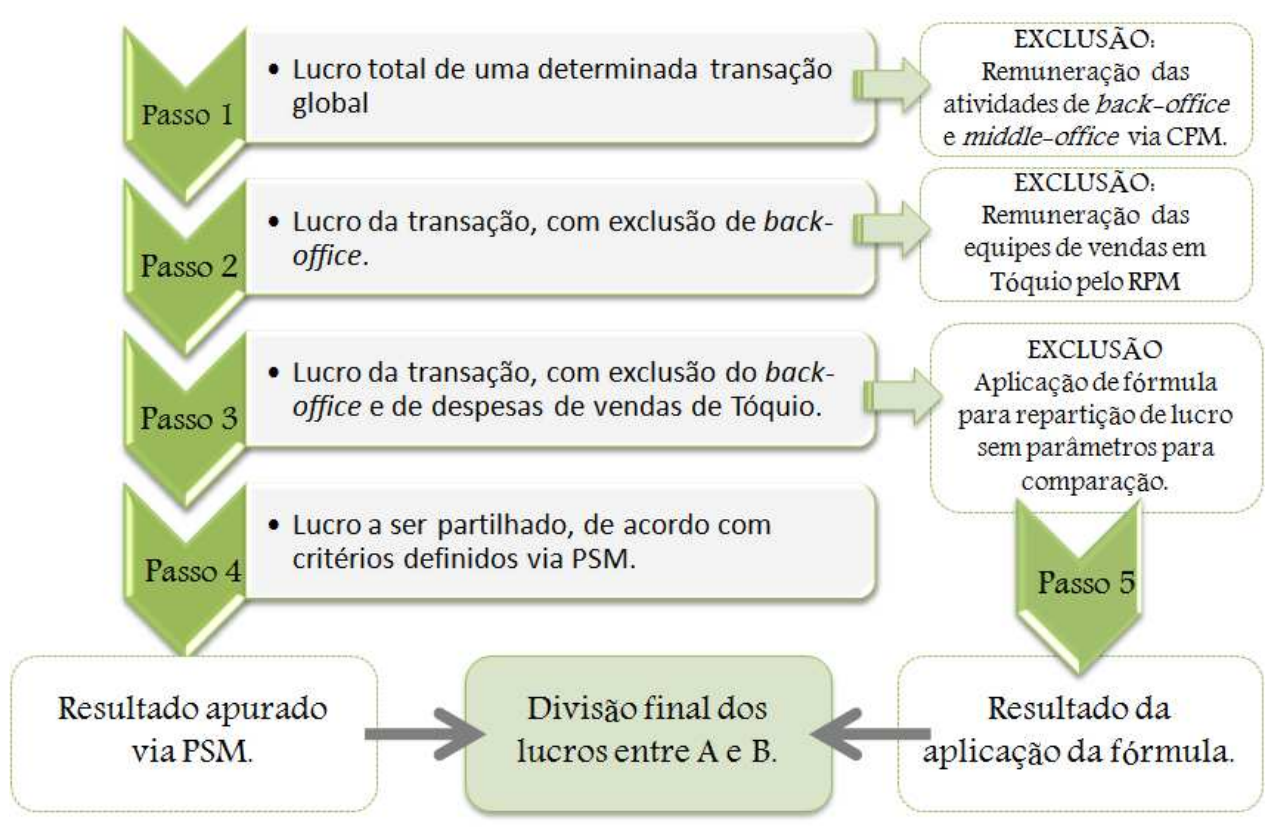

Especialmente no exemplo supra, o emprego conjugado do princípio da plena concorrência e dos métodos formulares apresentou-se útil, porque permitiu o aproveitamento dos benefícios de ambas as sistemáticas. Consoante salientado por Robert FEINSCHEREIBER, as transações globais são um exemplo típico em que é possível esta aplicação "conjugada"de critérios para o controle dos preços de transferência em operações transnacionais com nível elevado de integração entre as partes ${ }^{889}$. Esta "análise conjugada" será melhor explicada na seção 6.2.1, infra, após o exame do método formular, recorrentemente indicado como o substituto para o princípio da plena concorrência.

${ }^{889}$ In: FEINSCHREIBER, Robert. Transfer Pricing Handbook. op. cit., p. 396. 


\subsection{Alternativa ao princípio da plena concorrência: método da divisão do lucro global segundo fórmulas predeterminadas.}

\subsubsection{Conceito e forma de aplicação do método da divisão do lucro global segundo fórmulas predeterminadas.}

O método da divisão do lucro global segundo fórmulas predeterminadas examina o lucro agregado de todas as partes associadas em uma determinada transação, dividindo-o entre as jurisdições fiscais envolvidas por intermédio de uma fórmula. Este critério diferencia-se das metodologias decorrentes do princípio da plena concorrência, porque, com amparo neste último, respeita-se a "distinção jurídica" de cada um dos entes e cria-se um preço hipotético que teria sido praticado por terceiros independentes em circunstâncias análogas; este preço parâmetro é que permite a atribuição do lucro tributável a cada ente. No método da divisão global de lucros, de outro lado, assume-se a atuação dos grupos multinacionais é tão integrada que seria impossível [ou incorreto, sob a perspectiva econômica] examinar as empresas isoladamente; as distintas personalidades jurídicas são desconsideradas, com o objetivo de aproximar a situação jurídica da econômica.

A aplicação deste método é normalmente efetuada a partir da apuração do lucro total de um determinado grupo empresarial, em bases globais, seguida de sua divisão entre as empresas associadas e/ou filiais localizadas em distintos países, segundo uma fórmula de cálculo predeterminada. Há, assim, a estipulação de uma fórmula prévia de cálculo de divisão de lucros, que independe das condições de mercado verificadas em operações similares entre partes não-vinculadas [cuja análise é típica da aplicação do princípio da plena concorrência]. Claro que, na maioria dos casos, tal fórmula costuma ser fixada com amparo em parâmetros hauridos do livre mercado, de concorrentes etc., mas sempre num momento prévio à própria operação analisada. A aplicação desse método alternativo deve ser efetivada a partir de três passos básicos, a saber: (i.) determinação do grupo econômico que será tributado, i.e., definição das empresas, filiais e/ou sucursais envolvidas; (ii.) determinação do lucro global da unidade definida em (i.); e (iii.) aplicação de uma fórmula previamente estabelecida para divisão do lucro fiscal a ser reconhecido, por cada um dos envolvidos, proporcionalmente a certos fatores como, v.g., ativos, taxa de retorno, folha de salários e, em alguns casos, até a um percentual previamente fixado ${ }^{890}$. Para a aplicação do

890 "In an international context, an apportionment formula using only sales and labour costs would work as follows: suppose a transnational enterprise has a world-wide profit of 100. Assume its worldwide payroll is 
método da divisão do lucro global segundo fórmulas predeterminadas, não é necessária a pesquisa de dados de terceiros ou de operações das mesmas partes com partes nãorelacionadas a cada transação. Inexistem, portanto, elevados custos administrativos [compliance] para a implementação do controle dos preços de transferência, os quais estão dentre as principais críticas à aplicação do princípio da plena concorrência. A simplicidade dessa metodologia e sua aproximação da "realidade econômica" dos grupos multinacionais são os principais argumentos dos seus defensores para sustentar sua aplicação em operações altamente integradas ou envolvendo intangíveis exclusivos e valiosos, nas quais que o princípio da plena ser aplicado confiavelmente.

Este método da divisão do lucro global segundo fórmulas predeterminadas é aplicado, internamente, no Canadá, na Suíça e nos Estados Unidos da América, para a alocação de lucros, respectivamente, entre províncias, cantões e estados. No que respeita à federação norte-americana, saliente-se que a fórmula mais difundida para a divisão dos lucros globais das empresas envolve os seguintes fatores: folha de salários [“payroll”], ativos empregados ["property"] e vendas ["sales"], esquematicamente indicados na fórmula abaixo ${ }^{891}$ :

Renda tributável $(=) \quad \frac{\text { Folha salários A }}{\text { Folha salários Total }} \quad \frac{\text { Ativos A }}{\text { Ativo Total }} \quad \frac{\text { Vendas A }}{\text { Vendas Total }}$

800 and its worldwide sales are 2,000. Also assume that the payroll and sales in country A are 200 and 100 , respectively. If the apportionment formula gives twice as much weight to payroll as it gives to sales, the computation of the overall proportion is determined as follows: 200/800 for payroll, plus another 100/2,000 for sales. This adds up to $11 / 20$ and to get an average proportion from this figure it is divided by 3 , the number of fractions added together. This yields an average proportion of 11/60, which is the ratio applied to overall profits of 100 to determine the amount of profits allocated in country A, 18.33" (UNITED NATIONS. International Income Taxation and Developing Countries. op. cit., Chapter VII: "Transfer Prices Abuses and Developing Countries". Parte E.2).

891 "Most states apply three-factor apportionment formulas to property, payroll, and sales, either with equal weights or double weighting of sales. Double weighting of sales is a form of tax competition between states. The weighting tends to shift the state's tax burden from companies that produce within the state and export to companies that only sell within the state. Some states have carried this competition to its logical conclusion, and now employ a one-factor formula using only revenue.

In most state applications of formula apportionment, the property factor is real property and tangible personal property valued at historical cost (original cost plus additions and improvements, but before depreciation) plus the value of rented property (measured as a multiple, such as eight times the annual rental cost). Payroll is compensation paid to employees, where the numerator of the allocation fraction is generally compensation to employees with a base of operations within the state. For the sales factor, sales of tangible property are generally attributed to the state in which the unrelated buyer takes delivery of the goods, while receipts from services and rentals are attributed to the state in which the associated costs are incurred" (FEINSCHREIBER, Robert. Transfer Pricing Handbook. op. cit., p. 398). 
A despeito da existência de consistência com relação aos fatores a serem empregados $^{892}$, há discussões entre os estados sobre os itens que devem ser incluídos/excluídos dos fatores, bem assim sobre os pesos a serem atribuídos a cada um deles. Pondere-se, a este passo, que a aplicação destas fórmulas no âmbito interno é bastante mais simples que no âmbito externo, em especial no território estadunidense, tendo em vista que o imposto estadual é reduzido se comparado ao imposto de renda federal ou ao imposto de renda e outros países e, ademais, não obstante as diversas divergências, há alguma uniformidade nas fórmulas ${ }^{893}$. Na prática, a maior limitação para a adoção deste tipo de método consiste na fiabilidade da fórmula definida e nos parâmetros a serem observados ${ }^{894}$, bem assim na sua aplicabilidade aos mais diversos tipos de negócios vinculados, em especial as operações financeiras e derivativos.

Com amparo na legislação da federação norte-americana, Stanley I. LANGBEIN propôs, em 1992, um método para a divisão internacional de lucros, especialmente para linhas de bens cujo processo de produção é altamente integrado. $\mathrm{O}$ procedimento a ser adotado seria, resumidamente, o seguinte: (1.) soma-se o lucro global daquela espécie de transação [i.e., as transações da linha de produtos/serviços escolhida],

892 "The three factors are property, payroll, and sales, with capital and labor representing the manufacturing capacity that produces the income, and sales representing the market from which the income is derived. (...) Payroll is the easiest and the least controversial aspect of the formula, with issues only as to what constitutes compensation and when compensation is considered paid in a state. The property factor is computed on the average value of the taxpayer's real and tangible personal property owned or rented and used in the taxing state during the year. The value of the property is computed based on original cost, and rental property valued at eight times its net annual rental rate. Intangibles are not factored into the property formula.

The sales factor includes sales of tangible and intangible property. The place of sale for tangible assets is in the state where the goods are delivered to the purchaser. For intangible assets and services, sales are assigned to the state in which the income-producing activity is performed, or to the state where the greatest proportion of the activity is performed based on costs of performance" (GIANNI, Monica Brown. Transfer Pricing and Formulary Apportionment. Taxes. v. 74, mar. 1996, p. 169).

${ }^{893}$ If standard state formulas do not generally cause serious distortions, the major reason is that state tax rates are lower than most national tax rates. Another reason is that the state formulas are most frequently applied to single legal entities with integrated organizational structures. For such entities, the attribution of both risk and intangible value in proportion to factors that do not purport to measure either will be less subjective than attempting to measure financial results for separate functional segments.

For example, if the same organizational unit manages inventories of materials, work-in-progress, and finished goods from production through sales to end users, then it may require considerable subjective judgment to carve out a separate distribution segment that could be treated as not sharing manufacturing intangibles and risks. In contrast, when distribution is the function of a separate legal entity in a different country, it is not surprising that the distributor's host government would tend to reject any argument that it should share manufacturing risks. It is also not surprising that the manufacturer's host government would tend to reject any argument that the distributor should share in the profits from manufacturing intangibles, especially if the distributor has not been contributing to product development" (FEINSCHREIBER, Robert. Transfer Pricing Handbook. op. cit., p. 398).

894 Quanto mais as fórmulas gerarem resultados próximos dos lucros efetivamente auferidos pelos contribuintes, maior será a sua utilização espontânea e menores os custos administrativos, tanto para a administração tributária quanto para os contribuintes. 
formando-se uma única "base global" - a soma dos lucros totais e subseqüente divisão, no entendimento deste autor, possibilita uma melhor medição da capacidade contributiva total da empresa ${ }^{895}$; (2.) cada empresa associada envolvida na transação integrada recupera seus custos, acrescidos de uma margem de lucro razoável, normalmente aferida a partir da taxa de retorno dos ativos tangíveis empregados que seria exigida por terceiros independentes nesta parte específica, o método de Stanley I. LANGBEIN aproxima-se do princípio da plena concorrência; (3.) o lucro remanescente [a seguir determinado "lucro residual total"] poderia ser dividido a partir da seguinte fórmula de dois fatores, tendo sido excluído o elemento "folha de salários" em relação à fórmula original adotada pelos estados norteamericanos:

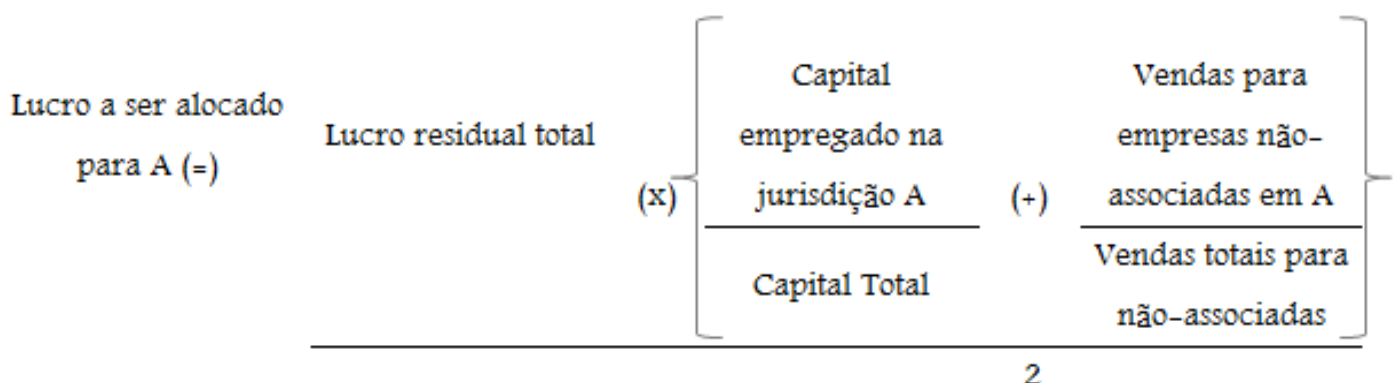

Stanley I. LANGBEIN sustenta que seu método atende ao princípio da plena concorrência, a despeito da sugestão de partição do lucro residual total segundo uma fórmula; concorda, ademais, com aqueles que entendem ser a aplicação do PSM uma "rachadura" do método ${ }^{896}$. Um ponto bastante favorável de sua proposta, que merece ser

895 "Conventional fractional apportionment, thus - is justified by reference to a 'benefit' principle taxation que conventional criteria measure the right of a state to tax by reference to what it offers to an enterprise; payroll, property, and sales reflect the protection of a state's legal regime offered the enterprise's operations. The suggested regime undertakes to frame a fractional system in light of an ability to pay regime. The enterprise's profits are the measure of its taxpaying capacity in toto; the suggested regime attempts to quantify the extent to which that ability derives, from or is attributable to its operations in a particular jurisdiction. The suggested regime does this through the interpretation of MNE operations, integration economies, and the relative 'contribution' principle" (LANGBEIN, Stanley I. A Modified Fractional Apportionment Proposal for Tax Transfer Pricing. Tax Notes. fev. 1992, p. 730).

896 "A final concern in the design of this system is its compatibility with what is said to be prevailing international norm, the arm's length standard. It would seem the system is compatible with that standard, at least on the broad conception now given it, notwithstanding the historic contradistinction between the standard and conventional fractional apportionment.

Perhaps a decade ago, it may have been conceived that the arm's length standard was a determinate standard - that it was intended to generate a determinate, or at least reasonably determinate, prices in every case. In the years since, however, it has come to be accepted that the arm's length standard is only a general rubric allowing a number of different approaches. (...)

In that light, the instant proposal is consistent with the arm's length approach. It is structurally similar to current approaches $[P S M]$, except for the particular that it dispenses with a search for comparable uncontrolled prices. By performing the first step, it ensures that each jurisdiction is allocated at least the 
ressaltado, está no fato de que este autor analisa "linhas de produtos", e não o "negócio único e integrado" do grupo multinacional.

No ano seguinte, em 1993, Reuven AVI-YONAH também desenvolveu o seu modelo para a divisão do lucro global segundo fórmulas predeterminadas ${ }^{897}$. Na visão deste autor, os três fatores adotados pela legislação dos estados norte-americanos [folha de pagamentos, ativos e receitas] não funcionariam no âmbito internacional, porque desestimulariam o aumento de negócios numa determinada jurisdição, transferindo-se funcionários e bens para países com tributação favorecida da renda. $\mathrm{O}$ direito tributário teria a função de incentivar a criação de novos negócios no país, e não de afastá-los; daí a impossibilidade de tributação internacional com amparo em folha de salários e ativos. Por decorrência, sustenta Reuven AVI-YONAH que as vendas num determinado país A [considerando-se a localização do cliente final] deveriam ser divididas pelas vendas globais do grupo; este seria o percentual do lucro total a ser alocado no país A. Este raciocínio está abaixo exposto de maneira formular:

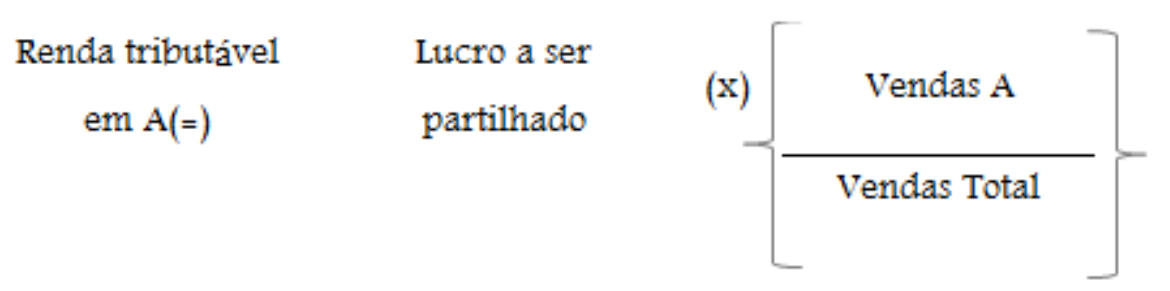

Para os defensores da aplicação do método da divisão do lucro global segundo fórmulas predeterminadas, seu emprego deveria envolver apenas os países-chave de determinada transação integrada, e não os países onde foram efetivadas simples vendas ou atividades concernentes ao back-office e ao middle-office; esta medida seria imprescindível para se tornar possível a negociação de fórmulas entre as diferentes nações ${ }^{898}$. Este

amount of the minimum that would be required to induce the component operating in that jurisdiction to enter the transaction were it an unrelated party - which appears to be the working definition of arm's length under the current approaches" (LANGBEIN, Stanley I. A Modified Fractional Apportionment Proposal for Tax Transfer Pricing. op. cit., p. 730).

${ }^{897}$ In: AVI-YONAH, Reuven. Slicing the Shadow: a Proposal for Updating US International Taxation. Tax Notes. mar. 1993, p. 1511-1515.

898 "Limitations of Formula Apportionment.

Formula apportionment should be limited to the multinational's risk-sharing core. This approach greatly increases the feasibility of choosing and applying a formula appropriate to the facts and circumstances of a specific multinational because of the following:

1. Only the limited number of governments that host core companies need to agree with the multinational enterprise (MNE) on appropriate apportionment formula.

2. Core companies tend to be relatively homogeneous compared with an MNE group as a whole. This homogeneity reduces the extent to which alternative formulas would be likely to produce significantly 
mecanismo, ademais, não deve ser utilizado para todos e quaisquer tipos de transações, sem restrições; isto seria impraticável, porque sobrecarregaria as administrações tributárias quando, um dos objetivos do método é, justamente, a redução dos custos administrativos e de compliance, tanto para os contribuintes quanto para as administrações tributárias. Este tipo de metodologia poderia, neste contexto, ser reservada para as situações nas quais a aplicação do princípio da plena concorrência é muito complexa, ou nas quais este último simplesmente não poderia ser aplicado ${ }^{899}$.

Sob o ponto de vista estritamente econômico, o fundamento para a aplicação dos método da divisão do lucro global segundo fórmulas predeterminadas seria idêntico ao fundamento para a aplicação do PSM, i.e., a existência de transações com alto grau de integração e de negócios únicos, sem comparáveis disponíveis para confronto de preços, margens ou lucros operacionais ${ }^{900}$. Na prática, a distinção crucial entre o PSM e o método da divisão global de lucros é tão-somente a de que, enquanto no primeiro pesquisa-se no livre mercado, caso a caso, os critérios que foram [ou teriam sido] utilizados por terceiros para a divisão daqueles lucros, no segundo simplesmente define-se uma fórmula, que pode ser amparada em razoabilidade, em dados de mercado, ou quaisquer critérios, predefinidos e aplicáveis a todos os contribuintes que se enquadrarem na situação descrita na norma. Como decorrência deste tênue limiar entre as duas sistemáticas, alguns autores sustentam que a forma de aplicação do PSM aceita por alguns países proporciona a utilização de uma divisão segundo fórmulas, ainda que sob a denominação $\mathrm{PSM}^{901}$. No que respeita à forma

different allocations of income, and thus to be favored by different governments" (FEINSCHREIBER, Robert. Transfer Pricing Handbook. op. cit., p. 395).

899 "A formulary apportionment method seems, however, to fit better with current and expected developments than the arm's length principle does. The arm's length principle, after all, is based on the idea of national economies and independent enterprises and not on that of integrated organizations and global trade" (HAMAEKERS. Arm's Length - How Long? op. cit., p. 38)

900 "The theoretical term often used for the tax base to which formula apportionment is applied is 'unitary business', which was described by Harley Duncan, the Executive Director of the Federation of Tax Administrators, as follows:

'The unitary business principle is a judicial doctrine developed to guide when principles of formula apportionment are allowable (or indeed preferable) over those of separate or geographic accounting. The unitary business principle, in its barest form, holds that when the activities of certain entities are so intertwined and interrelated to effectively comprise a single enterprise, that enterprise should be treated as a single unit for tax purposes and the income of the enterprise should be divided among the jurisdictions in which it does business according to a formula, rather than attempting to 'slice the shadow' and attempt to source each item of income and expense on a geographic basis'.

This description of a unitary business sounds like the situation in which a profit split would be considered the most appropriate transfer pricing method under either the U.S. transfer pricing regulations or the OECD Guidelines" (FEINSCHREIBER, Robert. Transfer Pricing Handbook. op. cit., p. 398).

901 "Under either the U.S. regulations or the OECD Guidelines, the profit-split option is an acknowledgement that for some intercompany transactions there are no good uncontrolled comparables. Both the U.S. regulations and the OECD Guidelines describe ways that may be appropriate for allocating the income 
de aplicação prática do PSM pelas autoridades tributárias estadunidenses, v.g., Stanley I. LANGBEIN sustenta que este país realmente aplica um método formular, e não o PSM baseado apenas em critérios de divisão de lucros adotados em transações não-vinculadas ${ }^{902}$.

Por fim, importa ressalvar que, enquanto o princípio da plena concorrência e o método da divisão global dos lucros segundo fórmulas predeterminadas forem compreendidos como metodologias antagônicas, o primeiro continuará sendo uma espécie de máxima no direito tributário internacional e os exemplos antes referidos, em especial as transações envolvendo a negociação global de instrumentos financeiros entre instituições do mesmo conglomerado bancário, que representam o objeto desta tese, permanecerão sujeitos a arbitrariedades no controle dos seus preços, porque, se não há dados comparáveis, também inexistem documentos que comprovem estes dados. Estes contribuintes serão, portanto, alvo das penalidades aplicáveis àqueles que simplesmente ignoraram a existência das regras para o controle dos preços de transferência; na prática, a ausência de aplicação dos métodos [por culpa ou má-fé] e a impossibilidade de aplicação, a despeito dos esforços do contribuinte, deveriam ter tratamentos distintos.

Se, de um lado, o princípio da plena concorrência não é "perfeito" para todas as situações, de outro ele não pode ser afastado completamente, porque efetivamente soluciona a maioria dos casos; os métodos de divisão global nunca serão aplicáveis a todas as espécies de transações existentes, por duas razões: a uma, porque, se houver uma única fórmula para todos os casos, a tributação será marcada por total e irrestrita injustiça; a

attributable to intangibles in particular circumstances, rather than prescribing a particular method that must be used.

The primary concern of the U.S. regulations is to discourage the use of any transfer pricing method that is not based on independent comparables. However, when the circumstances warrant a profit split, the Best Method Rule provides the authority to select a profit split approach, to choose appropriately between the residual method or a direct one-step allocation, and to choose the appropriate formula for allocating either the residual or the total profit. The Guidelines show less concern for the importance of independent comparables, and more concern that testing only one side of a controlled transaction might impose an inappropriate result on the other side. As a result, the Guidelines are relatively flexible regarding the use of profit splits, and very flexible regarding the form of profit split that might be used.

Thus, despite different language and priorities, both the U.S. regulations and the Guidelines provide enough flexibility for the use of profit splits when they are more appropriate than transactional methods. Further, both methods provide for the use of the customized profit allocation formula that will be most appropriate for the facts and circumstances of each individual case" (FEINSCHREIBER, Robert. Transfer Pricing Handbook. op. cit., p. 397-398).

902 “(...) the arm's length method to determine income of related corporations is not and never has been an internationally accepted norm. (...) but this campaign has failed because even our own courts $[E U A]$ are unwilling to apply the arm's length method. This unwillingness stems from weakness inherent in the standard. (...) the true norm is to use 'comparable uncontrolled prices' where comparable uncontrolled transactions can be found. Where such transactions cannot be found, the true norm applies formula apportionment" (LANGBEIN. The Unitary Method and the Myth of Arm's Length. op. cit., p. 625). 
duas, porque não é possível estipular fórmulas para todas as transações existentes [além de possível, não seria uma medida eficiente e prática]. A OCDE parece ter razão, assim, quando sustenta que inexiste uma alternativa que realisticamente possa substituir [completamente] o princípio da plena concorrência.

O método da divisão global de lucros segundo fórmulas predeterminadas serviria, contudo, para suprir o aludido princípio sempre que (i.) sua aplicação fosse muitíssimo complexa e custosa; ou (ii.) seu emprego fosse impossível. Justamente por este motivo é que a denominada "utilização combinada de métodos" parece ser, realmente, a metodologia mais adequada. De fato, ela permite que, a um mesmo tempo, que as transações mais rotineiras sejam comprovadas por intermédio do princípio da plena concorrência, enquanto os negócios mais complexos e/ou integrados sejam solucionados de forma mais simples, gerando-se menores custos para os contribuintes e para a administração tributária ${ }^{903}$. Na prática, a utilização conjunta de critérios aproveitar o benefício de ambos: utiliza-se o princípio da plena concorrência até onde for possível [i.e., até o limite em que ele produza resultados consistentes e confiáveis] e, em seguida, migrase para a divisão segundo fórmulas ${ }^{904}$.

903 "The Combination Approach.

The combination of formulary apportionment with arm's length methods should result in fewer transfer pricing disputes than would occur either all formula apportionment or all arm's length methods, because of the following:

1. Neither the core companies nor their host governments will need to track and test the arm's length nature of the various transactions among the core entities;

2. Noncore entities and their host governments will need to be concerned only with the measurement and testing of their own results, nor with the income and transactions of the rest of the group;

3. Using arm's length methods to test noncore entities reduces the likelihood of extreme results, such as controlled distributors that lose money when comparable independent distributors are profitable.

The combination of formula apportionment and arm's length methods discussed in this chapter is particularly appropriate for MNEs in manufacturing industries. However, there is a strong precedent for this approach in the IRS and Organization for Economic Cooperation and Development (OECD) approaches to transfer pricing issues involved global trading" (FEINSCHREIBER, Robert. Transfer Pricing Handbook. op. cit., p. 395-396).

${ }^{904}$ Veja-se, a respeito, sugestão de utilização combinada dos métodos, a qual também partiu do exame de transações financeiras globais:

"The solution advocated by this article challenges the traditional convention, which regards the two methods by which MNE's affiliated transactions are sourced: the arm's length standard and the unitary/formulary methods, as almost mutually exclusive. The article argues that tax authorities should source MNEs using both arm's length and formulary methods. Arm's length methods adequately source most MNE non-financial affiliated transactions, which have market comparables; therefore, tax authorities have a legitimate interest in continuing to use them for these types of transactions. However, because of their unique features, affiliated financial transactions should instead be sourced through unitary or formulary sourcing conventions"

(BENSHALOM, Ilan. The Quest to Tax Financial Income in a Global Economy: Emerging to an Allocating Phase. Virginia Tax Review. v. 28, p. 165). 


\subsubsection{Críticas da OCDE ao método da divisão do lucro global segundo} fórmulas predeterminadas.

Na perspectiva da OCDE, descrita na Diretiva e mantida na Minuta-2009, o método da divisão do lucro global segundo fórmulas predeterminadas NÃO possui as qualidades que lhe são atribuídas, em especial (i.) a conveniência administrativa; (ii.) a maior certeza para os contribuintes [em detrimento da insegurança gerada pela abertura do princípio da plena concorrência]; (iii.) um maior realismo sob a perspectiva econômica, se comparado à ficção das empresas independentes, especialmente nos grupos altamente integrados onde seria complexa a definição da contribuição de cada um para o lucro global; e (iv.) os custos de administrativos [compliance], ao contrário do alegado pelos defensores deste método, não seriam reduzidos, mas ampliados ${ }^{905}$.

Segundo a aludida organização, a principal dificuldade na migração do regime do princípio da plena concorrência para métodos amparados na negociação global seria evitar bitributação econômica do lucro e garantir a tributação do país de residência ao mesmo tempo. Ademais, pressupor-se que haveria coordenação e consenso internacionais para a definição de uma "fórmula universal" não é realista, porque seria necessário acordo com relação ao grupo que participaria da divisão, à fórmula, aos critérios contábeis e à medição e ponderação do elemento "faturamento" na fórmula. Sustenta a OCDE, outrossim, que haveria a possibilidade de "manipulação" de componentes da fórmula pelos contribuintes, que poderiam se valer deste estratagema para reduzir tributos após a sua predeterminação. Não fosse suficiente, pondera a OCDE que qualquer migração para o método da divisão global dos lucros segundo fórmulas predeterminadas deveria ser amparada por ampla cooperação política e administrativa; de fato, se maioria dos países não migrar para o novo regime, os contribuintes deverão sujeitar-se a dois tratamentos

\footnotetext{
905“1.19 Global formulary apportionment has been promoted as an alternative to the arm's length principle by advocates who claim that it would provide greater administrative convenience and certainty for taxpayers. These advocates also take the position that global formulary apportionment is more in keeping with economic reality. They argue that an MNE group must be considered on a group-wide or consolidated basis to reflect the business realities of the relationships among the associated enterprises in the group. They assert that the separate accounting method is inappropriate for highly integrated groups because it is difficult to determine what contribution each associated enterprise makes to the overall profit of the MNE group.

1.20 Apart from these arguments, advocates contend that global formulary apportionment reduces compliance costs for taxpayers since in principle only one set of accounts would be prepared for the group for domestic tax purposes.

1.21 OECD member countries do not accept these propositions and do not consider global formulary apportionment a realistic alternative to the arm's length principle" (OCDE. Proposed Revision of Chapters IIII of the Transfer Pricing Guidelines. $9^{\text {th }}$ September 2009- $9^{\text {th }}$ January 2010. op. cit., p. 10-11). Correspondentes aos itens 3.61 a 3.63 da Diretiva.
} 
totalmente distintos, ou seja, precisariam lidar com dois standards em dois países, para a mensuração da mesma operação ${ }^{906}$.

Outras preocupações manifestadas pela OCDE envolvem a possibilidade de as fórmulas predeterminadas serem arbitrárias e desconsiderarem totalmente condições de mercado, as circunstâncias particulares do contribuinte a alocação de recursos etc. ${ }^{907}$. Ademais, como regra geral, a tributação formular teria o condão de "gerar" lucros em empresas que teriam incorrido em prejuízos se tivessem efetivado as mesmas transações com partes independentes. Por fim, no que respeita aos custos de compliance, a OCDE pondera que, ao contrário do sustentado pelos defensores do método da divisão do lucro global segundo fórmulas predeterminadas, os custos administrativos envolvidos neste último são muito mais elevados, porque sua aplicação envolve o exame de livros de todas as empresas envolvidas e, ainda, a uniformização dos critérios contábeis para a aferição de um único lucro a ser partilhado ${ }^{908}$.

906 "1.24 The transition to a global formulary apportionment system therefore would present enormous political and administrative complexity and require a level of international cooperation that is unrealistic to expect in the field of international taxation. Such multilateral coordination would require the inclusion of all major countries where MNEs operate. If all the major countries failed to agree to move to global formulary apportionment, MNEs would be faced with the burden of complying with two totally different systems. In other words, for the same set of transactions they would be forced to calculate the profits accruing to their members under two completely different standards. Such a result would create the potential for double taxation (or under-taxation) in every case" (OCDE. Proposed Revision of Chapters I-III of the Transfer Pricing Guidelines. $9^{\text {th }}$ September 2009- $9^{\text {th }}$ January 2010. op. cit., p. 11). Correspondente ao item 3.66 da Diretiva.

907 “1.25. (...)One such concern is that predetermined formulae are arbitrary and disregard market conditions, the particular circumstances of the individual enterprises, and management's own allocation of resources, thus producing an allocation of profits that may bear no sound relationship to the specific facts surrounding the transaction. More specifically, a formula based on a combination of cost, assets, payroll, and sales implicitly imputes a fixed rate of profit per currency unit (e.g. dollar, euro, yen) of each component to every member of the group and in every tax jurisdiction, regardless of differences in functions, assets, risks, and efficiencies and among members of the MNE group. Such an approach could potentially assign profits to an entity that would incur losses if it were an independent enterprise" (OCDE. Proposed Revision of Chapters IIII of the Transfer Pricing Guidelines. $9^{\text {th }}$ September 2009- $9^{\text {th }}$ January 2010. op. cit., p. 12). Correspondente ao item 3.67 da Diretiva.

908 "1.27 Contrary to the assertions of its advocates, global formulary apportionment may in fact present intolerable compliance costs and data requirements because information would have to be gathered about the entire MNE group and presented in each jurisdiction on the basis of the currency and the book and tax accounting rules of that particular jurisdiction. Thus, the documentation and compliance requirements for an application of global formulary apportionment would generally be more burdensome than under the separate entity approach of the arm's length principle. The costs of a global formulary apportionment would be further magnified if not all countries could agree on the components of the formula or on the way the components are measured.

1.28 Difficulties also would arise in determining the sales of each member and in the valuation of assets (e.g. historic cost versus market value), especially in the valuation of intangible property. These difficulties would be compounded by the existence across taxing jurisdictions of different accounting standards and of multiple currencies. Accounting standards among all countries would have to be conformed in order to arrive at a meaningful measure of profit for the entire MNE group. Of course, some of these difficulties, for example the 


\subsection{Os princípios constitucionais tributários e sua relação com os métodos tradicionais, os métodos amparados na divisão global de lucros e as propostas alternativas ao princípio da plena concorrência.}

Como se demonstrou no CAPÍTULO 4, no direito tributário brasileiro existe apenas a previsão dos métodos tradicionais para a comprovação dos preços de transferência. Mas estes métodos, baseados no confronto dos preços e margens brutas das transações, foram, de certa forma, "tolhidos" pela legislação brasileira. De fato, no âmbito da Lei n. ${ }^{\text {o }}$ 9.430/96 praticamente inexistem garantias quanto à possibilidade de os contribuintes efetivarem ajustes para tornar os dados captados no mercado comparáveis às transações efetivamente praticadas; a Instrução Normativa n. ${ }^{0}$ 243/02, de outro lado, limitou bastante [e de forma ilegal] as possibilidades de ajustes. Não obstante esta limitação, consoante sustentado na seção 2.2 do CAPÍTULO 2, todos os ajustes razoáveis devem ser admitidos, sob pena de inconstitucionalidade da norma. Concordamos, neste sentido, com Ricardo MARIZ DE OLIVEIRA, no sentido de que o caráter rígido da legislação pátria não assegura um tratamento justo aos contribuintes ${ }^{909}$.

A admissão, no direito brasileiro, da aplicação "pura" do princípio da plena concorrência, a partir de todos os mecanismos atinentes à análise de comparabilidade descrita pela OCDE em sua Diretiva, complementada pela Minuta-2009, seria uma importante medida de justiça, porque possibilitaria a medição da adequada capacidade contributiva dos contribuintes; seria a busca da denominada capacidade contributiva "subjetiva" na forma discutida na subseção 1.6.2 do CAPÍTULO 1. Sob as perspectivas prática e técnica, contudo, um regime como o cogitado pela OCDE, que repugna inclusive a instituição de safe harbours, seria impraticável e ineficiente; não há dúvidas, como discutido na subseção ora mencionada, que a tributação sobre a renda precisa ser, na medida do possível, objetivada. Esta conclusão exsurge da ponderação dos princípios constitucionais: uma lei muito justa e apta a mensurar as especificidades de cada uma das transações dos contribuintes pode ser idealmente adequada, mas ela não será eficiente; pelo

valuation of assets and intangibles, also exist under the arm's length principle, although significant progress in respect of the latter has been made, whereas no credible solutions have been put forward under global formulary apportionment" (OCDE. Proposed Revision of Chapters I-III of the Transfer Pricing Guidelines. $9^{\text {th }}$ September 2009- $9^{\text {th }}$ January 2010. op. cit., p. 12). Correspondentes aos itens 3.69 a 3.70 da Diretiva.

909 "De mais a mais, o caráter extremamente rígido da Lei n. ${ }^{\circ} 9.430$ não assegura um tratamento justo em toda e qualquer situação, até porque, para se obter tal resultado, se teria que fugir dos critérios da lei e, mesmo nas hipóteses abrangidas pelo art. 20, o Ministro da Fazenda teria que atuar sem regras legais predeterminadas, quase que se transformando em legislador, ao invés de ser mero executor da lei” (MARIZ DE OLIVEIRA, Ricardo. Fundamentos do Imposto de Renda. op. cit., p. 847). 
contrário, ponderando-se a capacidade contributiva com o princípio da praticabilidade [cf. subseção 1.6.5 do CAPÍTULO 1], não há dúvidas de que a primeira deve ser buscada até o limite da lei "praticável"; daí por diante, a legislação, ao invés de atender ao valor Justiça, tornará todo o sistema injusto e inseguro ${ }^{910}$; de fato, o excesso de detalhes [ou a ausência total deles] permite a prática de arbitrariedades pelas autoridades tributárias, gera insegurança nos contribuintes [que sempre terão dúvidas sobre a correta aplicação da lei] e, ademais, amplia a margem de planejamentos e evasões fiscais. A capacidade contributiva deve, sempre, ser sopesada pela segurança jurídica, pela legalidade e pela praticabilidade ${ }^{911}$.

Dentre as técnicas para garantir a praticabilidade e a eficiência da lei tributária, pode ser destacada a presunção relativa, discutida pormenorizadamente na subseção 1.9.1 do CAPÍTULO 1. Por intermédio da presunção relativa, o legislador indica critérios objetivos para o cálculo do tributo; se o contribuinte verificar que aqueles parâmetros não se aplicam ao seu caso concreto, deverá fazer a contraprova e demonstrar tal situação; a presunção relativa gera, nesse sentido, a inversão do ônus da prova. Paralelamente à transferência de tal ônus, esta espécie de presunção simplifica os regimes de aplicação e de fiscalização do cumprimento da legislação tributária. Sob a perspectiva do contribuinte, a presunção é importante porque estabelece limites à tributação: se o contribuinte não

\footnotetext{
${ }^{910}$ Esta mesma discussão existe na ponderação entre o princípio da plena concorrência e o método amparado na divisão global de lucros. Confira-se:

"Is there a better method of handling transfer pricing issues? Specifically, is global formulary apportionment a superior method? The answer to these questions depend on the objective. If the objective is to compensate each legal entity fairly for the value it brings to a particular set of transactions, then a global formulary approach will not succeed; only the arm's length standard accomplishes that goal. The current problem with the application of the arm's length standard is that accountants and lawyers do not understand how to apply it properly. In this context, it is easy for companies to abuse the rules, either through ignorance or design. The best way to deal with the current issues in worldwide transfer pricing is through widespread training of the auditors employed by tax authorities. Competent, fair auditing worldwide will force companies to learn how to apply the standard properly and would convert this to a routine issue.

Global formulary has the advantage of not requiring analysis or thought on the part of either the company or the government and, as a formula, can be easily applied and understood by all parties. The downside of its use is that some governments will not receive the level of profits commensurate with the value added within their country (and some will receive a windfall)" (WRIGHT, Deloris R. Practical Application of Transactional Profit Methods. op. cit., p. 201).

911 "Enquanto as normas não toleram a contradição, os princípios coexistem harmoniosamente, se devidamente ponderados. No campo fiscal é necessário, para combater a elisão, o permanente equilíbrio e ponderação entre a legalidade e a capacidade contributiva.

De modo que o princípio arm's length, essencialmente ligado à justiça fiscal, deve abrir para a ponderação com os princípios vinculados à segurança jurídica, como os da legalidade, da proteção da confiança do contribuinte, plena produção de prova, ampla defesa, etc. Em cada hipótese, de aplicação o arm's length terá peso diferente, a depender do peso específico que os outros princípios apresentem" (TORRES, Ricardo Lobo. O Princípio Arm's Length, os Preços de Transferência e a Teoria da Interpretação do Direito Tributário. op. cit., p. 131).
} 
praticar nenhum ato, será tributado nos termos da lei, sem que tenha que comprovar especificamente o seu lucro, detalhes de receitas e despesas de suas operações etc.. Claro que as presunções não eliminam o dever de fiscalização das autoridades tributárias, mas facilitam e restringem muito este trabalho; de todo modo, nas presunções, os parâmetros para o cálculo dos tributos são objetivamente definidos em lei, garantindo-se maior segurança jurídica aos contribuintes. Neste contexto, em situações muito complexas como, v.g., a questão dos preços de transferência, a instituição de presunções é recomendada, desde que, claro, trate-se de presunção relativa, sujeita a prova em contrário por quaisquer meios em direito admitidos ${ }^{912}$.

Transpondo-se a discussão supra para a questão das margens prefixadas em relação aos métodos PVL, CPL, PVV, PVA e CAP, a técnica da presunção ali prevista parece, em teoria, louvável. Na prática, contudo, os processos de alterações propostos pelos contribuintes não têm gerado resultados, ao passo que o Ministro de Estado da Fazenda ainda não se valeu de sua prerrogativa de alteração de margens, inclusive em caráter setorial. A questão específica da predeterminação das margens foi discutida na seção 4.6 do CAPÍTULO 4. Como alternativa à prefixação de margens, o legislador brasileiro poderia instituir, v.g., um método semelhante ao CPI formular norte-americano, discutido na subseção 5.4.1. Este regime não deveria ser obrigatório, mas facultado a todos os contribuintes que pretendessem reduzir seus custos com o atendimento das regras para o controle dos preços de transferência. Poderiam ser previstos, v.g., EBIT por tipos de transações, ou por ramos de atividade, os quais deveriam ser "testados" apenas com relação às transações externas envolvendo partes vinculadas. Obviamente não deve ser prevista uma margem para todos e quaisquer tipos de transações: por intermédio de pesquisas econômicas sérias e fundamentadas, poderia a administração fixar um rol de índices, de modo que a maioria dos contribuintes pudesse ali enquadrar-se.

Não se sustenta a previsão de um sistema de comparação de índices tão complexo quanto aquele estruturado para o funcionamento do CPI. De fato, concorda-se com a constatação de que o CPI formular, nos moldes empregados nos Estados Unidos da América e discutidos na seção 5.4.1 do CAPÍTULO 5, apresenta-se bastante complicado

\footnotetext{
${ }^{912}$ O método da divisão global de lucros segundo fórmulas predeterminadas não seria compatível com a atual norma brasileira que, ao invés de preocupar-se com a questão da bitributação econômica, pretende reduzir os casos de fraudes, simulações ou evasão fiscal. Não faria sentido, neste cenário, a previsão de norma de divisão do lucro com autoridades fiscais estrangeiras.
} 
quando, ao contrário, deveria ser simplíssimo. Este tipo de experiência, contudo, não pode ser ignorado, devendo serem sopesados os seus aspectos positivos e negativos. Na seção 2.9.1 do CAPÍTULO 2, foram discutidas as vantagens de instituição de safe harbours, a despeito da posição da OCDE de que este tipo de técnica poderia (i.) gerar arbitrariedades e (ii.) propiciar a elevação dos casos de planejamento tributário internacional, mediante a tributação tão-somente do "lucro mínimo exigido"; além de (iii.) gerar regras simplificadoras não compatíveis com a mais adequada aplicação do princípio da plena concorrência. Não obstante estes argumentos, todos no sentido de que não podem haver exceções à amplitude e abertura do princípio da plena concorrência, não há dúvidas de que os safe harbours possibilitam (a.) a redução dos custos administrativos de compliance, (b.) maior segurança jurídica aos contribuintes; além de (c.) simplificação dos procedimentos de fiscalização dos preços de transferência pelas autoridades tributárias. Sopesando-se os prós e contras, concluiu-se que os safe harbours seriam adequados como medida de eficiência e praticabilidade. Aplicando-se as considerações supra à experiência do CPI formular, uma alternativa de safe harbour que poderia ser prescrito na legislação brasileira, em substituição às margens fixas por método, seria a previsão de índices de rentabilidade prefixados por CNAE [ou por grupos de CNAE], os quais seriam constantemente reavaliados, para garantir maior fidedignidade com o mercado.

Se a maioria dos contribuintes puder enquadrar-se nos índices de rentabilidade supra referidos, restará à administração tributária maior disponibilidade de tempo e de recursos para se dedicar aos casos efetivamente complexos, como, v.g., os casos envolvendo a negociação global de instrumentos financeiros ou intangíveis. Ainda não existe muita discussão sobre o tema no direito brasileiro, em especial porque as regras da Lei n. ${ }^{\circ}$ 9.430/96 e da Instrução Normativa n. ${ }^{\circ}$ 243/02 prevêem normas para o "teste" dos preços de transações envolvendo bens, ignorando-se, na maior parte dos casos, que a lei aplica-se também aos serviços e direitos. Também corrobora para esta situação a exclusão dos royalties do campo de abrangência dos artigos 18 a 24 da Lei n. ${ }^{\circ}$ 9.430/96.

Como se apontou na seção 4.1 do CAPÍTULO 4, os instrumentos para o controle dos preços de transferência existentes, em especial os métodos tradicionais adotados pela lei brasileira, nem sempre são suficientes para se tributar, de forma justa, as operações financeiras integradas. Mas como este tipo de operação, em especial as realizadas no mercado de balcão, cresce vertiginosamente, o direito brasileiro precisa estar 
apto a lidar com os novos desafios por ele trazidos. Sempre que, v.g., um derivativo de balcão for desenvolvido/estruturado num país e revendido por subsidiária localizada noutro, com atuação razoavelmente integrada entre as partes vinculadas, surgirá um desafio para a partição dos lucros entre as duas instituições e, por conseguinte, um problema concernente ao controle dos preços de transferência, para o qual o direito brasileiro não oferece respostas; por mais que os métodos pátrios sejam aplicados com todos os instrumentos de comparação discutidos na seção 2.2 do CAPÍTULO 2, ainda assim não seria possível a obtenção de margens ou preços comparáveis. Uma possível alternativa para estas situações específicas seria a adoção, pela lei brasileira, dos métodos amparados na divisão de lucros, em especial o PSM. Com efeito, como se demonstrou na seção 5.2.1 do CAPÍTULO 5, este método é muito útil em transações integradas e/ou envolvendo intangíveis exclusivos e valiosos. Sugere-se, portanto, a adoção do PSM pela lei pátria, o qual deveria ser adotado apenas em hipóteses excepcionais nas quais nenhum dos métodos tradicionais pudesse ser realmente aplicado.

Neste contexto, em apertada síntese, a melhor estratégia de política tributária a ser adotada seria aquela baseada na edição de normas "abertas", garantindo-se ao contribuinte o direito de comprovar os seus preços de transferência por quaisquer metodologias [CUP, RPM, CPM ou PSM] e sem limitações quanto a métodos ou documentos comprobatórios da regularidade de sua adoção. Para que o sistema fosse viável ou praticável, no entanto, deveriam ser previstos safe harbours, elaborados a partir de estudos econômicos fundamentados e baseados em critérios razoáveis e justos, os quais deveriam abranger a maior parte dos contribuintes. Uma alternativa de safe harbour seria, v.g., a instituição de índices de mensuração de lucratividade por tipo de empresa e/ou de atividade. O exame das discussões envolvendo a negociação global de instrumentos financeiros auxilia na conclusão de que, para serem justas, as normas para o controle dos preços de transferência precisam ser abrangentes, possibilitando-se a adequação dos métodos às especificidades de cada caso concreto; para o regular funcionamento do sistema tributário, contudo, é imprescindível a instituição de diversas espécies de safe harbours, aptos a abranger a maioria das situações, reservando-se às transações realmente peculiares o exame detalhado dos preços. 


\section{CONCLUSÃO.}

Desde 1933, com a publicação do Relatório CARROLL, o controle dos preços de transferência está amparado no princípio da plena concorrência, que representa uma espécie de dogma no direito tributário internacional. Mas, a despeito deste princípio ter constado, desde aquela época, de praticamente todas as minutas de Convenção-Modelo da Liga das Nações e, posteriormente, da Organização para a Cooperação e o Desenvolvimento Econômico (“OCDE”), apenas em 1979 foi publicado o primeiro relatório internacional sobre a sua interpretação e aplicação, denominado "Transfer Pricing and Multinational Enterprises". Este documento, que possui forte influência das normas norte-americanas editadas em 1968, prevê que o princípio da plena concorrência deve ser aplicado a partir dos seguintes métodos, denominados tradicionais: (i.) Método dos Preços Independentes Comparados ["Comparable Uncontrolled Price Method" ou "CUP"]; (ii.) Método do Preço de Revenda ["Resale Price Method" ou "RPM"]; e (iii.) Método do Custo mais Lucro ["Cost Plus Method" ou "CPM”]. Enquanto o CUP baseia-se na comparação dos preços praticados entre transações vinculadas e os preços praticados entre transações não-vinculadas em condições e circunstâncias análogas, o RPM e o CUP são métodos de comparação indireta; com efeito, para a aplicação destes métodos, comparamse margens brutas [de venda ou sobre o custo] praticadas entre partes associadas e partes não-associadas para, tão-somente em seguida, obter-se o preço parâmetro, i.e., o preço que será confrontado com o preço de transferência "testado".

O Relatório supra indicado foi, em 1995, substituído pelo “Transfer Pricing Guidelines for Multinational Enterprises and Tax Administrations" ("Diretiva"), no qual a OCDE consolidou vários estudos anteriores sobre o tema. $\mathrm{Na}$ Diretiva, foram recomendados dois novos métodos, também amparados no princípio da plena concorrência, mas vinculados à comparação de lucros operacionais. São eles: (i.) o Método da Divisão de Lucros ["Profit Split Method" ou "PSM"]; e (ii.) o Método da Comparação de Margens Líquidas ["Transaction Net Margin Method" ou "TNMM"]. Foi necessária a ampliação da quantidade e natureza dos métodos até então disponíveis, porque se percebeu que as metodologias tradicionais não eram mais suficientes para se lidar com as questões cada vez mais complexas relativas ao controle dos preços de transferência. Com efeito, as inovações tecnológicas, a desregulamentação dos mercados financeiros e a atuação cada vez mais integrada dos grupos multinacionais vinham apresentando muitos desafios para as 
autoridades tributárias que se dedicavam ao controle dos preços de transferência. Inicialmente, o TNMM e o PSM foram previstos como métodos excepcionais, que deveriam ser empregados apenas se os métodos tradicionais [CUP, RPM e CPM] não propiciassem resultados confiáveis. Em set./99, contudo, a OCDE publicou o documento para consulta pública denominado "Proposed Revision of Chapters I-III of the Transfer Pricing Guidelines". Se esta proposta tornar-se definitiva, os métodos baseados na comparação de lucros deixarão de ser excepcionais, passando a ser empregados sempre que gerarem resultados mais confiáveis que os métodos tradicionais. Seu emprego será relevante, notadamente, nas hipóteses de atuação integrada dos grupos multinacionais e nas transações envolvendo intangíveis de valiosos, únicos e exclusivos.

As negociações globais de instrumentos financeiros intra-grupo, praticadas de forma integrada entre instituições de um mesmo conglomerado bancário, também denominadas "around the world, around the clock" ou "24hour-basis", estão entre as situações que mais apresentam desafios ao princípio da plena concorrência. De fato, a mensuração da remuneração de cada instituição que participou, de forma integrada, da estruturação de um determinado instrumento derivativo de balcão, não é simples; pelo contrário, considerando que cada trader atuou em conjunto com traders de outros países, tendo todos eles sido responsáveis pelo lucro global do negócio, apresenta-se difícil a tarefa de dividir o lucro tributável entre os países envolvidos. Neste tipo de negócio, que possui alto grau de integração, devem ser remuneradas, primeiramente, as atividades de back-office e middle-office e, em seguida, as comissões de vendas; a aferição dos preços de transferência nestes tipos de operações mais rotineiras pode ser efetivada via métodos tradicionais. O saldo remanescente de lucro [ou prejuízo] pode ser dividido entre traders, administradores de riscos e marketers; como regra geral, é utilizado o PSM nestas hipóteses. Para a aplicação do PSM, os lucros devem ser repartidos segundo os mesmos critérios que seriam adotados por terceiros independentes em circunstâncias análogas. Há alguns casos, contudo, em que não são localizados critérios no mercado. Daí por diante, o princípio da plena concorrência não é mais suficiente para o controle dos preços.

Não obstante a existência de toda a gama de métodos supra indicada, há exemplos nos quais o princípio da plena concorrência não propicia mecanismos suficientes para o adequado controle dos preços de transferência, porquanto inexistem dados para a comparação dos preços, margens brutas ou lucros operacionais. Como alternativa, parte da 
doutrina internacional tem defendido a adoção do método da partilha do lucro global segundo fórmulas predeterminadas ou "formulary apportionment". Os principais argumentos destes teóricos são a constatação de que o princípio da plena concorrência, ao se apegar ao critério da entidade segregada, ignora os ganhos de eficiência e escala gerados no âmbito dos grupos econômicos; ademais, a aplicação deste princípio mostra-se complexa e custosa, dada a sua abertura e amplitude. Adicionalmente, admitir que todas as transações vinculadas dispõem de dados comparáveis - aferidos a partir de transações nãovinculadas similares e praticadas em condições análogas -, para que seja possível o teste dos respectivos preços de transferência, representa um ideal inalcançável.

O princípio da plena concorrência deve ser mantido como uma máxima de direito tributário internacional, seja porque apresenta critério justo e amplamente aceito para o "teste" dos preços de transferência, seja porque se adéqua à grande maioria das transações internacionais. Não se pode, entretanto, assumir que este princípio é apto a solucionar todas e quaisquer questões relativas ao controle dos preços de transferência: há limitações, as quais não podem ser ignoradas pela comunidade internacional. Nos Estados Unidos da América, e.g., as limitações do princípio da plena concorrência, que, por sinal, são inerentes ao seu próprio fundamento de validade [a necessidade de dados comparáveis], têm sido reconhecidas em acordos prévios de fixação de preços de transferência entre as autoridades tributárias estadunidenses e os conglomerados bancários que se dedicam à negociação global integrada de instrumentos derivativos naquele país. De fato, há exemplos nos quais a metodologia adotada para o controle dos preços seria a seguinte: (1.) emprego dos métodos tradicionais e remuneração das funções que não possuam elevado grau de integração; (2.) remuneração das funções integradas a partir do PSM; e, se for o caso, (3.) divisão do lucro que não puder ser atribuído via PSM a partir de fórmulas previamente fixadas entre os contribuintes e o fisco estadunidense. Esta sistemática foi exposta na Notice 94-40, de 25.04.94, referência: 1994-1 C.B. 351, elaborada pelo Internal Revenue Service ("IRS").

Além de servir para delinear os limites do princípio da plena concorrência, o exame da problemática envolvendo a negociação global de instrumentos financeiros corrobora a conclusão de que, para serem justas, as normas para o controle dos preços de transferência precisam ser abertas e abrangentes, possibilitando-se a adequação dos métodos às especificidades de cada caso concreto. São imprescindíveis, neste contexto, a 
realização de ajustes que tornem as transações similares realmente comparáveis com as transações cujo preço é alvo de controle. Deve ser permitida, sempre, a implementação da análise de comparabilidade; com efeito, a exigência de tributos sobre a renda com amparo em preço parâmetro obtido em transações com diferenças aptas a afetar materialmente os preços, além de não ser compatível com o princípio da plena concorrência, gera a tributação de um "valor" sem o conteúdo econômico de renda, violando-se, dentre outros, o princípio da capacidade contributiva. As transações globais também são, nesse sentido, um exemplo do quão complexas e custosas, tanto para os contribuintes quanto para as autoridades tributárias, podem ser as normas amparadas no aludido princípio.

Para o adequado funcionamento do sistema tributário, no entanto, é recomendável a adoção de medidas de simplificação e praticabilidade, técnicas que visam "evitar a investigação exaustiva do caso isolado, com o que se reduzem os custos de aplicação da lei; dispensar a colheita de provas difíceis ou mesmo impossíveis em cada caso concreto ou aquelas que representam ingerência indevida na esfera privada do cidadão e, com isso, assegurar a satisfação do mandamento normativo" "913. Não é concebível a estruturação de um ordenamento com amparo apenas em normas subjetivistas e que demandem enormes esforços para a sua aplicação em cada caso concreto. Se, sempre que os contribuintes brasileiros transacionarem com empresas vinculadas no exterior, for preciso efetivar uma análise de comparabilidade envolvendo dezenas de itens, a legislação não será exequíivel. Para que seja viável o controle dos preços de transferência, assim, devem ser instituídas diversas espécies de safe harbours, que devem abranger a maioria das situações, reservando-se às transações realmente peculiares o exame detalhado dos preços.

No direito brasileiro, as regras para o controle dos preços de transferência, a despeito de inspiradas nos métodos tradicionais disponíveis para a aplicação do princípio da plena concorrência, são muito simplificadas. Mas não no sentido de garantirem praticabilidade e economicidade na aplicação da lei. Pelo contrário, as normas pátrias, em especial as constantes da Lei n. ${ }^{\circ}$ 9.430/96 e da Instrução Normativa n. ${ }^{\circ}$ 243/02, precisam ser interpretadas à luz dos princípios constitucionais da capacidade contributiva, universalidade e generalidade da tributação da renda, legalidade e livre concorrência,

\footnotetext{
${ }^{913}$ DERZI, Misabel de Abreu Machado. Direito Tributário, Direito Penal e Tipo. São Paulo: Revista dos Tribunais, 1988, p. 105.
} 
dentre outros, sob pena de serem injustas e abusivas. Na prática, há margens fixas de preços, imposição da utilização de médias anuais, limitação de ajustes e uma gama de outros elementos que precisam ser examinados, sempre, à luz do sistema constitucional tributário. Sem dúvidas, a lei brasileira poderia prever mais mecanismos para garantir a adequada comparabilidade das transações.

Idealmente, a melhor estratégia de política tributária a ser adotada seria aquela baseada na edição de normas que, de um lado, (i.) prevejam margens predeterminadas de lucros por setor de atividade e região, por CNAE [ou grupos de CNAE], ou definam outros critérios objetivos, razoáveis sob a perspectiva econômica, para o cálculo dos preços parâmetro, mediante a utilização da técnica das presunções relativas, mas, de outro, (ii.) admitam que estas simplificações representam safe harbours, devendo, sempre, ser garantido ao contribuinte o direito de apresentar quaisquer argumentos ou provas admitidos em direito para demonstrar sua situação peculiar, sob pena de violação aos princípios do contraditório e da ampla defesa [cf. artigo $5^{\circ}$, LIV e LV, da Constituição Federal]. 


\section{BIBLIOGRAFIA.}

ABDALLAH, Wagdy M.; MURTUZA, Athar. Transfer Pricing Strategies of Intangible Assets, e-Commerce and International Taxation of Multinationals. International Tax Journal. Spring 2006, p. 05-46.

ABRUTYN, Michael; BISCHEL, Jon E. . IFA Branch Reports, United States of America. Cahiers de Droit Fiscal International. International Fiscal Association. Boston: Kluwer Law and Taxation Issues, v. LXXVII-a, 1992, p. 657-683.

ACKERMAN, Bob. et. al. Comparing the 'Discussion Draft on the Attribution of Profits to Permanent Establishments (PEs: Part III. Enterprises Carrying on Global Trading of Financial Instruments)' with the OECD's 'The Taxation of Global Trading of Financial Instruments'. Derivatives and Financial Instruments. Amsterdã: IBFD, jul./ago. 2003, p. 150-159.

; CHORVAT, Elizabeth. Modern Financial Theory and Transfer

Pricing. Paper presented at the Symposium 'The Future of International Transfer Pricing: Practical and Policy Opportunities', in Washington D.C., sponsored by the Tax Council Policy Institute, 7 February 2002. George Manson Law Review. v. 10. Summer, 2002, p. 637.

ADAMS, Charles et. al.. International capital market-developments, prospects, and key policy issues. Washington: International Monetary Fund, 1999.

ADAMS, Chris; COOMBES, Richard. Global Transfer Pricing. Principles and Practice. London: Tottel Publishing, 2007.

ALBERTAZZI, Ugo; GAMBACORTA, Leonardo. Bank Profitability and Taxation. Banca D'Italia Eurosistema, Working Paper n. ${ }^{\circ}$ 649, nov. 2007.

ALTAMIRANO, Alejandro C. Legalidad y Discrecionalidad. In: Heleno Taveira Tôrres (coord.), Tratado de Direito Constitucional Tributário. Estudos em homenagem a Paulo de Barros Carvalho. São Paulo: Saraiva, 2005, p. 149-175.

AMERKHAIL, Valerie. A. Arm's Length or Formulary Apportionment? Sometimes the Best Choice is Both. Tax Management Transfer Pricing Report. v. 13, nov. 2000, Appendices, p. 25. 
ANDERSON, Philip; GRAHAM, Peter. Judiciary Begins to Consider Transfer Pricing: The Daihatsu Case. International Transfer Pricing Journal. Amsterdã: IBFD, jan./fev. 2002, p. 36-39.

ANDRADE, André Martins de. Uma crítica e uma proposição alternativa ao regime legal brasileiro do 'transfer price'. In: Luís Eduardo Schoueri e Valdir de Oliveira Rocha (coord.), Tributos e preços de transferência. São Paulo: Dialética, 1999, v. 02, p. 51-60.

ANDRUS, Joseph L. IFA Branch Reports, United States of America. Cahiers de Droit Fiscal International. International Fiscal Association. The Netherlands: SDU FISCALE \& FINANCIËLE UITGEVERS, v. 92a, 2007, p. 629-651.

ANTIL, Regina M; DUTTA, Sunil. Negotiated Transfer Pricing and Divisional versus Firm-Wide Performance Evaluation. Acessado em 31.10.08. Disponível em www.ssrn.com.

ANTONINI, Massimo; GIACOMETTI, Paolo. Global Trading. International Transfer Pricing Journal. Amsterdã: IBFD, jan./fev. 2006, p. 29-32.

ASCARELLI, Tullio. Studi di Diritto Comparato e in tema de Interpretazione. Milano: Dott. A. Giuffrè Editore, 1952.

AVERY JONES, John F.. et. al. The Origins of Concepts and Expressions Used in the OECD Model and their Adoption by States Bulletin for International Taxation. Amsterdã: IBFD, jun. 2006, p. 220-254.

AVI-YONAH, Reuven S. B. The Structure of International Taxation: A proposal for Simplification. Tax Management Transfer Pricing Report. v. 13, nov. 2000, Appendices, p. 36.

International Taxation of Electronic Commerce. Symposium on Taxation and Electronic Commerce. Tax Law Review. v. 52, Spring 1997, p. 507.

Slicing the Shadow: a Proposal for Updating US International Taxation. Tax Notes. mar. 1993, p. 1511-1515.

The Rise and Fall of Arm's Length: A Study in the Evolution of US International Taxation. Virginia Tax Review. v. 15, p. 89.

U.S International Taxation. New York: Foundation Press, Chapter 6: The Transfer Pricing Problem, 2002, p. 152-186. 
BACCARO, Renato Fernandes. Manual de Preços de Transferência. Uma aplicação prática ante as margens de lucro predeterminadas. São Paulo, Editora Hipótese, 2002.

BAILEY, Charles D; COLLINS, Denton. Goliath Corporation: An Instructional case in Transfer Pricing Policy. Journal of Accounting Education. v. 23, 2005, 264-276.

BAISTROCCHI, Eduardo. The Arm's Length Standard in the $21^{\text {st }}$ Century: A Proposal for Both Developed and Developing Countries. Tax Notes International. out. 2004. p. 241255.

BAKER, Philip. Review of Recent Treaty Cases - NatWest II, NEC and AS Andritz. Bulletin for International Taxation. Amsterdã: IBFD, mai. 2004, p. 205-212.

BAKKER, Anuschka J. Attribution of Profit to a Permanent Establishment of a Global Trading Company. International Transfer Pricing Journal. Amsterdã: IBFD, nov./dez. 2004, p. 255-263.

Attribution of Profit to a Permanent Establishment of a Bank. International Transfer Pricing Journal. Amsterdã: IBFD, mar./abr. 2006, p. 74-78.

Global Trading. International Transfer Pricing Journal. Amsterdã: IBFD, mar./abr. 2006, p. 95-100.

; SMITH, Arthur van Hoey. Recent Developments Regarding Allocation of Profit to Permanent Establishments of Banks. International Transfer Pricing Journal. Amsterdã: IBFD, jan./fev. 2004, p. 20-25.

BALDENIUS, Tim; MELUMAD, Nahum D., REICHELSTEIN, Stefan J. Integrating managerial and tax objectives in transfer pricing. Acessado em 31.10.08. Disponível em www.ssrn.com.

BALEEIRO, Aliomar. Direito Tributário Brasileiro. $11^{\mathrm{a}}$ ed. at. por Misabel Abreu Machado Derzi. Rio de Janeiro: Forense, 2001.

. Limitações Constitucionais ao Poder de Tributar. $7^{\mathrm{a}}$ ed. rev. e compl. à luz da Constituição de 1998 até a Emenda Constitucional n. ${ }^{\circ}$ 10/1996 por Misabel Abreu Machado Derzi. Rio de Janeiro: Forense, 2001.

. Uma Introdução à Ciência das Finanças. $14^{\mathrm{a}}$ ed. rev. e atual. por Flávio Bauer Novelli. Rio de Janeiro: Forense, 1984. 
BARRETO, Paulo Ayres. Imposto sobre a renda e preços de transferência. São Paulo: Dialética, 2001.

BENNETT, Mary C; DUNAHOO, Carol A. The Attribution of Profits to a Permanent Establishment: Issues and Recommendations. Intertax. v. 33, issue 2, 2005, p. 51-67.

BENSHALOM, Ilan. The Quest to Tax Financial Income in a Global Economy: Emerging to an Allocating Phase. Virginia Tax Review. v. 28, p. 165.

BENTO, Paulo Marcelo de Oliveira. As Regras Brasileiras dos Preços de Transferência e o Princípio Arm's length. Uma Análise Multidisciplinar. Revista de Direito Tributário Internacional. São Paulo: Quartier Latin, ano 01, n. ${ }^{\circ}$ 02, fev. 2006. p. 103-130.

BERGLUND, Anna. Supreme Court Decision on Intra-Group Service Fees. International Transfer Pricing Journal. Amsterdã: IBFD, set./out. 2006, p. 271-275.

BERNHARDT, Lorenz; WEINREICH, Christina. Recent Court Cases Address Transfer Pricing. International Transfer Pricing Journal. Amsterdã: IBFD, mar./abr. 2002, p. 67-71. BERRY, Charles. et. al. Arm's Length Pricing: Some Economic Perspectives. Tax Notes. fev. 1992, p. 731-740.

BETTEN, Rijkele. Profit Split Agreement between the Netherlands and Germany on the International Allocation of Taxable Income of Netherlands Flower Salesmen. International Transfer Pricing Journal. Amsterdã: IBFD, jan./fev. 2003, p. 20-22.

BETTEN, Rijkele; ROTONDARO, Carmine. The Concept of an Arm's Length Range. International Transfer Pricing Journal. Amsterdã: IBFD, vol. 05, n. 04, jul/ago. 1998, p. 174-179.

BIFANO, Elidie Palma. Anotações sobre as regras de preços de transferência em contratos de mútuos. Revista de Direito Tributário Internacional. São Paulo: Quartier Latin, ano 03, n. ${ }^{\circ} 09$, ago. 2008, p. 107-122.

O investimento financeiro e o estabelecimento permanente. Revista de Direito Tributário Internacional. São Paulo: Quartier Latin, ano 03, n. ${ }^{\circ}$ 08, abr. 2008, p. 33-50.

BLANCO, Cristina García-Herrera. Precios de Transferencia y otras Operaciones Vinculadas en el Impuesto sobre Sociedades. Madrid: Instituto de Estudios Fiscales, 2001. 
BLOMME, Jozef. The Choice of a Transfer Pricing Method. International Transfer Pricing Journal. Amsterdã: IBFD, mai./abr. 2000, p. 42-43.

BLUMENSTEIN, Ernst. Sistema di Diritto delle Imposte. Traduzione e nota introduttiva di Francesco Forte. Milano: Dott. A. Giuffrè Editore, 1954.

BOIDMAN, Nathan. Interest-free Loans and Intercompany Pricing. International Transfer Pricing Journal. Amsterdã: IBFD, vol. 01, out. 1994, p. 35-43.

BOOS, Monica. International Transfer Pricing. The Valuation of Intangibles Assets. The Netherlands: Kluwer Law International, 2003.

BORKOWSKI, Susan C. Global Trading of Financial Instruments and Transfer Pricing: A Brief History and Exploratory Study. The International Tax Journal. v. 29, 2003, p. 22.

BORSTELL, T.; HUIBREGTSE, S. B. OECD: Global theory, local practice. International Tax Review. London: v. 08, issue 5, 1997, p. 33-39.

BREM, Markus. A New Approach to Transfer Pricing for Multinational Corporations. Tax Notes International. v. 33, mar. 2004, Column Commentary and Analysis, Special Reports, p. 1005.

BREM, Markus; TUCHA, Thomas. On Transfer Pricing: Conceptual Thoughts on the Nature of the Multinational Firm. Indian Institute of Management. Working Paper n. ${ }^{\circ}$ 2005-11-03, nov. 2005.

BRIGAGÃO, Gustavo; LYRA, Bruno. Transfer Pricing, Regras Brasileiras Frente aos Tratados Internacionais. Direito Tributário Internacional Aplicado. Volume IV. São Paulo: Quartier Latin, 2007. p. 433-458.

BROWN, Fred B. Federal Income Taxation of U.S. Branches of Foreign Corporations: Separate Entity or Separate Rules? Tax Law Review. v. 49, Fall 1993, p. 133.

BUHLER, Ottmar. Principios de Derecho Internacional Tributario, Versión Castellana de Fernando Cervera Torrejón. Madrid: Ed. Derecho Financiero, Parte II: Las Combinaciones de Sociedades (Derecho Internacional Tributario de los Concernos), 1968.

BULHÕES PEDREIRA, José Luiz. Finanças e demonstrações financeiras da companhia: conceitos e fundamentos. $2^{\mathrm{a}}$ ed. Rio de Janeiro: Forense, 1989.

Imposto de renda. Rio de Janeiro: Justec, 1979, 2 v. 
BUSINESS AND INDUSTRY ADVISORY COMITEE [BIAC]. Global Methods. A critical view. 03 abr. 2002.8 p. Texto não publicado.

CALAZANS, Fernanda Junqueira. Transfer Pricing Rules: Application to Financial Institutions. International Transfer Pricing Journal. Amsterdã: IBFD, set./out. 2005, p. 228-235.

CARISON, George N. The Proposed New Transfer Pricing Rules: New Wine in an Old Bottle? Tax Notes. fev. 1992, p. 691-717.

CARNEIRO, Paulo Baltazar. Preços de transferência no setor financeiro. Secretaria da Receita Federal. Disponível em www.receita.fazenda.gov.br e acessado em 31.10.08.

CARREÑO, Florentino; RODRÍQUEZ, Rebeca; MAYO, Ana. Global Trading. International Transfer Pricing Journal. Amsterdã: IBFD, nov./dez. 2005, p. 311-313.

CARRERO, José Manuel Calderón. Precios de Transferencia e Impuesto sobre Sociedades. Un análisis de la normativa española desde una perspectiva Internacional, Comunitaria y Constitucional. Valencia: Tirant lo Blanch, Colección Financiero n. ${ }^{\circ}$ 27, 2005 .

CARVALHO, Fábio Junqueira de e MURGEL, Maria Inês. Preços de Transferência. Presunção de Evasão Fiscal e Inexistência de Indicação do Método para Determinação dos Preços. In: Luís Eduardo Schoueri e Valdir de Oliveira Rocha (coord.), Tributos e preços de transferência. São Paulo: Dialética, 1999, v. 2, p. 143-154.

CARVALHO, Paulo de Barros. Curso de Direito Tributário, $16^{\mathrm{a}}$ ed.. São Paulo: Saraiva, 2004.

. O Princípio da Segurança Jurídica. Revista de Direito Tributário n. ${ }^{\circ}$ 61. São Paulo: Malheiros, jul./ set. 1992, p. 74-90.

Preços de Transferência no Direito Tributário Brasileiro. In: Marcelo Magalhães Peixoto (coord.), Tributação, Justiça e Liberdade. Curitiba: Juruá Editora, 2005, p. 547-563.

Sobre os Princípios Constitucionais Tributários. Revista de Direito Tributário n. ${ }^{\circ}$ 55. São Paulo: Malheiros, jan./ mar. 1991, p. 142-155. 
CASÁS, José O. El principio de legalidad en materia tributaria In: Heleno Taveira Tôrres (coord.), Tratado de Direito Constitucional Tributário. Estudos em homenagem a Paulo de Barros Carvalho. São Paulo: Saraiva, 2005, p. 179-231.

CASELLA, Paulo Borba. et. al. Preços de Transferência: 'Interface' entre Direito Interno e Direito Internacional. In: Luís Eduardo Schoueri e Valdir de Oliveira Rocha (coord.), Tributos e preços de transferência. São Paulo: Dialética, 1999, v. 2, p. 277-292.

CASLEY, Andrew. The Basic Framework of the Cost-Plus Method. International Transfer Pricing Journal. Amsterdã: IBFD, mar./abr. 1999, p. 38-44.

; ABU-EL-ATA, Ahmad. The Cost-Plus Method. International Transfer Pricing Journal. Amsterdã: IBFD, v. 06, n. ${ }^{\circ}$ 1, jan./fev. 1999, p. 20-26.

; HORROCKS, Victoria. United Kingdom. Practical Application of Transactional Profit Methods. International Transfer Pricing Journal. Amsterdã: IBFD, jul./ago. 2000, p. 135-141.

; KRITIKIDES, Artemis. Transactional Net Margin Method, Comparable Profits Method and the Arm's Length Principle. International Transfer Pricing Journal. Amsterdã: IBFD, set./out. 2003, p. 162-168.

CERUTTI, Eugenio. et al. How Banks Go Abroad: Branches or Subsidiaries? World Bank policy Research Working Paper. n. 3753, out. 2005.

CHANDLER, Clark J. et al. Transfer Pricing: Economic, Managerial, and Accounting. Principles. Tax Management. Washington D.C.: Bureau of National Affairs, 1995, Chapters 4, 5 e 6, p. 1-225.

CHAPMAN, Jane H.; ANDERSON, Philip. Cost-Plus Pricing: Approach and Application. International Transfer Pricing Journal. Amsterdã: IBFD, mai./jun. 1999, p. 81-86.

CHIKARA, Rajendra Singh. Transfer Pricing in Indian Banks. Journal of International Taxation. v. 16, ago. 2005, p. 34.

CHOVART, Elizabeth. Forcing Multinationals to Play Fair: Proposals for a Rigorous Transfer Pricing Theory. Alabama Law Review. v. 54, Summer, 2003, p. 1.251.

CHRISTENSEN, Steve. Formulary Apportionment: More Simple - on Balance Better? Law and Policy in International Business. v. 28, Summer 1997, p. 1.133. 
CID, José Manuel Amudí. El Régimen Jurídico de Transparencia Fiscal Internacional. Madri: Ministerio de Economía e Hacienda, Instituto de Estudios Fiscales, 2005.

CLARK, Dick; MIMO, Ella. Service Company Profitability: Results from an Empirical Analysis. Tax Management Transfer Pricing Report. v. 12, mar. 2004, p. 1.027.

CLARK, John A. K. IFA Branch Reports, United Kingdom. Cahiers de Droit Fiscal International. International Fiscal Association. Boston: Kluwer Law and Taxation Issues, v. LXXVII-a, 1992, p. 639-653.

CLARK, Robert G. Transfer Pricing, Section 482, and International Tax Conflict: Getting Harmonized Income Allocation Measures from Multinational Cacophony. American University Law Review. v. 42, Spring, 1993. p. 1155.

COCIANI, Simona Francesco. Attualitá o declinio del principio della capacità contributiva. (con postilla di Gaspare Falsitta). Revista di Diritto Tributario. Milano: Dott. A. Giuffrè Editore, vol. XIV, jul/ago. 2004, p. 823-906.

COCKFIELD, Arthur J. Formulary Taxation Versus the Arm's-Length Principle: The Battle Among Doubting Thomases, Purists, and Pragmatists. Canadian Tax Journal. v. 52, issue 01, jan. 2004, p. 114.

CODY, Brian J. Allocating Exchange Rate Risk. Allocating Exchange Rate Risk Has Tax Effects for Multinationals. The Journal of International Taxation. v. 03, n. ${ }^{\circ}$ 03, set./out. 1994, p. 156.

COÊLHO, Sacha Calmon Navarro. Manual de Direito Tributário. $2^{\mathrm{a}}$ ed. Rio de Janeiro: Forense, 2001.

COFFILL, Eric J. Federal Formulary Apportionment as An Alternative to Arm's Length Pricing: From the Frying Pan to the Fire? Tax Notes. mai. 1993, p. 1103-1117.

CONLON, Steven D. IRS Makes a Start Toward Workable Rules for Global Trading. Journal of Taxation. v. 89, set. 1998, p. 171.

CONTI, José Maurício. Princípios Tributários da Capacidade Contributiva e da Progressividade. São Paulo: Dialética, 1996.

COOLS, Martine. International Commercial Databases for Transfer Pricing Studies. International Transfer Pricing Journal. Amsterdã: IBFD, set./out. 1999, p. 167-182. 
CORNISH, Keir; DAVENPORT, Angela. Small to Medium-Sized Enterprises: A Simplified Approach. International Transfer Pricing Journal. Amsterdã: IBFD, mar./abr. 2005, p. 63-68.

COTTANI, Giammarco. Transfer Pricing and Intangibles: Summary of Discussions at the $61^{\text {st }}$ IFA Congress in Kyoto. International Transfer Pricing Journal. Amsterdã: IBFD, jan./fev. 2008, p. 58-60.

COUZIN, Robert. The OECD Project: Transfer Pricing Meets Permanent Establishment. Canadian Tax Journal. v. 53, n. ${ }^{\circ}$ 2, 2005, p. 400-416.

CREM, Daniel De. Margin and Cost Base for Applying the Cost-Plus Method. International Transfer Pricing Journal. Amsterdã: IBFD, v. 06, n. ${ }^{\circ}$, jan./fev. 1999, p. 1518.

; VERLINDEN, Isabel. Allocation of Functions and Risks within Multinational Enterprises. International Transfer Pricing Journal. Amsterdã: IBFD, vol. 04, n. ${ }^{\circ} 06$, nov./dez. 1997 p. 246-252.

CULBERTSON, Robert E. A Rose by Any Other Name: Smelling the Flowers at the OECD’s (Last) Resort. Tax Notes International. ago. 1995, Tax Policy Forum. p. 370-382.

DADAKIS, John D; JACOBS, Scott H. Arm's length transactions: are they real or are they replicated? Journal Of Deferred Compensation. New York: v. 08, issue 3, 2003, p. 65-76.

DAGNESE, Napoleão. Subordinando a fiscalidade à constitucionalidade: alinhamento do Transfer Pricing via PL 4.695/01. Revista de Direito Tributário Internacional. São Paulo: Quartier Latin, ano 02, n. ${ }^{\circ}$ 05, fev. 2007, p. 105-130.

DAGNESE, Napoleão; MARCHANT, Diego Alejandro Costa. Preços de Transferência e sua harmonização no Direito Comunitário europeu e mercosulino. Revista de Direito Tributário Internacional. São Paulo: Quartier Latin, ano 01, n. ${ }^{\circ} 03$, jun. 2006. p. 157-184.

DALLARI, Dalmo de Abreu. O renascer do Direito. São Paulo: José Bushatsky Editor, 1976.

DAM, Harmen van. The Cost-Plus Method. International Transfer Pricing Journal. Amsterdã: IBFD, mai./jun. 1999, p. 100-104.

DAU, Paul; DONELLY, Rod. Globalization of Intangibles-Based Businesses: Tax Aspects. Stanford Journal of Law, Business \& Finance. v. 9, Fall, 2003. p. 01. 
DELOITTE TOUCHE TOHMATSU. Margem Bruta de Lucro das Empresas Brasileiras, Pesquisa 2003.

DERZI, Misabel Abreu Machado. A Desconsideração dos Atos e Negócios Jurídicos Dissimulatórios, segundo a Lei Complementar n. ${ }^{\circ}$ 104, de 10 de janeiro de 2001. $O$ Planejamento Tributário e a Lei Complementar n. ${ }^{o}$ 104. São Paulo: Dialética, 2001, p. 205 a 232.

Direito Tributário, Direito Penal e Tipo. $2^{\mathrm{a}}$ ed. rev., atual. e ampl. São Paulo: Revista dos Tribunais, 2008.

Legalidade material, modo de pensar 'tipificante' e praticidade no direito tributário. Justiça Tributária: direitos do fisco e garantia dos contribuintes nos atos da administração e no processo tributário. Publicado no I Congresso Internacional de Direito Tributário do IBET em Vitória, ES, entre 12-15 ago. 1998, p. 627-650.

DEVOY, Annie. Transfer Pricing Comparables: friend or foe? Tax Planning International Review. The Bureau of National Affairs, Inc.,1998, p. 22-26.

DIAKONAVA, Irina. et. al. Financial Services Institutions: Dramatic Changes Regarding the Treatment of Permanent Establishments. Derivatives and Financial Instruments. Amsterdã: IBFD, nov./dez. 2002, p. 199-207.

DIAKONOVA, Irina. et. al. Where Do Financial Services Meet Transfer Pricing? Derivatives and Financial Instruments. Amsterdã: IBFD, mar./abr. 2000, p. 55-73.

; HUIBREGTSE, Steef. The Challenge: Transfer Pricing Solutions for E-Banking. Derivatives and Financial Instruments. Amsterdã: IBFD, mai./jun. 2001, p. 122-142.

DOMINIC, Paul. Interest-free Loans and Intercompany Pricing. International Transfer Pricing Journal. Amsterdã: IBFD, vol. 01, out. 1994, p. 19-28.

DONOVAN, Danielle; RAFIQ, Aamer. Charging for Intra-Group Services within Financial Services Institutions. Derivatives and Financial Instruments. Amsterdã: IBFD, jul./ago. 2000, p. 174-189.

DÓRIA, Antônio Roberto Sampaio. Direito Constitucional Tributário e 'Due Processo f Law'. Ensaio sobre o Controle Judicial da Razoabilidade das Leis. $2^{\text {a }}$ ed. rev. Rio de Janeiro: Forense, 1986. 
DOUVIER, Pierre-Jean. Transfer Pricing and Global Trading. International Transfer Pricing Journal. Amsterdã: IBFD, nov./dez. 2005, p. 298-305.

DUARTE, Sérgio Ilídio. Preços de Transferência. Aspectos Polêmicos da Legislação Brasileira. São Paulo: Saint-Paul Editora, 2005.

ENGEL, David C. Would Formula Apportionment for International Transactions Be a More Efficient Approach? The International Tax Journal. v. 24, 1998, p. 23-36.

ERNST \& YOUNG INTERNATIONAL LTD., 2007-2008 Global Transfer Pricing Survey. Global Transfer Pricing Trends, Practices and Analysis. dez./99.

FAIFERLICK, Chris; LABRUM, Stephen; RAFIQ, Aamer. Transfer Pricing for Financial Institutions: Global Trading. Derivatives and Financial Instruments. Amsterdã: IBFD, set./out. 2000, p. 238-253.

FEINSCHREIBER, Robert. Transfer Pricing Handbook, $3^{\mathrm{a}}$ ed. Nova York: John Wiley \& Sons, Inc., 2002.

. Transfer Pricing Methods. An Application Guide. New York: John Wiley \& Sons, Inc., 2004.

; KENT, Margaret. Transfer Pricing Comparability: Use of the Comparable Profits Methods to be Limited? Intertax. v. 32, issue 4, 2004, p. 193-196.

FERNANDES, Edison Carlos. Conceitos Básicos referentes ao Controle Fiscal dos Preços de Transferência. In: Alexandre Siciliano Borges et. al. (coord.) Manual dos Preços de Transferência no Brasil. Celebração dos 10 anos de vigência da lei. São Paulo: MP Editora, 2007, p. 13-34.

Constitucionalidade in thesi e in concreto de Contrato Fiscal de Preços de Transferência. In: Edílson Carlos Fernandes (coord.) Preços de Transferência. São Paulo: Quartier Latin, Verão 2007, p. 15-30.

Preço de Transferência no Mercado Comum do Sul. In: Luís Eduardo Schoueri e Valdir de Oliveira Rocha (coord.), Tributos e preços de transferência. São Paulo: Dialética, 1999, v. 2, p. 85-115.

FERNÁNDEZ, Juan Ignacio Moreno. La Tributación de las Operaciones Vinculadas. $2^{\mathrm{a}}$ ed. Navarra: Thomson Aranzadi, Colleción Monografías Aranzadi n. ${ }^{\circ}$ 128, 2003. 
FEYERABEND, Hans-Jügen A.; KIENINGER, Brigitta. Regulations on the Endowment Capital of Permanent Establishments of International Banks. Derivatives and Financial Instruments. Amsterdã: IBFD, mai./jun. 2005, p. 140-144.

FINNERTY, Chris. et. al. Fundamentals of International Tax Planning. Amsterdã: IBFD, 2007.

FLETCHER, Richard; PANTELIDAKI, Stephanie. IFA Branch Reports, United Kingdom. Cahiers de Droit Fiscal International. International Fiscal Association. The Netherlands: SDU FISCALE \& FINANCIËLE UITGEVERS, v. 92a, 2007, p. 605-627.

FRANCESCUCCI, David L. P. The Arm's Length Principle and Group Dynamics - Part 2: Solutions to Conceptual Shortcomings. International Transfer Pricing Journal. Amsterdã: IBFD, nov./dez. 2004, p. 235-246.

FRANCESCUCCI, David L. P. The Arm's Length Principle and Group Dynamics - Part 1: The Conceptual Shortcomings. International Transfer Pricing Journal. Amsterdã: IBFD, mar./abr. 2004, p. 55-75.

FRIS, Pim. Dealing with Arm's Length and Comparability in the Years 2000. International Transfer Pricing Journal. Amsterdã: IBFD, nov./dez. 2003, p. 194-203.

FULLER, James P. The IRS Section 482 White Paper. Tax Notes. nov. 1988, p.655-664. Transfer Pricing and Foreign Owned Corporation: Sections 482 and 6038A \& C. Intercompany Pricing under Section 482. Tax Law and Estate Planning Course Handbook Series. Tax Law and Practice. v. 314, jun. 1991, p. 239.

; AUD JR., Ernest F. Proposed Section 402 Regulations: A Wolf in Sheep's Clothing? Tax Notes. mar. 1993, p. 1517-1537.

GALHARDO, Luciana Rosanova. Preços de Transferência e Reorganizações Societárias. In: Valdir de Oliveira Rocha (coord.), Grandes Questões Atuais do Direito Tributário. $8^{\circ}$ Volume. São Paulo: Dialética, 2004, p. 322-338.

Preços de Transferência, Limites à Fiscalização. In: Luís Eduardo Schoueri e Valdir de Oliveira Rocha (coord.), Tributos e preços de transferência. São Paulo: Dialética, 1999, v. 2, p. 243-256.

GALVAÑ , Gemma Sala. Los Precios de Transferencia Internacionales. Su Tratamiento Tributario. Valencia: Tirant lo Blanch, 2003. 
GARCIA BENAU, Maria Antonia. Los Precios Internos de Transferencia. Madrid: Instituto de Planificación Contable, Colección Monografías n. ${ }^{\circ}$ 08, 1986.

GARCÍA PRATS, Francisco Alfredo. El Establecimiento Permanente. Análisis JurídicoTributario International de la Imposición societaria. Madrid: Tecnos, Capítulo VII: Atribución de rendimientos al establecimiento permanente (2): el criterio da empresa separada, 1996.

GARCÍA, Eusebio González; AYALA, José Luis Pérez de. Presunciones y Ficciones en Materia Tributaria. Madrid, Cronica Tributaria. n. 61, 1992, p. 47-60.

GELIN, Stéphane; BOULANGER, Arnaud Le. Transfer Pricing: From Arm's length Principle to Analysis of Value. Tax Planning International Review. The Bureau of National Affairs, Inc., 2002, p. 8-12.

GENETELLI, Richard W. Apportionment Factor Issues (Including Section 18 Type Adjustments: Alternative Apportionment Methodologies). State and Local Taxation 2005: What every Tax Lawyer Needs to Know. Tax Law and Estate Planning Course Handbook Series. Tax Law and Practice. v. 648, abr. 2005, p. 7.

GIANNATTASIO, Brian. Provision of Services under US Transfer Pricing Rules .International Transfer Pricing Journal. Amsterdã: IBFD, jul./ago. 2008, p. 110-120.

GIANNI, Monica Brown. Transfer Pricing and Formulary Apportionment. Taxes. v. 74, mar. 1996, p. 169-182.

GODBEE, Michael I. The British Threat to Retaliate Against the Unitary Method of Taxation. Tax Notes International. ago. 1993, p.538-542.

GOLDBERG, Stanford H. et. al. New Transfer Pricing Regs. Adhere more Closely to an Arm's Length Standard. Journal of Taxation. v. 78, n. ${ }^{\circ}$ 05, mai. 1993, p. 306.

GOMES, Orlando. Introdução ao Direito Civil. 10ª ed. Forense: Rio de Janeiro, 1993.

GOMMERS, Edwin. et. al. Pan-European Comparables Searches: Enhancing Comparability Using Diagnostic Ratios. International Transfer Pricing Journal. Amsterdã: IBFD, jul./ago. 2007, p. 219-227.

GOULART, André Moura Cintra. Gerenciamento de Resultados Contábeis em Instituições Financeiras no Brasil. São Paulo, USP, Tese de Doutorado, 2007, inédita. 
GRAU, Eros Roberto. Ensaio e Discurso sobre a Interpretação/Aplicação do Direito. São Paulo: Malheiros, 2002.

. Ensaio e discurso sobre a Interpretação/Aplicação do Direito. $5^{\mathrm{a}}$ ed.

Malheiros: São Paulo, 2009.

O direito posto e o direito pressuposto. $7^{\mathrm{a}} \mathrm{ed}$. rev. e ampl. Malheiros:

São Paulo, 2008.

GRECO, Marco Aurélio. Sobre o Futuro da Tributação: a Figura dos Intangíveis. In: Alcides Jorge Costa et. al.(coord.), Revista Direito Tributário Atual. n. 20. São Paulo: Dialética, 2006, p. 166-178.

GRESIK, Thomas A. Separate Acconting vc. Formula Apportionment: a Private Information Perspective. mar. 2006. Acessado em 31.10.08. Disponível em www.ssrn.com. Transfer Pricing in Vertically Integrated Industries. International Tax Public Finance. v. 15, 2008, p. 231-255.

GUERREIRO, Rutnéa Navarro e FILHO, Edmar Oliveira Andrade. Preços de transferência. In: Valdir de Oliveira Rocha (coord.), Tributos e preços de transferência. São Paulo: Dialética, 1997, p. 103-118.

GUSTAFSON, Charles H. et al. Taxation of International Transactions. Materials, Texts and Problems. $2^{\mathrm{a}}$ ed. St. Paul: American Case Book Series, 2001, Chapter 8: Transfer Pricing, p. 625-682.

GYGAX, Martin F.; DOUVIER, Pierre Jean. Transfer Pricing: Cost Plus What? Proposed for a Practical and Fair Arm's Length Remuneration for Manufacturing Entities within a Multinational Group of Companies. International Transfer Pricing Journal. Amsterdã: IBFD, v. 05, n. ${ }^{\circ}$, jan./fev. 1998, p. 03-06.

HAMAEKERS, Hubert. Arm's Length - How Long? International Transfer Pricing Journal. Amsterdã: IBFD, mar./abr. 2001, p. 30-40.

Can the Free Negotiations of Prices within a Multinational Enterprise serve as an arm's length transfer pricing method? International Transfer Pricing Journal. Amsterdã: IBFD, vol. 04, n. ${ }^{\circ}$ 01, jan./fev. 1997, p. 02-04. 
Introductory Speech of the panel discussion 'Income Allocation in the

$21^{\text {st }}$ Century: The End of Transfer Pricing?, organized on 6 May 2004. International Transfer Pricing Journal. Amsterdã: IBFD, mai./jun. 2005, p. 95-98.

Recent Developments in Legislation Internationally. Practical Experience With The OECD Transfer Pricing Guidelines. The Hague: Kluwer Law International, v. 23b, Proceedings of a Seminar Held in London, in 1998 during the $52^{\text {nd }}$ Congress of the International Fiscal Association, p. 01-06.

. The Comparable Profits Method and the Arm's Length Principle. International Transfer Pricing Journal. Amsterdã: IBFD, mai./jun. 2003, p. 90-93.

HAMMER, Richard M. et. al. International Transfer Pricing - OCDE Guidelines. United States: Thomson West, WGL Contents, 2005.

HASTBACKA, Mildred A. Valuation of Technology Intangibles for Transfer Pricing Time for Industry Initiatives? Tax Notes International. v. 32, out. 2003, Column Commentary and Analysis, Special Reports, p. 265.

HATCH, John. The Look-Back Rules and the Arm's-Length Standard. Tax Management Transfer Pricing Report. v. 12, mar. 2004, p. 1093.

HAUGEN, Lars P. In Tax Practice the Cost-Plus Method Is Often a TNMM in Disguise: What To Do about It? International Transfer Pricing Journal. Amsterdã: IBFD, set./out. 2005, p. 224-227.

HEJAZI, Jamal. Should Depreciation Be Marked Up in a Transactional Net Margin Method Context for Service Providers? International Transfer Pricing Journal. Amsterdã: IBFD, jan./fev. 2008, p. 26-30.

. Transfer Pricing within the North American Pharmaceutical Industry:

Has There Been a Structural Shift in Risk? International Transfer Pricing Journal. Amsterdã: IBFD, jan./fev. 2006, p. 08-14.

HELLERSTEIN, Walter. The Case for Formulary Apportionment. International Transfer Pricing Journal. Amsterdã: IBFD, mai./jun. 2005, p. 103-111.

HIGINBOTHAM, Harlow N. et al. When Arm's Length Isn't Really Arm's Length: Issues In Application of the Arm's Length Standard. Intertax. Kluwer Law International, v. 26, issue $8-9,1998$, p. 235-244. 
HILU NETO, Miguel. Preços de Transferência e Valor Aduaneiro - a Questão da Vinculação à Luz dos Princípios Tributários. In: Luís Eduardo Schoueri e Valdir de Oliveira Rocha (coord.), Tributos e preços de transferência. São Paulo: Dialética, 1999, v. 2, p. 257-276.

HOLMES, Kevin. The concept of income. A multi-disciplinary analysis. Doctoral Series no. 1, Academic Council. Amsterdã: IBFD Publications BV, 2001.

HOSSON, Fred C. De. Multinational Enterprises and the Development, Ownership and Licensing of Trademarks and Trade Names. Intertax. v. 27, issue 11, 1999, p. 398-412.

De. Multinationals and Development, Ownership, and Licensing of Trademarks and Trade Names: Part 1. Journal of International Taxation. v. 11, set. 2000, p. 22.

. De. Multinationals and Development, Ownership, and Licensing of Trademarks and Trade Names: Part 2. Journal of International Taxation. v. 11, out. 2000, p. 44.

HUCK, Hermes Marcelo. Evasão e elisão: Rotas Nacionais e Internacionais do Planejamento Tributário, São Paulo, Saraiva, 1997.

HUGON, Paul. O Impôsto: Teoria Moderna e Principais Sistemas. O Sistema Tributário Brasileiro. $2^{\text {a }}$ ed.. Rio de Janeiro: Financeiras, 1951.

HUMAN, Tifaine; PEGGS, Michael. The Issue of Comparability in Transfer Pricing. BNAI Tax Planning International Transfer Pricing. Toronto: v. 05, abr. 2004, p.04.

IBFD. International tax glossary, $5^{\text {th }}$ ed. completely revised, Amsterdam: IBFD, 2005. . The Tax Treatment of Transfer Pricing. Amsterdã: IBFD Publications B.V., folhas soltas.

ISENBERGH, Joseph. International Taxation. New York: Foundation Press, Chapter 4: International Transfer Pricing, 2000, p. 57-68.

JACOBS, Otto H. et al. ICT and Profit Allocation within Multinational Groups. Intertax. v. 32 , issue 6-7, 2004, p. 268-283

JARDIM NETO, José Gomes. A interpretação da legislação de preços de transferência por parte do Fisco no Brasil: podemos aprender com os erros? Revista de Direito Tributário Internacional. São Paulo: Quartier Latin, ano 02, n. ${ }^{\circ}$ 04, out. 2006. p. 109-128. 
JÁUREGUI, Maria de Los Angeles. Tratado sobre Instrumentos Financieros Derivados. Buenos Aires: La Ley, 2003.

JHABAKH, P. Raj Kumar. Supreme Court Clarifies Taxation of Captive Business Process Outsourcing Units in Morgan Stanley Case. International Transfer Pricing Journal. Amsterdã: IBFD, nov./dez. 2007, p. 345-349.

JIMÉNEZ, Adolfo J. Martín. Metodología y Derecho Financiero: Es Preciso Rehabilitar La Figura de B. Griziotti y el Análisis Integral da La Actividad Financiera Del Estado? Revista de Derecho Financiero y de Hacienda Pública. out./dez. 2000, p. 913-947.

JOSEPH, Anton. Derivatives: International Financial Reporting Standards and Taxation. Derivatives and Financial Instruments. Amsterdã: IBFD, nov./dez. 2005, p. 247-256. . NatWest Decision and Transfer Pricing: Global Implications for Banks. Derivatives and Financial Instruments. Amsterdã: IBFD, mar./abr. 2008, p. 42-44. Transfer Pricing Comparability: Perspectives of OECD, Australia and United States. International Transfer Pricing Journal. Amsterdã: IBFD, mar./abr. 2007, p. 89-99.

JÚNIOR, Onofre Alves Batista. A ‘Governamentalização’ do Poder de Decisão Tributário. In: Luís Eduardo Schoueri (coord.), Direto Tributário. Volume I. São Paulo: Quartier Latin do Brasil, Inverno 2003, p. 393-428.

KAMPHUIS, Erik. et. al. Group Financial Services companies: tax and transfer pricing policy. In: Rijkele Betten, The New Netherlands Transfer Pricing Regime. Amsterdã: IBFD, 2005, p. 29-89.

New Ruling Policy Regarding Companies that Provide Intra-group Financial Services. International Transfer Pricing Journal. Amsterdã: IBFD, set./out. 2001, p. 153-159.

KAPOOR, Shiv. Rolls Royce Decision: Income Attribution to Permanent Establishments. International Transfer Pricing Journal. Amsterdã: IBFD, mai./jun. 2008, p. 141-147.

KAUDER, Louis M. Intercompany Pricing and Section 482: a Proposal to Shift from Uncontrolled Comparables to Formulary Apportionment Now. Tax Notes. jan. 1993, p. 485-493. 
KELLEHER, Michael F. et al. The Applicability of Transfer Pricing Rules to 'Transactions' between a Head Office and its Foreign Permanent Establishment. International Transfer Pricing Journal. Amsterdã: IBFD, vol. 03, abr. 1996, p. 101-111.

KILLALY, Jim. Transfer Pricing: the Allocation of Income and expenses the experience of OECD an Dynamic Non-Member economies. Profit Methods in Theory and Practice. Seoul: OCDE, The Seoul DNME Workshop on Taxation. Issue Paper n. ${ }^{\circ}$ 6, abr. 1994.

KINGSON, Charles I.; BLUM, Cynthia A. International Taxation. United States: Aspen Law \& Business, 1998.

KOBETSKY, Michael. Intra-Bank Loans: Determining a Branch's Business Profits under Article 7 of the OECD Model. Bulletin for International Taxation. Amsterdã: IBFD, fev. 2005, p. 48-62.

. The Case for Unitary Taxation of International Enterprises. Bulletin for International Taxation. Amsterdã: IBFD, mai. 2008, p. 201-215.

KOPITS, George F. Taxation and Multinational Firm Behavior: a Critical Survey. International Monetary Fund Staff Papers, p. 624-673.

KRAMER, Jörg-Dietrich. Observations of Transfer Pricing in International Taxation. Tax Notes International. v. 29, jan. 2003, Column Commentary and Analysis, Special Reports, p. 283.

KROPPEN, Heinz-Klaus; EIGELSHOVEN, Axel. Tax Court Ruling on Transfer Prices and External Gross Margin Analyses. International Transfer Pricing Journal. Amsterdã: IBFD, jul./ago. 2000, p. 156-164.

; RASCH, Stephan. Interpretation of the Arm's Length Principle under Art. 9 of the OECD Model Tax Treaty: Does the Arm's Length Principle Cover Formal Requirements? International Transfer Pricing Journal. Amsterdã: IBFD, jan./fev. 2004, p. 26-29.

LANGBEIN, Stanley I. The Unitary Method and the Myth of Arm's Length. Tax Notes. fev. 1986, p. 625-681.

. U.S. Transfer Pricing and the Outsourcing Problem. Tax Notes International. v. 37, mar. 2005, Column Commentary and Analysis, Special Reports, p. 1065. 
A Modified Fractional Apportionment Proposal for Tax Transfer Pricing. Tax Notes. fev. 1992, p. 719-730.

LE GALL, Jean-Pierre. Some Thoughts on the 'Arm's-Length Principle'. International Transfer Pricing Journal. Amsterdã: IBFD, vol. 01, ago. 1994, p. 05-11.

LEBOWITZ, Brian E. C. Transfer Pricing and the End of International Taxation. Tax Management Transfer Pricing Report. v. 13, nov. 2000, Appendices, p. 62.

LEDURE, David; HOUARD, Alessandra. Global Trading. International Transfer Pricing Journal. Amsterdã: IBFD, nov./dez. 2005, p. 288-290.

LEHNER, Moris. Consideração Econômica e Tributação conforme a Capacidade Contributiva. Sobre a Possibilidade de Interpretação Teleológica das Normas com Finalidades Arrecadatórias. Traduzido por Luís Eduardo Schoueri. In: Luís Eduardo Schoueri et. al. (coord.) Direito Tributário. Estudos em Homenagem a Brandão Machado. São Paulo: Dialética, 1998, p. 143-154.

LEI, Wang. Allocation and Deductibility of Head Office Management Fees for Foreign Bank Branches. International Transfer Pricing Journal. Amsterdã: IBFD, nov./dez. 2002, p. 204-205.

LEONARDOS, Gabriel F. IFA Branch Reports, Brazil. Cahiers de Droit Fiscal International. International Fiscal Association. The Netherlands: SDU FISCALE \& FINANCIËLE UITGEVERS, v. 92a, 2007, p. 123-132.

LEPARD, Brian D. Is the United States Obligated to Drive on the Right? A Multidisciplinary Inquiry into the Authority of Contemporary International Law Using the Arm's Length Standard as a Case Study. Duke Journal of Comparative \& International Law. v. 10, Winter/Fall, 1999. p. 43.

LESTER, Eugene E. International Transfer Pricing Rules: Unconventional Wisdom. ILSA Journal of International \& Comparative Law. v. 02, Fall, 1995. p. 283.

LEUNG, Kevin K. Taxing Global Trading: an Appropriate Testing Ground for Formula Apportionment? Minnesota Journal of Global Trade. v. 01, Fall, 1992, p. 201.

LEVEY, Marc M. et al. Intangible Transfer Pricing and Penalties after DHL. Intertax. v. 30 , issue 12,2002 , p. 486-493. 
et al. The Quest for Marketing Intangibles. The Journal of International Taxation. v. 16, nov. 2005, p. 28.

. Transfer Pricing. Advanced Seminar on Trademark Law. Patents, Copyrights, Trademarks and Literary Property Course Handbook Series. v. 603, mai. 2000,. p. 39.

; BRANDMAN, Scott L. Tropicana: Inter-State Transfer Pricing, Lessons Learned. International Tax Journal. Fall 2001, p. 14-23.

; GRAUER, A. Gregg. APA Guidance. IRS Indicates a Preference for Profit-Split Method in Global Trading. The Journal of International Taxation. v. 05, n. ${ }^{\circ} 07$, jul. 1994, p. 300.

LI, Jinyan. Global Profit Split: An Evolutionary Approach to International Income Allocation. Canadian Tax Journal. v. 50, issue 03, jan. 2002, p. 823. . Slicing the Digital Pie with a Traditional Knife - Effectiveness of the Arm's-Length Principle in the Age of E-Commerce. Tax Notes International. v. 24, nov. 2001, Column Commentary and Analysis, Special Reports, p. 775.

LIMA GONÇALVES, José Artur. Certos Aspectos da Disciplina dos Preços de Transferência em face do Ordenamento Constitucional Brasileiro. In: Luís Eduardo Schoueri e Valdir de Oliveira Rocha (coord.), Tributos e preços de transferência. São Paulo: Dialética, 1999, v. 2, p. 217-242.

LINDSAY, John. Tax Treatment of Domestic and Cross-Border Securities Lending Transactions. Derivatives and Financial Instruments. Amsterdã: IBFD, jan./fev. 2001, p. $39-43$.

LOWELL, Cym H. Compaq: A Rare Complete Taxpayer Victory in a Transfer Pricing Case. Journal of International Taxation. v. 10, out. 1999, p. 43.

MAAS, Lex. Group Finance Facility. Derivatives and Financial Instruments. Amsterdã: IBFD, jan./fev. 2001, p. 06-19.

MACHADO, Brandão. Distribuição Disfarçada de Lucros no Direito Comparado. In: Ruy Barbosa Nogueira (coord.), Estudos Tributários em Homenagem à Memória de Rubens Gomes de Souza. São Paulo: Resenha Tributária, 1974, p. 145-183. 
MAISTO, Guglielmo. General Report of the Cahiers de Droit Fiscal International. International Fiscal Association. Boston: Kluwer Law and Taxation Issues, v. LXXVII-a, 1992, p. 17-76.

MALLOL, Carlos Herrero. Precios de Transferencia Internacionales. Estudio Tributario y Microeconómico. Espanha: Aranzadi Editorial, Collección Monografías Aranzadi n. ${ }^{\circ} 121$, 1999.

MANGANELLI, Andrea. Critical Analysis of Transactional Profit Methods and of their Practical Application. International Transfer Pricing Journal. Amsterdã: IBFD, nov./dez. 2000, p. 206-217.

MARIZ DE OLIVEIRA, Ricardo. Breves Considerações sobre a Capacidade Contributiva e a Isonomia. In: Luís Eduardo Schoueri (coord.). Direto Tributário. Volume I. São Paulo: Quartier Latin do Brasil, Inverno 2003, p. 457-527.

Fundamentos do Imposto de Renda. São Paulo: Quartier Latin do Brasil, verão 2008.

Preços de Transferência, o Método do Custo mais Lucro, o Conceito de Custo. O Método do Custo mais Lucro e as Indústrias de Alta Tecnologia. Como conciliar Dispêndios Intensivos, em Pesquisa e Desenvolvimento, com esse Método. In: Luís Eduardo Schoueri e Valdir de Oliveira Rocha (coord.), Tributos e preços de transferência. São Paulo: Dialética, 1999, v. 2, p. 293-338.

Presunções no Direito Tributário. In: Ives Gandra da Silva Martins (coord.). Presunções no Direito Tributário. São Paulo: Resenha Tributária Ltda., 1984, p. 276-330.

- Tributos e preços de transferência. In: Valdir de Oliveira Rocha (coord.), Tributos e preços de transferência. São Paulo: Dialética, 1997, p. 77-86.-

MARKHAM, Michelle. Tax in a Changing World: The Transfer Pricing of Intangible Assets. Tax Notes International. v. 40, dez. 2005, Column Commentary and Analysis, Special Reports, p. 895.

. The Transfer Pricing of Intangibles. The Netherlands: Kluwer Law

International, 2005. 
MARTÍN, Tomás Olalde. Practical Application of Transactional Profit Methods. International Transfer Pricing Journal. Amsterdã: IBFD, jul./ago. 2000, p. 130-135.

MARTINS, Ives Gandra da Silva. Preços de Transferência. In: Valdir de Oliveira Rocha (coord.), Tributos e preços de transferência. São Paulo: Dialética, 1997, p. 31-37.

MASCARELLO, Silvia. Attribution of Profits to Permanent Establishments of Banks. International Transfer Pricing Journal. Amsterdã: IBFD, mar./abr. 2006, p. 54-73.

MAY, George. Taxing Derivative Financial Instruments. Tax Strategies for Corporate Acquisitions, Dispositions, Spin-offs, Joint Ventures, Financing, Reorganizations \& Restructurings. Tax Law and Estate Planning Course Handbook Series. Tax Law and Practice. v. 553, out./nov. 2002, p. 1149.

MAYER, Stefan. Formulary Apportionment for the Internal Market. Doctoral Series no. 17, Academic Council. Amsterdã: IBFD Publications BV, 2009.

MAZEROV, Michael. Why arm's length falls short. International Tax Review. London: v. 5, issue 2, fev. 1994, p. 28.

MCLURE Jr., Charles E. Replacing Separate Entity Accounting and the Arm's Length Principle with Formulary Apportionment. Bulletin for International Taxation. Amsterdã: IBFD, dez. 2002, p. 586-599.

U.S. Federal Use of Formula Apportionment to Tax Income from Intangibles. Tax Management Transfer Pricing Report. v. 13, nov. 2000, Appendices, p. 68.

MEER-KOOISTRA, Jeltje van der. A Model for Making Qualitative Transfer Pricing Adjustments. International Transfer Pricing Journal. Amsterdã: IBFD, set./out. 2004, p. 190-195.

MEHAFDI, Messaoud. The ethics of international transfer pricing. Journal Of Business Ethics. Dordrecht: v. 28, issue 4, dez. 2000, Part 2, p. 365-381.

MEHTA, Narayan. An Integrated Approach to Formulating a Transfer Pricing Strategy Concerning Marketing and Distribution Affiliates. International Transfer Pricing Journal. Amsterdã: IBFD, mai./jun. 2006, p. 124-143.

MELO, José Eduardo Soares de (Coord.). Mesa de debates ' $F$ ' Tratados, preço de transferência. Revista de Direito Tributário. São Paulo: Malheiros, n. ${ }^{\circ}$ 81, p. 120-138. 
MESSINEO, Alejandro E. Transfer pricing in Latin America: New rules in Mexico and Brazil. Revista dos Tribunais Cadernos de Direito Tributário e Finanças Públicas. São Paulo: Revista dos Tribunais, n. ${ }^{\circ} 21,1997$, p. 141-156.

METZGER, Michael J.; HOGAN, Michael J. The Impact of the Internet on Financial Services. Futures \& Derivatives Law Report. v. 20, n. ${ }^{\circ}$ 04, jun. 2000, p. 01.

MIESEL, Victor H.; VERMA, Rohit. Transfer Pricing Economics: Potential Errors in Payment Terms Adjustments. International Tax Journal. Summer 2001, p. 01-11.

MILLER, Angharad; OATS, Lynne. Principles of International Taxation. United Kingdom: Tottel Publishing, 2006, Part IV, Chapter 14: Transfer Pricing, p. 205-248.

MILLER, Benjamin F. A Reply to 'From the Frying Pan to the Fire'. Tax Notes. out. 1993, p. 241-256.

None are so blind as those who will not see. Tax Notes. fev.1995, p. 1023-1035.

MINTZ, Jack M. Taxing Financial Activity. Bulletin for International Taxation. Amsterdã: IBFD, mar. 2004, p. 99-111.

MIRANDA, Pontes de. Tratado de Direito Privado, Parte Geral. Tomo III: Negócios Jurídicos, Representação, Conteúdo, Forma, Prova. $3^{\text {a }}$ ed. Rio de Janeiro: Editor Borsoi, 1970. Capítulo XVII: Prova dos Fatos Jurídicos, p. 404 a 454.

MIYATAKE, Toshio. General Report of the Cahiers de Droit Fiscal International. International Fiscal Association. The Netherlands: SDU FISCALE \& FINANCIËLE UITGEVERS, v. 92a, 2007, p. 17-38.

MOGLE, James R. Intercompany Transfer Pricing In The 1990's: Trading Old Lamps For New Ones? Taxes. v. 69, dez. 1991, p. 961.

MOICHE, M. Susana Bokobo Moiche. Los Cánones en el Régimen Tributario de los No Residentes sin Establecimiento Permanente. Madrid: Ministerio de Economía e Hacienda, Instituto de Estudios Fiscales, 2004.

MOLINA, Pedro M. Herrera. La irrelevancia jurídica del 'Concepto constitucional de tributo'. Quincena Fiscal. Revista de Actualidad Fiscal. España: Thomson Aranzadi, jan. 2004, n. 02. p. 09-21. 
MORISANO, Frank; YOUNG, John. An Arm's Length Approach to Levying Capital Taxes in Financial Services Sector. International Transfer Pricing Journal. Amsterdã: IBFD, p. 232-235.vol. 05, n. 05, set/out. 1998, p. 210-212.

MOSCHETTI, Francesco. Orientaciones Generales de la Capacidad Contributiva. Traduzido por Juan Gorospe Oviedo. Revista de Derecho Financiero y de Hacienda Publica. Madrid: Editorial de Derecho Financiero, vol. LIII, n. 269, set/dez. 2003, p.513561.

MOSQUERA, Roberto Quiroga; e FREITAS, Rodrigo de. Reflexos Financeiros dos Preços de Transferência: Conceito de Registro no Banco Central do Brasil das Operações Inbound e Outbound. In: Luís Eduardo Schoueri (coord.), Tributos e preços de transferência. São Paulo: Dialética, 2009, v. 03, p. 228-238.

MUSSELLI, Andrea; HUNTER, Donatella Marchetti. Glaxo Transfer Pricing Case: Economic Rationale, Legal Framework and International Issues. International Transfer Pricing Journal. Amsterdã: IBFD, mai./jun. 2007, p. 165-173.

NABAIS, José Casalta. Contratos Fiscais. Coimbra: Coimbra Editora, 1994.

NAVARRO COELHO, Sacha Calmon. Noções da Fiscalidade Internacional. Belo Horizonte: Produção gráfica da Faculdade de Direito da Universidade Federal de Minas Gerais, 1998.

NEIGHBOUR, John; OWENS, Jeffrey. Transfer Pricing in the New Millennium: Will the Arm's Length Principle Survive? Paper presented at the Symposium 'The Future of International Transfer Pricing: Practical and Policy Opportunities', in Washington D.C., sponsored by the Tax Council Policy Institute, 7 February 2002. George Manson Law Review. v. 10, Summer, 2002, p. 951.

NIENTIMP, Axel; ROEDER, Achim. Global Trading. International Transfer Pricing Journal. Amsterdã: IBFD, nov./dez. 2005, p. 306-310.

NILSSON, Inga. OECD Transfer Pricing Guidelines, Practical Experience. Practical Experience With The OECD Transfer Pricing Guidelines. The Hague: Kluwer Law International, v. 23b, Proceedings of a Seminar Held in London, in 1998 during the $52^{\text {nd }}$ Congress of the International Fiscal Association, p. 07-12.

NIYAMA, Jorge Katsumi; GOMES, Amaro L. Oliveira. Contabilidade de Instituições Financeiras. $3^{\text {a }}$ ed. São Paulo: Atlas, 1996. 
NOVAIS, Raquel; BEHRNDT, Marco Antonio. A Interpretação das Regras de Preços de Transferência pelo Conselho de Contribuintes. Revista de Direito Tributário Internacional. São Paulo: Quartier Latin, ano 02, n. ${ }^{\circ}$ 06, ago. 2007, p. 61-100.

OLDMAN, Oliver. The Unitary Method and the Less Developed Countries: Preliminary Thoughts. Paper presented at the Eleventh Meeting of Ad Hoc Group of Experts on International Cooperation in Tax Matters. Geneva, 15-19 dez. 2003. Documento n. ${ }^{\circ}$ ST/SG/AC. 8/2003/CRP. 7, da United Nations Secretariat.

OLIVEIRA, Yonne Dolácio de. Presunções no Direito Tributário. In: Ives Gandra da Silva Martins (coord.). Presunções no Direito Tributário. São Paulo: Resenha Tributária Ltda., 1984, p. 357-412.

OOSTERHOFF, Danny. Global Transfer Pricing Trends. International Transfer Pricing Journal. Amsterdã: IBFD, mai./jun. 2008, p. 119-125.

. The True Importance of Significant People Functions. International Transfer Pricing Journal. Amsterdã: IBFD, mar./abr. 2008, p. 68-75.

- Transfer Pricing Risk Management. International Transfer Pricing Journal. Amsterdã: IBFD, mar./abr. 2006, p. 46-53.

; DONGA, Jean Paul. Practical Application of Transactional Profit Methods. International Transfer Pricing Journal. Amsterdã: IBFD, jan./fev. 2001, p. 0206.

ORGANIZATION FOR ECONOMIC COOPERATION AND DEVELOPMENT [OCDE]. Brazil: German, OECD Officials say Brazil's Law does not Embrace Arm'sLength Principle. Tax Management Transfer Pricing Report. v. 25, abr. 1999, p. 966.

OCDE Documents - The Taxation of Global Trading of Financial Instruments. Paris: OCDE, 1998.

Report on the Attribution of Profits to Permanent Establishments.

Paris: OCDE, Centre for Tax Policy and Administration, 17 jul. 2008.

The Taxation of Global Trading of Financial Instruments: A Discussion Draft. Paris: OCDE, 1997.

Transfer Pricing Guidelines for Multinational Enterprises and Tax

Administrations. Paris: OCDE, 2001. 
E-Commerce: Transfer Pricing and Business Profits Taxation. Paris: OECD Publishing, Tax Policy Studies n. ${ }^{\circ}$ 10, 2005.

. Model Tax Convention on Income and Capital. Condensed version. Paris: OECD, 2008.

Modelo de Convenção Fiscal sobre o Rendimento e o Patrimônio. Cadernos de Ciência e Técnica Fiscal n. ${ }^{\circ}$ 172. Lisboa: Centro de Estudos Fiscais, 1995.

. Proposed Revision of Chapters I-III of the Transfer Pricing

Guidelines. $\quad 9^{\text {th }} \quad$ September 2009- $\quad 9^{\text {th }} \quad$ January 2010. Disponível em http://www.oecd.org/document/26/0,3343,en_2649_33753_43656346_1_1_1_1,00.html.

Report of the OECD Committee on Fiscal Affairs on Transfer Pricing and Multinational Enterprises. Paris: OCDE, 1979.

Report of the Committee on Fiscal Affairs on Transfer Pricing and MNEs. Three Taxation Issues. N. 2 The Taxation of Multinational Banking Enterprises. Paris: OCDE, 1984.

Reports of the Tax Force of the OECD Committee on Fiscal Affairs on US Transfer Pricing Regulations. Paris: OCDE, 1983.

ORSINI, Elen Peixoto. O Princípio “Arm's Length’ e a Legislação Interna Brasileira. In: Luís Eduardo Schoueri e Valdir de Oliveira Rocha (coord.), Tributos e preços de transferência. São Paulo: Dialética, 1999, v. 2, p. 117-142.

OWENS, Jeffrey. Promoting Fair Tax Competition. Acessado em 31.10.08. Disponível em www.ocde.org.

. Should the Arm's Length Principle Retire? International Transfer Pricing Journal. Amsterdã: IBFD, mai./jun. 2005, p. 99-102.

PARDO, Maria Luisa Esteve. Fiscalidad de Las Operaciones entre Sociedades Vinculadas y Distribuciones Encubiertas de Beneficios. Valencia: Tirant lo Blanch, Colección Financiero n. ${ }^{\circ}$ 03, 1996.

PASSARELLA, Leandro M. Taxation of Derivatives: Risk as the Criterion for Determining the Source of Income. Derivatives and Financial Instruments. Amsterdã: IBFD, mar./abr. 1999, p. 43-74. 
PÁUL, Ángel Esteban. Fiscalidad de Los Productos Financieros. Madrid: Instituto de Estudios Fiscales do Ministerio de Economía e Hacienda, 2005.

PÉREZ, Juan J. Zarnoza. Determinación de Los Precios de Transferencia en ausencia de Precios de Mercado Comparables. Crónica Tributaria. Madrid: n. ${ }^{\circ}$ 67, 1993, p. 123-136.

PETERSON, Shirley D; HORNER, Frances M. Secondary Adjustments and related aspects of Transfer Pricing Corrections. Secondary Adjustments and related aspects of Transfer Pricing Corrections. The Hague: Kluwer Law International, Proceedings of a Seminar Held in Canada, in 1994 during the $48^{\text {th }}$ Congress of the International Fiscal Association, p. 01-42.

PETROULIAS, Nick. et al. Australia's Embrace of Functional Analysis Profit Splitting Through the Back Door. International Transfer Pricing Journal. Amsterdã: IBFD, vol. 02, jun. 1995, p. 05-41.

PICCIOTTO, Sol. International Business Taxation. A Study in the Internationalization of Business Regulation. New York: Quorum Books, 1992.

PIJL, Hans. Morgan Stanley: Issues regarding Permanent Establishments and Profit Attribution in Light of the OECD View. Bulletin for International Taxation. Amsterdã: IBFD, mai. 2008, p. 174-182.

PINHEIRO, Jurandi Borges. Direito Tributário e Globalização. Ensaio crítico sobre preços de transferência. Rio de Janeiro: Renovar, 2001.

PISANI, José Roberto. GALHARDO, Luciana Rosanova. Preços de Transferência. Presunções tributárias. Acordos Internacionais. Valorização aduaneira. Revista Dialética de Direito Tributário. São Paulo: Dialética, v. 21, jun./97, p. 66 a 70.

PLAMBECK, Charles T. Transfer Pricing Analysis of Global Trading Operations and Procedural Alternatives. Taxes. v. 74, dez. 1996, p. 1.129.

POMP, Richard D. Issues in the Design of Formulary Apportionment in the Context of Nafta. New York University Tax Law Review. v. 49, 1993-1994, p. 795.

PRATS, Francisco Alfredo García. Los Precios de Transferencia: su Tratamiento Tributario desde una Perspectiva Europea. In: Heleno Taveira Tôrres (coord.), Direito Tributário Internacional Aplicado, Volume III. São Paulo: Quartier Latin, Primavera de 2005, p. 254-326. 
PRICEWATERHOUSECOOPERS International Shared Service Centre Group. Shared Service Centers. International Transfer Pricing Journal. Amsterdã: IBFD, vol. 05-c, set/out. 1998, p. 213-232.

PRZYSUSKI, Martin. et. al. Determination of Intangible Property Ownership in Transfer Pricing Analyses. Tax Notes International. v. 33, jan. 2004, Column Commentary and Analysis, Special Reports, p. 285.

et. al. Transfer Pricing of Intangible Property: A Canadian - U.S. Comparison. BNAI Tax Planning International Transfer Pricing. Toronto: v. 05, dez. 2004, p. 12.

- Secret Transfer Pricing Comparables Still Popular in Some Jurisdictions. BNAI Tax Planning International Transfer Pricing. Toronto: v. 06, jul. 2005, p. 07.

PUPO, Marcelo Botelho. Preços de Transferência e os Limites Constitucionais dos Ajustes do Lucro. In: Alexandre Siciliano Borges et. al. (coord.), Manual do Preços de Transferência no Brasil. São Paulo: MP Editora, 2007, p. 205-216.

PURVIS, S. E. C. et al. At Arm's length in the BALRM. Tax Notes. jul. 1989, p. 327-334. et. al. Transfer Pricing and the Basic Arm's Length Return Method. The International Tax Journal. v. 16, 1989-1990, p. 23.

PUSHKAR, Susmit. Legislative Response to the Sony Transfer Pricing Case. International Transfer Pricing Journal. Amsterdã: IBFD, nov./dez. 2007, p. 350-353.

RAFFERTY, James G. The Profit-Split Method of Income Allocation in Intercompany Pricing Disputes: The Eli Lilly Case. Taxes. v. 64, out. 1986, p. 662.

RAIMONDOS-MOLLER, Pascalis; SCHARF, Kimberly. Transfer Pricing Rules and Competing Governments. Oxford Economic Papers. Oxford: v. 54, issue 02, abr. 2002, p. 230-246.

RAMANUJAN, Adarsh; JHABAKH, P. Raj Kumar. Aztec Software Case: A Watershed in Transfer Pricing. International Transfer Pricing Journal. Amsterdã: IBFD, mai./jun. 2008, p. $148-158$.

RANDALL, Peter. Attribution of Profits to Permanent Establishments of Financial Institutions. Paper presented at the Symposium 'The Future of International Transfer 
Pricing: Practical and Policy Opportunities', in Washington D.C., sponsored by the Tax Council Policy Institute, 7 February 2002. George Manson Law Review. v. 10, Summer 2002, p. 875.

RANGEL, Vicente Marotta. Instalação de filiais de banco estrangeiro. Revista Trimestral de Direito Público. São Paulo: Malheiros Editores, v. 02, 1993, p. 100-106.

REICHERT, Timothy A.; WRIGHT, Deloris R. Proposed Cost Sharing Regulations: A Departure from Arm's Length? International Transfer Pricing Journal. Amsterdã: IBFD, jan./fev. 2006, p. 02-07.

REST, Arnout van der; BREGGEN, Michel van der. Intercompany Finance Activities Structured via the Netherlands: Time To Act. International Transfer Pricing Journal. Amsterdã: IBFD, mar./abr. 2005, p. 81-86.

RIBEIRO, Maria de Fátima; KEMMELMEIER, Carolina Spack. Preços de Transferência no Mercosul: Preservação da Base Tributária versus Compatibilização da Legislação Tributária dos Estados-Partes. In: Gilberto de Castro Moreira Júnior e Marcelo Magalhães Peixoto (coord.), Direito Tributário Internacional. São Paulo: MP Editora, 2006, p. $203-$ 230.

RIDOLFO, Arthur. Controle Fiscal das Transações Financeiras. In: Edílson Carlos Fernandes (coord.) Preços de Transferência. São Paulo: Quartier Latin, Verão 2007, p. 211-226.

ROBINSON, Peyton H. The Globally Integrated Multinational, the Arm's-Length Standard, and the Continuum Price Problem. Tax Management Transfer Pricing Report. v. 13, Nov. 2000, p.01.

RODRIGUES DO AMARAL, Antonio Carlos. Bases globais do imposto de renda e transfer pricing no Brasil. In: Cadernos de Direito Tributário e Finanças Públicas. São Paulo: Revista dos Tribunais, ano 5, n. 17, out./dez. 1996, p. 109-118. . O preço da transferência (transfer pricing) no Mercosul - II Jornada Tributária do Mercosul. Cadernos de Direito Tributário e Finanças Públicas. São Paulo: Revista dos Tribunais, ano 6, n. 22, jan./mar. 1998, p. 206-243.

O preço de transferência e critérios de comparabilidade. In: Luís Eduardo Schoueri e Valdir de Oliveira Rocha (coord.), Tributos e preços de transferência. São Paulo: Dialética, 1999, v. 2, p. 61-84. 
O preço de transferência no Brasil e a experiência internacional. In: Valdir de Oliveira Rocha (coord.), Tributos e preços de transferência. São Paulo: Dialética, 1997, p. 9-28.

RODRIGUES, Deusmar José. Preços de Transferência. São Paulo: Quartier Latin, 2006.

ROSENBLOOM, H. David. Angels on a Pin: Arm's Length in the World. Tax Notes International. v. 38, mai. 2005, Column Commentary and Analysis, Special Reports, p. 523.

O Regime Americano sobre Preços de Transferência: Benchmarks e Hallmarks. In: Heleno Taveira Tôrres (coord.), Direito Tributário Internacional Aplicado, Volume III. São Paulo: Quartier Latin, Primavera de 2005, p. 327-340. - Souse-Basis Taxation of Derivative Financial Instruments: Some Unanswered Questions. University of Miami Law Review. Miami: vol. 50, abr. 1996, p. 597.

ROTHMANN, Gerd W. Preços de Transferência. Método do Preço de Revenda menos Lucro: Base CIF (+II) ou FOB. A margem de lucro (20\% ou 60\%) em Processos de Embalagem e Beneficiamento. Revista Dialética de Direito Tributário. São Paulo: Dialética, v. 165, jun./09, p. 37 a 56.

ROTONDARO, Carmine. Transfer Pricing of Intangibles: Court Rulings on the Administrative Safe Harbour. International Transfer Pricing Journal. Amsterdã: IBFD, set./out. 1999, p. 213-217.

ROZEK, Richard P.; KORENKO, George G. Using In-Country Comparables To Measure the Returns Due to Pharmaceutical Marketing and Distribution Affiliates. International Transfer Pricing Journal. Amsterdã: IBFD, nov./dez. 2003, p. 211-217.

RUCHELMAN, Stanley C. International: US Tax Considerations in International Derivative Products. Bulletin for International Taxation. Amsterdã: IBFD, mai. 2003, p. p. 235-254.

RUSSO, Antonio. Formulary Apportionment for Europe: an Analysis and a Proposal. Intertax. v. 33, issue 1, 2005, p. 02-31. 
RUSSO, Raffaele. The Attribution of Profits to Permanent Establishments. The taxation of intra-company dealings. Amsterdã: IBFD, 2005, Part I: The Attribution of Profits to Permanent Establishments under the OECD Approach, p. 01-41.

RUTGES, Dave. SPORKEN, Eduard. When finance companies should pursue a Dutch APA. International Tax Review. London: 2003, p. 24-27.

SADIQ, Kerrie. The Fundamental Failing of the Traditional Transfer Pricing Regime Applying the Arm's Length Standard to Multinational Banks based on a Comparability Analysis. Bulletin for International Taxation. Amsterdã: IBFD, fev. 2004, p. 67-81. Unitary Taxation - The Case for Global Formulary Apportionment. Bulletin for International Taxation. Amsterdã: IBFD, jul. 2001, p. 275-286.

SAHAY, Savita A. Transfer Pricing Based on Actual Cost. Journal of Management Accounting Research. v. 15, p. 177.

SAUNDERS, Anthony. Administração de Instituições Financeiras. Traduzido por Antônio Zoratto Sanvicente. São Paulo: Atlas, 2000.

SCHNORBERGER, Stephan. The Cost-Plus Method: Determination of Margin and Cost. International Transfer Pricing Journal. Amsterdã: IBFD, mar./abr. 1999, p. 56-63.

SCHOUERI, Luís Eduardo. Aplicação Concomitante da Legislação de Preços de Transferência e da Tributação do Lucro em Bases Mundiais. In: Heleno Taveira Tôrres (coord.), Direito Tributário Internacional Aplicado, Volume III. São Paulo: Quartier Latin, Primavera de 2005, p. 239-254.

Distribuição Disfarçada de Lucros. São Paulo: Dialética, 1996, $2^{a}$ Parte, p. 97-168.

Preços de transferência e acordos de bitributação. In: Luís Eduardo Schoueri e Valdir de Oliveira Rocha (coord.), Tributos e preços de transferência. São Paulo: Dialética, 1997, p. 53-70.

Preços de Transferência no Direito Tributário Brasileiro. $2^{\mathrm{a}}$ ed. rev. e atual., São Paulo: Dialética, 2006.

SECRETARIA DA RECEITA FEDERAL. Tributação da Renda no Brasil Pós-Real. Brasília: Dupligráfica, 2001. 
SHAPIRO, Lawrence W. LEVEY, Marc M. Observations from a US Perspective on the OECD'S Approach to Transfer Pricing. International Company and Commercial Law Review. v. 6(3), 1995, p. 93-98.

SHELANSKI, Howard. A. Transaction-level determinants of Transfer-Pricing Policy: Evidence from the High-Technology Sector. Industrial and Corporate Change. v. 13, n. 6, p. 953-966.

SILBERZTEIN, Caroline. Practical Application of Transactional Profit Methods. International Transfer Pricing Journal. Amsterdã: IBFD, jul./ago. 2000, p. 126-129.

SILVA, Ednaldo A. Transfer Pricing under Gross Profit Methods: Adjustment for Functions Performed. Global Transfer Pricing. ago/set. 1999, p. 33-39.

SILVA, Mauro. Os limites para a capacidade contributiva - Mínimo Existencial e Confisco - como Elementos de Tensão entre Justiça Fiscal e Segurança Jurídica. In: Alcides Jorge Costa et. al.(coord.), Revista Direito Tributário Atual. n. 20. São Paulo: Dialética, 2006, p. 179-201.

SIMONTACCHI, Stefano. The Cost-Plus Method: Determination of the Margin and Cost Base. International Transfer Pricing Journal. Amsterdã: IBFD, mai./jun. 1999, p. 86-93.

SIMPSON, John. et al. An Economic Analysis of the Arm's length Standard Under the New IRS Regulations for Intercompany Pricing. Tax Notes. fev. 1993, p. 1089.

SOUSA, Rubens Gomes de. Compêndio de legislação tributária. São Paulo: Resenha Tributária, 1975.

Um caso de ficção legal no direito tributário: a pauta de valores como base de cálculo do ICM. Revista de Direito Público. São Paulo: Revista dos Tribunais, v. 11, jan.-mar. 1970, p. 13-32.

SOUTHERN, David. The Taxation of Derivatives. British Tax Review. v. 4, 1998, p. 348363.

SWARTZ, Linda Z. ABCS of Cross-Border Derivatives [Part 1]. Futures \& Derivatives Law Report. v. 24, n. ${ }^{\circ} 05$, jul./ago. 2004, p. 01.

ABCS of Cross-Border Derivatives [Part 2]. Futures \& Derivatives Law Report. v. 24, n. ${ }^{\circ} 07$, out. 2004, p. 16. 
SYMONS, Terry A.; ROACH, David. Profit-Oriented versus Transaction-Based Methods. International Transfer Pricing Journal. Amsterdã: IBFD, vol. 04, n. o 03, mai.jun. 1997, p. 126-132.

SZTAJN, Rachel. Futuros e swaps: uma visão jurídica. São Paulo: Cultural Paulista, 1999. TABOADA, Carlo Palao. El Principio de capacidad contributiva como criterio de justicia tributaria: aplicación a los impuestos directos e indirectos. In: Heleno Taveira Tôrres (coord.), Tratado de Direito Constitucional Tributário. Estudos em homenagem a Paulo de Barros Carvalho. São Paulo: Saraiva, 2005, p. 285-304.

TAVOLARO, Agostinho Toffoli. Tributos e Preços de Transferência. In: Luís Eduardo Schoueri e Valdir de Oliveira Rocha (coord.), Tributos e preços de transferência. São Paulo: Dialética, 1999, v. 2, p. 23-50.

TAYLOR, Rodney; HAYARD, Stoy. International Transfer Pricing of Services. Tax Planning International Review. The Bureau of National Affairs, Inc., 1991, p. 14-16.

TERRA, Ben J. M; WATTEL, Peter J. European Tax Law. Abridged Student Edition. $5^{\mathrm{a}}$ ed. The Netherlands: Kluwer Law International, 2008.

TEUBNER, Gunther. O direito como sistema autopoiético. Traduzido por José Engrácia Antunes. Lisboa: Fundação Calouste Gulbenkian, 1989.

THOMAS, Chantal. Customary International Law and State Taxation of Corporate Income: The Case for the Separate Accounting Method. Berkeley Journal of International Law. v. 14, 1996, p. 99.

TIPKE, Klaus. A Necessidade de Igualdade na Execução das Leis Tributárias. In: Luís Eduardo Schoueri (coord.), Direto Tributário. Volume I. São Paulo: Quartier Latin do Brasil, Inverno 2003, p. 361-374.

Princípio de Igualdade e Idéia de Sistema no Direito Tributário. In: Brandão MACHADO (coord.), Direito Tributário, Estudos em Homenagem ao Prof. Rui Barbosa Nogueira. São Paulo: Saraiva, 1984, p. 515-527.

TÔRRES, Heleno Taveira. Direito Tributário e Autonomia Privada. O poder de tributar e a teoria dos negócios jurídicos na atualidade. Metodologia para a interpretação dos fatos tributários. In: Heleno Taveira Tôrres (coord.), Tributação nos Mercados Financeiro e de Captais. São Paulo: Quartier Latin, Outono de 2005, p. 69-114. 
. Direito Tributário e Direito Privado. São Paulo: Revista dos

Tribunais, 2003.

Direito tributário internacional: planejamento tributário e operações transnacionais. São Paulo: Revista dos Tribunais, 2001.

Dupla (Múltipla) Tributação Internacional das Rendas de Empresas:

Dupla Tributação Jurídica Internacional e Dupla Tributação Jurídica Internacional. Revista de Direito Tributário. São Paulo: Malheiros, 1993, v. 65, p. 67-95.

- Garantias constitucionais aplicadas ao controle sobre preços de transferência (legalidade e uso de presunções no arbitramento da base de cálculo dos tributos, a partir do controle de preços de transferência. $\mathrm{O}$ direito ao emprego do melhor método. Um caso: limites ao uso do PRL-60 na importação). In: Octavio Campos Fischer (coord.), Tributos e direitos fundamentais. São Paulo: Dialética, 2004, p. 95-123.

Pluritributação internacional sobre as rendas de empresas. $2^{\mathrm{a}}$ ed. rev., atual. e ampl. São Paulo: Revista dos Tribunais, 2001.

Segurança Jurídica em matéria tributária. In: MARTINS, Ives Gandra da Silva. Limitações ao Poder Impositivo e Segurança Jurídica. São Paulo: Centro de Extensão Universitária, 2005, p. 157-182.

; UTUMI, e Ana Claudia Akie. O Controle Fiscal dos Preços de Transferência e os Meios de Prova Admitidos para a Definição de Preços e Custos Médios. In: Tributos e preços de transferência. São Paulo: Dialética, 1999, v. 2, p. 165-208.

TORRES, Ricardo Lobo. A Legitimação da Capacidade Contributiva e dos Direitos Fundamentais do Contribuinte. in: Luís Eduardo Schoueri (coord.), Direto Tributário. Volume I. São Paulo: Quartier Latin do Brasil, Inverno 2003, p. 430-456.

. Legalidade Tributária e Riscos Sociais. Revista Dialética de Direito Tributário. São Paulo: Dialética, v. 59, ago./00, p. 95-99.

O Princípio Arm's Length, os Preços de Transferência e a Teoria da Interpretação do Direito Tributário. Revista Dialética de Direito Tributário. São Paulo: Dialética, v. 48, set./99, p. 122 a 135.

Tratado de Direito Constitucional, Financeiro e Tributário. Rio de Janeiro: Renovar, 2005, v. II: Valores e Princípios Constitucionais Tributários. 
TSANEVA, Elena R. Transfer Pricing in the World of Services and Intangibles: A New Challenge to Preserve the Corporate Tax Base. UCLA Journal. v. 09, Fall/Winter 2004, p. 323.

TURNER, Robert. The Ford Motor Company of Canada Case: An Analysis. International Transfer Pricing Journal. Amsterdã: IBFD, jul./ago. 2004, p. 172-178.

UCKMAR, Victor. Princípios Comuns de Direito Constitucional Tributário. $2^{\mathrm{a}}$ ed. rev. e ampl. Tradução e Notas ao Direito Brasileiro por Marco Aurélio Greco. São Paulo: Malheiros, 1999.

ULHÔA CANTO, Gilberto de. A Aquisição e Disponibilidade e o Acréscimo Patrimonial no Imposto sobre a Renda. In: Ives Gandra da Silva Martins (coord.), Estudos sobre o Imposto de Renda (em memória de Henry Tilbery). São Paulo: Resenha Tributária Ltda., jul. 2004, p. 33-40.

UNITED NATIONS CONFERENCE ON TRADE AND DEVELOPMENT [UNCTAD]. World Investment Report. Geneva: UNCTAD, 2008. Disponível em www.unctad.org.

UNITED NATIONS. [UN]. International Income Taxation and Developing Countries. New York: UN, 1988. Chapter VII: "Transfer Prices Abuses and Developing Countries". . United Nations Model Double Taxation Convention Between Developed and Developing Countries. New York: UN, 1980.

UNITED STATES OF AMERICA, DEPARTMENT OF TREASURY. Federal Register/v. 63, no. 44, Friday, March 6, 1988, obtido em www.irs.gov. Federal Register/v. 74, no. 148, Tuesday April 4, 2009, obtido em Www.irs.gov. IRS. Notice 94-40, de 25.04.94, referência: 1994-1 C.B. 351; 1994 IRB LEXIS 213; 1994-17 I.R.B. 22; Notice 94-40, extraída do sítio eletrônico www.irs.gov].

UTUMI, Ana Cláudia Akie, Preços de Transferência no Direito Brasileiro, São Paulo, PUC, Dissertação de Mestrado, 2001, inédita.

VANISTENDAEL, F. The European Tax Paradox: How Less Begets More. Bulletin. Amsterdam: IBFD, nov/dez. 1996, p. 531-534. 
VARELA, Pablo Sergio. Precios de transferencia. Una breve aproximacion. Revista Tributária e de Finanças Públicas. São Paulo: Revista dos Tribunais, n. 36, 2001, p. 9-31. VERDONER, L.A.; SOLVAY, Duphar. Interest-free Loans and Intercompany Pricing. International Transfer Pricing Journal. Amsterdã: IBFD, vol. 01, out. 1993, p. 59-68. Global Trading: Na Adventure in Financial Markets and Instruments. International Transfer Pricing Journal. Amsterdã: IBFD, nov./dez. 2005, p. 282-287.

VERLINDEN, Isabel; BOONE, Patrick; HEMELAER, Ruth. Practical Application of Transactional Profit Methods. International Transfer Pricing Journal. Amsterdã: IBFD, jul./ago. 2000, p. 122-126.

VILLANI, Piero. Preço de transferência de bens entre empresas afiliadas e seu controle no direito italiano. Revista de Direito Tributário. São Paulo: Malheiros, n. ${ }^{\circ}$ 51, 1990. p. 29-43.

VILlanUEVA, V. E. Combarros, Régimen Tributario de las Operaciones entre Sociedades Vinculadas en el Impuesto sobre Sociedades. Madrid: Tecnos, 1988.

VINCENT, François. Transfer Pricing and Attribution of Income to Permanent Establishments: The Case for Systematic Global Profit Splits (Just Don't Say Formulary Apportionment). Canadian Tax Journal. v. 53, issue 02, abr. 2005, p. 409.

VINCENTE, Marcelo Álvares. Do controle fiscal dos preços de transferência: Consequiências da aplicação dos ajustes e hipóteses de não aplicação. Revista de Direito Tributário Internacional. São Paulo: Quartier Latin, ano 03, n. 09, ago. 2008, p. 131-160.

VOGEL, Klaus. Klaus Vogel on Double Taxation Conventions. $3^{\mathrm{a}}$ ed. London: Kluwer Law International, 1997, Introduction, p. 01-76 e Article 9: Associated Enterprises, p. 510574.

Reflections on the Future of the OECD Model Convention and Commentary. Bulletin for International Taxation. Amsterdã: IBFD, nov/dez. 1996, p. 527530.

- Tributação da renda mundial, Cadernos de Direito Tributário e Finanças Públicas. Traduzido por Luís Eduardo Schoueri. São Paulo: Revista dos Tribunais, n. ${ }^{\circ}$, 1994, p. 133-143.

WACKER, Raymond. et. al. The Comparable Profits Method Under the Temporary Section 482 Regulations: A radical Attempt to Introduce an Objective Standard for 
International Transfer-Pricing Activities. International Tax and Business Lawyer. V. 11, 1993 , p. 26.

WASSERMEYER, Franz. The Arm's Length Principle in German Tax Law. Bulletin for International Taxation. Amsterdã: IBFD, ago./set. 2000, p. 417-424.

WEINER, Joann Martens. Formulary Apportionment and Group Taxation in the European Union: Insights From the United States and Canada. Working Paper - Taxation and Customs Union n. ${ }^{\circ}$ 8, mar. 2005. Acessado em 31.10.08. Disponível em HTTP://europa.eu.int/comm/taxation_customs/taxation/taxation.htm.

WICKHAM, Dale W. KERESTER, Charles J. New Directions Needed for Solution of the International Transfer Pricing Tax Puzzle: Internationally Agreed Rules or Tax Welfare? Tax Notes, jun. 1992, p. 339-361.

WILKIE, J. Scott. Global Trading: Some Comments on the Canadian Transfer Pricing Practice and on Part III of the OECD's Study of Profit Attribution to Permanent Establishments. International Transfer Pricing Journal. Amsterdã: IBFD, nov./dez. 2005, p. 291-297.

WILLIAMS, Richard C. at. all. Supervision of Banks Foreign Establishments. In International Capital Markets, Recent Developments and Short-Term Prospects. Washington: International Monetary Fund, 1981, p. 29.

WOLF, Martin. Does Globalization Render States Impotent? British Tax Review n. ${ }^{\circ}$, 2000, p. 537-544.

WRAPPE, Steven C. The Transfer Price is Right, or is it? (Tax Liability issues in Transfer Pricing Practice). Strategic Finance. v. 81, issue 01, jul. 1999, p. 38.

WRIGHT, Deloris R. Economics, Intangibles, and Section 482. The International Tax Journal. v. 10, 1983-1984, p. 223.

Practical Application of Transactional Profit Methods. International Transfer Pricing Journal. Amsterdã: IBFD, set./out. 2000, p. 198-203.

Report on the Application and Administration of Section 482: A Commentary. International Transfer Pricing Journal. Amsterdã: IBFD, set./out. 1999, p. 218-225. 
Transfer Pricing When Losses Arrive. International Transfer Pricing Journal. Amsterdã: IBFD, set./out. 2002, p. 174-179.

; KEATES, Harry A. The Cost-Plus Method. International Transfer

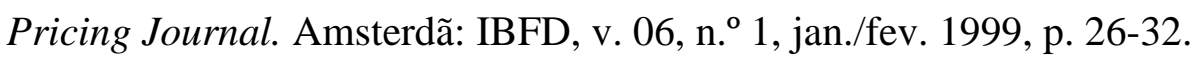

; KEATES, Harry A. The DHL Case: What Lessons Can Be Learned? International Transfer Pricing Journal. Amsterdã: IBFD, mai./jun. 1999, p. 74-78.

WÜNDISCH, Karl. Pharmaceutical Industry and Transfer Pricing: Anything Special? International Transfer Pricing Journal. Amsterdã: IBFD, nov./dez. 2003, p. 204-210.

XAVIER, Alberto. Direito Tributário Internacional do Brasil, $6^{\mathrm{a}}$ ed., ref. e atual. Rio de Janeiro: Forense, 2004.

Os Princípios da Legalidade e da Tipicidade da Tributação. São Paulo: Revista dos Tribunais, 1978.

Problemas Jurídicos das Filiais de Sociedades Estrangeiras no Brasil e de Sociedades Brasileiras no Exterior. Revista de Direito Mercantil. São Paulo: Editora Revista dos Tribunais, ano XIX (nova série), n. ${ }^{\circ}$ 39, jul./set,/1980, p. 76-83.

Tipicidade da Tributação, Simulação e Norma Antielisiva. São Paulo:

Dialética, 2001.

ZILVETI, Fernando Aurélio. Capacidade Contributiva e Mínimo Existencial. In: Luís Eduardo Schoueri et. al. (coord.) Direito Tributário. Estudos em Homenagem a Brandão Machado. São Paulo: Dialética, 1998, p. 36-47. 


\section{RESUMO.}

O controle dos preços de transferência está amparado no princípio da plena concorrência, que representa espécie de dogma no direito tributário internacional. Para a sua concretização, há duas espécies de metodologias distintas: os métodos tradicionais, apoiados na comparação dos preços ou margens brutas de lucro das transações, e os métodos baseados na comparação de lucros operacionais entre as transações cotejadas. Não obstante a existência desta gama de métodos, há exemplos nos quais o princípio da plena concorrência não propicia mecanismos suficientes para o adequado controle dos preços de transferência, porquanto inexistem dados para a comparação dos preços, margens brutas ou lucros operacionais.

As negociações globais de instrumentos financeiros intra-grupo, praticadas de forma integrada entre instituições de um mesmo conglomerado bancário, estão entre as situações que mais apresentam desafios ao aludido princípio. Como alternativa, parte da doutrina internacional tem defendido a adoção do método da partilha de lucros segundo fórmulas predeterminadas ou "formulary apportionment". Os principais argumentos destes teóricos são a constatação de que o princípio da plena concorrência, ao se amparar no critério da entidade segregada, ignora os ganhos de eficiência e escala gerados no âmbito dos grupos econômicos; ademais, a aplicação deste princípio mostra-se complexa, dada a sua abertura e amplitude.

No direito brasileiro, as regras para o controle dos preços de transferência, a despeito de inspiradas nos métodos tradicionais disponíveis para a aplicação do princípio da plena concorrência, são simplificadas a tal ponto que os métodos envolvendo margens brutas tornaram-se semelhantes aos métodos envolvendo fórmulas predeterminadas. Esta simplificação é desejável, em especial com vistas ao atendimento da praticabilidade, legalidade, eficiência administrativa etc.. Idealmente, a melhor estratégia de política tributária a ser adotada seria aquela baseada na edição de normas que, de um lado, (i.) prevejam margens predeterminadas de lucros por setor de atividade e região, ou definam outros critérios objetivos, razoáveis sob a perspectiva econômica, para o cálculo dos preços parâmetro, mas, de outro, (ii.) admitam que estas simplificações representam "safe harbours", sendo garantido ao contribuinte o direito de apresentar quaisquer argumentos ou provas admitidos em direito para comprovar sua situação peculiar. $\mathrm{O}$ exame das discussões envolvendo a negociação global de instrumentos financeiros auxilia na conclusão de que, para serem justas, as normas para o controle dos preços de transferência precisam ser abrangentes, possibilitando-se a adequação dos métodos às especificidades de cada caso concreto; para o adequado funcionamento do sistema tributário, contudo, é imprescindível a instituição de diversas espécies de "safe harbours", aptos a abranger a maioria das situações, reservando-se às transações realmente peculiares o exame detalhado dos preços. 


\begin{abstract}
.
Transfer pricing control rests on the arm's length principle, one of the international consensus of international tax law. Control takes place under either of two methodologies: one comprising the Traditional Transaction Methods based on the comparison of prices and/or gross margins, and the other comprising Transactional Profits Methods based on the comparison of operating incomes from the relevant transactions. Notwithstanding the several methods in existence, the arm's length principle may sometimes fail as a mechanism for adequate control of transfer pricing, insofar as data for the comparison of prices, gross margins or operational income are not available.
\end{abstract}

The integrated global trading of financial instruments between units of a same banking group is an example of challenging situation for the effective application the arm's length principle in transfer pricing control. Seeking an alternative approach, recent studies make the case for apportioning profits in accordance with preset formulas - the so-called formulary apportionment. The main arguments behind this proposal revolve around the arm's length principle ignoring economies of scale and other efficiency gains that normally breed within an economic group, as well as it being overly complex and open-ended.

Although inspired by the Traditional Transactional Methods, Brazilian transfer price rules are simplified to such extent, that the gross margin comparison methods have become similar to a preset formula. Simplification is desirable from the standpoint of practicability, legal strictness, administrative efficiency, and so on. The ideal tax legislation policy would include rules that (i.) either pre-set gross margin parameters by industry and geographic location, or set forth objective, economically reasonable criteria for determination of parameter prices; but also (ii.) acknowledge such simplifications as no more than safe harbours and offer the taxpayer an opportunity to demonstrate deviation from the norm in a given peculiar situation. An analysis of the discussions on global trading of financial instruments fosters the conclusion that in order to be fair, transfer pricing rules must be all-encompassing; efficiency of the tax system, however, cannot forego the use of safe harbours that cover the majority of cases, thus restricting detail analysis to transactions that are actually peculiar. 


\section{RIASSUNTO}

Il controllo dei prezzi di trasferimento è sostenuto dal principio della piena concorrenza, il che all'interno del diritto tributario internazionale è una vera sorta di dogma. Affinché effettivamente avvenga la sua concretizzazione vi sono due tipi di metodologie distinte: da una parte si trovano i metodi tradizionali basati su un'analisi comparativa fra i prezzi o fra i margini lordi di profitto delle transazioni, mentre dall'altra parte, si trovano i metodi basati sul confronto dei profitti operazionali fra le transazioni analizzate. Nonostante l'esistenza di tale diversità fra i metodi vi sono degli esempi in cui il principio della piena concorrenza non propizia la pratica di quei meccanismi sufficienti all'adeguato controllo dei prezzi di trasferimento, proprio perché non esistono dati attinenti alla comparazione dei prezzi, dei margini lordi o dei profitti operazionali. Le trattative globali di strumenti finanziari intergruppo, praticate in modo integrato fra le istituzioni di un medesimo conglomerato bancario, vengono elencate fra le situazioni che offrono il maggior numero di sfide al nominato principio.

Come alternativa a tale situazione, una parte della dottrina internazionale sostiene che si adotti il metodo della divisione di profitti secondo formule prefissate oppure "formulary apportionment". I principali argomenti presentati da tali teorici sono la constatazione che il principio della piena concorrenza, quando si fa sostenere dal criterio dell'ente segregato, ignora tanto i guadagni d'efficienza e scala _entrambi ricavati all'interno dei gruppi economici_quanto la complessità e vasta dimensione del principio della piena concorrenza.

Nel diritto brasiliano, le regole attinenti al controllo dei prezzi di trasferimento, sebbene ispirate ai metodi tradizionali disponibili, rivolti all'applicazione del principio della piena concorrenza, sono semplificate a tale punto che i metodi dove si osserva la presenza dei margini lordi, diventano addirittura simili ai metodi applicati alle formule prefissate. Tale semplificazione è apprezzabile, specie se si punta sulla praticabilità, sulla legalità, sull'efficienza amministrativa ecc. In modo ideale la miglior strategia di politica tributaria da adottare sarebbe quella basata sull'edizione di norme che, da una parte, (i) prevedessero dei margini prefissati di profitti per ogni settore di attività e regione, o definissero altri criteri obiettivi, ragionevoli dal punto di vista economico, che puntassero ancora sul calcolo dei prezzi parametri, ma che, però, d'altra parte (ii) ammettessero che tali semplificazioni rappresentano "safe harbours", assicurando al contribuente il diritto di presentare qualunque prova o argomento ammessi in diritto affinché sia comprovata la sua situazione peculiare. L'analisi delle discussioni attinenti alle trattative globali di strumenti finanziari contribuisce a concludere che, perché siano giuste, le norme rivolte al controllo dei prezzi di trasferimento devono mirare ad un orizzonte ampio, permettendo quindi che vi sia l'adeguamento dei metodi alle particolarità di ogni singolo caso reale; va ricordato però che, 
affinché si osservi il giusto funzionamento del sistema tributario non si può fare a meno dell'esistenza di istituzione di diversi tipi di "safe harbours", che siano in grado di coprire e rispondere alla maggior parte delle situazioni, riservando piuttosto alle transazioni veramente peculiari l'esame particolareggiato dei prezzi. 